A BIBLIOGRAPHY OF ATRAZINE

AND ITS SIMPLE DEGRADATION PRODUCTS

IN THE ENVIRONMENT

Paul D. Camel

USS. GEOLOGICAL SURVEY

Open-File Report 89-613

St. Paul, Minnesota

1989 


\section{DEPARTMENT OF THE INTERIOR}

MANUEL LUJAN, JR., Secretary

\section{U.S. GEOLOGICAI SURVEY}

Dallas L. Peck, Director

For additional information write to:

District Chief

U.S. Geological Survey

702 Post Office Building

St. Paul, Minnesota 55101
Copies of this report can be purchased from:

U.S. Geological Survey

Books and Open-File Reports Section Federal Center, Building 41

Box 25425

Denver, Colorado 80225 


\section{CONTENTS}

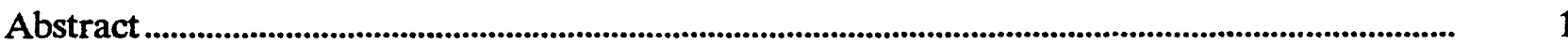

Introduction.......................................................................................................................................................

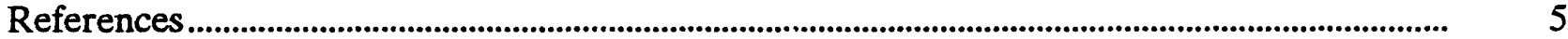

Environmental Processes........................................................................................................................ 6

Transformation Processes ............................................................................................................................ 6

Biodegradation/Biotransformation ....................................................................................... 6

Hydrolysis/Chemical Reactions ................................................................................................ 24

Photolysis ...................................................................................................................................... 32

Transfer Processes..................................................................................................................... 34

Volatilization ................................................................................................................. 34

Uptake by Biota ............................................................................................................................... 36

Sorption/Partitioning ............................................................................................................ 48

Associations with Humic Material................................................................................................ 48

Associations with Plant Material ............................................................................................... 51

Associations with Surfactants ............................................................................................. 54

Sorption to Resins ..................................................................................................

Sorption to Sediments....................................................................................................... 66

Sorption to Soil.......................................................................................................................... 67

Transport Processes ...................................................................................................................... 80

Leaching ........................................................................................................................... 80

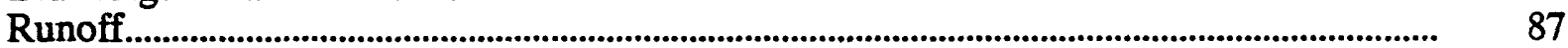

Field Residuals........................................................................................................................

Environmental Observations............................................................................................... 99

Atmospheric Observations.................................................................................................................. 99

Drinking Water Observations..................................................................................................... 100

Ground Water Observations........................................................................................................ 101

Surface Water Observations ................................................................................................................... 104

Waste Water Observations and Treatment.............................................................................. 106

Miscellaneous.......................................................................................................................................................... 109

Analytical Methods/Quantification..................................................................................... 109

Degradation Products ............................................................................................................................. 135

Miscellaneous Environmental .................................................................................................... 150

Physical/Chemical Properties ........................................................................................................................ 153

Toxicity............................................................................................................................................................ 159

\section{TABLES}

Table 1. The chemicals referenced in this bibliography .................................................................. 3

2. The categories referenced in this bibliography .................................................................... 


\title{
A BIBLIOGRAPHY OF ATRAZINE \\ AND ITS SIMPLE DEGRADATION PRODUCTS \\ IN THE ENVIRONMENT
}

By Paul D. Capel

\begin{abstract}
Citations from the scientific literature on the environmental behavior and occurrence of atrazine and its simple degradation products were obtained from three computerized bibliographic databases: Chemical Abstracts Service, Selected Water Resources Abstracts, and Agricola. More than 2,500 citations were categorized by environmental process, occurrence, analysis, toxicity or physical/chemical property.
\end{abstract}

\section{INTRODUCTION}

Agricultural chemical contamination of surface and ground water is a topic of current concern. Agricultural chemicals have been observed in all components of the hydrologic cycle, establishing a need for research into their environmental fate and transport.

Atrazine (2-chloro, 4-ethyl-amino, 6-isopropyl-amino-s-triazine) provides an excellent environmental surrogate of other herbicides. It has the appropriate set of physical and chemical properties to allow its movement within and between all environmental compartments (air, rain, soil, surface water, biota, ground water, and so forth). It also has a sufficiently wide range of environmental half-lives to allow for its potential movement and subsequent observation in these compartments. Atrazine is also the most common organic contaminant in ground water in the mid-continent of North America (Chen and Druliner 1987, Detroy and others 1988, Klaseus and others 1988) and is the second most popular herbicide in use (Gianessi and Puffer 1988). Therefore, a growing number of studies, both within and outside of the U.S. Geological Survey's Water Resources Division, focus on the environmental behavior of this triazine herbicide (Burkart and others 1988).

To help facilitate the current and future research on nonpoint source contamination by agricultural chemicals, an extensive search of the scientific literature was performed for atrazine and its simple degradation products by means of computerized library databases (table 1). More than 5,000 citations in the scientific literature on these chemicals were found in computerized searches of three bibliographic databases: Chemical Abstracts , Selected Water Resources Abstracts, and Agricola. About half of the citations were eliminated from this bibliography as having limited usefulness to environmental studies based on examination of the citation's abstract and title or title only (whichever was available). The eliminated citations were directed strictly toward the agricultural usefulness of atrazine.

\footnotetext{
'Use of trade namea in this report is for identification purpones only and does not conetitute endorsement by the U.S. Geological
Survey.
} 
The remainder of the citations were organized into categories (table 2). The first major category (Environmental Processes) includes the physical, chemical, and biological processes that control the transport (movement within an environmental compartment), transfer (movement between environmental compartments), and transformation (change in the chemical structure) of atrazine and its simple degradation products. The second major category (Environmental Observations) includes citations of observations of atrazine and its simple degradation products in the major environmental compartments. The third major category (Miscellaneous) includes other topics such as analytical methods, physical/chemical properties, toxicity, and the degradation pioducts.

Each citation is composed of (1) a bibliographic reference, (2) language of the article, (3) keywords assigned to the citation in this bibliography, and (4) the data base reference number. Reference numbers for citations from the Chemical Abstract Service begin with CA; those from the Agricola data base begin with CAIN, CAT, OWRT, or IND, and those from the Selected Water Resources Abstracts data base do not have a reference number listed.

This is not an exhaustive bibliography of atrazine and its simple degradation products, but it contains the works which will be most accessible to the researchers. The citations are those which were available from the computerized library systems at the end of 1988. 


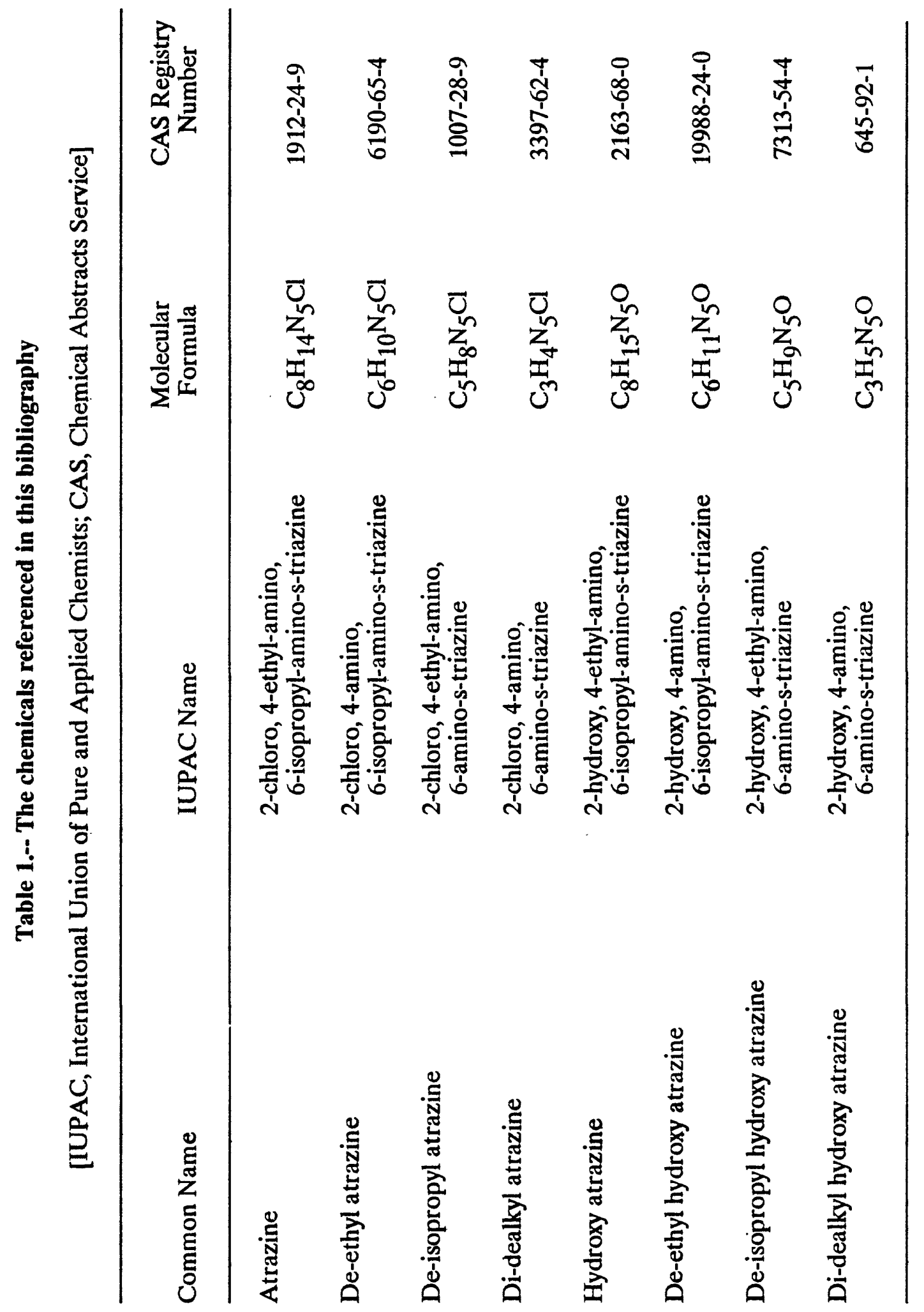


I. Environmental Processes

A. Transformation Processes

Biodegradation/Biotransformation

Hydrolysis/Chemical Reactions

Photolysis

B. Transfer Processes

Volatilization

Uptake by Biota

Sorption/Partitioning

Associations with Humic Material

Associations with Plant Material

Associations with Surfactants

Sorption to Resins

Sorption to Sediments

Sorption to Soil

C. Transport Processes

Leaching

Runoff

Field Residuals

II. Environmental Observations

Atmospheric Observations

Drinking Water Observations

Ground Water Observations

Surface Water Observations

Waste Water Observations and Treatment

III. Miscellaneous

Analytical Methods/Quantification

Degradation Products

Miscellaneous Environmental

Physical/Chemical Properties

Toxicity 


\section{REFERENCES}

Burkart, Michael R., Ragone, Stephen E., Thurman, E. Michael, and Perry, Charles A., 1989, Planned studies of herbicides in ground and surface water in the midcontinental United States, in U.S. Geological Survey Toxic Substances Hydrology Program-Proceedings of the technical meeting, Phoenix, Arizona, Sept. 26-30, U.S. Geological Survey Water-Resources Investigation Report 88-4220, 1988, p. 445-452.

Chen, Hsiu-Hsiung and Druliner, A. Douglas, 1987, Nonpoint-source agricultural chemicals in ground water in Nebraska--Preliminary results for six areas of the High Plains aquifer: U.S. Geological Survey, Water-Resources Investigation Report 86-4338, no. 315, p. 170-196.

Detroy, Mark, G., Hunt, Pamela, K.B., and Holub, Maureen, A., 1988, Ground-water-qualitymonitoring program in Iowa; nitrate and pesticides in shallow aquifers, U.S. Geological Survey, Water-Resources Investigation Report 88-4123, $31 \mathrm{p}$.

Gianessi, L. P. and Puffer, C. M., 1988 Use of selected pesticides for agricultural crop protection in the United States, 1982-1985; Quality of the Environment Division, Resources for the Future, Inc., 1616 P Street, NW, Washington, D.C., 490 p.

Klaseus, Tomas, G., Buzicky, Greg C., and Schneider, Edward C., 1988, Pesticides and groundwater; surveys of selected Minnesota wells: Minnesota Department of Health and Minnesota Department of Agriculture, Report to the Legislative Commission on Minnesota Resources, $95 \mathrm{p}$. 
Adams, R. S., Jr., and Pritchard, D. J., Sept/Oct 1977, Influence of soil pH on the phytotoxicity of three s-triazine herbicides: Agronomy Journal, v. 69, no. 5, p. 820-824. English.

Biodegradation/Biotransformation,Hydrolysis/Chemical Reactions.

CA88(1):1453d.

Agapov, V. I., and Tulupova, M. Y., 1980, Behavior of atrazine in the soil: Vestnik Moskovskogo Universiteta, Biologiya, Pochvovedenie, Series 17, v. 35, no. 4, p. 55-58.

Russian.

Leaching,Biodegradation/Biotransformation, Analytical Techniques/Quantification,Sorption to Soil. CA94(1):998x.

Agnihotri, N. P., Panday, S. Y., and Jain, H. K., 1976, Detoxification of atrazine by chemical treatments: Indian Journal of Agricultural Chemistry, v. 9, no. 1-2, p. 15-22. English.

Hydrolysis/Chemical Reactions,Biodegradation/

Biotransformation.

CA89(13):101299x.

Agnihotri, N. P., 1970, Relative biological and nonbiological inactivation of atrazine in soil, Dissertation submitted in partia! fulfillment of Ph.D. requirements, Auburn University, Aubum, Ala.

English.

Biodegradation/Biotransformation.

CA75(25):150611n.

Ali, A, and Souza Machado, V., 1984, A comparative analysis of leaf chlorophyll fluorescence, Hill reaction activity and 14C-atrazine tracer studies to explain differential atrazine susceptibility in wild turnif rape (Brassica campestris) biotypes: Canadian Journal of Plant Science, v. 64, no. 3, p. 707-713.

English.

Uptake by Biota,Biodegradation/Biotransformation,Degradation Products.

CA101(21):186049e.

Anderson, J. R., Stephenson, G. R, and Corke, C. T., 1980, Atrazine and cyanazine activity in Ontario and Manitoba soils: Canadian Journal of Soil Science, v. 60 , no. 4 , p. 773-781.

English.

Biodegradation/Biotransformation,Field Residuals. CA94(13):97922d.

Avidov, E., Aharonson, N., Katan, J., Rubin, B., and Yarden, O., 1985 , Persistence of terbutryn and atrazine in soil as affected by soil disinfestation and fungicides: Weed Science, v. 33 , no. 4 , p. $457-61$.

Enylish.

Biodegradation/Biotransformation.

CA103(11):83510k.

Baggi, G., 1981, Study of the biodegradibility of substituted triazine compounds: Annali di Microbiologia ed Enzimologia, v. 31, p. $13-17$.

Italian.

Biodegradation/Biotransformation.

CA99(9):65886g
Bakalivanov, D., 1984, Adaptation of soil microorganisms to decomposition of some herbicides: Tasiss for Vegetation Science, v. 13, no. Being Alive Land, p. 313-317.

English.

Toxicity,Biodegradation/Biotransformation.

CA101(23):205664v.

Bakalivanov, D., 1975, Distribution of microscopic fungi decomposing some herbicides in the soils of Bulgaria: Roceniki Gleboznaweze, v. 26, no. 2, p. 49-54.

English.

Biodegradation/Biotransformation.

CA84(11):70052b.

Bakalivanov, D., and Kostov, A., 1981, Detoxication of the herbicide atrazine, and microorganisms in water-logged soils: Pochvoznanie i Agrokhimiya, v. 16, no. 6, p. 102-106. Bulgarian.

Biodegradation/Biotransformation,Toxicity. CA97(5):34697a.

Bakke, J. E., Larson, J. D., and Price, C. E., 1972, Metabolism of atrazine and 2-hydroxyatrazine by the rat: Journal of Agriculture and Food Chemistry, v. 20, no. 3, p. 602-607. English.

Degradation Products,Biodegradation/Biotransformation. CA77(11):71068d.

Bakke, J. E., Robbins, J. D., and Feil, V. J., 1971, Metabolism of 2-methoxy-4-ethylamino-6-sec-butylamino-s-triazine by the dairy cow and the goat: Journal of Agriculture and Food Chemistry, v. 19 , no. 3 , p. $462-466$.

English.

Biodegradation/Biotransformation,Atmospheric Observations. CA75(7):47722a.

Bakke, J. E., Shimabukuro, R. H., Davison, K. L., and Lamoureux, G. L., 1972, Sheep and rat metabolism of the insoluble 14Cresidues present in 14C-atrazine-treated sorghum:

Chemosphere, v. 1, nu. 1, p. 21-24.

English.

Biodegradation/Biotransformation. CA77(5):299796.

Barrett, M. R. 1982, Effects of soil water content on the dissipation of pendimethalin, oxadiazon, and atrazine, Dissertation submitted in partial fulfillment of $\mathrm{Ph} . \mathrm{D}$. requirements, University of Arkansas, Fayetteville, AR English.

Biodegradation/Biotransformation. CA100(7):47054u.

Basile, B., and Scognamiglio, D., 1983, Mobility and degradation of atrazine residues in soil: Inquinamento, v. 25 , no. 7-8, p. 39-41.

Italian.

Leaching,Biodegradation/Biotransformation. CA100(17):134287r.

Bauman, T. T., Movement and persistence of atrazine in soil with three tillage systems, Dissertation submitted in partial fulfillment of Ph.D. requirements, Purdue University, West Lafayette, Indiana, USA. English. Leaching,Biodegradation/Biotransformation. CA87(3):17198q. 
Bauman, T. T., and Ross, M. A., 1983, Effect of three tillage systems on the persistance of atrazine: Weed Science, v. 31, no. 3, p. $423-426$.

English.

Biodegradation/Biotransformation.

CA99(3):17994u.

Behki, R. M., and Khan, S. U., July/Aug 1986, Degradation of atrazine by Pseudomonas: N-dealkylation and dehalogenation of atrazine and its metabolites: Journal of Agriculture and Food Chemistry, v. 34, no. 4, p. 746-749.

English.

Analytical Techniques/Quantification,Biodegradation/

Biotransformation,Degradation Products.

CA105(5):37405y.

Bellinck, C., 1983, Effect of a few amendments on the mineralization of atrazine-14C in a fresh meadow soil and the immobilization of carbon-14 residues: Revue d'Ecologie et de Biologie du Sol, v. 20 , no. 4, p. 435-444:

French.

Biodegradation/Biotransformation,Sorption to Soil.

CA100(25):204977s.

Bellinck, C., and Mayaudon, J., 1979, Degradation of (14C)phenmedipham and (14C)-atrazine in soil; immobilization in soil and absorption by plants of the carbon-14-labeled herbicides and their carbon-14-labeled residues: Revue d'Ecologie et de Biologie du Sol, v. 16, no. 4, p. 465-476. French.

Adjunct/Conjugate Formation,Biodegradation/Biotransformation. CA93(1):2229a.

Best, J. A., and Weber, J. B., 1974, Disappearance of s-triazines as affected by soil pH using a balance-sheet approach: Weed Science, v. 22, no. 4, p. 364-373.

English.

Biodegradation/Biotransformation.

CA81(19):115823k.

Beynon, K. I., Stoydin, G., and Wright, A. N., 1972, Comparison of the breakdown of the triazine herbicides cyanazine, atrazine, and simazine in soils and in maize: Pesticide Biochemistry and Physiology, v. 2, no. 2, p. 153-161. English.

Biodegradation/Biotransformation.

CA78(3):12626g.

Bezhanishvili, K. N., Durmishidze, S. V., Ugrekhelidze, D. S., Khubutiya, R. A., and Kakhniashvili, K, 1982, Conjugation of atrazine with peptides as the main course of its metabolism in plants: Doklady Akademi Nauk SSSR, v. 262, no. 2, p. 473-476. Russian.

Biodegradation/Biotransformation. CA97(7):51142h.

Boehme, C., and Baer, F., 1967, Transformation of triazine herbicides in the animal: Food and Cosmetics Toxicology, $v$. 5 , no. 1, p. 23-28.

German.

Biodegradation/Biotransformation.

CA66(21):94161r.
Boydston, R. A., and Slife, F. W., 1986, Alteration of atrazine uptake and metabolism by tridiphane in giant foxtail (Setaria faberi) and corn (Zea mays): Weed Science, v. 34, no. 6, p. 850-858.

English.

Uptake by Bioca,Biodegradation/Biotransformation. CA106(5):28780v.

Bradway, D. E., and Moseman, R. F., 1982, Determination of urinary residue levels of the $\mathrm{N}$-dealkyl metabolites of triazine herbicides: Joumal of Agriculture and Food Chemistry, v. 30, no. 2, p. 244-247.

English.

Degradation Products,Analytical Techniques/Quantification, Uptake by Biota,Biodegradation/Biotransformation. CA96(13):98864q.

Brockway, D. L., Smith, P. D., and Stancil, F. E., 1984, Fate and effects of atrazine in small aquatic microcosms: Bulletin of Environmental Contamination and Toxicology, v. 32, no. 3, p. 345-353.

English.

Toxicity,Biodegradation/Biotransformation,Miscellaneous Environmental. CA100(21):169612v.

Brown, C. B., and Rahman, S. F., Jan/Feb 1977, Chemical detoxication of atrazine by dexon: Joumal of the Soil Science Society of America, v. 41, no. 1, p. 141-142. English.

Biodegradation/Biotransformation. CAIN 779051397.

Buchanan, G. A., and Hiltbold, A. E., Sept 1973, Performance and persistence of atrazine.: Weed Science, v. 21, no. 5, p. 413416.

English.

Biodegradation/Biotransformation.

CAIN 739223983.

Burkhard, N., and Guth, J. A., 1981, Chemical hydrolysis of 2 chloro-4,6-bis(alkylamino)-1,3,5-triazine herbicides and their breakdown in soil under the influence of adsorption: Pesticide Science, v. 12, no. 1, p. 45-52.

English.

Hydrolysis/Chemical Reactions,Sorption to Soil, Biodegradation/Biotransformation. CA95(5):1778q.

Burnside, O. C., and Schultz, M. E., 1978, Soil persistence of herbicides for corn, sorghum, and soybeans during the year of application: Weed Science, v. 26, no. 2, p. 108-115. English.

Biodegradation/Biotransformation. CA90(13): $98462 \mathrm{~h}$.

Burnside, O. C., Fenster, C. R., Wicks, G. A., and Drew, J. V., 1969, Effect of soil and climate on herbicide dissipation: Weed Science, v. 17, no. 2, p. 241-245.

English. Biodegradation/Biotransformation,Sorption to Soil. CA71(1):2419h. 
ENVIRONMENTAL PROCESSES

TRANSFORMATION PROCESSES

Biodegradation/Biotransformation

Burt, G. W., 1974, Translocation and metabolism of atrazine in Canada thistle: Weed Science, v. 22, no. 2, p. 116-119. English.

Uptake by Biota,Biodegradation/Biotransformation. CAIN 749021344.

Butler, G. L., Deason, T. R, and O'Kelley, J. C., 1975, Loss of five pesticides from cultures of twenty-one planktonic algae: Bulletin of Environmental Contamination and Toxicology, v. 13 , no. 2, p. 149-152.

English.

Toxicity,Biodegradation/Biotransformation. CA82(23):150200x.

Capriel, P., and Haisch, A., 1983, Persistence of atrazine and its metabolites in soils after a single herbicide application: Zeitschrift fuer Pflanzenemaehrung und Bodenkunde, v. 146, no. 4, p. 474-480.

German.

Biodegradation/Biotransformation. CA99(23):189674f.

Catizone, P., Fusi, P., and Franci, M., 1983, Persistence of atrazine in soil: results of cleven years of experiments: Rivista di Agronomia, v. 17, no. 4, p. 449-457.

Italian.

Field Residuals,Biodegradation/Biotransformation. CA101(11):86660s.

Cervelli, S., Ciardi, C., and Perna, A., Jan/Mar 1982, Effect of atrazine on soil transformation of nitrogen and uptake by corn: Journal of Environmentai Quality, v. 11, no. 1, p. 82 86.

English.

Biodegradation/Biotransformation, Uptake by Biota. IND 82011979.

Cesari, A., Bentivogii, P. G., and Flori, P., 1974, Degradation of herbicides in soil and their effects on crops: Notiziario Sulle Malattie delle Piante, v. 90-91, p. 265-282.

Italian.

Biodegradation/Biotransfonnation.

CA85(11):73363k.

Chio, H., and Sanborn, J. R., 1977, Atrazine inhibition of carbofuran metabolism in the house cricket: Journal of Economic Entomology, v. 70, no. 5, p. 544-546. English.

Biodegradation/Biotransformation,Toxicity. CA87(25):195491n.

Chio, H., and Sanborn, J. R., 1978, The metabolism of atrazine, chloramben, dicamba in earthworms (Lumbricus terrestris) from treated and untreated plots: Weed Science, v. 26, no. 4, p. 331-335.

English.

Biodegradation/Biotransformation. CA90(13):98457k.
Conti, G. G., Quintodei, V., Aquilanti, A., and Sprocati, M. T., 1983, Evaluation of the behavior of residues of atrazine and its dealkylated metabolites. I. Determination of residues in the soil: Notizario Sulle Malattie delle Piante, v. 104 p. 147-168.

Italian.

Degradation Products,Biodegradation/Biotransformation,Field Residuals,Analytical Techniques/Quantification.

CA100(25):204976r.

Cook, A. M., and Huetter, R, 1982, Ametryne and prometryne as sulfur sources for bacteria: Applied Environmental Microbiology, v. 43, no. 4, p. 781-786.

English.

Degradation Products,Biodegradation/Biotransformation. CA97(3):20413t.

Cook, A. M., and Huetter, R., 1982, Decomposition of 2,4 dihydroxy-6-amino-s-triazine derivatives in wastewater. Appl. 81/810365, 4 Sep 1981; CH Appl. 80/6796, 10 Sep 1980. German.

Biodegradation/Biotransformation. CA96(24):204905r.

Cook, A. M., and Huetter, R., 1985, Decomposition of s-triazine derivatives in aqueous solutions: Appl. 84/810524, 29 Oct 1984; CH Appl. 83/5968, 4 Nov 1983.

German.

Biodegradation/Biotransformation. CA103(16):128552u.

Cook, A. M., and Huetter, R, 1984, Deethylsimazine: bacterial dechlorination, deamination, and complete degradation: Joumal of Agriculture and Food Chemistry, v. 32, no. 3, p. 581-585.

English.

Degradation Products,Biodegradation/Biotransformation. CA100(25):204726j.

Cook, A. M., and Huetter, R, 1986, Ring dechlorination of deethylsimazine by hydrolases from Rhodococcus corallinus: FEMS Microbiology, v. 34, no. 3, p. 335-338.

English.

Degradation Products,Biodegradation/Biotransformation. CA105(7):56842e.

Cook, A. M., and Huetter, R., 1981, s-Triazines as nitrogen sources for bacteria: Joumal of Agriculture and Food Chemistry, v. 29, no. 6, p. 1135-1143.

English.

Biodegradation/Biotransformation. CA95(19):165301y.

Cook, A. M., and Hutter, R., 1985, Purification of effluents containing 2,4-dihydro-6-amino-triazine derivatives: Appl. 81/DE565.

English.

Biodegradation/Biotransformation. CA105(22):196684e.

Cudney, D. W., 1982, Effect of the environment on herbicides in the soil: Proceedings, Annual California Weed Conference, v. 34, p. 69-73.

English. Biodegradation/Biotransformation. CA99(11):83583k 
Dao, Thanh Hung, May, 1977, Factors affecting atrazine adsorption, degradation and mobility in soil, Dissertation submitted in partial fulfillment of $\mathrm{Ph} . \mathrm{D}$. requirements, Nebraska.

English.

Biodegradation/Biotransformation,Leaching,Sorption to Soil. CA88(7):46255g.

Dao, T. H., Lavy, T. L., and Sorensen, R. C., 1979, Atrazine degradation and residue distribution in soil: Joumal of the Soil Science Society of America, v. 43, no. 6, p. 1129-1134. English.

Biodegradation/Biotransformation,Field Residuals. CA92(15):123418z.

Darwent, A. L., and Behrens, R, 1968, Dissipation and leaching of atrazine in a Minnesota soil after repeated applications: Proceedings of the North Central Weed Control Conference, v. 23, p. 66-69.

English.

Leaching,Biodegradation/Biotransformation.

CA71(13):599346.

Davidson, J. M., Ou Li-Tse, and Rao, P. S. C., 1978, Adsorption, movement, and biological degradation of high concentrations of selected pesticides in soils: EPA-600/9-78-016, Environmental Protection Agency.

English.

Sorption to Soil,Leaching,Biodegradation/Biotransformation. CA89(23):192489y.

Davidson, J. M., Rao, P. S. C., Ou, L. T., Wheeler, W. B., and Rothwell, D. F., 1980, Adsorption, movement, and biological degradation of large concentrations of selected pesticides: EPA-600/2-80-124, Environmental Protection Agency. English.

Biodegradation/Biotransformation.

CA94(11):78414y.

Davidson, J. M., Rao, P. S., Ou, L. T., Wheeler, W. B., and Rothwell, D. F., August, 1980, Adsorption, movement, and biological degradation of large concentrations of selected pesticides in soils: EPA-600/2-80-124, Environmental Protection Agency.

English.

Biodegradation/Biotransformation,Sorption to Soil. CA94(11):78414y.

Davidson, J. M., Rao, P. S., and Ou., L. T., March, 1980, Disposal of Hazardous Wastes; Proceedings of the Sixth Annual Research Symposium, March 17-20, p. 93-107.

English.

Biodegradation/Biotransformation,Sorption to Soil,Leaching. CA94(1):1054y.

Davis, D. E., Weete, J. D., Pillai, C. G. P., Plumley, F. G., and McEnerney, J. T., 1979, Atrazine fate and effects in a salt marsh: EPA-600/3-79-111; Order No. PB80-150634, Auburn, AL, Environmental Protection Agency.

English.

Surfacewater Observations,Biodegradation/Biotransformation. CA94(2):7403h.
Doyle, R. C., Kaufman, D. D., and Burt, G. W.. 1978, Effect of dairy manure and sewage sludge on $14 \mathrm{C}$-pesticide degradation in soil: Journal of Agriculture and Food Chemistry, v. 26, no. 4, p. 987-989.

English.

Biodegradation/Biotransformation. CA89(7):54340s.

Dries, D., De Corte, B., Liessens, J., Steurbaut, W., Dejonckheere, W., and Verstraete, W., 1987, Recalcitrance of atrazine at low levels to aerobic and hydrogenotrophic microorganisms: Biotechnology Letters, v. 9, no. 11, p. 811816.

English.

Biodegradation/Biotransformation.

CA108(6):43614u.

Drimalovskii, A. M., Lisnichenko, V. M., and Glovatskaya, M. P., 1983, Degradation dynamics of atrazine and prometrin in soil under com monoculture: Khimiya-v Sel'skom. Khozyaistve, no. 9, p. 57-59.

Russian.

Biodegradation/Biotransformation.

CA100(1):2067j.

Duaterman, W. C., and Muecke, W., June 1974, In vitro metabolism of atrazine by rat liver. Pesticide Biochemistry and Physiology, v. 4, no. 2, p. 212-219.

English.

Biodegradation/Biotransformation.

CAIN 749062158.

Dvornikova, T. P., Boiko, I. I., Granatskaya, T. A., and Platsynda, V. A., 1983, Degradation of triazine herbicides by microorganisms: Trudy - Vsesoyuznyi Nauchno-Issledovatel'skii Institut Sel'skokhozyaistuennoi Mikrobiologii, v. 52, p. 70-74. Russian.

Biodegradation/Biotransformation.

CA101(1):3719f.

Edwards, R, and Owen, W. J., 1986, Comparison of glutathione Stransferases of Zea mays responsible for herbicide detoxification in plants and suspension-cultured cells: Planta, v. 169, no. 2, p. 208-215.

English.

Biodegradation/Biotransformation.

CA106(3):14997z.

Emtsev, V. T., Tepper, E. Z., Tlas Farzat, K. S., and Maksimova, E. N., 1982, Microorganisms participating in the degradation of herbicide derivatives of symmetric triazines in sodpodzolic soil: Izvestiya Timiryazevskoi

Sel'skokhozyaistvennoi Akademii, no. 5, p. 102-109.

Russian.

Biodegradation/Biotransformation.

CA97(21):176902n.

Epishina, L. V., Kurbatskii, N. Y., Lebedeva, G. F., and Tsikin, Y. E., 1981, Behavior of triazine-like compounds in sodpodzolic soils: Biologicheskie Nauki (Moscow), no. 10, p. 9598.

Russian.

Biodegradation/Biotransformation.

CA96(5):29844w. 
ENVIRONMENTAL PROCESSES

TRANSFORMATION PROCESSES

Biodegradation/Biotransformation

Erb, F., Dequidt, J., Pommery, J., Colein, P., and Gontier, C., 1980 , Migration of some chlorine- or nitrogen-containing herbicides in a trophodynamic chain in fresh water.

Environmental Technology Letters, v. 1, no. 1, p. 58-63.

French.

Volatilization,Biodegradation/Biotransformation. CA93(3):20384b.

Erickson, M. D., Frank, C. W., and Morgan, D. P., 1979, Determination of s-triazine herbicide residues in urine: studies of excretion and metabolism in swine as a model to human metabolism: Journal of Agriculture and Food Chemistry, v. 27 , no. 4 , p. 743-746.

English.

Degradation Products,Analytical Techniques/Quantification,

Biodegradation/Biotransformation.

CA91(7):50677a.

Ezra, G, and Stephenson, G. R, 1985, Comparative metabolism of atrazine and EPTC in proso millet (Panicum miliaceum L.) and corn: Pesticide Biochemistry and Physiology, v. 24, no. 2, p. 207-212.

English.

Biodegradation/Biotransformation.

CA103(23):191374c.

Fernandez-Quintanilla, C., Cole, M. A., and Slife, F. W., 1981, Symposium on the Theory and Practice of the Use of Soil Applied Herbicides: Proceedings, p. 301-308.

English.

Biodegradation/Biotransformation.

CA97(23):194580k.

Fernandez-Quintanilla, C. 1979, Microbial and chemical degradation of atrazine: two possible herbicide disposal methods, Dissertation submitted in partial fulfillment of Ph.D. requirements, University of Illinois, Urbana, Illinois. English.

Biodegradation/Biotransformation.

CA93(1):2242z.

Fhaolain, I. N., and Coughlan, M. P., 1978, Further observations on the effects of s-triazine derivatives on purine metabolizing enzymes: Intemational Journal of Biochemistry, v. 9 , no. 9, p. 659-662.

English.

Degradation Products,Biodegradation/Biotransformation. CA90(5):35516h.

Foster, T. S., Khan, S. U., and Akhtar, M. H., 1979, Metabolism of atrazine by the soluble fraction $(105000 \mathrm{~g})$ from chicken liver homogenates: Journal of Agriculture and Food Chemistry, v. 27 , no. 2, p. $300-303$.

English.

Biodegradation/Biotransformation. CA90(17):133670y.

Fournier, J. C., and Catroux, G., 1980, Use of microbial strains from a collection in the study of pesticide biodegradability: Chemosphere, v. 9, no. 1, p. 33-38.

French.

Biodegradation/Biotransformation. CA92(21):175754a.
Fournier, J. C., Massenot, D., and Drogoul, C., 1981, Theory and Practice in the Use of Soil Applied Herbicides, Symposium, p. 103-110.

English.

Biodegradation/Biotransformation.

CAY7(25):210420r.

Francis, B. M., Lampman, R. L., and Metcalf, R. L., 1985, Model ecosystem studies of the environmental fate of five herbicides used in conservation tillage: Archives of Environmental Contamination and Toxicology, v. 14, no. 6, p. 693-704.

English.

Biodegradation/Biotransformation.

CA104(1):1924g.

Frank, R, and Sirons, G. J., Apr 1985, Dissipation of atrazine residues from soils: Bulletin of Environmental Contamination and Toxicology, v. 34, no. 4, p. 541-548.

English.

Sorption to Soil,Leaching,Field Residuals,Biodegradation/

Biotransformation.

CA102(23):199566s.

Freitag, D., Ballhorn, L., Geyer, H., and Korte, F., 1985, Environmental hazard profile of organic chemicals. An experimental method for the assessment of the behavior of organic chemicals in the ecosphere by means of simple laboratory tests with carbon-14-labeled chemicals:

Chemosphere, v. 14, no. 10, p. 1589-1616.

English.

Chemical/Physical Properties,Biodegradation/

Biotransformation,Associations with Plants.

CA103(25):208313g.

Fuka, T., and Pitter, P., 1984, Biodegradability of selected pesticide types: Vodni Hospodarstvi B, Priloha, v. 34, no. 8, p. 205-209.

Czechoslovakian.

Biodegradation/Biotransformation. CA102(3):19605x.

Fusi, P., and Franci, M., 1972, Chemical and biological study of atrazine residues in soil: Agrochimica, v. 16, no. 4-5, p. $377-386$. Italian.

Biodegradation/Biotransformation,Field Residuals. CA77(19):125309d.

Fusi, P., and Franci, M., 1971, Persistence of atrazine in sterile and nonsterile soils with various moisture contents: Agrocnimica, v. 15, no. 6, p. 557-563. Italian.

Biodegradation/Biotransformation. CA77(3):15439p.

Gardner, G., Sanbom, J. R, and Goss, J. R., Nov 1987, Nalkylaryltriazine herbicides: a possible link between triazines and phenylureas: Weed Science, v. 35, no. 6, p. 763-769.

English.

Biodegradation/Biotransformation. IND 87090436 . 
Geller, A, 1980, Studies on the Degradation of Atrazine by Bacterial Communities Enriched from Various Biotopes: Archives of Environmental Contamination and Toxicology, v. 9, no. 3, p. 289-305.

English.

Biodegradation/Biotransformation.

Geller, A., 1980, Studies on the degradation of atrazine by bacterial communities enriched from various biotopes: Archives of Environmental Contamination and Toxicology, v. 9, no. 3, p. 289-305.

English.

Biodegradation/Biotransformation.

CA93(5):39004z.

Gergaya, M. S., and Burchuladze, I. T., 1986, Detoxication of triazine herbicides in vineyards and apple orchards:

Soobshcheniya Akademii Nauk Gruzinskoi SSR, v. 124, no. 2, p. 385-388.

Russian.

Biodegradation/Biotransformation.

CA106(11):80286t.

Ghadiri, H., Shea, P. J., Wicks, G. A., and Haderiie, L. C., Oct/ Dec 1984, Atrazine dissipation in conventional-till and notill sorghum: Journal of Environmental Quality, v. 13, no. 4, p. 549-552.

English.

Biodegradation/Biotransformation.

GUA 84132889.

Giardi, M. T., Giardina, M. C., and Filacchioni, G., June 1985, Chemical and biological degradation of primary metabolites of atrazine by a Nocardia strain: Agricultural and Biological Chemistry, v. 49, no. 6, p. 1551-1558.

English.

Degradation Products,Analytical Techniques/Quantification, Biodegradation/Biotransformation.

CA103(13):100291j.

Giardini, L., and Giovanardi, R, 1974, Persistence of several herbicides in the soil in field and glasshouse trials:

Rivista di Agronomia, v. 8, no. 2-3, p. 180-194.

Italian.

Biodegradation/Biotransformation.

CA82(5):27071d.

Giardina, M. C., Giardi, M. T., and Filacchioni, G., 1980, 4 amino-2-chloro-1,3,5-triazine: a new metabolite of herbicide atrazine by a soil bacterium Nocardia, phytotoxic activity: Agricultural and Biological Chemistry, v. 44, no. 9, p. 20612066.

English.

Degradation Products,Biodegradation/Biotransformation. IND 81000006 .

Giardina, M. C., Giardi, M. T., and Filacchioni, G., 1980, 4 Amino-2-chloro-1,3,5-triazine: a new metabolite of atrazine by a soil bacterium: Agricultural and Biological Chemistry, v. 44 , no. 9, p. $2067-2072$.

English.

Degradation Products,Biodegradation/Biotransformation. CA93(21):199220v.
Giardina, M. C., Giardi, M. T., and Filacchioni, G., 1982, Atrazine metabolism by Nocardia: elucidation of initial pathway and synthesis of potential metabolites: Agricultural and Biological Chemistry, v. 46, no. 6, p. 1439-45.

English.

Biodegradation/Biotransformation.

CA97(9):67718m.

Giardina, M. C., Giardi, M. T., and Buffone, R, 1979, Soil enrichment studies with atrazine. Long-term atrazine effects on degradation and microbiological composition: Chemosphere, v. 8 , no. $11-12$, p. $831-834$.

English.

Degradation Products,Biodegradation/Biotransformation. CA92(15):123353z.

Gigineishvili, A. A., and Dzhugeli, M. G., 1973, Factors of the detoxification of soil herbicides: Trudy Nauchno-

Issledovatel'skogo Instituta Zashchity Rastenii (Tblisi), v. 25, p. 24-26.

Russian.

Biodegradation/Biotransformation.

CA83(1):2098a.

Gill, H. S., Randhawa, S. K, and Brar, L. S., 1982, Bioassay studies on the persistence of s-triazines in soil: Joumal of Research (Punjab Agricultural University), v. 19, no. 3, p. 203-206.

English.

Biodegradation/Biotransformation.

CA98(15):121275a.

Goswami, K. P., and Green Richard Ervin, 1971, Microbial degradation of the herbicide atrazine and its 2-hydroxy analog in submerged soils: Environmental Science and Technology, v. 5, no. 5, p. 426-429.

English.

Degradation Products,Biodegradation/Biotransformation. CA74(25):139847c.

Goswami, K. P., and Green, R. E., 1971, Microbial degradation of the herbicide atrazine and its 2-hydroxy analog in submerged soils: Environmental Science and Technology, v. 5, no. 5, p. 426-429.

English.

Degradation Products,Biodegradation/Biotransformation, Sorption to Soil,Surfacewater Observations,Hydrolysis/ Chemical Reactions. CA74(25):139847c.

Grant, M. A., and Williams, F. D., 1982, Bacterial metabolism under conditions representing disposal pits: Journal of Environmental Science and Health, Part B, v. B17, no. 4, p. 393-407.

English.

Biodegradation/Biotransformation. CA97(10):78170c.

Green, R E, Yamare, V. K, and Obien, S. R, 1968, Transport of atrazine in a latosolic soil in relation to adsorption, degradation, and soil water variables: International Society of Soil Science, Transactions, 9th, v. 1, p. 195-204. English.

Sorption to Soil, Biodegradation/Biotransformation,Leaching. CA72(1):2409a. 
ENVIRONMENTAL PROCESSES

TRANSFORMATION PROCESSES

Biodegradation/Biotransformation

Gressel, J., Shimabukuro, R. J., and Duysen, M. E., 1983, NDealkylation of atrazine and simazine in Senecio vulgaris biotypes: a major degradation: Pesticide Biochemistry and Physiology, v. 19, no. 3, p. 361-370.

English.

Biodegradation/Biotransformation,Degradation Products,

Toxicity.

CA99(1):1752c.

Grimalouskii, A. M., Lisnichenko, V. M., and Glovatskaya, M. P., 1983, Dymanics of atrazine and prometryne decomposition in the soil at continuous cultivation of maize: Khimiya $v$

Sel'skom Khozyaistve (Moskva), no. 9, p. 57-59.

Russian.

Biodegradation/Biotransformation.

IND 85065366.

Grossenbacher, H., Horn, C., Cook, A. M., and Huetter, R, 1984, 2-Chloro-4-amino-1,3,5-triazine-6(5H)-one: a new intermediate in the biodegradation of chlorinated striazines: Applied Environmental Microbiology, v. 48, no. 2, p. $451-453$.

English.

Degradation Products,Biodegradation/Biotransformation. CA101(13):107137f.

Hammons, R.H., May 1977, Atrazine persistence in a valentine loamy fine sand profile, Dissertation submitted in partial fulfillment of $\mathrm{Ph} . \mathrm{D}$. requirements.

English.

Degradation Products,Biodegradation/Biotransformation.

OWRT B-030-NEB(4).

Hance, R. J., 1973, Effect of nutrients on the decomposition of the herbicides atrazine and linuron incubated with soil:

Pesticide Science, v. 4, no. 6, p. 817-822.

English.

Biodegradation/Biotransformation.

CA80(21):116863q.

Hance, R. J., 1974, Soil organic matter and the adsorption and decomposition of the herbicides atrazine and linuron: Soil Biology and Biochemistry, v. 6, no. 1, p. 38-42.

English.

Biodegradation/Biotransformation,Associations with Humic Material.

CA81(7):34430c.

Hance, R. J., and Segal, G. M., 1980, A comparison of the decomposition of atrazine and diuron in soils of different fertilizer content and pH: Agrochimica, v. 24, no. 4, p. 265 273.

English.

Biodegradation/Biotransformation.

CA94(17):134135x.

Hance, R. J., Smith, P. D., Byast, T. H., and Cotterill, E. G., 1978, Effects of cultivations on the persistence and phytotoxicity of atrazine and propyzamide: Proceedings, British Crof Protection Conference on Weeds, v. 14, no. 2, p. 541-547.

English.

Biodegradation/Biotransformation.

CA9(1):1288r.
Hance, R. J., Smith, P. D., Cotterill, E. G., and Reid, D. C., 1978, Herbicide persistence: effects of plant cover previous history of the soil and cultivation: Mededingen van de Faculteit Landbouwwetenschappen, Rijksuniversiteit Gent, v. 43, no. 2 Pt. 2, p. 1127-1134.

English.

Biodegradation/Biotransformation. CA90(19):146883v.

Hance, R. J., 1969, Decomposition of herbicides in soil: Journal of the Science of Food Agriculture, v. 20, no. 3, p. 144-145. English.

Biodegradation/Biotransformation. CA70(21):95668f.

Hance, R. J., 1979, Effect of $\mathrm{pH}$ on the degradation of atrazine, dichlorprop, linuron and propyzamide in soil: Pesticide Science, v. 10, no. 1, p. 83-86.

English.

Biodegradation/Biotransformation.

CA92(3):17014e.

Hance, R. J., and Chesters, G., 1969, Fate of hydroxyatrazine in a soil and a lake sediment: Soil Biology and Biochemistry, $v$. 1, no. 4, p. 309-315.

English.

Degradation Products,Biodegradation/Biotransformation, Sorption to Sediments.

CA72(21):110138v.

Hance, R. J., and McKone, C. E., 1971, Effect of concentration of the decomposition rates in soil of atrazine, linuron, and picloram: Pesticide Science, v. 2, no. 1, p. 31-34.

English.

Biodegradation/Biotransformation.

CA74(23):123922n.

Harris, C. I., 1967, Fate of 2-chloro-s-triazine herbicides in soil: Journal of Agriculture and Food Chemistry, v. 15, no. 1, p. $157-162$

English.

Biodegradation/Biotransformation. CA66(15):64589u.

Harvey, R. G., 1987, Herbicide dissipation from soils with different herbicide use histories: Weed Science, v. 35, no. 4 , p. $583-589$.

English.

Biodegradation/Biotransformation,Field Residuals. CA107(11):91811g.

Harvey, R G., 1973, Influence of cropping and activated carbon on persistance of atrazine in sand: Weed Science, v. 21, no. 3, p. 204-206.

English.

Biodegradation/Biotransformation,Sorption to Resins. CA79(3):14357q

Hiltbold, A. E., and Buchanan, G. A., 1977, Influence of soil pH on persistence of atrazine in the field: Weed Science, v. 25, no. 6 , p. 515-520.

English.

Biodegradation/Biotransformation,Hydrolysis/Chemical Reactions.

CA88(11):70384u 
Hiltbold, A. E., and Buchanan, G. A., 1977, Soil acidity reduces effectiveness of atrazine: Highlights - Agricultural Research, Summer 1977, v. 24, no. 2, p. 5.

English.

Biodegradation/Biotransformation.

CAIN 779104787.

Hiltbold, A. E., and Buchanan, G. A., Fall 1972, What happens to atrazine in the soil?: Highlights - Agricultural Research, Alabama Station, v. 19, no. 3, p. 8. English.

Biodegradation/Biotransformation. CAIN 729102250.

Hogrefe, W., Grossenbacher, H., Cook, A. M., and Hutter, R, September 1985, Biological treatment specific for an industrial wastewater containing s-triazines: Biotechnology and Bioengineering, v. 27, no. 9, p. 1291-1296.

English.

Biodegradation/Biotransformation.

Hogrefe, W., Grossenbacher, II., Cook, A. M., and Huetter, R, 1986, Biotreatment of s-triazine-containing wastewater in a fluidized bed reactor. Biotechnology and Bioengineering, v. 28 , no. 10 , p. $1577-1581$.

English.

Biodegradation/Biotransformation.

CA105(26):231805u.

Horowitz, M., 1969, Evaluation of herbicide persistence in soil: Weed Research, v. 9, no. 4, p. 314-321.

English.

Biodegradation/Biotransformation,Field Residuals.

CA72(15):77812k.

Hunter, R., Wallace, A., and Romney, E. M., 1978, Persistent atrazine toxicity in Mohave Desert shrub communities: Journal of Range Management, v. 31, no. 3, p. 199-203.

English.

Biodegradation/Biotransformation.

CA89(15):124432z.

Hurle, K, 1978, Effects of straw burning on the activity, absorption, and degradation of herbicides in soils: Mededingen van de Faculteit Landbouwwetenschappen, Rijksuniversiteit Gent, v. 43, no. 2 Pt. 2, p. 1097-1107. German.

Sorption to Soil,Biodegradation/Biotransformation. CA90(17): $133890 v$.

Hurle, K, and Kibler, E., 1976, The effect of changing moisture conditions on the degradation of atrazine in soil: Proceedings of the British Weed Control Conference, v. 13, no. 2, p. 627-633.

English.

Biodegradation/Biotransformation.

CA87(11):79658y.

Hurter, J., 1966, Degradation products of simazin in gramineal: Experientia, v. 22 , no. 11, p. 741-742.

German.

Biodegradation/Biotransformation.

CA66(1):1786k.
Huss, M., and Adamovic, V. M., May 30, 1973, Determination of Ametrine and Atrazine Residues in Soil by Thin-Layer Chromatography: Journal of Chromatography, v. 80 , no. 1 , p. 137-139.

English.

Analytical Techniques/Quantification,Biodegradation/

Biotransformation.

CA79(21):122488s.

Ikonen, R., Kangas, J., and Savolainen, H., 1988, Urinary atrazine metabolites as indicators for rat and human exposure to atrazine: Toxicology Letters, v. 44, no. 1-2, p. 109-112. English.

Degradation Products,Biodegradation/Biotransformation. CA110(3):19608r.

liescu, E., 1986, Oxido-reductive metabolism in maize plant cultivated in soil treated with herbicides: Analele Institutului de Cercetari Prot Plante, Academia de Stiinte Agricole si Silvice, v. 19, p. 251-258.

Romanian.

Biodegradation/Biotransformation. CA107(21):192943g.

Isensee, A. R, 1976, Variability of aquatic model ecosystemderived data: International Journal of Environmental Studies, v. 10 , no. 1 , p. $35-41$.

English.

Biodegradation/Biotransformation.

CA86(21):151104p.

Jachetta, J. J., and Radosevich, S. R, 1980, Enhanced metabolism of atrazine by corn (Zea mays): Proceedings, Annual California Weed Conference, 32nd, v. 34.

English.

Biodegradation/Biotransformation.

CA96(5):29653h.

Jachetta, J. J., and Radosevich, S. R, 1981, Enhanced degradation of atrazine by corn (Zea mays): Weed Science, $v$. 29 , no. 1 , p. $37-44$.

English.

Biodegradation/Biotransformation. CA94(15):115897f.

Jessee, J. A., Benoit, R. E., Hendriciss, A. C., Alien, G. C., and Neal, J. L., 1983, Anaerobic degradation of cyanuric acid, cysteine, and atrazine by a facultative anaerobic bacterium: Applied Environmental Microbiology, v. 45, no. 1, p. 97-102. English.

Degradation Products,Biodegradation/Biotransformation. CA98(10):77581w.

Johnson, L. M., and Hartman, P. A., September 1980, Microbiology of a pesticide disposal pit: Bulletin of Environmental Contamination and Toxicology, v. 25, no. 3, p. 448-455. English. Biodegradation/Biotransformation. 
Jones, T. W., Kemp, W. M., Stevenson, J. C., and Means, J. C., October-December, 1982, Degradation of atrazine in estuarine water/sediment systems and soils: Journal of Environmental Quality, v. 11, no. 4, p. 632-638.

English.

Biodegradation/Biotransformation,Associations with

Surfactants,Field Residuals,Sorption to Sediments,Sorption to Soil,Degradation Products.

CA97(25):210373c.

Junk, G. A., Richard, J. J., and Dahm, P. A., 1984, Degradation of pesticides in controlled water-soil systems: American Chemical Society, Symposium Series, v. 259, no. Treatment and Disposal of Pesticide Wastes, p. 37-67.

English.

Biodegradation/Biotransformation. CA101(25):224614v.

Junk, G. A., and Richard, J. J., 1984, Pesticide disposal sites: sampling and analyses: American Chemical Society, Symposium Series, v. 259, no. Treatment and Disposal of Pesticide Wastes, p. 69-95.

English.

Analytical Techniques/Quantification,Volatilization, Biodegradation/Biotransformation.

CA101(25):224803f.

Jury, W. A., Focht, D. D., and Farmer, W. J., 1987, Evaluation of pesticide groundwater pollution potential from standard indexes of soil-chemical adsorption and biodegradation: Journal of Environmental Quality, v. 16, no. 4, p. 422-428. English.

Groundwater Observations,Biodegradation/Biotransformation, Sorption to Soil.

CA108(3):17760u.

Jutzi, K., Cookk, A. M., and Huetter, R, 1982, The degradative pathway of the s-triazine melamine. The steps to ring cleavage: Biochemistry Joumal, v. 208, no. 3; p. 679-684.

English.

Biodegradation/Biotransformation.

CA99(3):19391u.

Kakhniashvili, K. A., Durmishidze, S. V., Ugrekhelidze, D. S., and Bezhanishvili, K. N., 1985, Formation of common conjugates with peptides and monosaccharides in the metabolism of phenoxyacetic and 2,4-dichlorophenoxyacetic acids and atrazine in crops: Doklady Akademii Nauk SSSR, v. 282, no. 2, p. 441-445.

Russian.

Biodegradation/Biotransformation.

CA103(15):118098m.

Kakhniashvili, K. A., Durmishidze, S. V., and Gigauri, M. S., 1987, Pathway of $14 \mathrm{C}$-atrazine metabolism in tea plants: Agrokhimiya, no. 1, p. 89-93.

Russian.

Biodegradation/Biotransformation.

CA106(21):170986a.

Kaufman, D. D., and Blake, J., 1970, Degradation of atrazine by soil fungi: Soil Biology and Biochemistry, v. 2, no. 2, p.

73-80.

English.

Biodegradation/Biotransformation,Degradation Products. CA73(9):425\%6m.
Kaushik, S. H., and Moolani, M. K., June 1974, Persistence of atrazine in soil cropped with corn (Zea mays L.): Indian Journal of Weed Science, v. 6, no. 1, p. 53-60.

English.

Biodegradation/Biotransformation.

Kearney, P. C., Muldoon, M. T., Somich, C. J., Ruth, J. M., and Voaden, D. J., 1988, Biodegradation of ozonated atrazine as a wastewater disposal system: Journal of Agriculture and Food Chemistry, v. 36, no. 6, p. 1301-1306.

English.

Biodegradation/Biotransformation, Wastewater Observations, Hydrolysis/Chemical Reactions.

CA109(22):196446m.

Keller, A. E., and Guth, J. A., 1981, Theory and Practice in the Use of Soil Applied Herbicides, Symposium, p. 80-88. English.

Degradation Products,Biodegradation/Biotransformation. CA97(25):2103286.

Kells, J. J., Rieck, C. E., Blevins, R. L., and Muir, W. M., 1980, Atrazine dissipation as affected by surface $\mathrm{pH}$ and tillage: Weed Science, v. 28, no. 1, p. 101-104.

English.

Biodegradation/Biotransformation. CA92(17):141675k.

Khan, S. U., and Saiclak, W. J., 1981, Residues of atrazine herbicide applied to maize and its metabolites after prolonged usage: Weed Research, v. 21, no. 1, p. 9-12. English.

Biodegradation/Biotransformation,Degradation Products,Field Residuals.

CA95(11):92225q.

Khan, S. U., Warwick, S. I., and Marriage, P. B., 1985, Atrazine metabolism in resistant and susceptible biotypes of Chenopodium album L., Chenopodium strictum Roth., and Amaranthus powellii S. Wats: Weed Research, v. 25, no. 1, p. 33-37.

English.

Biodegradation/Biotransformation.

CA102(13):108142m.

Khan, S. U., Marriage, P. B., and Hamill, A. S., 1981, Effects of atrazine treatment of a corn field using different application methods, times, and additives on the persistence of residues in soil and their uptake by oat plants.: Journal of Agriculture and Food Chemistry, v. 29, no. 2, p. 216-219. English.

Associations with Plants, Biodegradation/Biotransformation. CA94(17):133965f.

Khan, S. U., and Marriage, P. B., 1977, Residues of atrazine and its metabolites in an orchard soil and their uptake by oat plants: Journal of Agriculture and Food Chemistry, v. 25, no. 6, p. 1408-1413.

English.

Field Residuals, Uptake by Biota,Biodegradation/ Biotransformation,Degradation Products. CA87(23):178954y. 
Koch, W., Baumeister, P., and Hurle, K., 1979, Herbizide, p. 7277 .

German.

Volatilization,Biodegradation/Biotransformation. CA93(3):20724n.

Kozina, L. S., Berezouskii, M. Y., and Tepper, E. S., 1970, Primenenie Pestitsidov v Sel'skom Khozyaistve, Materialy Nauchnoi, 1969, p. 105-106.

Russian.

Biodegradation/Biotransformation. CA74(25):139845a.

Kretova, L. G., Khegai, T. A., Rachinskii, V. V., and Fokin, A. D., 1986, Degradation of 14C-atrazine sorbed by different soil components: Pochvovedenie, no. 10, p. 21-27. Russian.

Sorption to Soil,Biodegradation/Biotransformation. CA106(3):14619c.

Kruglov, Y. V., and Moneim, A., 1983, Decomposition of the herbicide atrazine by soil bacteria: Pochvovedenie, no. 7, p. 112-114.

Russian.

Biodegradation/Biotransformation.

CA99(21):171260h.

Kulshrestha, G., Dewan, R. S., and Mani, V. S., Oct 1976, Dissipation of simazine and atrazine in soil and their uptake by corn plants: Pesticides, v. 10, no. 10, p. 21-24.

English.

Biodegradation/Biotransformation, Uptake by Biota.

Kuzyakina, T. I., Rachinskii, V. V., and Nepomiluev, V. F., 1970 , Microbiological decomposition of atrazine in various types of soils (carbon-14 tests): Izvestiya Timiryazevkoi

Sel'skokhozaistvennoi Akademii, no. 6, p. 119-124.

Russian.

Biodegradation/Biotransformation.

CA74(13):63504r.

Ladlie, J. S., Meggitt, W. F., and Penner, D., 1976, Effect of soil pH on microbial degradation, adsorption, and mobility of metribuzin: Weed Science, v. 24, no. 5, p. 477-481.

English.

Degradation Products,Biodegradation/Biotransformation, Sorption to Soil.

CA85(23):172771y.

Lamoureux, G. L., Stafford, L. E., Shimabukuro, R. H., and Zaylskie, R. G., Nov/Dec 1973, Atrazine metabolism in sorghum: Catabolism of the glutathione conjugate of atrazine: Journal of Agriculture and Food Chemistry, v. 21, no. 6, p. $1020-1030$.

English.

Biodegradation/Biotransformation.

CAIN 739233608.

Lamoureux, G. L., Shimabukuro, R. H., Swanson, H. R, and Frear, D. S., 1970, Metabolism of 2-chloro-4-thylamino-6isopropylamino-s-triazine (atrazine) in excised sorghum leaf: Journal of Agriculture and Food Chemistry, v. 18, no. 1, p. 81-86.

English.

Biodegradation/Biotransformation,Associations with Plants.

CA72(13):65655y.
Larson, J. D., and Bakke, J. E., 1971, Metabolism of plant metabolites of s-triazine in the rat: Proceedings of the North Dakota Academy of Science, v. 24, no. 2, p. 178-187.

English.

Biodegradation/Biotransformation.

CA76(1):698c.

Lavy, T. L., 1974, Mobility and deactivation of herbicides in soil-water systems: PB Rep., No. 238632/4GA, U.S. NTIS. Engish.

Leaching,Biodegradation/Biotransformation,Sorption to Soil. CA83(5):38731r.

Lavy, T. L., Roeth, F. W., and Fenster, C. R., 1973, Degradation of 2,4-D and atrazine at three soil depths in the field: Journal of Environmental Quality, v. 2, no. 1, p. 132-137. English.

Biodegradation/Biotransformation.

CA79(5):28388n.

Lebedeva, G. F., Chernova, N. I., and Epishina, L. V., 1978, Persistence of sym-triazines in sod-podzolic soil and their effect on microflora: Vestnik Moskouskogo Universiteta, Seriya 16: Biologiya, no. 2, p. 44-46.

Russian.

Biodegradation/Biotransformation, Toxicity. CA89(17):141772c.

Lebedeva; G. F., and Shustrova, Z. A., 1975, Problemy Sel'skokhozyaistvennoi Nauki v Moskovskom Universitete, p. 292-296.

Russian.

Biodegradation/Biotransformation.

CA85(3):15334r.

Leela, D., 1984, Studies on the persistence of herbicides in sandy loam soils: Indian Journal of Horticulture, v. 41, no. $1 / 2$, p. 123-126.

English.

Biodegradation/Biotransformation.

GUA 85031166 .

Leininger, V. E., 1968, Microbial decomposition of ring and chain labeled atrazine in Chalmers silt loam soil, Dissertation submitted in partial fulfillment of Ph.D. requirements, Purdue University, Lafayette, Indiana, USA.

English.

Biodegradation/Biotransfonmation.

CA74(1):2929m.

Libik, A. W., and Romanowski, R. R., Nov 1976, Soil persistence of atrazine and cyanazine: Weed Science, v. 24, no. 6, p. 627-629.

English.

Field Residuals,Biodegradation/Biotransformation. CA86(19):134787w.

Litvinov, I. A., and Mazina, E. I., 1979, Effect of soil microorganisms on the decomposition of atrazine: Trudy Khar'kovskii Sel'skokhozyaistvennyi Institut imeni, no. 260, p. 44-50.

Russian.

Biodegradation/Biotransformation.

CA93(25):2325332. 
ENVIRONMENTAL PROCESSES

TRANSFORMATION PROCESSES

Biodegradation/Biotransformation

Liu, L. C., Cibes-Viade, H. R, and Gonzalez-Ibanez, J., 1970, Persistence of atrazine, ametryne, prometryne, and diuron in soils under greenhouse conditions: Journal of the

Agricultural University of Puerto Rico, v. 54, no. 4, p. 631-

639.

English.

Biodegradation/Biotransformation.

CA739210:108552c.

Lowder, S. W., and Weber, J. B., May 1982, Atrazine efficacy and longevity as affected by tillage, liming, and fertilizer type: Weed Science, v. 30, no. 3, p. 273-280.

English.

Field Residuals,Biodegradation/Biotransformation. CA97(1):2192r.

Lukman, M., Zuran, A., and Megusar, F., 1987, Atrazine and ammonifying, nitrifying and denitrifying potential in soils: Zbornik Biotehnice Fakulty Univ. Edvarda Kardelja Ljubl. Kmetijstvo., no. 47, p. 167-179.

Slovenian.

Biodegradation/Biotransformation,Degradation Products. IND 87110521.

Manninger, E., Gartner, B. A., Bakondi-Zamory, E., and Soos, T., 1977, Soil Biology and Conservation of the Biosphere, (Proceedings of the Meetings), 7th, 1975, p. 79-85. English.

Biodegradation/Biotransformation,Sorption to Soil CA89(19):158658t.

Manorik, A. V., and Malichenko, S. M., 1970, Role of soil and plants in the inactivation of simazine and atrazine: Agrolkimiya, no. 9, p. 114-119.

Russian.

Biodegradation/Biotransformation. CA73(25):129887f.

Manorik, A. V., and Malichenko, S. M., 1971, Utilization of triazines by soil microorganisms as sources of nitrogen and carbon nutrition: Dopoviđi Akademii Nauk Ukrains'koi RSR, Seriya B, v. 33, no. 9 , p. $848-850$.

Ukrainian.

Biodegradation/Biotransformation.

CA75(25):150612p.

Maslennikova, V. G., 1976, Voprosy Ekologii i Fiziologii Microorganizmov, Ispol'znemykh v Sel'skom Khozyaistve, p. 68 73.

Russian.

Biodegradation/Biotransformation.

CA88(23):165307k.

McClure, G. W., 1970, Accelerated degradation of herbicides in soil by the application of microbial nutrient broths:

Contributions of the Boyce Thompson Institute, v. 24, na. 11, p. 235-240.

English.

Biodegradation/Biotransformation.

CA73(19):97726j.
McEnerney, J. T., and Davis, D. E., 1977, Metabolism of atrazine and its degradation products by fiddler crabs (Uca pugnax) (Abstract only): Proceedings of the Southern Weed Science Society, v. 30, p. 354.

English.

Biodegradation/Biotransformation,Degradation Products. CAIN 779078053 .

McEnemey, J. T., and Davis, D. E., 1979, Metabolic fate of atrazine in the Spartina alterniflora-Detritus-Uca pugnax food chain: Journal of Environmental Quality, v. 8, no. 3, p. 335-338.

English.

Biodegradation/Biotransformation.

CA91(19):152393x.

McIntyre, B. L., 1971, Persistence of atrazine as influenced by population densities, Dissertation submitted in partial fulfillment of Ph.D. requirements, Kansas State University, Kansas.

English.

Biodegradation/Biotransformation.

CAT 8277459.

Mickowski, M., and Verona, O., 1967, Decomposition of triazine herbicides by some soil fungi: Agricultura Italiana (Pisa), v. 67, no. 2, p. $67-76$.

Italian.

Biodegradation/Biotransformation.

CA67(23):107564x.

Montgomery, M. L., Botsford, D. L., and Freed, V. H., 1969, Metabolism of hydroxysimazine by corn plants: Journal of Agriculture and Food Chemistry, v. 17, no. 6, p. 1241-1243. English

Degradation Products,Biodegradation/Biotransformation, Anaiytical Techniques/Quantification. CA72(1):2396u.

Moreale, A., and Van Bladel, R, 1980, Study on the behavior of pesticides in soils using the radiotracer technique. Part 2. Migration and distribution in the soil profile: Bulletin des Recherches Agronomiques de Gembloux, v. 15, no. 2, p. 191206.

French.

Leaching,Biodegradation/Biotransformation. CA95(11):92336b.

Mozheiko, A. M., and Litvinov, I. A., 1969, Dynamies of the herbicide hungazin in soil: Trudy Khar'kovskii Sel'skokhozyaistvennyi Institutimeni, v. 92, p. 48-52. Russian.

Biodegradation/Biotransformation,Leaching. CA77(3):15420a.

Mozheiko, A. M., and Litvinov, I. A., 1971, Metabolism of atrazine in plants: Khimiya v Sel'skom Khozyaistve, v. 9, no. 2, p. 121-122.

Russian. Biodegradation/Biotransformation. CA74(21):110679p. 
Muir, D. C. G., and Baker, B. E., 1978, The disappearance and movement of three triazine herbicides and several of their degradation products in soil under field conditions: Weed Research, v. 18, no. 2, p. 111-120.

English.

Degradation Products,Biodegradation/Biotransformation,Field Residuals,Leaching.

CA89(17):141769g.

Nearpass, D. C., Edwards, W. M., and Taylor, A. W, 1978, Triazine persistence in soil in eastern Ohio: Agronomy Journal, v. 70, no. 6, p. 937-940.

English.

Biodegradation/Biotransformation.

CA90(9):67612c.

Nedyalkov, N., and Stoinova, E., 1977, Nitrogen metabolism in leaves of atrazine treated corn grown under various water supply conditions: Fiziologiya Rasteneveniudni (Sofia), v. 3, no. 4 , p. $62-71$.

Bulgarian.

Biodegradation/Biotransformation.

CA89(5):37975k.

Nepomiluev, V. F., and Kuzyakina, T. I., 1972, Action of atrazine and simazine on the soil fungi, and decomposition of the herbicides in soil: Biologicheskie Nauki, v. 15, no. 8, p.

127-131.

Russian.

Toxicity,Biodegradation/Biotransformation.

CA78(3):12585t.

Nicholls, P. H., Walker, A., and Baker, R. J., 1982, Measurements and simulation of the movement and degradation of atrazine and metribuzin in a fallow soil: Pesticide Science, v. 13, no. 5, p. 484-494.

English.

Sorption to Soil,Leaching,Biodegradation/Biotransformation. CA98(25):211430b.

O'Kelley, J. C., and Deason, T. R, 1976, Degradation of pesticides by algae: EPA-600/3-76-022, U.S. Environmental Protection Agency, Office of Research and Development. English.

Biodegradation/Biotransformation.

CA85(1):984d.

Obien, S. R, and Green, R. E., 1969, Degradation of atrazine in four Hawaiian soils: Weed Science, v. 17, no. 4, p. 509-514. English.

Biodegradation/Biotransformation. CA72(1):2433d.

Obien, S. R, 1970, Degradation of atrazine and related triazines in Hawaiian soils, Dissertation submitted in partial fulfillment of Ph.D. requirements, University of Hawaii, Honolulu, Hawaii, USA.

English.

Biodegradation/Biotransformation.

CA75(1):4390y.
Ortuno, A., Parra, M., and Egea Caballero, J., 1979, Degradation of simazine and atrazine in saline soils of southeast Spain: Anales de Edafologia y Agrobiologia, v. 38, no. 7-8, p. 13511356. Spanish.

Biodegradation/Biotransformation. CA93(3):20717n.

Ortuno, A., Parra, M., Hernansaez, A., and Egea, J., 1975, Persistence of chlorotriazine herbicides in citrus soils: Anales de Edafologia y Agrobiologia, v. 34, no. 1-2, p. 2534. Spanish.

Biodegradation/Biotransformation. CA83(3):23388k.

Owens, D. C., 1980, Degradation of pesticide residues: US Appl. 917902.

English.

Biodegradation/Biotransformation. CA93(1):2255f.

Owens, D. C., and Eaton, S. E., 1980, A study of induced acceleration of the degradation of residual levels of six triazines in soil: Proceedings, Southern Weed Science Society, p. 299-306.

English.

Biodegradation/Biotransformation. CA93(11):108852p.

Pallotti, E., Shikony, E N., and Nyaku, N. Y., 1977, Proceedings of the East African Weed Science Conference, 1976, p. 97-103. English.

Biodegradation/Biotransformation. CA93(7):63593m.

Paris, D. F., and Lewis, D. L., 1973, Chemical and microbial degradation of ten selected pesticides in aquatic systems: Residue Reviews, v. 45, p. 95-124.

English.

Hydrolysis/Chemical Reactions,Biodegradation/

Biotransformation.

CA79(21):122470e.

Paris, D. F., Lewis, D. L., Barnett, J. T., Jr., and Baughman, G. L., 1975, Microbial degradation and accumulation of pesticides in aquatic systems: U.S. NTIS, PB Rep., No. 241293.

English.

Biodegradation/Biotransformation. CA83(17):14297h.

Paris, D. F., Lewis, D. L., Bamett, J. T., Jr., and Baughman, G. L., 1975, Microbial degradation and accumulation of pesticides in aquatic systems: US NTTS, PB Rep., No. 241293, $54 \mathrm{p}$. English.

Biodegradation/Biotransformation,Associations with Surfactants,Sorption to Sediments. CA83(17):142974h. 
Parra, L. A., 1971, Fate of atrazine and paraquat in three West Virginia soils, Dissertation submitted in partial fulfillment of Ph.D. requirements, West Virginia University, Morgantown, W. Va., USA.

English.

Biodegradation/Biotransformation. CA76(7):31151y.

Peng, S. Y., 1978, On the persistence of soil-applied herbicides: Taiwan Sugar, v. 25, no. 5, p. 168-171. English.

Biodegradation/Biotransformation. CA90(11):81794v.

Percich, J. A., and Lockwood, J. L., 1978, Interaction of atrazine with soil microorganisms: population changes and accumulation: Canadian Journal of Microbiology, v. 24, no. 10, p. $1145-1152$.

English.

Uptake by Biota,Biodegradation/Biotransformation,Associations with Plants.

CA90(5):34969w.

Pestemer, W., Radulescu, V., Walker, A, and Ghinea, L., 1984, Residual effects of chlorotriazine herbicides in soil at three Romanian sites. I. Prediction of the persistence of simazine and atrazine: Weed Research, v. 24, no. 5, p. 359369.

German.

Field Residuals,Biodegradation/Biotransformation. CA101(23):205993b.

Peterson, C. A., 1977, The metabolic pathways and physiological effects of atrazine in Douglas-fir seedlings, Dissertation submitted in partial fulfilment of $\mathrm{Ph}$.D. requirements, Oregon State University, Corvallis, Oregon.

English.

Biodegradation/Biotransformation.

CA86(23):166139c.

Phogat, B. S., Malik, R. K, and Bhan, V. M., 1984, The rate of atrazine degradation in sterilized and unsterilized soil:

Beitraege zur Tropischen Landwirtschaften und

Veterinaermedizin, v. 22, no. 4, p. 391-396.

English.

Biodegradation/Biotransformation.

CA102(23):199472h.

Pillai, C. G. Parthasarathy, Weete, J. D., and Davis, D. E., 1977, Metabolism of atrazine by Spartina alterniflora. 1. Chloroform-soluble metabolites: Journal of Agriculture and Food Chemistry, v. 25, no. 4, p. 852-855.

English.

Biodegradation/Biotransformation.

CA87(5):34159v.

Pillai, C. G. P., Weete, J. D., and Davis, D. E., July/Aug 1977, Metabolism of atrazine by Spartina alternifolia.1. chloroform metabolites: Journal of Agriculture and Food Chemistry, v. 25 , no. 4, p. 852-855.

English.

Degradation Products,Biodegradation/Biotransformation. CAIN 779079637.
Pillai, P., Weete, J. D., Diner, A. M., and Davis, D. E., 1979, Atrazine metabolism in box crabs: Joumal of Environmental Quality, v. 8, no. 3, p. 277-280.

English.

Biodegradation/Biotransformation.

CA91(25):205355v.

Rahman, A., and Matthews, L. J., 1979, Effect of soil organic matter on the phytotoxicity of thirteen s-triazine herbicides: Weed Science, v. 27, no. 2, p. 158-161. English.

Sorption to Soil,Biodegradation/Biotransformation. CA90(25):198787m.

Rakhov, G. M., Petrov, R. V., Tsapko, V. V., and Vanyurikhina, L. N., 1976, Effect of the use of toxic chemicals and fertilizers in the water-protective zone with sources of artificial replacement of subsurface water reserves: Gigiena i Sanitariya, no. 3, p. 101-102.

Russian.

Biodegradation/Biotransformation.

CA85(14):98904a.

Raynaud, S., Bastide, J., and Coste, C., Nov 1985, Use of a mathematical model to determine the fate of atrazine in barley (Hordeum vulgare): Weed Science, v. 33, no. 6, p. 906912.

English.

Biodegradation/Biotransformation.

IND 86027564

Roberts, D. R., 1967, Fate of atrazine in corn, cotton, and soybeans, Dissertation submitted in partial fulfillment of Ph.D. requirements, Auburn University, Auburn, Alabama, USA. English.

Biodegradation/Biotransformation.

CA67(15):72682e.

Robinson, D. E., and Greene, D. W., Sept 1976, Metabolism and differential susceptibility of crabgrass (Digitaria sanguinalis) and witchgrass (Panicum capillare) to s...: Weed Science, v. 24, no. 5, p. 500-504.

English.

Biodegradation/Biotransformation.

CAIN 769096867.

Roeth, F. W., Lavy, T. L., and Burnside, O. C., 1969, Atrazine degradation in two soil profiles: Weed Science, v. 17, no. 2, p. 202-205.

English.

Biodegradation/Biotransformation. CA71(1):2417f.

Roeth, F. W., and Lavy, T. L., 1971, Atrazine<2-chloro-4(ethylamino)-6-(isopropylamino)-s-triazine $>$ translocation and metabolism in sudangrass, sorghum, and corn: Weed Science, $v$. 19 , no. 1, p. 98-101.

English.

Uptake by Biota,Biodegradation/Biotransformation. CA74(21):110669k. 
ENVIRONMENTAL PROCESSES

TRANSFORMATION PROCESSES

Biodegradation/Biotransformation

Roeth, F. W., 1970, Comparison of atrazine uptake, metabolism, and resistance in sorghum and com, Dissertation submitted in partial fulfillment of Ph.D. requirements, University of Nebraska, Lincoln, Nebraska, USA.

English.

Biodegradation/Biotransformation, Uptake by Biota CA75(3):19082y.

Rohde, W. A., Asmussen, L. E., Hauser, E. W., Hester, M. L., and Allison, H. D., 1981, Atrazine persistence in soil and transport in surface and subsurface runoff from plots in the coastal plain of the southem United States: Agro-Ecosystems, v. 7 , no. 3, p. 225-238.

English.

Run-off,Biodegradation/Biotransformation. CA96(1):2119b.

Ruban, E. L., 1973, Decomposition of synthetic compounds by microorganisms. Literature review. Izvestiya Akademii Nauk Moldavskoi SSR, Seriya Biologicheskikhi, no. 3, p. 301-312. Russian.

Biodegradation/Biotransformation.

CA79(23):133349y.

Sachdev, M. S., and Luthra, V. K., 1981, Effect of simazine and atrazine on the decomposition of $14 \mathrm{C}$-glucose in soil: Journal of Nuclear Agriculture and Biology, v. 10, no. 2, p. 53-56. English. Toxicity,Biodegradation/Biotransformation. CA95(15):1274C8f.

Scheunert, I., and Korte, F., 1985, Interactions in the fate of chemicals in terrestrial systems: Ecotoxicology and Environmental Safety, v. 9, no. 3, p. 385-391. English.

Biodegradation/Biotransformation,Miscellaneous Environmental, Sorption to Soil.

CA103(7):49747h.

Scheunert, I., Qiao, Z, and Korte, F., 1986, Comparative studies of the fate of 14C-atrazine and 14C-pentachlorophenol in various laboratory and outdoor soil-plant systems: Journal of Environmental Science and Health, Part B, v. B21, no. 6, p. 457-485.

English.

Sorption to Soil,Biodegradation/Biotransformation. CA106(13):98083j.

Schiavon, M., 1988, Studies of the leaching of atrazine, of its chlorinated derivatives, and of hydroxyatrazine from soil using carbon-14 ring-labeled compounds under outdoor conditions: Ecotoxicology and Environmental Safety, v. 15, no. 1, p. 46-54.

English.

Leaching,Degradation Products,Sorption to Soil, Biodegradation/Biotransformation.

CA108(23):200133f.

Schiavon, M., 1988, Studies of the movement and the formation of bound residues of atrazine, of its chlorinated derivatives, and of hydroxyatrazine in soil using carbon-14 ring-labeled compounds under outdoor conditions: Ecotoxicology and Environmental Safety, v. 15, no. 1, p. 55-61.

English.

Sorption to Soil,Biodegradation/Biotransformation.

CA108(23):200134g.
Schiavon, M., and Jacquin, F., 1975, Herbicides and soils. Biodegradation of atrazine and the mineralization of organic matter. Bulletin de l'Ecole Nationale Superieure d'Agronomie et des Industries Alimentaires, v. 17, no. 1, p. 45-51.

French.

Biodegradation/Biotransformation. CA84(21):145926a.

Schmidt, B., Ebing, W., and Schuphan, I., 1988, Use of a plant cell culture test for evaluation of the metabolic behavior of pesticides: Gesunde Pflanzen, v. 40, no. 6, p. 245-249.

German.

Biodegradation/Biotransformation. CA109(11):87559e.

Schmidt, G., 1975, Problems of testing the behavior of plant protectives in surface waters: Schriftenreihe ders Vereins fuer Wasser, Boden und Lufthygiene, Berlin-Dahlem, v. 46, p. 155-164.

German:

Biodegradation/Biotransformation,Surfacewater Observations. CA85(8):51566b.

Schocken, M. J., and Speedie, M. K., 1984, Physiological aspects of atrazine degradation by higher marine fungi: Archives of Environmental Contamination and Toxicology, v. 13, no. 6, p. 707-714.

English.

Toxicity,Biodegradation/Biotransformation. CA102(5):41258h.

Schoen, S. R, and Winterlin, W. L., 1987, The effects of various soil factors and amendments on the degradation of pesticide mixtures: Journal of Environmental Science and Heaith, Part B, v. B22, no. 3, p. 347-377.

English.

Biodegradation/Biotransformation,Sorption to Soil. CA107(13):111096h.

Seibert, K, and Fuehr, F., 1984, Effect of water conent on atrazine degradation in soil: Zeitschrift fuer

Pflanzenerhachrung und Bodenkunde, v. 147, no. 4, p. 485-496. German.

Biodegradation/Biotransformation.

CA101(25):224691t.

Seibert, K., Fuhr, F., and Cheng, H. H., 1981, Symposium on the Theory and Practice of the Use of Soil Applied Pesticides: Proceedings, p. 137-146.

English.

Degradation Products,Biodegradation/Biotransformation. CA97(25):210330m.

Shevade, A., and Dubey, P. S, 1985, Current Pollution Research in India, p. 331-334.

English.

Biodegradation/Biotransformation.

CA103(25):208881r.

Shimabukuro, R. H., 1985, Detoxication of herbicides: Weed Physiology, v. 2, p. 215-240.

English.

Biodegradation/Biotransformation.

IND 86005400 . 
Shimabukuro, R. H., Waish, W. C., Lamoureux, G. L., and Stafford, L. E., Nov/Dec 1973, Atrazine metabolism in sorghum: chloroform-soluble intermediates in the $\mathrm{N}$-dealkylation and glutathione conju...: Journal of Agriculture and Food Chemistry, v. 21, no. 6, p. 1031-1036. English.

Biodegradation/Biotransformation,Degradation Products.

Shimabukuro, R. H., 1967, Atrazine metabolism and herbicidal selectivity: Plant Physiology, v. 42, no. 9, p. 1269-1276. English. Biodegradation/Biotransformation. CA67(23):107578e.

Shimabukuro, R. H., 1968, Atrazine metabolism in resistant com and sorghum: Plant Physiology, v. 43, no. 12, p. 1925-1930. English.

Biodegradation/Biotransformation. CA70(13):56560v.

Shimabukuro, R. H., 1967, Significance of atrazine dealkylation in root and shoot of pea plants: Journal of Agriculture and Food Chemistry, v. 15, no. 4, p. 557-562.

English.

Biodegradation/Biotransformation,Degradation Products. CA67(13):63196x

Shimabukuro, R. H., and Swanson, H. R, 1969, Atrazine metabolism, selectivity, and mode of action: Journal of Agriculture and Food Chemistry, v. 17, no. 2, p. 199-205. English.

Biodegradation/Biotransformation. CA71(5):21091m.

Shimabukuro, R. H., and Swanson, H. R, 1970, Atrazine metabolism in cotton as a basis for intermediate tolerance: Weed Science, v. 18, no. 2, p. 231-234.

English.

Biodegradation/Biotransformation.

CA72(25): $131344 z$.

Sikka, H. C., 1967, Role of crop and weed species in dissipation of atrazine from soil, Dissertation submitted in partial fulfillment of Ph.D. requirements, Aubum University, Auburn, Alabama, USA.

English.

Biodegradation/Biotransformation.

CA67(17):81376k

Sikka, H. C., and Davis, D. E., 1966, Dissipation of atrazine from soil by corn, sorghum, and Johnson grass: Weeds, v. 14, no. 4, p. 289-293.

English.

Biodegradation/Biotransformation.

CA66(5):18238f.

Sirons, G. J., Frank, R, and Sawyer, T., November/December 1973, Residues of atrazine, cyanazine, and their phytotoxic metabolites in a clay loam soil: Journal of Agricultural and Food Chemistry, v. 21, no. 6, p. 1016-1020.

English.

Field Residuals,Degradation Products,Sorption to Soil. Biodegradation/Biotransformation,Hydrolysis/Chemical Reactions.
Skipper, H. D., Gilmour, C. M., and Furtick, W. R, 1967, Microbial versus chemical degradation of atrazine in soils: Soil Science Society of America, Proceedings, v. 31, no. 5, p. $653-656$.

English.

Hydrolysis/Chemical Reactions,Biodegradation/

Biotransformation.

CA68(5):21119q.

Skipper, H. D., and Volk, V. V., 1972, Biological and chemical degradation of atrazine in three Oregon soils: Weed Science, v. 20 , no. 4 , p. $344-347$.

English.

Hydrolysis/Chemical Reactions,Biodegradation/

Biotransformation.

CA77(17):113114y.

Skipper, H. D., 1970, Hydrolysis and biological degradation of atrazine in soils, Dissertation submitted in partial fulfilment of Ph.D. requirements, Oregon State University, Corvallis, Oregon, USA.

English.

Hyurolysis/Chemical Reactions,Biodegradation/

Biotransformation.

CA74(1):2900v.

Smit, N. S. H., Nel, P. C., and Folscher, W. J., 1980, Factors affecting sorption and degradation of atrazine in soils: Gewasproduksie, v. 9, p. 135-139.

Afrikaans.

Sorption to Soil,Biodegradation/Biotransformation. CA95(11):92218q.

Smit, N. S. H., Nel, P. C., and Folscher, W. J., 1981, Phosphate sorption: a possible criterium for biological activity of atrazine in soil: Gewasproduksie, v. 10, p. 209-213.

Afrikaans.

Biodegradation/Biotransformation.

IND 83007264.

Smit, N. S. H., and Nel, P. C., 1976, Residual activity and degradation of atrazine in different soil types: Gewasproduksie, v. 5, p. 91-93.

Afrikaans.

Field Residuals,Biodegradation/Biotransformation. CA87(3):17178h.

Smith, A. E., Grover, R, Emmond, G. S., and Korven, H. C., 1975, Persistence and movement of atrazine, bromacil, monuron, and simazine in intermittently-filled irrigation ditches: Canadian Joumal of Plant Science, v. 55, no. 3, p. 809-816. English.

Leaching, Run-off,Biodegradation/Biotransformation. CA83(15):127459a.

Smith, W. F., III, 1973, Phytotoxicity and degradacion of atrazine in selected zoysiagrass varieties, Dissertation submitted in partial fulfillment of Ph.D. requirements, Rutgers State University, New Brunswick, NJ..

English.

Biodegradation/Biotransformation. CA81(19):115543u. 
Sosnovaya, O. N., and Mereszhinskii, Y. G., 1979, Regulation of the rate of detoxification of atrazine by corn plants: Dollady Vsesoyuznoi Akademii Sel'skokhozyaistvennykh Nauk, no. 7, p. 11-13.

Russian.

Biodegradation/Biotransformation.

CA91(17):135449.

Spiridonov, Y. Y., and Kamenskii, V. 1., 1970, Factors determining the stability of atrazine in soil: Agrokhimiya, no. 6 , p. $112-120$.

Russian.

Biodegradation/Biotransformation.

CA73(21):108599y.

Stojanovic, B. J., Kennedy, M. V., and Shuman, F. L., Jr., 1972, Edaphic aspects of the disposal of unused pesticides, pesticide wastes, and pesticide containers: Journal of Envirommental Quality, v. 1, no. 1, p. 54-62.

English.

Biodegradation/Biotransformation. CA76(13):69169y.

Strzelec, A., 1982, Effect of peat and bentonite added to a light soil on the development of microflora and rate of atrazine degradation: Roczniki Gleboznawcze, v. 33, no. 1/2, p. 47-59. Polish.

Associations with Plants,Biodegradation/Biotransformation. CA99(1):1762f.

Strzelec, A., 1982, Effect of copper and zinc on the rate of atrazine degradation and development of soil microflora: Roczniki Gleboznawcze, v. 33, no. 1/2, p. 61-72.

Polish.

Biodegradation/Biotransformation, Toxicity. CA99(1):1761e.

Suess, A., and Eben, C., 1977, Decomposition of atrazine and NaTA in different soils: Gesunde Pflanzen, v. 29, no. 8, p. 188-

192.

German.

Biodegradation/Biotransformation. CA88(5):33168f.

Suess, A., Fuchsbichler, G., Siegmund, H., and Eben, C., 1979, Herbizide, p. 88-95.

German.

Sorption to Soil, Biodegradation/Biotransformation. CA93(5):39477f.

Suess, A., Siegmund, H., and Fuchsbichler, G., 1980, Agrochemical Residue-Biota Interactions in Soil and Aquatic Ecosystems. Proceedings and Report of Combined Advisory Group Meeting and Research Coordination Meeting, 1978, p. 201-213. English. Biodegradation/Biotransformation. CA95(13):110051m.

Suss, A., and Eben, C, 1977, Breakdown of atrazine and Nata in various soils: Gesunde-Pflanz, v. 29, no. 8, p. 188-192.

German.

Biodegradation/Biotransformation.

CAIN 7890225913.
Swain, D. J., 1981, Atrazine dissipation in irrigated sorghum cropping in southern New South Wales: Weed Research, v. 21, no. 1, p. 13-21.

English.

Sorption to Soil,Biodegradation/Biotransformation. CA105(19):166811b.

Terce, M., Lefebvre-Drouet, E., and Calvet, R, 1977, Degradation of adsorbed atrazine on an aluminum montmorillonite: Chemosphere, v. 6 , no. 11 , p. $753-758$.

English.

Sorption to Soil,Biodegradation/Biotransformation. CA88(11):70464v.

Thompson, L. J., Houghton, J. M., Slife, F. W., and Butler, H. S., 1971, Metabolism of atrazine by fall panicum and large crabgrass: Weed Science, v. 19, no. 4, p. 409-412.

Unavailable.

Biodegradation/Biotransformation.

CA75(17):106226s.

Todorovic, M., Kalinovic, D., Vrbanic, J., and Konstantinovic, B., 1985, The effect of molasses on the degradation of biologically active atrazine residues: Mikrobiologija, v. 22, no. 2, p. 113-124.

Serbo-Croatian.

Biodegradation/Biotransformation.

CA106(11):80308b.

Tsukerman, V. G., and Lunev, M. I., 1983, Analysis of chlorourganic and sym-triazine pesticides by gas liquid chromatography and study of their behavior in soil: Rezul't Razrab Metodov Anal Pochv, Rast Udobr. Moscow, USSR Tsentr. Inst. Agrokhim. Obsluzhivaniya Sel'sk. Khoz., p. 113-123. Russian.

Sorption to Soil,Analytical Techniques/Quantification, Biodegradation/Biotransformation. CA103(11):83387a.

Vacher, C., and Fabre, E., 1983, "Study Days on Weeding," 12th conference of the French Weed Control Committee, 15-16 December 1983.

French.

Biodegradation/Biotransformation. IND 86071662

Vacher, C., Fabre, E., and Loubinoux, P., 1983, "Study Days on Weeding," 12th Conference of the French Weed Control Committee, 15-16 December.

French.

Biodegradation/Biotransformation. IND 86071661

Vacher, C., and Fabre, E., 1984, Simulation of the persistence of atrazine in a French soil: Monograph - British Crop Protection Council, 27(Soil and Crop Protection Chemistry), p. 109-115.

English.

Biodegradation/Biotransformation.

CA101(25):224816n. 
ENVIRONMENTAL PROCESSES

TRANSFORMATION PROCESSES

Biodegradation/Biotransformation

Vaintraub, F. P., Vylegzinanina, G. F., Dron, L. P., Keiser, L. S., Nesterova, I. P., and Patrashku, F. I., 1979, Migratsiya i Prevrashcheniya Pestitsidor v Okruzhayushchei Srede, Trudy Sovetsko-Amerikanskogo Simposiuma, 1976, p. 87-93.

Russian.

Biodegradation/Biotransformation. CA93(23):216662k

Valentine, J. P., and Bingham, S. W., 1976, Influence of algae on amitrole and atrazine residues in water. Canadian Journal of Botany, v. 54 , no. 18 , p. $2100-2107$.

English.

Biodegradation/Biotransformation,Surfacewater Observations. CA85(25):187441q.

Van Bladel, R, and Moreale, A., 1980, Study on the behavior of pesticides in soils using the radiotracer technique. Part $\mathrm{I}$. Adsorption-desorption and degradation processes: Bulletin des Recherches Agronomiques de Gembloux, v. 15, no. 2, p. 177 . 189.

French.

Sorption to Soil,Biodegradation/Biotransformation. CA95(11):92335a.

Vega, L. A, and Chauarria, P. L., July 1974, Mobility and persistence of atrazine and metribuzin in four soils from Puerto Rico: Journal of the Agricultural University of Puerto Rico, v. 58 , no. 3 , p. $372-380$.

English.

Field Residuals, Leaching,Biodegradation/Biotransformation. CA81(25):164559n.

Visi, G. M., 1984, Study of the concentration decrease of pesticides in aquatic systems: Novenyvedelem (Budapest), v. 20 , no. 8, p. 358-363.

Hungarian.

Biodegradation/Biotransformation,Surfacewater Observations. CA101(17):146107r.

Voinova, G., and Bakalivanov, D., 1970, Detoxication of certain aminotriazine herbicides by soil bacteria: Mededelingen van de Faculteit Landbouwwetenschappen, Rijksuniversiteit Gent, v. 35 , no. 2 , p. 839-846.

French.

Biodegradation/Biotransformation.

CA75(19):117414c

Vong, P. C., and Schiavon, M., 1982, Effect of atrazine on the mineralization of organic materials in soils and in the presence of carbon-14-labeled substrates: Bulletin de l'Ecole Nationale Superieure d'Agronomie et des Industries Alimentaires, v. 24, p. 43-53.

French.

Toxicity,Biodegradation/Biotransformation,Sorption to Soil. CA99(21):171257n.

Wagner, G. H., and Chahal, K. S., 1966, Decomposition of carbon14 labeled atrazine in soil samples from Sanborn Field: Soil Science Society of America Proceedings, v. 30, no. 6, p. 752754.

English.

Biodegradation/Biotransformation.

CA66(19):84990w.
Walker, A., and Zimdahl, R. L., 1981, Simulation of the persistence of atrazine, linuron and metolachlor in soil at different sites in the USA: Weed Research, v. 21, no. 6, p. 255-265.

English.

Biodegradation/Biotransformation.

CA96(13):99407e.

Walker, A., and Brown, P. A., 1981, Theory and Practice of the Use of Soil Applied Herbicides, Symposium, p. 63-71. English.

Biodegradation/Biotransformation.

CA97(23):194577q.

Webster, H. L., 1969, Response of plants to atrazine-dexon combinations and the influence of dexon on the absorption, distribution, and metabolism of atrazine by plants, Dissertation submitted in partial fulfillment of Ph.D. requirements, North Carolina State University, Raleigh, N.C.. English.

Uptake by Biota,Biodegradation/Biotransformation. CA72(23):120321p.

Weete, J. D., Pillai, P., and Davis, D. D., 1980, Metabolism of atrazine by Spartina alterniflora. 2. Water-soluble metabolites: Journal of Agriculture and Food Chemistry, v. 28 , no. 3, p. $636-640$.

English.

Degradation Products,Biodegradation/Biotransformation. CA92(25):210078g.

Wehtje, G. R., Spalding, R. F., Burnside, O. C., Lowry, S. R. and Leavitt, J. R. C., 1983, Biological significance and fate of atrazine under aquifer conditions: Weed Science, v. 31, no. 5, p. $610-618$.

English.

Biodegradation/Biotransformation,Leaching,Groundwater Observations,Sorption to Soil. CA99(21):171005d.

Weidner, C. W., 1974, Degradation in ground water and mobility of herbicides: PB Rep., No. 239242/1GA, U.S. NTIS.

English.

Groundwater Observations, Leaching,Biodegradation/

Biotransformation.

CA83(11)92347h.

Weimer, M. R, Swisher, B. A., and Vogel, X. P., July 1988, Metabolism as a basis for differential atrazine tolerance in warm-season forage grasses: Weed Science, v. 36, no. 4, p. $436-440$.

English.

Biodegradation/Biotransformation. IND 88032365.

Wichman, J. R, and Byrnes, W. R, 1975, Uptake, distribution, and degradation of simazine by black walnut and yellow poplar seedlings: Weed Science, v. 23, no. 6, p. 448-453. English. Biodegradation/Biotransformation,Uptake by Biota. CA84(17):116584g. 
Winkler, R, Beitz, H., Jany, H., and Mueller, R, 1987, Decontamination of polluted wastewaters from agricultural operations: Appl. 292497, East Germany.

German.

Biodegradation/Biotransformation.

CA108(24):209657n.

Wolf, D. C., and Martin, J. P., 1975, Microbial decomposition of carbon-14 ring-labeled atrazine, cyanuric acid, and 2-chloro4,5-diamino-s-triazine: Journal of Environmental Quality, v. 4, no. 1, p. 134-139.

English.

Degradation Products,Biodegradation/Biotransformation. CA83(1):1813t.

Wolf, D. C., 1973, Degradation of bromacil, terbacil, 2,4-D, and atrazine in soil and pure culture and their effect on microbial activity, Dissertation submitted in partial fulfillment of Ph.D. requirements, University of California, Riverside, California.

English.

Biodegradation/Biotransformation,Toxicity.

CA81(13):73262u.

Wolf, D. C., and Jackson, R. L., 1982, Atrazine degradation, sorption, and bioconcentration in water systems: W83-01607, OWRT-B-062-ARK(1); Order No. PB83-150151.

English.

Biodegradation/Biotransformation.

CA99)3):17978s.

Wolfe, N. L., Zepp, R. G., Gordon, J. A., and Fincher, R. C., Mar 1976, $\mathrm{N}$-nitrosamine formation from atrazine: Bulletin of

Environmental Contamination and Toxicology, v. 15, no. 3, p. 342-347.

English.

Degradation Products,Biodegradation/Biotransformation, Hydrolysis/Chemical Reactions.

CA85(9):57729d.

Wu, T. L., 1980, Dissipation of the herbicides atrazine and alachlor in a Maryland corn field soil profile: Journal of Environmental Quality, v. 9, no. 3, p. 459-465.

English.

Biodegradation/Biotransformation,Field Residuals. IND 80103963.

Wu, T. L., and Fox, B. M., 1980, Rate of disappearance of atrazine and alachlor in cornfield soils: Proceedings of the Annual Meeting of the Northeastern Weed Science Society, v. 34, p. 147-154.

English.

Biodegradation/Biotransformation.

CA92(19):158954y.

Zeyer, J., Bodmer, J., and Huetter, R, 1981, Microbial degradation of ammeline: Zentralblatt fuer Bakteriologie, Mikrobiologie, und Hygiene, Abteilung 1, Orig. C, v. 2, no. 3, p. 289-298.

English.

Degradation Products,Biodegradation/Biotransformation.

CA96(11):81319t.
Zimdahl, R. L., Freed, V. H., Montgomery, M. L., and Furtick, W. $R, 1970$, Degradation of triazine and uracil herbicides in soil: Weed Research, v. 10, no. 1, p. 18-26.

English.

Biodegradation/Biotransformation.

CA73(1):2890w. 
Adams, R. S., Jr., and Pritchard, D. J., Sept/Oct 1977, Influence of soil $\mathrm{pH}$ on the phytotoxicity of three s-triazine inerbicides: Agronomy Journal, v. 69, no. 5, p. 820-824.

English.

Biodegradation/Biotransformation,Hydrolysis/Chemical

Reactions.

CA88(1):1453d:

Agnihotri, N. P., Panday, S. Y., and Jain, H. K., 1976, Detoxification of atrazine by chemical treatments: Indian Journal of Agricultural Chemistry, v. 9, no. 1-2, p. 15-22. English.

Hydrolysis/Chemical Reactions,Biodegradation/

Biotransformation.

CA89(13): 101299x.

Anon., 1970, Chloroamino-S-triazines: Rom. RO 52080, 24 Apr 1970, 3 p.

Romanian.

Hydrolysis/Chemical Reactions,Degradation Products.

CA73(25):131044x.

Anon., 1976, Chloroamino-s-triazines: IT Appl. 75/67013, 3 Jan

1975.

French.

Hydrolysis/Chemical Reactions.

CA88(1):6942x.

Aries, R, 1975, Bisthiotriazines: Appl. or Pr. 73 33,298, 17 Sep

1973.

French.

Hydrolysis/Chemicai Reactions.

CA83(13): $114497 \mathrm{~m}$.

Aries, R, 1975, Thiocarbamoyltriazine: Appl. or Pr. 73 28,944, 6 Aug 1973.

French.

Hydrolysis/Chemical Reactions.

CA83(19):164244x.

Armstrong, D. E., and Chesters, G., Sept 1968, Adsorption catalyzed chemical hydrolysis of atrazine: Environmental Science and Technology, v. 2, no. 9, p. 683-689.

English.

Hydrolysis/Chemical Reactions,Sorption to Soil.

CA69(17):66344w.

Baldi, L. F., Renato, and Collecchia, F., 1980, Continuous production of chlorobis-(alkylamino)-s-triazines: Appl. or Pr. 2912267, 28 Mar 1979.

German.

Hydrolysis/Chemical Reactions.

CA94(13):103437t.

Baldi, L., Ferrari, C, and Francese, R., 1980, Chloroamino-striazines: IT Appl. 75/7013, 3 Jan 1975.

Italian.

Hydrolysis/Chemical Reactions,Degradation Products. CA94(23):192386r.

Baldi, L., Messori, V., and Francese, R, 1980, Chlorobis(alkylamino)-s-triazines: IT Appl. 78/28220, 17 Apr $1980,25 \mathrm{p}$.

German.

Hydrolysis/Chemical Reactions.

CA93(13):132519f.

Berkowitz, S.. 1980, Oxidative hydrolysis of amino-substituted triazines: US Appl. 721297, 8 Sep 1976.

English.

Hydrolysis/Chemical Reactions.

CA93(23):220783t.

Berkowitz, S., 1979, Preparation of <mono(trichloro)tetra(monopotassium)

dichloro) > pentaisocyanurate: Appl. or Pr. 78/26446, 7 Jun 1978.

English.

Degradation Products,Hydrolysis/Chemical Reactions. CA93(9):95300e.

Berkowitz, S., and Juelke, C. V., 1977, High pressure thermal hydrolysis to decompose triazines in acid waste streams: Appl. or Pr. 569019, 17 Apr 1975.

English.

Hydrolysis/Chemical Reactions, Wastewater Observations. CA87(2):11140t.

Bertelli, G., and Locatelli, R, 1982, Self-extinguishing polyolefinic compositions: Appl. 82/103721, 30 Apr 1982; IT Appl. 81/21459, 30 Apr 1981.

English.

Degradation Products,Hydrolysis/Chemical Reactions. CA98(10):73419b.

Bitzer, D., 1980, Diamino-s-triazines: Appl. or Pr. 2834543, 14 Feb 1980, 16 p.

German.

Hydrolysis/Chemical Reactions, Degradation Products. CA93(1):8217s.

Bitzer, D., 1981, Diamino-s-triazines: Appl. or Pr. 2940780, 8 Oct 1979.

German.

Hydrolysis/Chemical Reactions,Degradation Products. CA95(5):43177s.

Bordas, B., Matolesy, G., and Andriska, V., 1983, 2-Mercapto-4,6diamino-s-triazines: Appl. 79/NO239, 26 Nov 1979. Hungarian. Hydrolysis/Chemical Reactions. CA101(5):38479e.

Brown, C. B., and White, J. L., 1969, Reactions of 12 s-triazines with soil clays: Soil Science Society of America, Proceedings, v. 33, no. 6, p. 863-867. English.

Degradation Products, Chemical/Physical Properties,Sorption to Soil,Hydrolysis/Chemical Reactions.

CA72(9):42089c.

Bucholtz, D. L., and Lavy, T. L., 1977, Effects of cobalt-60 radiation on herbicides in aqueous solution: Weed Science, $v$. 25 , no. 3, p. 200-202.

English.

Hydrolysis/Chemical Reactions. CA87(3):18277b. 
Burkhard, N., and Guth, J. A., 1981, Chemical hydrolysis of 2 chloro-4,6-bis(alkylamino)-1,3,5-triazine herbicides and their breakdown in soil under the influence of adsorption: Pesticide Science, v. 12, no. 1, p. 45-52.

English.

Hydrolysis/Chemical Reactions,Sorption to Soil, Biodegradation/Biotransformation.

CA95(5):1778q.

Burton, W. B., 1982, Synthesis of 4-azido-2-isopropylamino-6ethylamino-s-triazine (ring UL 14C): Microchemical Journal, v. 27 , no. 3, p. $429-432$.

English.

Degradation Products,Hydrolysis/Chemical Reactions. CA98(1):4521s.

Cappadona, C., Guarino, P., Calderaro, E., Petruso, S., and Ardica, S., 1975, Radiation for Clean Environment, Proceedings of the International Symposium, p. 265-284. Engtish. Hydrolysis/Chemical Reactions. CA86(6):33764f.

Carstea, M., Dragusin, E., Bader, B., and Nica, C., 1983, Chloro(alkylamino)-s-triazines: Appl. 103543, 27 Feb 1981.

Romanian.

Hydrolysis/Chemical Reactions.

CA102(7):62279f.

Chen, J. T., 1967, Infrared absorption spectra and polymeric structures of three s-triazine herbicides and their metabolites: Journal of the Association of Official Analytical Chemists, v. 50, no. 3, p. 595-600.

English.

Degradation Products, Chemical/Physical Properties. CA67(13):63556q.

Colby, T. H., Freitas, E. R., and Durland, W. R, 1979, Substituted triazine: US Appl. 871656, 23 Jan 1978. English.

Hydrolysis/Chemical Reactions,Degradation Products. CA92(9):76558h.

Cosma, N., Gherghina, I., Tincu, L. N., Dragos, C., Velea, S., Oprea, C., and Stepan, E., 1979, 2-Chloro-4-ethylamino-6isopropylamino-s-triazine: Appl. or Pr. 89640, 10 Mar 1977. Romanian.

Hydrolysis/Chemical Reactions.

CA95(1):7347p.

Costache, S., Dejan, O., Dejan, M., Visan, D., and Dedu, M., 1978, Chloroamino-s-triazines: Appl. or Pr. 76001, 6 Sep 1973.

Romanian.

Hydrolysis/Chemical Reactions.

CA92(23):198429n.

Dacy, Z., 1987, Predesign studies of the incineration of pesticide in the Biprowod pilot plant in Zabrze: Zeszyty Naukowe Politechniki Slaskiej, Energetyka, v. 97, p. 161-170. Polish.

Hydrolysis/Chemical Reactions.

CA109(20):175682v.
Demovic, S., Babik, V., and Hauskrecht, P., 1986, Method of purifying 2-isopropylamino-4-ethylamino-6-chloro-s-triazine: Appl. 83/232643 B1, 15 Dec 1986, 3 p.

Slovenian.

Hydrolysis/Chemical Reactions.

CA107(23):217652b.

Dovlatyan, V. V., Eliazyan, K. A., and Kazaryan, E. A., 1987, Some transformations of sym-triazinyl oxyamines: Armyanskii Khimicheskii Zhurnal, v. 40, no. 12, p. 749-755.

Russian.

Hydrolysis/Chemical Reactions.

CA110(3):23842e.

Foye, W. O., Abood, N., Kauffman, J. M., Kim, Y.-H., and Patel, B. R., 1980, A direct synthesis of heterocyclic thiols: Phosphorus Sulfur, v. 8, no. 2, p. 205-207.

English.

Hydrolysis/Chemical Reactions.

CA93(25):239367g.

Freiberg, R, and Bulka, E., 1985, Synthesis of 2,4bis < alkyi(aryl)amino > -6-(cyanoamino)-1,3,5-triazines: Journal fuer Praktische Chemie, v. 327, no. 3, p. 471-478. German.

Hydrolysis/Chemical Reactions,Degradation Products. CA104(9):68822r.

Gamble, D. S., Khan, S. U., and Tee, O. S., Oct 1983, Atrazine hydrolysis. I. Proton catalysis at 25 degrees C: Pesticide Science, v. 14, no. 5, p. 537-545.

English.

Hydrolysis/Chemical Reactions.

CA100(1):2103t.

Gamble, D. S., and Khan, S. U., 1985, Atrazine hydrolysis in soils: catalysis by the acidic functional groups of fulvic acid: Canadian Journal of Soil Science, v. 65 , no. 3, p. 435443.

English.

Associations with Humic Material,Hydrolysis/Chemical Reactions.

CA103(21):173931c.

Gamble, D. S., and Khan, S. U., 1988, Atrazine hydrolysis in aqueous suspensions of humic acid at 25 degrees $\mathrm{C}$ : Canadian Journal of Chemistry, v. 66, no. 10, p. 2605-2617.

English.

Hydrolysis/Chemical Reactions.

CA109(23):206672y.

Giannopolitis, G. N., and Ries, S. K., 1977, In vitro production of superoxide radical from paraquat and its interactions with monuron and diuron: Weed Science, v. 25, no. 4, p. 298-303. English. Hydrolysis/Chemical Reactions. CA87(21): $162644 \mathrm{~m}$.

Gontarz, Z, and Podsiadlo, S., 1984, Stages of reaction between boron oxy compounds and compounds of the urea group. Part $I$. Classification and reaction stages of the synthesis of boron nitride with the use of urea, biuret and dicyandiamide: Polish Journal of Chemistry, v. 58, no. 1-2-3, p. 3-11. English. Degradation Products,Hydrolysis/Chemical Reactions. CA102(14):124446u. 
Gorski, A., and Podsiadlo, S., 1984, Stages of reaction between boron oxy compounds and compounds of the urea group. Part II. Stages of boron nitride synthesis triuret and striazines and general scheme of the processes: Polish Journal of Chemistry, v. 58, no. 1-2-3, p. 13-21.

English.

Degradation Products,Hydrolysis/Chemical Reactions. CA102(14):124447v.

Goswami, K. P., and Green, R. E., 1971, Microbial degradation of the herbicide atrazine and its 2-hydroxy analog in submerged soils: Environmental Science and Technology, v. 5, no. 5, p. 426-429.

English.

Degradation Products,Biodegradation/Biotransformation, Sorption to Soil,Surfacewater Observations,Hydrolysis/ Chemical Reactions.

CA74(25):139847c.

Grayson, B. T., 1980, Hydrolysis of cyanazine and related diaminochloro-1,3,5-triazines. Part II. Hydrolysis in sulfuric acid solutions: Pesticide Science, v. 11, no. 5, p. 493-505.

English.

Degradation Products,Hydrolysis/Chemical Reactions. CA94(21):173869j.

Grayson, B. T., 1986, Hydrolysis of cyanazine in aqueous solutions of weak acids: Pesticide Science, v. 17, no. 4, p. 363-379.

English.

Hydrolysis/Chemical Reactions. CA105(19):166873y.

Gromova, T. I., Lyubarskii, M. V., and Sukhanova, T. G., 1984, Heats of combustion and formation of sym-triazine derivatives: Zhumal Fizicheskoi Khimii, v. 58, no. 6, p. 1556-1558.

Russian.

Degradation Products, Chemical/Physical Properties, Hydrolysis/Chemical reactions. CA101(10:79448n.

Hance, R. J., 1967, Decomposition of herbicides in the soil by nonbiological chemical process: Joumal of the Science of Food Agriculture, v. 18, no. 11, p. 544-547.

English.

Hydrolysis/Chemical Reactions.

CA68(5):21105g.

Harris, A. F., 1977, Stabilizers of nitrile polymers using triazine derivatives: Appl. or Pr. 719806, 2 Sep 1976. English.

Hydrolysis/Chemical Reactions.

CA88(4):23859t.

Hauskrecht, P., Husar, S., Fancovic, K., Zeljazkov, V., and Vlachynsky, I., 1987, Preparation of 2-isopropylamino-4 ethylamino-6-rhloro-s-triazine (i.e., atrazine) as a herbicide: Appl. 83/3401, 16 May 1983.

Slovenian.

Hydrolysis/Chemical Reactions.

CA109(7):54793y.
Hiltbold, A. E., and Buchanan, G. A., 1977, Influence of soil pH on persistence of atrazine in the field: Weed Science, v. 25, no. 6 , p. 515-520.

English.

Biodegradation/Biotransformation,Hydrolysis/Chemical

Reactions.

CA88(11):70384u.

Honda, I., and Shimomura, Y., 1983, Synthesis of 2,4-diamino-1,3, 5-triazines: Fukui Daigaku Kogakubu Kenkyu Hokoku, v. 31, no. 1, p. $19-26$.

Japanese.

Hydrolysis/Chemical Reactions.

CA99(19):158387k.

Honda, I., Unishi, T., Hashimoto, Y., and Shimomura, Y., 1980, Syntheses and oxidation of hydrazino-1,3,5-triazines. V.

Reactions of chloro-1,3,5-triazines with arylhydrazines:

Kenkyu Hokoku - Asahi Garasu Kogyo Gijutsu Shoreikai, v. 36, p. 153-167.

Japanese.

Degradation Products,Hydrolysis/Chemical Reactions.

CA95(9):80899.

Hopkins, T. R., Neighbors, R. P., and Phillips, L. V., 1967, Synthesis and herbicidal activity of small-ring compounds: Journal of Agriculture and Food Chemistry, v. 15, no. 3, p. 501-507.

English.

Hydrolysis/Chemical Reactions. CA67(13):63888z.

Janicke, W., 1983, Chemical oxidizability of organic components in water. WaBolu Bericht, no. 1, p. 114 pp..

German.

Hydrolysis/Chemical Reactions.

CA100(2):12290r.

Janzowski, C., Klein, R, and Preussmann , R, 1980, Formation of $\mathrm{N}$-nitroso compounds of the pesticides atrazine, simazine and carbaryl with nitrogen oxides: IARC Science Publication, $v$. 31, no. N-Nitroso Compd.: Anal., Form. Occurrence, p. 329-339. English.

Hydrolysis/Chemical Reactions,Degradation Products. CA95(9):74984g.

Janzowski, C., Klein, R, Preussmann, R, and Eisenbrand, G., 1983, Nitrosamin-Problem, Bericht uebr das AbschlusskoHoquium der Senatskommission zur Pruefung von Lebensmitte Izusatz-und-Inhaltsstoffen zum Schwerpunktprogramm "Analytik und Entstehung von N-Nitroso-Verbindungen", Bonn, 1982, p. 245-254.

German.

Hydrolysis/Chemical Reactions.

CA100(23):187315e.

Joshi, O. P., Sachdev, M. S., Sahrawat, K. L., and Kohli, B. N., Apr 1976, Effect of simazine and atrazine on the mineralization of fertilizer and manure nitrogen: Plant and Soil, v. 44, no. 2, p. 367-375.

English.

Hydrolysis/Chemical Reactions, Toxicity. CA85(3):19749c. 
ENVIRONMENTAL PROCESSES

TRANSFORMATION PROCESSES

Hydrolysis/Chemical Reactions

Jursinic, P. A., and Pearcy, R. W., 1988, Determination of the rate limiting step for photosynthesis in a nearly isonuclear rapeseed (Brassica napus L.) biotype resistant to atrazine: Plant Physiology, v. 88, no. 4, p. 1195-1200.

English.

Hydrolysis/Chemical Reactions. CA110(9):72693r.

Karlik, V. M., and Zagranichnyi, V. I., 1971, Hydrolysis of triazines suitable for purifying waste waters from melamine production: Khimycheskaya Promyshlennost (Moscow), v. 47, no. 10, p. $784-785$.

Russian.

Hydrolysis/Chemical Reactions.

CA75(26): $154805 b$.

Karlik, V. M., and Zagranichnyi, V. I., 1971, Kinetics of the hydrolysis of triazines. Hydrolysis of melamine, ammeline, and ammelide: Zhumal Vsesoyuznogo Khimicheskogo Obshchestva, v. 16 , no. 1 , p. 116 .

Russian.

Hydrolysis/Chemical Reactions,Degradation Products. CA74(25): 140431u.

Kearney, P. C., Muldoon, M. T., Somich, C. J., Ruth, J. M., and Voaden, D. J., 1988, Biodegradation of ozonated atrazine as a wastewater disposal system: Journal of Agriculture and Food Chemistry, v. 36, no. 6, p. 1301-1306.

English.

Biodegradation/Biotransformation, Wastewater Observations, Hydroiysis/Chemical Reactions.

CA109(22):196446m.

Kearney, P. C., Zeng, Q., and Ruth, J. M., 1984, A large scale UV-ozonation degradation unit. Field trials on soil pesticide waste disposal: American Chemical Society, Symposium Series, v. 259, no. Treatment and Disposal of Pesticide Wastes, p. 195-209.

English.

Hydrolysis/Chemical Reactions,Sorption to Soil. CA101(25):224806j.

Kennedy, M. V., Stojanovic, B. J., and Shuman, F. L., Jr., 1972 , Chemical and thermal aspects of pesticide disposal: Journal of Environmental Quality, v. 1, no. 1, p. 63-65.

English.

Hydrolysis/Chemical Reactions.

CA76(13):69170s.

Kennedy, M. V., Stojanovic, B. J., and Shuma, F. L., Jr., 1972, Analysis of decomposition products of pesticides: Journal of Agriculture and Food Chemistry, v. 20, no. 2, p. 341-343. English.

Analytical Techniques/Quantification,Hydrolysis/Chemical Reactions. CA77(1):1629p.

Kennedy, M. V., Stojanovic, B. J., and Shuman, F. L., Jr., 1969, Chemical and thermal methods for disposal of pesticides: Residue Reviews, v. 29, p. 89-104.

English.

Hydrolysis/Chemical Reactions.

CA72(11):53996x.
Khan, S. U., 1978, Kinetics of hydrolysis of atrazine in aqueous fulvic acid solution: Pesticide Science, v. 9, no. 1, p. 3943.

English.

Hydrolysis/Chemical Reactions,Associations with Humic Material. CA89(1):1604z.

Khmel'nitskaya, E. Y., 1977, Polarography of s-triazine series compounds. III. Mechanism of the electrochemical reduction of arylaminochlorotriazines: Zhurnal Obshchei Khimii, v. 47, no. 5, p. 1158-1165.

Russian.

Hydrolysis/Chemical Reactions,Degradation Products. CA87(13): 101655 u.

Kollar, T., Bacaloglu, R, and Safta, M., 1979, Syntheses of formaldehyde stabilizers: Bulletinul Stiintific si Tehnic al Insticutului Politehnic "Traian Vuia" Timisoara, Seria Chimie, v. 24, no. 1, p. 97-101

German.

Hydrolysis/Chemical Reactions,Degradation Products. CA95(15):132822r.

Larson, R. A, and Zepp, R. G., 1988, Reactivity of the carbonate radical with aniline derivatives: Environmental Toxicology and Chemistry, v. 7, no. 4, p. 265-274.

English.

Hydrolysis/Chemical Reactions. CA109(1):1958z.

Legube, B., Guyon, S., and Dore, M., 1987, Ozonation of aqueous solutions of nitrogen heterocyclic compounds: benzotriazoles, atrazine and amitrole: Ozone: Science and Engineering, v. 9, no. 3, p. 233-246. English.

Hydrolysis/Chemical Reactions. CA108(14):118590u.

Li, G. C, and Felbeck, G. T., Sept 1972, Atrazine hydrolysis as catalyzed by humic acids: Soil Science, v. 114, no. 3, p. 201-209.

English.

Hydrolysis/Chemical Reactions,Associations with Humic Material. CA77(23): $150971 w$.

Lykins, B. W., Jr., Koffskey, W. E., and Miller, R. G., 1986, Chemical products and toxicologic effects of disinfection: Journal - American Water Works Association, v. 78, no. 11, p. 66-75.

English.

Hydrolysis/Chemical Reactions.

CA105(26):232130g.

Mallevialle, J., Bruchet, A, and Schmitt, E., 1984, Nitrogenous organic compounds: identification and significance in several French water treatment plants: Proceedings - American Water Works Association, Water Quality Technology Conference, 11 th, v. 11, p. 83-96.

English.

Hydrolysis/Chemical Reactions, Observations in Drinking Water. CA102(14):119308w. 
ENVIRONMENTAL PROCESSES

TRANSFORMATION PROCESSES

Hydrolysis/Chemical Reactions

Mansour, M., Moza, P. N., Barlas, H., and Parlar, H., 1985, Photostability of environmental organic chemicals in the presence of hydrogen peroxide in an aqueous medium: Chemosphere, v. 14, no. 10, p. 1469-1474.

\section{German.}

Hydroiysis/Chemical Reactions.

CA104(4):23928p.

Marchidan, S., 1977, Polarographic reduction of some s-triazine herbicides: Revue Roumaine de Chimie, v. 22, no. 1, p. 127 132.

English.

Hydrolysis/Chemical Reactions.

CA87(11):79443z.

McCracken, P. G., Myatt, H., and Petree, H. E., 1981, Causticfree process for monochloro-diamino-s-triazines: Appl. 118375, 4 Feb 1980; US Appl. 753032, 22 Dec 1976; US Appl. 933375, 14 Aug 1978; US Appl. 48868, 15 Jun 1979.

English.

Degradation Products,Hydrolysis/Chemical Reactions.

CA96(3):20129j.

Messori, V., 1980, Chloro-bis(alkylamino)-S-triazines: Appl. or Pr. 484109, 12 Sep 1979.

Spanish.

Hydrolysis/Chemical Reactions.

CA93(23):220787x.

Messori, V., Esposito, R, and Francese, R, 1981, Chlorobis(allylamino)-s-triazines: Appl. or Pr. 79/7293, 12 May 1981, 27 p.

Portuguese.

Hydrolysis/Chemical Reactions.

CA95(17):150712j.

Messori, V., and Francese, R, 1980, Chloro-bis(alkylamino)-striazines: IT Appl. 78/28219, 29 Sep 1978.

English.

Hydrolysis/Chemical Reactions, Chemical/Physical Properties. CA94(11):84177q.

Messori, V., Francese, R, and Esposito, R, 1981, Chlorobis(alkylamino)-s-triazines: Appl. 79/23587, 21 Sep 1979.

French.

Hydrolysis/Chemical Reactions.

CA96(1):6765g.

Mildner, P., Mihanovic, B., and Poje, M., 1973, Synthesis of di(s-triazinyl) sulfides and disulfides. Promoting effect of oxidants on the cleavage of the thioether bond: Croatica Chemica Acta, v. 45, no. 3, p. 489-494.

English.

Hydrolysis/Chemical Reactions.

CA80(11):59918k.

Miller, R. A., and Swientoniewski, M. D., 1983, The destruction of various organic substances by a catalyzed wet oxidation process: U.S. Environmental Protection Agency, Office of Research and Development, EPA-600/9-83-003, In 213-221. English.

Hydrolysis/Chemical Reactions.

CA100(16):126399p.
Moldovan, I. V. Florian, Dejan, O., Tincu, L V., Defan, M., and Dobrin, E., 1980, Industrial production of aminochloro-striazines in an aqueous medium: Appl. 74826, 18 May 1973. Romanian.

Hydrolysis/Chemical Reactions.

CA96(19):162746g.

Morita, E., 1983, Prevulcanization inhibitors of thio-triazineamines for rubber: Appl. 312572, 19 Oct 1981.

English.

Hydrolysis/Chemical Reactions.

CA99(2):6771t.

Nita, T., Porosnicu, G., Stoian, T., Gonciulea, I., and Popescu, M., 1976, 2-Chloro-4-ethylamino-6-isopropylamino-s-triazine: Appl. or Pr. 69351, 11 Jan 1972.

Romanian.

Hydrolysis/Chemical Reactions.

CA89(5):43513z.

Obokata, J., 1987, Synthesis of an atrazine-binding protein of the PSII reaction center in isolated wheat etiochloroplasts: Plant Cell Physiology, v. 28, na. 6, p. 1167-1171.

English.

Hydrolysis/Chemical Reactions.

CA107(19):172742n.

Paris, D. F., and Lewis, D. L., 1973, Chemical and microbial degradation of ten selected pesticides in aquatic systems: Residue Reviews, v. 45, p. 95-124.

English.

Hydrolysis/Chemical Reactions,Biodegradation/

Biotransformation.

CA79(21):122470e.

Pelizzetti, E., Minero, C., Pramauro, E., Barbeni, M., Maurino, V., and Tosato, M., 1987, Photocatalytic degradation of atrazine at ppb levels under solar light and in the presence of titania particles: Chimia e l'Industria (Milan), v. 69, no. 10 , p. $88-89$.

English.

Hydrolysis/Chemical Reactions.

CA108(2):10930r.

Penner, D., and Earty, R. W., 1972, Role of pH in the observed effect of plant growth regulators on DNA: Phytochemistry, $v$. 11, no. 11, p. 3135-3138.

English.

Hydrolysis/Chemical Reactions.

CA78(15):93483h.

Perdue, E. M., 1983, Aquatic and Terrestrial Humic Materials, (Selected Papers from the Symposium), 1981, p. 441-460. English.

Hydrolysis/Chemical Reactions,Field Residuals,Associations with Humic Materiat.

CA98(15):124787e.

Petkova, R. A., 1972, DCMU <N-(3,4-dichlorophenyl-N,N'dimethylurea) $>$ and atrazine dependent photoreduction in chloroplast suspensions: Doklady Bolgarskoi Akademii Nauk, v. 25, no. 7, p. $985-988$.

English.

Hydrolysis/Chemical Reactions.

CA78(5):25273q. 
ENVIRONMENTAL PROCESSES

TRANSFORMATION PROCESSES

Hydrolysis/Chemical Reactions

Petrovskaya, Z V., Boitsov, B. N., Brudnik, B. M., and Gazizov, R.T., 1985, Preparation of sewage waters from triazine production for underground disposal: Khimiya i Tekhnologiya Vody, v. 7, no. 1, p. 50-51.

Russian.

Hydrolysis/Chemical Reactions, Wastewater Observations. CA102(26):225478m.

Petukhova, N. P., Sergeeva, V. P., and Prilezhaeva, E. N., 1986, Reaction of chlorosym-triazines with thioacetic acid:

Izvestiya Akademii Nauk Moldavskoi SSSR, Seriya Khimichesikh Nauk, no. 6, p. 1432-1434.

Russian.

Hydrolysis/Chemical Reactions.

CA106(15):119852b.

Pilgram, K. H., and Gale, L. H., 1988, Synthesis and structure determination of $\mathrm{N}$-(alkoxycarbonylsulfenyi)-s-triazine herbicides: Journal of Heterocyclic Chemistry, v. 25, no. 1, p. 193-200.

English.

Hydrolysis/Chemical Reactions.

CA109(19):170385r.

Plimmer, J. R, Kearney, P. C, and Klingebici, U. I., 1971, sTriazine herbicide dealkylation by free-radical generating systems: Journal of Agriculture and Food Chemistry, v. 19, no. 3, p. 572-573.

English.

Degradation Products,Hydrolysis/Chemical Reactions. CA75(3):1906\%

Plust, S. J., Loehe, J. R., Feher, F. J., Benedict, J. H., and Herbrandson, H. F., 1981, Kinetics and mechanism of hydrolysis of chloro-1,3,5-triazines. Atrazine: Journal of Organic Chemistry, v. 46, no. 18, p. 3661-3665.

English.

Hydrolysis/Chemical Reactions.

CA95(11):96485x.

Renger, G., Fromme, R, and Hagemann, R, 1988, The modification of atrazine binding by the redox state of the endogenous high-spin iron and by specific proteolytic enzymes in photosystem II membrane fragments and intact thylakoids: Biochimica et Biophysica Acta, v. 935, no. 2, p. 173-183. English.

Chemical/Physical Properties,Hydrolysis/Chemical Reactions. CA109(21):187528n.

Richard, Y., and Brener, L., 1984, Removal of pesticides from drinking water with ozone: (s1Sin(s0S Handbook of ozone technolugy and applications: Boston, Massachusetts, Ann Arbor Science, p. 77-97.

English.

Observations in Drinking Water,Hydrolysis/Chemical Reactions.

Rubin, B., Leavitt, J. R. C., Penner, D., and Saettler, A. W., 1980 , Interaction of antioxidants with ozone and herbicide stress: Bulletin of Environmental Contamination and Toxicology, v. 25, no. 4, p. 623-629.

English.

Hydrolysis/Chemical Reactions.

CA94(11):780136.
Ruzo, L. O., Zabik, M. J., and Schuetz, R. D., 1973, Photochemistry of bioactive compounds. Kinetics of selected s-triazines in solution: Journal of Agricultue and Food Chemistry, v. 21, no. 6, p. 1047-1049.

English.

Hydroiysis/Chemical Reactions.

CA80(3):11140y.

Sapozhnikov, Y. E., Yasman, Y. B., Sukhanova, T. G., and Danilov, V. A., 1984, Electronic effects in chlorine-containing heterocyclic compounds. 1. Amino derivatives of 2,4,6trichloro-1,3,5-triazine: Organic Reactivity (Tartu), v. 21, no. 4 , p. $441-448$.

English.

Chemical/Physical Properties.

CA105(3):23852e.

Saul, G. A., and Eckert, R. J., Jr., 1972, Suppression of tris(alkylamino)-s-triazine formation in the production of chloro bis(alkylamino)-s-triazines through adjustment of $\mathrm{pH}$ : Appl. or pr. 102,737, 30 Dec 1970.

English.

Hydrolysis/Chemical Reactions.

CA77(19):126695p.

Sheradsky, T., Salemnick, G., and Nir, Z, 1972, Introduction of the aminooxy group onto nitroaromatic and heterocyclic rings. Synthesis and properties of $\mathrm{O}$-(nitroaryl)hydroxylamines: Tetrahedron, v. 28, no. 14, p. 3833-3843.

English.

Hydrolysis/Chemical Reactions. CA77(11):74992m.

Sirons, G. J., Frank, R, asd Sawyer, T., November/December 1973, Residues of atrazine, cyanazine, and their phytotoxic metabolites in a clay loam soil: Journal of Agricultural and Food Chemistry, v. 21, no. 6, p. 1016-1020.

English.

Field Residuals,Degradation Products,Sorption to Soil, Biodegradation/Biotransformation,Hydrolysis/Chemical Reactions.

Skipper, H. D., Gilmour, C. M., and Furtick, W. R, 1967, Microbial versus chemical degradation of atrazine in soils: Soil Science Society of America, Proceedings, v. 31, no. 5, p. $653-656$.

English.

Hydrolysis/Chemical Reactions,Biodegradation/Biotransformation. CA68(5):21119q.

Skipper, H. D., and Volk, V. V., 1972, Biological and chemical degradation of atrazine in three Oregon soils: Weed Science, v. 20 , no. 4 , p. $344-347$.

English.

Hydrolysis/Chemical Reactions,Biodegradation/Biotransformation. CA77(17):113114y.

Skipper, H. D., Volk, V. V., and Frech, R., 1976, Hydrolysis of a chloro-s-triazine herbicide: Journal of Agriculture and Food Chemistry, v. 24, no. 1, p. 126-129.

English.

Hydrolysis/Chemical Reactions. CA84(9):55296r. 
Skipper, H. D., Volk, V. V., Mortland, M. M., and Raman, K. V., 1978, Hydrolysis of atrazine on soil colloids: Weed Science, v. 26 , no. 1 , p. $46-51$.

English.

Hydrolysis/Chemical Reactions,Associations with Humic Material.

CA90(13):98546p.

Skipper, H. D., 1970, Hydrolysis and biological degradation of atrazine in soils, Dissertation submitted in partial fulfillment of $\mathrm{Ph} . \mathrm{D}$. requirements, Oregon State University, Corvallis, Oregon, USA.

English.

Hydrolysis/Chemical Reactions,Biodegradation/Biotransformation. CA74(1):2900v.

Solinas, V., Gessa, C., Melis, P., Franco, M. A., and Sabbatini, M., 1983, Fixation of hydroxy-atrazine on homionic clay surface during hydrolysis of atrazine: Agrochimica, v. 27, no. 5-6, p. 464-473.

English.

Hydrolysis/Chemical Reactions,Sorption to Soil. CA102(1):1870v.

Supin, G. S., Mel'nikova, I. A., Bykhovskaya, T. N., and Mel'nikov, N. N., 1974, Reduction of 2-chloro-4-(ethylamino)6-(isopropylamino)-s-triazine on a mercury electrode: Zhumal Obshchei Khimii, v. 44, no. 5, p. 1208.

Russian.

Hydrolysis/Chemical Reactions.

CA81(10):57565q.

Sweeny, K. H., 1981, The reductive treatment of industrial wastewaters. II. Process applications: AIChE Symposium Series, v. 77 , no. 209 , p. $72-78$.

English.

Hydrolysis/Chemical Reactions.

CA96(8):57210e.

Sweeny, K. H., 1980, Treatment of a reducible hydrocarboncontaining aqueous stream: Appl. 780849, 24 March 1977. English.

Hydrolysis/Chemical Reactions, Wastewater Observations. CA94(16):126851n.

Takasu, L, Murata, J., Yoko, H., and Suzuki, A., 1977, 2-Chloro4,6-disubstituted-s-triazines: Appl. or Pr. 76/48752, 27 Apr 1976.

Japanese.

Hydrolysis/Chemical Reactions.

CA88(15):105422j.

Takic, Z. D., and Ries, S. K., 1971, Thermal and ultrasonic dealkylation of s-triazines via the cyclic transition state: Journal of Agriculture and Food Chemistry, v. 19, no 1, p. 46-49.

English.

Degradation Products,Hydrolysis/Chemical Reactions. CA74(9):38271e.
Tincu, V. L., Oprea, C., Velea, S., Dragos, C. E., Stepan, E., Caravaniez, D. M., Zugravescu, M., and Zaharia, E. M., 1979, Methoxydialkylamino-s-triazines: Appl. or Pr. 90390, 19 May 1977.

Romanian.

Degradation Products,Hydrolysis/Chemical Reactions. CA9S(3):25144z.

Trebst, A., Depka, B., Kraft, B., and Johanningmeier, U., 1988, The QB site modulates the conformation of the photosystem II reaction center polypeptides: Photosynthesis Research, v. 18, no. 1-2, p. 163-177.

English.

Hydrolysis/Chemical Reactions.

CA109(23):208519c.

Truchlik, S., Splhacek, R., Muchova, J., Paldan, M., and Mostecky, J., 1987, Production of stable mixture of striazines as herbicides physico-chemically stable mixture production: Appl. 84?1455, 1 Mar 1984.

Slovenian.

Hydrolysis/Chemical Reactions,Degradation Products. CA108(13):108168y.

Turcu, S., Cirstea, M., Chivulescu, E., and Dragusin, E., 1978 , Thermal decomposition of 2-substituted 4,6-bis(alkylamino)striazines: Revista de Chimie (Bucharest), v. 29, no. 2, p. 109-113.

Romanian.

Hydrolysis/Chemical Reactions,Analytical Techniques/ Quantification.

CA89(13):107554y.

Ungvarsky, C., Macko, J., Michalek, M., Hutar, E., and Mueller, Z, 1976, Herbicidal 2-alkoxy-4,6-bis-(alkylamino)-triazines: Appl. or Pr. 74/927, 11 Feb 1974. Hydrolysis/Chemical Reactions. CA86(25):190015e.

Veselinovic, D., Markovic, D., and Besic, B., 1985, Rad. Jugosl. Simp. Elektrohem., 9 th, p. 429-432.

Serbo-Croatian.

Hydrolysis/Chemical Reactions.

CA108(1):5377m.

Violova, A., Hauskrecht, P., Antalova, O., and Dubalaj, J., 1986, Isolation of 2-(isopropylamino)-4-(ethylamino)-6-chloro-striazine: Appl. 82/9125, 14 Dec 1982.

Slovenian.

Hydrolysis/Chemical Reactions,Analytical Techniques/

Quantification.

CA106(1):5089c.

Violova, A., Hauskrecht, P., Antalova, O., Dubalaj, J., and Cerny, P., 1986, Isolation of 2-(isopropylamino)-4(ethylamino)-6-chloro-s-triazine: Appl. 82/9126, 14 Dee 1982. Slovenian.

Analytical Techniques/Quantification,Hydrolysis/Chemical Reactions.

CA106(1):5090w. 
ENVIRONMENTAL PROCESSES

TRANSFORMATION PROCESSES

Hydrolysis/Chemical Reactions

White, J. L., 1975, Determination of susceptibility of s-triazine herbicides to protonation and hydrolysis by mineral surfaces: Archives of Environmental Contamination and Toxicology, v. 3, no. 4, p. 461-469.

English.

Hydrolysis/Chemical Reactions,Sorption to Soil.

CA85(1):1054n.

White, J. L., 1976, Proceedings of the International Clay Conference, 1975, p. 391-398.

English.

Hydrolysis/Chemical Reactions.

CA85(23):172779g.

Wojtowicz, J. A., 1977, Trichloroisocyanuric acid from selected symmetrical triazines: Appl. or Pr. 699825, 25 Jun 1976. English.

Degradation Products,Hydrolysis/Chemical Reactions. CA88(5):37846y.

Wolfe, N. L., Zepp, R. G., Baughman, G. L., Fincher, R. C., and Gordon, J. A., 1976, Chemical and photochemical transformation of selected pesticides in aquatic systems: U.S. NTIS, PB Rep., PB-258846, 153 p.

English.

Hydrolysis/Chemical Reactions,Photolysis, Wastewater

Observations.

CA86(23):166378e.

Wolfe, N. L., Zepp, R. G., Gordon, J. A., and Fincher, R. C., Mar 1976, N-nitrosamine formation from atrazine: Bulletin of

Environmental Contamination and Toxicology, v. 15, no. 3, p. 342-347.

English.

Degradation Products,Biodegradation/Biotransformation, Hydrolysis/Chemical Reactions.

CA85(9):57729d. 
Acher, A. J., 1985, Sunlight photooxidation of organic pollutants in wastewater. Water Science and Technology, v. 17, no. 4/5, p. 623-632.

English.

Photolysis.

Burkhard, N., and Guth, J. A., 1976, Photodegradation of atrazine, atraton and ametryne in aqueous solution with acetone as a photosensitizer. Pesticide Science, v. 7, no. 1, p. 65-71.

English.

Photolysis.

CA85(7):42046e.

Chen, Z., 1985, Comparative study on photodegradative rates of 35 pesticides: Huanjing Kexue Xuebao, v. 5, no. 1, p. 70-84.

Chinese.

Photolysis.

CA103(11):83496k.

Chen, Z., Zabik, M. J., and Leavitt, R. A., 1984, Comparative study of thin film photodegradative rates for 36 pesticides: Industrial and Engineering Chemistry Product Kesearch and Development, v. 23, no. 1, p. 5-11.

English.

Photolysis.

CA100(11):81216h.

Gore, R. C., Hannah, R. W.: Pattacini, Silvio C., and Porro, T. J., 1971, Infrared and ultraviolet spectra of seventy-six pesticides: Journal of the Association of Official Analytical Chemists, v. 54, no. 5, p. 1040-1082.

English.

Photolysis, Chemical/Physical Properties. CA75(19):117202g.

Hustert, K., Kotzias, D., and Korte, F., 1983, Photocatalytic decomposition of organic compounds on titanium dioxide: Chemosphere, v. 12, no. 1, p. 55-58.

German.

Photolysis.

CA98(14):1130792.

Kempny, J., Kotzias, D., and Korte, F., 1981, Reaction of atrazine in an adsorbed phase with UV radiation: Chemosphere, v. 10 , no. 5 , p. $487-490$.

German.

Photolysis.

CA95(7):563632.

Khan, S. U., and Schnitzer, M., 1978, UV irradiation of atrazine in aqueous fulvic acid solution: Journal of Environmental Science and Health, Part B, v. B13, no. 3, p. 299-310.

English.

Associations with Humic Material,Photolysis. CA89(21):174935m.

Kotzias, D., Nitz, S., and Korte, F., 1981, Light-induced total decomposition of an organic molecule adsorbed on silica ge!: Chemosphere, v. 10, no. 4, p. 415-422.

German.

Photolysis.

CA9S(7):61011n.
Kotzias, D., Parlar, H., and Korte, F., 1982, Photoreactivity of organic chemicals in water in the presence of nitrate and nitrite: Naturwissenschaften, v. 69, no. 9, p. 444-445.

German.

Photolysis.

CA97(25):2151902.

Lotz, F., Kempny, J., and Graells de Kempny, R. S., 1983, Lightinduced decomposition of adsorbed chemicals. A simple device for comparative studies: Chemosphere, v. 12, no. 6, p. 873878.

German.

Photolysis.

CA99(9):65750h.

Mansour, M., Hustert, K, and Korte, F., 1981, Observations with test methods for determining the photostability of organic compounds in a gas phase: Chemosphere, v. 10, no. 11-12, p. $1275-1280$.

German.

Photolysis.

CA96(9):68142k.

Pape, B. E., and Zabik, M. J., 1970, Photochemistry of bioactive compounds. Photochemistry of selected 2-chloro- and 2methylthio-4,6-di(alkylamino)-S-triazine herbicides: Journal of Agriculture and Food Chemistry, v. 18, no. 2, p. 202-207. English.

Photolysis,Degradation Products. CA72(21):110111f.

Pape, B. E., and Zabik, M. J., 1972, Photochemistry of bioactive compounds. Solution-phase photochemistry of symmetrical triazines: Journal of Agriculture and Food Chemistry, v. 20, no. 2, p. 316-320.

English.

Photolysis.

CA76(19):112384d.

Rejto, M., Saltzman, S., Acher, A. J., and Muszkat, L., 1983, Identification of sensitized photooxidation products of striazine herbicides in water. Journal of Agriculture and Food Chemistry, v. 31, no. 1, p. 138-142.

English.

Degradation Products, Photolysis.

CA98(5):29596h.

Takimoto, M., 1982, Studies of: Nippon Kagaku Kaishi, no. 4, p. 662-669.

Japanese.

Photolysis, Degradation Products. CA97(9):72331j.

Takimoto, M., Funakawa, T., Shiba, R., and Tajima, M., 1982, Studies of hydroxymethylation of ammeline, ammelide, melam, and melem by ultraviolet spectroscopy: Nippon Kagaku Kaishi, no. 4, p. $662-669$.

Japanese.

Photolysis, Run-off. CA97(9):72331j. 
Tanaka, F. S., Wien, R. G., and Mansager, E. R., 1981, Survey for surfactant effects on the photodegradation of herbicides in aqueous media: Journal of Agriculture and Food Chemistry, v. 29 , no. 2, p. $227-230$.

English.

Associations with Surfactants, Photolysis. CA94(17):133968j.

Taran, P. N., Vakulenko, V. F., Grechko, A. V., Shevchenko, M. A, and Goncharuk, V. V., 1988, Simplified technology for removal of pesticides from wastewaters: Khimiya i

Tekhnologiya Vody, v. 10, no. 6, p. 542-544.

Russian.

Sorption to Resins, Wastewater Observations, Photolysis. CA110(14):120579g.

Weintraub, F. P., Vylegzhanina, G. F., Dron, L. P., Keiser, L. S., Nesterova, I. P., and Patrashku, F., 1978, Pathways of pesticide dissipation and decomposition: EPA-600/9-78-003, Symp. Environ. Transp. Transform. Pestic.; PB 280714,140 150, U.S. Environ. Prot. Agency, Off. Res. Devl., (Rep.) EPA. English.

Photolysis.

CA90(3):17654x. 


\section{ENVIRONMENTAL PROCESSES \\ TRANSFER PROCESSES \\ Volatilization}

Atroshchenko, G. P., 1980, Residual amount of pesticides in corn after treatment: Nauchno Transactions of the Leningrade Sel'skogo Khozyaistua institute, v. 389, p. 15-16.

Russian.

Volatilization.

CA95(13):113559u.

Baker, J. L., and Johnson, L. A, 1984, Water and pesticide volatilization from a waste disposal pit: Transactions of the American Society of Agricultural Engineers, v. 27, no. 3, p. 809-816.

English.

Volatilization.

CA101(17):146104n.

Blume, H. P., and Bruemmer, G., 1987, Prediction of the behavior of pesticides in soils by using simple field methods:

Landwirtschaftliche Forschung, v. 40, no. 1, p. $41-50$.

German.

Sorption to Soil,Volatilization,Leaching.

CA108(5):33490m.

Burt, G. W., 1974, Volatility of atrazine from plant, soil, and glass surfaces: Journal of Environmental Quality, v. 3, no. 2, p. 114-117.

English.

Volatilization

CA81(9):46302a.

Businelli, M., Patumi, M., Marucchini, C., and Tafuri, F., 1978 , Atrazine and atrazine metabolite residues in soil and maize: Annali della Facolta di Agraria, University degli Studi di Perugia, v. 32, no. 2, p. 891-901.

Italian.

Degradation Products,Field Residuals, Volatilization. CA92(1):1573a.

Caramete, A., Pintilie, C., Rughinis, D., Diaconu, E., Dumitrescu, M., Cosma, S., Bernaz, G., and Bredt, H., 1977 . 1978, Herbicide residues in plant crops: Lucrari Stiintifice - Institutal Agronomic "Nicolae Balcescu", Bucuresti, Seria A.: Agronomie, v. 20-21, p. 87-97.

Romanian.

Volatilization.

CA93(5):39003y.

Dobbs, A. J., Hart, G. F., and Parsons, A. H., 1984, The determination of vapor pressures from relaxive volatilization rates: Chemosphere, v. 13, no. 5-6, p. 687-692.

English.

Volatilization.

CA101(9):67448z.

Erb, F., Dequidt, J., Pommery, J, Colein, P., and Gontier, C. 1980, Migration of some chlorine- or nitrogen-containing herbicides in a trophodynamic chain in fresh water. Environmental Technology Letters, v. 1, no. 1, p. 58-63. French.

Volatilization,Biodegradation/Biotransformation. CA93(3):20384b.
Hellmann, H., 1987, Model tests on volatilization of organic trace substances in surface waters: Fresenius' Zeitung fuer Analytical Chemistry, v. 328, no. 6, p. 475-479.

German.

Volatilization.

CA107(24):2222919y.

Junk, G. A., and Richart, J. J., 1984, Pesticide disposal sites: sampling and analyses: American Chemical Society, Symposium Series, v. 259, no. Treatment and Disposal of Pesticide Wastes, p. 69-95.

English.

Analytical Techniques/Quantification,Volatilization, Biodegradation/Biotransformation. CA101(25):224803f.

Jury, W. A., Spencer, W. F., and Farmer, W. J., 1984, Behavior assessment model for trace organics in soil: III. Application of screening model: Journal of Environmental Quality, v. 13, no. 4, p. 573-579. English.

Toxicity, Volatilization,Leaching. CA101(25):224814k.

Koch, W., Baumeister, P., and Hurle, K, 1979, Herbizide, p. 72 77.

German.

Volatilization,Biodegradation/Biotransformation. CA93(3):20724n.

Kofman, I. S., 1980, Gas-chromatographic determination of simazine, atrazine, and prometryn when all are present in cultivated plants: Fiziol. Biokhim. Kul't Rast., v. 12, no. 2, p. $198-201$

Russian.

Analytical Techniques/Quantification,Volatilization. CA92(25):210013g.

Kuz'minskaya, V. A., 1981, Translocation of atrazine in plants, pretreated with 2,4-D and its effect on photosynthesis: Izvestiya Timiryazevskoi Sel'skokhozyaistvennoi Akademii, no. 4, p. 95-101.

Russian.

Volatilization.

CA95(11):92243u.

Nalewaja, J. D., and Adamczewski, K. A., 1976, Vaporization and uptake of atrazine with additives: Weed Science, v. 24, no. 2, p. 217-223.

English.

Volatilization,Uptake by Biota. CA84(25):175129k.

Ponomarev, G. S., Luk'yanchenko, A. S., and Nizhko, L. V., 1979, Features of the absorption and movement of triazine herbicides and sodium trichloroacetate in peat soil: Visnik Sir's'kogospodars'koi Nauki, no. 9, p. 16-18.

Ukrainian.

Sorption to Soil, Volatilization.

CA92(13):105699n. 
Scott, H. D., and Phillips, R. E., 1972, Diffusion of selected herbicides in soil: Soil Science Society of America,

Proceedings, v. 36, no. 5, p. 714719.

English.

Sorption to Soil, Volatilization.

CA78(15):93509w.

Sosnovaya, O. N., 1980, Prometryn detoxication by potato and corn plants: Fiziologiya i Biokhimiya Kul'turnykh Rastenii, v. 12, no. 4 , p. $367-370$.

Russian.

Volatilization.

CA93(15):144608x.

Teasdale, J. R., 1985, Avoidance of herbicide injury by placement between rows of polyethylene mulch: HortScience, v. 20, no. 5, p. 871-872.

English.

Run-off, Volatilization.

CA103(23): 191387j.

Walker, A., 1972, Volatility of (14C)-labeled atrazine and linuron from aluminum planchets: Weed Research, v. 12, no. 3, p. 275-278.

English.

Volatilization.

CA78(13):80677z.

West, L. D., Muzik, T. J., and Witters, R. E., 1976, Differential gas exchange responses of two biotypes of redroot pigweed (Amaranthus retroflexus) to atrazine: Weed Science, v. 24, no. 1, p. 68-72.

English.

Volatilization.

CAIN 769022183.

Winterlin, W. L., Schoen, S. R, and Mourer, C. R, 1984, Disposal of pesticide wastes in lined evaporation beds: American Chemical Society Symposium Series, v. 259, no. Treatment and Disposal of Pesticide Wastes, p. 97-116. English.

Volatilization.

CA101(25):224804g. 
Ali, A., and Souza Machado, V., 1984, A comparative analysis of leaf chlorophyll fluorescence, Hill reaction activity and 14C-atrazine tracer studies to explain differential atrazine susceptibility in wild turnip rape (Brassica campestris) biotypes: Canadian Journal of Plant Science, v. 64, no. 3, p. 707-713.

English.

Uptake by Biota,Biodegradation/Biotransformation,Degradation Products.

CA101(21):186049e.

Anliker, R, Moser, P., and Poppinger, D., 1987, Bioaccumulation of dyestuffs and organic pigments in fish. Relationships to hydrophobicity and steric factors: Chemosphere, v. 17, no. 8 , p. $1631-44$.

English.

Uptake by Biota.

CA110(5):34913e.

Anon., 23 Nov 1979, Atrazine: tolerances for residues: Federal Register, v. 44, no. 227, p. 67115-67116.

English.

Uptake by Biota,Degradation Products.

CA92(11):92849j.

Anon., 12 January 1978, Simazine; tolerances for residues:

Federal Register, v. 43, no. 8, p. 1796.

English.

Uptake by Biota.

CA88(15):103440q.

Anon., 27 January 1982, Tolerances for pesticide chemicais in or on raw agricultural commodities; atrazine: Federal Register, v. 47, no. 18 , p. 3771 .

English.

Uptake by Biota.

CA96(13):102615d.

Anon., 24 February 1982, Tolerances for pesticide chemicals in or on raw agricultural commodities; atrazine: Federal Register, v. 47 , no. 37, p. 8012.

English.

Uptake by Biota.

CA96(15):121016a.

Anpalov, V. A., Novikov, A. A., Buryi, V. S., Zadordonets, V. A., Drozdova, O. A., and Gzhegotskii, M. I., 1970, Herbicide residues in soil and strawberries: Khimiya v Sel'skom Khozyaistve, v. 8, no. 10, p. 774-777.

Russian.

Field Residuals,Uptake by Biota.

CA74(21):110675j.

Arruda, J. A., Cringan, M.S., Layher, W. G, Kersh, G., and: Bever, C., 1988, Pesticides in fish tissue and water from Tuttle Creek Lake, Kansas: Bulletin of Environmental Contamination and Toxicology, v. 41, no. 4, p. 617-624. English.

Uptake by Biota.

CA109(22):196722y.
Bagaev, V. B., Zhukov, I. P., and Ovcharenko, G. S., Feb 1975, The uptake of atrazine by maize plants depending on the conditions of mineral nutrition: Agrokhimia, v. 2, p. 125129.

Russian.

Uptake by Biota.

Baker, E. A., and Hunt, G. M., 1987, Factors affecting foliar penetration and translocation of pesticides: American Chemical Society Symposium Series, v. 371, p. 8-21. English.

Uptake by Biota.

CA109(13):106539s.

Bakke, J. E., and Price, C. E., 1973, Rat urinary metabolites from 2-methoxy-4,6-bis(isopropylamino)-s-triazine (prometone): Journal of Agriculture and Food Chemistry, v. 21, no. 4 , p. $640-644$.

English.

Uptake by Biota,Toxicity. CA79(25):143365q.

Balinova, A., and Minkov, M., 1973, Investigation of residual amounts of simazine and atrazine in the grapevine: Rastitelna Zashtita, v. 21, no. 6, p. 6-9.

Bulgarian.

Uptake by Biota.

Balke, N. E., and Price, T. P., Mar 1988, Relationship to lipophilicity to influx and efflux of triazine herbicides in oat roots: Pesticide Biochemistry and Physiology, v. 30, no. 3, p. 228-237.

English.

Uptake by Biota.

IND 88018861

Baranov, Y. S., Khilik, L. A., and Klisenko, M. A., 1979, Determination of s-triazine herbicides in essential oils and plants: Khimiya v Sel'skom Khozynaistve, v. 17, no. 6, p. 5759.

Russian.

Uptake by Biota,Analytical Techniques/Quantification. CA91(11):84412a.

Benson, D., Baker, C. D., Forsyth, B. J., and Castrale, J. S., 1984, Herbicide (alachlor, atrazine, linuron and paraquat) residues in deer mice inhabiting conventional and minimum tillage row-crop fields: Proceedings of the Indiana Academy of Science, v. 94, p. 373-380.

English.

Uptake by Biota.

CA105(17):147817s.

Best, I. A, Weber, J. B., and Monaco, T. J., 1975, Influence of soil pH on s-triazine availability to plants: Weed Science, v. 23, no. 5 , p. $378-382$.

English.

Uptake by Biota,Sorption to Soil. CA83(21):173782y.

Bezuglov, V. G., 1969, Absorption, translocation, and inactivation of atrazine in plants resistant and sensitive to it: Khimiya v Sel'skom Khozyaistve, v. 7, no. 5, p. 378-381. Russian.

Uptake by Biota.

CA71(17):80036v. 
Boydston, R. A., and Slife, F. W., 1986, Alteration of atrazine uptake and metabolism by tridiphane in giant foxtail (Setaria faberi) and corn (Zea mays): Weed Science, v. 34, no. 6, p. 850-858.

English.

Uptake by Biota,Biodegradation/Biotransformation. CA106(5):28789v.

Bradway, D. E., and Moseman, R. F., 1982, Determination of urinary residue levels of the $\mathrm{N}$-dealkyl metabolites of triazine herbicides: Journal of Agriculture and Food Chemistry, v. 30, no. 2, p. 244-247.

English.

Degradation Products,Analytical Techniques/Quantification, Uptake by Biota,Biodegradation/Biotransformation. CA96(13):98864q.

Bridges, J. M., and Andrews, R. D., 1977, Agricultural pesticides in wild turkeys in southern Illinois: Transactions of the Illinois State Academy of Sciences, v. 69, no. 4, p. 473-478. English.

Uptake by Biota.

CA89(1):1389h.

Brookhart, G., and Johnson, L. D., 1977, Analysis of fish tissue for Kepone, mirex, atrazine, linuron and alachlor. EPA/903/978/018; Order No. PB-285865, 15 p, Environmental Protection Agency.

English.

Uptake by Biota.

CA90(19): $146660 \mathrm{v}$.

Budoi, G., and Ries, S. K, 1968, Absorption of radioactive simazin; increased protein content due to atrazine application to rye plants: Studii si Cercetari de Biochimie, v. 11 , no. 4 , p. $371-375$.

Romanian.

Uptake by Biota.

CA70(21):95685j.

Burroughs, F. G., 1983, Field and laboratory evaluations of the herbicidal efficacy, uptake and translocation of tridiphane and its effects of atrazine uptake, translocation and metabolism, Dissertation submitted in partial fulfiliment of Ph.D. requirements, University of Illinois, Urbana, Illinois, USA.

English.

Uptake by Biota.

CA100(11):81147m.

Burt, G. W., 1974, Translocation and metabolism of atrazine in Canada thistle: Weed Science, v. 22, no. 2, p. 116-119. English.

Uptake by Biota,Biodegradation/Biotransformation. CAIN 749021344.

Capriel, P., and Haisch, A., 1983, Uptake of atrazine metabolites by oats nine years after the herbicide application:

Zeitschrift fuer Pflanzenernaehrung und Bodenkunde, v. 146, no. 6, p. $736-740$.

German.

Uptake by Biota,Degradation Products.

CA100(9):63427y.
Caramete, A., Pintilie, C., Sandoiu, D. D., and Constantinescu, D., 1981, Studies on herbicide residues in soil and plants: Lucrari Stiintifice - Institutal Agronomic "Nicolae Baicescu", Bucuresti, Seria A.: Agronomie, v. 24, p. 69-74.

Romanian.

Field Residuals, Uptake by Biota.

CA97(11):87022h.

Cervelli, S., Ciardi, C., and Perna, A., Jan/Mar 1982, Effect of atrazine on soil transformation of nitrogen and uptake by corn: Journal of Environmental Quality, v. 11, no. 1, p. 8286.

English.

Biodegradation/Biotransformation,Uptake by Biota.

IND 82011979.

Chesalin, G. A., and Timofeeva, A. A., 1971, Distribution of atrazine in sunflower plants and its effect on nitrogen metabolism: Trudy Vsesoyuznogo Nauchno-Issledovatel'skogo Instituta Udobrenii i Agropochvovedeniya, v. 51, p. 195-200. Russian.

Uptake by Biota.

CA78(13):80758b.

Dabydeen, S., and Leavitt, J. R. C., 1981, Absorption and effect of simazine and atrazine on Elodea canadensis: Bulletin of Environmental Contamination and Toxicology, v. 26, no. 3, p. 381-385.

English.

Uptake by Biota,Toxicity.

CA9S(5):36948r.

Davies, R. P., and Dobbs, A. J., 1984, The prediction of bioconcentration in fish: Water Research, v. 18, no. 10, p. 1253-1262.

English.

Uptake by Biota.

CA101(19):165015a.

Davis, D. G., and Dushabek, K. E., 1973, Effect of diallate on foliar uptake and translocation of herbicides in pea: Weed Science, v. 21, no. 1, p. 16-18. English.

Uptake by Biota.

CA78(11):67890u.

Debelyi, A. S., Troshko, E. V., and Galkina, G. A., 1971, Use of triazines in the growing of medicinal plants, and determination of their residual amounts: Agrokhimiya, no. 8, p. 110-114

Russian.

Uptake by Biota,Analytical Techniques/Quantification. CA76(9):42616e.

Delley, R., Friedrich, K, Karlhuber, B., Szekely, G., and Stammbach, $K, 1967$, Identification and determination of various triazine herbicides in biological materials: Fresenius' Zeitung fuer Analytische Chemie, v. 228, no. 1, p. 23-38.

English.

Uptake by Biota,Analytical Techniques/Quantification. CA67(17):81380g. 
Doll, J. D., Penner, D., and Meggitt, W. F., 1970, Herbicide and phosphorus influence on root absorption of amiben and atrazine: Weed Science, v. 18, no. 3, p. 357-359.

English.

Uptake by Biota.

CA73(9):44192a.

Dorozhkina, L. A., Kalinin, V. A., Kuz'minskaya, V. A., and Gbianza, T. A., 1974, Nature of the interaction of atrazine and 2,4-D in bean plants: Khimiya v Sel'Skom Khozyaistve, $v$. 12 , no. 2 , p. $127-130$.

Russian.

Uptake by Biota.

CA81(5):22168k.

Dorozhkina, L. A., Kuz'minskaya, V. A., Kalinin, V. A., and Druzdev, G. S., 1975, Phytotoxicity of atrazine during its uptake through the roots and leaves of beans: Izvestiya Timiryazevskoi Sel'skokhozyaistvennoi Akademii, no. 3, p. 156-162.

Russian.

Uptake by Biota.

CA83(9):73060t.

Ellgehausen, H., Guth, J. A., and Esser, H. O., 1980, Factors determining the bioaccumulation potential of pesticides in the individual compartments of aquatic food chains:

Ecotoxicology and Environmental Safety, v. 4, no. 2, p. 134157.

English.

Uptake by Biota.

CA93(11):108505c.

Farkas, P., and Tekel, J., 1986, Determination of herbicide residues in beet sugar: Sbornik UVTTZ, Potravin Vedy, v. 4, no. 2 , p. 129-134.

Siovenian.

Uptake by Biota,Analytical Techniques/Quantification. CA105(25):224732q.

Foster, T. S., Morley, H. V., Purkayastha, R, Greenhalgh, R, and Hunt, J. R, 1972, Residues in eggs and tissues of hens fed a ration containing low levels of pesticides with and without charcoal: Journal of Economic Entomology, v. 65, no. 4, p. $982-988$.

English.

Uptake by Biota.

CA77(23):148190x.

Frear, D. S., and Swanson, H. R, 1970, Biosynthesis of S-(4ethylamino-6-isopropylamino-2-s-triazino)glutathione: partial purification and properties of a glutathione $S$ transferase from corn: Phytochemistry, v. 9, no. 10, p. 21232132.

English.

Association with Plants, Uptake by Biota. CA74(5):19676z.

Freitag, D., Lay, J. P., and Korte, F., 1984, Quantitative Structure/Activity Relationships in Environmental Toxicology, Proceedings of the Workshop, 1983, p. 111-136. English.

Chemical/Physical Properties, Uptake by Biota,Toxicity. CA102(16):137152v.
Gabor, T., Henscei, P., Mato-Kovacs, G., Brandt-Petrik, E., and Nagy, J., 1973, Spectrophotometric determination of the active substances in triazine- and phenoxyacetic derivatives in plant preservatives: Periodica Polytechnica, Chemical Engineering, v. 17, no. 3, p. 219-231.

German.

Uptake by Biota.

CA82(7):39294s.

Gajdustrova, V., 1983, Problems of oecurrence and determination of residues of herbicides on the basis of diazines and triazines in milk: Ceskoslovenska Hygiena, v. 28, no. 1, p. 6-10.

Czechoslovakian.

Uptake by Biota.

CA98(21):177585u.

Geller, A., 1979, Sorption and desorption of atrazine by three bacterial species isolated from aquatic systems: Archives of Environmental Contamination and Toxicology, v. 8, no. 6, p. 713-720.

English.

Uptake by Biota.

CA92(11):88978h.

Geyer, H., Politzki, G., and Freitag, D., 1984, Prediction of ecotoxicological behavior of chemicals: relationship between n-octanol/water partition coefficient and bioaccumulation of organic chemicals by alga Chlorella: Chemosphere, v. 13, no. 2, p. $269-284$.

English.

Uptake by Biota.

CA100(21):169486g

Ghadiri, H., Shea, P. J., and Wicks, G. A., 1983, Interception and retention of atrazine by wheat (Triticum aestivum $L$.) stubble: Weed Science, v. 32, no. 1, p. 24-27.

English.

Uptake by Biota,Associations with Plantss.

CA100(13):98219j.

Gluth, G., Freitag, D., Hanke, W., and Korte, F., 1985, Accumulation of pollutants in fish: Comparative Biochemistry and Physiology, C: Comparative Pharmacology and Toxicology, v. $81 \mathrm{C}$, no. 2, p. 273-277.

English.

Uptake by Biota.

CA103(11):82945u.

Gobas, F. A. P.C., Lahittete, J. M., Garofalo, G., Shiu, W. Y., and Mackay, D., 1988, A novel method for measuring membranewater partition coefficients of hydrophobic organic chemicals: comparison with 1-octanol-water partitioning: Journal of Pharmaceutical Sciences, v. 77, no. 3, p. 265-272. English.

Uptake by Biota.

CA108(25):215834j.

Grenier, G., and Beaumont, G., 1983, Physiological effects of sublethal doses of atrazine on Lemna minor. VII. 1,2(14C)acetate incorporation into the groups of lipids and their fatty acids: Physiology Plantarum, v. 57, no. 4, p. 477-484.

French.

Uptake by Biota,Toxicity.

CA98(23):195046y. 
Grossbard, E., 1970, Distribution of carbon-14 labeled simazine and atrazine before and after incubation detected by autoradiography of soil particles: Mededingen van de Faculteit Landbouwwetenschappen, Rijksuniversiteit, Gent., v. 35 , no. 2, p. 531-542.

English.

Uptake by Biota.

CA75(17):108804c.

Gunkel, G., and Streit, B., 1980, Mechanisms of bioaceumulation of a herbicide (atrazine, s-triazine) in a freshwater mollusk (Ancylus fluviatilis Muell.) and a fish (Coregonus fera Jurine): Water Research, v. 14, no. 11, p. 1573-1584.

English.

Uptake by Biota.

CA94(9):59409j.

Gunkel, G., 1984, Investigations of the ecotoxicologial effect of a herbicide in an aquatic model ecosystem. II. Food chain significance and pesticide balance: Archives of Hydrobiology, Supplement, v. 69 , no. 1, p. $130-168$.

German.

Surfacewater Observations, Uptake by Biota. CA100(15):116111z.

Gunkel, V. G., January 1984, Investigations of the ecotoxicological effect of a herbicide in an aquatic model ecosystem; II. Food chain significance and pesticide balance (Untersuchungen zur okotoxikologischen wirkung eines herbizids in einem aquatischen modellokosystem; II.

Nahrungskettenprobleme und schadstoffbilanzierung): Archiv fur Hydrobiologie, v. 1, p. 130-168.

Uptake by Biota.

Gzhegotskii, M. I., Shklyaruk, L. V., and Kychok, L. A., 1977, Toxicological characteristics of the herbicide Zeazin:

Vrachebnoe Delo, no. 5, p. 133-136.

Russian.

Uptake by Biota,Toxicity.

CA87(15):112660t.

Hamilton, P. B., Jackson, G. S.,, Kaushik, N. K, and Solomon, K. R., 1987, The impact of atrazine on lake periphyton communities, including carbon uptake dynamics using track autoradiography: Environmental Pollution, v. 46, no. 2, p. 83-103.

English.

Uptake by Biota.

CA107(17):148896v.

Heisig-Gunkel, G., and Gunkel, G., 1982, Distribution of a herbicide (atrazine, s-triazine) in Daphnia pulicaria: a new approach to determination: Archives of Hydrobiology, Supplement, v. 59. no. 4, p. 359-376.

English.

Uptake by Biota.

CA98(13):102314w.
Hera, C., Triboi, E., Ghinea, L., Chirita, V., and Bologa, M., 1973, Uptake and metabolism of nitrogen from soil and nitrogen-15-labeled fertilizers in atrazine treated corn plants: Analele Institutului de Cercetari Cereale si Plante Tehnice - Fundulea, Academia de Stïnte Agricole si Silvice, Seria B, v. 39, p. 219-226.

Romanian.

Uptake by Biota.

CA82(7):39359s.

Hilton, H. W., Yuen, Q. H., and Nomura, N. S., 1970, Distribution of residues from atrazine, ametryne, and pentachlorophenol in sugarcane: Journal of Agriculture and Food Chemistry, v. 18, no. 2, p. $217-220$.

English.

Uptake by Biota.

CA72(21):110112g.

Hoffman, D. W., and Lavy, T. L., Jan 1978, Plant competition for atrazine: Weed Science, v. 26, no. 1, p. 9499.

English.

Uptake by Biota.

CAIN 789043300.

Huber, S. J., and Sautter, C., Dec 1986, Immunofluorescence localization of conjugated atrazine in leaf pieces of corn: Zeitschrift fuer Pflanzenkrenkheiten Pflanzenschutz, v. 93, no. 6, p. 608-613.

English.

Uptake by Biota.

ND 87015617.

Isnard, P., and Lambert, S., 1988, Estimating bioconcentration factors from octanol-water partition coefficient and aqueous solubility: Chemosphere, v. 17, no. 1, p. 21-34.

English.

Uptake by Biota.

CA108(19):162772d.

Ivantsov, N. K., 1972, Residual amounts of herbicides in several agricultural crops: Trudy, Velikolukskii

Sel'skokhozyaistvennyi Institut, v. 23, p. 25-28.

Russian.

Uptake by Biota.

CA81(21):131482d.

Jacob, F., and Neumann, S., 1983, Pesticide Chemistry: Human Welfare and the Environment, Proceedings of the International Congress of Pesticide Chemistry, 5th, 1982, p. Volume 1, 357362.

English.

Uptake by Biota.

CA99(7):48887r.

Jones, D. W., and Foy, C. L., 1972, Tracer studies with carbon14-labeled herbicides, dimethyisulfoxide (DMSO), and surfactant: Weed Science, v. 20, no. 1, p. 81-86.

English.

Uptake by Biota,Associations with Surfactants. CA76(25):149850d. 
Jones, T. W., and Estes, P. S., 1984, Uptake and phytotoxicity of soil-sorbed atrazine for the submerged aquatic plant, Potamogeton perfoliatus L.: Archives of Environmental Contamination and Toxicology, v. 13, no. 2, p. 237-241. English.

Associations with Plants, Uptake by Biota,Toxicity. CA100(19):152227a.

Jones, T. W., Kemp, W. M., Estes, P. S., and Stevenson, J. C., 1986, Atrazine uptake, photosynthetic inhibition, and shortterm recovery for the submersed vascular plant, Potamogeton perfoliatus L: Archives of Environmental Contamination and Toxicology, v. 15, no. 3, p. 277-283.

English.

Uptake by Biota,Toxicity.

Jones, T. W., and Winchell, L., April-June 1984, Uptake and photosynthetic inhibition by atrazine and its degradation products on four species of submerged vascular plants: Journal of Environmental Quality, v. 13, no. 2, p. 243-247. English.

Associations with Surfactants, Uptake by Biota,Degradation Products, Toxicity. CA101(1):2244k.

Jones, T. W., Kemp, W. M., Estes, P. S., and Stevenson, J. C., 1986, Atrazine uptake, photosynthetic inhibition, and shortterm recovery for the submerged vascular plant, Potamogeton perfoliatus L.: Archives of Environmental Contamination and Toxicology, v. 15, no. 3, p. 277-283.

English.

Uptake by Biota.

CA105(1):1955p.

Jowett, P. L. H., and Gamble, G. A., 1986, Tissue levels of atrazine in a case of bovine poisoning. Veterinary and Human Toxicology, v. 28, no. 6, p. 539-540.

English.

Uptake by Biota,Toxicity.

CA106(7):45421m.

Jursinic, P., and Stemler, A., Nov 1983, Changes in $14 C$ atrazine binding associated with the oxidation-reduction state of the...: Plant Physiology, v. 73, no. 3, p. 703-708.

English.

Uptake by Biota,Associations with Plants,Degradation

Products.

IND 83126519.

Kavoliunaite, I., 1973, Voprosy Epidemiologii i Gigieny v Litovskoi SSR Materiały Nauchnoi Koinferentsii po Ozdorovleniyu Vneshnei Sredy, p. 207-209.

Russian.

Uptake by Biota, Field Residuals.

CA83(9):73305b.

Khan, S. U., and Foster, T. S., 1976, Residues of atrazine and its metabolites in chicken tissues: Joumal of Agriculture and Food Chemistry, v. 24, no. 4, p. 768-771.

English.

Uptake by Biota,Degradation Products.

CA85(7):45015e.
Khan, S. U., and Akhtar, M. H., 1983, In vitro release of bound (nonextractable) atrazine residues from corn plants by chicken liver homogenate and bovine rumen liquor: Journal of Agriculture and Food Chemistry, v. 31, no. 3, p. 641-644. English.

Toxicity,Degradation Products, Uptake by Biota,Assoriations with Plants.

CA98(23):192994v.

Khan, S. U., Kacew, S., and Molnar, S. J., 1985, Bioavailability in rats of bound carbon-14 residues from com plants treated with (14C)atrazine: Journal of Agriculture and Fond Chemistry, v. 33, no. 4, p. 712-717.

English.

Uptake by Biota,Degradation Products, Toxicity. CA103(5):33244f.

Khan, S. U., and Marriage, P. B., 1977, Residues of atrazine and its metabolites in an orchard soil and their uptake by oat plants: Journal of Agriculture and Food Chemistry, v. 25, no. 6, p. 1408-1413.

English.

Field Residuals,Uptake by Biota,Biodegradation/

Biotransformation,Degradation Products. CA87(23):178954y.

Klaassen, H. E., and Kadoum, A. M., 1979, Distribution and retention of atrazine and carbofuran in farm pond ecosystems: Archives of Environmental Contamination and Toxicology, v. 8, no. 3, p. 345-353.

English.

Surface Water Observations,Sorption to Sediments, Uptake by Biota. CA91(1):1346h.

Knake, E. L., Appleby, A. P., and Furtick, W. R, 1967, Soil incorporation and site of uptake of preemergence herbicides: Weeds, v. 15, no. 3, p. 228-232.

English.

Sorption to Soil, Uptake by Biota.

CA67(19):90003p.

Knake, E. L., and Wax, L. M., 1968, The importance of the shoot of giant foxtail for uptake of preemergence herbicides: Weed Science, v. 16, no. 3, p. 393-395.

Engtish.

Uptake by Biota. CA69(9):34891f.

Kobel, W., Sumner, D. D., Campbell, J. B., Hudson, D. B., and Johnson, J. L, 1985, Protective effect of activated charcoal in cattle poisoned with atrazine: Veterinary and Human Toxicology, v. 27, no. 3, p. 185-188.

English:

Sorption to Resins, Toxicity, Uptake by Biota. CA103(15):117775t.

Kuhn, M., Thiel, A., and Boeger, P., 1986, Binding of phenylglyoxal to the herbicide-binding protein: Physiologie Vegetale, v. 24, no. 4, p. 485-490.

English.

Uptake by Biota.

CA105(21):185583v. 
Kulshrestha, G., Dewan, R. S., and Mani, V. S., Oct 1976, Dissipation of simazine and atrazine in soil and their uptake by com plants: Pesticides, v. 10, no. 10, p. 21-24.

English.

Biodegradation/Biotransformation,Uptake by Biota.

Kuz'minskaya, V. A, and Dorozhkina, L. A., 1975, Migration of atrazine-14C through the bean plant: Khimiya v Sel'skom Khozyaistve, v. 13, no. 4, p. 54-55.

Russian.

Uptake by Biota.

CAIN 759079305.

Kuz'minskaya, V. A., and Dorozhkina, L. A., 1975, Movement of atrazine-14C along a bean plant: Khimiya v Sel'skom Khozyaistve, v. 13, no. 4, p. 294-295.

Russian.

Uptake by Biota.

CA83(7):54489y.

Kuz'minskaya, V. A., and Kalinin, V. A., May/June 1980, Effect of 2,4-D dichlorophenoxyacetic acid and atrazine on the distribution of labeled assimilates in kidney beans: Izvestiya Timiriazevskoi Sel'skokhozyaistvennoi Akademii Moskva, no. 3, p. 9-16.

Russian.

Uptake by Biota.

IND 81021586.

Kuz'minskaya, V. A, and Kalinin, V. A., 1980, Movement of 2,4-D in bean plants used in combination with atrazine: Izvestiya Timiryazevskoi Sel'skokhozyaistvennoi Akademii, no. 4, p. 1115.

Russian.

Uptake by Biota.

CA93(15):144247d.

Ladonin, V. F., and Spesivtsev, L. G., 1972, Action of atrazine on metabolic processes not connected with photosynthesis in relation to the localization of atrazine in plant cells: Agrokhimiya, no. 1, p. 104-113.

Russian.

Uptake by Biota.

CA76(23):136763c.

Ladonin, V. F., and Spesivtsev, L. G., 1973, Localization of 2,4$\mathrm{D}$ and atrazine in the cells of plants differing in their sensitivity to them: Doklady Vsesoyuznoi Akademii Sel'skokhozyaistvennykh Nauk, no. 8, p. 13-15.

Russian.

Uptake by Biota.

CA80(5):23450n.

Larsen, G. L., and Bakke, J. E., 1975, Metabolism of 2-chloro-4 cyclopropylamino-6-isopropylamino-s-triazine (cyprazine) in the rat: Journal of Agriculture and Food Chemistry, v. 23, no. 3, p. 388-392.

English.

Toxicity,Uptake by Biota.

CA83(9):73051r.
Lefebvre-Drouet, E, and Calvet, R, 1983, Use of a biological dosage of atrazine for algae (Chlorella) for studying the adsorption-phytotoxicity relation: Chemosphere, v. 12, no. 910, p. 1355-1362.

French.

Toxicity, Uptake by Biota. CA100(1):2068k.

Lefebvre-Drouet, E, Rousseau, M. F., and Calvet, R, 1988, Bioavailability of atrazine to green algae (Chlorella) in suspension: Chemosphere, v. 17, no. 10, p. 2113-2126.

English.

Uptake by Biota.

CA110(5):35059t.

Lupea, V., Preda, A, and Albert, E., 1978, Contribution to the study of some triazine herbicide residues in wine and grapes: Timisoara Medicala, v. 23, no. 2, p. 133-136.

Romanian.

Uptake by Biota.

CA90(23):184852s.

Maier-Bode, H., 1972, Retention of herbicides in water, sludge, and fish after application in fish ponds: Schriftenreihe ders Vereins fuer Wasser, Boden und Lufthygiene, v. 37, p. 67-75. German. Uptake by Biota. CA79(2):9528s.

Mailhot, H., 1987, Prediction of algal bioaccumulation and uptake rate of nine organic compounds by ten physicochemical properties: Environmental Science and Technology, v. 21, no. 10, p. 1009-1013.

English.

Uptake by Biota.

CA107(16):140714p.

Malefyt, T., and Duke, W. B., 1981, The site of uptake of atrazine, cyanazine, and pendimethalin by velvetleaf. Herbicides, Abutilon theophrasti, abstract only.: Proceedings of the Annual Meeting of the Northeastern Weed Science Society, p. 14-15.

English.

Uptake by Biota.

IND 81059638.

Malikova, M., Urbanova, E., Gajduskova, V., Masek, J., and Docekalova, H., 1983, Presence of foreign substances in raw and pasteurized milk: Veterinary Medicine (Prague), v. 28, no. 10, p. $633-640$.

Czechoslovakian.

Uptake by Biota.

CA100(5):33375n.

Marco, G. J., Simoneau, B. J., Williams, S. C., Cassicy, J. E., Bissig, R, and Muecke, W., 1985, Radiotracer approaches to rodent dermal studies: American Chemical Society, Symposium Series, v. 273, no. Dermal Exposure Related to Pesticide Use, p. $43-61$.

English.

Uptake by Biota.

CA102(19):161861w. 
Matthies, M., Behrendt, H., and Muenzer, B., 1987, EXSOL. Model for the transport and persistence of substances in soil: GSFBer., 23/87.

German.

Leaching,Sorption to Soil, Uptake by Biota. CA109(1):5636r.

McFarlane, C., and Wickliff, C., 1985, Excised barley root uptake of several carbon-14-labeled organic compounds: Environmental Monitoring and Assessment, v. 5, no. 4, p. 385-391.

English.

Uptake by Biota.

CA104(9):63566a.

Millard, E. S., 1979, Biomagnification of atrazine in lake column simulators: Windsor, Ont.: International Joint Commission, 1979. viii, 27 p.

English.

Uptake by Biota.

CAT 81753401.

Minshall, W. H., Mar 1975, Translocation of atrazine: accumulation versus passage through petioles (Tomatoes): Weed Science, v. 23, no. 2, p. $97-99$.

English.

Uptake by Biota.

CAIN 759035651.

Minshall, W. H., Sample, K. C., and Robinson, J. R, ;977, The effect of urea on atrazine uptake from soil by tomato plants: Weed Science, v. 25, no. 5, p. 460-464.

English.

Uptake by Biota.

CAIN 779118237.

Minshall, W. H., 1969, Effect of nitrogenous materials on the uptake of triazine herbicides: Weed Science, v. 17, no. 2, p. 197-201.

English.

Uptake by Biota.

CA71(3):12008n.

Moody, K., Kust, C. A., and Buchholtz, K. P., 1970, Release of herbicides by soybean roots in culture solutions: Weed

Science, v. 18, no. 2, p. 214-218.

English.

Uptake by Biota.

CA72(25):131343y.

Moody, K., Kust, C. A., and Buchholtz, K. P., 1970, Uptake of herbicides by soybean roots in culture solutions: Weed Science, v. 18 , no. 5 , p. $642-647$.

English.

Uptake by Biota.

CA73(23):119524w.

Mueller, B., 1973, Determination of pesticide residues in bee honey. II. Semiquantitative thin-layer chromatographic determination of herbicide residues in bee honey: Nahrung, $v$. 17, no. 3, p. 387-392.

German.

Uptake by Biota,Analytical Techniques/Quantification. CA79(25):144932j.
Mueller, P. W., Payot, P. H., and Geigy, J. R, 1966, Isotopes in Weed Research, Proceedings of the Symposium on the Use of Isotopes in Weed Research, International Atomic Engergy Agency. Symp., 1965, p. 61-68, discussion 69-70.

English.

Uptake by Biota.

CA66(5):18221v.

Nalewaja, J. D., and Adamezewskj, K. A., 1976, Vaporization and uptake of atrazine with additives: Weed Science, v. 24, no. 2, p. 217-223.

English.

Volatilization,Uptake by Biota.

CA84(25):175129k.

Neumann, S., and Jacob, F., 1983, New results in the carboxyl hypothesis of the transport of xenobioties by the phloem: Abhandlungen der Akademie der Wissenschaften der DDR, Abteilung Mathematik, Naturwissenschaften, Technik, no. 1N, p. 47-53.

German.

Uptake by Biota.

CA99(11):83623y.

Neumann, S., Grimm, E., and Jacob, F., 1985, Transport of xenobiotics in higher plants. I. Structural prerequisites for translocation in the phloem: Biochemie und Physiologie der Pflanzen, v. 180, no. 4, p. 257-268.

English.

Uptake by Biota.

CA102(13):108112b.

Norris, R. F., and Fong, I. E., 1983, Localization of atrazine in corn (Zea mays), oat (Avena sativa), and kidney bean (Phaseolus): Weed Science, v. 31, no. S, p. 664-671.

English.

Uptake by Biota.

CA99(21):171006e.

O'Brien, L. P., and Prendeville, G. N., 1972, Shoot zone uptake of soil applied herbicides in Pisum sativum: Weed Research, v. 12 , no. 3, p. 248-253.

English.

Uptake by Biota.

CA78(13):80766c.

O'Donovan, J. T., and Prendeville, G. N., 1975, Shoot zone uptake of soil-applied herbicides in some legume species: Weed

Research, v. 15, no. 6, p. 413-417.

English.

Uptake by Biota.

CA84(19):131177v.

Otun'kov, P. S., 1978, Permissible pesticide residues in feeds: Veterinariya (Moscow), no. 7, p. 85-86.

Russian.

Uptake by Biota.

CA89(15):127866e.

Penner, D., Jan/Feb 1974, Effect of disulfoton, diazinon, and fensulfothion on atrazine absorption by soybean: Agronomy Journal, v. 66, no. 1, p. 107-109.

English.

Uptake by Biota.

CAIN 749025848. 
Percich, J. A., and Lockwood, J. L., 1978, Interaction of atrazine with soil microorganisms: population changes and accumulation: Canadian Journal of Microoiology, v. 24, no. 10, p. 1145-1152.

English.

Uptake by Biota,Biodegradation/Biotransformation,Associations with Plants.

CA90(5):34969w.

Pillay, A. R, and Tchan, Y. T., 1972, Soil algae. VII. Adsorption of herbicides in soil and prediction of their rate of application by algal methods: Plant and Soil, v. 36, no. 3, p. 571-594.

English.

Uptake by Biota.

CA77(19):125348r

Popova, D., 1980, Translccation and phytotoxicity of $14 \mathrm{C}$ carbon isotope labeled-atrazine in kidney beans depending on the level of: Pochvoznanie i Agrokhimiya, v. 15, no. 2, p.

$77-85$.

Bulgarian.

Uptake by Biota.

IND 83003337.

Price. T. P., and Balke, N. E., 1982, Characteriaztion of rapid atrazine absorption by excised velvetleaf (Albutilon theophrasti) roots: Weed Science, v. 30, no. 6, p. 633-639. English.

Uptake by Biota,Associations with Plants.

Ca98(5):29617r.

Price, T. P., and Balke, N. E., 1983, Characterization of atrazine accumulation by excised velvetleaf (Abutilon theophrasti) roots: Weed Science, v. 31, no. 1, p. 14-19. English.

Uptake by Biota.

CA98(13):102581f.

Rachinskii, V. V., Fokin, A. D., Ibragimov, K. S., Kretova, L. G., and Synyaev, K. K., 1986, Radiotracer investigation of 14C-triazine in plants: Izvestiya Timiryazevskoi Sel'skokhozyaistvennoi Akademii, no. 3, p. 120-124.

Russian.

Uptake by Biota.

CA105(7):56260p.

Ranfft, K, Deller, B., and Kipplinger, A., 1982, Effect of pesticide contamination of different soils in bariey seedlings. 2. Plant uptake and persistance of pesticides: Landwirtschaftliche Forschung, v. 35, no. 3-4, p. 227-237. German.

Uptake by Biota.

CA99(15):117296m.

Richard, E. P., Jr., Goss, J. R, Amtzen, C. J., and Slife, F. W., 1983, Determination of herbicide inhibition of photosynthetic electron transport by fluorescence: Weed Science, v. 31, no. 3, p. 361-367.

English.

Analytical Techniques/Quantification,Uptake by Biota. CA99(3):17988v.
Rieder, G., Buchholtz, K. P., and Kust, C. A., 1970, Uptake of herbicides by soybean seed: Weed Science, v. 18, no. $1, p$.

101-105.

English.

Uptake by Biota.

CA72(21):110160w.

Rivera, J., Caixach, J., De Torres, M., and Ventura, F., 1986, Fate of atrazine and trifluralin from an industrial waste dumping at Llobregat River. Presence in fish, raw, and finished water.: International Journal of Environmental Analytical Chemistry, v. 24, no. 3, p. 183-191.

English.

Surfacewater Observations, Uptake by Biota. CA105(5):37147r.

Robinson, R. C., and Dunham, R. J., 1982, The uptake of soilapplied chlorotriazines by seedlings and its prediction: Weed Research, v. 22, no. 4, p. 223-226.

English.

Uptake by Biota.

CA97(19):157924e.

Roeth, F. W., and Lavy, T. L., 1971, Atrazine <2-chloro-4 (ethylamino)-6-(isopropylamino)-s-triazine $>$ translocation and metabolism in sudangrass, sorghum, and corn: Weed Science, v. 19 , no. 1 , p. 98-101.

English.

Uptake by Biota,Biodegradation/Biotransformation.

CA74(21):110669k.

Roeth, F. W., and Lavy, T. L., 1971, Atrazine <2-chloro-4 (ethylamino)-6-(isopropylamino)-s-triazine $>$ uptake by sudangrass, sorghum, and corn: Weed Science, v. 19, no. 1, p. 93-97.

English.

Uptake by Biota.

CA74(19):98608e.

Roeth, F. W., 1970, Comparison of atrazine uptake, metabolism, and resistance in sorghum and com, Dissertation submitted in partial fulfillment of Ph.D. requirements, University of Nebraska, Lincoln. Nebraska, USA.

English.

Biodegradation/Biotransformation, Uptake by Biota. CA75(3):19082y.

Romanov, A. I., 1975, Voprosy Intensifikatsii

Sel'skokhozyaistvennogo Proizvodstva, p. 90-92.

Russian.

Uptake by Biota.

CA84(25):175028b.

Sanderson, J., and Shone, M. G. T., 1974, Micro-autoradiographic studies of the uptake of atrazine and ethirimol by barley roots: Annual Report - Agricultural Research Council, Letcombe Laboratory, p. 66-68.

English.

Uptake by Biota.

CA85(9):57973d. 


\section{ENVIRONMENTAL PROCESSES \\ TRANSFER PROCESSES \\ Uptake by Biota}

Schmidt, G. H., 1986, Use of grasshoppers as test animals for the ecotoxicological evaluation of chemicals in the soil:

Agricultural Ecosystems and the Environment, v. 16, no. 3-4, p. 175-188.

English.

Uptake by Biota.

CA105(17):147603u.

Schmoranzer, A., Neumann, G., Theimann, K G., and Strohbach, C., 1974, Simazine as a performance-reducing factor in productive livestock and possibilities for analytical assay of triazine derivatives: Monatshefte fuer Veterinaermedizin, v. 29, no. 13, p. $491-493$.

German.

Uptake by Biota,Analytical Techniques/Quantification.

CA82(15):93899f.

Schnoor, J. L., Rao, N., Cartwright, K. J., Noll, R. M., and Ruiz-Calzada, C., 1983, Verification of a toxic organic substance transport and bioaccumulation model: EPA-600/3-83007.

English.

Surfacewater Observations, Uptake by Biota. CA99(5):34178y.

Schocken, M. J., 1982, Interaction of the herbicide atrazine with marine higher fungi: bioaccumulation, degradation, and effects on growth, Dissertation submitted in partial fulfillment of Ph.D. requirements, Baltimore Prof. Sch., University of Maryland, Baltimore, MD, USA.

English.

Uptake by Biota.

CA98(5):31634n.

Schocken, M. J, and Speedie, M. K., 1982, Interaction of higher marine fungi with the herbicide atrazine. III. Adsorption of atrazine to the marine fungus Dendryphiella salina:

Chemosphere, v. 11, no. 9, p. 885-890.

English.

Uptake by Biota.

CA98(3):12643y.

Schocken, M. J., and Speedie, M. K., 1982, Interaction of higher marine fungi with the herbicide atrazine. II. Sorption of atrazine to four species of marine fungi: Bulletin of Environmental Contamination and Toxicology, v. 29, no. 1, p. 101-106.

English.

Uptake by Biota.

CA97(15):121653b.

Schocken, M. J., Speedie, M. K, and Kirk, P. W., Jr., 1982, Interaction of higher marine fungi with the herbicide atrazine. L. Survey of interactive modes: Mycologia, v. 74, no. 5, p. 801-808.

English.

Toxicity, Uptake by Biota.

CA97(25):212345u.
Schoenherr, J., 1988, Methods for ecotoxicological evaluation of chemicals. Accumulation, persistence, and permeability of chemicals in plant cuticle: Spez. Ber. Kernforschungsanlage Juelich, Juel-Spex-441, Methoden Oekotoxikol. Bewertung Chem., Band 11, 56-92.

German.

Uptake by Biota.

CA109(21):185082p.

Schueuermann, G., and Klein, W., 1988, Advances in bioconcentration prediction: Chemosphere, v. 17 , no. 8, p. 1551-1574.

English.

Uptake by Biota.

CA110(1):2347g.

Seibert, K., 1981, Effect of plant root on the accumulation of atrazine and 2,4-D herbicides in plants: JUEL-1748, $150 \mathrm{p}$, Juelich, Fed. Rep. Ger., Ber. Kernforschungsanlage Juelich. German.

Uptake by Biota.

CA97(5):34686w.

Shimabukuro, R. H., and Linck, A. J., 1967, Root absorption and translocation of atrazine in oats: Weeds, v. 15, no. 2, p.

175-178.

English.

Uptake by Biota.

CA66(25):114848a.

Shimabukuro, R. H., Swanson, H. R, and Walsh, W. C., 1970, Glutathione conjugation. Atrazine detoxication mechanism in corn: Piant Physiology, v. 46, no. 1, p. 103-107.

English.

Uptake by Biota.

CA74(1):2916e.

Shone, M. G. T., Bartiett, B. O., and Wood, A. V., 1974, Comparison of the uptake and transiocation of some organic herbicides and a systemic fungicide by barley. II. Relation between uptake by roots and translocation to shoots: Journal of Experimental Botany, v. 25, no. 85, p. 401-409.

English.

Uptake by Biota.

CA81(21):131488k.

Shone, M. G. T., and Wood, A. V., 1974, Comparison of the uptake and transiocation of some organic herbicides and a systemic fungicide by barley. I. Absorption in relation to physicochemical properties: Journal of Experimental Botany, v. 25 , nc. 85 , p. $390-400$.

English.

Uptake by Biota.

CA82(9):52513g

Shone, M. G. T., and Wood, A. V., 1976, Uptake and translocation of some pesticides by hypocotyls of radish seedlings: Weed Research, v. 16, no. 4, p. 229-238.

English.

Uptake by Biota.

CA85(21):155047z. 
Shtabskii, B. M., Gzhegotskii, M. I., and Martynyuk, V. Z, 1971, Use of vital staining of tissues for revealing the actions of small doses of chemical substances: Gigiena i Sanitariya, v. 36 , no. 2, p. 51-53.

Russian.

Uptake by Biota.

CA74(25):139833v.

Smith, C. N., Jr., and Nalewaja, J. D., 1972, Uptake and translocation of foliarly-applied atrazine: Weed Science, $v$. 20, no. 1, p. $36-40$.

English.

Uptake by Biota.

CA76(25):149846g.

Sosnovaya, O. N., and Timofeev, M. M., 1976, Uptake of herbicides into plants in relation to nutritional conditions: Dolvady

Vsesoyuznoi Akademii Sel'skokhozyaistvennykk Nauk, no. 12, p. 17-19.

Russian.

Uptake by Biota.

CA86(11):70730n.

Stein, R. R., Castellvi, A. L., Bogacz, J. P., and Wraight, C. A., 1984, Herbicide-quinone competition in the acceptor complex of photosynthetic reaction centers from

Rhodopseudomonas sphaeroides: a bacterial model for PS-IIherbicide activity in plants: Journal of Cellular

Biochemistry, v. 24, no. 3, p. 243-259.

English.

Uptake by Biota.

CA101(11):87600w.

Stevens, P. J. G., and Bukovac, M. J., 1985, Properties of octyiphenoxy surfactants and their effects on foliar uptake: Proceedings, British Crop Protection Conference on Weeds, no. 1, p. 309-316.

English.

Uptake by Biota,Associations with Surfactants.

CA104(17):143839g.

Stevens, P. J. G., and Bukovac, M. J., 1987, Studies on octylphenoxy surfactants. Part 2: Effects on foliar uptake and translocation: Pesticide Science, v. 20, no. 1, p. 37-52. English.

Uptake by Biota.

CA107(19):170508s.

Stolp, C. F., and Penner, D., 1973, Enhanced phytotoxicity of atrazine-phosphate combinations: Weed Science, v. 21, no. 1, p. $37-40$.

English.

Uptake by Biota.

CA78(9):53962\&.

Streit, B., 1978, Uptake, accumulation, and release of organic pesticides by benthic freshwater invertebrates: Archives of Hydrobiology, Supplement, v. 55, no. 1, p. 1-23.

German.

Uptake by Biota.

CA9O(15):116129m.
Streit, B., 1979, Uptake, accumulation, and release of organic pesticides by benthic invertebrates. 3. Distribution of carbon-14labelled atrazine a carbon-14-labelled lindane in an experimental three-step food chain microcosm: Archives of Hydrobiology, Supplement, v. 55, no. 3-4, p. 373-400.

English.

Uptake by Biota.

CA92(1):1355f.

Streit, B., and Schwoerbel, J., 1977, Verhandlungen-Gesellschaft fuer Oekologie, Jahresversammlung, 6th, 1976, p. 371-383.

German.

Toxicity,Uptake by Biota,Surfacewater Observations. CA89(7):54386m.

Suess, A., 1977, Uptake of the herbicides monolinuron and atrazine by plant crops: Kali-Briefe, v. 12, no. 6, p. 13

pp..

German.

Uptake by Biota.

CA88(21):147362v.

Tames R., and Hance, R. J., 1969, Absorption of herbicides by roots: Plant Soil, v. 30, no. 2, p. 221-226.

English.

Uptake by Biota.

CA71(3):11994u.

Thacker, E. J., 1971, International Symposium on the Identification and Measurement of Environmental Pollutants, Proceedings, p. 92-97.

English.

Toxicity,Uptake by Biota.

CA80(15):78934d.

Thompson, L., and Slife, F. W., May 1970, Root and foliar absorption of atrazine applied postemergence to broadleaf weeds: Weed Science, v. 18, no. 3, p. 349-351.

English.

Uptake by Biota.

CAIN 709051465

Thompson, L. J., and Slife, F. W., 1969, Foliar and root absorption of atrazine applied postemergence to giant foxtail: Weed Science, v. 17, no. 2, p. 251-256.

English.

Uptake by Biota.

CA71(1):2421c.

Topp, E., Scheunert, I., Attar, A., and Korte, F., 1986, Factors affecting the uptake of carbon-14-labeled organic chemicals by plants from soil: Ecotoxicology and Environmental Safety, v. 11 , no. 2, p. 219-228.

English.

Uptake by Biota:

CA104(23):201848x.

Travis, C. C., and Arms, A. D., 1988, Bioconcentration of organics in beef, milk, and vegetation: Environmental Science and Technology, v. 22, no. 3, p. 271-274.

English.

Uptake by Biota.

CA108(11):93226q. 
Veber, K, Zahradnik, J., Breyl, I., and Kredl, F., 1981, Toxic effect and accumulation of atrazine in algae: Bulletin of Environmental Contamination and Toxicology, v. 27, no. 6, p. 872-876.

English.

Toxicity,Uptake by Biota.

CA96(9):63916f.

Virmani, M., Evans, J. O., and Lynn, R. I., 1975, Effects of striazine, carbamate, urea, and karbutilate herbicides on growth of fresh water algae: Chemosphere, v. 4, no. 2, p. 65 71.

English.

Toxicity, Uptake by Biota.

CA83(13): 109472v.

Vostral, H. J., Buchholtz, K. P., and Kust, C. A., 1970, Effect of root temperature on absorption and translocation of atrazine in soybeans: Weed Science, v. 18, no. 1, p. 115-117. English.

Uptake by Biota.

CA72(21):110162y.

Walker, A., 1972, Availability of atrazine to plants in different soils: Pesticide Science, v. 3, no. 2, p. 139-148.

English.

Uptake by Biota,Sorption to Soil.

CA77(9):57483d.

Walker, A., 1973, Vertical distribution of herbicides in soil and their availability to plants. Treatment of different proportions of the total root system: Weed Research, v. 13, no. 4 , p. $416-421$.

English.

Uptake by Biota.

CA80(15):79057g.

Walker, A., 1973, Vertical distribution of herbicides in soil and their availability to plants. Shoot compared with root uptake: Weed Research, v. 13, no. 4, p. 407-415.

English.

Uptake by Biota.

CA80(15):79056f.

Walker, A., and Featherstone, R. M., 1973, Absorption and translocation of atrazine and linuron by plants with implications concerning linuron selectivity. Journal of Experimental Dotany, v. 24 , no. 79 , p. $450-458$.

English.

Uptake by Biota,Associations with Plants.

CA79(5):28299j.

Walker, A., 1971, Effects of soil moisture content on the availability of soil-applied herbicides to plants: Pesticide Science, v. 2, no. 2, p. 56-59.

English.

Uptake by Biota.

CA75(3):19084a.
Webster, H. L., 1969, Response of plants to atrazine-dexon combinations and the influence of dexon on the absorption, distribution, and metabolism of atrazine by plants, Dissertation submitted in partial fulfillment of Ph.D. requirements, North Carolina State University, Roleigh, N.C. English.

Uptake by Biota,Biodegradation/Biotransformation. CA72(23):120321p.

Wheeler, H. L, and Hamilton, R. H., 1968, Leaf concentrations of atrazine in cereal crops as related to tolerance: Weed Science, v. 16, no. 1, p. 7-10.

English.

Uptake by Biota.

CA68(17):77139p.

Wichman, J. R, and Bymes, W. R, 1975, Uptake, distribution, and degradation of simazine by black walnut and yellow poplar seedlings: Weed Science, v. 23, no. 6, p. 448-453.

English.

Biodegradation/Biotransformation, Uptake by Biota. CA84(17):116584g.

Wilkinson, R. E., and Karunen, P., 1976, Influence of S-ethyl dipropylthiocarbamate on atrazine absorption by wheat: Annals of Botany (London), v. 40, no. 169, p. 1043-1046. English.

Uptake by Biota,Associations with Plants. CA86(1):986b.

Wolf, D. C., and Jacksen, R. L., August 1982, Atrazine degradation, sorption, and bioconcentration in water systems: Publication No. 87, PB83-150151.

English.

Uptake by Biota.

Woli, D. C., and Jacisson, R. L., Atrazine degradation, sorption, and bioconcentration in water systems: Report, W83-01607, OWRT-B-062-ARK(1); Order No. PB83-150151.

English.

Uptake by Biota.

CA99(3):17978s.

Zadrozinska, J., Ludwicki, J. K, and Klosinska, J., 1985, Determination of residues of triazine herbicides in plant material: Roczniki Panstwowego Zakladu Higieny, v. 36, no. 4, p. 313-321.

Polish.

Uptake by Biota,Analytical Techniques/Quantification. CA105(3):20341b.

Zero, M., 1973, Residues of simazine and atrazine in certain fruits and vegetables: Roczniki Panstwowego Zakladu Higieny, v. 24, no. 4, p. 413-417.

Polish.

Uptake by Biota:

CA81(5):24235d.

Zhirmunskaya, N. M., and Kol'tsova, S. S., 1973, Permeability of barley root cells for the herbicide atrazine: Fiziologiyu na Rasteniyata, v. 20 , no. 1, p. 151-157.

Russian.

Uptake by Biota.

CA78(19):120151g. 
Zhirmunskaya, N. M., and Kol'tsova, S. S., 1975, Mekhanizm Deistviya Gerbitsidov, (Doklady Simpozium), 1971, p. 83-90.

Russian.

Uptake by Biota.

CA85(15):104983u.

Zhirmunskaya, N. M., Shapovalov, A. A., and Ovsyannikova, T. V., 1982, Determination of carrot permeability to several herbicides and growth regulators: Fiziologiyn na Rasteniyata, v. 29, no. 6, p. 1176-1181.

Russian.

Uptake by Biota.

CA98(9):67039m.

Zhirnumskaya, N. M., and Kol'tsova, S. S., Jan/Feb 1973, A study on permeability of barley root cells for herbicide atrazine:

Fiziologiyn na Rasteniyata, v. 20, no. 1, p. 151-157.

Russian.

Uptake by Biota.

Zhukov, Y. P., and Karpukhina, N. S., 1974, Atrazine content in corn and pea shoots under various nutritional conditions: Doklady TSKhA, v. 198 , p. $77-80$.

Russian.

Uptake by Biota.

CA82(13):81411c.

Zhukov, Y. P., and Karpukhina, N. S., 1982, Content and distribution of atrazine in plant organs in relation to mineral nutrition conditions: Izvestiya Timiryazevskoi Sel'skokhozyaistvennoi Akademii, no. 5, p. 70-75.

Russian.

Uptake by Biota.

CA97(21):176900k.

Zsoldos, F., Haunold, E., and Vashegyi, A., 1986, The effects of phosphate supply on uptake of potassium ions, 2,4-D and atrazine by wheat and maize: Physiology Plantarum, v. 68, no. 1, p. 154-158.

English.

Uptake by Biota.

CA105(21):190077n. 


\section{Associations with Humic Material}

Bobyr, L. F., Batal'kin, G. A., Bulgakova, M. P., Epishina, L. A., Prikhodko, L. A., Stepchenko, L. M., and Khristeva, L. A., 1984, Proceedings of the International Peat Congress, 7th, p. 106-117.

English.

Associations with Humic Material.

CA104(5):30351y.

Bulgakova, M. P., and Prikhod'ko, L. A., 1983, Effect of physiologically active humic substances and mineral fertilizers in decreasing the inhibitory action of herbicides on crops sensitive to them: Guminovye Udobreniya Teoriya i Praktika Ikh Primenehiya, p. 14-18.

Russian.

Associations with Humic Material.

CA101(21):186036y.

Chassin, P., Calvet, R., and Terce, M., 1981, Symposium on the Theory and Practice of the Use of Soil Applied Herbicides: Proceedings, p. 10-17.

French.

Sorption to Soil,Associations with Humic Material. CA97(21):176914t.

Chassin, P., Calvet, R, and Terce, M., 1980, Adsorption mechanisms of atrazine by calcium humates: $C$. $R$. Seances Acad. Sci., Ser. C., v. 291, no. 6, p. 165-168.

French.

Associations with Humic Material. CA94(5):26132k.

Dell' Agnola, G., Ferrari, G., and Nardi, S., 1981, Antidote action of humic substances on atrazine inhibition of sulfate uptake in barley roots: Pesticide Biochemistry and Physiology, v. 15, no. 2, p. 101-104.

English.

Associations with Humic Material. CA95(3):19291d.

Dunigan, E. P., and McIntosh, T. H., May 1971, Atrazine-soil organic matter interactions: Weed Science, v. 19, no. 3, p. 279-282.

English.

Associations with Humic Material.

Fusi, P., and Corsi, R., 1967, Influence of some electrolytes on the adsorption-desorption of symmetrical triazines by organic colloids: Ricerca Scientifica, v. 37, no. 7-8, p. 699-700.

Italian.

Associations with Humic Material.

CA68(12):53636x.

Gaillardon, P., 1975, Sorption phenomena between two triazine herbicides and humic acids: Weed Research, v. 15, no. 6, p. 393-399.

French.

Associations with Humic Material. CA84(21):145938f.
Gamble, D. S., Haniff, M. I., and Zienius, R. H., 1986, Solution phase complexing of atrazine by fulvic acid: a batch ultrafiltration technique: Analyrical Chemistry, v. 58, no. 4, p. 727-731.

English.

Associations with Humic Material.

CA104(15):124835m.

Gamble, D. S., Haniff, M. I., and Zienius, R. H., 1986, Solution phase complexing of atrazine by fulvic acid: a theoretical comparison of ultrafiltration methods: Analytical Chemistry, v. 58 , no. 4 , p. $732-734$.

English.

Associations with Humic Materials.

CA104(15):124834k.

Gamble, D. S., and Khan, S. U., 1985, Atrazine hydrolysis in soils: catalysis by the acidic functional groups of fulvic acid: Canadian Journal of Soil Science, v. 65, no. 3, p. 435443.

English.

Associations with Humic Material,Hydrolysis/Chemical Reactions. CA103(21):173931c.

Gilmour, J. T., and Coleman, N. T., 1971, s-Triazine adsorption studies: calcium-hydrogen-humic acid: Soil Science Society of America, Proceedings, v. 35, no. 2, p. 256-259.

English.

Associations with Humic Material.

CA74(23): $124168 \mathrm{~h}$.

Hance, R. J., 1974, Soil organic matter and the adsorption and decomposition of the herbicides atrazine and linuron: Soil Biology and Biochemistry, v. 6, no. 1, p. 38-42.

English.

Biodegradation/Biotransformation,Associations with Humic Material.

CA81(7):34430c.

Hance, R. J., 1969, Adsorption of linuron, atrazine, and EPTC by model aliphatic adsorbents and soil organic preparations: Weed Research, v. 9, no. 2, p. 108-113.

English.

Associations with Humic Material.

CA71(11):48575j.

Haniff, M. I., 1984, The equilibrium complexing of atrazine to a soil futvic acid at various $\mathrm{pH}$ values, ionic strength, and fulvic acid concentration, Dissertation submitted in partial fulfillment of Ph.D. requirements, Concordia University, Montreal, PQ, Can..

English.

Associations with Humic Material. CA102(21):180818d.

Haniff, M. I., Zienius, R. H., Langford, C. H., and Gamble, D. S., 1985, The solution phase complexing of atrazine by fulvic acid: equilibria at 25 degrees: Journal of Environmental Science and Health, Part B, v. B20, no. 2, p. 215-262. English.

Associations with Humic Material.

CA103(5):33419s.

Hayes, M. H. B., Stacey, M., and Thompson, J. M., 1968, Isotopes 
and Radiation in Soil Organic-Matter Studies, Proceedings of the Symposium, 2nd, p. 75-90.

English.

Associations with Humic Material.

CA71(5):21090k.

Kalouskova, N., 1987, Interaction of humic acids with atrazine: Journal of Environmental Science and Health Part B, v. 22, no. 1, p. 113-123.

English.

Associations with Humic Material.

IND 87024824.

Khan, S. U., and Schnitzer, M., 1978, UV irradiation of atrazine in aqueous fulvic acid solution: Joumal of Environmental Science and Health, Part B, v. B13, no. 3, p. 299-310.

English.

Associations with Humic Material,Photolysis.

CA89(21):174935m.

Khan, S. U., 1978, Kinetics of hydrolysis of atrazine in aqueous fulvic acid solution: Pesticide Science, v. 9, no. 1, p. 3943.

English.

Hydrolysis/Chemical Reactions,Associations with Humic Material.

CA89(1):1604z.

Khlebnikova, M. V., and Konchits, V. A., 1975, Mekhanizm Deistviya Gerbitsidov i Sinteticheskikh Regulyatorov Rosta Rastenii i Ikh Sud'ba v Biosfere, Materialy Mezhdunarodnogo Simpoziuma, p. 81-85.

Russian.

Associations with Humic Material.

CA88(21):147341n.

L'Hopitault, J. C., and Pommery, J., 1982, Sequestering properties of various fractions of humic matters with pesticides and heavy metals: Revue Francaise des Sciences de l'Eau, v. 1, no. 1, p. 85-92.

French.

Associations with Humic Material.

CA97(10):78585s.

Li, G. C., and Felbeck, G. T., 1972, Atrazine hydrolysis as catalyzed by humic acids: Soil Science, v. 114, no. 3, p. 201-209.

English.

Hydrolysis/Chemical Reactions_Associations with Humic

Material.

CA77(23):150971w.

Li, G. C., 1971, A study of the interaction of atrazine with fractions of soil organic matter, Dissertation submitted in partial fulfillment of $\mathrm{Ph}$.D. requirements, University of Rhode Island; Rhode Island.

English.

Sorption to Soil, Associations with Humic Material. CAT 81752316.
Li, G.-C., and Felbeck, G. T., Jr., 1972, Study of the mechanism of atrazine adsorption by humic acid from muck soil: Soil Science, v. 113, no. 2, p. 140-148.

English.

Associations with Humic Material.

CA77(3): $15389 x$.

Means, J. C., and Wijayaratne, R, 1982, Role of natural colloids in the transport of hydrophobic pollutants: Science, v. 215, no. 4535, p. $968-970$.

English.

Associations with Humic Material.

CA96(18):148727v.

Mueller-Wegener, U., 1983, Adsorption of chemicals relevant to the environment in soils. II. Binding to suspended and dissolved humic acids: Chemie der Erde, v. 42, no. 2, p. 111119.

German.

Associations with Humic Material.

CA99(20):163251r.

Mueller-Wegener, U., 1977, The binding of s-triazines to humic acids: Geoderma, v. 19, no. 3, p. 227-235.

German.

Associations with Humic Material.

CA88(13):84550g.

Muller-Wegener, U., and Ziechmann, W., 1980, Electron-donoracceptor-complexes between aromatic nitrogen heterocycles and humic acid: Zeitschrift Pflanzenerhaehrung und Bodenkunde, v. 143 , no. 2, p. 247-249.

German.

Associations with Humic Material. CA93(13):131902p.

Peeper, T. F., and Weber, J. B., 1976, Activity and persistence of atrazine, procyazine, and Vel 5026 as influenced by soil organic matter and clay. Proceedings of the Southern Weed Science Society, v. 29, p. 387-398.

English.

Sorption to Soil,Associations with Humic Material. CA85(9):58068z.

Perdue, E. M., 1983, Aquatic and Terrestrial Humic Materials, (Selected Papers from the Symposium), 1981, p. 441-460. English.

Hydrolysis/Chemical Reactions,Field Residuals,Associations with Humic Material.

CA98(15):124787e.

Saint-Fort, R, and Visser, S. A., 1988, Study of the interactions between atrazine, diazinon and lindane with humic acids of various, molecular weights: Joumat of Environmental Science and Health, Part A, v. A23, no. 6, p. 613-624.

English.

Associations with Humic Material. CA109(23):206732t.

Schiavon, M., Jacquin, F., and Goussault, C., 1977, Soil Organic Matter Studies, Proceedings of the Symposium, 1976, p. 327332.

French.

Associations with Humic Material.

CA89(25):210397y. 


\section{ENVIRONMENTAL PROCESSES \\ TRANSFER PROCESSES \\ Sorption/Partitioning}

Skipper, H. D., Volk, V. V., Mortland, M. M., and Raman, K. V., 1978, Hydrolysis of atrazine on soil colloids: Weed Science, v. 26, no. 1, p. 46-51.

English.

Hydrolysis/Chemical Reactions,Associations with Humic Material.

CA90(13):98546p.

Sullivan, J. D., Jr., and Felbeck, G. T., Jr., 1968, A study of the interaction of s-triazine herbicides with humic acids from three different soils: Soil Science, v. 106, no. 1, p. 42-52.

English.

Associations with Humic Material.

Tripathi, H. P., and Moolani, M. K., 1972, Effect of simazine and atrazine applied under different levels of organic matter on maize, and their residual effect on succeeding crops: Indian Journal of Agricultural Science, v. 42, no. 7, p. 604-609.

English.

Sorption to Soil,Associations with Humic Material.

CA78(11):68102a.

Turski, R, and Steinbrich, A, 1972, Possibilities of binding herbicides of triazine derivates by humic acids: Polish Journal of Soil Science, v. 4, no. 2, p. 119-124.

English.

Associations with Humic Material.

CA78(1):3161z.

Wijayaratne, R. D., and Means, J. C., 1984, Affinity of hydrophobic pollutants for natural estuarine colloids in aquatic environments: Environmental Science and Technology, v. 18 , no. 2 p. $121-123$.

English.

Associations with Humic Material.

CA100(6):39216h.

Wu, T. L., Lambert, L., Hastings, D., and Banning, D., 1980, Enrichment of the agricultural herbicide atrazine in the microsurface water of an estuary: Bulletin of Environmental Contamination and Toxicology, v. 24, no. 3, p. 411-414. English.

Surfacewater Observations,Associaticns with Humic Material. CA92(25):210172h. 


\section{Associations with Plant Material}

Boehm, H. H., and Mueller, H., 1976, Model studies on the accumulation of herbicides by microalgae:

Naturwissenschaften, v. 63, no. 6, p. 296.

English.

Associations with Plants.

CA85(9):57761h.

Calamari, D., Vighi, M., and Bacci, E., 1987, The use of terrestrial plant biomass as a parameter in the fugacity model: Chemosphere, v. 16, no. 10-12, p. 2359-2364.

English:

Associations with Plants.

CA108(15):126684t.

Darmstadt, G. L., Balke, N. E., and Price, T. P., 1984, Triazine absorption by excised corn root tissue and isolated corn root protoplasts: Pesticide Biochemistry and Physiology, v. 21, no. 1 , p. 10-21.

Engiish.

Associations with Plants.

CA100(11):81157q.

Darmstadt, G. L., Balke, N. E., and Schrader, L. E., 1983, Use of corn root protoplasts in herbicide absorption studies: Pesticide Biochemistry and Physiology, v. 19, no. 2, p. 172 183.

English.

Associations with Plants.

CA98(19):1579232.

Embling, S. J., Cotterill, E. G., and Hance, R. J., 1983, Effect. of heat-treating soil and straw on the subsequent adsorption of chlortoluron and atrazine: Weed Research, v. 23, no. 6, p. 357-363.

English.

Associations with Plants.

CA100(3):19222d.

Frear, D. S., and Swanson, H. R, 1970, Biosynthesis of S-(4ethylamino-6-isopropylamino-2-s-triazino)glutathione: partial purification and properties of a glutathione $S$ transferase from corn: Phytochemistry, v. 9, no. 10, p. 21232132.

English.

Association with Plants, Uptake by Biota.

CA74(5):19676z.

Freitag, D., Ballhorn, L., Geyer, H., and Korte, F., 1985, Environmental hazard profile of organic chemicals. An experimental method for the assessment of the behavior of organic chemicals in the ecosphere by means of simple laboratory tests with carbon-14-labeled chemicals: Chemosphere, v. 14, no. 10, p. 1589-1616.

English.

Chemical/Physical Properties,Biodegradation/Biotransformation, Associations with Plants. CA103(25):208313g.
Huckins, J. N., Petty, J. D., and England, D. C., 1986, Distribution and impact of trifluralin, atrazine, and fonofos residues in microcosms simulating a northern prairie wetland: Chemosphere, v. 15 , no. 5, p. 563-588.

English.

Associations with Plants.

CA105(25):220345t.

Jacob, F., and Neumann, S., 1987, Quantitative aspects of the mobility of xenobiotics: Tagungsbericht-Akademie der

Landwirtschaftswissenschaften der Deutschen Demokratischen Republik, v. 253, no. Syst. Fungic. Antifungal Compd., p. 229-234.

English.

Associations with Plants.

CA108(25):217768q.

Jones, T. W., and Estes, P. S., 1984, Uptake and phytotoxicity of soil-sorbed atrazine for the submerged aquatic plant, Potamogeton perfoliatus L.: Archives of Environmental Contamination and Toxicology, v. 13, no. 2, p. 237-241. English.

Associations with Plants, Uptake by Biota,Toxicity. CA100(19):152227a.

Jursinic, P., and Stemler, A., Now 1983, Changes in 14C atrazine binding associated with the oxidation-reduction state of the...: Plant Physiology, v. 73, no. 3, p. 703-708.

English.

Uptake by Biota,Associations with Plants,Degradation Products.

IND 83126519.

Kerier, F., and Schoenherr, J., 1988, Accumulation of lipophilic chemicals in plant cuticles: prediction from octanol/water partition: Archives of Environmental Contamination and Toxicology, v. 17 , no. 1, p. $1-6$.

English.

Associations with Plants.

CA108(13):107600w.

Kerler, F., and Schoenherr, J., 1988, Permeation of lipophilic chemicals across plant cuticles: prediction from partition coefficients: Archives of Environmental Contamination and Toxicology, v. 17 , no. 1, p. 7-12.

English.

Chemical/Physical Properties,Associations with Plants. CA108(9):70365v.

Khan, S. U., and Akhtar, M. H., 1983, In vitro release of bound (nonextractable) atrazine residues from com plants by chicken liver homogenate and bovine rumen liquor. Journal of Agriculture and Food Chemistry, v. 31, no. 3, p. 641-644. English.

Toxicity,Degradation Products, Uptake by Biota,Associations with Plants. CA98(23):192994v. 
Khan, S. U., Marriage, P. B., and Hamill, A. S., 1981, Effects of atrazine treatment of a corn field using different application methods, times, and additives on the persistence of residues in soil and their uptake by oat plants.: Joumal of Agriculture and Food Chemistry, v. 29, no. 2, p. 216-219. English.

Associations with Plants,Biodegradation/Biotransformation. CA94(17):133965f.

Khan, S. U., and Rauthan, B. S., 1985, In vitro release of bound carbon-14-labeled (nonextractable) residues from plants by corn leaves homogenates: Chemosphere, v. 14, no. 2, p. 209 214.

English.

Associations with Plants.

CA102(19):16211p.

Khubutiya, R. A., Ugulava, N. A., and Tvalchrelidze, E. V., 1975, Mekhanizm Deistviya Gerbitsidov i Sinteticheskikh

Regulyatorov Rosta Rastenii i Ikh Sud'ba v Biosfere, Materialy Mezhdunarodnogo Simpoziuma., p. 114-118. Russian.

Association with Plants.

CA88(21):147343q.

Kulikova, O. A., Razvodovskaya, L. V., Mel'nikov, N. N., and Negrebetskii, V. V., 1982, Phosphorus-containing striazinylureas: Zhurnal Obshchei Khimii, v. 52, no. 5, p. 1108-1112.

Russian.

Associations with Plants. CA97(17):144928j.

Lamoureux, G. L., Shimabukuro, R. H., Swanson, H. R, and Frear, D. S., 1970, Metabolism of 2-chloro-4-ethylamino-6-isopropylamino-s-triazine (atrazine) in excised sorghum leaf: Journal of Agriculture and Food Chemistry, v. 18, no. 1, p. 81-86. English. Biodegradation/Biotransformation,Associations with Plants. CA72(13):65655y.

Leuthold, U., Bruechler, C., and Ebert, E., 1978, The distribution of agrochemicals on leaf surfaces: a methodical study: Weed Research, v. 18, no. 5, p. 265-268.

English.

Associations with Plants.

CA90(13):98406t.

Lowder, S. W., and Weber, J. B., 1979, Atrazine retention by crop residues in reduced-tillage systems: Proceedings, Southern Weed Science Society, p. 303-307.

English.

Associations with Plants. CAO3(11):110817z.

Neumann, W., Laasch, H., and Urback, W., 1987, Mechanisms of herbicide sorption in microalgae and the influence of environmental factors: Pesticide Biochemistry and Physiology, v. 27, no. 2, p. $189-200$.

English.

Associations with Plants.

CA106(15):115172g.
Ohori, Y., and Ihashi, Y., 1987, Foliar absorption of pesticides using an isolated cucumber membrane: Research and Developinent Review - Mitsubishi Chemical, v. 1, no. 2, p. 22-26.

Japanese.

Associations with Plants.

CA107(19):170242a.

Orwick, P. L., Schreiber, M. M., and Hodges, T. K., 1976, Absorption and efflux of chloro-s-triazines by Setaria roots: Weed Research, v. 16, no. 2, p. 139-144.

English.

Associations with Plants.

CA84(25):175027a.

Percich, J. A., and Lockwood, J. L., 1978, Interaction of atrazine with soil microorganisms: population changes and accumulation: Canadian Journal of Microbiology, v. 24, no. 10, p. 1145-1152.

English.

Uptake by Biota,Biodegradation/Biotransformation,Associations with Plants.

CA9O(5):34969w.

Phillips, R. E., Egli, D. B., and Thompson, L. J., 1972, Absorption of herbicides by soybean seeds and their influence on emergence and seedling growth: Weed Science, v. 20, no. 5, p. 506-510.

English.

Associations with Plants.

CA79(1):1226w.

Price, T. P., and Balke, N. E., 1982, Characteriaztion of rapid atrazine absorption by excised velvetleaf (Albutilon theophrasti) roots: Weed Science, v. 30, no. 6, p. 633-639. English.

Uptake by Biota,Associations with Plants. Ca98(5):29617r.

Price, T. P., and Balke, N. E., 1983, Comparison of atrazine absorption by underground tissues of several plant species: Weed Science, v. 31, no. 4, p. 482-487.

English.

Associations with Plants.

CA99(17):135425g.

Schultz, D. P., and Tweedy, B. G., Mar 1971, Incorporation of atrazine side-chain into amino acids of corn: Weed Science, v. 19 , no. 2, p. $133-134$.

English.

Association with Plants.

CAIN 719064777 .

Scott, H. D., and Phillips, R. E., 1973, Absorption of herbicides by soybean seed: Weed Science, v. 21, no. 1, p. 71-76. English. Associations with Plants. CA78(11):68097c.

Shimabukuro, R. H., Frear, D. S., Swanson, H. R, and Walsh, W. C., 1971, Glutathione conjugation. Enzymic basis for atrazine resistance in corn: Plant Physiology, v. 47, no. 1, p. 10-14. English. Association with Plants. CA74(19):986306. 
Shone, M. G. T., and Wood, A. V., 1973, A comparison of the absorption and translocation of some organic molecules by barley roots: Annual Report of the Agriculture Research

Council, Letcombe Laboratory, p. 45-47.

English.

Associations with Plants.

CA85(9):57938w.

Strand, O. E., 1971, Effect of adjuvants on the phytotoxicity of foliar sprays of atrazine, Dissertation submitted in partial fulfillment of Ph.D. requirements, University of Minnesota, Minnesota.

English.

Associations with Plants.

\section{CAT 80732338.}

Strzelec, A, 1982, Effect of peat and bentonite added to a light soil on the development of microflora and rate of atrazine degradation: Roczniki Gleboznawcze, v. 33, no. 1/2, p. 47-59. Polish.

Associations with Plants,Biodegradation/Biotransformation. CA99(1):1762f.

Walker, A., and Featherstone, R. M., 1973, Absorption and translocation of atrazine and linuron by plants with implications concerning linuron selectivity: Journal of Experimental Botany, v. 24, no. 79, p. 450-458.

\section{English.}

Uptake by Biota,Associations with Plants.

CA79(5):28299j.

Wilkinson, R. E., and Karunen, P., 1976, Influence of S-ethyl dipropylthiocarbamate on atrazine absorption by wheat: Annals of Botany (London), v. 40, no. 169, p. 1043-1046.

English.

Uptake by Biota,Associations with Plants.

CA86(1):986b.

Winkle, M. E., Leavitt, J. R. C., and Burnside, O. C., 1981, Effects of weed density on herbicide absorption and bioactivity: Weed Science, v. 29, no. 4, p. 405-409. English.

Associations with Plants.

CA95(13):110081w. 


\section{ENVIRONMENTAL PROCESSES \\ TRANSFER PROCESSES \\ Sorption/Partitioning}

\section{Associations with Surfactants}

Abildt, U., and Langauer, T., 1983, Flowable herbicidal compositions in an aqueous dispersion form: Appt. 83/4739, 21 Feb 1983; US Appl. 352437, 25 Feb 1982.

English.

Associations with Surfactants.

CA100(9):63506y.

Albrecht, K, and Frisch, G., 1984, Liquid pesticide composition in the form of suspension concentrates: Appl. 3240862, 5 Nov 1982.

German.

Associations with Surfactants. CA101(19):165599u.

Allan, G. G., 1985, Sustained release compositions for biologically active materials: Appl. 84/108953, 27 Jul 1984; US Appl. 518281, 28 Jul 1983.

English.

Associations with Surfactants.

CA102(25):216903u.

Almodovar Vega, L., and Ilnicki, R. D., Oct 1970, Enhancing atrazine activity with additions of mineral and vegetable oils: Puerto Rico University Journal of Agriculture, v. 54, no. 4, p. $657-659$.

English.

Associations with Surfactants. CAIN 719045394.

Andriska, V., Gyorffy, B., Bonnyay, P., Dombay, Z., Grega, J. M., Matyas, L., Nagy, J., Pavlisesak, C., and Tarpai, G., 1985, Plant protective composition containing stabilized ester-type compound: Appl. 83/2567, 21 Jul 1983.

Hungarian.

Associations with Surfactants. CA104(19):163750z.

Andriska, V., Monostory, A. M., Nagy, B., Tomordi, E., Nyakas, P., Benczik, J., Czimer, L., Horvath, A., Maljucoskova, L., and Ratkovszky, J., 1984, Liquid, stabilized, selective herbicide: Appl. 81/1994, 9 Jul 1981.

Hungarian.

Associations with Surfactants. CA101(1):2323k.

Anon., 1978, Agrochemical compositions: Appl. or Pr. 76/22477, 23 Jul 1976.

French.

Associations with Surfactants. CA89(19):158777f.

Anon., 1977, Aqueous dispersions of insoluble solid materials: GB Appt. 75/37837, 15 Sep 1975. Netherlands.

Associations with Surfactants. CA88(26):193206v.

Anon., 1978, Heterocyclic safening agents for herbicides: Appl. or Pr. 76/100477,23 Aug 1976. Japanese.

Associations with Surfactants.
Anon., 1975, Pesticide suspensions in aqueous salt solutions: US Appl. 410,797, 23 Oct 1973.

French.

Aseociations with Surfactants.

CA84(5):26911g.

Arranz, F., and Lopez Garcia, F. J., 1977, Incorporation of striazine derivatives into poly(vinyl alcohol) partially metalated with sodium hydroxide: Revista de Plasticos Modernos, v. 33, no. 252, p. 815-820.

Spanish.

Associations with Surfactants.

CA87(16):118354t.

Bahadir, M., and Korte, F., 1987, Pesticide Science Biotechnology, Proceedings of the International Congress of Pesticide Chemists, 6th, 1986, p. 265-272.

English.

Associations with Surfactants.

CA107(19):170478g

Banki, L., Bendefy, I., Buczko, J., Halasz, M. G., Kadar, A., Radvany, B., Sere, J., Sovegjarto, O., Valovits, E., and Vilagi, E., 1975, Oily pesticide compositions: Appl. or Pr. BU-649, 23 Mar 1973.

Hungarian.

Associations with Surfactants.

CA84(1):1264k.

Barth, P., Wildgrube, W., Mueller, L., Gruen, H. J., Pfuetzner, P., Schossig, R, Weidner, K. F., Reinhardt, P., and Kramer, W., 1984, Mineral oil-free tank mixtures: Appl. 24779, 13 Apr 1983.

German.

Associations with Surfactants.

CA103(3):18435a.

Barth, P., Wildgrube, W., Riedel, M., Hesse, H., Mueller, L. K, Wilfried, and Wolter, G., 1985, Oil-containing plant protection product combinations with low phytotoxicity. Appl. 243059, 7 Sep 1982

German.

Associations with Surfactants. CA103(17):1371812.

Becher, P., Trifiletti, S. E., and Petty, P. C., 1981, Adsorption of surface-active agents from aqueous solution: hydrophobic substrates: Journal of Dispersion Science and.Technology, $v$. 2, no. 1, p. 53-66.

English.

Associations with Surfactants. CA94(20): $163193 v$.

Beestman, G. B., and Deming. J. M., 1983, Encapsulation by interfacial polycondensation: Appl. 286092, 22 Jul 1981; US Appl. 23566, 26 Mar 1979.

English.

Associations with Surfactants.

CA100(19):152493j. 
Bishop, R T., 1979, Controlled solubility of soil additives: Appl. or Pr. 77/6918, 21 Nov 1977.

English.

Associations with Surfactants.

CA91(15):122883q.

Bohus, P., Hadobas, J. M., Pal, J. M., and Pinter, J., 1987, Process for preparing wettable powders: Appl. 85/3294, 30 Aug 1985.

Hungarian.

Associations with Surfactants.

CA107(19):170627e.

Bonnyai, P., Sceh, E., Dombay, Z., Grega, J. M., Jakab, E., Lorik, E., Matyas, L., Nagy, J., Pavliczek, C., and et al., 1985, Stable regulator and/or plant protective suspension concentrate: Appl. 83/2889, 17 Aug 1983.

Hungarian.

Associations with Surfactants.

CA104(23):202344s.

Bowden, G. H., 1980, Process for preparing composite granules of agrochemicals: Appl. or Pr. 79/14110, 23 Apr 1979.

English.

Associations with Surfactants.

CA95(3):19716w.

Bozzay, J., Rusznak, I., Torok, A., Dombai, Z., and Ekes, G., 1981, Kolloidkemiai Konferencia Eloadasai, 3rd, p. 328-331. Hungarian.

Associations with Surfactants.

CA96(17):137981x.

Bozzay, J., Dombai, Z, Rusznak, I., and Torok, L., 1983, Development of a new granulation technique. I: Periodica Polytechnica, Chemical Engineering, v. 27, no. 1, p. 5-11. English.

Associations with Surfactants.

CA99(25):208118w.

Bozzay, J., Torok, L. M. Arki, A., Dombay, Z, Grega Jozsef, Nagy, J., Pavlisesak, C., Tarpai, G., Tasi, L., and Matyas, L., 1983, Pesticide granules by binder precipitation: Appl. 82/351, 5 Feb 1982.

Hungarian.

Associations with Surfactants.

Bozzay, J., Torok, M. L., Bekefi, E., Bonnyay, P., Dombay, Z., Grega, M. J., and Nagy, J., 1982, Preparation of granules containing pesticides and gypsum by the suspension method: Appl. 80/1313, 26 May 1980.

Hungarian.

Associations with Surfactants.

CA98(17):139019e:

Bronnikova, G. V., Polyakov, P. P., and Smirnova, E. B., 1973, Effect of the technology of incision tapping on the processing of oleoresin: Gidroliznaya i Lesokhimicheskaya Promyshlennost, no. 8, p. 17-18.

Russian.

Associations with Surfactants.

CA80(18):97584f.
Burr, R. J., and Warren, G. F., 1971, Enhancement of herbicide activity with an isoparafinic oil carrier. Weed Science, v.

19 , no. 6 , p. $701-705$.

English.

Associations with Surfactants.

CA76(13):69108c.

Burridge, L. E., and Haya, K, 1988, The use of a fugacity model to assess the risk of pesticides to the aquatic environment on Prince Edward Island: Advances in Environmental Science and Technology, v. 22, no. Aquat. Toxicol. Water Qual. Manage., p. 193-203.

English.

Associations with Surfactants.

CA110(10):82085h.

Cardarelli, N. F., 1982, Controlied release of active compounds from a polymer-based dispenser. Appl. 81/22447, 21 Jul 1981; US Appl. 171834, 24 Jul 1980; US Appl. 171835, 24 Jul 1980. Engtish.

Associations with Surfactants.

CA97(9):67814q.

Cardarelli, N. F., 1983, Controlled release of herbicide compounds utilizing a thermoplastic matrix: Appl. 171834, 24 Jul 1980; US Appl. 916570, 19 Jun 1978; US Appl. 5174, 22 Jan 1979; US Appl. 14118, 22 Feb 1979; US Appl. 51102, 22 Jun 1979.

English.

Associations with Surfactants.

CA99(25):208142z.

Carpenter, D. A., and Meusburger, K. E., 1970, Oil-in-water emulsions of herbicides: Ger. Offen. DE 1811643, 11 Jun 1970 , 17 p.

German.

Associations with Surfactants.

CA73(11):54902w.

Cheng, C.-H., and Wang, C.-C., 1979, Effect of surfactants on the phytotoxic activity and selectivity of several herbicides:

Kuo Li T'ai-wan Ta Hsueh Hung Hsueh Yuan Yen Chiu Pao Kao, v. 19, no. 2, p. 1-16.

Chinese.

Associations with Surfactants.

CA95(5):37024y.

Cheng, C.-H., and Wang, C.-C., 1979, Effects of surfactants on the efficacy and selectivity of several herbicides: Kuo Li Tai-wan Ta Hsueh Nung Hsueh Yuan Yen Chiu Pao Kao, v. 19, no. 2, p. 1-16.

Chinese.

Associations with Surfactants.

CA95(3):19619s.

Chwedoruk, A., and Domanska, H., 1980, Effect of oil additives on the effectiveness of sprayed liquid herbicides: Acta

Agrobotanica, v. 33, no. 1, p. 131-137.

Polish.

Associations with Surfactants.

CA94(19):151751n. 
Cierco Sanchez, E., 1983, Compositions with herbicidal activity containing a substituted urea and a substituted s-triazine: Appl. 517808, 30 Nov 1982.

Spanish.

Associations with Surfactants.

CA100(3):19298h.

Clark, D. E., Fawcett, R. s., Jennings, V. M., and Staniforth, D. W., 1978, Herbicide adjuvant effects on weed control and yield: Proceedings - North Central Weed Control Conference, v. 33, p. 96-97.

English.

Associations with Surfactants.

CA91(9):69816s.

Coats, G. E., and Foy, C. L., May 1974, Effect of atrazinephytobland oil combinations on 14CO2(carbon dioxide 14)fixation and transpiration: Weed Science, v. 22, no. 3, p. 215-220.

English.

Associations with Surfactants.

CAIN 749042231.

Coats, G. E., and Foy, C. L., 1974, Effects of petroleum oils on the uptake of carbon-14-labeled atrazine by corn: Weed

Science, v. 22, no. 3, p. 220-226.

English.

Associations with Surfactants.

CA81(11):59193r.

Coats, G. E., 1971, Influence of phytcbland oils on the activity of foliarly applied atrazine, Dissertation submitted in partial fulfillment of Ph.D. requirements, Virginia Polytechnic Institute and State University, Virginia. English.

Associations with Surfactants.

CAT 81757608.

Colli, H. T. Delli, 1987, Pesticide Science Biotechnology, Proceedings of the International Congress of Pesticide Chemists, 6th, 1986, p. 279-286.

English.

Associations with Surfactants.

CA107(15):128992v.

Cserhati, T., 1981, Interaction of nonionic surfactants and pesticides: Proceedings of the Hungarian Annual Meeting of Biochemists, p. 47-48.

English.

Associations with Surfactants.

CA96(19):157353x.

Cserhati, T., Bordas, B., Tyihak, E., and Bohus, P., 1982, Proceedings of the International Symposium on Instruments of High. Performance Thin-Layer Chromatography, 2nd, p. 74-88. English.

Associations with Surfactants. CA97(21):177005j.

Cserhati, T., Szogyi, M., and Kanyar, B., 1981, Application of chromatographic methods to membrane biochemistry: Magyar Tudomanyos Akademia Biologiai Tudomenyok Oszta lyanak Koziemenyei, v. 24, no. 1-2, p. 209-217.

Hungarian.

Associations with Surfactants.

CA96(17):137972v.
Dejan, O., Dejan, M., Visan, D., Ghidarcea, I., Radu, I., and Gojgau, M., 1981, Emulsifiable concentrates of s-triazine herbicides: Appl. 81662, 17 Mar 1975; RO Appl. 76001, 6 Sep 1973.

Romanian.

Associations with Surfactants. CA98(7):48683a.

Delescluse, C. L. Louis, 1983, Wettable powders of solid hydrophobic substances and wettable dispersible and nonfoaming adjuvants used therefor: Appl. 82/401727, 24 Sep 1982; FR Appl. 81/18772, 6 Oct 1981.

French.

Associations with Surfactants. CA99(15):117849u.

Deming, J. M., and Kramer, R. M., 1971, Granular herbicidal composition containing acetanilides and s-triazines or substituted ureas: Ger. Offen. DE 2117998, 28 Oct 1971, 31 p. German.

Associations with Surfactants.

CA76(17):95755f.

Dragusin, E., Cerneaga, M., Masala, F., Mitrea, D., and Bader, B., 1984, Stabilizing a composition based on herbicidal striazine mixtures: Appl. 108460, 12 Aug 1982.

Romanian.

Associations with Surfactants.

CA103(3):18421t.

Elliott, J. H., 1976, Triazine and surfactant-containing aqueous herbicidal composition: US Appl. 120358, 2 Mar 1971. Unavailable.

Associations with Surfactants. CA86(13):84746j.

Ercegovich, C. D., Raleigh, S. M., and Frear, D. E. H., 1968, Effects of oil and surfactant on residues of atrazine in field gruwn corn: Proceedings of the Northeastem Weed Control Conference, v. 22, p. 488-490.

English:

Associations with Surfactants.

CA68(19):861822.

Frajstak, P., and Abalova, I., 1985, Powdery dispersion agent: Appl. 81/3479, 12 May 1981.

Slovenian.

Associations with Surfactants.

CA103(25):208958w.

Frisch, G., and Albrecht, K., 1988, Pesticidal suspoemulsions: Ap 3631558, 17 Sep 1986.

German.

Associations with Surfactants.

CA109(7):50279n.

Fusi, P., and Corsi, R., 1969, Effects of some electrolytes and surfactants on the adsorption and release of atrazine in typical soils: Agrochimica, v. 13, no. 1-2, p. 44-55. Italian.

Associations with Surfactants. CA70(25):1140436. 
Ghyezy, M., Etschenberg, E., and Wendel, A., 1984, Encapsulation of biocidal agents: Appl. 3226147, 13 Jul 1982.

German.

Associations with Surfactants.

CA100(15):116511e.

Gillings, C., and Jewry, I. C., 1976, Herbicide compositions: GB Appl. 33,298/74, 27 Jul 1974.

German.

Associations with Surfactants.

Girardeau, Y., Gaudinet, P., and Queuche, S., 1986, Surfactant composition and its preparation and use: Appl. 86/400949, 30 Apr 1986; FR Appl. 85/6827, 6 May 1985.

French.

Associations with Surfactants.

CA106(10):69171f.

Girardeau, Y., Ruffo, G., and Segaud, C., 1988, Phosphoric ester surfactants for granular or flowable pesticide formulations: Appl. 87/401564, 3 Jul 1987; FR Appl 86/10159, 11 Jul 1986. French.

Associations with Surfactants.

CA108(25):217810x.

Gorog, K., Dudar, E., Gardi, I., Kocsis, M., Gaal, S., and Tasnadi, M., 1982, Herbicidal compositions: Appl. 80/8024852, 30 Jul 1980.

English.

Associations with Surfactants.

CA97(7):51217m.

Green, W. E., 1975, Soil treatment: Appl. or Pr. 138,050, 24 Mar 1972.

Unavailable.

Associations with Surfactants.

CA84(17):116937z.

Grossman, M., Faber, R, and Unrig, H., 1973, Sulfosuccinic acid hemiesters of poly(oxyalkylene alkylphenyl) alkylphenols as dispersion or wetting agents for organic biocides: Appl. or Pr. P 2132 405.50, 30 Jun 1971.

German.

Associations with Surfactants.

CA78(17):107010r.

Gyorffy, B., Szabo, J. L., Andriska, V., Gorog, M. L., Grega, M. J., Gribowszki, P., Farkas, K, Laszlo, I., Gyapai, J., and Benyai, P., 1975, Oily herbicide suspensions: Appl. or Pr. MA-2554, 28 Mar 1974.

Hungarian.

Associations with Surfactants.

CA84(3):13518j.

Hacker, R. K. Wilfried, and Steinke, W., 1978, Liquid herbicides: Appl. or Pr. 198462, 19 Apr 1977.

German.

Associations with Surfactants.

CA90(25):198883q.
Hammond, J. W., and Waddell, M. T., 1966, Use of superior spray oils to improve the herbicidal activity of Atrazine:

Proceedings of the North Central Weed Control Conference, v. 20, p. $5-6$.

English.

Associations with surfactants.

CA67(17):81400p.

Hausmann, H., and Schmidt, R. R, 1984, Selective herbicidal composition containing a triazine derivative in combination with lecithin or linoleic acid: Appl. 3300107, 4 Jan 1983. German.

Associations with surfactants.

CA101(13):105800t.

Huggenberger, F., Letey, J., and Farmer, W. J., 1973, Effect of two nonionic surfactants on adsorption and mobility of selected pesticides in a soil-system: Soil Science Society of America, Proceedings, v. 37, no. 2, p. 215-219.

English.

Associations with Surfactants.

Ilka, P., and Sukenikova, A., 1983, Quality of Zeazin 50 and atrazine residues in the soil: Agrochemia (Bratislava), $v$. 23, no. 11, p. 335-337.

Slovenian.

Field Residuals,Associations with Surfactants.

CA100(7):46949c.

Jagnow, G., Heinemeyer, O., and Draeger, S., 1979, Choice of liquid, semisolid, or soil suspension media: an important factor modifying the effect of pesticides on the nitrogenase (C2H2) activity of Clostridium pasteurianum, Azoto bacter chroococeum, and Spirillum lipoferum Beijerinck:

Ecotoxicology and Environmental Safety, v. 3, no. 2, p. 152 -

158.

English.

Associations with Surfactants.

CA91(15):118246s.

Johnson, B. T., 1986, Potential impact of selected agricultural chemical contaminants on a northern prairie wetland: a microcosm evaluation: Environmental Toxicology and Chemistry, v. 5 , no. 5 , p. $473-485$.

English.

Toxicity,Associations with Surfactants.

CA105(1):1958s.

Jolley, R. L., and Pitt, W. W. Jr., Proceedings of the 1977 Disinfection Symposium, American Water Works Association, 813 May 1977.

English.

Associations with Surfactants.

Jones, D. W., and Foy, C. L., 1972, Tracer studies with carbon14-labeled herbicides, dimethylsulfoxide (DMSO), and surfactant: Weed Science, v. 20, no. 1, p. 81-86.

English.

Uptake by Biota,Associations with Surfactants.

CA76(25):149850d. 
Jones, T. W., Kemp, W. M., Stevenson, J. C., and Means, J. C., October-December, 1982, Degradation of atrazine in estuarine water/sediment systems and soils: Journal of Environmental Quality, v. 11, no. 4, p. 632-638.

English.

Biodegradation/Biotransformation,Associations with Surfactants, Field Residuals,Sorption to Sediments,Sorption to Soil,Degradation Products.

CA97(25):210373c.

Jones, T. W., and Winchell, L., April-June 1984, Uptake and photosynthetic inhibition by atrazine and its degradation. products on four species of submerged vascular plants: Journal of Environmental Quality, v. 13, no. 2, p. 243-247. English.

Associations with Surfactants, Uptake by Biota,Degradation Products, Toxicity.

CA101(1):2244k.

Juhas, M., Teren, J., Nadvornik, R., Hutar, E., and Novak, J., 1985, Suspension stabilizer. Appl. 81/2800, 14 Apr 1981.

Slovenian.

Associations with Surfactants.

CA103(25):208959x

Kaneko, T. M., 1986, Pesticide granules: Appl. 436147, 7 Sep 1983; US Appl. 430174, 30 Sep 1982.

English.

Associations with Surfactants.

CA106(3):14741m

Karoly, G., and Biro, A., 1985, Study of Balaton Lake and its tributaries for pesticide residues by the Department of Veszprem from 1976 to 1983: Novenyvedelem (Budapest), v. 21, no. 1, p. 32-36.

Hungarian.

Associations with Surfactants.

CA102(15):127318q.

Karoly, G., Harmath, A., and Kaizer, M. J., 1982, Analysis of water from Balaton and its tributaries in 1976-1981 for pesticide residues from Veszprem County: Novenyvedelem (Budapest), v. 18, no. 2, p. $49-53$.

Hungarian.

Associations with Surfactants.

CA96(23):195103y.

Kemp, W. M., Boynton, W. R., Cunningham, J. J., Stevenson, J. C., Jones, T. W., and Means, J. C., 1985, Effects of atrazine and linuron on photosynthesis and growth of the macrophytes, Pctamogeton perfoliatus and Myriophyllum spicatum in an estuarine environment: Marine Environmental Research, v. 16, no. 4 , p. 255-280.

* English:

Toxicity,Associations with Surfactants. CA104(11):83390.

Kettle, W. D., DeNoyelles, F. J., Heacock, B. D., and Kadoum, A. M., 1987, Diet and reproductive success of bluegill recovered from experimental ponds treated with atrazine: Bulletin of Environmental Contamination and Toxicology, v. 38, no. 1, p. 47-52.

English.

Toxicity,Associations with Surfactants.

CA106(13):97704a.
McCall, P. J., Stafford, L. E., Zorner, P. S., and Gavit, P. D., 1986, Modeling the foliar behavior of atrazine with and without crop oil concentrate on giant foxtail and the effect of tridiphane on the model rate constants: Journal of Agriculture and Food Chemistry, v. 34, no. 2, p. 235-238. English.

Associations with Surfactants.

CA104(15):124874y.

Mente, D. C., 1987, Nonionic surfactants as associative thickeners in aqueous flowable pesticide formulations: American Society of Testing Materials, Special Technical Publication, v. 943, no. Pesticide Formulations and Application Systems: 6th Vol., p. 20-26. English.

Associations with Surfactants.

CA108(13):17754v.

Meyer, L. J., Murphy, L. S., and Russ, O. G., May 1973, Atrazine and suspension fertilizer compatibility. (Com): Weed Science, v. 21, no. 3, p. 217-220.

English.

Associations with Surfactants. CAIN 739181558.

Mitrea, N., Nica, C., Graiu, C., and Cociasu, C., 1981, 2-Chloro4-alkylamino-s-triazines: Appl. 88744, 16 Dec 1976.

Romanian.

Associations with Surfactants. CA98(1):4571h.

Modi, J. J., 1986, Evaluation of water soluble polymers as cosuspending agents for flowable pesticides: American Society of Testing Materials, Special Technical Publication, v. 915, no. Pesticide Formulations and Application Systems, p. 65-77. English.

Chemical/Physical Properties, Associations with surfactants. CA106(17):133777n.

Morgan, L. J., and Bell, M., 1987, Aqueous pendimethalin suspension concentrate: Appl. 87/107495, 22 May 1987; US Appl. 867107, 23 May 1986.

English.

Associations with Surfactants.

CA108(13):108176z.

Mosinski, S., and Ostrowski, J., 1986, Activity of concentrated suspensions of some herbicides. I. Atrazine: Zeszyty Problemowe Postepow Nauk Rolniczych, v. 319, p. 89-93. Polish.

Associations with Surfactants. CA106(23):191071p.

Moucharafieh, H. C., 1983, Thiolcarbamate-triazine liquid herbicide composition: Appi. 83/400451, 4 Mar 1983; US Appl. 354980, 5 Mar 1982; US Appl. 468671, 28 Feb 1983.

Engiish.

Associations with Surfactants.

CA100(7):47068b.

Murray, J. M., 1975, Flowable oil extendible herbicidal compositions including a petroleum distillate and a nononic emulsifier. US Appl. 149,053, 1 Jun 1971.

Associations with Surfactants. CA84(21):146155k. 
Musselman, J. M., and Schieman, R. D., 1969, Hydrocarbon oils for herbicide preparations: Fr. FR 1567522, 16 May 1969, 22 p. French.

Associations with Surfactants.

CA72(11):53980n.

Nalewaja, J. D., 1986, Seed oils with herbicides: Mededelingen van de Faculteit Landbouwwetenschappen, Rijksuniversiteit Gent, v. 51, no. 2A, p. 301-310.

English.

Associations with Surfactants.

CA106(9):62914s.

Nkedi-Kizza, P., Rao, P. S. C., and Hornsby, A. G., Oct 1985, Influence of organic cosolvents on sorption of hydrophobic organic chemicals by soils: Environmental Science and Technology, v. 19, no. 10, p. 975-979.

English.

Sorption to Soil,Associations with Surfactants. CA103(15):122253a.

Nkedi-Kizza, P., Rao, P. S. C., and Hornsby, A. G., Nov 1987, Influence of organic cosolvents on ieaching of hydrophobic organic chemicals through soils: Environmental Science and Technology, v. 21, no. 11, p. 1107-1111.

English.

Associations with Surfactants, Leaching

CA107(20):182796x.

Oehmichen, U., and Haberer, K, 1988, Long-term and peak load of pesticides in of the Rhine river. Vom Wasser, v. 70, p. 221-

232.

German.

Associations with Surfactants.

CA109(16): 134605 d.

Paris, D. F., Lewis, D. L., Barnett, J. T., Jr., and Baughman, G. L., 1975, Microbial degradation and accumulation of pesticides in aquatic systems: US NTIS, PB Rep., No. 241293 54 p. English.

Biodegradation/Biotransformation,Associations with Surfactants,Sorption to Sediments. CA83(17):142974h.

Parochetti, J. V., 1975, Field evaluation of surfactants with paraquat: Proceedings of the Northeastem Weed Science Society, v. 29 , p. $78-80$.

English.

Associations with Surfactants.

CA83(7):54211b.

Peacock, J. F., 1970, Enhancement of foliar penetration and herbicide activity by oils, Dissertation submitted in partial fulfillment of Ph.D. requirements, South Dakota State University, Brookings, S. Dak., USA.

English.

Associations with Surfactants. CA75(11):75185\%.

Pettis, R. W., and Wake, L. V., 1976, Proceedings - Inter-Naval Corrosion Conference, 5 th.

English.

Associations with Surfactants.

CA90(4):24838p.
Ploss, H., and Ingwersen, W., 1985, Granulated composition of difficultly water-soluble or insoluble active ingredient dispersible in aqueous media: Appl. 3333872, 20 Spe 1983.

German.

Associations with Surfactants.

CA103(9):66790j.

Pudelko, J., 1976, Effect of additions of oil on the performance of some herbicides in relation to air termperature and humidity: Roczniki Akademii Rolniczej w Poznaniu, Prace Habilitacyjne, v. 63, p. 39 pp..

Polish.

Associations with Surfactants. CA85(13):88417e.

Pudelko, J., Dubas, A., and Duhr, E., 1981, Effect of oil additives on weed control efficacy of Gesaprim and bladex on maize. Part II. Evaluation of the effect of different oils and emulsifiers on the weed control efficacy of Gesaprim: Roczniki Akademii Rolniczej w Poznaniu, v. 128, p. 127-136. Polish.

Associations with Surfactants.

CA96(1):2002h.

Raheel, M., 1987, Laundering variables in removing carbaryl and atrazine residues from contaminated fabrics: Bulletin of Environmental Contamination and Toxicology, v. 39, no. 4, p. 671-679.

English.

Associations with Surfactants.

CA107(22):200981k.

Rahman, A., 1984, Influence of particle size and type of formulation on phytotoxicity and persistence of atrazine: Weed Research, v. 24 , no. 4 , p. $255-260$.

English.

Sorpticn to Soil,Associations with Surfactants.

CA101(15):124800j.

Ratledge, E. L., 1975, Herbicide carrier oil composition: US Appl. 70,876, 9 Sep 1970.

Unavailable.

Associations with Surfactants.

CA83(5):38807v.

Reinhardt, P., Wildgrube, W., Gruen, H. J., Pfuetzner, P., Schossig, R, Hunger, H., Schnelle, W., Lober, M., Barth, P., and et al., 1984, Stable suspension concentrations of growth regulating agents: Appl. 249782, 13 Apr 1983.

German.

Associations with Surfactants.

CA103(5):33505s.

Ronning, P. M., and Vandesteeg, G. A., 1985, Compositions containing surfactant and broadleaf foliar herbicide: Appl. 242174, 10 Mar 1981.

English.

Associations with Surfactants.

CA104(13):104435c. 


\section{ENVIRONMENTAL PROCESSES TRANSFER PROCESSES \\ Sorption/Partitioning}

Scheunert, I., Vockel, D., Bahig, M. E., and Korte, F., 1987, Influence of atrazine on the mineralization of $14 \mathrm{C}-\mathrm{n}$ dodecylbenzenesulfonate in soil: Chemosphere, v. 16, no. 7, p. 1521-1526.

English.

Associations with Surfactants. CA107(13):111101f.

Schrader, J. W., 1970, Influence of oil and environmental factors on phytotoxicity and foliar penetration of 2-chloro-4ethylamino-6-isopropylamino-s-triazine, Dissertation submitted in partial fulfilment of $\mathrm{Ph} . \mathrm{D}$. requirements, Michigan State University, East Lansing, Michigan, USA. English. Associations with Surfactants. CA75(9):62418z.

Schuppiser, J. L., 1987, Aqueous xanthan gum compositions as thickeners for pesticides containing quaternary ammonium compounds: Appl. 87/400478, 4 Mar 1987; FR Appl. 86/3337, 10 Mar 1986.

French.

Associations with Surfactants.

CA108(6):39994a.

Schuppiser, J. L., and Knipper, M., 1988, Xanthan gums as thickeners for cationic pesticides: Appl. 88/400353, 17 Feb 1988; FR Appl. 87/2294, 23 Feb 1987.

French.

Associations with Surfactants.

CA10\%(20):172469v.

Silowiecki, A., Adamczewski, K, and Bojarski, S., 1986, New preparation increasing adherence of plant protection chemicals: Zeszyty Problemowe Postepow Nauk Rolniczych, v. 319, p. 229-234.

Polish.

Associations with Surfactants.

CA106(23):191074s.

Singh, M., Orsenigo, J. R, and Shah, D. O., 1984, Surface tension and contact angle of herbicide solutions affected by surfactants: Journal of the American Oil Chemists Society, v. 61 , no. 3 , p. 596-600.

English.

Associations with Surfactants.

CA100(21):169856c.

Sosnovaya, O. N., and Merezhinskii, Y. G., 1980, Effect of atrazine on corn in the presence of surfactants: Fiziologiya i Biokhimiya.Kul'turnykh Rastenii, v. 12, no. 6, p. 615-619. Russian.

Associations with Surfactants.

CA94(11):78306q.

Sosnovaya, O. N., and Merezhinstii, Y. G., 1980, Use of fertilizer nutrients by plants in relation to the use of herbicides and the presence of surfactants: Doklady Vsesoyuznoi Akademii Sel'skokhozyaistvennykh Nauk, no. 11, p. 18-20.

Russian.

Associations with Surfactants.

CA94(9):59659r.
Stanova, A., and Gaher, S., 1974, Herbicidal activity of atrazine oil dispersions under laboratory conditions: Agrochemia (Bratislava), v. 14, no. 10, p. 308-310.

Slovak.

Associations with Surfactants. CAIN 749107783.

Steinke, W., Grosshoff, W., and Hacker, R, 1973, Highly concentrated, spray-dried herbicides: Appl. or Pr. 154,666, 26 Apr 1971.

German.

Associations with Surfactants. CA80(3):11229j.

Steinke, W., and Hacker, R., 1973, Herbicidal suspensions: Appl. or Pr. 162,738, 4 May 1972.

German.

Associations with Surfactants. CA80(17):92008m.

Stevens, P. J. G., and Bukovac, M. J., 1985, Properties of octylphenoxy surfactants and their effects on foliar uptake: Proceedings, British Crop Protection Conference on Weeds, no. 1, p. 309-316. English.

Uptake by Biota,Associations with Surfactants. CA104(17):143839g.

Stevens, P. J. G., and Bukovac, M. J., 1987, Studies of octylphenoxy surfactants. Part 1: Effects of oxyethylene content on properties of potential relevance to foliar absorption: Pesticide Science, v. 20, no. 1, p. 19-35. English.

Associations with Surfactants. CA107(17):149164s.

Stevens, P. J. G., and Bukovac, M. J., 1987, Studies on octylphenoxy surfactants. Part 2: Effects on foliar uptake and translocation: Pesticide Science, v. 20, no. 1, p. 37-52. English.

Associations with Surfactants.

CA107(19):170508s.

Stonov, L. D., Zhirmunskaya, N. M., Tropin, V. P., Golyadkina, A. G., and Borovikova, L. N., 1970, Relation of the herbicidal activity of atrazine and simazine to the physicochemical properties of the preparations: Khimicheskie Sredstva Zashchita Rastenii, v. 1, p. 201-209.

Russian.

Associations with Surfactants. CA78(9):53904q.

Stull, E. B., 1983, Chemical compounds and compositions for controlling agricultural pests: Appl. 82/1122, 3 Mar 1982; US Appl. 251369, 6 Apr 1981. Portuguese.

Associations with Surfactants. CA98(23):193397q.

Takematsu, T., Konnai, M., and Takeuchi, Y., 1978, Research on efficient use of Simazine (CAT) by adding resin emulsion in turfgrass: Shibakusa Kenkyu, v. 7, no. 2, p. 129-132. Japanese. Associations with Surfactants. CA90(25):198759d. 
Takematsu, T., Masuda, F., Tanaka, K, Nishida, K, and Nakamura, A., 1978, Agricultural chemical compositions: Appl. or Pr. 2632735, 21 Jul 1976.

German.

Associations with Surfactants.

CA88(25):184668v.

Takematsu, T., Masuda, F., Tanaka, K., Nishida, K, and Nakamura, A., 1977, Agrochemical compositions: Appl. or Pr. 76/29373, 14 Jul 1976.

English.

Associations with Surfactants.

CA88(21):147499v.

Takematsu, T., Masuda, F., Tanaka, K, Nishida, K, and Nakamura, A., 1978, Enhancement of herbicidal effect by polyurethane resins: Appl. or Pr. 76/89995, 27 Jul 1976.

Japanese.

Associations with Surfactants.

CA89(9):72078s.

Tanaka, F. S., Wien, R. G., and Mansager, E. R., 1981, Survey for surfactant effects on the photodegradation of herbicides in aqueous media: Journal of Agriculture and Food Chemistry, v. 29 , no. 2, p. 227-230.

English.

Associations with Surfactants, Photolysis.

CA94(17):133968j.

Violova, A., Hauskrecht, P., and Cesnek, J., 1987, Mixed defoamer: Appl، 82/9127, 14 Dec 1982.

Slovenian.

Associations with Surfactants.

CA107(18):157026p.

Visan, D., Paloiu, G., and Dragusin, E., 1980, 2-Chloro-4,6bis(alkylamino)-s-triazine: Appl. 90038, 16 Apr 1977.

Romanian.

Associations with Surfactants.

CA98(15):126162w.

Wicks, G. A., 1977, What surfactants or additives to use with paraquat and atrazine in winter wheat stubble: Proceedings of the Annual Meeting of the North Central Weed Control Conference, v. 32, p. 67-69.

English.

Associations with Surfactants.

CAIN 789083126.

Wicks, G. A., Burnside, O. C., and Fenster, C. R, 1968, Effect of atrazine and oil on weed control in sorghum across. Nebraska: Proceedings of the North Central Weed Control Conference, v. 23, p. 14.

English.

Associations with Surfactants.

CA71(13):599262.

Wiese, A. F., 1967, Oiling Herbicides, National Petroleum Refiners Association, (Technical Publication).

English.

Associations with Surfactants.

CA71(17):80040s.
Wildgrube, W., Barth, P., Kochmann, W., Kramer, W., Mueller, L., Steinke, W., Wolter, G., Taeuber, M., and Schoeppe, G., 1984, Stabilization of herbicide tank mixtures containing mineral oil: Appl. 243057, 7 Sep 1982.

German.

Associations with Surfactants.

CA101(15):124943h.

Wilson, H. P., and IInicki, R. D., 1968, Effects of phytobland oils and spray volume on postemergence activity of atrazine and combinations of atrazine with linuron in corn:

Proceedings of the Northeastern Weed Control Conierence, $v$. 22, no. Jan., p. 272-278.

English.

Associations with Surfactants.

CA68(19):86347g.

Wilson, H. P., and Innicki, R. D., 1968, Effects of surfactants and spray volume on postemergence activity of atrazine and combinations of atrazine and linuron in corn: Proceedings of the Northeastern Weed Control Conference, v. 22, no. Jan., p. 119-126.

English.

Associations with Surfactants.

CA68(19):86343c.

Witter, R, 1988, Aqueous dispersions comprising two pesticides: Appl. 3702604, 29 Jan 1987.

German.

Associations with Surfactants.

CA109(15):124429k.

Zhang, Q., and Scheunert, I., 1987, The fate and interaction of 14C-atrazine, sodium dodecylbenzol-14C-sulfonate and urea in soil-maize system: Yuanzineng Nongye Yingyong, no. 1, p. 54 59.

Chinese.

Associations with Surfactants.

CA107(11):91795e. 
ENVIRONMENTAL PROCESSES

TRANSFER PROCESSES

Sorption/Partitioning

\section{Sorption to Resins}

Bagnati, R., Benfenati, E., Davoli, e., and Fanelli, R., 1988, Screening of 21 pesticides in water by single extraction with C18 silica bonded phase columns: Chemosphere, v. 17, no. 1 , p. 59-65.

English.

Sorption to Resins.

CA108(17):145284d.

Le Cloirec, C., Le Cloirec, P., Elmghari, M., Morvan, J., and Martin, G., 1983, Concentration and analysis of numerous nitrogenous organic substances in natural waters: International Journal of Environmental Analytical Chemistry, v. 14, no. 2, p. 127-145.

English.

Sorption to Resins.

CA98(14):113396a.

Coyle, G. T., Maloney, S. W., Gibs, J., and Suffet, I. H., 1983, Broad-spectrum analysis of the removal of trace organics in an ozone-granular activated carbon potable-water pilot plant study: Water Chlorination: Environmental Impact and Health Effects, v. 4, no. Book 1, p. 421-423.

English.

Sorption to Resins.

CA99(4):27717.

Cserhati, T., Bordas, B., Fenyvesi, E., and Szejtli, J., 1983, Chromatographic properties of s-triazine in the presence of soluble B-cyclodextrin polymer: Journal of Inclusion Phenomena, v. 1, no. 1, p. 53-59.

English.

Sorption to Resins,Analytical Techniques/Quantification. CA100(7):46853s.

Cserhati, T., Darwish, Y. M., and Matolesy, G., 1983, Effect of support characteristics on the determination of the lipophilicity of some neutral acidic and alkaline compounds by reversed-phase thin-layer chromatography. Journal of Chromatography, v. 270, p. 97-104.

English.

Analytical Techniques/Quantification,Sorption to Resins. CA100(22):180581e.

DeFilippi, R. P., Kyukonis, V. J., Robey, R. J., and Modell, M., 1980, Supercritical fluid regeneration of activated carbon adsorption of pesticides: EPA-600/2-80-054.

English.

Sorption to Resins.

CA93(23):220629x.

Di Corcia, A, Marchetti, M., and Samperi, R, 1987, Rapid determination of simazine and atrazine in water at the parts jer trillion level. Extraction by a miniaturized Carbopack B. trap followed by high-performance liquid chromatography: Journal of Chromatography, v. 405, p. 357-363.

English.

Analytical Techniques/Quantification,Sorption to Resins. CA107(17):149101u.
Dore, M., Simon, P., Deguin, A., and Victot, J., 1986, Removal of nitrate from drinking water by ion exchange - impact on the chemical quality of treated water. Water Research, v. 20, no. 2, p. 221-232.

English.

Sorption to Resins.

CA104(12):95169q.

Erb, F., Dequidt, J., Dourlens, A., Pommery, J., Colein, P., and Gontier-Renard, C., 1978, Behavior of several herbicides in contact with ion exchange resins: Journal Francais d'Hydrologie, v. 9, no. 1, p. 9-18.

French.

Analytical Techniques/Quantification,Sorption to Resins. CA90(1):1513q.

Frima, H. A. Jean, and Marcais, J. L. Marie Andre, 1984, Granules of solid substances with phytopharmaceutical activity. Appl. 83/7572, 6 May 1983.

French.

Sorption to Resins.

CA103(1):2169f.

Frimmel, F. H., Millington, D. S., and Chrisman, R. F., 1987, Quantitative determination of organic compounds in extracts of activated carbon by means of GC/MS: Fresenius' Zeitung fuer Analytical Chemistry, v. 327, no. 2, p. 149-153.

German.

Sorption to Resins.

CA107(14):126283r.

Fusi, P., Franci, M., and Bosetto Fusi, M., 1978, Adsorption and desorption of prometryn and prometone by an activated charcoal: Agricultura Italiana (Pisa), v. 78, no. 1-2, p. 93 109.

English.

Sorption to Resins.

CASO(5):34856g.

Fusi, P., Franci, M., and Malquori, A., 1977, Adsorption and desorption of atrazine by an activated charcoal: Annali di Chimica (Rome), v. 67, no. 3-4, p. 241-253.

English.

Sorption to Resins.

CA88(18):126806c.

Gilmour, J. T., 1970, Adsorption of weak organic bases by weak acid adsorbents, Dissertation submitted in partial fulfillment of $\mathrm{Ph}$.D. requirements, University of California, Riverside, California USA.

English.

Sorption to Resins.

CA75(23):139850u.

Gyapai, J., Szanto, A., Szudy, G., Besan, J. M., Kollath, F., Nagy, B., Hevesik, J., Olah, S. M., and Takacs, K., 1986, Pesticidal suspension concentrates containing fertilizers: Appl. 83/3575, 14 Oct 1983.

Hungarian.

Sorption to Resins

CA105(21): 1858962. 


\section{ENVIRONMENTAL PROCESSES \\ TRANSFER PROCESSES \\ Sorption/Partitioning}

Harvey, R. G., 1973, Influence of cropping and activated carbon on persistance of atrazine in sand: Weed Science, v. 21, no.

3, p. 204-206.

English.

Biodegradation/Biotransformation,Sorption to Resins.

CA79(3):14357q.

Holiday, A. D., and Hardin, D. P., 1981, Activated carbon removes pesticides from wastewater. Chemical Engineering (N.Y.), v. 88 , no. 6 , p. $88-89$.

English.

Sorption to Resins.

CA94(22):180162b.

Jordan, P. D., and Smith, L. W., 1971, Adsorption and deactivation of atrazine and diuron by charcoals: Weed Science, v. 19 , no. 5 , p. 541-544.

English.

Sorption to Resins.

CA76(9):42679c.

Junk, G. A., and Richard, J. J., 1988, Organics in water: solid phase extraction on a small scale: Analytical Chemistry, v. 60 , no. 5, p. 451-454.

English.

Sorption to Resins.

CA108(10:81648r.

Junk, G. A., Richard, J. J., Svec, H. J., and Fritz, J. S., 1976, Simplified resin sorption for measuring selected contaminants: Journal - American Water Works Association, $\mathbf{v}$ 68 , no. 4 , p. 218-222.

English,W.

Sorption to Resins.

CA85(18):130275j.

Junk, G. A., Richard, J. J., Grieser, M. D., Witiak, D., Witiak, J. L., Arguello, M. D., Vick, R, Svec, H. J., Fritz, J. S., and Calder, G. V., 1974, Use of macroreticular resins in the analysis of water for trace organic contaminants: Joumal of Chromatography, v. 99, p. 745-762.

English.

Analytical Techniques/Quantification,Sorption to Resins. CA82(4):21599k.

Junk, G. A., and Richard, J. J., 1988, Solid phase extraction on a small scale: Journal of Research of the National Bureau of Standards (U.S.), v. 93, no. 3, p. 274-276.

English.

Analytical Techniques/Quantification, Sorption to Resins. CA109(24):215647w.

Kabakchieva, E., 1981, Adsorption characteristics of Bulgarian activated carbon in relation to wastewater pollution from triazine herbicde synthesis: Khimiya i Industria (Sofia), no. 3, p. 129-131.

Bulgarian.

Wastewater Observations,Sorption to Resins.

CA95(20):174918g.
Kaczvinsky, J. R, Jr., Saito, K, and Fritz, J. S., 1983,

Cation-exchange concentration of basic organic compounds from aqueous solution: Analytical Chemistry, v. 55, no. 8, p.

1210-1215.

English.

Sorption to Resins.

CA99(2):10507d.

Kemp, M. V., and Wightman, J. P., 1981, Interaction of 2,4-D and Dicamba with chitin and chitosan: Virginia Journal of Science, v. 32, no. 2, p. 34-37.

English.

Sorption to Resins.

CA95(13):109802a.

Kobel, W., Sumner, D. D., Campbell, J. B., Hudson, D. B., and Johnson, J. L., 1985, Protective effect of activated charcoal in cattle poisoned with atrazine: Veterinary and Human Toxicology, v. 27, no. 3, p. 185-188.

English.

Sorption to Resins, Toxicity,Uptake by Biota.

CA103(15):117775t.

Kratky, B. A., and Warren, G. F., June 1970, Tomato protection from atrazine residue by activated carbon root dips:

Hortscience, v. 5, no. 3, p. 179.

English.

Sorption to Resins.

CAIN 709063323.

Kring, J. B., and Ahrens, J. F., 1968, Activated carbon, pesticide residues, and potatoes: American Potato Joumal, v. 45, no. 11, p. $405-408$.

English.

Sorption to Resins.

CA70(13):56617u.

Lawrence, J. F., and Leduc, R, 1978, High performance liquid chromatography of acidic and basic organic compounds on silica gel with mobile phases containing organic acids: Analytical Chemistry, v. 50, no. 8, p. 1161-1164.

English.

Degradation Products,Analytical Techniques/Quantification, Sorption to Resins.

CA89(5):37888j.

Lee, W. O., 1978, Carbon protectants: Proceedings of the Western Society of Weed Science, v. 31, p. 63-64.

English.

Sorption to Resins.

CA89(17):141757b.

Lorincz, S., and Lorincz, M. C., 1982, Separation of nitrogencontaining organic bases: Appl. 71/RI456, 24 Nov 1971.

Hungarian.

Analytical Techniques/Quantification,Sorption to Resins. CA99(2):10854q.

Mangani, F., and Bruner, F., 1983, Sample enrichment and GC-MS determination of herbicides in water. Chromatographia, v. 17, no. 7, p. $377-380$.

English.

Analytical Techniques/Quantification, Sorption to Resins. CA99(17):135385u. 
Mangani; F., Crescentini, G., Palma, P., and Bruner, F., 1988, Performance of graphitized carbon black cartridges in the extraction of some organic priority: Jcurnal of

Chromatography, v. 452, p. 527-534.

English.

Sorption to Resins.

CA109(24):215680b.

Mangani, F., and Bruner, F., 1984, Chromatographic properties and analytical applications of a low-surface-area graphitized carbon black: Journal of Chromatography, v. 289, p. 85-94. English.

Analytical Techniques/Quantification,Sorption to Resins. CA101(4):32603u.

Masala, F., Mitrea, D., Dragusin, E., Cernega, M., and Bader, B., 1983, Study on some s-triazine two-component systems using physical methods: Revista de Chemie (Bucharest), v. 34, no. 11, p. 981-986.

Romanian.

Sorption to Resins.

CA100(23):191269k

Millington, D. S., Bertino, D. J., Kamei, T., and Christman, R. F., 1983, Analysis of organic cumpounds adsorbed on granular activated carbon filters used in treatment plants: Water Chlorination: Environmental Impact and Health Effects, v. 4, no. Book 1, p. 445-454.

English.

Analytical Techniques/Quantification, Sorption to Resins. CA98(26):2215406.

Normann, S., Haberer, K, and Oehmichen, U., 1987, Behavior of nitrogen-containing herbicides in drinking water treatment: Vom Wasser, v. 69, p. 233-249.

German.

Sorption to Resins.

CA108(12):100989w.

Pestemer, W., and Nordmeyer, H., 1988, Adsorption of selected pesticides on different tubing materials: Zentralblatt fuer Bakteriologie, Mikrobiologie und Hygiene, Series B, v. 186, no. 4 , p. 375-379.

German.

Analytical Techniques/Quantification, Sorption to Resins. CA109(15):124297r.

Pettis, R W., Phillip, A. T., Smith, G. C., and Wake, L. V., 1977 , Antifouling activity of phytotoxic compounds and experimental polymeric algicides: Report - Material Research Laboratory, MRL-R-698, 25 p:

English.

Sorption to Resins.

CA88(26):192810a.

Pfister, G., Bahadir, M., and Korte, F., 1986, Release characteristics of herbicides from calcium alginate gel formulations: Journal of Controlled Release, v. 3, no. 4, p. 229-233.

English.

Sorption to Resins.

CA105:20414c.
Raheel, M., 1987, Resistance of selected textiles to pesticide penetration and degradation: Journal of Environmental Health, v. 49 , no. 4, p. $214-219$.

English.

Sorption to Resins.

CA106(16):121288r.

Raheel, M., and Gitz, E. C., 1985, Effect of fabric geometry on resistance to pesticide penetration and degradation: Archives of Environmental Contamination and Toxicology, v. 14, no. 3, p. 273-279.

English.

Sorption to Resins.

CA102(26):222045g.

Rees, G. A. V., and Au, L., 1979, Use of XAD-2 macroreticular resin for the recovery of ambient trace levels of pesticides and industrial organic pollutants from water: Bulletin of Environmental Contamination and Toxicology, v. 22, no. 4-5, p. $561-566$

English.

Analytical Techniques/Quantification, Sorption to Resins. CA91(24):1985432.

Richard, J. J., and Junk, G. A., 1986, Solid phase versus solvent extraction of pesticides from water. Mikrochimica Acta, v. 1, no. 5-6, p. 387-394.

English.

Sorption to Resins,Analytical Techniques/Quantification. CA107(1):2495s.

Sharom, M. S., and Solomon, K. R, 1981, Adsorption and desorption of permethrin and other pesticides on glass and plastic materials: Canadian Joumal of Fisheries and Aquatic Science, v. 38, no. 2, p. 199-204.

English.

Sorption to Resins.

CA94(19):151864b.

Sherma, J., 1986, Determination of triazine and chlorophenoxy acid herbicides in natural water samples by solid phase extraction and quantitative thin layer chromatography: Journal of Liquid Chromatography, v. 9, no. 16, p. 3433-3438. English.

Sorption to Resins,Analytical Techniques/Quantification. CA106(13):97891j.

Subra, P., Hennion, M. C., Rosset, R, and Frei, R. W., 1988, Recovery of organic compounds from large-volume aqueous samples using on-line liquid chromatographic preconcentration techniques: Journal of Chromatography, v. 456, no. 1, p. 121 141.

English.

Sorption to Resins,Analytical Techniques/Quantification. CA110(6):44622y.

Svec, H. J., 1977, Comparison of macroreticular resin and activated carbon as sorbents: Journal of the American Water Works Association, v. 69, no. 12, p. 669-674.

English.

Sorption to Resins.

CA88(16):110304b. 
Taran, P. N., Vakulenko, V. F., Grechko, A. V., Sheuchenko, M. A., and Goncharuk, V. V., 1988, Simplified technology for removal of pesticides from wastewaters: Khimiya $i$

Tekhnologiya Vody, v. 10, no. 6, p. 542-544.

Russian.

Sorption to Resins, Wastewater Observations,Photolysis. CA110(14):120579g.

Taylor, A. G., and Warholic, D. T., 1987, Protecting fluid drilled lettuce from herbicides by incorporating activated carbon into gels: Journal of Horticultural Science, v. 62, no. 1, p. 31-37.

English.

Sorption to Resins.

CA106(15):114912m.

Terce, M., and Calvet, R, 1975, Role of aluminum in the adsorption of atrazine: Special Publication, Agricultual Research Organic Volcani. Cent. Div. Sci. Publ., 48: 8-10. French.

Sorption to Resins. CAIN779095368.

Turner, M. A., and Adams, R. S., Jr., 1968, Adsorption of atrazine and atratone by anion- and cation-exchange resins: Soil Science Society of America Proceedings, v. 32, no. 1, p. 62-63.

English.

Sorption to Resins.

CA68(21):94820w.

Walther, H. J., 1985, On the elimination of organic microcontaminants by flocculation with lime hydrate: Acta Hydrochimica et Hydrobiologica, v. 13, no. 2, p. 223-228. English.

Wastewater Observations,Sorption to Resins.

CA103(2):11123p.

Wilson, H. P., Hines, T. E., and Belote, J. N., III, 1974, Relations between activated carbon and atrazine on cucumbers and snap beans: Proceedings of the Northeastern Weed Science Society, v. 28, p. 235-241.

English.

Sorption to Resins.

CA80(21):116890w.

Woodrow, J. E., Majewski, M. S., and Seiber, J. N., 1986, Accumulative sampling of trace pesticides and other organics in surface water using XAD-4 resin: Joumal of Environmental Science and Health, Part B, v. B21, no. 2, p. 143-164.

English.

Analytical Techniques/Quantification.

CA105(3):20342c.

Zurawski, H., and Gonetowa, I., 1973, Effect of silica addition and of crops on herbicide deactivation in light soil: Pamietnik Pulawski, v. 58, p. 221-231.

Polish.

Sorption to Resins.

CA82(7):39415g. 


\section{Sorption to Sediments}

Green, R. E., Goswami, K. P., Mukhtar, M., and Young, H. Y., 1977, Herbicides from cropped watersheds in stream and estuarine sediments in Hawaii: Journal of Environmental Quality, v. 6, no. 2, p. 145-154.

English.

Surfacewater Observations, Run-off,Sorption to Sediments. CA87(5):34335z.

Hance, R. J., and Chesters, G., 1969, Fate of hydroxyatrazine in a soil and a lake sediment: Soil Biology and Biochemistry, v. 1 , no. 4, p. 309-315.

English.

Degradation Products,Biodegradation/Biotransformation, Sorption to Sediments.

CA72(21):110138v.

Isensee, A. R., Sept 1987, Persistence and movement of atrazine in a sait marsh sediment microecosystem: Bulletin of Environmental Contamination and Toxicology, v. 39, no. 3, p. 516-523.

English.

Sorption to Sediments, Surfacewater Observations, Leaching. CA107(15):129055d.

Jones, T. W., Kemp, W. M., Stevenson, J. C., and Means, J. C., October-December, 1982, Degradation of atrazine in estuarine water/sediment systems and soils: Journal of Environmental Quality, v. 11, no. 4, p. 632-638.

English.

Biodegradation/Biotransformation,Associations with

Surfactants,Field Residuals,Sorption to Sediments,Sorption to Soil,Degradation Products.

CA97(25):210373c.

Klaassen, H. E., and Kadoum, A. M., 1979, Distribution and retention of atrazine and carbofuran in farm pond ecosystems: Archives of Environmental Contamination and Toxicology, v. 8, no. 3, p. 345-353.

English.

Surface Water Observations,Sorption to Sediments, Uptake by Biota. CA91(1):1346h.

Kornmayer, R, and Streit, B., 1978, Adsorption and accumulation of atrazine and its degradation products by stream sediment: Archives of Hydrobiology, Supplement, v. 55, no. 2, p. 186210.

German.

Sorption to Sediments. CA90(15):116411x.

Lopez-Avila, V., and Hites, R. A., 1980, Organic compounds in an industrial wastewater. Their transport into sediments: Environmental Science and Technology, v. 14, no. 11, p. 1382 1390.

English.

Wastewater Observations,Sorption to Sediments.

CA94(16):126959d.
Paris, D. F., Lewis, D. L., Barnett, J. T., Jr., and Baughman, G. I., 1975, Microbial degradation and accumulation of pesticides in aquatic systems: US NTIS, PB Rep., No. 241293, 54 p.

English.

Biodegradation/Biotransformation,Associations with Surfactants,Sorption to Sediments. CA83(17):142974h.

Richard, J. J., Junk, G. A., Avery, M. J., Nehring, N. L., Fritz, J. S., and Svec, H. J., 1975, Analysis of various Lowa waters for selected pesticides: atrazine. DDE, and dieldrin-1974: Pesticide Monitoring Journal, v. 9, no. 3, p. 117-123. English.

Analytical Techniques/Quantification,Surfacewater Observations,Sorption to Sediments. CA84(23):160585g.

Wauchope, R. D., and Myers, R. S., January/March 1985, Adsorption-desorption kinetics of atrazine and linuron in freshwater-sediment aqueous slurries: Journal of Environmental Quality, v. 14, no. 1, p. 132-136. English. Sorption to Sediments. 


\section{Sorption to Soil}

Agapov, V. I., and Tulupova, M. Y., 1980, Behavior of atrazine in the soil: Vestnik Moskouskogo Universiteta, Biologiya,

Pochvovedenie, Series 17, v. 35, no. 4, p. 55-58.

Russian.

Leaching,Biodegradation/Biotransformation, Analytical

Techniques/Quantification,Sorption to Soil.

CA94(1):998x.

Ammon, H. U., 1985, Parameters governing the leaching of chemicals in the soil: Colloque INRA, v. 31, no. Comportement Eff. Second. Pestic. Sol, p. 105-116.

English.

Sorption to Soil.

CA103(21):174011q.

Apostolides, Z, Vermeulen, N. M. J., Potgieter, D. J. J., Smit, N. S. H., and Nel, P. C., 1981, Determination of atrazine in soils: Proceedings of the National Weeds Conference of South Africa, v. 4, p. $175-180$.

English.

Analytical Techniques/Quantification,Sorption to Soil.

CA97(17):140117w.

Armstrong, D. E., and Chesters, G., Sept 1968, Adsorption catalyzed chemical hydrolysis of atrazine: Emvironmental Science and Technology, v. 2, no. 9, p. 683-689.

English.

Hydrolysis/Chemical Reactions,Sorption to Soil.

CA.69(17):66344w.

Armstrong, D. E., Chesters, G., and Harris, R. F., 1967, Atrazine hydrolysis in soil: Soil Science Society of America,

Proceedings, v. 31, no. 1, p. 61-66.

English.

Sorption to Soil.

CA67(5):20917r.

Ashley, R A., 1968, Factors affecting adsorption of atrazine and diphenamid by soils, Dissertation submitted in partial fulfillment of Ph.D. requirements, University of Delaware, Newark, Delaware, USA.

English.

Sorption to Soil.

CA70(21):95689p.

Bahnick, D. A., and Doucette, W. J., 1988, Use of molecular connectivity indexes to estimate soil sorption coefficients for organic chemicals: Chemosphere, v. 17, no. 9, p. 17031715.

English.

Sorption to Soil.

CA110(4):28786z.

Bailey, G. W., Barnett, A. P., Payne, W. R., Jr., and Smith, C. N., 1974, Herbicide runoff from four coastal plain soil types: EPA-660/2-74-017, 98 p, U.S. Environmental Protection Agency, Research and Development.

English.

Sorption to Soil,Run-off.

CA84(19):131473p.
Bakalivanov, D., and Chuldzhiyan, K, 1983, Organic matter in soil and the environment: Pochvoznanie i Agrokhimiya, v. 18, no. 3, p. 115-122.

Bulgarian.

Sorption to Soil.

CA99(25):208036t.

Baker, J. H., and Young Shin, O., June 2, 1967, Massachusetts University, Water Resources Research Center, Symposium Proceedings, p. 75-88.

English.

Sorption to Soil.

Bellinck, C., 1983, Effect of a few amendments on the mineralization of atrazine-14C in a fresh meadow soil and the immobilization of carbon-14 residues: Revue d'Ecologie et de Biologie du Sol, v. 20, no. 4, p. 435-444.

French.

Biodegradation/Biotransformation,Sorption to Soil. CA100(25):204977s.

Bellinck, C, and Mayaudon, J., 1979, Degradation of (14C)phenmedipham and (14C)-atrazine in soil; immobilization in soil and absorption by plants of the carbon-14-labeled herbicides and their carbon-14-labeled residues: Revue d'Ecologie et de Biologie du Sol, v. 16, no. 4, p. 465-476. French.

Sorption to Soil,Biodegradation/Biotransformation. CA93(1):2229a.

Berezovskii, M. Y., and Nemova, G. N., 1971, Sorption of labeled atrazine by sod-podzolic and peat soils: Doklady TSKHA (Timiryazev Sel'skogo Khozyaistua Akad), v. 162, p. 105-110. Russian.

Sorption to Soil. CA75(15):97458q.

Berezovskii, M. Y., and Nemova, G. N., 1973, Use of s-triazine derivatives as herbicides on peat soils: Agrokhimiya, no. 12, p. $102-110$.

Russian.

Sorption to Soil.

CA80(17):91921s.

Best, J. A., Weber, J. B., and Monaco, T. J., 1975, Influence of soil pH on s-triazine availability to plants: Weed Science, v. 23, no. 5, p. 378-382.

English.

Uptake by Biota,Sorption to Soil.

CA83(21):173782y.

Blume, H. P., and Bruemmer, G., 1987, Prediction of the benavior of pesticides in soils by using simple field methods: Landwirtschaftliche Forschung, v. 40, no. 1, p. 41-50.

German.

Sorption to Soil,Volatilization,Leaching. CA108(5):33490m. 


\section{ENVIRONMENTAL PROCESSES \\ TRANSFER PROCESSES \\ Sorption/Partitioning}

Borggaard, O. K, and Streibig, J. C., 1988, Atrazine adsorption by some soil samples in relation to their constituents: Acta Agriculturae Scandinavica, v. 38, no. 3, p. 293-301.

English

Sorption to Soil.

CA110(9):71035r.

Bomemisza, E., Chavarria, P. L., Rangel, J. L., and Castrillo, A. L., Sept 1979, Effect of calcium, magnesium, potassium and pH hydrogen ion concentration on the initial inactivation of atrazine and m...: Agronomia Costarricense, v. 3, no. 2, p. 175-180.

Spanish.

Sorption to Soil

IND 80132695.

Bouchand, D. C., Wood, A. L., Campbell, M. L., Nkedi-Kizza, P., and Rao, P. S. C., 1988, Sorption nonequilibrium during solute transport: Joumal of Contaminant Hydrology, v. 2, no. 3, p. 209-223.

English.

Sorption to Soil.

CA109(14):115711u.

Bouchard, D. C., and Wood, A. L., 1988, Pesticide sorption on geologic material of varying organic carbon content: Toxicological Industrial Health, v. 4, no. 3, p. 341-349. English.

Sorption to Soil.

CA109(15):124359n.

Brown, C. B., and White, J. L., 1969, Reactions of 12 s-triazines with soil clays: Soil Science Society of America,

Proceedings, v. 33, no. 6, p. 863-867.

English.

Degradation Products, Chemical/Physical Properties,Sorption to Soil,Hydrolysis/Chemical Reactions.

CA72(9):42089c.

Browne, J. E., Fledkamp, J. R, White, J. L., and Hem, S. L., 1980, Potential of organic cation-saturated montmorillonite as treatment for poisoning by weak bases: Journal of Pharmaceutical Sciences, v. 69, no. 12, p. 1393-1395. English.

Sorption to Soil.

CA94(15):115343x:

Burkhard, N., and Guth, J. A., 1981, Chemical hydrolysis of 2chloro-4,6-bis(alkylamino)-1,3,5-triazine herbicides and their breakdown in soil under the influence of adsorption: Pesticide Science, v. 12, no. 1, p. 45-52.

English.

Hydrolysis/Chemical Reactions,Sorption to Soil, Biodegradation/Biotransformation: CA95(5): $1778 q$.

Burnside, O. C., Fenster, C. R., Wicks, G. A., and Drew, J. V., 1969, Effect of soil and climate on herbicide dissipation: Weed Science, v. 17, no. 2, p. 241-245.

English.

Biodegradation/Biotransformation,Sorption to Soil. CA71(1):2419h.
Calvet, R, and Tabareau, A. M., 1977, Kinetic study of dissolution phenomena in aqueous phases. Application to the dissolution of atrazine: Annales Agronomiques, v. 28, no. 2, p. 117-136.

French.

Chemical/Physical Properties,Sorption to Soil. CA87(17):128876d.

Calvet, R, and Teree, M., 1975, Adsorption of atrazine by aluminum montmorillonites: Arnales Agronomiques, v. 26, no. 6, p. 693-707.

French.

Sorption to Soil.

CA85(19):138505e.

Catvet, R, 1976, Rapid measurement of the diffusion coefficient of atrazine in aqueous solution: Weed Research, v. 16, no. 1, p. 53-55.

French.

Chemical/Physical Properties,Sorption to Soil. CA84(17):116749q.

Calvet, R, and Teree, M., 1975, Solubility of atrazine in calcium montmorillonite gels: C.R. Hebd. Seances Acad. Sci. Ser. D, v. 281, no. 4, p. 247-250.

French.

Chemical/Physical Properties,Sorption to Soil.

CA84(1):1213t.

Capriel, P., Haisch, A., and Khan, S. U., 1985, Distribution and nature of bound (nonextractable) residues of atrazine in a mineral soil nine years after the herbicide application: Joumal of Agriculture and Food Chemistry, v. 33, no. 4, p. 567-569.

English.

Sorption to Soil,Degradation Products,Analytical Techniques/ Quantification,Wadj.

CA103(5):33437w.

Chang, S.-S., 1980, Effect of soil pH on adsorption and phytotoxicity of triazine herbicides: Chung-hua Hung Hsueh Hui Pao, v. 109, p. 17-29.

Chinese.

Sorption to Soil.

CA93(21): $199208 x$.

Chantladze, Z. I., and Shavliashvili, L. U., 1980, Evaluation of the effect of fertilizers and toxic chemicals applied to agricultural fields on the chemical composition of soil and natural waters in various climatic and soil regions of Georgia, USSR: Trudy, Zakavkazayzikogo Nauchno Issledovatel'skogo Gidrometeologicheskogo Instituta, v. 66, p. $60-70$.

Russian.

Surfacewater Observations, Sorption to Soil. CA97(3):22682d.

Chapman, L. J., 1967, Influence of an organic soil in mixtures with sand on the phytotoxicity of atrazine, Dissertation submitted in partial fulfillment of Ph.D. requirements, Univ. of Florida, Gainesville, Fla., USA.

English.

Sorption to Soil.

CA68(11):48522c. 
Chassin, P., Calvet, R, and Terce, M., 1981, Symposium on the Theory and Practice of the Use of Soil Applied Herbicides: Proceedings, p. 10-17.

French.

Sorption to Soil,Associations with Humic Material. CA97(21):176914t.

Clay, S. A., Allmaras, R. R., Koskinen, W. C., and Wyse, D. L., 1988, Desorption of atrazine and cyanazine from soil: Journal of Environmental Quality, v. 17, no. 4, p. 719-723.

English.

Sorption to Soil.

CA110(1):2789c.

Clay, S. A., Koskinen, W. C., Allmaras, R. R, and Dowdy, R. H., 1988, Differences in herbicide adsorption on soil using several soil $\mathrm{pH}$ modification techniques: Joumal of Environmental Science and Health, Part B, v. B23, no. 6, p. 559-573.

English.

Sorption to Soil.

CA110(9):71059b.

Colbert, F. O., Volk, V. V., and Appleby, A. P., Sept 1975, Sorption of atrazine, terbutryn, and GS-14254 on natural and lime-amended soils: Weed Science, v. 23, no. 5, p. 390-394. English.

Sorption to Soil.

CA83(19):159131d.

Dao, T. H., and Lavy, T. L., May 1978, Atrazine adsorption on soil as influenced by temperature, moisture content and electrolyte concentration: Weed Science, v. 26, no. 3, p. 303-308.

English.

Sorption to Soil.

CA90(11):82024f.

Dao, T. H., and Lavy, T. L., 1978, Extraction of soil solution using a simple centrifugation method for pesticide adsorption-desorption studies: Journal of the Soil Science Society of America, v. 42, no. 2, p. 375-377.

English.

Sorption to Soil,Analytical Techniques/Quantification. CA89(7):54539p.

Dao, T. H., 1977, Factors affecting atrazine adsorption, degradation and mobility in soil: Report, W79-03670, OWRT-B030-NEB(5).

English.

Sorption to Soil.

CA91(9):69860b.

Dao, T. H., 1977, Factors affecting atrazine adsorption, degradation and mobility in soil, Dissertation submitted in partial fulfiliment of $\mathrm{Ph} . \mathrm{D}$. requirements, Nebraska.

Biodegradation/Biotransformation,Leaching,Sorption to Soil. CA88(7):46255g.
Davidson, J. M., Ou Li-Tse, and Rao, P. S. C., 1978, Adsorption, movement, and biological degradation of high concentrations of selected pesticides in soils: EPA-600/9-78-016, Environmental Protection Agency.

Engtish.

Sorption to Soil,Leaching,Biodegradation/Biotransformation. CA89(23):192489y.

Davidson, J. M., Rao, P. S., Ou, L. T., Wheeler, W. B., and Rothwell, D. F., August, 1980, Adsorption, movement, and biological degradation of large concentrations of selected pesticides in soils: EPA-600/2-80-124, Environmental Protection Agency.

English.

Biodegradation/Biotransformation,Sorption to Soil. CA94(11):78414y.

Davidson, J. M., Rao, P. S., and Ou., L. T., March, 1980, Disposal of Hazardous Wastes; Proceedings of the Sixth Annual Research Symposium, March 17-20, p. 93-107.

English.

Biodegradation/Biotransformation,Sorption to Soil,Leaching. CA94(1): $1054 y$.

DeBeer, D. J. G., DuToit, D., and Human, J. J., 1984, Atrazine in different types of soil: Gewasproduksie, v. 13, p. 34.

Airrikaans.

Sorption to Soil.

IND 85045617.

Dechkov, Z, 1984, Weed control in maize fields with differing mineral fertilizer application: Rastenievudni Nauki, v. 21, no. 1, p. 6-11.

Bulgarian.

Sorption to Soil.

CA101(11):89708m.

Dragun, J., and Helling, C. S., 1981, Evaluation of molecular modelling techniques to estimate the mobility of organic chemicals in soils: II. Water solubility and the molecular fragment mobility coefficient: U.S. EPA, Off. Res. Dev., (Rep.) EPA, EPA-600/9-81-0026, Land Disposal: Hazardous Waste, Proc. Annu. Res., 7th, PB81-173882, 58-70.

English.

Sorption to Soil.

CA96(14):109778t:

Dunigan, E. P., 1968, Atrazine-soil organic matter relationships and methodology for determination of atrazine residues, Dissertation submitted in partial fulfillment of $\mathrm{Ph} . \mathrm{D}$. requirements, University of Arizona, Tucson; Arizona, USA. English.

Analytical Techniques/Quantification,Sorption to Soil. CA69(7):26176m.

Effer, W. R, 1970, Proceedings of the Northeastem Weed Control Conference, p. 257-263.

English.

Sorption to Soil.

CA73(25):129990j. 


\section{ENVIRONMENTAL PROCESSES \\ TRANSFER PROCESSES \\ Sorption/Partitioning}

Ehlers, J. G., Reinhardt, C. F., and Nel, P. C., 1988, Effect of some soil factors on the activity of atrazine: South African Journal of Plant Soil, v. 5, no. 1, p. 32-36.

Afrikaans.

Sorption to Soil.

CA108(17):145372f.

Filep, G., Konya, J., and Kaposztassy, M. A., 1979, Evaluation of the adsorption of herbicides in the soil: Agrokemia es Talaitan, v. 28, no. 1-2, p. 181-194.

Hungarian.

Sorption to Soil.

CA92(7):53362a.

Filippova, N. V., Lavrova, E. K, and Antokhina, M. P., 1981, Features of the accumulation of sym-triazine herbicides in soils of apple tree orchards of the Moscow region: Toksikol. i Radiol. Kontrol Sostoyaniya Pochv i Rast. v Protsesse Khimiz. S. Kh., M., p. 32-40.

Russian.

Sorption to Soil.

CA97(15):121994p.

Franci, M., and Fusi, P., 1977, The heat-activated adsorption of s-triazines by some clay minerals: Agrochimica, v. 21, no. 34, p. 279-285.

Italian.

Sorption to Soil.

CA88(15):103816s.

Frank, R., Sirons, G. J., and Allderson, G. W., 1983, Atrazine: the impact of persistent residues in soil on susceptible crop species: Canadian Journal of Soil Science, v. 63, no. 2, p. 315-325.

English.

Sorption to Soil.

CA99(5):34463n.

Frank, R, and Sirons, G. J., Apr 1985, Dissipation of atrazine residues from soils: Bulletin of Environmental Contamination and Toxicology, v. 34, no. 4, p. 541-548.

English.

Sorption to Soil,Leaching,Field Residuals,Biodegradation/

Biotransformation.

CA102(23):199566s.

Gerber, H. R, 1977, Crop Protection Agents - Their Biological Evaluation, Proceedings of the International Conference, 1975, p. 307-321.

English.

Chemical/Physical Properties,Sorption to Soil,Analytical

Techniques/Quantification.

CA89(9):71961n.

Gerber, H. R, Ziegler, P., and Dubach, P., 1971, Proceedings of the British Weed Control Conference, 10th, 1970, p. 118-125. English.

Sorption to Soil.

CA75(15):97429f.
Gergaya, M. S., Mgeladze, E. M., and Dolidze, L. G., 1984, Behavior of 1,3,5-triazine herbicide residues in soils and crops of the Georgian SSR: Okhrana Pochv i Rast. v Usloviyakh Intensiv. Primeneniya Pestetsidov i Dr. Sredstv Khimiz. v S. kh., M., p. 51-61.

Russian.

Sorption to Soil.

CA104(13):104291.

Gerstl, Z, and Helling, C. S., 1987, Evaluation of molecular connectivity as a predictive method for the adsorption of pesticides by soils: Journal of Environmental Science and Health, Part B, v. B22, no. 1, p. 55-69.

English.

Sorption to Soil.

CA106(25):209329f.

Ghinea, L., Radulescu, V., Vladutu, I., Fritea, T., and Turcu, M., 1985, Some aspects of residual effects of atrazine: Analele Institutului de Cercetari Cereale si Plante Tehnice Fundulea, Academia de Stiinte Agricole si Silvice, Seria B, v. 53, p. 415-434.

Romanian.

Sorption to Soil,Leaching,Field Residuals. CA107(11):91798h.

Goetz, A. J., Wehtje, G., Walker, R. H., and Hajek, B., 1986, Soil solution and mobility characterization of imazaquin: Weed Science, v. 34, no. 5, p. 788-793.

English.

Degradation Products,Sorption to Soil,Leaching. CA105(19):166811b.

Gorder, G. W., and Dahm, P. A, 1981, Analysis of carbofuran and atrazine in soil samples: Journal of Agriculture and Food Chemistry, v. 29, no. 3, p. 629-634.

English.

Analytical Techniques/Quantification,Sorption to Soil. CA95(1):1696e.

Gorzelak, A., 1972, Bioindicator determination of the adsorption of herbicides by three types of soils: Prace Naukowe Instytutu Technologii Organiczneji Tworzyw Sztucznych Politechniki Wroclawskiej, v. 9, p. 85-87.

Polish.

Sorption to Soil.

CA77(15):97631g.

Goswami, K. P., and Green, R. E., 1971, Microbial degradation of the herbicide atrazine and its 2-hydroxy analog in submerged soils: Environmental Science and Technology, v. 5, no. 5, p. 426-429.

English.

Degradation Products, Biodegradation/Biotransformation, Sorption to Soil,Surfacewater Observations, Hydrolysis/ Chemical Reactions. CA74(25):139847c.

Goswami, K. P., and Green, R. E., 1973, Simultaneous extraction of hydroxyatrazine, atrazine, ametryne from some Hawaiian soils: Soil Science Society of America, Proceedings, v. 37, no. 5, p. 702-707.

English.

Analytical Techniques/Quantification,Degradation Products, Sorption to Soil.

CA80(1):663v. 
Green, R. E., and Corey, J. C., July/Aug 1971, Pesticide adsorption measurement by flow equilibration and subsequent displacement: Soil Science Society of America, Proceedings, v. 35 , no. 4 , p. 561-565.

English.

Leaching Sorption to Soil.

CAIN 729011080

Green, R. E., Yamane, V. K., and Obien, S. R., 1968, Transport of atrazine in a latosolic soil in relation to adsorption, degradation, and soil water variables: International Society of Soil Science, Transactions, 9th, v. 1, p. 195-204.

Engiish.

Sorption to Soil, Biodegradation/Biotransformation,Leaching. CA72(1):2409a.

Green, R. E., and Young, R. H. T., 1971, Herbicide and fertilizer movement in Hawaiian sugarcane soils in relation to subsurface water quality. Hawaii. Sugar Technol., Rep., p 88-96. English.

Sorption to Soil.

CA75(11):75400n.

Green, R. E., and Obien, S. R, 1969, Herbicide equilibrium in soils in relation to soil water content: Weed Science, v. 17, no. 4, p. 514-519.

English.

Sorption to Soil.

CA72(1):2434e.

Green, Richard Ervin, and Yamane, V. K., 1970, Precision in pesticide adsorption measurements: Soil Science Society of America, Proceedings, v. 34, no. 2, p. 353-355.

English.

Sorption to Soil.

CA73(1):2848p.

Grice, R. E., and Hayes, M. H. B., 1971, Proceedings of the British Weed Control Conference, 10th, 1970, p. 1089-1100. English.

Sorption to Soil.

CA75(7):47724c.

Grover, R, and Hance, R. J., Feb 1970, Effect of ratio of soil to water on adsorption of Linuron and atrazine: Soil Science, v. 109 , no. 2 , p. $136-138$.

English.

Sorption to Soil.

CAIN 709045207.

Grover, R., Morse, P. M., and Huang, P. M., Apr 1983, Bioactivity of atrazine in nine Saskatchewan soils: Canadian Plant

Science Review, v. 63, no. 2, p. 489-496.

English.

Sorption to Soil,Toxicity.

CA99(1):1764k.

Grover, R, and Hance, R. J., 1969, Adsorption of some herbicides by soil and roots: Canadian Journal of Plant Science, v. 49,

no. 3, p. 378-380.

English.

Sorption to Soil.

CA71(9):37666p.
Guth, J. A., 1972, Adsorption and elution behavior of plant protective agents in soils: Schriftenreihe des Vereins fuer Wasser, Boden und Lufthygiene, v. 37, p. 143-154.

German.

Sorption to Soil.

CA79(5):30833x

Hall, J. K., Pawlus, M., and Higgins, E. R., 1972, Losses of atrazine in runoff water and soil sediment: Joumal of Environmental Quality, v. 1, no. 2, p. 172-176.

English.

Field Residuals, Run-off,Sorption to Soil.

CA77(9):57533v.

Hall, J. K, and Pawlis, M., March-April 1973, Runoff and soil losses on Hagerstown silty clay loam: effect of herbicide treatment: Joumal of Soil and Water Conservation, v. 28, no. 2, p. 73-76.

Engtish.

Sorption to Soil,Run-off.

Hance, R. J., 1971, Complex formation as an adsorption mechanism for linuron and atrazine: Weed Research, v. 11, no. 2-3, p. 106-110.

English.

Sorption to Soil. CA76(1):793e.

Hance, R. J., 1986, Quantification of Natural Bioavailability Bound 14C-Pesticide Residues in Soil, Plants, and Food, Proceedings of Final Research Co-ordinatorsMeeting, 1985, p. 1-11.

English.

Field Residuals,Sorption to Soil,Analytical Techniques/

Quantification.

CA108(5):33523z.

Hance, R. J., 1969, Influence of $\mathrm{pH}$, exchangeable cation, and the presence of organic matter on the adsorption of some herbicides by montmorillonite: Canadian Journal of Soil Science, v. 49, no. 3, p. 357-364.

English.

Sorption to Soil.

CA72(1):2386r.

Hance, R. J., 1967, Speed of attainment of sorption equilibria in some systems involving herbicides: Weed Research, v. 7, no. 1, p. 29-36.

English.

Sorption to Soil.

CA66(23):104248r.

Hance, R. J., and Chesters, G., 1970, Extraction of hydroxyatrasine from soil: Analyst (London), v. 95, no. 1126, p. 106.

English.

Degradation Products,Analytical Techniques/Quantification, Sorption to Soil.

CA72(21):110029k

Handra, M., and Vladutiu, I., 1968, Atrazine adsorption depending on some soil characters: Bucarest Inst. Cent. Cercet. Agr.

Ser. B., v. 36, p. 47-56.

Romanian.

Sorption to Soil.

CAIN 719154129 
ENVIRONMENTAL PROCESSES

TRANSFER PROCESSES

Sorption/Partitioning

Helling, C. S., and Gish, T. J., 1986, Soil characteristics affecting pesticide movement into ground water. American Chemical Society Symposium Series, no. 315, p. 14-38. English.

Leaching,Sorption to Soil, Groundwater Observations. CA105(15):129452q.

Helling, C. S., 1971, Pesticide mobility in soils. I. Parameters of thin-layer chromatography: Soil Science Society of Amererica, Proceedings, v. 35, no. 5, p. 732-737. English.

Sorption to Soil.

CA76(13):69012s.

Helling, C. S., 1971, Pesticide mobility in soils. III. Influence of soil properties: Soil Science Society of America, Proceedings, v. 35, no. 5, p. 743-748.

English.

Sorption to Soil.

CA76(13):69014u.

Helling, C. S., 1971, Pesticide mobility in soils. II. Applications of soil thin-layer chromatography: Soil Science Society of America, Proceedings, v. 35, no. 5, p. 737-743. English.

Sorption to Soil.

CA76(13):69013t.

Higgins, E. R, 1970, Atrazine availability to plants in claywater systems, Dissertation submitted in partial fulfillment of Ph.D. requirements, Pennsytvania State University, Pennsylvania.

English.

Sorption to Soil.

CA75(25):150651a.

Hodson, J., and Williams, N. A., 1988, The estimation of the adsorption coefficient (Koc) for soils by high performace liquid chromatography: Chemosphere, v. 17, no. 1, p. 67-77. English.

Sorption to Soil.

CA108(13):108011s.

Huang, P. M., and McKercher, R. B., July 1984, Components and particle size fractions involved in atrazine adsorption by soils: Soil Science, v. 138, no. 1, p. 20-24.

English.

Sorption to Soil.

GUA 84127082.

Huggenberger, F., Letey, J. J., and Farmer, W. J., 1973, Adsorption and mobility of pesticides in soil: California Agriculture, v. 27, no. 2, p. 8-10.

English.

Sorption to Soil.

CA79(11):62593k.

Huggenberger, F., 1972, Adsorption and mobility of pesticides in soils, Dissertation submitted in partial fulfillment of Ph.D. requirements, Univ. California, Riverside, California, USA. English.

Sorption to Soil.

CA80(3):11144c.
Hurle, K, 1978, Effects of straw burning on the activity, absorption, and degradation of herbicides in soils: Mededingen van de Faculteit Landbouwwetenschappen, Rjjksuniversiteit Gent, v. 43, no. 2 Pt. 2, p. 1097-1107. German.

Sorption to Soil,Biodegradation/Biotransformation. CA9O(17): $133890 v$.

Hurle, K. B., and Freed, V. H., 1972, Effect of electrolytes on the solubility of some 1,3,5-triazines and substituted ureas and their adsorption on soil: Weed Research, v. 12, no. 1, p. 1-10. English.

Sorption to Soil, Chemical/Physical Properties.

CA77(3):15466v.

Johnson, H. P., and Baker, J. L., June 1975, Movement of herbicides in soil by mass flow: Completion Report, Iowa State Water Resources Res. Inst. No. 66.

English.

Leaching,Sorption to Soil. OWRT A-043-IA(1).

Jonas, K, Olaszi, V., and Elek, S., 1977, Proceedings of the Conference of Applied Chemistry, Unit Operational Processes, 3rd, p. 599-603.

English.

Sorption to Soil.

CA89(10):80747z.

Jones, T. W., Kemp, W. M., Stevenson, J. C., and Means, J. C., October-December, 1982, Degradation of atrazine in estuarine water/sediment systems and soils: Journal of Environmental Quality, v. 11, no. 4, p. 632-638.

English.

Biodegradation/Biotransformation,Associations with

Surfactants, Field Residuals,Sorption to Sediments,Sorption to Soil,Degradation Products. CA97(25):210373c.

Jury, W. A., Focht, D. D., and Farmer, W. J., 1987, Evaluation of pesticide groundwater pollution potential from standard indexes of soil-chemical adsorption and biodegradation: Joumal of Environmental Quality, v. 16, no. 4, p. 422-428. English.

Groundwater Observations,Biodegradation/Biotransformation, Sorption to Soil. CA108(3):17760u.

Kadoum, A. M., and Mock, D. E., 1978, Herbicide and insecticide residues in tailwater pits: water and pit bottom soil from irrigated com and sorghum fields: Joumal of Agriculture and Food Chemistry, v. 26, no. 1, p. 45-50.

English.

Sorption to Soil.

CA88(11):70461s.

Karickhoff, S. W., and Bailey, G. W., 1976, Protonation of organic bases in clay-water systems: Clays and Clay Minerals, v. 24 , no. 4 , p. $170-176$.

English.

Sorption to Soil.

CA86(14):96436w. 
Karoly, G., 1986, Study of interactions between the soil and herbicides: Novenyvedelem (Budapest), v. 22, no. 10, p. 438 444.

Hungarian.

Sorption to Soil.

CA108(17):145360a.

Kearney, P. C., Oliver, J. E., Helling, C. S., Isensee, A. R, and Kontson, A., 1977, Distribution, movement, persistence, and metabolism of $\mathrm{N}$-nitrosoatrazine in soils and a model aquatic ecosystem: Journal of Agriculture and Food Chemistry, v. 25 , no. 5, p. $1177-1181$.

English.

Degradation Products,Leaching,Sorption to Soil. CA87(19):146889q

Kearney, P. C., Zeng, Q., and Ruth, J. M., 1984, A large scale UV-ozonation degradation unit. Field trials on soii pesticide waste disposal: American Chemical Society, Symposium Series, v. 259, no. Treatment and Disposal of Pesticide Wastes, p. 195-209.

English.

Ifydrolysis/Chemical Reactions,Sorption to Soil.

CA101(25):224806j.

Khlebnikova, M. V., 1974, Adsorption of atrazine by soil absorbents: Doklady TSKhA, v. 198, p. 107-112.

Russian.

Sorption to Soil.

CA82(13):81584m.

Khiebnikova, M. V., Aleshin, S. N., and Konchits, V. A., 1976, Adsorption of atrazine by adsorbents of sod-podzolic soil: Doklady TSKhA, v. 218, p. 157-161.

Russian.

Sorption to Soil.

CA86(15):101857r.

Khlebnikova, M. V., and Konchits, V. A., 1984, Adsorption of atrazine by soil absorbents: Prognozir Povedeniya Pestitsidov v Okruzh Srede, Transactions of the Soviet-American Symposium., Erevan, Okt., 1981., p. 72-79.

Russian.

Sorption to Soil.

CA102(23):199491p.

Kibler, E., and Huric, K., 1978, Reciprocal effects of paraquat and atrazine on their sorption in montmorillonite and soils: Mededelingen van de Faculteit Landbouwwetenschappen, Rijksuniversiteit Gent, v. 43, no. 2 Pt. 2, p. 1117-1126.

German.

Sorption to Soil.

CA90(19):146994g.

Kislushko, P. M., and Skur'yat, A. F., 1984, Behavior in soil and phytotoxicity of chlorotriazine herbicides under conditions: of the Belorussian SSR: Okhrana Pochv i Rast. v Usloviyakh Intensiv. Primeneniya Pestetsidov i Dr. Sredstv Khimiz v S. kh., M., p. 69-76.

Russian.

Sorption to Soil.

CA104(13):104290b.
Kloskowski, R, and Fuehr, F., 1983, Formation of bound simazine residues in para brown soils: Chemosphere, v. 12, no. 11-12, p. $1545-1556$.

German.

Sorption to Soil.

CA100(9):63400j.

Kloskowski, R, and Fuehr, F., 1984, Methods for characterizing bound simazine residues in soils: Chemosphere, v. 13, no..12, p. 1353-1361.

German.

Sorption ta Soil.

CA102(13):108042d.

Kloskowski, R, and Fuehr, F., 1983, Studies for characterization and biodegradability of nonextractable simazine residues in soils: Chemosphere, v. 12, no. 11-12, p. 1557-1574.

German.

Sorption to Soil.

CA100(7):46959f.

Knake, E. L., Appleby, A. P., and Furtick, W. R., 1967, Soil incorporation and site of uptake of preemergence herbicides: Weeds, v. 15, no. 3, p. 228-232.

English.

Sorption to Soil, Uptake by Biota.

CA67(19):90003p.

Koch, W., Harris, G., Wolf, E., and Hurle, K., 1979, Herbizide, p. 96-101.

German.

Sorption to Soil.

CA93(5):39348q.

Kolar, L., 1982, Sorption, desorption, and detoxication of herbicides in the soil. Conditions in the mountains of Sumava: Sbornik Vysoke Skoly Zemedelske v Praze, Provozne Ekonomicke Fakulty v Ceskych Budejovicich, Rado Biologicka, no. 1, p. 13-26.

Czechoslovakian.

Sorption to Soil.

CA100(11):81139k.

Kretova, L. G., Khegay, T. A., Rachinskiy, V. V., and Fokin, A. D., Nov/Dec 1986, Decomposition of 14C-atrazine sorbed by various soil components: Soviet Soil Science, v. 18, no. 6, p. 59-65.

English, Russian.

Sorption to Soil.

IND 87060242.

Kretova, L. G., Khegai, T. A., Rachinskii, V. V., and Fokin, A. D., 1986, Degradation of 14C-atrazine sorbed by different soil components. Pochvovedenie, no. 10, p. 21-27.

Russian.

Sorption to Soil,Biodegradation/Biotransformation. CA106(3):14619c.

Ladlie, J. S., Meggitt, W. F., and Penner, D., 1976, Effect of soil pH on microbial degradation, adsorption, and mobility of metribuzin: Weed Science, v. 24, no. 5, p. 477-481.

English.

Degradation Products,Biodegradation/Biotransformation, Sorption to Soil.

CA85(23):172771y. 
Ladonin, V. F., and Tsimbalist, N. I., 1975, About the problem of extraction of atrazine from soil as related to the level of (applied) fertilizers: Doklady Vsesoyuznoi Akademii Sel'skokhczyaistvennykh Nauk, v. 8, p. 14-16. Russian.

Analytical Techniques/Quantification,Sorption to Soil.

Ladonin, V. F., and Tsimbalist, N. I., 1975, Extractability of atrazine from soil in relation to its degree of fertilization: Doklady Vsesoyuznoi Akademii Sel'skokhozyaistvennykh Nauk, no. 8, p. 14-16. Russian.

Sorption to Soil,Analytical Techniques/Quantification. CA84(13):85427b.

Lavy, T. L., Jan 1970, Diffusion of three chloro s-triazines in soil: Weed Science, v. 18, no. 1, p. 53-56.

English.

Sorption to Soil.

CA72(21):110152v.

Lavy, T. L., 1968, Micromovement mechanisms of s-triazines in soil: Soil Science Society of America, Proceedings, v. 32, no. 3, p. 377-380.

English.

Sorption to Soil.

CA69(11):42955v

Lavy, T. L., 1974, Mobility and deactivation of herbicides in soil-water systems: PB Rep., No. 238632/4GA, U.S. NTTS. English.

Leaching,Biodegradation/Biotransformation,Sorption to Soil. CA83(5):38731r.

Li, G. C., 1971, A study of the interaction of atrazine with fractions of soil organic matter, Dissertation submitted in partial fulfillment of Ph.D. requirements, University of Rhode Island, Rhode Island.

English.

Sorption to Soil, Associations with Humic Material. CAT 81752316.

Lim, S.-U., Lee, J.-K. and Han, K-H., 1977, Studies on the behaviors of some pesticides in soils. Part $I$. Adsorption of the herbicides atrazine and alachlor. Hanguk Nonghwa Hakhoe Chi, v. 20, no. 3, p. 310-316.

Korean.

Sorption to Soil.

CA88(11):70463u.

Liu, L. C., and Cibes Viade, H., 1968, Influence of soil properties on the phytotoxicity of atrazine, ametryne, prometryne, and diuron in Puerto Rican soils: Journal of the

- Agricultural University of Puerto Rico, v. 52, no. 4, p. 269-

280.

English.

Sorption to Soil.

CA69(21):85630C.

Liu, L. C., Cubes Viade, H., and Koo, F. K. S., Oct 1971, Adsorption of atrazine and terbacil by soils: Journal of the Agricultural University of Puerto Rico, v. 55, no. 4, p. 451460.

English.

Sorption to Soil.

CA76(5):21852p.
Liu, L. C., 1967, Effect of oils on herbicidal activity of atrazine and linuron and of waxes and oils on the movement of EPTC (ethyl N,N-di-n-propylthiocarbamate) in soil, Dissertation submitted in partial fulfillment of $\mathrm{Ph} . \mathrm{D}$. requirements, Rutgers State University, New Brunswick, N.J., USA.

English.

Sorption to Soil.

CA67(25):116043d.

Malquori, A., Fusi, P., and Stacciolo, G., 1967, Soil-herbicide interactions. II. Effect of electrolytes on adsorption and release of symmetrical triazines by argillaceous minerals: Chimia e l'Industria (Milan), v. 49, no. 3, p. $279-284$. Italian.

Sorption to Soil.

CA67(13):63188w.

Manninger, E., Gartner, B. A., Bakondi-Zamory, E., and Soos, T., 1977 , Soil Biology and Conservation of the Biosphere, (Proceedings of the Meetings), 7th, 1975, p. 79-85. English.

Biodegradation/Biotransformation,Sorption to Soil. CA89(19):158658t.

Matthies, M., Behrendt, H., and Muenzer, B., 1987, EXSOL. Model for the transport and persistence of substances in soil: GSFBer., 23/87.

German.

Leaching,Sorption to Soil, Uptake by Biota. CA109(1):5636r.

Matveev, Y. M., Agapov, V. I., and Lebedeva, G. F., 1988, Diffusion of atrazine and simazine in soils: Vestnik Moskovskogo Universiteta, Biologiya, Pochwovedenie, no. 1, p. 50-52.

Russian.

Sorption to Soil.

CA108(13):108078u.

McGlamery, M. D., Slife, F. W., and Butler, H., 1967, Extraction and determination of atrazine from soil: Weeds, v. 15, no. 1 , p. 35-38.

Engish.

Sorption to Soil,Analytical Techniques/Quantification. CA66(13):54455h.

Melis, P., and Cucchiarelli, E., 1981, Adsorption of some symmetric triazines on a bentonite from Uri (Sardinia): Studi Sassaresi, Sezione 3, v. 27, p. 28-35.

Italian.

Sorption to Soil.

CA97(15):122046t.

Miller, N. A., Wolf, D. C., and Scott, H. D., 1988, Influence of methanol and hexane on soil adsorption of atrazine: Water, Air, and Soil Pollution, v. 39, no. 1-2, p. 101-112.

English.

Sorption to Soil.

CA109(25):224636u. 
Moreale, A., and Van Bladel, R, 1981, Adsorption of 13 herbicides and insecticides by the soil. Solubilityreactivity relation: Revue de l'Agriculture(Brussels), v. 34, no. 4 , p. $939-952$

French.

Sorption to Soil.

CA96(3):16060n.

Moyer, J. R, Hance, R. J., and McKone, C. E., 1972, Effect of adsorbents on the rate of degradation of herbicides incubated with soil: Soil Biology and Biochemistry, v. 4, no. 3, p. 307-311.

English.

Sorption to Soil.

CA77(23):148421y.

Moyer, J. R, McKercher, R. B., and Hance, R. J., 1972 Desorption of some herbicides from montmorillonite and peat: Canadian Journal of Soil Science, v. 52, no. 3, p. 439-447.

English.

Sorption to Soil.

CA78(15):93506t.

Mueller-Wegener, U., 1982, Adsorption of chemicals relevant to the environment in soils: Chemie der Erde, v. 41, no. 2 p. 175-181.

German.

Sorption to Soil.

CA97(11):87021g.

Nearpass, D. C., 1967, Effect of the predominating cation on the adsorption of simazine and atrazine by Bayboro clay: Soil Science, v. 103, no. 3, p. 177-182.

English.

Sorption to Soil.

CA66(23):104244m.

Neely, W. B., 1987, Pesticide Science and Biotechnology, Proceedings of the International Congress of Pesticide Chemists, 6th, 1986, p. 391-399.

English.

Sorption to Soil.

CA107(13):110981f.

Neururer, H., 1972, Behavior of herbicides in soil: Bodenkultur, v. 43-73, na 2, p. 138-172.

German.

Sorption to Soil.

CA77(15):97624g.

Nicholk, P. H., Walker, A., and Baker, R.J., 1982, Measurements and simulation of the movement and degradation of atrazine and metribuzin in a fallow soil: Pesticide Science, v. 13, no. 5 , p. 484-494.

English.

Sorption to Soil,Leaching,Biodegradation/Biotransformation. CA98(25):211430b.

Nkedi-Kizza, P., Rao, P. S. C., and Hornsby, A. G., Oct 1985, Influence of organic cosolvents on sorption of hydrophobic organic chemicals by soils: Environmental Science and Technology, v. 19, no. 10, p. $975-979$.

English.

Sorption to Soil,Associations with Surfactants.

CA103(15):122253a.
Parochetti, J. V., 1972, Herbicides for com on high organic matter soils: Proceedings of the Northeastem Weed Science Society, v. 26, p. 31-35.

English.

Sorption to Soil.

CA76(19):109088e.

Parochetti, J. V., 1973, Soil organic matter effect on activity of acetanilides, CDAA (N,N-diallyl-s-chloroacetimide), and atrazine: Weed Science, v. 21, no. 3, p. 157-160.

English.

Sorption to Soil.

CA79(5):28277a.

Peeper, T. F., and Weber, J. B., 1976, Activity and persistence of atrazine, procyazine, and Vel 5026 as influenced by soil organic matter and clay: Proceedings of the Southern Weed Science Society, v. 29, p. 387-398.

English.

Sorption to Soil,Associations with Humic Material. CA85(9):58068z.

Peter, C. J., and Weber, J. B., 1985, Adsorption, mobility, and efficacy of metribuzin as influenced by soil properties: Weed Science, v. 33, no. 6, p. 868-873.

English.

Sorption to Soil,Leaching.

CA104(1):2143p.

Petkova, D., 1978, Effect of adsorption on the phytotoxicity of certain sym-triazine and urea herbicides: Pochvoznanie i Agrokhimiya, v. 13, no. 3, p. 90-96.

Bulgarian.

Sorption to Soil.

CA90(21):163258n.

Polizu, A., and Rughinis, D., 1977, Adsorption of some chloro-striazine herbicides in the soil: Analele Institutului de Cercetari Prot Plante, Academia Stiinte Agricole si Silvice, v. 13 , p. $279-286$.

Romanian.

Sorption to Soil.

CA89(19):158751t.

Ponomarev, G. S., Luk'yanchenko, A. S., and Nizhko, L. V., 1979, Features of the absorption and movement of triazine herbicides and sodium trichloroacetate in peat soil: Visnik Sil's'kogospodars'koi Nauki, no. 9, p. 16-18.

Ukrainian.

Sorption to Soil,Volatilization.

CA92(13):105699n.

Radke, R. O., 1967, Adsorption of atrazine by soils and soil colloidal components, Dissertation submitted in partial. fulfillment of Ph.D. requirements, University of Wisconsin, Madison, Wisconsin, USA.

English.

Sorption to Soil.

CA69(13):51098v.

Rahman, A, 1984, Influence of particle size and type of formulation on phytotoxicity and persistence of atrazine: Weed Research, v. 24, no. 4, p. 255-260.

English.

Sorption to Soil,Associations with Surfactants. CA101(15):124800j. 
Rahman, A., Dyson, C. B., and Burney, B., 1978, Effect of soil organic matter on the phytotoxicity of soil-applied herbicides - field studies: New Zealand Joumal of Experimental Agriculture, v. 6, no. 1, p. 69-75.

English.

Sorption to Soil.

CA89(17):141798r.

Rahman, A., and Matthews, L. J., 1979, Effect of soil organic matter on the phytotoxicity of thirteen s-triazine herbicides: Weed Science, v. 27, no. 2, p. 158-161. English. Sorption to Soil,Biodegradation/Biotransformation. CA90(25):198787m.

Raman, S., Krishna, M., and Rao, P. C., 1988, Adsorptiondesorption of atrazine on four soils of Hyderabad: Water, Air, and Soil Pollution, v. 40, no. 1-2, p. 177-184. Engiish.

Sorption to Soil.

CA110(9):71054w.

Randhawa, S. K, and Gill, H. S., 1984, Leaching behavior of herbicides in soils: Journal of Research (Punjab Agricultural University), v. 21, no. 2, p. 159-162.

English.

Sorption to Soil.

CA102(11):91414b.

Rao, P. S. C., and Davidson, J. M., 1979, Adsorption and movement of selected pesticides at high concentrations in soils: Water Research, v. 13 , no. 4 , p. $375-380$.

English.

Sorption to Soil.

CA91(3):15163h.

Rao, P. S. C., Davidson, J. M., Jessup, R. E., and Selim, H. M., 1979, Evaluation of conceptual models for describing nonequilibrium adsorption-desorption of pesticides: Journal of the Soil Science Society of America, v. 43, no. 1, p. 22-28. English. Sorption to Soil.

CA9O(25):198853e.

Ritter, W. F., Johnson, H. P., and Lovely, W. G., Sept 1973, Diffusion of atrazine, propachlor, and diazinon in a silt loam soil: Weed Science, v. 21, no. 5, p. 381-384. English.

Sorption to Soil,Leaching. CA80(3):11193t.

Scheunert, I., and Korte, F., 1985, Interactions in the fate of chemicals in terrestrial systems: Ecotoxicology and Environmental Safety, v. 9, no. 3, p. 385-391.

English.

Biodegradation/Biotransformation,Miscellaneous Environmental, Sorption to Soil.

CA103(7):49747h.
Scheunert, I., Qiao, Z, and Korte, F., 1986, Comparative studies of the fate of 14C-atrazine and 14C-pentachlorophenol in various laboratory and outdoor soil-plant systems: Journal of Environmental Science and Health, Part B, v. B21, no. 6, p. 457-485.

English.

Sorption to Soil,Biodegradation/Biotransformation. CA106(13):98083j.

Schiavon, M., 1988, Studies of the leaching of atrazine, of its chlorinated derivatives, and of hydroxyatrazine from soil using carbon-14 ring-labeled compounds under outdoor conditions: Ecotoxicology and Environmental Safety, v. 15, no. 1, p. 46-54.

English.

Leaching,Degradation Products,Sorption to Soil, Biodegradation/Biotransformation.

CA108(23):200133f.

Schiavon, M., 1988, Studies of the movement and the formation of bound residues of atrazine, of its chlorinated derivatives, and of hydroxyatrazine in soil using carbon-14 ring-labeled compounds under outdoor conditions: Ecotoxicology and Environmental Safety, v. 15, no. 1, p. 55-61. English.

Sorption to Soil,Biodegradation/Biotransformation. CA108(23):200134g.

Schneider, A. D., Wiese, A. F., and Jones, O. R., 1977, Movement of three herbicides in a fine sand aquifer. Agronomy Journal, v. 69, no. 3, p. $432-436$.

English.

Sorption to Soil,Groundwater Observations. CA87(17):128671h.

Schoen, S. R, and Winterlin, W. L., 1987, The effects of various soil factors and amendments on the degradation of pesticide mixtures: Journal of Environmental Science and Health, Part B, v. B22, no. 3, p. 347-377.

English.

Biodegradation/Biotransformation,Sorption to Soil. CA107(13):111096h.

Scott, H. D., and Lutz, J. F., 1971, Release of herbicides from clay minerals as a function of water content. I. Kaolinite: Soil Science Society of America, Proceedings, v. 35, no. 3, p. 374-379.

English.

Sorption to Soil.

CA75(3):19085b.

Scott, H. D., and Phillips, R. E., 1972, Diffusion of selected herbicides in soil: Soil Science Society of America, Proceedings, v. 36, no. 5, p. 714-719.

English.

Sorption to Soil,Volatilization:

CA78(15):93509w.

Shin, Y.-O., and Baker, J. H., 1974, Factors influencing the adsorption of atrazine in Massachusetts soils: Hanguk T'oyang Bilyo Hakhoe Chi, v. 7, no. 4, p. 193-196.

English.

Sorption to Soil.

CA84(25):175131e. 
Simon-Sylvestre, G., 1983, Difficulty of using the structural stability modifications of soils to evaluate the effects of pesticides on the degradation of organic matter and to define a classification test for these products: Agrochimica, v. 27, no. 4, p. 326-327.

French.

Sorption to Soil.

CA101(5):34523s.

Sirmunskaja, N. M., and Stonov, L. D., 1970, Physico-chemical causes of the interaction between an atrazine suspension and the soil: Deutsche Akademie der Landwirtschaftswissenschaften zu Berlin, Tagungsbericht, v. 109, p. 133-143.

German.

Sorption to Soil.

CAIN 729060435.

Sirons, G. J., Frank, R, and Sawyer, T., November/December 1973, Residues of atrazine, cyanazine, and their phytotoxic metabolites in a clay loam soil: Joumal of Agricultural and Food Chemistry, v. 21, no. 6, p. 1016-1020.

English.

Field Residuals,Degradation Products,Sorption to Soil, Biodegradation/Biotransformation,Hydrolysis/Chemical Reactions.

Smika, D. E., 1984, Importance of soil characteristics on herbicide performance: Publication of the Great Plains Agriculture Council, Bozeman, Montana, Montana State University, Coop. Ext. Serv..

English.

Sorption to Soil.

IND 86032174.

Smit, N. S. H., and Nel, P. C., 1977, The activity of atrazine on two South African soils: Gewasproduksie, v. 6, p. 67-71. English.

Analytical Techniques/Quantification,Leaching,Sorption to Soil.

CA88(7):46270h.

Smit, N. S. H., Nel, P. C., and Folscher, W. J., 1981, Proceedings of the Fourth National Weeds Conference, South Africa.

Eaglish.

Sorption to Soil.

IND 83128198.

Smit, N. S. H., Nel, P. C., and Folscher, W. J., 1979, Effect of $\mathrm{pH}$ on availability, residual activity and desorption of atrazine in soils with the same clay content: Gewasproduksie, v. 8, p. 125-129.

Afrikaans.

Sorption to Soil:

CA92(13):105718t.

Smit, N. S. H., Nel, P. C., and Folscher, W. J., 1980, Factors affecting sorption and degradation of atrazine in soils: Gewasproduksie, v. 9, p. 135-139.

Afrikaans.

Sorption to Soil,Biodegradation/Biotransformation. CA95(11):92218q.
Snelling, K. W., Hobbs, J. A., and Powers, W. L., Nov/Dec 1969, Effects of surface area, exchange capacity, and organic matter content on miscible displacement of atrazine in soils: Agronomy Journal, v. 61, no. 6, p. 875-878.

English.

Sorption to Soil.

CA72(7):30504w.

Solinas, V., Gessa, C., Melis, P., Franco, M. A., and Sabbatini, M., 1983, Fuxation of hydroxy-atrazine on homionic clay surface during hydrolysis of atrazine: Agrochimica, v. 27, no. $5-6$, p. $464-473$.

English.

Hydrolysis/Chemical Reactions,Sorption to Soil.

CA102(1):1870v.

Streibig, J. C., 1980, Measured and predicted concentration of striazine in soil water. Arsskrift - den Kongelige Veterinaerog Landbohoejskole (Copenhagen), p. 47-56.

English.

Sorption to Soil.

CA93(5):39480b.

Streibig, J. C., 1979, Soil properties influencing soil adsorption and phytotoxicity of atrazine and simazine in nine Danish soils: Acta Agriculture Scandinavia, v. 29, no. 1, p. 33-41. English.

Sorption to Soil.

CA91(1):1344f.

Suess, A., 1978, Behavior of monolinuron (Aresin) and atrazine (Gesaprim) in field trials: Bayerisches Landwirtschaftliches Jahrbuch, Jonderheft, v. 55, no. 5, p. 565-570.

German.

Sorption to Soil.

CA90(13):98472m.

Suess, A., and Eben, C., 1977, Studies on the sorption of herbicides: Dali-Briefe, v. 1, no. 6, p. 10 pp..

German.

Sorption to Soil.

CA87(13):97377k.

Suess, A., Fuchsbichler, G., Siegmund, H., and Eben, C., 1979, Herbizide, p. 88-95.

German.

Sorption to Soil, Biodegradation/Biotransformation. CA93(5):39477f.

Swain, D. J., 1981, Atrazine dissipation in irrigated sorghum cropping in southern New South Wales: Weed Research, v. 21, no. 1, p. 13-21.

English.

Sorption to Soil,Biodegradation/Biotransformation. CA105(19):166811b.

Swanson, R. A., 1972, Prediction of atrazine distribution and movement in soil systems, Dissertation submitted in partial fulfillment of Ph.D. requirements, University of Arizona, Arizona.

English.

Sorption to Soil,Leaching.

CA78(3):14810m. 


\section{ENVIRONMENTAL PROCESSES \\ TRANSFER PROCESSES \\ Sorption/Partitioning}

Tafuri, F., Marucchini, C., Businelli, M., and Patumi, M., 1978 Residues of atrazine and its metabolites in a clay-sand soil: Annali della Facolta di Agraria, Univ. degli Studi d Perugia, v. 32 , no. 1 , p. $257-268$.

English.

Sorption to Soil.

CA92(5):35813u.

Terce, M., 1983, Effect of dilution of kaolinite and montmorillonite suspensions on the adsorption of atrazine: Agron. Sci. Prod. Veg. Environ., v. 3, no. 9, p. 883-890.

French.

Sorption to Soil.

IND 84052903.

Terce, M., and Calvet, R, 1977, Role of aluminum in the adsorption of atrazine by clay minerals: Spec. Publ. Agric. Res. Organ. Volcani. Cent. Div. Sci. Publ., 82: 33-39. English.

Sorption to Soil. CA87(25):195522y.

Terce, M., Lefebvre-Drouet, E., and Calvet, R, 1977, Degradation of adsorbed atrazine on an aluminum montmorillonite: Chemosphere, v. 6, no. 11, p. 753-758.

English.

Sorption to Soil,Biodegradation/Biotransformation. CA88(11):70464v.

Terce, M., and Calvet, R, 1974, Adsorption of atrazine on the biionic calcium-aluminum clays: C.R. Hebd. Seances Acad. Sci., Ser. D., v. 279, no. 25, p. 1859-1862.

French.

Sorption to Soil.

CA82(23):154326r.

Terce, M., and Calvet, R, 1978, Adsorption of several herbicides by montmorillonite, kaolinite and illite clays: Chemosphere, v. 7, no. 4, p. 365-370.

English.

Sorption to Soil.

CA89(9):71972s.

Tlas Farzat, K. S., 1982, Zashch. Rast. Usloviyakh Intensivn. Khimiya v Sel'skom Khozyaistve, p. 58-62.

Russian.

Sorption to Soil.

CA101(9):67718n.

Tripathi, H. P., and Moolani, M. K., 1972, Effect of simazine and atrazine applied under different levels of organic matter on maize, and their residual effect on succeeding crops: Indian Journal of Agricultural Science, v. 42, no. 7, p. 604-609. English.

Sorption to Soil,Associations with Humic Material. CA78(11):68102a.
Tsukerman, V. G., and Lunev, M. I., 1983, Analysis of chloroorganic and sym-triazine pesticides by gas liquid chromatography and study of their behavior in soil: Rezul't. Razrab. Metodov Anal. Pochv, Rast.

Udobr. Moscow, USSR, Tsentr. Inst. Agrokhim. Obsluzhivaniya Sel'sk. Khoz., p. 113-123.

Russian.

Sorption to Soil,Analytical Techniques/Quantification, Biodegradation/Biotransformation.

CA103(11):83387a.

Van Bladel, R, and Moreale, A., 1982, Statistical correlative analysis of the effect of soil properties on adsorption of herbicides and insecticides: Chemosphere, v. 11, no. 12, p. $1159-1178$.

French.

Sorption to Soil.

CA98(7):48654s.

Van Bladel, R, and Moreale, A., 1980, Study on the behavior of pesticides in soils using the radiotracer technique. Part $\mathrm{I}$.

Adsorption-desorption and degradation processes: Bulletin des Recherches Agronomiques de Gembloux, v. 15, no. 2, p. 177-189. French.

Sorption to Soil,Biodegradation/Biotransformation. CA95(11):92335a.

Van Drecht, G., and Tiktak, A., Contaminated Soil, International TNO Conference, 1st, 1985, p. 153-155.

English.

Sorption to Soil.

CA104(17):143815w.

Voitekhova, V. A, 1969, Adsorption of herbicides by soil: Agrolkhimiya, no. 9, p. 102-110.

Russian.

Sorption to Soil.

$\operatorname{CA72}(T): 30500 \mathrm{~s}$.

Voitekhova, V. A., 1971, Effect of a soil absorbing complex on the phytotoxicity of herbicides: Khimiya v Sel'Skom Khozyaistve, v. 9, no. 5, p. 359-363.

Russian.

Sorption to Soil.

CA76(19):109134s.

Vong, P. C., and Schiavon, M., 1982, Effect of atrazine on the mineralization of organic materials in soils and in the presence of carbon-14-labeled substrates: Bulletin de l'Ecole Nationale Superieure d'Agronomie et des Industries Alimentaires, v. 24, p. 43-53.

French.

Toxicity,Biodegradation/Biotransformation,Sorption to Soil. CA99(21):171257n.

Wachob, G. D., 1984, Solid-phase extraction of triazine herbicides from soil samples: Liquid Chromatography, v. 2, no. 10, p. $756,758-759$.

English.

Analytical Techniques/Quantification,Sorption to Soil. CA102(1):1838r. 
Walker, A., 1972, Availability of atrazine to plants in different soils: Pesticide Science, v. 3, no. 2, p. 139-148.

English.

Uptake by Biota,Sorption to Soil.

CA77(9):57483d.

Walker, A., 1972, Influence of soil factors on availability of atrazine and linuron to plants. (Wheat): British Weed Control Conference Proceedings, 11th, v. 2, p. 800-805.

English.

Chemical/Physical Properties,Sorption to Soil. CA85(5):29458w.

Walker, A., and Crawford, D. V., 1968, Isotopes and Radiation in Soil Organic-Matter Studies. Proceedings of the Symposium on the use of Isotopes and Radiation in Soil Organic Matter Studies, p. 91-105.

English.

Sorption to Soil.

CA71(3):12179u.

Wallace, A., Mueller, R T., and El Gazzar, A., 1970, Effects of some triazines on corn and bean plants grown on natural and amended soils: Agronomy Joumat, v. 62, no. 3, p. 373-375.

English.

Sorption to Soil.

CA73(5):24094s.

Wauchope, R. D., and Koskinen, W. C., 1983, Adsorption-desorption equilibria of herbicides in soil: a thermodynamic perspective: Weed Science, v. 31, no. 4, p. 504-512. English.

Sorption to Soil.

CA99(15):117755k.

Weber, J. B., 1970, Adsorption of s-triazines by montmorillonite as a function of $\mathrm{pH}$ and molecular structure: Soil Science Society of America, Proceedings, v. 34, no. 3, p. 401-404.

English.

Sorption to Soil.

CA73(6):29273j.

Weber, J. B., and Whitacre, D. M., 1982, Mobility of herbicides in soil columns under saturated- and unsaturated-flow conditions: Weed Science, v. 30, no. 6, p. 579-584.

English.

Sorption to Soil.

CA98(5):29613m.

Wehtje, G. R, Spalding, R. F., Burnside, O. C., Lowry, S. R, and Leavitt, J. R. C., 1983, Biological significance and fate of atrazine under aquifer conditions: Weed Science, v. 31, no. 5 , p. 610-618.

English.

Biodegradation/Biotransformation,Leaching,Groundwater Observations,Sorption to Soil.

CA99(21):171005d.

Whin, Y.-O., and Baker, J. H., 1974, Application of the distribution law to soil-pesticide systems: Hanguk Toyang Bilyo Hakhoe Chi, v. 7, no. 1, p. 1-4.

English.

Sorption to Soil.

CA84(25):175130d.
White, J. L., 1975, Determination of susceptibility of s-triazine herbicides to protonation and hydrolysis by mineral surfaces: Aurchives of Environmental Contamination and Toxicology, v. 3, no. 4 , p. $461-469$.

English.

Hydrolysis/Chemical Reactions,Sorption to Soil.

CA85(1):1054n.

Wilkinson, R. E, and Karunen, P., 1976, EPTC influence on atrazine absorption: Proceedings of the Southern Weed Science Society, p. 417.

English.

Sorption to Soil.

CAIN 779075698.

Zhirmunskaya, N. M., and Stonov, L. D, 1968, Interaction of an atrazine suspension with soil: Khimiya $v$ Sel'Skom Khozyaistve, v. 6, no. 11, p. 841-844.

Russian.

Sorption to Soil.

CA70(17):76646f. 
Agapov, V. I., and Tulupova, M. Y., 1980, Behavior of atrazine in the soil: Vestnik Moskouskogo Universiteta, Biologiya, Pochvovedenie, Series 17, v. 35, no. 4, p. 55-58.

Russian.

Leaching,Biodegradation/Biotransformation, Analytical Techniques/Quantification,Sorption to Soil. CA94(1):998x.

Albanis, T. A., Pomonis, P. J., and Sdoukos, A. T., 1988, Movement of methyl parathion, lindane and atrazine through lysimeters in field conditions: Toxicological and Environmental Chemistry, v. 17, no. 1, p. 35-45. English.

Leaching.

CA108(25):217772m.

Albanis, T., Pomonis, P., and Sdoukos, A., 1988, Describing movement of three pesticides in soil using a CSTR in series model: Water, Air and Soil Pollution, v. 39, no. 3-4, p. 293302.

English.

Leaching.

CA110(6):44528x.

Andreeva-Fetvadzhieva, N., 1967, Penetration of simazine, atrazine, and prometryn and their detoxication in various soil layers: Rastenievudni Nauki, v. 4, no. 6, p. 85-101.

Bulgarian.

Leaching.

CA68(19):86351d.

Basile, B., and Scognamiglio, D., 1983, Mobility and degradation of atrazine residues in soil: Inquinamento, v. 25, no. 7-8, p. 39-41. Italian.

Leaching,Biodegradation/Biotransformation. CA100(17):134287r.

Bauman, T.T., Movement and persistence of atrazine in soil with three tillage systems, Dissertation submitted in partial fulfilment of Ph.D. requirements, Purdue University, West Lafayette, Indiana, USA.

English.

Leaching,Biodegradation/Biotransformation. CA87(3):17198q.

Blume, H. P., and Bruemmer, G., 1987, Prediction of the behavior of pesticides in soils by using simple field methods: Landwirtschaftliche Forschung, v. 40, no. 1, p. 41-50.

\section{German.}

Sorption to Soil, Volatilization, Leaching. CA108(5):33490m.

Bouchard, D. C., 1987, Monitoring transport of selected. pesticides and phenols in soil columns by high performance liquid chromatography: Journal of Environmental Science and Heaith, Part B, v. B22, no. 4, p. 391-402.

English.

Leaching,Analytical Techniques/Quantification. CA107(21):192856f.
Bowmer, K. H., 1972, Long-term use of herbicides. Measurement of residues of diuron and simazine in an orchard soil:

Australian Journal of Experimental Agriculture and Animal

Husbandry, v. 12 , no. 58 , p. 535-539.

English.

Leaching.

CA78(7):39089w.

Brejda, J. J., Shea, P. J., Moser, L. E., and Walier, S. S., 1988, Atrazine dissipation and off-plot movement in a Nebraska Sandhills subirrigated meadow: Journal of Range Management, v. 41, no. 5, p. 416-420.

English.

Leaching.

CA109(25):224625q.

Burnside, O. C., Fenster, C. R, and Wicks, G. A., 1971, Soil persistence of repeated annual applications of atrazine: Weed Science, v. 19, no. 3, p. 290-293.

English.

Leaching.Field Residuals.

CA75(5):343332.

Chapman, T., Gabbott, P. A., and Osgerby, J. M., 1970, Technique for measuring the relative movement of herbicides in soil under leaching conditions: Pesticide Science, v. 1, no. 2, p. 56-58.

English.

Leaching.

CA73(5):24048e.

Chelebiev, M., 1982, Biological activity and migration of some herbicides in vineyard soils: Lozarstro i Vinarstvo, v. 31, no. 6; p. 31-35.

Bulgarian.

Leaching.

CA98(1):1622q.

Chevreuil, M., and Chesterikoff, A., 1979, Study on the transfer of pesticides on a basin under various circumstances and an attempt at a balance: $C$. R. Seances Academy, France, v. 65 ; no. 10, p. $835-845$.

French.

Leaching, Run-off. CA95(3): $19693 \mathrm{~m}$.

Dao, Thanh Hung, 1977, Factors affecting atrazine adsorption, degradation and mobility in soil, Dissertation submitted in partial fulfilment of $\mathrm{Ph} . \mathrm{D}$. requirements, Nebraska. English.

Biodegradation/Biotransformation,Leaching,Sorption to Soil. CA88(7):46255g.

Darwent, A. L, and Behrens, R, 1968, Dissipation and leaching of atrazine in a Minnesota soil after repeated applications: Proceedings of the North Central Weed Control Conference, v. 23, p. 66-69.

English.

Leaching,Biodegradation/Biotransformation. CA71(13):59934b. 
Davidson, J. M., Ou Li-Tse, and Rao, P. S. C., 1978, Adsorption, movement, and biological degradation of high concentrations of selected pesticides in soils: EPA-600/9-78-016,

Environmental Protection Agency.

English.

Sorption to Soil,Leaching,Biodegradation/Biotransformation. CA89(23):192489y.

Davidson, J. M., Rao, P. S., and Ou., L. T., March, 1980, Disposal of Hazardous Wastes; Proceedings of the Sixth Annual Research Symposium, March 17-20, p. 93-107.

English.

Biodegradation/Biotransformation,Sorption to Soil,Leaching. CA94(1):1054y.

Deleu, R, and Copin, A., 1987, Pesticide residue analysis by capillary gas chromatography-mass spectrometry. Application to carbofuran and atrazine analysis: Bulletin des Recherches Agronomiques de Gembloux, v. 22, no. 2, p. 121-132. French.

Analytical Techniques/Quantification,Leaching. CA108(21):182101n.

Djumija, L., and Horgas, D., 1977, Dynamic movement of residues of triazine herbicides in the vegetation period of some agricultural crops: Poljoprivredna Znanstvena Smotra, v. 40, p. 143-153.

Croatian.

Run-off,Leaching.

CA88(11):70377u.

Djumija, L., Lozovina, M., and Horgas, D., 1977, Movement of striazine herbicides in soils of the pilot farm Jezevo: Poljoprivredna Znanstvena Smotra, v. 40, p. 119-130. Croatian.

Leaching

CA88(23):165303t.

Donigian, A. S., Jr., and Carsel, R. F., 1987, Modeling the impact of conservation tillage practices on pesticide concentrations in ground and surface waters: Environmental Toxicology and Chemistry, v. 6, no. 4, p. 241-250.

English.

Leaching,Surfacewater Observations.

CA106(25):209463e.

Eglite, A., Spalvins, Z., Folkmane, A., and Goba, A., 1979, Effect of dalapon and atrazine on forest biogeocenoses: Jaunakais Mezsaimn., v. 21, p. 61-70.

Latvian.

Leaching, Toxicity.

CA93(1):2144u.

E1-Deeb, S. T., Tag-El-Din, A. T. F., Kadous, E. A., Khalifa, M. A. S., and Shaaban, M. A., 1979, Soil pollution with herbicides. 1. Leachability of some herbicides from the soil: Alexandria Journal of Agricultural Research, v. 27, no. 2, p. 439-445.

English.

Leaching.

CA92(23): $192546 \mathrm{~b}$.
Evdokimov, V. V., 1984, Presowing tillage and application of herbicides in corn cultivation: Khimiya v Sel'skom Khozyaistve, no. 3, p. 43-45.

Russian.

Leaching.

CA100(23):187918u.

Felding, G., Kelstrup, N., Helweg, A., and Christiansen, J. C., 1986, Leaching of atrazine from cultivated soils: Tidsskrift for Planteavl, v. 90, no. 4, p. 349-357.

Danish.

Leaching.

CA106(23):191083u.

Frank, R, and Sirons, G. J., Apr 1985, Dissipation of atrazine residues from soils: Bulletin of Environmental Contamination and Toxicology, v. 34, no. 4, p. 541-548.

English.

Sorption to Soil,Leaching,Field Residuals,Biodegradation/ Biotransformation.

CA102(23):199566s.

Ghinea, L., Radulescu, V., Vladutu, I., Fritea, T., and Turcu, M., 1985, Some aspects of residual effects of atrazine: Analele Institutului de Cercetari Cereale si Plante Tehnice. Fundulea, Academia de Stiinte Agricole si Silvice, Seria B, v. 53, p. $415-434$.

Romanian.

Sorption to Soil,Leaching,Field Residuals. CA107(11):91798h.

Giardini, L., June/Sept 1974, Laboratory research on the downward movement of atrazine in the soil: Rivista di Agronomia, v. 8, no. $2 / 3$, p. $166-172$

Italian.

Leaching.

CAIN 749097057.

Gish, T. J., Zhuang, W., Helling, C. S.,., and Keamey, P. C., 1986, Chemical transport under no-till field conditions: Geoderma, v. 38, no. 1-4, p. 251-259. English.

Leaching. CA105(21):185809y.

Goetz, A. J., Wehtje, G., Walker, R. H., and Hajek, B., 1986, Soil solution and mobility characterization of imazaquin: Weed Science, v. 34, no. 5, p. 788-793.

English.

Degradation Products,Sorption to Soil,Leaching. CA105(19):166811b.

Green, R. E., and Corey, J. C., July/Aug 1971, Pesticide adsorption measurement by flow equilibration and subsequent displacement: Soil Science Society of America, Proceedings, v. 35, no. 4, p. 561-565.

English.

Leaching,Sorption to Soil.

CAIN 729011080. 


\section{ENVIRONMENTAL PROCESSES TRANSPORT PROCESSES \\ Leaching}

Green, R. E., Yamane, V. K, and Obien, S. R., 1968, Transport of atrazine in a latosolic soil in relation to adsorption, degradation, and soil water variables: International Society of Soil Science, Transactions, 9th, v. 1, p. 195-204.

English.

Sorption to Soil, Biodegradation/Biotransformation,Leaching. CA72(1):2409a.

Hall, J. K, and Hartwig, N. L., 1978, Atrazine mobility in two soils under conventional tillage: Journal of Environmental Quality, v. 7, no. 1, p. 63-68.

English.

Leaching.

CA88(17):116280n.

Harris, C. 1., 1967, Movement of herbicides in soil: Weeds, v. 15 , no. 3, p. 214-216.

English.

Leaching.

CA67(17):81395r.

Harris, C. I., Woolson, E. A., and Hummer, B. E., 1969, Dissipation of herbicides at three soil depths: Weed Science, v. 17 , no. 1 , p. 27-31.

English.

Leaching.

CA70(13):56576e.

Helling, C. S., and Gish, T. J., 1986, Soil characteristics affecting pesticide movement into ground water. American Chemical Society Symposium Series, no. 315, p. 14-38. English.

Leaching,Sorption to Soil,Groundwater Observations. CA105(15):129452q.

Helling, C. S., Kaufman, D. D., and Dieter, C. T., 1971, Algae bioassay detection of pesticide mobility in soils: Weed Science, v. 19 , no. 6 , p. $685-690$.

English.

Leaching.

CA76(13):69105z.

Helling, C. S., Zhuang, W., Gish, T. J., Coffman, C., Benjamin, Isensee, A. R.: Kearney, Philip C., Hoagland, D. R, and Woodward, M. D., 1988, Persistence and leaching of atrazine, alachlor, and cyanazine under no-tillage practices:

Chemosphere, v. 17, no. 1, p. 175-187.

English.

Leaching.

CA108(13):108089y.

Herzel, F., and Schmidt, G., 1979, Testing the leaching behavior of herbicides on lysimeters and small columns: WaBoLu Bericht, no. 3, p. 16 pp..

German.

Leaching.

CA91(11):85071a.

Hiranpradit, H., 1974, Atrazine movement with water and effects of contaminant levels on nontarget organisms, Dissertation submitted in partial fulfillment of $\mathrm{Ph}$.D. requirements, Virginia Polytech. Inst., Blacksburg, VA, USA.

English.

Toxicity,Leaching.

CA83(13):109521k
Isensee, A. R, Sept 1987, Persistence and movement of atrazine in a salt marsh sediment microecosystem: Bulletin of

Environmental Contamination and Toxicology, v. 39, no. 3, p.

516-523.

English.

Sorption to Sediments, Surfacewater Observations,Leaching. CA107(15):129055d.

Isensee, A. R, Helling, C. S., Gish, T. J., Kearney, P. C., Coffman, C. B., and Zhuang, W., 1988, Groundwater residues of atrazine, alachlor. and cyanazine under no-tillage practices: Chemosphere, v. 17, no. 1, p. 165-174. English.

Groundwater Observations, Leaching. CA108(13):108088x.

Jamet, P., and Thoisy-Dur, J. C., 1988, Pesticide mobility in soils: assessment of the movement of isobaxen by soil thinlayer chromatography: Bulletin of Environmental Contamination and Toxicology, v. 41, no. 1, p. 135-142.

English.

Leaching.

CA109(7):50197)

Johnson, H. P., and Baker, J. L., June 1975, Movement of herbicides in soil by mass flow: Completion Report, Iowa State Water Resources Res. Inst. No. 66.

English.

Leaching,Sorption to Soil. OWRT A-043-IA(1).

Jury, W. A., Spencer, W. F., and Farmer, W. J., 1984, Behavior assessment model for trace organics in soil: III. Application of screening model: Journal of Envircnmental Quality, v. 13, no. 4, p. 573-579.

English.

Toxicity, Volatilization,Leaching. CA101(25):224814k.

Kearney, P. C., Oliver, J. E., Helling, C. S., Isensee, A. R. and Kontson, A., 1977, Distribution, movement, persistence, and metabolism of $\mathrm{N}$-nitrosoatrazine in soils and a model aquatic ecosystem: Journal of Agriculture and Food Chemistry, v. 25 , no. 5 , p. $1177-1181$.

English.

Degradation Products,Leaching,Sorption to Soil.

CA87(19):146889q.

Klaine, S. J., Hinman, M. L., Winkelmann, D. A., Sauser, K. R. Martin, J. R, and Moore, L. W., 1988, Characterization of agricultural nonpoint pollution: pesticide migration in a west Tennessee watershed: Environmental Toxicology and Chemistry, v. 7, no. 8, p. 609-614.

English.

Leaching,Run-off. CA109(17):144505k.

Kreuger, J. K., and Brink, N., Pesticides: Food and Environmental Implications, Proceedings of the International Symposium, 1987, p. 101-112.

English.

Run-off,Leaching,Field Residuals.

CA110(11):90597s. 
Lavy, T. L., 1974, Mobility and deactivation of herbicides in soil-water systems: PB Rep., No. 238632/4GA, U.S. NTIS. English.

Leaching,Biodegradation/Biotransformation,Sorption to Soil. CA83(5):38731r.

Leonard, R. A., Shirmohammadi, A., Johnson, A. W., and Marti, L. R, 1988, Pesticide transport in shallow groundwater.

Transactions of ASAE, v. 31, no. 3, p. 776-788.

English.

Leaching

CA109(24):215601b.

Liang, T. T., and Lichtenstein, E. P., 1974, Synergism of insecticides by herbicides. Effect of environmental factors: Science, v. 186, no. 4169, p. 1128-1130.

English.

Toxicity, Leaching.

CA82(21):133984p.

Lichtenstein, E. P., Liang, T. T., and Koeppe, M. K., 1982, Effects of fertilizers, captafol, and atrazine on the fate and translocation of $14 \mathrm{C}$ carbon isotope parathion in a soil...: Journal of Agriculture and Food Chemistry, v. 30, no. 5 , p. $871-878$.

English.

Leaching.

IND 82109673

Liu, L. C., and Cibes-Viade, H., 1970, Leaching of atrazine, ametryne, and prometryne in the soil: Journal of the Agricultural University of Puerto Rico, v. 54, no. 1, p. 518.

English.

Leaching.

CA72(15):77764w.

Lopez-Avila, V., Hirata, P., Kraska, S., Flanagan, M., Taylor, J. H., Jr., Hem, S. C., Melancon, S., and Pollard, J., 1986, Movement of selected pesticides and herbicides through columns of sandy loam: American Chemical Society, Symposium Series, v. 315, no. Evaluation of Pesticides in Ground Water, p. 311-328.

English.

Leaching.

CA105(13):110507q.

Lupi, C., Bucchi, A. R, Piccioni, A., and Zapponi, G. A., 1988, The environmental behavior of chemicals in soil: atrazine as an example: Ecotoxicology and Environmental Safety, v. 16, no. 2, p. 133-142.

English.

Leaching.

CA110(5):35276m.

Matthies, M., Behrendt, H., and Muenzer, B., 1987, EXSOL. Model for the transport and persistence of substances in soil: GSF-

Ber., 23/87.

German.

Leaching,Sorption to Soil,Uptake by Biota.

CA109(1):5636r.

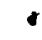

McCall, E. C., Jr., Lane, D. D., and Parr, A. D., 1983, Transport modeling of an agricultural herbicide: a laboratory simulation: Report, CONTRIB-240, W84-00969; Order No. PB140623, 34 p.

English.

Leaching, Run-off.

CA101(1):2307h.

Melancon, S. M., Pollard, J. E., and Hern, S. C., 1986, Evaluation of SESOIL, PRZM and PESTAN in laboratory column leaching experiment: Environmental Toxicology and Chemistry, v. 5 , no. 10 , p. $865-878$.

English.

Leaching.

CA105(25):220835c.

Moreale, A., and Van Bladel, R, 1982, Mobility and vertical dispersion of some pesticides in undisturbed soil columns: Mededelingen van de Faculteit Landbouwwetenschappen, Rijksuniversiteit Gent, v. 47, no. 1, p. 381-394.

Netherlands.

Leaching.

CA98(7):48651p.

Moreale, A., and Van Bladel, R, 1980, Study on the behavior of pesticides in soils using the radiotracer technique. Part 2. Migration and distribution in the soil profile: Bulletin des Recherches Agronomiques de Gembloux, v. 15, no. 2, p. 191206.

French.

Leaching,Biodegradation/Biotransformation. CA95(11):92336b.

Moreale, A., and Van Bladel, R, 1983, Vertical transport of solutes toward subterranean water. An approach using an undisturbed soil column. 1. Characterization of solute-soil interactions: Revue de l'Agriculture (Brussels), v. 36, no. 6, p. 1669-1676.

French.

Leaching.

CA101(7):53936v.

Mozheiko, A. M., and Litvinov, I. A., 1969, Dynamics of the herbicide hungazin in soil: Trudy Khar'kouskii

Sel'skokhozyaistvennyi Institutimeni, v. 92, p. 48-52.

Russian.

Biodegradation/Biotransformation,Leaching. CA77(3):15420a.

Muir, D. C. G., and Baker, B. E., 1978, The disappearance and movement of three triazine herbicides and several of their degradation products in soil under field conditions: Weed Research, v. 18, no. 2, p. 111-120.

English.

Degradation Products,Biodegradation/Biotransformation,Field Residuals, Leaching. CA89(17):141769g.

Nel, P. C., 1975, The role of soil type and degree of leaching on the effectivity of atrazine: Gewasproduksie, v. 4, p. 83-86. Afrikaans.

Leaching. CA84(25):174991y. 


\section{ENVIRONMENTAL PROCESSES TRANSPORT PROCESSES \\ Leaching}

Nicholls, P. H., Walker, A., and Baker, R. J., 1982, Measurements and simulation of the movement and degradation of atrazine and metribuzin in a fallow soil: Pesticide Science, v. 13, no. 5 , p. $484-494$

English.

Sorption to Soil,Leaching,Biodegradation/Biotransformation. CA98(25):211430b.

Nkedi-Kizza, P., Rao, P. S. C., and Hornsby, A. G., Nov 1987, Influence of organic cosolvents on leaching of hydrophobic organic chemicals through soils: Environmental Science and Technology, v. 21, no. 11, p. 1107-1111.

English.

Associations with Surfactants, Leaching. CA107(20):182796x.

Omel'yanenko, A. Y., 1973, Khimicheskie i Ukhod za Lesom, p. 149154.

Russian.

Leaching.

CA86(23):166303b.

Patni, N. K, Grank, R, and Clegg, S., 1987, Pesticide persistence and movement under farm conditions: American Society of Agricultural Engineerings Microfiche Collection, fiche no. 87-2627, St. Joseph, Michigan.

English.

Field Residuals,Leaching.

IND 88039868.

Peter, C. J., and Weber, J. B., 1985, Adsorption, mobility, and efficacy of metribuzin as influenced by soil properties: Weed Science, v. 33, no. 6, p. 868-873.

English.

Sorption to Soil,Leaching.

CA104(1):2143p.

Petkova, D., 1981, Penetration of atrazine into the depth of soil profile: Pochvoznanie i Agrokhimiya, v. 16, no. 4, p. 66-69. Bulgarian.

Leaching.

CA96(23):195027b.

Pop, L., Gingioveanu, I., Matei, I., and Preda, A., 1968, The migration of atrazine in soil: Probleme Agricole, v. 20, no. 11, p. 49-56.

Romanian.

Leaching.

CA71(1):23996.

Popovich, N. A., Babicheve, A. F., and Samosvat, L. S., 1982, Migration of pesticides in irrigated soils: Gigiena i

Sanitariya, no. 11, p. 80-81.

Russian.

Leaching. CA98(7):48649u.

Rao, P. S. C., Hornsby, A. G., and Jessup, R. E., 1985, Indices for ranking the potential for pesticide contamination of groundwater. Proceedings - Soil Crop Science Society of Florida, v. 44, p. 1-8.

English.

Groundwater Observations,Leaching.

CA103(25):208883t.
Ritter, W. F., Johnson, H. P., and Lovely, W. G., Sept 1973, Diffusion of atrazine, propachlor, and diazinon in a silt loam soil: Weed Science, v. 21, no. 5, p. 381-384.

English.

Sorption to Soil,Leaching.

CA80(3):11193t.

Ritter, W. F., 1971. Environmental factors affecting the movement of atrazine, propachlor, and diazinon in Ida silt loam, Dissertation submitted in partial fulfillment of Ph.D. requirements, Iowa State University, Iowa.

English.

Leaching.

CA77(7):44143t.

Ritter, W. F., Johnson, H. P., Lovely, W. G., and Molnau, M., 1974, Atrazine, propachlor, and diazinon residues on small agricultural watersheds. Runoff losses, persistence, and movement: Environmental Science and Technology, v. 8, no. 1 , p. $38-42$.

English.

Field Residuals, Leaching, Run-off. CA80(15):79065h.

Rodgers, E. G., 1968, Leaching of seven s-triazines: Weed Science, v. 16, no. 2, p. 117-120.

English.

Leaching.

CA69(1):2082b.

Schiavon, M., 1988, Studies of the leaching of atrazine, of its chiorinated derivatives, and of hydroxyatrazine from soil using carbon-14 ring-labeled compounds under outdoor conditions: Ecotoxicology and Environmental Safety, v. 15, no. 1, p. 46-54.

English.

Leaching,Degradation Products,Sorption to Soil,

Biodegradation/Biotransformation.

CA108(23):200133f.

Scott, H. D., and Phillips, R. E., 1973, Movement of herbicides through soil to soybean roots: Agronomy Journal, v. 65, no. 3, p. 386-390.

English.

Leaching.

CA82(19):1199906.

Sharom, M. S., and Edgington, L. V., 1982, The adsorption, mobility, and persistence of metalaxyl in soil and aqueous systems: Canadian Journal of Plant Pathology, v. 4, no. 4, p. 334-340.

English.

Leaching.

CAS8(23):193257u.

Signori, L. H., Deuber, R., and Forster, R., 1978, Leaching of trifluralin, atrazine and bromacil in three different soils: Planta Daninha, v. 1, no. 1, p. 39-44.

Portuguese.

Leaching.

CA91(11):85241f. 
Smit, N. S. H., and Nel, P. C., 1977, The activity of atrazine on two South African soils: Gewasproduksie, v. 6, p. 67-71.

English.

Analytical Techniques/Quantification,Leaching,Sorption to

Soil.

CA88(7):46270h.

Smith, A. E., Grover, R, Emmond, G. S., and Korven, H. C., 1975, Persistence and movement of atrazine, bromacil, monuron, and simazine in intermittently-filled irrigation ditches:

Canadian Joumal of Plant Science, v. 55, no. 3, p. 809-816.

English.

Leaching, Run-off,Biodegradation/Biotransformation.

CA83(15):127459a.

Smith, C. N., Parrish, R. S., and Carsel, R. F., 1987, Estimating sample requirements for field evaluations of pesticide leaching. Environmental Toxicology and Chemistry, v. 6, no. 5, p. 343-357.

English.

Leaching,Analytical Techniques/Quantification.

CA106(25):209321g.

Snelling, K. W., 1968, Miscible displacement of atrazine through soil columns, Dissertation submitted in partial fulfillment. of Ph.D. requirements, Kansas State University, Manhattan, Kansas, USA.

English.

Leaching.

CA70(13):56536s.

Stancheva, P., 1977, Effect of atrazine on the mobility of some trace elements in the soil: Pochvoznanic i Agrokhimiya, v.

12 , no. 1 , p. $53-60$.

Bulgarian.

Leaching.

CA88(3):17206m.

Stefanovits, P., and Tomko, B., 1976, Movement of Hungazin PK in soil: Agrartudomanyi Egyetem Kozlemenyei,

Mezogazdasagtudomanyi Kar, p. 269-284.

Hungarian.

Leaching.

CA88(17):116345n.

Stepanova, Z A., 1965, Depth of penetration of simazine and atrazine in light chestnut soils: Sbornik Nauchno-

Issledovatel'skikh Rabot Aspirantovi Molodykh Uchenykh

Vsesoyuznogo Nauchno-Issledovatel'skogo Instituta

Agrolesomelioratsii, v. 49, p. 138-139.

Russian.

Leaching.

CA68(1):2175p.

Stevens, C., Jenkins, D. K. W., and Wilson, D. C., 1983, Testing procedure for eraluating codisposal of industrial wastes and municipal refuse with particular reference to pesticides:

American Society for Testing Material, Special Technical

Publication, v. 805, no. Hazardous and Industrial Solid Waste

Testing, p. 111-126.

English.

Leaching, Chemical/Physical Properties.

CA102(10):83864h
Swanson, R. A., 1972, Prediction of atrazine distribution and movement in soil systems, Dissertation submitted in partial fulfillment of Ph.D. requirements, University of Arizona, Arizona.

English.

Sorption to Soil,Leaching.

CA78(3):14810m

Tabagua, M. L., 1975, Penetration of herbicides along a profile of reclaimed soils of the Colchis Plain: Khimiya v Sel'skom Khozyaistve, v. 13, no. 1, p. 64-65.

Russian.

Leaching.

CA82(25):165748f.

Takematsu, T., Takeuchi, Y., and Ogasawara, M., 1982, Studies on the movements of herbicides in soil under turf: Shibakusa Kenkyu, v. 11, no. 2, p. 189-193.

Japanese.

Leaching

CA100(9):63385h

Trzecki, S., and Kowalski, E., 1974, Translocation of Gesatop and Gesaprim (simazine and atrazine) in relation to precipitation and type and compaction of soil: Zeszyty Naukowe Akademii Rolniczeji w Warszawie, Rolnictwo, v. 15, p. 93-101.

Polish.

Leaching

CA83(9):73445x

Tsimbalist, N. I., 1979, Behavior of some herbicides in soils during its fertilization and liming. Pochvovedenie, no. 3, p. 139-144.

Russian.

Analytical Techniques/Quantification,Leaching.

CA91(1):1226u.

Vavra, J., 1987, Assessment of pesticides for chemical protection of cereals and grasslands with respect to groundwater quality: Agrochemia (Bratislava), v. 27, no. 3, p. 82-84. Czechoslovakian.

Leaching, Groundwater Observations. CA106(23):191199m.

Vega, L. A., and Chauarria, P. L., July 1974, Mobility and persistence of atrazine and metribuzin in four soils from Puerto Rico: Journal of the Agricultural University of Puerto Rico, v. 58, no. 3, p. 379-380.

English.

Field Residuals,Leaching,Biodegradation/Biotransformation. CA81(25):164559n.

Wehtje, G., Mielke, L. N., Leavitt, R. C., and Schepers, J. S. Oct/Dec 1984, Leaching of atrazine in the root zone of an alluvial soil in Nebraska: Journal of Environmental Quality, v. 13, no. 4, p. $507-513$.

English.

Leaching

CA101(25):224700v. 


\section{ENVIRONMENTAL PROCESSES}

TRANSPORT PROCESSES

Leaching

Wehtje, G. R., Spalding, R. F., Burnside, O. C.. Lowry, S. R, and Leavitt, J. R. C., 1983, Biological significance and fate of atrazine under aquifer conditions: Weed Science, v. 31, no. 5 , p. $610-618$.

English.

Biodegradation/Biotransformation,Leaching,Groundwater Observations,Sorption to Soil.

CA9r(21):171005d.

Weidner, C. W., 1974, Degradation in ground water and mobility of herbicides: PB Rep., No. 239242/1GA, U.S. NTIS.

English.

Groundwater Observations, Leaching,Biodegradation/

Biotransformation.

CA83(11)92347h.

Wu, T. L., 1979, The distribution of atrazine in corn field soils at various elevations: Proceedings of the Northeastern Weed Science Society, v. 33, p. 121-130.

English.

Leaching,Run-off.

CA90(21):163218z.

Zemanek, J., Kovar, J., and Sterba, R, 1976, Biological methods of herbicide residue determination in water. Ochr Rostl, v. 12, no. 2, p. 99-107. Czechoslovakian.

Leaching,Analytical Techniques/Quantification. 
Bailey, G. W., Barnett, A. P., Payne, W. R., Jr., and Smith, C. N., 1974, Herbicide runoff from four coastal plain soil types: EPA-660/2-74-017, 98 p, U.S. Environmental Protection Agency, Research and Development.

English.

Sorption to Soil,Run-off.

CA84(19):131473p.

Bailey, G. W., Barnett, A. P., Payne, W. R., Jr., and Smith, C. N., 1974, Herbicide runoff from four coastal plain soil types: AD Rep., No. 235571/GA, 109 p, U.S.N.T.I.S.

English.

Run-off.

CA83(1):2223n.

Baker, J. L., Laflen, J. M., and Hartwig, R. O., 1982; Effects of corn residue and herbicide placement on herbicide runoff losses: Transactions of the American Society of Agricultural Engineers, v. 25, no. 2, p. 340-343.

English.

Run-off.

CA97(9):67800g.

Baker, J. L., and Laflen, J. M., 1979, Runoff losses of surfaceapplied herbicides as affected by wheel tracks and incorporation: Journal of Environmental Quality, v. 8, no. 4, p. $602-607$.

English.

Run-off.

CA92(1):1637z.

Baker, J. L., and Johnson, H. P., 1978, Movement of pesticides and nutrients with water and sediment as affected by tillage practices: a field study: W79-05050, OWRT-A-050-LA(1); Order No. PB-293145, 94 p.

English.

Run-off.

CA91(11):85261n.

Burton, T. M., 1978, The Felton-Herron Creek, Mill Creek pilot watershed study: EPA/905/9-78/002; Order No. PB-291609, 233 p.

English.

Run-off.

CA91(11):85250h.

Burwell, R. E., Schuman, G. E., Piest, R. F., Spomer, R. G., and McCalla, T. M., 1974, Quality of water discharged from two agricultural watersheds in southwestem Iowa: Water Resources Research, v. 10, no. 2, p. 359-365.

English.

Run-off.

CA81(4):16377.

Chevreuil, M., and Chesterikoff, A., 1979, Study on the transfer of pesticides on a basin under various circumstances and an attempt at a balance: C. R. Seances Academy, France, v. 65, no. 10, p. $835-845$.

French.

Leaching, Run-off.

CA95(3):19693m.
Coote, D. R., MacDonald, E. M., and DeHaan, R., 1979, Best Management Practices for Agriculture and Silviculture, Proceedings of the Cornell Agriculture Waste Management Conference, 10th, 1978, p. 79-82.

English.

Run-off.

CA90(24):192271s.

Correll, D. L., Pierce, J. W., and Wu, T. L., 1978, Studies of the transport of atrazine and alachlor from minimum till com fields into Chesapeake Bay tidal waters: Proceedings of the Northeastern Weed Science Society, v. 32, no. (Suppl.), p. 21-32.

English.

Run-off,Surfacewater Observations. CA89(17):141889w.

Djumija, L., and Horgas, D., 1977, Dynamic movement of residues of triazine herbicides in the vegetation period of some agricultural crops: Poljoprivreơna Znanstvena Smotra, v. 40, p. 143-153.

Croatian.

Run-off,Leaching.

CA88(11):70377u.

Donigian, A. S., Jr., and Carsel, R. F., 1987, Modeling the impact of conservation tillage practices on pesticide concentrations in ground and surface waters: Environmental Toxicology and Chemistry, v. 6, no. 4, p. 241-250.

Engtish.

Run-off.

CA106(25):209463e.

Douglass, J. E, Cochrane, D. R., Bailey, G. W., and Teasley, J. I., 1969, Low herbicide concentration found in streamflow after a grass cover is killed: US Forest Service Southeast. Forest Expt Station Paper No. SE-108, 4 p. English.

Run-off.

Dowell, F. E., Solie, J. B., and Pepper, T. F., 1985, No-till drill design for atrazine treated soils: Am. Soc. Agric. Eng. Microfiche Collect., fiche no. 85-1514, St. Joseph, Michigan. English.

Run-off.

IND 87007261.

Dreuger, J., and Brink, N., 1988, Losses of pesticides from arable land: Vaextskyddsrapporter, Jordbruk, v. 49, no. Ograes- Vaextskyddskonf., 1988, p. 50-61.

English.

Run-off.

CA109(8):61082u.

Evans, J. O., and Duseja, D. R., 1973, Herbicide contamination of surface runoff waters: NTIS, PB Rep., No. 222283/4, 106 p. English.

Run-off.

CA80(10):52093d. 


\section{ENVIRONMENTAL PROCESSES \\ TRANSPORT PROCESSES \\ Runoff}

Evans, J. O., and Duseja, D. R, 1973, Herbicide contamination of surface runoff waters: EPA-R2-73-266, 99 pp,., U.S.

Environmental Protecttion Agency, Office of Research and Development.

English.

Run-ơff.

CA84(19):131474.

Formey, D. R, 1980, Effects of Atrazine on Chesapeake Bay aquatic plants, Dissertation submitted in partial fulfillment of Ph.D. requirements.

English.

Run-off.

OWRT-A-067-ALA(1).

Foy, C. L., and Hiranpradit, H., January 1977 ; Herbicide movement with water and effects of contaminant levels on non-target organisms: Virginia Water Resources Research Center, Blacksburg, Completion Report, 89 p.

English.

Run-off.

OWRT-A-046-VA(1).

Frank, R., Braun, H. E., Holdrinet, M. V. H., Sirons, G. J., and Ripley, B. D., 1982, Agriculture and water quality in the Canadian Great Lakes Basin: V. Pesticide use in 11 agricultural watersheds and presence in stream water, 1975 1977: Joumal of Environmental Quality, v. 11, no. 3, p. 497 SOS.

English.

Run-off.

Frank, R, and Sirons, J., 1979, Atrazine: its use in corn production and its loss to stream waters in Southem Ontario, 1975-1977: Science of the Total Environment, v. 12, no. 3, p. 223-239.

English.

Run-off.

CA91(13):103621m.

Gaynor, J. D., and Volk, V. V., 1981, Runoff losses of atrazine and terbutryn from unlimed and limed soil: Environmental Science and Technology, v. 15, no. 4, p. 440-443. English.

Run-off.

CA94(19):151869g.

Ghadiri, H., 1983, Atrazine dissipation, stubble interception and retention in soils under various tillage systems, Dissertation submitted in partial fulfillment of Ph.D. requirements, University of Nebraska, Lincoln; NE, USA. English.

Run-off.

CA100(1):2119.

Glotfelty, D. E., Taylor, A. W., Isensee, A. r., Jersey, J., and Glenn, S., 1984, Atrazine and simazine movement to Wye River estuary: Journal of Environmental Quality, v. 13, no. 1, p. 115-121.

English.

Run-off,Surfacewater Observations.

CA100(11):80985w.
Green, R. E., Goswami, K. P., Mukhtar, M., and Young, H. Y., 1977 , Herbicides from cropped watersheds in stream and estuarine sediments in Hawaii: Journal of Environmental Quality, v. 6, no. 2, p. 145-154.

English.

Surfacewater Observations, Run-off,Sorption to Sediments. CA87(5):34335z

Haith, D. A., July-September 1980, A mathematical model for estimating pesticide losses in runoff: Journal of Environmental Quality, v. 9, no. 3, p. 428-433.

English.

Run-off.

Haith, D. A., 1985, Variability of pesticide loads to surface waters: Journal - Water Pollution Control Federation, v. 57, no. 11, p. 1062-1067.

English.

Run-off.

CA104(5):30419b.

Haith, D. A, 1987, Extreme event analysis of pesticide loads to surface waters: Journal - Water Pollution Control Federation, v. 59 , no. 5 , p. $284-288$.

English.

Run-off.

CA107(8):64425c.

Haith, D. A., 1986, Simulated regional variations in pesticide runoff: Joumal of Environmental Quality, v. 15, no. 1, p. 5 -

English.

Run-off.

CA104(13):104411s.

Hall, J. K., 1974, Erosional losses of s-triazine herbicides: Journal of Environmental Quality, v. 3, no. 2, p. 174-180. English.

Run-off.

CA81(11):59189.

Hall, J. K, Hartwig, N. L., and Hoffman, L. D., July/Sept 1983, Application mode and alternate cropping effects on atrazine losses from a hillside herbicide: Journal of Environmental Quality, v. 12, no. 3, p. 336-340.

English.

Run - off.

IND 83081377.

Hall, J. K. Pawlus, M., and Higgins, E. R, 1972, Losses of atraxine in runoff water and soil sediment: Journal of Environmental Quality, v. 1, no. 2, p. 172-176.

English.

Field Residuals, Run-off,Sorption to Soil. CA77(9):57533v.

Hall, J. K, and Pawtis, M., March-April 1973, Runoff and soil losses on Hagerstown silty clay loam: effect of herbicide treatment: Journal of Soil and Water Conservation, v. 28, no. 2, p. 73-76.

English.

Sorption to Soil,Run-off. 
Hall, J. K., 1977, Quantification of s-triazine losses in surface runoff: a summary: Proceedings of the Northeastern Weed Science Society, v. 31, p. 117-121.

English.

Run-off.

CA87(15):112904a.

Huckins, J. N., Petty, J. D., and England, D. C., 1986, Distribution and impact of trifluralin, atrazine, and fonofos residues in microcosms simulating a northern prairie wetland: Chemosphere, v. 15, no. 5, p. 563-588.

English.

Run-off.

CA105(25):220345t.

Kenimer, A. L., Mostaghimi, S., Young, R. W., Dillaha, T. A., and Shanholtz, V. O., 1986, Effects of residue cover on pesticide losses from conventional and no-tillage systems: Am Soc. Agric. Eng. Microfiche Collect., fiche no. 86-2541, St. Joseph, Michigan.

English.

Run-off.

IND 87069345.

Klaine, S. J., Hinman, M. L., Winkelmann, D. A., Sauser, K. R, Martin, J. R, and Moore, L. W., 1988, Characterization of agricultural nonpoint pollution: pesticide migration in a west Tennessee watershed: Environmental Toxicology and Chemistry, v. 7, no. 8, p. 609-614.

English.

Leaching, Run-off.

CA109(17):144505k.

Kreuger, J. K, and Brink, N., Pesticides: Food and

Environmental Implications, Proceedings of the International Symposium, 1987, p. 101-112.

English.

Run-off,Leaching,Field Residuals.

CA110(11):90597s.

Leonard, R. A., Langdale, G. W., and Fleming, W. G., 1979, Herbicide runoff from upland Piedmont watersheds - data and implications for modeling pesticide transport: Journal of Environmental Quality, v. 8, no. 2, p. 223-229.

English.

Run-off.

CA91(1):1292n.

Logan, T. J., 1981, Pesticide use in the Lake Erie basin and the impact of accelerated conservation tillage on pesticide use and runoff losses: Report, Order No. AD-A098 281, 39 p. English.

Run-off.

CA95(21):182257f.

Lorber, M. N., and Mulkey, L. A., 1982, An evaluation of trhee pesticide runoff loading models: Journal of Environmental Quality, v. 11, no. 3, p. 519-529.

English.

Run-off.

CA97(17):140268w.
McCall, E. C., Jr., Lane, D. D., and Parr, A. D., 1983, Transport modeling of an agricultural herbicide: a laboratory simulation: Report, CONTRIB-240, W84-00969; Order No. PB140623, 34 p.

English.

Leaching, Run-off. CA101(1):2307h.

McCall, E. C., Jr., and Lane, D. D., 1982, Transport modeling of an agricultural pesticide. Phase I: Contributions - Kansas Water Resources Research Institute, v. 229, p. 43 pp..

English.

Run-off.

CA100(1):2176u.

Moore, L. W., Matheny, H., Tyree, T., Sabatini, D., and Klaine, S. J., 1988, Agricultural runoff modeling in a small west Tennessee watershed: Journal of the Water Pollution Control Federation, v. 60, no. 2, p. 242-249.

English.

Run-off.

CA108(14):118529f.

Muir, D. C. G., Yoo, J. Y., and Baker, B. E., 1978, Residues of atrazine and $\mathrm{N}$-deethylated atrazine in water from five agricultural watersheds in Quebec: Archives of Environmental Contamination and Toxicology, \%. 7, no. 2, p. 221-235.

English.

Surfacewater Observations, Run-off.

CA89(7):54644u.

Nikolaeva, N. G., Shutkina, A. I., and Navrotskaya, A. V., 1983, Effect of weed control methods on the yield of grapes, quality of juice, and accumulation of herbicide residues in the soil: Khimiya v Sel'skom Khozyaistve, no. 3, p. 35-40. Russian.

Run-off.

CA98(25):211464r.

Pakhov, G. M., Petrov, R. V., Tsapko, V. V., and Vanyurikhina, L. N., 1976, The effect of the use of pesticides and fertilizers in the water protection zone with sources of artificial replenishment of underground water reserves: Gigiena i Sanitariya, v. 3, p. 101-102.

Russian.

Run-off.

Paschal, D., Bichnell, R, and Siebenmann, K., 1978, Determination of atrazine in runoff water by high performance liquid chromatography. Journal of Environmental Science and Health; Part B, v. B13, no. 2, p. 105-115.

English.

Run-off,Analytical Techniques/Quantification. CA89(7):54596e.

Ritter, W. F., Johnson, H. P., Lovely, W. G., and Molnau, M., 1974, Atrazine, propachlor, and diazinon residues on small agricultural watersheds. Runoff losses, persistence, and movement: Environmental Science and Technology, v. 8, no. 1, p. 38-42.

English.

Field Residuals,Leaching,Run-off.

CA80(15):79065h. 


\section{ENVIRONMENTAL PROCESSES \\ TRANSPORT PROCESSES \\ Runoff}

Rohde, W. A., Asmussen, L. E., Hauser, E. W., Hester, M. L., and Allison, H. D., 1981, Atrazine persistence in soil and transport in surface and subsurface runoff from plots in the coastal plain of the southern United States: Agro-Ecosystems, v. 7 , no. 3, p. 225-238.

English.

Run-off,Biodegradation/Biotransformation.

CA96(1):21198.

Sauer, T. J., and Daniel, T. C., Mar/Apr 1987, Effect of tillage system on runoff losses of surface-applied pesticides: Journal of the Soil Science Society of America, v. 51, no. 2, p. 410-415.

English.

Run-off.

IND 87025381.

Schnoor, J. L., Rao, N. B., Cartwright, K. J., and Noll, R. M., 1982, Fate and transport modeling for toxic substances: Modeling the fate of chemicals in the aquatic environment: Ann Arbor, Michigan, Ann Arbor Science, p. 145163.

English.

Run-off.

Smith, A. E., Grover, R, Emmond, G. S., and Korven, H. C., 1975, Persistence and movement of atrazine, bromacil, monuron, and simazine in intermittently-filled irrigation ditches:

Canadian Journal of Plant Science, v. 55, no. 3, p. 809-816.

English.

Leaching,Run-off,Biodegradation/Biotransformation.

CA83(15):127459a.

Sutton, W. F., Brown, A. E., and Truelove, B., 1984, Atrazineand diuron-resistant strains of Rhodopseudomonas sphaeroides: Weed Science, v. 32, no. 5, p. 664-669.

English.

Run-off,Toxicity.

CA101(21):187877k.

Takimoto, M., Funakawa, T., Shiba, R., and Tajima, M., 1982 , Studies of hydroxymethylation of ammeline, ammelide, melam, and melem by ultraviolet spectroscopy: Nippon Kagaku Kaishi, no. 4, p. $662-669$.

Japanese.

Photolysis, Run-off. CA97(9):72331j.

Teasdale, J. R, 1985, Avoidance of herbicide injury by placement between rows of polyethylene mulch: HortScience, v. 20 , no. 5, p. 871-872.

English.

Run-off,Volatilization.

CA103(23):191387j.

Triplett, G. B., Jr., Conner, B. J., and Edwards, W. M., 1978, Transport of atrazine and simazine in runoff from conventional and no-tillage corn: Journal of Environmental Quality, v. 7, no. 1, p. 77-84.

English.

Run-off.

CA88(17):116281p.
Visi, G. M., Orosz, F., and Csernatoni, L. M., 1986, Factors influencing the pollution of overground waters by pesticides in drainage areas under agricultural use: Novenyvedelem (Budapest), v. 22, no. 4, p. 172-175.

Hungarian.

Run-off

CA105(3):20505h.

Waldron, A. C., 1974, Pesticide movement from cropland into Lake Erie: U.S. NTIS, PB Rep., No. 235650/9GA, 103 p.

English.

Run-off.

CA82(16):102819j.

Wauchope, R. D., 1987, Tilted-bed simulation of erosion and chemical runoff from agricultural fields: II. Effects of formulation on atrazine runoff: Journal of Environmental Quality, v. 16, no. 3, p. 212-216.

English.

Run-off. CA107(11):91887m.

White, A. W., Barnett, A. P., Wright, B. G., and Holladay, J. H., 1967 , Atrazine losses from fallow land caused by runoff and erosion: Environmental Science and Technology, v. 1, no. 9, p. 740-744.

English.

Run-off.

CA67(19):89978d.

Wrage, L. J., 1987, Atrazine carryover. Field Facts Soils Insects Dis. Weeds Drops S.D. State Univ. Coop. Ext. Serv. Plant Sci. Dept., Brookings, S.D..

English.

Run-off.

IND 87071857 .

Wu, T. L., Correll, D. L., and Remenapp, H. E. H., 1983, Herbicide runoff from experimental watersheds: Journal of Environmental Quality, v. 12, no. 3, p. 330-336.

English.

Run-off.

CA99(13):100914p.

Wu, T. L., Mick, N. J., and Fox, B. M., 1977, Runoff studies of the agricultural herbicides alachlor and atrazine from the Rhode River watershed during the 1976 growing season: Report No. NSF/RA-770255, Edgewater, Maryland, Chesapeake Bay Center for Environmental Studies, Smithsonian Institute.

English.

Run-off.

EPA R804536-01.

Wu, T. L, 1979, The distribution of atrazine in com field soils at various elevations: Proceedings of the Northeastern Weed Science Society, v. 33, p. 121-130.

English.

Leaching, Run-off.

CA90(21):163218z. 
Albright, R, Johnson, N., Sanderson, T. W., Farb, R. M., Melton, R., Fisher, L., and Wells, G., 1974, Pesticide residues in the top soil of five west Alabama counties: Bulletin of Environmental Contamination and Toxicology, v. 12, no. 3, p. 378-384.

English.

Field Residuals.

CA82(5):27192u.

Amor, R. L., Kent, A., Ridge, P. E., and Binns, R. M., 1987, Persistence of atrazine in chemical fallows in the Victorian Wimmera and Mallee: Plant Protection Quarterly, v. 2, no. 1, p. $38-40$.

English.

Field Residuals.

CA107(3):19419t.

Anderson, J. R, Stephenson, G. R, and Corke, C. T., 1980, Atrazine and cyanazine activity in Ontario and Manitoba soils: Canadian Journal of Soil Science, v. 60 , no. 4 , p. 773-781.

English.

Biodegradation/Biotransformation,Field Residuals.

CA94(13):97922d.

Anderson, R. L, and Greb, B. W., 1987, Residual herbicides for weed control in proso millet (Panicum miliaceum L.): Crop

Protection, v. 6, no. 1, p. 61-63.

English.

Field Residuals.

CA106(21):170982w.

Anon., Mar 1977, Atrazine can lower com/soybean rotation odds: Soybean Digest, v. 37, no. 5, p. 27.

English.

Field Residuals.

CAIN 779036228.

Anon., 12 May. 1975, Atrazine; tolerances for residues: Federal Register, v. 40, no. 92, p. 20629.

English.

Field Residuals.

CA83(9):77119s.

Anon., 31 Aug 1987, Atrazine. Tolerances for residues: Federal Register, v. 32, p. 12605.

English.

Field Residuals.

CA67(21):98964y.

Anpalov, V. A., 1974, Persistence of soil herbicides in leached chernozems of the Central Chernozem Region: Khimiya $v$ Sel'skom Khozynaistve, v. 12, no. 9, p. 613-615.

Russian.

Field Residuals.

CA83(7):54441b.

Anpalov, V. A., Novikov, A. A., Buryi, V. S., Zadordonets, V. A., Drozdova, O. A., and Gzhegotskii, M. I., 1970, Herbicide residues in soil and strawberries: Khimiya v Sel'skom

Khozyaistve, v. 8, no. 10, p. 774-777.

Russian.

Field Residuals, Uptake by Biota.

CA74(21):110675j.
Arkharova, L. A., 1973, Residual toxicity of some herbicides in soil: Bylletin Vsesoyuznogo Nauchno - Issledovatel' skogo Instituta Zashchity Rastemii, v. 25, p. 13-18.

Russian.

Field Residuals.

CA83(3):23337t.

Balinov, I., and Balinova, A., 1983, Investigations on the residual pesticide content in soils of Bulgaria:

Rastenievudni Nauki, v. 20, no. 5, p. 11-16.

Bulgarian.

Field Residuals.

CA100(5):30911y.

Blanco, H. G., and Oliveira, D. D. Azevedo, 1987, Persistence of herbicides in yellow-red Latosol under sugarcane: Pesquisa Agropecuaria Brasileira, v. 22, no. 7, p. 681-687.

Portuguese.

Field Residuals.

CA110(7):5285\%.

Bourgain, F., Guckert, A., and Schiavon, M., 1977, Consequences of atrazine persistence after the crop rotation corn-wheat or corn-barley. Bulletin de l'Ecole Nationale Superieure d'Agronomic et des Industries Alimentaires, v. 19, no. 1-2, p. 81-89.

French.

Field Residuals.

CA88(17):116078c.

Brecke, B. J., Currey, W. L., and Teem, D. H., 1981, Atrazine persistence in a corn-soybean doublecropping system: Agronomy Journal, v. 73 , no. 3, p. 534-537.

English.

Field Residuals.

CA95(7):56361x.

Brinkman, M. A., Langer, D. K., Harvey, R. G., and Burger, W. C., Nov/Dec 1981, Effect of atrazine carryover on maiting quality of barley: Crop Science, v. 21, no. 6, p. 973-976.

English

Field Residuals.

IND 8201454i.

Briski, A., Cencelj, J., Hocevar, J., Macek, J., and Sisakovic, V., 1973, Ground contamination by herbicides: Agrohemija, no. 1-2, p. $37-43$.

Croatian.

Field Residuals.

CA79(7):39161j.

Burnside, O. C., Fenster, C. R, and Wicks, G. A., 1971, Soil persistence of repeated annual applications of atrazine: Weed Science, v. 19, no. 3, p. 290-293.

English.

Leaching, Field Residuals.

CA75(5):34333z.

Burnside, O. C., and Wicks, G. A., 1980, Atrazine carryover in soil in a reduced tillage crop production system: Weed

Science, v. 28, no. 6, p. 661-666.

English.

Field Residuals.

IND 81000507. 
Buryi, V. S., Popovich, N. A., Bidnenko, L. I., and Goshka, A. T., 1975, Mekhanizm Deistviya Gerbitsidov, (Doklady, Zachitannye na Simpoziume), 10th, p. 15-19.

Russian.

Field Residuals.

CA88(19):131909t.

Buryskova, L., 1987, Acceptable levels of herbicide residues in soil for winter wheat: Agrochemia (Bratislava), v. 27, no. 1, p. 18-22.

Czechoslovakian.

Field Residuals.

CA106(19):151523f.

Businelli, M., Patumi, M., Marucchini, C., and Tafuri, F., 1978, Atrazine and atrazine metabolite residues in soil and maize: Annali della Facolta di Agraria, University degli Studi di Perugia, v. 32, no. 2, p. 891-901.

Italian.

Degradation Products, Field Residuals,Volatilization. CA92(1):1573a.

Caramete, A., Pintilie, C., Schiopu, D., and Sandoiu, D., 1987, Effect of fertilizers and tilling on soil atrazine residues and maize harvest: Analele Institutului de Cercetari pentru Prot. Plant., Acad. Stiinte Agric. Silvice, v. 20, p. 249259.

Romanian.

Field Residuals.

CA107(21):192946k.

Caramete, A., Pintilie, C., Sandoiu, D. D., and Constantinescu, D., 1981, Studies on herbicide residues in soil and plants: Lucrari Stiintifice - Institutal Agronomic "Nicolae Balcescu", Bucuresti, Seria A.: Agronomie, v. 24, p. 69-74. Romanian. Field Residuals, Uptake by Biota. CA97(11):87022h.

Carey, A. E., Gowen, J. A., Tai, H., Mitchell, W. G., and Wiersma, G. B., 1978, Pesticide residue levels in soils and crops, 1971 - National Soils Monitoring Program (III): Pesticide Monitoring Journal, v. 12, no. 3, p. 117-136. English.

Field Residuals. CA90(17):133996j.

Carey, A. E., Gowen, J. A., Tai, H., Mitchell, W. G., and Wiersma, G. B., 1979, Pesticide residue levels in soils and crops from 37 states, 1972 - National Soils Monitoring Program (IV): Pesticide Monitoring Journal, v. 12, no. 4, p. 209-229.

English.

Field. Residuals.

CA91(5):34033g.

Catizone, P., Fusi, P., and Franci, M., 1983, Persistence of atrazine in soil: results of eleven years of experiments: Rivista di Agronomis, v. 17, no. 4, p. 449-457. Italian.

Field Residuals,Biodegradation/Biotransformation. CA101(11):86660s.
Caverly, D. J., 1987, Advisory problems with residual soil herbicides: Proceedings of the British Crop Protection Conference on Weeds, v. 2, p. 601-610.

English.

Field Residuals.

IND 87106111

Cesari, A., Flori, P., and Malucelli, G., 1975, Phytotoxicity effects determined for herbicide residues on rotation crops (principal contribution): Notizario Sulle Malattie delle Piante, v. 92-93, p. 191-208.

Italian.

Field Residuals. CA88(1):1234h.

Cesari, A., Rapparini, G., and Flori, P., 1976, Symposium on the Status, Biology and Control of Grassweeds in Eurupe, 1975, p. 267-277.

French.

Field Residuals.

CA87(25): $195530 \mathrm{z}$.

Chopra, S. L., Sethi, B. K, and Baweja, A. S., Sept 1973, Residues of atrazine in soils: Joumal of the Indian Society of Soil Science, v. 21, no. 3, p. 319-322.

English.

Field Residuals.

Conti, G. G., Quintodei, V., Aquilanti, A., and Sprocati, M. T. 1983, Evaluation of the behavior of residues of atrazine and its dealkylated metabolites. I. Determination of residues in the soil: Notizario Sulle Malattie delle Piante, v. 104, p. 147-168.

Italian.

Degradation.Products,Biodegradation/Biotransformation,Field Residuals,Analytical Techniques/Quantification. CA100(25):204976r.

Damanakis, M. E., and Daris, B. T., 1981, Residues of trizzine herbicides in a vineyard after a long-term application: Vitis, v. 20 , no. 4 , p. 329-334.

English.

Field Residuals.

CA97(3):18944y.

Dao, T. H., Lavy, T. L., and Sorensen, R. C., 1979, Atrazine degradation and residue distribution in soil: Journal of the Soil Science Society of America, v. 43, no. 6, p. 1129-1134. English.

Biodegradation/Biotransformation,Field Residuals. CA92(15):123418z.

Drogoszewski, B., 1979, The effect of triazine accumulation in the soil on the growth of Pinus silvestris seedlings and other tree species and on weeds: Proce Komisyi Nauk Rolniczych i Komixyi Nauk Lesnych, Poznanskie Towarzystwo Przyjaciol Nauk, v. 48, p. 11-19.

Polish.

Field Residuals.

CA92(1):1548w. 
Eagle, D. J., 1978, Interpretation of soil analyses for herbicide residues: Proceedings, British Crop Protection Conference on Weeds, v. 14, no. 2, p. 535-539.

English.

Field Residuals.

CA91(3):15101m.

Eagle, D. J., 1981, Symposium on the Theory and Practice of the Use of Soil Applied Herbicides: Proceedings, p. 201-207.

English.

Field Residuals.

CA97(23):194509u.

Eckert, R. E., Jr., 1974, Atrazine residue and seedling

establishment in furrows: Journal of Range Management, v. 27, no. 1, p. 55-56.

English.

Fieid Residuals.

CAIN 749016161.

Eckert, R. E., Jr., Klomp, G. J., Evans, R. A., and Young, J. A., 1972, Establishment of perennial wheatgrasses in relation to atrazine residue in the seedbed: Journal of Range Management, v. 25 , no. 3 , p. 219-224.

English.

Field Residuals.

CA77(13):84325k.

Fink, R. J., and Fletchall, O. H., 1969, Soybean injury from triazine residues in soil: Weed Science, v. 17, no. 1 , p. 35 36.

English.

Field Residuals.

CA70(13):56578g.

Frank, R, and Sirons, G. J., Apr 1985, Dissipation of atrazine residues from soils: Bulletin of Environmental Contamination and Toxicology, v. 34, no. 4, p. 541-548.

English.

Sorption to Soil,Leaching,Field Residuals,Biodegradation/

Biotransformation.

CA102(23):199566s.

Frolisek, M., Foltyn, J., and Matousek, M., 1986, Soil residues of triazine and triazinone herbicides following application in alfalfa: Agrochemia (Bratislava), v. 26, no. 7, p. 208-

211.

Czechoslovakian.

Field Residuals.

CA105(19):166792w.

Furrer, J. D., and Lavy, T., 1978, A quick test for atrazine carryover. Ext. Bull. Mich. State Univ. Coop. Ext. Serv., May 1978, E1215, 3 p.

English.

Field Residuals;Analytical Techniques/Quantification:

CAIN 789108103.

Fusi, P., and Franci, M., 1972, Chemical and biological study of atrazine residues in soil: Agrochimica, v. 16, no. 4-5, p. $377-386$.

Italian.

Biodegradation/Biotransformation,Field Residuals.

CA77(19):125309d.
Gaynor, J. D., Stone, J. A., and Vyn, T. J., Nov 1987, Tillage systems and atrazine and alachlor residues on a poorly drained soil: Canadian Journal of Soil Science, v. 67, no. 4, p. 959-963.

English.

Field Residuals.

CA108(11):89426n.

Ghinea, L., Radulescu, V., Vladutu, I., Fritea, T., and Turcu, M., 1985, Some aspects of residual effects of atrazine: Analele Institutului de Cercetari Cereale si Plante Tehnice Fundulea, Academia de Stiinte Agricole si Silvice, Seria B, v. 53, p. 415-434.

Romanian.

Sorption to Soil,Leaching,Field Residuals.

CA107(11):91798h.

Gill, H. S., Sandhu, K. S., Mehra, S. P., and Singh, T., 1988, Residual effect of simazine and atrazine applied to maize on succeeding field and vegetable crops: Journal of Research (Punjab Agricultural University), v. 25, no. 2, p. 175-180. English.

Field Residuais.

CA110(7):52884a.

Goguadze, V. D., 1973, Study of residual toxicity of some herbicides in the soil, green leaf and fruit of the mandarin orange: Subtropicheskie Kul'tury, v. 5, p. 139-141.

Russian.

Field Residuals.

Gruebner, P., 1983, Results pertaining to the occurrence of persistent herbicides in farm soils and their significance: Nachrichtenblatt fuer den Pflanzenshutzdienst in der DDR, v. 37 , no. 7, p. 145-149.

German.

Field Residuals.

CA99(25):208117v.

Gupta, O. P., and Dhupia, B. K., 1971, Efficacy of atrazine in maize planted on different dates as affected by its residual phytotoxicity under varying levels and methods of its application: Indian Journal of Agricultural Science, v. 41, no. 3, p. 221-227.

English.

Field Residuals.

CA77(1):1671w.

Hall, J. K., Pawlus, M., and Higgins, E. R, 1972, Losses of atrazine in runoff water and soil sediment: Journal of Environmental Quality, v. 1, no: 2, p. 172-176.

English.

Field Residuals,Run-off,Sorption to Soil. CA77(9):57533v.

Hance, R. J., 1986, Quantification of Natural Bicavailability Bound 14C-Pesticide Residues in Soil, Plants, and Food, Proceedings of Final Research Co-ordinatorsMeeting, 1985, p. 1-11.

English.

Field Residuals,Sorption to Soil,Analytical Techniques/

Quantification.

CA108(5):33523z. 


\section{ENVIRONMENTAL PROCESSES \\ TRANSFER PROCESSES \\ Field Residuals}

Harrison, G. W., Weber, J. B., and Baird, J. V., 1976, Herbicide phytotoxicity as affected by selected properties of North Carolina soils: Weed Science, v. 24, no. 1. p. 120-126.

English.

Field Residuals.

CA84(17):116852t.

Harvey, R. G., 1987, Herbicide dissipation from soils with different herbicide use histories: Weed Science, v. 35, no. 4, p. 583-589.

English.

Biodegradation/Biotransformation, Field Residuals. CA107(11):91811g.

Hocevar, J., and Cencelj, J., 1978, Residues of atrazine in soil and maize: Sodob-Kmetij, v. 11, no. 2; p. 58-62.

Slovenian.

Field Residuals.

CAIN 789151865 .

Horowitz, M., 1969, Evaluation of herbicide persistence in soil: Weed Research, v. 9, no. 4, p. 314-321.

English.

Biodegradation/Biotransformation,Field Residuals. CA72(15):77812k

Ilka, P., and Sukenikova, A., 1983, Quality of Zeazin 50 and atrazine residues in the soil: Agrochemia (Bratislava), v. 23 , no. 11, p. $335-337$.

Slovenian.

Field Residuals,Associations with Surfactants.

CA100(7):46949c.

Isom, W. H., Ford, H. P., Lavalleye, M. P., and Jordan, L. S., 1970, Proc., Annu. Calif. Weed Conf., p. 58-63.

English.

Field Residuals.

CA74(1):2933h.

Ivantsov, N. K, 1971, Aftereffect of herbicides applied under corn on the yield of the following crops (Barley and millet): Khimiya v Sel'Skom Khozyaistve, v. 9, no. 4, p. 262-265. Russian.

Field Residuals.

CA75(1):4357t.

Ivany, J. A., Sadler, J. M., Kimball, E. R, and McRae, K. B., Apr 1985, Atrazine persistence and residue effects on rotation crops: Canadian Journal of Plant Science Review, v. 65 , no. 2, p. 363-368.

English.

Field Residuals.

CA103(3):18383g.

Jones, T. W., Kemp, W. M., Stevenson, J. C., and Means, J. C., October-December, 1982, Degradation of atrazine in estuarine water/sediment systems and soils: Journal of Environmental Quality, v. 11, no. 4, p. 632-638.

English.

Biodegradation/Biotransformation,Associations with

Surfactants, Field Residuals,Sorption to Sediments,Sorption to Soil,Degradation Products.

CA97(25):210373c.
Kavoliunaite, I., 1973, Voprosy Epidemiologii i Gigieny v Litouskoi SSR Materialy Nauchnoi Koinferentsii po

Ozdorcvleniyu Vneshnei Sredy, p. 207-209.

Russian.

Uptake by Biota, Field Residuals.

CA83(9):73305b.

Khan, S. U., and Saidak, W. J., 1981, Residues of atrazine herbicide applied to maize and its metabolites after prolonged usage: Weed Research, v. 21, no. 1, p. 9-12. English.

Biodegradation/Biotransformation,Degradation Products, Field Residuals.

CA95(11):92225q

Khan, S. U., and Marriage, P. B., 19m, Residues of atrazine and its metabolites in an orchard soil and their uptake by oat plants: Journal of Agriculture and Food Chemistry, v. 25, no. 6, p. $1408-1413$.

English.

Field Residuals, Uptake by Biota,Biodegradation/

Biotransformation,Degradation Products.

CA87(23):178954y.

Khubutiza, R. A., and Gigineishvili, A. A., 1971, Determination of residual amounts of soil herbicides in the soil and Aurantiaceae: Khimiya v Sel'Skom Khozyaistve, v. 9, no. 12, p. $924-928$.

Russian.

Field Residuals.

CA76(19):109052p.

Kreuger, J. K, and Brink, N., Pesticides: Food and Environmental Implications, Proceedings of the International Symposium, 1987, p. 101-112.

English.

Run-off,Leaching,Field Residuals.

CA110(11):90597s.

Kuthan, A., 1977, Residues of atrazine in agricultural soils of Slovakia: Agrochemia, v. 17, no. 1, p. 20-22.

Slovenian.

Field Residuals.

CA86(19):134814c.

Labrada, R, and Garcia, F., 1976, Residual effect of atrazine applied to com on subsequent crops: Agrotecnica de Cuba, v. 8, no. 1, p. 33-36.

Spanish.

Field Residuals.

CA90.(15):116334z.

Ladonin, V. F., and Tsimbalist, N. I., 1975, Mekhanizm Deistviya Gerbitsidov i Sinteticheskikh Regulyatorov Rosta Rastenii i Ikh Sud'ba v Biosfere, Materialy Mezhdunarodnogo Simpoziuma, p. $100-103$.

Russian.

Field Residuals.

CA88(21):147342p. 
Lazowski, E. J., Hartwig, N. L., and Hall, J. K., 1986, Alfalfa and oat yields as influenced by triazine herbicide residues in three tillage systems: Proceedings of the Annual Meeting of the Northeastern Weed Science Society, v. 40, p. 10-15. English.

Field Residuals.

CA104(23):202224c.

Lebedeva, G. F., 1970, Effects of some factors on the duration of triazine toxic action in soils: Biologicheskie Nauki, no. 10, p. 93-96.

Russian.

Field Residuals.

CA74(7):30944f.

Leonard, O. A., McHenry, W. B., and Lider, L. A., 1975, Herbicide residues in soil of the vine row 21 months following 9 successive annual applications: Proceedings, Annual California Weed Conference, v. 26, p. 115-122.

English.

Field Residuals.

CA83(3):23375d.

Libershtein, I. I., Shutkina, A. T., Rogoshevskii, L. P., Strekachinskaya, L. S., and Pleshko, L. S., 1986, Maximum permissible levels of herbicides in soil: Zashchita Rastenii (Moscow), no. 9, p. 13-14.

Russian.

Field Residuals.

CA106(1):1745r.

Libik, A. W., and Romanowski, R. R., Nov 1976, Soil persistence of atrazine and cyanazine: Weed Science, v. 24, no. 6, p. 627-629.

English.

Field Residuals,Biodegradation/Biotransformation. CA86(19):134787w.

Lolas, P. C., and Galopoulos, A., 1984, Herbicide residuat activity in some tobacco soils: Zizaniologia, v. 1, no. 3, p. $177-185$.

Greek.

Field Residuals.

CA104(1):2124h.

Lowder, S. W., and Weber, J. B., May 1982, Atrazine efficacy and longevity as affected by tillage, liming, and fertilizer type: Weed Science, v. 30, no. 3, p. 273-280.

English.

Field Residuals,Biodegradation/Biotransformation. CA97(1):2192r.

Lysenko, A. K., 1971, Aftereffect of simazine and atrazine on the yield of agricultural crops under irrigation conditions: Khimiya v Sel'Skom Khozyaistve, v. 9, no. 3, p. 211-215. Russian.

Field Residuals.

CA75(3):19094d.

Lyubenov, Y., 1971, Residual amounts of some triazine herbicides in soil and their impact on the next crops in the crop rotation: Rastenievudni Nauki, v. 8, no. 4, p. 131-149. Bulgarian.

Field Residuals. CA76(5):21857u.
Maas, G., 1982, Pesticide dose rate reduction by combining with phospholipids of plant origin. Part 1: Nachrichtenblatt fuer den Pflanzenschutzdienst in der DDR, v. 34, no. 8, p. 113-114. German.

Field Residuals.

CA98(1):1606n.

Marriage, P. B., Saidak, W. J., and Von Stryk, F. G., 1976, Residues of atrazine, simazine, linuron and diuron after repeated annual applications in a peach orchard: Weed Research, v. 15, no. 6, p. 373-379.

English.

Field Residuals.

CA84(21):145936d.

Martynenko; A. I., 1984, Many years of simazine and atrazine application in an apple orchard: Sadovodstvo, Kiev, no. 32, p. 39-44.

Russian.

Field Residuals.

CA102(15):127271u.

Mitchell, B. J. F., May/June 1973, Atrazine residues can cause problems: Farm Food Research, v. 4, no. 3, p. 54-55.

English.

Field Residuals.

CAIN 739199552.

Muir, D. C. G., and Baker, B. E., 1978, The disappearance and movement of three triazine herbicides and several of their degradation products in soil under field conditions: Weed Research, v. 18, no. 2, p. 111-120.

English.

Degradation Products,Biodegradation/Biotransformation,Field Residuals,Leaching CA89(17):141769g.

Naish, R. W., and Forgie, C. D., 1976, Atrazine residues under commercial maize cropping conditions: Proceedings of the New Zealand Weed and Pest Control Conference, 29th, p. 120-123. English.

Field Residuals.

CAIN 779026282.

Pal'chik, L. M., Litvinenko, V. V., and Bestaka, R. P., 1980, Pesticide residues in the soil and plants of the northern Ukrainian steppe: Khimiya v Sel'skom Khozyaistve, v. 18, no. 10, p. 39-41.

Russian.

Field Residuals.

CA94(5):25914e.

Palaniappan, S., and Ramaswamy, R., Mar 1977, Residual effect of atrazine.applied to sorghum on the succeeding crops: Madras Agricultural Journal, v. 63, no. 3, p. 196-197.

English:

Field Residuals.

CAIN 779094611.

Pamplona, P. P., and Moody, K, 1984, Residual effects of weed control treatments applied to sorghum preceding mungbean: Philippine Journal of Agriculture, v. 67, no. 4, p. 427-432. English.

Field Residuals. CA103(3):18316n. 
Patni, N. K, Grank, R, and Clegg, S., 1987, Pesticide persistence and movement under farm conditions: American Society of Agricultural Engineerings Microfiche Collection, fiche no. 87-2627, St. Joseph, Michigan.

English.

Field Residuals, Leaching

IND 88039868 .

Patumi, M., Marucchini, C., Businelli, M., and Tafuri, F., 1981, Effect of repeated atrazine treatments on its persistence in soils used only for growing maize: Agrochimica, v. 25, no. 2, p. 162-167.

Italian.

Field Residuals.

CA96(13):99403a.

Perdue, E. M., 1983, Aquatic and Terrestrial Humic Materials, (Selected Papers from the Symposium), 1981, p. 441-460. English.

Hydrolysis/Chemical Reactions,Field Residuals,Associations with Humic Material.

CA98(15):124787e.

Pestemer, W., Ghinea, L, and Radulescu, V., 1984, Residual effects of chlorotriazine herbicides in soil at three

Romanian sites. II. Prediction of the possible subsequent cultivation with atrazine residues in soil: Weed Research, $v$. 24 , no. 5, p. 371-377.

German.

Field Residuals.

CA101(23):205695f.

Pestemer, W., Radulescu, V., Walker, A., and Ghinea, L, 1984, Residual effects of chlorotriazine herbicides in soil at three Romanian sites. I. Prediction of the persistence of simazine and atrazine: Weed Research, v. 24, no. 5, p. 359369.

German.

Field Residuals,Biodegradation/Biotransformation. CA101(23):205993b.

Pestemer, W., Stalder, L., and Eckert, B., 1980, Availability to plants of herbicide residues in soil. Part II: data for use in vegetable crop rotations: Weed Research, v. 20, no. 6, p. 349-353.

English.

Field Residuals.

CA95(3): $19287 \mathrm{~g}$

Rahman, A., and Brown, N. S., 1977, Atrazine residues in the Gisborne Plains and Waikato regions: Proceedings of the New Zealand Weed and Pest Control Conference, v. 30, p. 19-24. English.

Field Resicuals.

CA87(21):162778h.

Rahman: A., Gray, M. H., and James, T. K., July 1986, Persistence of repeated annual applications of atrazine - results after eight years: Proceedings of the New Zealand Weed and Pest Control Conference, v. 39 , p. 249-252.

English.

Field Residuals.

CA105(21):185794q.
Rahman, A., Manson, B. E., and Burney, B., 1976, Effect of phosphorus on phytotoxicity and residual activity of atrazine: Proceedings of the New Zealand Weed and Pest Control Conference, 29th, p. 124-128.

English.

Field Residuals.

Rahman, A., Manson, B. E., Burney, B., and Whitham, J. M., 1975, Residual activity of atrazine, alachlor and linuron under different soil and climatic conditions: Proceedings of the New Zealand and Weed Pest Control Conference, 28th, p. 104 108.

English.

Field Residuals.

CAIN 769004844.

Rao, A. N., 1982, Residual effect of a few herbicides on chlorophyll content and primary productivity of succeeding crops and associated weeds: Acta Agrobotanica, v. 35, no. 1, p. 133-143. English.

Field Residuals.

CA104(9):64103j.

Rauta, C., Grou, E., Cicotti, M., and Botha, V., 1983, Persistence of triazine herbicides in soil following the application of Pitezin in com under different soil and climate conditions: Analele Institutului de Cercetari pentru Pedologie si Agrochimie, Academia de Stiinte Agricole si Silvice, v. 45, p. 263-269.

Romanian.

Field Residuals.

CA103(11):83505n.

Reifenstein, H., Heinisch, E., and Crymia, W., 1972, Triazine residues in the soil under the conditions of practical farming. Archiv fuer Pflanzenschutz, v. 8, no. 1, p. 65-84. German.

Field Residuals. CA77(21):138789k.

Ritter, W. F., Johnson, H. P., Lovely, W. G., and Molnau, M. 1974, Atrazine, propachlor, and diazinon residues on small agricultural watersheds. Runoff losses, persistence, and movement: Environmental Science and Technology, v. 8, no. 1, p. $38-42$.

English.

Field Residuals,Leaching, Run-off. CA80(15):79065h.

Saghir, A. R., and Choudhary, A. H., 1967, Triazine herbicides on maize and their residual effects on following crops: Weed Research, v. 7, no. 4, p. 272-280.

English.

Field Residuals.

CA68(11):48532f.

Sarpe, N., Ionescu, F., and Popescu, A., 1981, Symposium on the Theory and Practice of the Use of Soil Applied Herbicides: Proceedings. English.

Field Residuals. IND 83066748. 
Sengalevich, G., Kuzmanov, N., and Kostadinova, P., 1979, A contribution to determination of standards for persistent herbicide residues in soil: Nauchni Trudove - Vissh Selskostopanski Institut "Vasil Kolarov," Plovdiv, v. 24, no. 3, p. $145-147$.

Bulgarian.

Field Residuals.

CA93(25):232141u.

Sharma, R. K, and Sandhu, K. S., 1985, Residual effect of simazine and atrazine applied to maize and potato on succeeding bread wheat crop: Journal of Research (Punjab Agricuitural University), v. 22, no. 2, p. 213-219.

English.

Field Residuals.

CA104(11):83716c.

Shushu, G. E., 1973, Residual effects of herbicides under irrigation conditions: Trudy Kishinevskii

Sel'skokhozyaistvennyi Institutimeni, v. 99, p. 77-84.

Russian.

Field Residuals.

CA81(13):73274z.

Siradze, S. K., 1969, Aftereffect of simazine and atrazine on the soil level of elements used for the mineral nutrition of plants: Trudy Instituta Zaschchity Rastenii, Tiflis, v. 21, p. $451-456$.

Georgian.

Field Residuals.

CA75(5):34350c.

Sirons, G. J., Frank, R, and Sawyer, T., November/December 1973, Residues of atrazine, cyanazine, and their phytotoxic metabolites in a clay loam soil: Journal of Agricultural and Food Chemistry, v. 21, no. 6, p. 1016-1020.

English.

Field Residuals,Degradation Products,Sorption to Soil, Biodegradation/Biotransformation,Hydrolysis/Chemical Reactions.

Smika, D. E., and Sharman, E. D., 1982, Atrazine carryover and its soil factor relationship to no-tillage and minimum tillage fallow-winter wheat cropping in...: Technical Bulletin, Colorado Agricultural Experimental Station, Fort Collins, CO, May 1982, (144), 4 p..

English.

Field Residuals.

IND 82108659.

Smit, N. S. H., and Nel, P. C., 1980, Proceedings of the Third National Weeds Conference, South Africa.

English.

Field Residuals.

IND 82122594.

Smit, N. S. H., and Nel, P. C., 1976, Residual activity and degradation of atrazine in different soil types: Gewasproduksie, v. 5, p. 91-93.

Afrikaans. Field Residuals,Biodegradation/Biotransformation. CA87(3):17178h.
Spynu, E. I., and Molozhanova, E. G., 1981, Factors determining soil pollution with pesticides: Gigiena i Sanitariya, no. 5 , p. 16-18.

Russian.

Field Residuals.

CA95(9): 75437 t.

Stanova, A., Kurocova, M., and Vittekova, J., 1987, Residues of triazine herbicides in soil after application of Zeazin Mix: Agrochemia (Bratislava), v. 27, no. 1, p. 15-17. Slovenian.

Field Residuals. CA106(21):170996d.

Swain, D. J., Jan 1975, The atrazine carry-over risk: Farmers Newsletter, v. 93, p. 19-20.

English.

Field Residuals.

CAIN 759058012.

Swanson, R. A., and Dutt, G. R., 1973, Chemical and physical processes that affect atrazine and distribution in soil systems: Soil Science Society of America, Proceedings, v. 37, no. 6 , p. $872-876$.

English.

Chemical/Physical Properties, Field Residuals.

CA80(17):91996v.

Thompson, L. J., Slife, F. W., and Butler, H. S., 1970, Environmental influence on the tolerance of corn to atrazine: Weed Science, v. 18 , no. 4 , p. 509-514.

English.

Field Residuals.

CA73(19):97720c.

Van Himme, M., Stryckers, J., and Bulcke, R, 1981, Theory and Practice of the Use of Soil Applied Herbicides, Symposium, p. 226-237.

French.

Field Residuals.

CA98(9):67030b.

Vazzana, C., Franci, M., and Vecchio, v., 1981, Symposium on the Theory and Practice of the Use of Soil Applied Herbicides: Proceedings.

English.

Field Residuals, Toxicity.

IND 83066729.

Vega, L. A., and Chauarria, P. L., July 1974, Mobility and persistence of atrazine and metribuzin in four soils from Puerto Rico: Journal of the Agricultural University of Puerto Rico, v. 58, no. 3 , p. $379-380$.

English.

Field Residuals,Leaching,Biodegradation/Biotransformation. CA81(25):164559n.

Voets, J. P., Meerschman, P., and Verstraete, W., 1974, Soil microbiclogical and biochemical effects of long-term atrazine applications: Soil Biology and Biochemistry, v. 6, no. 3, p. 149-152.

English.

Toxicity,Field Residuals.

CA81(19):115614t. 
ENVIRONMENTAL PROCESSES

TRANSFER PROCESSES

Field Residuals

Warfa, A. M., and Noor, M. A., 1978, The residual effect of gesaprim in various crops: Studi e Ricerche - Universita Nazionale Somala, Facolta di Agraria, v. 2, p. 125-129.

English.

Field Residuais.

CA91(19):152737n.

Wicks, G. A. Hergert, G.W., and Roeth, F. W., 1981, Ecofarming: management of atrazine carryover in Ecofallow: .

English.

Field Residuals.

ADU 82001017.

Wicks, G. A., and Smika, D. E., 1973, Chemical fallow in a winter wheat-fallow rotation: Weed Science, v. 21, no. 2, p. 97-102.

English.

Field Residuals.

CA78(23):144223h.

Wiersma, G. B., Tai, H., and Sand, P. F., 1972, Pesticide residue levels in soils, fiscal year 1969. National Soils Monitoring Program: Pesticide Monitoring Journal, v. 6, no. 3, p. 194 228.

English.

Field Residuals.

CA78(15):96498c.

Wiseman, J. S., and Lawson, H. M., 1971, Proceedings of the British Weed Control Conference, 10th, p. 768-7?4.

English.

Field Residuals.

CA75(7):47695u.

Wrucke, M. A., 1986, Atrazine and cyanazine interception and retention on crop residue, Dissertation submitted in partial fulfillment of Ph.D. requirements, South Dakota State

University, Brookings, SD, USA.

English.

Field Residuals.

CA106(21):171034a.

Wu, T. L., 1980, Dissipation of the herbicides atrazine and alachlor in a Maryland corn field soil profile: Joumal of Environmental Quality, v. 9, no. 3, p. 459-465.

English.

Biodegradation/Biotransformation,Field Residuals.

IND 80103963.

Yamada, T., Krasaesindhu, P., Maneechote, C., and Chaiyamart, K, 1987, Residues of atrazine in soils from comfield plots at Pak Chong in Thailand: Zasso Kenkyu, v. 32, no: 3, p. 217222.

English.

Field Residuals.

CA109(1):2408g.

Yeh, H. J., 1986, The effect of herbicide residues on sugareane: T'ai-wan Tang Yeh Yen Chiu So Yen Chiu Hui Pao, v. 114, p. 17-25.

English.

Field Residuals.

CA107(1):5907p.
Zemanek, J., Nov 1984, Plant regeneration - a sensitive criterion of the presence of triazine herbicide residues in soil: Sbornik UVTIZ, v. 20, no. 4.

Czechoslovakian.

Field Residuals.

IND 85042114.

Zimdahl, R. L., Gwynn, S. M., and Haufler, K. Z, 1979, The effect of soil residues of atrazine on sugarbeets (Beta vulgaris): Journal of the American Society of Sugar Beet Technology, v. 20, no. 3, p. 297-306.

English.

Field Residuals.

CA92(5):35867q.

Zimdahl, R. L., Martin, P. K, and Henson, M. A., Oct 1983, Minimum effective levels and interaction of three herbicides with atrazine residues: Journal of the American Society of Sugar Beet Technology, v. 22, no. 2, p. 146-154.

English.

Field Residuals.

IND 85030804. 
Elling, W., Huber, S. J., Bankstahl, B., and Hock, B., 1987, Atmospheric transport of atrazine: a simple device for its detection: Environmental Pollution, v. 48, no. 1, p. 77-82. English.

Atmospheric Observations.

CA108(3):17350k.

Glotfelty, D. E., Seiber, J. N., and Liljedahl, L. A., 1987, Pesticides in fog: Nature (London), v. 325, no. 6105, p. 602605.

English.

Atmospheric Observations. CA106(14):107713u.

MacLeod, K. E., and Lewis, R. G., 1982, Portable sampler for pesticides and semivolatile industrial organic chemicals in air: Analytical Chemistry, v. 54, no. 2, p. 310-315.

English.

Atmospheric Observations.

CA96(6):40050e.

Mel'nikova, L. V., and Belyakov, A. A., 1971, Determination of atrazine, cyanuric chloride, hydrogen cyanide, and aliphatic amines in the air. Gigiena i Sanitariya, v. 36, no. 9, p. 6769.

Russian.

Atmospheric Observations,Analytical Techniques/Quantification. CA75(22):132630p.

Overton, E. B., Mascarella, S. W., McFall, J. A., and Laseter, J. L., 1980, Organies in the water column and air-water interface samples of Mississippi. River water. Chemosphere, v. 9 , no. 10, p. 629-633.

English.

Atmospheric Observations.

CA94(16):127010z.

Pawlowskj, F., and Kapeluszny, J., 1969, Germination of seeds of some crop plants stored in an atmosphere polluted with herbicides: Annales Universitatis Mariae Curie-Sklodowska, Section E, v. 23, p. 151-160. Polish.

Atmospheric Observations. CA73(13):65252k.

Pilenkova, I. I., and Yurkova, R. G., 1981, Method for the selective determination of Atrazine, Prometryn and Simazine in the air during the production of Agelon and Sitrin: Gigiena Truda i Professional'nye Zabolevaniya, no. 7, p. 5152.

Russian.

Atmospheric Observations.

CA96(2):10957p.

Raszyk, J., Knotek, Z., Gajduskova, V., Masek, J., Docekalova, H., Willomitzer, J., Wiktora, J., Vodickova, M., Bartos, J., and et al., 1986, Physical, chemical and biological examination of dust deposition in large pig-fattening houses: Veterinary Medicine (Prague), v. 31, no. 4, p. 233-244. Czechoslovakian. Atmospheric Observations. CA105(4):29159f.
Reed, J. C., Chaturvedi, R. K, and Moore, B. L., 1978 , Incineration of hazardous air pollutants: Proceedings, Annual Meetings - Air Pollution Control Association, 71st., v. 5. English. Atmospheric Observations. CA92(18):152272c.

Richards, R. P., Kramer, J. W., Baker, D. B., and Krieger, K. A., 1987 , Pesticides in rainwater in the northeastern United States: Nature (London), v. 327, no. 6118, p. 129-131. English.

Atmospheric Observations. CA107(3):19506u.

Romanowski, R. R, Dec 1980, Simulated drift studies with herbicides on field-grown tomato alachlor, atrazine, linuron, cyanazine, glyphosate: Hortscience, v. 15, no. 6, p. 793-794. English.

Atmospheric Observations. IND 81019620.

Schairer, L. A., 1983, Mutagenicity of ambient air at selected sites in the United States using Tradescantia as a monitor: NATO Conference Series, v. 1, no. 5A, p. 167-90.

English.

Atmospheric Observations.

CA98(18): $148826 t$.

Schairer, L. A., Sutkulis, R. C., and Tempel, N. R, 1982, Monitoring ambient air for mutagenicity using the higher plant Tradescantia: Environmental Science and Research, v. 25(Genotoxic Eff. Airborne Agents), p. 123-140.

English.

Atmospheric Observations.

CA97(5):34541v.

Shmidel, E. B., Kalabina, L. I., and Kolomiets, L. N., 1980, Highly sensitive method for monitoring the level of toxic substances in the air of industrial zones: Neftyanoe Khozyaistvo, no. 1, p. 53-57.

Russian.

Atmospheric Observations,Analytical Techniques/Quantification. CA92(22):184965x.

Trofimova, S. I., 1969, Determination of some triazine group herbicides in the air. Gigiena Primeneniya, Toksikologiya Pestitsidov i Klinika Otravlenii, v. 7, p. 636-640. Russian.

Atmospheric Observations,Analytical Techniques/Quantification. CA76(21):122728h.

Trofimova, S. I., 1969, Novoe v Oblasti Promyshlenno - Sanitarnoi Khimii, p. 80-83.

Russian.

Atmospheric Observations,Analytical Techniques/Quantification. CA72(4):15540m.

Wu, T. L., 1981, Atrazine residues in estuarine water and the aerial deposition of atrazine into Rhode River, Maryland: Water, Air, and Soil Pollution, v. 15, no. 2, p. 173-184. English.

Surfacewater Observations,Atmospheric Observations. 
De Mattia, M., 1987, Potability of water: the role of reverse osmosis: AES, v. 9, no. 5, p. 18-21.

Italian.

Observations in Drinking Water.

CA107(20):183199s.

Fielding, M., Gibson, T. M., James, H. A., McLoughlin, K., and Steel, C. P., 1981, Organic micropollutants in drinking water. , Medmenham, England, Water Research Center. English.

Observations in Drinking Water.

CA95(20):175226s.

Galassi, S., Gussella, L., and Sora, S., 1989, Mutagenic potential of drinking waters from surface supplies in northern Italy: Environmental Toxicology and Chemistry, v: 8, no. 2, p. 109-116.

English.

Toxicity, Observations in Drinking Water.

CA110(14):120804b.

Johnen, B. G., and Iwan, J., 1988, Results and implications from monitoring German raw water for residues of a wide range of pesticides: Brighton Crop Protection Conference, no. 1, p. 319-328.

English.

Analytical Techniques/Quantification, Observations in drinking water.

CA110(13):110103h.

Keith, L. H., Garrison, A. W., Allen, F. R., Carter, M. H., Floyd, T. L., Pope, J. D., and Thruston, A. D., Jr., 1976, Identification and Analysis of Organic Pollutants in Water, (Chemical Congress of North America), 1st, 1975, p. 329-373. English.

Observations in Drinking Water.

CA86(14):95747m.

Kleopfer, R D., 1976, Identification and Analysis of Organic Pollutants in Water, (Chemical Congress of North America), 1st, 1975 , p. $399-416$.

English.

Observations in Drinking Water.

CA86(14):95748n.

Mallevialle, J., Bruchet, A., and Schmitt, E., 1984, Nitrogenous organic compounds: identification and significance in several French water treatment plants: Proceedings - American Water Works Association, Water Quality Technology Conference, 11th, v. 11, p. 83-96.

English.

Hydrolysis/Chemical Reactions, Observations in Drinking Water. CA102(14):119308w.

McCarthy, E. M., June 1976, National survey of pesticides in drinking water: PB-259 659, Washington, D.C., Environmentad Protection Agency.

English.

Observations in Drinking Water.

Richard, Y., and Brener, L., 1984, Removal of pesticides from drinking water with ozone: (s1Sin(s0S Handbook of ozone technology and applications: Boston, Massachusetts, Ann Arbor Science, p. 77-97.

English.

Observations in Drinking Water,Hydrolysis/Chemical Reactions.
Rizet, M., Blanc, J., Cognet, M., Derons, M., Dorizon, N., and Filippi, G., 1984, Quality of water in distribution systems and its biological and chemical evolution: Journal Francais d'Hydrologie, v. 15, no. 3, p. 207-221.

French.

Observations in Drinking Water.

CA103(16):128643z.

Wehtje, G. R, 1982, Atrazine contamination of water supplies from agricultural use in Nebraska, Dissertation submitted in partial fulfillment of $\mathrm{Ph} . \mathrm{D}$. requirements, University of Nebraska, Lincon, NE, USA.

English.

Observations in Drinking Water.

CA97(21):176926y.

Winter, H., and Lidner, K, 1987, Drinking water supply from the Rhine River after the Sandoz accident: GWF, Gas- Wasserfach: Wasser/Abwasser, v. 128, no. 10, p. 525-532.

German.

Observations in Drinking Water.

CA108(6):43602p.

Wnuk, M., Kelley, R, Breuer, G., and Johnson, L., 1987, Pesticides in water supplies using surface water sources: . English. Observations in Drinking Water. CA109(16):134715q.

World Health Organization, and Registration Office Europe, 1987, Drinking-water quality: guidelines for selected herbicides: Report, EH-27; Order No. PB88-204136, 32 p. English. Observations in Drinking Water. CA110(10):82105q 


\section{ENVIRONMENTAL OBSERVATIONS GROUND WATER OBSERVATIONS}

Adams, R. S. Jr., Crow, S., and Alexander, E. C. Jr., 1985, The presence of "apparent" atrazine in groundwater of southeast Minnesota: Miscellaneous Publications of the University of Minnesota Agricultural Experimental Station, p. 160-162.

English.

Groundwater Observations.

IND 85025483.

Berri, A., Allievi, C., and Burzi, F., 1983, Atrazine and molinate residues in underground water of areas subjected to herbicide treatment: Acqua Aria, no. 3, p. 259-264.

Italian.

Groundwater Observations.

CA99(20):163674f.

Davoli, E., Benfenati, E., Bagnati, R, and Fanelli, R., 1987, Analysis of atrazine in underground waters at part per trillion levels as an early warning method for contamination and for soil distribution studies: Chemosphere, v. 16, no. 7, p. $1425-1430$.

English.

Groundwater Observations,Analytical Techniques/

Quantification.

CA107(13):110987n.

Exner, M. E., and Spalding, R. F., 1985, Groundwater contamination and well construction in southeast Nebraska: Ground Water, v. 23, no. 1, p. 26-34.

English.

Groundwater Observations.

CA102(16):137384x.

Frank, R., Clego, B. S., Ripley, B. D., and Braun, H. E., 1987, Investigations of pesticide contaminations in rural wells, 1979-1984, Ontario, Canada: Archives of Environmental Contamination and Toxicology, v. 16, no. 1, p. 9-22.

English.

Groundwater Observations.

CA106(12):89784m.

Frank, R, Ripley, B. D., Braun, H. E., Clegz B. S., Johnston, R, and O'Neill, T. J., 1987, Survey of farm wells for pesticides residues, southem Ontario, Canada, 1981-1982, 1984: Archives of Environmental Contamination and Toxicology, v. 16 , no. 1 , p. $1-8$.

English.

Groundwater Observations.

CA106(13):98076j.

Frank, R., Sirons, G. J., and Ripley, B. D., 1979, Herbicide contamination and decontamination of well waters in Ontario, Canada, 1969-1978: Pesticide Monitoring Journal, v. 13, no. 3, p. 120-127.

English.

Groundwater Observations.

CA92(17):141784v.

Helling, C. S., and Gish, T. J., 1986, Soil characteristics affecting pesticide movement into ground water: American Chemical Society Symposium Series, no. 315, p. 14-38. English.

Leaching,Sorption to Soil,Groundwater Observations. CA105(15):129452q.
Hrlec, G., 1987, Groundwater pollution by herbicides used on railroad tracks: Tehnika (Belgrade), v. 42, no. 11, p. TO9TO11.

Serbo-Croatian.

Groundwater Observations.

CA108(17):145398u.

Hurle, K., Giessl, H., and Kirchhoff, J., 1987, Occurrence of some selected pesticides in groundwater. Schriftenreihe des Vereins fuer Wasser, Boden und Lufthygiene, v. 68, no. Grundwasserbeeinflussung Pflanzenschutzm., p. 169-190. German.

Groundwater Observations. CA107(13):111091c

Isensee, A. R., Helling, C: S., Gish, T. J., Kearney, P. C., Coffman, C. B., and Zhuang, W., 1988, Groundwater residues of atrazine, alachlor, and cyanazine under no-tillage practices: Chemosphere, v. 17 , no. 1, p. 165-174.

English.

Groundwater Observations,Leaching CA108(13):108088x

Iwan, J., 1988, Pesticides in ground and drinking water. Results of a monitoring program conducted in the Federal Republic of Germany: Gesunde Pflanzen, v. 40, no. 5, p. 208-213.

Germany.

Groundwater Observations.

CA109(18):155674r.

Junk, G. A., Spalding, R. F., and Richard, J. J., July/Sept 1980, Areal, vertical, and temporal differences in ground water chemistry. II. Organic constituents: Joumal of Environmental Quality, v. 9, no. 3, p. 479-483.

English.

Groundwater Observations.

CA95(8):67660v.

Jury, W. A., Focht, D. D., and Farmer, W. J., 1987, Evaluation of pesticide groundwater pollution potential from standard indexes of soil-chemical adsorption and biodegradation: Journal of Environmental Quality, v. 16, no. 4, p. 422-428. English. Groundwater Observations,Biodegradation/Biotransformation, Sorption to Soil. CA108(3):17760u.

Kim, N. K, Grey, A. J., Tramontano, R., Hudson, C., and Laccetti, G., 1986, Two ground water contamination problems. Case studies: American Chemical Society Symposium Series, no. 315 , p. $530-540$.

English.

Groundwater Observations.

CA105(12):102210x.

Krill, R. M., and Sonzogni, W. C., 1986, Chemical monitoring of Wisconsin's groundwater. Joumal - American Water Works Association, v. 78, no. 9, p. 70-75.

English.

Groundwater Observations.

CA105(20):178027p. 
Loch, J. P., and Hoekstra, R, 1987, Traces of agrochemicals in ground water concept and first results of studies in highpermeability soil in the Netherlands: Schriftenreihe ders Vereins fuer Wasser, Boden Lufthygiene, v. 68, no. Grundwasserbeeinflussung Pflanzenschutzm., p. 247-264. German. Groundwater Observations. CA107(9):72845e.

Marti, L. R, De Kanel, J., and Dougherty, R. C., 1984, Screening for organic contamination of groundwater. ethylene dibromide in Georgia irrigation wells: Environmental Science and Technology, v. 18, no. 12, p. $973-974$.

English. Groundwater Observations. CA101(24):216087k.

Montgomery, H. A. C., Beard, M. J., and Baxter, K. M., 1984, Effects of the recharge of sewage effluents upon the quality of Chalk groundwater. Water Pollution Control (Maidstone England), v. 83, no. 3, p. 349-366.

English.

Groundwater Observations, Wastewater Observations. CA102(4):31641p.

Nellor, M. H., Baird, R. B., and Garrison, W. E., 1981, Health effects of water reuse by groundwater recharge: Proceedings of the Water Reuse Symposium, no. 3, p. 2138-2166. English.

Groundwater Observations. CA100(6):39238s.

Pal'usova, O., Sackmauerova, M., and Mahel'ova, E., 1972, Kongres "Chemia v Pol'nohospodarstve", (Prace), 2nd, p. 10 pp.. German.

Surfacewater Observations, Groundwater Observations. CA85(12):83054z.

Pionke, H. B., Glotfelty, D. E., Lucas, A. D., and Urban, J. B., 1988, Pesticide contamination of groundwaters in the Mahantango Creek watershed: Journal of Environmental Quality, v. 17 , no. 1 , p. $76-84$.

English.

Groundwater Observations.

CA108(13):108146q.

Rao, P. S. C., Hornsby, A. G., and Jessup, R. E., 1985, Indices for ranking the potential for pesticide contamination of groundwater. Proceedings - Soil Crop Science Society of Florida, v. 44, p. 1-8.

English.

Groundwater Observations, Leaching. CA103(25):208883t.

Rosival, L, and Uhnak, J., 1983, Pesticides in water. , v. 28, no. 6. p. 327-331.

Slovenian.

Surfacewater Observations, Groundwater Observations. CA99(21):171326j.

Schneider, A. D., Wiese, A. F., and Jones, O. R., 1977, Movement of three herbicides in a fine sand aquifer. Agronomy Journal, v. 69 , no. 3 , p. $432-436$.

English.

Sorption to Soil, Groundwater Observations.

CA87(17):128671h.
Schneider, A. D., Wiese, A. F., Jones, O. R, and Mathers, A. C., 1971, Fate of herbicides in the Ogallala aquifer. Texas Agricultural Experimnet Stataion, Bulletın, B1112, 15 p. English.

Groundwater Observations.

CA76(7):31160a.

Spalding, R. F., Exner, M. E., Sullivan, J. J., and Lyon, P. A., 1979 , Chemical seepage from a tail water recovery pit to adjacent ground water. Journal of Environmental Quality, $v$. 8, no. 3, p. 374-383.

English.

Groundwater Observations.

CA91(24):198458a.

Spalding, R. F., Junk, G. A., and Richard, J. J., Sept 1980, Pesticides in ground water beneath irrigated farmland in Nebraska: Pesticide Monitoring Journal, v. 14, no. 2, p. 70-73. English.

Groundwater Observations.

Steichen, J., Koelliker, J., Grosh, D., Heiman, A., Yearout, R, and Robbins, V., 1988, Contamination of farmstead wells by pesticides, volatile organics, and inorganic chemicals in Kansas: Ground Water Monitoring Review, v. 8, no. 3, p. 153 160.

English.

Groundwater Observations. CA109(14):115691n.

Stock, R., Friesel, P., and Milde, G., 1987, Groundwater contamination by pesticides in Schleswig-Holstein and Emsland: Schriftenreihe ders Vereins fuer Wasser, Boden Lufthygiene, v. 68, no. Grundwasserbeeinflussung Pflanzenschutzm., p. 209-223.

German.

Groundwater Observations. CA107(9):72844d.

Vavra, J., 1987, Assessment of pesticides for chemical protection of cereals and grasslands with respect to groundwater quality: Agrochemia (Bratislava), v. 27, no. 3, p. 82-84. Czechoslovakian. Leaching,Groundwater Observations. CA106(23):191199m.

Villani, G., 1987, Alternatives to atrazine: Inquinamento, v. 29, no. 11, p. 71-73.

Italian. Groundwater Observations. CA108(17):145272y.

Wehtje, G., Leavitt, J. R. C., Spalding, R. F., Mielke, L. N., and Schepers, J. S., 1981, Atrazine contamination of groundwater in the Platte Valley of Nebraska from nonpoint sources: Science of the Total Environment, v. 21, p. 47-51. English. Groundwater Observations. CA96(4):24540j. 


\section{ENVIRONMENTAL OBSERVATIONS}

GROUND WATER OBSERVATIONS

Wehtje, G. R, Spalding, R. F., Burnside, O. C., Lowry, S. R, and Leavitt, J. R. C., 1983, Biological significance and fate of atrazine under aquifer conditions: Weed Science, v. 31, no. 5, p. $610-618$.

English.

Biodegradation/Biotransformation,Leaching, Groundwater Observations,Sorption to Soil.

CA99(21):171005d.

Weidner, C. W., 1974, Degradation in ground water and mobility of herbicides: PB Rep., No. 239242/1GA, U.S. NTIS.

English.

Groundwater Observations,Leaching,Biodegradation/

Biotransformation.

CA83(11)92347h.

Werner, G., 1988, Plant treatment and pest control agents in groundwater and drinking water. Berichte aus

Wasserguetewirtschaft und Gesundheitsingenieurwesen

Technische Unversitaet Muenchen, v. 79, no. Schadst.

Grundwasser, p. 263-282.

German.

Groundwater Observations.

CA108(26):226528p.

Werner, G., 1987, Strategies for and results of monitoring of groundwater for agrochemical pollutants: Schriftenreihe ders Vereins fuer Wasser, Boden Lufthygiene, v. 68, no.

Grundwasserbeeinflussung Pflanzenschutzm., p. 149-67.

German.

Groundwater Observations.

CA107(14):120718q.

Wilson, M. P., Savage, E. P., Adrian, D. D., Aaronson, M. J., Keefe, T. J, Hamar, D. H., and Tessari, J. T., Nov 1987, Groundwater transport of the herbicide atrazine, Weld County, Colorado: Bulletin of Environmental Contamination and Toxicology, v. 39, no. 5, p. 807-814.

English.

Groundwater Observations.

IND 87082042.

Wilson, M. P., 1986, Groundwater contamination by the herbicide atrazine, Weld County, Colorado, Dissertation submitted in partial fulfillment of $\mathrm{Ph}$.D. requirements, Colorado State University, Fort Collins, CO, USA.

English.

Groundwater Observations.

CA107(10):83534d. 
Csematoni, M., Gyorfi, L., and Hargitai, E., 1988, Hazardous Waste: Detection, Control, and Treatment, Proceedings of World Conference, 1987, p. 861-868.

English.

Surfacewater Observations.

CA109(26):236501j.

D'Andrea, G., Desideri, N., and Manna, F., 1986, Pesticides in surface waters of the Pontine and Fondi plains. Study and determination using HPLC: Inquinamento, v. 28, no. 7-8, p. 44-46.

Italian.

Surfacewater Observations,Analytical Techniques/

Quantification.

CA105(15):129457v.

Donigian, A. S., Jr., and Carsel, R. F., 1987, Modeling the impact of conservation tillage practices on pesticide concentrations in ground and surface waters: Environmental Toxicology and Chemistry, v. 6, no. 4, p. 241-250.

English.

Leaching,Surfacewater Observations. CA106(25):209463e.

Evans, J. O., and Duseja, D. R., 1973, Herbicide contamination of surface runoff waters: EPA-R2-73-266, 99 pp,., U.S.

Environmental Protecttion Agency, Office of Research and Development.

English.

Run-off, Surface Water Observations.

CA84(19):131474.

Galassi, S., Vigano, L., and Battaglia, C., 1985, Toxic effects of trace organic pollutants in surface waters: Acqua Aria, no. 9, p. 821-826.

Italian.

Toxicity,Surface Water Observations.

CA104(15):124841k.

Haith, D. A., 1985, Variability of pesticide loads to surface waters: Joumal - Water Pollution Control Federation, v. 57, no. 11, p. 1062-1067.

English.

Run-off,Surface Water Observations. CA104(5):30419b.

Haith, D. A., 1987, Extreme event analysis of pesticide loads to surface waters: Joumal - Water Pollution Control Federation, v. 59, no. 5, p. 284-288.

English.

Run-off,Surface Water Obervations.

CA107(8):64425c.

Haith, D. A., 1987, Extreme event analysis of pesticide loads to surface waters: Joumal - Water Pollution Control Federation, v. 59, no. 5, p. 284-288.

English.

Surfacewater Observations.

CA107(8):64425c.

Hall, J. K., 1977, Quantification of s-triazine losses in surface runoff: a summary: Proceedings of the Northeastern Weed Science Society, v. 31, p. 117-121.

English.

Run-off,Surface Water Observations.

CA87(15):112904a.
Hassett, A. J., Viljoen, P. T., and Liebenberg, J. J. E., 1987, An assessment of chlorinated pesticides in the major surface water resources of the Orange Free State during the period September 1984 to September 1985: Water SA, v. 13, no. 3, p. 133-136.

English.

Surfacewater Observations.

CA107(18):161148x.

Klaassen, H. E, and Kadoum, A. M., 1979, Distribution and retention of atrazine and carbofuran in farm pond ecosystems: Archives of Environmental Contamination and Toxicology, v. 8, no. 3, p. 345-353.

English.

Surface Water Observations,Sorption to Sediments, Uptake by Biota. CA91(1):1346h.

Kramer, J. W., and Baker, D. B., 1985, An analytical method and quality control program for studies of currently used pesticides in surface waters: American Society of Testing Materials, Special Technical Publication, v. 867, no. Quality Assurance in Environmental Measurements, p. 116-132. English.

Analytical Techniques/Quantification,Surface Water Observations. CA103(23): 191328r.

Marcosi, S., and Cusa Engen, 1982, Establishment of maximum leveis of toxic substance mixtures in surface waters: Hidrotehnica, v. 27, no. 7, p. 206, 211.

Romanian.

Surfacewater Observations, Toxicity. CA98(19):156386q.

Miltner, R. J., Baker, D. B., Speth, T. F., and Fronk, C. A, 1989, Treatment of seasonal pesticides in surface waters: Journal - American Water Works Association, v. 81, no. 1, p. 43-52.

English.

Surfacewater Observations. CA110(14):12087\%

Pal'usova, O., Sackmauerova, M., and Mahel'ova, E, 1972, Kongres "Chemia v Pol'nohospodarstve", (Prace), 2nd, p. 10 pp.. German.

Surfacewater Observations, Groundwater Observations. CA85(12):83054z.

Schmidt, G., 1975, Probiems of testing the behavior of plant protectives in surface waters: Schriftenreihe ders Vereins fuer Wasser, Boden und Lufthygiene, Berlin-Dahlem, v. 46, p. 155-164.

German.

Biodegradation/Biotransformation,Surfacewater Observations. CA85(8):51566b.

Sontheimer, H., Weindel, W., Kuehn, W., and Brauch, H. J., 1986, Surface water quality and water use: Vom Wasser, v. 66, p. 120.

German.

Surfacewater Observations.

CA105(18):158427r. 
Tornes, L. H., 1981, Quality of surface water before implementation of a flood-control project in Chaska, Minnesota (USA): USGS/WRI-81-83, USGS/WRD/WRI/82-035.

English.

Surfacewater Observations.

CA97(24):202856x.

Wnuk, M., Kelley, R, Breuer, G., and Johnson, L., 1987, Pesticides in water supplies using surface water sources: English.

Observations in Drinking Water,Surface Water Observations. CA109(16):134715q. 
Acher, A, 1981, Rapid decomposition of uracil, urea, triazine and acetanilide herbicidal residues in industrial wastewaters into nonphytoxic products: IL Appl. 58495, 19 Sep 1979.

Portuguese.

Wastewater Observations.

CA95(14):120615n

Anon., E. P. Agency, 4 October 1985, Pesticide chemicals category effluent limitations guidelines, pretreatment standards, and new source performance standards: Federal Register, v. 50, no. 193 , p. $40672-4077$.

English.

Wastewater Observations.

CA104(18):155419h.

Arendt, G., Eggersdorfer, R., Faltin, M., Frische, R. H., Franz, Lichtwer, L., Rippen, G., and Steinsiek, E., 1983,

Determination of sources of selected substances and their retention in sewage sludge: Forschungsbericht -

Bundesminister Forschungs Technology, Technology Forschungs Entwicklung, BMFT-FB-T 83-281 $136 \mathrm{p}$.

German.

Analytical Techniques/Quantification,Wastewater Observations. CA101(22):197481r.

Baker, J. L., and Johnson, L. A., 1984, Water and pesticide volatilization from a waste disposal pit: Transactions of the American Society of Agricultural Engineers, v. 27, no. 3, p. 809-816.

English.

Volatilization, Wastewater Observations.

CA101(17):146104n.

Berkowitz, S., and Juelke, C. V., 1977, High pressure thermal hydrolysis to decompose triazines in acid waste streams: Appl. or Pr. 569019, 17 Apr 1975.

English.

Hydrolysis/Chemical Reactions, Wastewater Observations. CA87(2):11140t.

Burrows, E. P., Brueggemann, E. E., Hoke, S. H., MeNamee, E. H., and Baxter, L. J., 1984, Nitroguanidine wastewater pollution control technology: phase II. Wastewater characterization and analytical methods development for organics: Report, USAMBRDL-TR-8311.

English.

Degradation Products, Wastewater Observations,Analytical Techniques/Quantification.

CA102(2):12055j.

Cook, A. M., and Huetter, R., 1982, Decomposition of 2,4 dihydroxy-6-amino-s-triazine derivatives in wastewater. Appl. 81/810365, 4 Sep 1981; CH Appl. 80/6796, 10 Sep 1980. German.

Biodegradation/Biotransformation, Wastewater observations. CA96(24):204905r.

Has, T., 1979, Treatment of wastewater from chlorotriazine production: Appl. or Pr. 84723, 7 Feb 1976.

Romanian.

Wastewater Observations.

CA95(8):67540f.
Janicke, W., and Hilge, G., 1977, Evaluating the elimination of hazardous substances in water. Zeitschrift fuer Wasser und Abwasser Forschung, v. 10, no. 1, p. 4-9.

German.

Wastewater Observations.

CA87(6):43975k.

Jany, H., Mueller, R, Hellmig, R, Feistel, L., Matthias, Winkler, R, Boehm, R, and Schwachula, G., 1987, Treatment of wastewater containing pesticides: Appl. 290549, 26 May 1986, Ger. Dem. Rep..

German.

Wastewater Observations.

CA108(18):155973s.

Kabakehieva, E, 1981, Adsorption characteristics of Bulgarian activated carbon in relation to wastewater pollution from triazine herbicde synthesis: Khimiya i Industria (Sofia), no. 3, p. 129-131.

Bulgarian.

Wastewater Observations,Sorption to Resins.

CA95(20):174918g.

Kabakchieva, E., 1983, Chemical composition of wastewaters from herbazin and zeazin production: Trudy Vodosnabdyavane, Kanalizatsiya i Sanitama Tekhnika, v. 16, no. 2, p. 93-103. Bulgarian.

Wastewater Observations. CA101(2):11795t.

Kearney, P. C., Muldoon, M. T., Somich, C. J., Ruth, J. M., and Voaden, D. J., 1988, Biodegradation of ozonated atrazine as a wastewater disposal system: Journal of Agriculture and Food Chemistry, v. 36, no. 6, p. 1301-1306.

English.

Biodegradation/Biotransformation, Wastewater Observations, Hydrolysis/Chemical Reactions. CA109(22):196446m.

Kearney, P. C., Zeng, Q., and Ruth, J. M., 1984, A large scale UV-ozonation degradation unit. Field trials on soil pesticide waste disposal: American Chemical Society, Symposium Series, v. 259, no. Treatment and Disposal of Pesticide Wastes, p. 195-209.

English.

Hydrolysis/Chemical Reactions,Sorption to Soil,Wastewater observations.

CA101(25):224806j.

Krauth, K, 1988, Residues in sewage treatment plant discharges evaluation of previously unrestricted substances: Berichte der Abwassertechnischen Verenigung, v. 38, no. ATVLandesgruppen-Tag., 1987, p. 49-58.

German.

Wastewater Observations. CA109(12):98240v.

Ladonin, V. G., and Tsimbalist, N. I., Aug 1975, The dynamics of the content of atrazine in washing waters as related to the levels of the herbicides and of the mincral: Agrokhimia, $v$. 8, p. 111-115.

Russian.

Surfacewater Observations, Wastewater Observations. 


\section{ENVIRONMENTAL OBSERVATIONS WASTE WATER OBSERVATIONS AND TREATMENT}

Little, L. W., Zweidinger, R. A., Monig, E. C., and Fith, W. J., 1980, Treatment technology for pesticide manufacturing effluents: Atrazine, Maneb, MSMA, and Oryzalin: Report, EPA600/280-043; Order No. PB80-173941, 280 p.

English.

Wastewater Observations.

CA94(12):89549x.

Lopez-Avila, V., and Hites, R. A., 1980, Organic compounds in an industrial wastewater. Their transport into sediments:

Environmental Science and Technology, v. 14, no. 11, p. 1382-

1390.

English.

Wastewater Observations,Sorption to Sediments.

CA94(16):126959d.

Lykins, B. W., Jr., and Koffskey, W., 1986, Products identified at an alternative disinfection pilot plant: Environmental Health Perspective, v. 69, p. 119-127.

English.

Wastewater Observations.

CA106(10):72606g.

Miko, M., Dockal, P., and Vajdova, D., 1985, New biochemical method for the evaluation of biocide effectiveness of compounds using activated sludge: Biologia (Bratislava), v. 40 , no. 3, p. $277-287$.

Slovenian.

Wastewater Observations,Analytical Techniques/Quantification. CA102(25):216744t.

Miller, H., Cramer, P., Drinkwine, A., Shan, A., and Trischan, G., 1981, Development of methods for pestidices in wastewater. Applicability of a general approach: Advances in the identification and analysis of organic pollutants in water. Ann Arbor, Michigan, Ann Arbor Science, p. 115-138.

English.

Wastewater Observations.

Monnig, E, and Zweidinger, R. A., 1980, Treatability studies of pesticide manufacturing wastewaters: dinoseb and atrazine: Report, EPA/600/2-80-077C; Order No. PB81-178840, 50 p, Environmental Protection Agency.

English.

Wastewater Observations.

CA95(22):191783b.

Monning, E. C., Little, L. W., and Zweidinger, R., April 1981, Proceedings of the Confernece on Combined Municipal/ Industrial Wastewater Treatment, 25-27 March 1980, p. 259. 271.

English.

Wastewater Observations.

Montgomery, H. A. C., Beard, M. J., and Baxter, K. M., 1984, Effects of the recharge of sewage effluents upon the quality of Chalk groundwater. Water Pollution Control (Maidstone England), v. 83, no. 3, p. 349-366.

English.

Groundwater Observations, Wastewater Observations.

CA102(4):31641p.
Petrovskaya, Z. V., Boitsov, B. N., Brudnik, B. M., and Gazizov, R. T., 1985, Preparation of sewage waters from triazine production for underground disposal: Khimiya i Tekhnologiya Vody, v. 7, no. 1, p. 50-51.

Russian.

Hydrolysis/Chemical Reactions, Wastewater Observations. CA102(26):225478m.

Stojanovic, B. J., Kennedy, M. V., and Shuman, F. L., Jr., 1972 , Edaphic aspects of the disposal of unused pesticides, pesticide wastes, and pesticide containers: Journal of Environmental Quality, v. 1, no. 1, p. 54-62

English.

Biodegradation/Biotransformation, Wastewater Observations. CA76(13):69169y.

Sweeny, K. H., 1979, Reductive degradation treatment of industrial and municipal wastewaters: Proceedings of the Water Reuse Symposium, v. 2, p. 1487-1497.

English.

Wastewater Observations.

CA94(12):89562w.

Sweeny, K. H., 1981, The reductive treatment of industrial wastewaters. II. Process applications: AIChE Symposium Series, v. 77, no. 209 , p. $72-78$.

English.

Hydrolysis/Chemical Reactions, Wastewater Observations. CA96(8):57210e.

Sweeny, K. H., 1980, Treatment of a reducible hydrocarboncontaining aqueous stream: Appl. 780849, 24 March 1977. English. Hydrolysis/Chemical Reactions, Wastewater Observations. CA94(16):126851n.

Taran, P. N., Vakulenko, V. F., Grechko, A. V., Shevchenko, M. A., and Goncharuk, V. V., 1988, Simplified technology for removal of pesticides from wastewaters: Khimiya i Tekhnologiya Vody, v. 10 , no. 6 , p. 542-544.

Russian.

Sorption to Resins, Wastewater Observations, Photolysis. CA110(14):120579g

Van Rensburg, J. F. J., Hassett, A., Theron, S., and Wiechers, S. G., 1981, The removal of organic micropollutants by an integrated waste water treatment/water reclamation system: Water Science and Technology, v. 13, no. 1, p. 537-552. English.

Wastewater Observations. CA94(22):180152y.

Walther, H. J., 1985, On the elimination of organic microcontaminants by flocculation with lime hydrate: Acta Hydrochimica et Hydrobiologica, v. 13, no. 2, p. 223-228. English. Wastewater Observations,Sorption to Resins. CA103(2):11123p.

Winkler, R, Beitz, H., Jany, H., and Mueller, R., 1987, Decontamination of polluted wastewaters from agricultural operations: Appl. 292497, East Germany. German.

Biodegradation/Biotransformation, Wastewater Observation. CA108(24):209657n. 


\section{ENVIRONMENTAL OBSERVATIONS \\ WASTE WATER OBSERVATIONS AND TREATMENT}

Winkler, R, and Beitz, H., 1981, Disposal of wastewater containing biocides in the Agrochemical Center of Gross

Kreutz: Tagungsbericht - Akademie der

Landwirtschaftswissenschaften der Deutschen demokratischen Republik, v. 187, p. 129-135.

German.

Wastewater Observations.

CA97(4):28097p.

Winkler, R, Beitz, H., Jany, H., and Mueller, R, 1981, Inactivation of toxicants in wastewaters: Appl. or Pr. 215712, 21 Sept 1979.

\section{German.}

Wastewater Observations.

CA95(14): 120616p.

Winkler, $R$, and Mueller, $R$, 1979, Removal and deactivation of wastewater containing plant protectants from agrochemicial centers: Wasserwirtschaft-Wassertechnik, WWT, v. 29, no. 11, p. $369-371$

German.

Wastewater Observations.

CA92(24):202994n.

Winterlin, W. L., Schoen, S. R, and Mourer, C. R., 1984, Disposal of pesticide wastes in lined evaporation beds: American Chemical Society Symposium Series, v. 259, no. Treatment and Disposal of Pesticide Wastes, p. 97-116. English.

Volatilization, Wastewater Observations.

CA101(25):224804g.

Wolfe, N. L., Zepp, R. G., Baughman, G. L., Fincher, R. C., and Gordon, J. A., 1976, Chemical and photochemical transformation of selected pesticides in aquatic systems: U.S. NTIS, PB Rep., PB-258846, 153 p.

English.

Hydrolysis/Chemical Reactions, Photolysis, Wastewater Observations.

CA86(23):166378e. 
Aaronson, M. J., Kirby, K. W., and Tessari, J. D., 1980, Identification and confirmation of atrazine in pond water. Bulletin of Environmental Contamination and Toxicology, v. 25 , no. 3, p. $492-497$.

English.

Surfacewater Observations,Analytical Techniques/Quantification. CA93(23):216669t.

Agapov, V. I., and Tulupova, M. Y., 1980, Behavior of atrazine in the soil: Vestnik Moskovskogo Universiteta, Biologiya, Pochvovedenie, Series 17, v. 35, no. 4, p. 55-58.

Russian.

Leaching,Biodegradation/Biotransformation, Analytical

Techniques/Quantification,Sorption to Soil.

CA94(1):998x.

Ambrus, A., Hargitai, E., Karoly, G., Fulop, A., and Lantos, J., 1981, General method for determination of pesticide residues in samples of plant origin, soil, and water. II. Thin layer chromatographic determination: Journal of the Association of Official Analytical Chemists, v. 64, no. 3, p. 743-748.

English.

Analytical Techniques/Quantification.

CA95(5):36910x.

Apostolides, Z., Vermeulen, N. M. J., Potgieter, D. J. J., Smit, N. S. H., and Nel, P. C., 1981, Determination of atrazine in soils: Proceedings of the National Weeds Conference of South Africa, v. 4, p. 175-180.

English.

Analytical Techniques/Quantification,Sorption to Soil. CAY7(17):140117w.

Arendt, G., Eggersdorfer, R., Faltin, M., Frische, R. H., Franz, Lichtwer, L, Rippen, G, and Steinsiek, E., 1983, Determination of sources of selected substances and their retention in sewage sludge: Forschungsbericht -

Bundesminister Forschungs Technology, Technology Forschungs Entwicklung, BMFT-FB-T 83-281 136 p.

German.

Analytical Techniques/Quantification, Wastewater Observations. CA101(22):197481r.

Atkins, C. A., and Tchan, Y. T., 1967, Soil algae. VI. Bioassay of atrazine and the prediction of its toxicity in soils using an algal growth method: Plant Soil, v. 27, no. 3, p. 432-442. English.

Toxicity_Analytical Techniques/Quantification. C468(7):28687g.

Babaev, I. I., and Baratov, K. B., 1978, Universal method for determining herbicides of the triazine group: prometryn, atrazine, simazine, and kretazine: Lzvestija Akademii Nauk Tadzhilsskoi SSR, Otdelenie Biologicheskikh Nauk, no. 3, p. 94-97.

Russian.

Analytical Techniques/Quantification. CA90(23):181385f.

Bacaloglu, R, Csunderlik, C., and Ostrogovich, G., 1968, Quantitative determination of melamine, ammeline, ammelide, and cyanuric acid in the quaternary mixture. II: Fresenius' Zeitung fuer Analytische Chemie, v. 240, no. 4, p. 244-251. German.

Analytical Techniques/Quantification.

CA69(26):113380s.
Bache, C. A., and Lisk, D. J., 1068, Microwave-powered emission determination of residues of organic bromine, chlorine, iodine, phosphorus, and sulfur pesticides in a helium plasma: Biomedical Applications of Gas Chromatography, v. 2, p. 165178.

English.

Analytical Techniques/Quantification.

CA73(15):76019r.

Bache, C. A., and Lisk, D. J., 1968, Microwave emission residue analysis of carbamate and triazine pesticides: Journal of Gas Chromatography, v. 6, no. 5, p. 301-304.

English.

Analytical Techniques/Quantification.

CA69(1):2034n.

Bagnati, R, Benfenati, E., Davoli, E, and Fanelli, R, 1988, Screening of 21 pesticides in water by single extraction with C18 silica bonded phase columns: Chemosphere, v. 17 , no. 1 , p. 59-65.

English.

Analytical Techniques/Quantification. CA108(17):145284d.

Bailey, R., LeBel, G., and Lawrence, J. F., 1978, Gas-liquid chromatography of triazine herbicides as heptafluorobutyryl derivatives and some applications to analysis in fooos: Journal of Chromatography, v. 161, p. 251-257.

English.

Analytical Techniques/Quantification.

CA90(3):20909q.

Bakalivanov, D., 1969, Measurement of the atrazine herbicide by means of biotests with Aspergillus niger. Pochvoznanie i Agrokhimiya, v. 6, p. 111-115.

Bulgarian.

Analytical Techniques/Quantification.

CAIN 709085639.

Bakalivanov, D., 1969, Quantitative determination of the herbicide atrazine by means of biotests with Aspergillus niger. Pochwoznanie i Agrokhimiya, v. 4, no. 6, p. 111-115. Bulgarian.

Analytical Techniques/Quantification.

CA73(11):54808v.

Balinova, A., 1972, Use of some aromatic amines as developers during the thin-layer chromatography of triazine herbicides: Khimiya i Industriya (Sofia), v. 44, no. 9, p. 402-404. Bulgarian.

Analytical Techniques/Quantification. CA79(9):49690v.

Banelli, G., 1974, Gas chromatographic analysis of triazine residues with a bromide thermionic detector. Bollettino dei Laboratori Chimici Provinciali, v. 25, no. 1, p. 17-27. Italian. Analytical Techniques/Quantification. CA81(17):100497h. 
Baranov, Y. S., Khilik, L. A., and Klisenko, M. A., 1979, Determination of s-triazine rerbicides in essential oils and plants: Khimiya v Sel'skom Khozynaistve, v. 17, no. 6, p. 57 59.

Russian.

Uptake by Biota,Analytical Techniques/Quantification. CA91(11):84412a.

Barcarolo, R., Tealdo, E., and Tutta, C., 1988, Multiresidue determination of organochlorine and triazine pesticides in homogenized milk: Journal of High Resolution Chromatography and Chromatography Communications, v. 11, no. 7, p. 539-541. English.

Analytical Techniques/Quantification.

CA109(15):127403h.

Bardalaye, P. C., and Wheeler, W. B., 1986, Solid-phase extraction and capillary gas chromatographic determination of triazine herbicides in water. International Joumal of Environmental Analytical Chemistry, v. 25, no. 1-3, p. 105113.

English.

Analytical Techniques/Quantification.

Battista, M., Di Corcia, A., and Marchetti, M., 1988, Highperformance liquid chromatographic method for determining triazine herbicide residues in soil: Journal of

Chromatography, v. 454, p. 233-242.

English.

Analytical Techniques/Quantification.

CA110(1):2747n.

Bauer, N. J., Seidler, R. J., and Knittel, M. D., November 1981, A simple, rapid bioassay for detecting effects of pollutants on bacteria: Bulletin of Environmental Contamination and Toxicology, v. 27, no. 5, p. 577-582.

English.

Toxicity,Analytical Techniques/Quantification.

Beckier, G., 1979, Multimethod for simultaneous detection of 75 plant treatment preparations on plant material: Deutsche Lebensmittel-Rundsch, v. 75, no. 5, p. 148-152. German.

Analytical Techniques/Quantification. CA91(7):54679a.

Behki, R. M., and Khan, S. U., July/Aug 1986, Degradation of atrazine by Pseudomonas: N-dealkylation and dehalogenation of atrazine and its metabolites: Journal of Agriculture and Food Chemistry, v. 34, no. 4, p. 746-749.

English.

Analytical Techniques/Quantification,Biodegradation/

Biotransformation,Degradation Products.

CA105(5):37405y.

Beilstein, P., Cook, A. M., and Huetter, R., 1981, Determination of seventeen s-triazine herbicides and derivatives by highpressure liquid chromatography: Journal of Agriculture and Food Chemistry, v. 29, no. 6, p. 1132-1135.

English.

Analytical Techniques/Quantification.

CA95(19):163699k.
Bellar, T. A., and Budde, W. L., 1988, Determination of nonvolatile organic compounds in aqueous environmental samples using liquid chromatograpny/mass spectrometry. Analytical Chemistry, v. 60, no. 19, p. 2076-2083.

English.

Analytical Techniques/Quantification.

CA109(14):121799v.

Benada, J., and Vanova, M., Nov 1976, Determination of atrazine residues (in soil) by a bioassay method (using barley and oat leaf segments): Ochrana Rostlin, v. 12, no. 4, p. 307-314. English.

Analytical Techniques/Quantification.

CAIN789021764.

Benadikova, H., Stastny, M., and Volf, R., 1979, Determination of low concentration of atrazine and prometryn by differential pulse polarography: Sbomik Vysoke Skoly ChemickoTechnologicke v Praze, Analyticka Chemie, v. 14, p. 67-78. German.

Analytical Techniques/Quantification. CA94(16):127049u.

Binner, R, 1981, Liquid chromatographic determination of triazine herbicides and urea derivatives: Tagungsbericht Akademie der Landwirtschaftswissenschaften der Deutschen Demokratischen Republik, v. 187, p. 151-158.

German.

Analytical Techniques/Quantification. CA97(3):1892n.

Biros, F. J., 1971, Recent applications of mass spectrometry and combined gas chromatography-mass spectrometry to pesticide residue analysis: Residue Reviews, v. 40, p. 1-63. Engtish.

Analytical Techniques/Quantification.

Boland, P. A., Kingsley, B. A., Stivers, D. F., and Pomerantz, I. H., 1981, Advances in the Identification and Analysis of Organic Pollutants in Water, p. 831-838.

English.

Analytical Techniques/Quantification. CA102(14):119273f.

Bosshardt, H. P., Nowak, K, and Eberle, D. O., 1971, Collaborative CIPAC study of titrimetric methods for the assay of methylthio- and chlorotriazines: Journal of the Association of Official Analytical Chemists, v. 54, no. 4, p. 749-755.

English.

Analytical Techniques/Quantification.

CA75(7):47749q.

Bouchard, D. C., and Lavy, T. L., 1983, High-performance liquid chromatographic determination of hexazinone residues in soil and water. Journal of Chromatography, v. 270, p. 396-401. English.

Analytical Techniques/Quantification. CA100(3):19147h. 
Bouchard, D. C., 1987, Monitoring transport of selected pesticides and phenols in soil columns by high performance liquid chromatography: Journal of Environmental Science and Health, Part B, v. B22, no. 4, p. 391-402.

English.

Leaching,Analytical Techniques/Quantification. CA107(21):192856f.

Boulanger, P., and Rondia, D., 1986, Recovery of organic pollutants from surface waters: Tribune CEBEDEAU, v. 39, no. 517, p. 13-17.

French.

Analytical Techniques/Quantification.

CA107(6):45907v.

Bowman, M. C., Oller, W. L., Caims, T., Gosnell, A. B., and Oliver, K. H., 1981, Stressed bioassay systems for rapid screening of pesticide residues. Part I: Evaluation of bioassay systems: Archives of Environmental Contamination and Toxicology, v. 10, no. 1, p. 9-24.

English.

Analytical Techniques/Quantification.

CA94(21):172950s.

Bradway, D. E., Lores, E. M., and Edgerton, T. R, 1980, Minimizing occupational exposure to pesticides: recent developments in methodology for monitoring pesticide metabolites in human urine: Residue Reviews, v. 75, p. 51-65. English.

Degradation Products,Analytical Techniques/Quantification. CA94(26):213335r.

Bradway, D. E., and Moseman, R. F., 1982, Determination of urinary residue levels of the $\mathrm{N}$-dealkyl metabolites of triazine herbicides: Journal of Agriculture and Food Chemistry, v. 30, no. 2, p. 244-247.

English.

Degradation Products,Analytical Techniques/Quantification, Uptake by Biota,Biodegradation/Biotransformation. CA96(13):98864q.

Brattain, R. L., Fay, P. K, and Lockerman, R H., 1983, Comparison of bioassays for atrazine residue in soils: Agronomy Joumal, v. 75, no. 2, p. 192-194.

English.

Analytical Techniques/Quantification.

CA99(1):1714s.

Braumann, T., Weber, G., and Grimme, L. H., 1983, Quantitative structure-activity relationships for herbicides. Reversedphase liquid chromatographic retention parameter, $\log \mathrm{kw}$, versus liquid-liquid partition coefficient as a model of the hydrophobicity of phenylureas, s-triazine and phenoxycarbonic acid derivatives: Journal of Chromatography, v. 261, no. 3, p. 329-343.

English.

Chemical/Physical Properties,Analytical Techniques/

Quantification.

CA99(5):34410t.

Brodesser, J., and Schoeler, H. F., 1987, Determination of pesticides in water. Vom Wasser, v. 69, p. 61-71.

German.

Analytical Techniques/Quantification.

CA108(12):100917w.
Brodesser, J., and Schoeler, H. F., 1987, An improved extraction method for the quantitative analysis of pesticides in water: Zentralblatt fuer Bakteriologie, Mikrobiologie und Hygiene, v. 185 , no. $1-2$, p. $183-185$.

English.

Analytical Techniques/Quantification. CA108(8)62148m.

Bruchet, A., Cognet, L., and Mallevialle, J., 1984, Continuous composite sampling and analysis of pesticides in water. Water Research, v. 18, no. 11, p. 1401-1409.

French.

Analytical Techniques/Quantification. CA102(3):19450t.

Bruner, F., Crescentini, G., Mangani, F., Palma, P., and Xiang, M., 1987, Performance and use of wall-coated open tubular fused-silica columns with liquid-modified graphitized carbon black: Journal of Chromatography, v. 399, p. 87-97.

English.

Analytical Techniques/Quantification.

CA108(6):48463d.

Burrows, E. P., Brueggeman, E. E., and Hoke, S. H., 1984, Chromatographic trace analysis of guanidine, substituted guanidines and s-triazine in water. Joumal of Chromatography, v. 294, p. 494-498.

English.

Analytical Techniques/Quantification.

CA101(14):116455k.

Burrows, E. P., Brueggemann, E. E., Hoke, S. H., McNamee, E. H., and Baxter, L. J., 1984, Nitroguanidine wastewater pollution control technology: phase II. Wastewater characterization and analytical methods development for organics: Report, USAMBRDL-TR-8311.

English.

Degradation Products, Wastewater Observations,Analytical Techniques/Quantification. CA102(2):12055j.

Bushway, R J., Perkins, B., Savage, S. A., Lekousi, S. J., and Ferguson, B. S., 1988, Determination of atrazine residues in water and soil by enzyme immunoassay: Bulletin of Environmental Contamination and Toxicology, v. 40, no. 5, p. 647-654.

English.

Analytical Techniques/Quantification. CA109(1):2328f.

Byast, T. H., 1977, Reversed-phase high-performance liquid chromatography of some common herbicides: Journal of Chromatography, v. 134, no. 1, p. 216-218.

English.

Analytical Techniques/Quantification. CA87(3):17040g

Capriel, P., Haisch, A., and Khan, S. U., 1985, Distribution and nature of bound (nonextractable) residues of atrazine in a mineral soil nine years after the herbicide application: Journal of Agriculture and Food Chemistry, v. 33, no. 4, p. 567-569.

English.

Sorption to Soil,Degradation Products,Analytical Techniques/ Quantification CA103(5):33437w. 
Capriel, P., Haisch, A., and Khan, S. U., 1986, Supercritical methanol: an efficacious technique for the extraction of bound pesticide residues from soil and plant samples: journal of Agriculture and Food Chemistry, v. 34, no. 1, p. 70-73. English.

Analytical Techniques/Quantification. CA104(11):83634z.

Chesters, G., Pionke, H. G., and Daniel, T. C., 1974, Extraction and analytical techniques for pesticides in soil, sediment, and water. (s1Sin(sOS Pesticides in soil and water. Madison, Wisconsin, Soil Science Society of America, Inc., p. 451-549.

English.

Analytical Techniques/Quantification.

Chmil, V. D., 1987, Thin-layer chromatography of s-triazine derivatives: Zhumal Analiticheskoi Khimii, v. 42, no. 11, p. 2048-2053.

Russian.

Analytical Techniques/Quantification.

CA108(7):51128d.

Le Cloirec, C., Le Cloirec, P., Elmghari, M., Morvan, J., and Martin, G., 1983, Concentration and analysis of numerous nitrogenous organic substances in natural waters:

International Journal of Environmental Analytical Chemistry, v. 14 , no. 2 , p. $127-145$.

English.

Analytical Techniques/Quantification.

CA98(14):113396a.

Cochrane, W. P., and Greenhalgh, R., 1976, Evaluation and comparison of selective gas chromatographic detectors for the analysis of pesticide residues: Chromatographia, v. 9, no. 6, p. 255-265.

English.

Analytical Techniques/Quantification. CA85(9):57845p.

Cochrane, W. P., and Wilson, B. P., 1971, Electrolytic conductivity detection of some nitrogen-containing herbicides: Journal of Chromatography, v. 63, no. 2, p. 364 369.

English.

Analytical Techniques/Quantification.

CA76(21):122725e.

Cognet, L., Argoud, C. M., Francois, and Mallevialle, J., 1984, Apparatus for liquid-liquid extraction by mixing and decantation: Appl. 83/7253, 2 May 1983.

French.

Analytical Techniques/Quantification.

CA103(6):42344r.

Cohen, S. Z, Zweig, G., Law, M., Wright, D., and Bontoyan, W. $R, 1978$, Analytical determination of $N$-nitroso compounds in pesticides by the United States Environmental Protection Agency - a preliminary study: IARC Scientific Publications, v. 19, no. Environ. Aspects N-Nitroso Compd.), p. 333-342. English.

Analytical Techniques/Quantification.

CASO(1):1323c.
Colas, A., Royer, J., and Simon, R, 1975, Identification and determination of triazines in effluents. Comparison of thin layer and gas-liquid chromatography: Analysis, v. 3, no. 7, p. 355-362.

French.

Analytical Techniques/Quantification. CA84(22):155219m.

Conti, G. G., Quintodei, V., Aquilanti, A., and Sprocati, M. T., 1983, Evaluation of the behavior of residues of atrazine and its dealkylated metabolites. I. Determination of residues in the soil: Notizario Sulle Malattie delle Piante, v. 104, p. 147-168.

Italian.

Degradation Pmducts,Biodegradation/Biotransformation,Field Residuals,Analytical Techniques/Quantification. CA100(25):204976r.

Cook, A. M., Beilstein, P., and Huetter, R, 1983, Qualitative analysis of wastewater from ametryne production: International Joumal of Environmental Analytical Chemistry, v. 14, no. 2, p. 93-98.

English.

Degradation Products,Analytical Techniques/Quantification. CA98(26):221492n.

Cossarini-Dunier, M., and Hattenberger, A. M., 1988, Effect of pesticides (atrazine and lindane) on the replication of spring viremia of carp virus in vitro: Annales de Recherches Veterinaires, v. 19 , no. 3, p. 209-211.

English.

Analytical Techniques/Quantification. CA109(19):165405t.

Cotterill, E. G., 1979, Effect of ammonium nitrate on the gaschromatographic determination of some pesticide residues in soils: Analyst (London), v. 104, no. 1242, p. 878-880.

English.

Analytical Techniques/Quantification.

CA92(3):16964c.

Cotterill, E. G., 1980, The efficiency of methanol for the extraction of some herbicide residues from soil: Pesticide Science, v. 11, no. 1, p. 23-28.

English.

Analytical Techniques/Quantification. CA93(17):162514t.

Crathorne, B., Fielding, M., Steel, C. P., and Watts, C. D., 1984 , Organic compounds in water. analysis using coupledcolumn high-performance liquid chromatography and softionization mass spectrometry: Environmental Science and Technology, v. 18 , no. 10 , p. $797-802$.

English.

Analytical Techniques/Quantification. CA101(14):116459q.

Cserhati, T., and Bellay, T., 1988, Prediction of high performance liquid chromatographic behavior with thin-layer chromatography: Acta Phytopathologica Entomologica Hungaricac, v. 23, no. 1-2, p. 257-264.

English.

Analytical Techniques/Quantification. CA110(7):52826h. 
Cserhati, T., Bordas, B., Fenyvesi, E., and Szejtli, J., 1983, Chromatographic properties of s-triazine in the presence of soluble B-cyclodextrin polymer. Joumal of Inclusion Phenomena, v. 1, no. 1, p. 53-59.

English.

Sorption to Resins,Analytical Techniques/Quantification. CA100(7):46853s.

Cserhati, T., Danwish, Y. M., and Matolcsy, G., 1983, Effect of support characteristics on the determination of the lipophilicity of some neutral acidic and alkaline compounds by reversed-phase thin-layer chromatography: Journal of Chromatography, v. 270, p. 97-104.

English.

Analytical Techniques/Quantification,Sorption to Resins. CA100(22):180581e.

Cserhati, T., and Janos, E., 1981, Separation of symmetric triazines and their hydroxy derivatives by thin-layer chromatography: Novenyvedelem (Budapest), v. 17, no. 1, p. 23-28.

Hungarian.

Analytical Techniques/Quantification.

CA97(13):105490r.

D'Andrea, G., Desideri, N., and Manna, F., 1986, Pesticides in surface waters of the Pontine and Fondi plains. Study and determination using HPLC. Inquinamento, v. 28, no. 7-8, p. 44-46.

Italian.

Surfacewater Observations,Analytical Techniques/

Quantification.

CA105(15):129457v.

Dabrowksa, A., Gwiazda, M., and Kotarski, A., 1986, Quality of methods used for studies of pesticide formulations: Zeszyty Problemowe Postepow Nauk Rolniczych, v. 319, p. 255-264. Polish.

Analytical Techniques/Quantification.

CA106(23):190974y.

Dao, T. H., and Lavy, T. L., 1978, Extraction of soil solution using a simple centrifugation method for pesticide adsorption-desorption studies: Journal of the Soil Science Society of America, v. 42, no. 2, p. 375-377.

English.

Sorption to Soil,Analytical Techniques/Quantification. CA89(7):54539p.

Daugherty, D. T., and Mosesman, N. H., 1987, Application of wide bore capillary columns to analyses of pesticides and herbicides: Proceedings - Water Quality Technology Conference, v. 15, no. Issue Answers Today's Water Qual. Prof., p. 183-193.

English.

Analytical Techniques/Quantification.

CA110(11):90471w.

Davies, R. D., and Pretorius, V., 1978, Fluorescence of pesticides of silica gel thin-layer plates by use of a gaseous electrical discharge technique: Journal of Chromatography, v. 155, no. 1, p. 229-232.

English.

Analytical Techniques/Quantification.

CA89(17):141697g.
Davis, J. P., Grace, H. C., and Nabors, J. B., 1980, Separation of a tris(alkylamino)-s-triazine byproduct from chlorobis(alkylamino)-s-triazines: Appl. or Pr. 971574, 20 Dec 1978.

English.

Analytical Techniques/Quantification.

CA92(21):181235y.

Davoli, E., Benfenati, E., Bagnati, R, and Fanelli, R, 1987, Analysis of atrazine in underground waters at part per trillion levels as an early waming method for contamination and for soil distribution studies: Chemosphere, v. 16, no. 7, p. $1425-1430$.

English.

Groundwater Observations,Analytical Techniques/

Quantification.

CA107(13):110987n.

Debelyi, A. S., Troshko, E. V., and Galkina, G. A., 1971, Use of triazines in the growing of medicinal plants, and determination of their residual amounts: Agrokhimiya, no. 8, p. 110-114.

Russian.

Uptake by Biota,Analytical Techniques/Quantification. CA76(9):42616e.

Decleire, M., De Cat, W., and Bastin, R, 1975, Rapid detection of various herbicides in water by the in vivo determination of nitrate reductase in Lemna minor L: Zeitschrift fuer Pflanzenphysiologie, v. 77, no. 4, p. 315-322.

French.

Analytical Techniques/Quantification. CAs4(19):131280y.

Deleu, R, and Copin, A., 1987, Pesticide residue analysis by capillary gas chromatography-mass spectrometry. Application to carbofuran and atrazine analysis: Bulletin des Recherches Agronomiques de Gembloux, v. 22, no. 2, p. 121-132. French.

Analytical Techniques/Quantification,Leaching. CA108(21):182101n.

Delley, R, Friedrich, K, Karlhuber, B., Szekely, G., and Stammbach, K, 1967, Identification and determination of various triazine herbicides in biological materials: Fresenius' Zeitung fuer Analytische Chemie, v. 228, no. 1, p. 23-38.

English.

Uptake by Biota,Analytical Techniques/Quantification. CA67(17):81380g.

Demian, B. A., Borbely, V., Kerek, F., Bader, B., Cirstea, M., and Dragusin, E., 1979, High-performance liquid chromatographic determination of some sym-triazine derivatives: Revista de Chemie (Bucharest), v. 30, no. 3, p. 281.

Romanian.

Analytical Techniques/Quantification.

CA91(14):116898g. 
DeNoyelles, F. J., and Kettle, W. D., 1985, Experimental ponds for evaluating bioassay predictions: American Society of Testing Materials, Special Technical Publication, v. 865, no. Validation Predict. Lab. Methods Assess. Fate Eff. Contam. Aquat. Ecosyst., p. 91-103.

English.

Analytical Techniques/Quantification.

CA104(7):46892m.

Di Corcia, A., Marchetti, M., and Samperi, R, 1987, Rapid determination of simazine and atrazine in water at the parts per trillion level. Extraction by a miniaturized Carbopack.B trap followed by high-performance liquid chromatography: Journal of Chromatography, v. 405, p. 357-363.

English.

Analytical Techniques/Quantification,Sr. CA107(17):149101u.

Dietrich, A. M., Millington, D. S., and Christman, R. F., 1983, Specific identification of organic pollutants in Haw River water using gas chromatography/mass spectrometry: Report Water Resource Rescarch Institute of the University of North Carolina, v. 206, p. 144 pp..

English.

Analytical Techniques/Quantification,Surfacewater

Observations.

CA102(14):119237x.

Dietrich, A. M., Millington, D. S., and Seo, Y. H., 1988, Specific identification of synthetic organic chemicals in river water using liquid-liquid and accurate mass measurement gas chromatography-mass spectrometry analyses: Journal of Chromatography, v. 436, no. 2, p. 229-241.

English.

Analytical Techniques/Quentification,Sr.

CA108(18):156076p.

DiGiano, F. A., Elliot, D., and Leith, D., 1988, Application of passive dosimetry to the detection of trace organic contaminants in water. Environmental Science and Technology, v. 22, no. 11, p. 1365-1367.

English.

Analytical Techniques/Quantification.

CA109(20):175901r.

Dobi, D., and Szautner, S., 1984, Measurement of triazine residues endangering the corn-wheat rotation by analytical and biological methods: Novenyvedelem (Budapest), v. 20, no. 2, p. 74-76.

Hungarian.

Analytical Techniques/Quantification.

CA100(23):187318h.

Doll, J. D., 1977, A simple test for atraxine residues (in rotational crops, such as oats, alfalfa, and soybeans, that follow maize, herbi): .

English.

Analytical Techniques/Quantification.

CAIN 789020140.

Doroz, J., 1986, Detection of trace amounts of herbicides in carriers: Zeszyty Problemowe Postepow Nauk Rolniczych, v. 319, p. 301-304.

Polish.

Analytical Techniques/Quantification.

CA106(21):170938m.
Dron, L. P., 1971, Thin-layer chromatographic and uv spectroscopic determination of Gesaprim 1798: Trudy Vsesoyuznoi Soveshchaniya - Issledovatel'skii po Ostatkov Pestits. Profilakt. Zagryazneniya Prod. Pitan., Kormov Vnesh. Sredy, v. 2, p. 155-157.

Russian.

Analytical Techniques/Quantification. CA78(9):53837v.

Dufek, P., and Pacakova, V, 1980, Comparison of the highperformance liquid chromatographic behavior of s-triazine derivatives on various stationary phases: Journal of Chromatography, v. 187, no. 2, p. 341-349.

English.

Analytical Techniques/Quantification. CA92(14):121287g.

Dufek, P., Pacakova, V., and Tesarova, E., 1980, Separation and behavior of s-triazine derivatives on a NH2-chemically bonded stationary phase by high-performance liquid chromatography: Journal of Chromatography, v. 191, no. 1, p. 115-120. English. Analytical Techniques/Quantification. CA93(1):2057t.

Dunbar, B. D., Niswender, G. D., and Hudson, J. M., 1985, Antibody for the detestion and quantification of atrazine: Appl. 647044, 4 Sep 1984.

English.

Analytical Techniques/Quantification. CA103(21):174017w.

Dunigan, E. P., 1968, Atrazine-soil organic matter relationships and methodology for determination of atrazine residues, Dissertation submitted in partial fulfilment of Ph.D. requirements, University of Arizona, Tucson, Arizona, USA. English.

Analytical Techniques/Quantification,Sorption to Soil. CA69(7):26176m.

Durell, G. S., Christman, R. F., and Dietrich, A. M., 1987, Development and evaluation of analytical procedures for broad spectrum analysis of synthetic organic chemicals in source and finished drinking waters: Report - Water Resource Research Institute of the University of North Carolina, v. 234, p. 134 pp.

English.

Analytical Techniques/Quantification. CA108(6):43623w.

Ebing, W., 1972, Routine method for identification of pesticide residues of triazine, carbamate, urea, and uracil type compounds by thin-layer chromatography. Joumal of Chromatography, v. 65, no. 3, p. 533-545.

German.

Analytical Techniques/Quantification. CA77(1):1626k.

Edwards, R. W., Nonnemaker, K. A., and Cotter, R. L., 1979, The trace-level determination of organics by high-pressure liquid chromatography: National Bureau of Standards Special Publication (U.S.), v. 519, no. Trace Organic Analysis: New Frontiers in Analytical Chemistry, p. 87-94.

English.

Analytical Techniques/Quantification.

CA91(15):118418z 
Eichner, M., and Renner, R, 1980, Quick residue determination of plant and animal food, tobacco and tobacco-products by Sweep$\mathrm{Co}$ analysis. Part 2. Herbicide residues: Zeitschrift fuer Lebensmittel-Untersuchung und Forschung, v. 170, no. 1, p. 14. German.

Analytical Techniques/Quantification. CA92(21):179140v.

Elling, W., Huber, S. J., Bankstahl, B., and Hock, B., 1987 Atmospheric transport of atrazine: a simple device for its detection: Environmental Pollution, v. 48, no. 1, p. 77-82. English.

Analytical Techniques/Quantification,Atmospheric Observation. CA108(3):17350k.

Erb, F., Dequidt, J., Dourlens, A., Pommery, J., Colein, P., and Gontier-Renard, C., 1978, Behavior of several herbicides in contact with ion exchange resins: Journal Francais d'Hydrologie, v. 9, no. 1, p. 9-18.

French.

Analytical Techniques/Quantification,Sorption to Resins. CA90(1):1513q.

Erickson, M. D., Frank, C. W., and Morgan, D. P., 1979, Determination of s-triazine herbicide residues in urine: analytical method development: Joumal of Agriculture and Food Chemistry, v. 27, no. 4, p. 740-743.

English.

Analytical Techniques/Quantification.

CA91(7):50413m.

Erickson, M. D., Frank, C. W., and Morgan, D. P., 1979, Determination of s-triazine herbicide residues in urine: studies of excretion and metabolism in swine as a model to human metabolism: Journal of Agriculture and Food Chemistry, v. 27 , no. 4 , p. $743-746$.

English.

Degradation Products,Analytical Techniques/Quantification, Biodegradation/Biotransformation.

CA91(7):50677a.

Evans, N., and Williamson, J. E., 1981, The construction and use of simple interfaces for combined liquid chromatography mass spectrometry. Biomedical Mass Spectrometry, v. 8, no. 7, p. 316-321.

English.

Analytical Techniques/Quantification.

CA96(3):19475n.

Fanelli, R, Chiabrando, C., and Airoldi, L., 1978, Determination of volatile $\mathrm{N}$-nitrosamines as pesticide contaminants by gas chromatography-mass fragmentography. Analytical Letters, v. A11, no. 10, p. 845-854.

English.

Analytical Techniques/Quantification.

CA90(3):17660w.

Farkas, P., and Tekel, J., 1986, Determination of herbicide residues in beet sugar: Sbornik UVTIZ, Potravin Vedy, v. 4, no. 2, p. 129-134.

Slovenian.

Uptake by Biota,Analytical Techniques/Quantification. CA105(25):224732q.
Fedorova, L. N., and Samosvat, L. S., 1971, Combination of thinlayer chromatography and ultraviolet spectrophotometry to determine triazines in soils and water. Trudy Vsesoyuznogo Soveshchaniya po Issledovaniyu Ostatkov Pestitsidov i Profilaktike Zagryazneniya Imi Produktor Pitaniya, Kormovi Vneshnei Sredy, v. 2, p. 207-209.

Russian.

Analytical Techniques/Quantification. CA78(17):106845e.

Fehringer, N. V., and Walters, S. M., 1984, Evaluation of capillary gas chromatography for pesticide and industrial chemical residue analysis. I. Comparison of retention ratios obtained on methyl silicone-coated capillary columns with published values for packed columns: Journal of the Association of Official Analytical Chemists, v. 67, no. 1, p. 91-95.

English.

Analytical Techniques/Quantification.

CA100(23): $187145 z$.

Ferris, I. G., and Haigh, B. M., 1987, A rapid and sensitive HPLC procedure for the determination of atrazine residues in soilwater extracts: Journal of Chromatographic Science, v. 25, no. 4, p. 170-173.

English.

Analytical Techniques/Quantification.

CA106(23):190979d.

Flint, G. T., and Aue, W. A., 1970, Gas-liquid chromatographic determination of 2-hydroxy-s-triazines: Journal of

Chromatography, v. 52, no. 3, p. 487-490.

English.

Analytical Techniques/Quantification. CA74(13):63357v.

Frimmet, F. H., Millington, D. S., and Chrisman, R. F., 1987, Quantitative determination of organic compounds in extracts of activated carbon by means of GC/MS: Fresenius' Zeitung fuer Analytical Chemistry, v. 327, no. 2, p. 149-153.

German.

Analytical Techniques/Quantification.

CA107(14):126283r.

Furrer, J. D., and Lavy, T., 1978, A quick test for atrazine carryover. Ext. Bull. Mich. State Univ. Coop. Ext. Serv., May 1978, E1215, 3 p..

English.

Field Residuals,Analytical Techniques/Quantification. CAIN 789108103.

Furusawa, M., Oohira, Y., and Iwassaki, S., 1972, Determination of monoguanylmelanine by cation-exchange separation: Yamanashi Daigaku Kogakubu Kenkyu Hokoku, no. 23, p. $84-86$. Japanese. Analytical Techniques/Quamification. CA81(12):72341g.

Fysh, R. R, and Jones, L. V., 1980, Forensic Toxicology, Proceedings of the European Meetings of the International Association of Forensic Toxicologists, 1979, p. 189-203. English.

Analytical Techniques/Quantification. CA94(1):774w. 
Gabinska, K., 1983, Bioindykacja Skazen Przemyslowychi i

Rolniczych, Materialy Pokonferencyjne, Wroclaw, 1980, p. $363-$

373.

Polish.

Analytical Techniques/Quantification.

CA101(15):124754x.

Gabrio, T., and Ennet, D., 1982, Gas chromatographic determination of residues of sym-triazine herbicides in drugs from vegetable sources: Pharmazie, v. 37, no. 5, p. 375-377.

German.

Analytical Techniques/Quantification.

CA97(16):133658v.

Gaskill, A, and Jayanty, R. K. M., 1981, A quality assurance program for determination of herbicides in estuarine waters: Journal of Environmental Science and Health, Part B, v. B16, no. 4 , p. $453-563$.

English.

Analytical Techniques/Quantification,Surfacewater

Observations.

CA95(15):127225u.

Gerber, H. R, 1977, Crop Protection Agents - Their Biological Evaluation, Proceedings of the International Conference, 1975, p. 307-321.

English.

Chemical/Physical Properties,Sorption to Soil,Analytical

Techniques/Quantification.

CA89(9):71961n.

Giardi, M. T., Giardina, M. C., and Filacchioni, G., June 1985, Chemical and biological degradation of primary metabolites of atrazine by a Nocardia strain: Agricultural and Biological Chemistry, v. 49 , no. 6 , p. 1551-1558.

English.

Degradation Products,Analytical Techniques/Quantification, Biodegradation/Biotransformation.

CA103(13):100291j.

Giandi, M. T., Giandina; M. C., and Brancaleoni, E., 1983, An improved method of isolation and characterization of atrazine metabolites: Analytical Chemistry Symposium Series, v. 13, no. Chromatogr. Biochem., Med. Environ. Res. 1, p. 53-61. English.

Degradation Products,Analytical Techniques/Quantification. CA98(23):193244n.

Glennie-Holmes, M., 1974, Rapid determination of atrazine residues in soil using infrared spectrophotometry. Pesticide Science, v. 5, no. 3, p. 251-254.

English.

Analytical Techniques/Quantification.

CA81(17):100495f.

Golovkin, G: V., and Smol'chenko, A. 1., 1981, Relarions between electron-capture detector response and molecular structure of organohalogen: Zhurnal Analiticheskoi Khimii, v. 36, no. 10, p. 2013-2019.

Russian.

Analytical Techniques/Quantification.

CA96(5):29799k.
Gorder, G. W., and Dahm, P. A., 1981, Analysis of carbofuran and atrazine in soil samples: Journal of Agriculture and Food Chemistry, v. 29, no. 3, p. 629-634.

English.

Analytical Techniques/Quantification,Sorption to Soil. CA9S(1):1696e.

Goswami, K. P., and Green, R. E., 1973, Simultaneous extraction of hydroxyatrazine, atrazine, ametryne from some Hawaiian soils: Soil Science Society of America, Proceedings, v. 37, no. 5, p. $702-707$.

English.

Analytical Techniques/Quantification,Degradation Products, Sorption to Soil. CA80(1):663v.

Goza, S. W., September 1972, Infrared analysis of pesticide formulations: Journal of the Association of Official Anałytical Chemists, v. 55, no. 5, p. 913-917. English. Analytical Techniques/Quantification. CA77(25):160898s.

Grandet, M., Weil, L., and Quentin, K. E., 1988, Determination of triazine-herbicides and their metabolites in water samples by gas chromatography: Zeitschrift fuer Wasser und Abwasser Forschung, v. 21, no. 1, p. 21-24.

German.

Analytical Techniques/Quantification.

CA108(22):192486f.

Greenhalgh, R, and Doldadalova, J., 1972, Evaluation of the Pye Thermionic Detector. Column, v. 14, p. 4-9.

English.

Analytical Techniques/Quantification.

CA78(17):106838e.

Greenhalgh, R, and Kovacicova, J., 1975, Confirmation of atrazine and fenuron by alkylation at the ppm level: Bulletin of Environmental Contamination and Toxicology, v. 14, no. 1 , p. $47-48$.

English.

Analytical Techniques/Quantification.

CA83(19):158954n.

Greenhalgh, R, and Kovacicova, J., 1975, Chemical confirmatory test for organophosphorus and carbamate insecticides and triazine and urea herbicides with reactive imino moieties: Journal of Agriculture and Food Chemistry, v. 23, no. 2, p. 325-329.

English:

Analytical Techniques/Quantification. CA83(7):54373f.

Grims, M., Kuftinec, J., and Besic, J., 1976, Determination of dichloroamino-triarine present as impurity in compounds of monochloroamino-s-triazinic structure: Acta Pharmaceutica Jugoslavica, v. 26, no. 1, p. 45-52.

English.

Analytical Techniques/Quantification.

CA85(7):41992y. 
Gunkel, G., 1980, Sample preparation and quantitative determination of the herbicide atrazine (s-triazine) from water and organic matter. the use of gas chromatographic methods in biological experiments: Archives of Hydrobiology, Supplement, v. 59, no. 1, p. 17-31.

German.

Analytical Techniques/Quantification.

CA94(3):11557d.

Guz, A. F., 1974, Aktual'nye Voprosy Zashchity Rastenii v BSSR, Materialy Respublikanskoi Konferentsii Molodyk'h Uchenykh, 1st Minsk, p. 121-122.

Russian.

Analytical Techniques/Quantification.

CA85(23):172561e.

Gyorfi, L., Ambrus, A., and Bolygo, E., 1987, Pesticide Science and Bictechnology, Proceedings of the International Congress of Pesticide Chemists, 6th, 1986, p. 353-356.

English.

Analytical Techniques/Quantification,Miscellaneous

Environmental.

CA107(15):132730a.

Gzhegotskii, M. I., 1967, Colorimetric method of determing Dipterex and atrazine in preparations and biological material: Gigiena i Sanitariya, v. 32, no. 6, p. 71-72. Russian.

Analytical Techniques/Quantification.

CA67(15):72749g.

Haase-Strey, H., Heidemann, W., and Ruessel, H. A., 1984, GC-MS determination of nitrogen-containing pesticides in biological material: Fresenius' Zeitung fuer Analytical Chemistry, v. 318, no. 2, p. 111-115.

German.

Analytical Techniques/Quantification.

CA101(9):67665t.

Hall, G. L., Whitehead, W. E., Mourer, C. R, and Shibamoto, T., 1986, A new gas chromatographic retention index for pesticides and related compounds: Journal of High Resolution Chromatography and Chromatography Communications, v. 9, no. 5, p. 266-271.

English.

Analytical Techniques/Quantification.

CA105(17):148041w.

Hance, R. J., 1986, Quantification of Natural Bioavailability Bound 14C-Pesticide Residues in Soil, Plants, and Food, Proceedings of Final Research Co-ordinatorsMeeting, 1985, p. 1-11.

English.

Field Residuals,Sorption to Soil,Analytical Techniques/

Quantification.

CA108(5):33523iz.

Hance, R. J., and Chesters, G., 1970, Extraction of hydroxyatrazine from soil: Analyst (London), v. 95, no. 1126, p. 106. English.

Degradation Products,Analytical Techniques/Quantification, Sorption to Soil.

CA72(21):110029k.
Haque, R., and Lilley, S., 1972, Nuclear magnetic resonance studies of substituted s-triazines in solution: Applied Spectroscopy, v. 26, no. 2, p. 309-310.

English.

Analytical Techniques/Quantification. CA77(6):41060c.

Herzel, F., 1976, A simple quick method for the extraction of organic trace materials from water. Chemie fuer Labor and Betrieb, v. 27, no. 5, p. 171-172.

German.

Analytical Techniques/Quantification.

CA87(7):48805q.

Hill, B. D., and Stobbe, E. H., 1974, Use of ultrasonic extraction in the determination of some S-triazine herbicides in soils: Journal of Agriculture and Food Chemistry, v. 22, no. 6, p. 1143-1144.

English.

Analytical Techniques/Quantification.

CA81(25):164642j.

Hoermann, W. D., and Eberly, D. O., 1971, Pesticide Chemistry, Proceedings of the Intermational Congress on Pesticide Chemistry, 2nd, p. 245-260.

English.

Analytical Techniques/Quantification.

CA80(3):11059d.

Hoermann, W. D., Formica, G., Ramsteiner, K, and Eberle, D. O., 1972, Automated method for extraction, cleanup, and gas chromatographic determination of triazine herbicides in soil: Journal of the Association of Official Analytical Chemists, v. 55 , no. 5 , p. 1031-1038.

English.

Analytical Techniques/Quantification.

CA77(25):160904r.

Hoffman, D. W., December 1976, Plant competition for atrazine, Dissertation submitted in partial fulfillment of $\mathrm{Ph} . \mathrm{D}$. requirements.

English.

Analytical Techniques/Quantification.

OWRT B-030-NEB(3).

Hsu, J. P., Wheeler, H. G., Jr., Camann, D. E., Schattenberg, H. J., III, Lewis, R. G., and Bond, A. E., 1988, Analytical methods for detection of nonoccupational exposure to pesticides: Joumal of Chromatographic Science, v. 26, no. 4, p. 181-189.

English.

Analytical Techniques/Quantification.

CA108(23):200077r.

Huber, S. J., 1985, Improved solid-phase enzyme immunoassay systems in the ppt range for atrazine in fresh water. Chemosphere, v. 14, no. 11-12, p. 1795-1803.

English.

Analytical Techniques/Quantification.

CA104(11):83639e. 
Huber, S. J., and Hock, B., 1985, A solid-phase enzyme immunoassay for quantitative determination of the herbicide terbutryn: Zeitschrift fuer Pfanzenkrankheiten Pflanzenschutz, v. 92, no. 2, p. 147-156.

English.

Analytical Techniques/Quantification. CA103(13): $100252 x$.

Hurle, K, 1977, A comparison of bioassays with chemical methods of analysis for the determination of atrazine, 2,4-D, DNOC, and napropamide in the soil: Weed Research, v. 17, no. 1, p. 25-32.

German.

Analytical Techniques/Quantification.

CA86(15):101777q.

Huss, M., and Adamovic, V. M., May 30, 1973, Determination of Ametrine and Atrazine Residues in Soil by Thin-Layer Chromatography. Journal of Chromatography, v. 80, no. 1, p. 137-139.

English.

Analytical Techniques/Quantification,Biodegradation/ Biotransformation.

CA79(21):122488s.

Hutzinger, O., Jamieson, W. D., Macneil, J. D., and Frei, R. W., September 1971, Electron-donor-acceptor complexing reagents for the analysis of pesticides. I. Survey of reagents and instrumental trechniques: Journal of the Association of Official Analytical Chemists, v. 54, no. 5, p. 1100-1109. English.

Analytical Techniques/Quantification.

Hyeon, S. B., Nishida, M., Ohsaka, A., Kim; J. M., and Suzuki, A., 1982, A simple bioassay for chemicals active on the photosynthetic or respiratory systems of plants: Agricultural and Biological Chemistry, v. 46, no. 3, p. 811-812.

English.

Analytical Techniques/Quantification.

CA96(19):157177t.

Hyeon, S. B., and Suzuki, A., 1982, A simple bioassay with an oxygen electrode for chemicals active in the photosynthetic or respiration systems of plants: Shokubutsu no Kagaku Chosetsu, v. 17, no. 2, p. 157-162.

Japanese.

Analytical Techniques/Quantification.

CA99(7):49887c.

Janda, V., and Marha, K, 1985, Recovery of s-triazines from water and their analysis by gas chromatography with photoionization detection: Journal of Chromatography, v. 329 , no. 1, p. $186-188$.

English.

Analytical Techniques/Quantification. CA103(11):83391x

Jandera, P., and Spacek, M., 1986, Method for characterization of selectivity in reversed-phase liquid chromatography. III. Retention behavior in gradient-elution chromatography. application to the chromatography of pesticide compounds: Journal of Chromatography, v. 366, p. 107-126.

English.

Analytical Techniques/Quantification.

CA105(23):204626e.
Jandera, P.. Svohoda, L., Chracek, J., and Kubat, J., 1985, Enrichment of water samples containing herbicides in small sorbent-packed columns: Chemicky Prumysl, v. 35, no. 12, p. 653-657.

Czechoslovakian.

Analytical Techniques/Quantification. CA104(12):95125x.

Janos, E., Cserhati, T.. Bordas, B., and Dobrovolszky, A., 1985, Lipophilicity of triazine herbicides measured by ges chromatography: Acta Phytopathologica Academiciae Scientriarum Hungaricae, v. 20, no. 1-2, p. 219-224. English.

Analytical Techniques/Quantification,Chemical/Physical Properties.

CA105(1):2089w.

Jeney, K, 1967, Concomitant determination of alkylamino triazines: Kiserlletugyi Kozlemenyek A Kotet: Novemytermesztes, v. 60, no. 1-3, p. 57-62 Hungarian.

Analytical Techniques/Quantification.

CA71(1):2336d.

Johnen, B. G., and Iwan, J., 1988, Results and implications from monitoring German raw water for residues of a wide range of pesticides: Brighton Crop Protection Conference, no. 1, p. 319-328.

English.

Analytical Techniques/Quantification, Observations in drinking water.

CA110(13):110103h.

Jork, H., and Roth, B., 1977, Comparative chromatographic analyses of s-triazines: Journal of Chromatography, v. 144, no. 1, p. 39-56.

German.

Analytical Techniques/Quantification. CA88(1):1370z.

Junk, G. A., and Richard, J. J., 1984, Pesticide disposal sites: sampling and analyses: American Chemical Society, Symposium Series, v. 259, no. Treatment and Disposal of Pesticide Wastes, p. 69-95.

English.

Analytical Techniques/Quantification,Volatilization, Biodegradation/Biotransformation. CA101(25):224803t.

Junk, G. A., Richard, J. J., Grieser, M. D., Witiak, D., Witiak, J. L., Arguello, M. D., Vick, R, Svec, H. J., Fritz, J. S., and Calder, G. V., 1974, Use of macroreticular resins in the analysis of water for trace organic contaminants: Journal of Chromatography, v. 99, p. 745-762.

English.

Analytical Techniques/Quantification,Sorption to Resins. CA82(4):2159\%k.

Junk, G. A., and Richard, J. J., 1988, Solid phase extraction on a small scale: Journal of Research of the National Bureau of Standards (U.S.), v. 93, no. 3, p. 274-276.

English.

Analytical Techniques/Quantification, Sorption to Resins. CA109(24):215647w. 
Kabakchieva, E., and Zhelyazkova, B., 1981, New titrimetric method for the determination of ethyl- and propylamines in wastewater from the production of triazine pesticides:

Khimiya i Industriya (Sofia), no. 10, p. 448-450.

Bulgarian.

Analytical Techniques/Quantification.

CA96(24):205069h.

Kadenczki, L., Arpad, Z., Ambrus, A., and Gyorffy, L., 1985, Extraction of pesticide residues from fruit and vegetable samples by using a column-extraction method: Novenyvedelem (Budapest), v. 21, no. 9, p. 394-400.

Hungarian.

Analytical Techniques/Quantification.

CA103(25):213493v.

Karlhuber, B. A., Hormann, W. D., and Ramsteiner, K. A., 1975, Pesticide residue analysis by mass fragmentography:

Analytical Chemistry, v. 47, no. 14, p. 2450-2452.

English.

Chemical/Physical Properties,Analytical Techniques/

Quantification.

CA83(25):202637n.

Kavetskii, V. N., Bublik, L. I., and Fuzik, G. V., 1987, Chromatographic analysis of pesticide mixtures in environmental samples: Zhurnal Analiticheskoi Khimii, v. 42, no. 7, p. 1302-1304.

Russian.

Analytical Techniques/Quantification.

CA108(5):33487r.

Kennedy, M. V., Stojanovic, B. J., and Shuma, F. L., Jr., 1972, Analysis of decomposition products of pesticides: Journal of Agriculture and Food Chemistry, v. 20, no. 2, p. 341-343. English.

Analytical Techniques/Quantification,Hydrolysis/Chemical Reactions.

CA77(1):1629p.

Khan, S. U., Greenhalgh, R, and Cochrane, W. P., 1975, Chemical derivatization of hydroxyatrazine for gas chromatographic analysis: Journal of Agriculture and Food Chemistry, v. 23, no. 3, p. $430-434$.

English.

Analytical Techniques/Quantification,Degradation Products. CA83(5):38612c.

Khan, S. U., and Purkayastha, R, 1975, Application of a thermionic detector in the analysis of s-triazine herbicides: Journal of Agriculture and Food Chemistry, v. 23, no. 2, p. 311-314.

English.

Analytical Techniques/Quantification.

CA82(21):133879h

Khmel'nitskaya, E. Y., 1975, Polarography of s-triazine compounds. I. Mechanism of the reduction of chlorosubstituted s-triazine studied by the latent limiting current method: Elektrokhimiya, v. 11, no. 6, p. 873-881.

Russian.

Chemical/Physical Properties,Analytical Techniques/

Quantification.

CA83(18):154656u.
Kirchhoff, J., 1974, Extraneous substances from filter paper as a reason for interfering signals during gas chromatographic determination of herbicide residues with alkali flame ionization detector: Deutsche Lebensmittel-Rundschau, v. 70, no. 8, p. 284-285.

German.

Analytical Techniques/Quantification.

CA82(21):133899q

Klosinska, J., and Zadrozinska, J., 1986, Hill reaction used for determination of herbicide residues in plants: Roczniki Panstwowego Zakladu Higieny, v. 37, no. 3, p. 189-194. Polish.

Analytical Techniques/Quantification. CA106(23):194887v.

Kofanov, V. I., Kofman, I. S., and Baranov, Y. S., 1978, Use of a thermion detector of the gas chromatograph "Tsvet-106" for determining nitrogen-containing pesticides: Gigiena $i$ Sanitariya, no. 2, p. 83-84.

Russian.

Analytical Techniques/Quantification.

CA88(19):131815j.

Kofman, I. S., 1980, Gas-chromatographic determination of simazine, atrazine, and prometryn when all are present in cultivated plants: Fiziol. Biokhim. Kul't Rast., v. 12, no. 2, p. 198-201.

Russian.

Analytical Techniques/Quantification,Volatilization. CA92(25):210013g.

Kofman, I. S., 1985, Proceedings of the International Symposium of Instrumental High Performance Thin-Layer Chromatography, 3rd, p. 113-124.

English.

Analytical Techniques/Quantification.

CA107(7):54017g.

Korsos, I. M., and Lantos, J., 1984, Thin-layer chromatographic identification of pesticides: Novenyvedelem (Budapest), $v$. 20 , no. 1 , p. $30-34$.

Hungarian.

Analytical Techniques/Quantification.

CA100(25):204855a.

Koudela, S., 1970, Modified detection of triazine herbicide residues and their hydroxy-derivatives on thin-layer chromatograms: Joumal of Chromatography, v. 53, no. 3, p. 589-591.

English.

Analytical Techniques/Quantification. CA74(11):52318g.

Kovac, J., and Henselova, M., 1976, A rapid method for detection of Hill reaction inhibitors: Photosynthetica, v. 10, no. 3, p. 343-344.

English.

Analytical Techniques/Quantification.

CA85(23):172556g. 
Kovac, J., and Henselova, M., 1977, Detection of triazine herbicides in soil by a Hill-reaction inhibition technique after thin-layer chromatography: Journal of Chromatography, v. 133, no. 2, p. 420-422.

English.

Analytical Techniques/Quantification. CA87(3):17037m.

Kovac, J., Tekel, J, and Kurucova, M., 1987, Determination of herbicide residues in agricultural crops, foods, soil and water by chronometric method: Zeitschrift fuer LebensmittelUntersuchung und Forschung, v. 184, no. 2, p. 96-100. English.

Analytical Techniques/Quantification. CA106(23):194864k.

Kovac, J,, Zelenak, J., Kurucova, M., and Tekel, J., 1986, Determination of residues of urea herbicides and atrazine in wheat by a chronometric method: Agrochemia (Bratislava), $v$. 26, no. 4, p. 115-118.

Slovenian.

Analytical Techniques/Quantification. CA105(7):59516n.

Kozak, J., 1987, Spectrophotometric determination of some herbicides: Sbomik Vysoke Skoly Zemedelske v Praze, Provozne Ekonomicke Fakulty v Ceskych Budejovicich, Rado Biologicka, v. A46, p. 157-168.

Czechoslovakian.

Analytical Techniques/Quantification.

CA107(23):213468y.

Kramer, J. W., and Baker, D. B., 1985, An analytical method and quality control program for studies of currently used pesticides in surface waters: American Society of Testing Materials, Special Technical Publication, v. 867, no. Quality Assurance in Environmental Measurements, p. 116-132. English.

Analytical Techniques/Quantification.

CA103(23):191328r.

Kratky, B. A., and Warren, G. F., 1971, Rapid bioassay for photosynthetic and respiratory inhibitors: Weed Science, v. 19 , no. 6, p. 658-661.

English.

Analytical Techniques/Quantification.

CA76(13):69030w.

Kratky, B. A, and Warren, G. F., 1971, Use of three simple, rapid bioassays on forty-two herbicides: Weed Research, $v$. 11 , no. 4; p. 257-262.

English.

Analytical Techniques/Quantification. CA76(21):12737k.

Kreind1, T. G., Malissa, H., and Winsaver, K, 1986, Method for the simultaneous determination of traces of atrazine, pyrazon and lindane for monitoring potable water supplies:

Mikrochimica Acta, v. 4, no. 1-2, p. 1-13.

English.

Analytical Techniques/Quantification.

CA106(9):62883f.
Kruglov, Y. V., 1970, Algological method of determining atrazine in the soil: Izvestiya Akademii Nauk SSR, no. 1, p. 144-147. Russian.

Analytical Techniques/Quantification. CA73(1):2847n.

Kuthan, A, 1985, Methods for determination of triazines in waters: Vodni Hospodarstvi: B, v. 35, no. 7, p. 187-190. Slovenian.

Analytical Techniques/Quantification. CA103(21):173874m.

Ladonin, V. F., Chesalin, G. A., Samoilov, L. N., Spesivtsev, L. G., and Taova, V. I., 1980, Use of nitrogen-15 for the study of the action of herbicides on cultivated plants and seeds. 2. Characteristics of the action of herbicides con nitrogen metabolism of plants which are resistant and sensitive to them: Agrokhimiya, no. 9, p. 116-122. Russian.

Analytical Techniques/Quantification. CA94(15):115843k.

Ladonin, V. F., and Lunev, M. I., 1983, Determination of pesticide residues from the phytotoxic index, Zashchita Rastenii (Moscow), no. 4, p. $28-29$.

Russian.

Toxicity,Analytical Techniques/Quantification. CA99(3):17924w.

Ladonin, V. F, and Tsimbalist, N. I., 1975, About the problem of extraction of atrazine from soil as related to the level of (applied) fertilizers: Doldady Vsesoyuznoi Akademii Sel'skokhozyaistvennylkh Nauk, v. 8, p. 14-16.

Russian.

Analytical Techniques/Quantification,Sorption to Soil.

Ladonin, V. F., and Tsimbalist, N. I., 1975, Extractability of atrazine from soil in relation to its degree of fertilization: Doklady Vsesoyuznoi Akademii Sel'skokhozyaistvennykh Nauk, no. 8, p. 14-16. Russian. Sorption to Soil,Analytical Techniques/Quantification. CA84(13):85427b.

Lantos, J., Ambrus, A., and Visi, E., 1983, Pesticide Chemistry: Human Welfare and the Environment, Proceedings of the International Congress of Pesticide Chemistry, Sth, 1982, p. 129-134.

English.

Analytical Techniques/Quantification. CA99(3):20991w.

Laski, R. R, 1977, Multiresidue determination of nitrogen containing herbicides and fungicides: EDRO SARAP Research and Technology Report, v. 2, p. 1-22. English. Analytical Techniques/Quantification. CA88(21):150739d.

Lawerenz, A., 1983, Thin layer chromatographic analysis methods for herbicidal triazine agents in water. Acta Hydrochimica et Hydrobiologica, v. 11, no. 3, p. 347-350. German.

Analytical Techniques/Quantification. CA99(21):171205u. 
Lawerenz, A., Goralczyk, H., and Hermenau, H., 1986, Thin-layer chromatographic analysis of primary aromatic amines, chlorophenols, phenols, and some groups of herbicidal substances in water. Acta Hydrochimica et Hydrobiologica, v. 14 , no. 2, p. 121-133.

German.

Analytical Techniques/Quantification.

CA104(26):230131p.

Lawrence, J. F., 1976, Gas chromatographic separation of herbicides of major interest in Canada, with electrolytic conductivity detection in the nitrogen and chlorine modes: Journal of Chromatography, v. 121, no. 1, p. 85-87.

English.

Analytical Techniques/Quantification. CA85(7):42009v.

Lawrence, J. F., Brinkman, U. A. T., and Frei, R. W., 1979 Continuous post-column ion-pair extraction detection of some basic organic compounds in normal-phase chromatography: Journal of Chromatography, v. 185, no. 1, p. 473-481.

English.

Degradation Products,Analytical Techniques/Quantification. CA92(14):116528g

Lawrence, J. F., and Laver, G. W., 1974, Analysis of triazine herbicides by combined thin-layer chromatography and fluorimetry. Journal of Chromatography, v. 100, no. 1, p. 175-179.

English.

Analytical Techniques/Quantification.

CA82(21):133868d.

Lawrence, J. F., and McLeod, H. A., 1974, Low temperature cleanup procedure for triazine herbicides in root crops: Bulletin of Environmental Contamination and Toxicology, v. 12, no. 6, p. 752-758.

English.

Analytical Techniques/Quantification.

CA83(1):1598b.

Lawrence, J. F., 1974, Comparison of extraction methods for triazine herbicides in root crops using electrolytic conductivity detection: Journal of Agriculture and Food Chemistry, v. 22, no. 1, p. 137-140.

English.

Analytical Techniques/Quantification.

CA80(13):69237b.

Lawrence, J. F., 1974, Confirmation techniques for triazine herbicides by gas chromatography with electrolytic conductivity detection: Journal of Agriculture and Food Chemistry, v. 22, no. 6, p. 936-938.

English.

Analytical Techniques/Quantification.

CA81(25):167916n.

Lawrence, J. F., 1976, Confirmation of some organonitrogen herbicides and fungicides by chemical derivatization and gas chromatography. Journal of Agriculture and Food Chemistry, v. 24 , no. 6 , p. $1236-1238$.

English.

Degradation Products,Analytical Techniques/Quantification. CA85(23):175659d.
Lawrence, J. F., 1976, Sensitivity enhancement of the Coulson conductivity detector by modification of the bridge circuitry. Journal of Chromatography, v. 128, no. 1, p. 154156.

English.

Analytical Techniques/Quantification.

CA86(13):84561v.

Lawrence, J. F., 1980, Simple, sensitive, and selective thin layer chromatographic technique for detecting some photosynthesis inhibiting herbicides: Journal of the Association of Official Analytical Chemists, v. 63, no. 4, p. 758-761.

English.

Analytical Techniques/Quantification.

CA93(13):126913p.

Lawrence, J. F., 1981, Use of 214-nm and 229-nm discrete-line sources for the UV absorbance detection of some pesticides separated by high-performance liquid chromatography. Journal of Chromatography, v. 211, no. 1, p. 144-149.

English.

Analytical Techniques/Quantification. CA95(9):75231w.

Lawrence, J. F., and Leduc, R, 1978, High performance liquid chromatography of acioic and basic organic compounds on silica gel with mobile phases containing organic acids: Analytical Chemistry, v. 50, no. 8, p. 1161-1164.

English.

Degradation Products,Analytical Techniques/Quantification, Sorption to Resins.

CA89(5):37888j.

Lawrenz, A., 1983, Method of analysis by thin-layer chromatography for active components of triazine herbicides in water: Acta Hydrochimica et Hydrobiologica, v. 11, no. 3, p. 347-350.

Analytical Techniques/Quantification.

Leclercq, P. A, and Pacakova, V., 1979, Gas chromatography and mass spectrometry of bis(alkylamino)-s-triazines: Journal of Chromatography, v. 178, no. 1, p. 193-207.

English.

Degradation Products,Analytical Techniques/Quantification, Chemical/Physical Properties.

CA92(15):128188j.

Lee, H. B., and Chau, A. S. Y., 1983, Determination of trifluralin, diallate, triallate, atrazine, barban, diclofopmethyl, and benzoylprop-ethyl in natural waters at parts per trillion levels: Journal of the Association of Official Analytical Chemists, v. 66, no. 3, p. 651-658.

English.

Analytical Techniques/Quantification. CA99(1):1716u.

Lee, H. B., and Chau, A. S. Y., 1983, Gas chromatographic determination of trifluralin, diallate, triallate, atrazine, barban, diclofop-methyl, and benzoylprop-ethyl in sediments at parts per billion levels: Journal of the Association of Official Analytical Chemists, v. 66, no. 6, p. 1322-1326. English.

Analytical Techniques/Quantification. CA100(3):19144e. 
Lee, H. B., and Stokker, Y. D., 1986, Analysis of eleven triazines in natural waters: Journal of the Association of Official Analytical Chemists, v. 69, no. 4, p. 568-572. English.

Analytical Techniques/Quantification.

CA105(11):92834a.

Leela, D., 1981, Bioassays for detection of soil residues: Pesticides, v. 15, no. 5, p. 24-26.

English.

Analytical Techniques/Quantification.

CA95(13):110019g

Lefebure-Drouet, E., and Calvet, R., 1978, The detection and estimation of herbicides using Chlorella: investigation of optimum experimental conditions and their application to the analysis of several herbicides: Weed Research, v. 18, no. 1, p. $33-39$.

French.

Analytical Techniques/Quantification.

CA89(5):37896k.

Lefebure-Drouet, E, and Calvet, R, 1982, Use of Chlorella for biotogical estimation of atrazine in soil: Weed Research, $v$. 22 , no. 5, p. 257-262.

French.

Analytical Techniques/Quantification.

CA97(21):176782y.

Leoni, V., Puccetti, G., Cremisini, C., Ciaramella, I., De Luca d'Alessandro, E., Casuccio, A., Sirilii, D., and Grella, A., 1987, Standard method for the identification and determination of some herbicides in drinking waters: Metodi Analitici per le Acque, v. 7, no. 4, p. 41-51.

Italian.

Analytical Techniques/Quantification.

CA108(26):226567a.

Lewis, R G., Bond, A. E., Fitz-Simons, T. R., Johnson, D. E., and Hsu, J. P., 1986, Monitoring for non-occupational exposure to pesticides in indoor and personal respiratory air. Proceedings - APCA Annual Meetings, 79th, v. 2, no. 86/ 37.4 , p. 15 pp..

English.

Analytical Techniques/Quantification, Atmoshperic Observations. CA106(20):161861d.

Lichtenstein, E. P., Liang, T. T., and Anderegg, B. N., August 1973, Synergism of insecticides by herbicides: Science, v. 181 , no. 4102 , p. $847-849$.

English.

- Toxicity,Analytical Techniques/Quantification.

Lienig, D., Schaefer, K., and Reichelt, G., 1985, Identification of selected pesticides in water by a screening system based on thin-layer chromatography: Aicta Hydrochimica et Hydrobiologica, v. 13, no. 4, p. 443-452. German.

Analytical Techniques/Quantification. CA103(15):1180439.
Lienig, D., Wiemer, B., and Zoelfel, I., 1984, Thin-layer chromatographic determination of triazine herbicides in water. Acta Hydrochimica et Hydrobiologica, v. 12, no. 1, p. 29-37.

German.

Analytical Techniques/Quantification.

CA100(21):169809q.

Lippolis, M. T., and Concialini, V., 1988, Differential pulse polarographic determination of the herbicides atrazine, prometrine, and simazine: Talanta, v. 35, no. 3, p. 235-236. English.

Analytical Techniques/Quantification. CA109(1):2327e.

Liu, L-C., and Cedeno Maldonado, A., 1979, A bionssay method for detecting herbicide concentration in water. Journal of the Agricultural University of Puerto Rico, v. 63, no. 1, p. 8083.

English.

Analytical Techniques/Quantification. CA90(3):17488w.

Lohse, E., and Lauermann, I., 1977, Contribution to the detection

- of plant protectants and pesticides by color reactions and thin-layer chromatography: Krimimalistik und Forensische Wissenschaften, v. 27, p. 37-47.

German.

Analytical Techniques/Quantification. CA89(7):54184u.

Lohse, E., 1986, Use of Y29 adsorber resin for extraction of pesticides from aqueous solutions: Wissenschaftliche Zeitschrift-Martin-Luther-Universitaet Halle-Wittenberg, Mathematisch-Naturwissenschaftliche Reihe, v. 35, no. 3, p. 84-85.

German.

Analytical Techniques/Quantification. CA105(17):147614y.

Loos, M. A., and Kearney, P. C., 1978, Thin-layer and paper chromatography of potential degradation products of striazine herbicides: Journal of Chromatographic Science, $v$. 16 , no. 2, p. $86-89$.

English.

Degradation Products,Analytical Techniques/Quantification. CA89(19):158611x.

Lopez-Avila, V., Hirata, P., Kraska, S., Flanagan, M., Taylor, J. H., Jre, and Hern, S. C., 1985, Determination of atrazine, lindane, pentachlorophenol, and diazinon in water and soil by isotope: Analytical Chemistry, v. 57, no. 14, p. 2797-2801. English.

Analytical Techniques/Quantification. CA103(21):173866k.

Lora-Tamayo, C., Rams, M. A., and Chacon, J. M. R., 1986, Gas chromatographic data for 187 nitrogen- or phosphoruscontaining drugs and metabolites of toxicological interest analyzed on methyl silicone capillary columns: Journal of Chromatography, v. 374, no. 1, p. 73-85.

English.

Analytical Techniques/Quantification.

CA104(11):81418h. 
Lorincz, S., and Lorincz, M. C., 1982, Separation of nitrogencontaining organic bases: Appl. 71/RI456, 24 Nov 1971. Hungarian.

Analytical Techniques/Quantification,Sorption to Resins. CA99(2):10854q.

Luke, M. A., Froberg, J. E., and Masumoto, H. T., 1975, Extraction and cleanup of organochlorine, organophosphate, organonitrogen, and hydrocarbon pesticides in produce for determination by gas-liquid chromatogarphy. Journal of the Association of Official Analytical Chemists, v. 58, no. 5, p. $1020-1026$.

English.

Analytical Techniques/Quantification.

CA83(21):176802r.

Lusby, W. R., and Keamey, P. C., 1978, Gas chromatographic-mass spectral analyses of s-triazine metabolites: Joumal of Agriculture and Food Chemistry, v. 26, no. 3, p. 635-638. English.

Analytical Techniques/Quantification. CA88(25):184412g.

Lyande, Y. V., Savenkova, V. V., and Cherkasskii, A. A., 1975, Methods of analysis of trichloro-s-triazine and its derivatives containing active chlorine atoms: Zhurnal Analiticheskoi Khimii, v. 30, no. 9, p. 1817-1821.

Russian.

Analytical Techniques/Quantification. CA84(8):53629c.

MacNeil, J. D., Frei, R. W., and Hutzinger, O., 1973, Electrondonor-acceptor complexing reagents in the analysis of pesticides. VI. Influence of structure in detection and identification: Mikrochimica Acta, no. 5, p. 641-650. English.

Analytical Techniques/Quantification. CA79(21):122492p.

Madejski, Z, Ledwozyw, A., and Walkuska, G., 1984, Simple method for determining simazine and atrazine in biological materials by thin layer chromatography: Medycyna Weterynaryjna, v. 40, no. 5 , p. 309-311.

Polish.

Analytical Techniques/Quantification.

CA101(25):224121g.

Malan, C., Visser, J. H., and Van de Venter, H. A., 1986, Quantitative estimation of atrazine, hydroxyatrazine and 6 . methoxy-2-benzoxazinone (MBOA) in maize plants: South African Journal of Plant Soil, v. 3, no. 2, p. 82-84.

English.

Degradation Products,Analytical Techniques/Quantification. CA105(7):55762s.

Mallet, V., and Frei, R: W., 1971, Investigation of flavones as fluorgenic spray reagents for organic compounds on a cellulose matrix. II. Detection of pesticides: Journal of Chromatography, v. 56, no. 1, p. 69-77.

English.

Analytical Techniques/Quantification.

CA74(23):123973e.
Mandava, N. B., Ito, Y., and Ruth, J. M., 1985, Separation of Striazine herbicides by countercurrent chromatography: Journal of Liquid Chromatography, v. 8, no. 12, p. 2221-2238.

English.

Analytical Techniques/Quantification.

CA104(1):2066r.

Mangani, F., and Bruner, F., 1983, Sample enrichment and GC-MS determination of herbicides in water. Chromatographia, v. 17, no. 7 , p. $377-380$.

English.

Analytical Techniques/Quantification, Sorption to Resins. CA99(17):135385u.

Mangani, F., and Bruner, F., 1984, Chromatographic properties and analytical applications of a low-surface-area graphitized. carbon black: Journal of Chromatography, v. 289, p. 85-94. English.

Analytical Techniques/Quantification,Sorption to Resins. CA101(4):32603u.

Marriage, P. B., 1975, Detection of triazine and urea herbicide residues by various characteristics of oat seedlings in bioassays: Weed Research, v. 15, no. 5, p. 291-298.

English.

Analytical Techniques/Quantification.

CA84(1):1169h.

Matisova, E., Krupcik, J., Liska, O., and Szentivanyi, N., 1979, Qualitative analysis of multi-component s-triazine herbicides by gas-liquid chromatography: Journal of Chromatography, $v$. 169, p. 261-269.

English.

Analytical Techniques/Quantification.

CA90(21):163147a.

Matisova, E., Krupcik, J., and Liska, O., 1979, Quantitative analysis of s-triazine herbicides by glass capillary column gas-liquid chromatography. Journal of Chromatography, v. 173, no. 1, p. 139-146.

English.

Analytical Techniques/Quantification.

CA91(13):15048z.

Matorin, D. N., Venediktov, P. S., and Makevnina, M. G., 1975, Use of recording method of afterglow of green algae in determining soil and water pollution by phytoxic substances: Biologicheskie Nauki (Moscow), v. 18, no. 12, p. 122-125. Russian.

Analytical Techniques/Quantification.

McGlamery, M. D., Slife, F. W., and Butler, H., 1967, Extraction and determination of atrazine from soil: Weeds, v. 15, no. 1, p. 35-38. English.

Sorption to Soil,Analytical Techniques/Quantification. CA66(13):54455h.

McKone, C. E., Byast, T. H., and Hance, R. J., 1972, Comparison of some methods for the determination of triazine herbicides in water: Analyst (London), v. 97, no. 1157, p. 653-656.

English.

Analyticar Techniques/Quantification.

CA77(23):148322s. 
Mel'nikova, L. V., and Belyakov, A. A., 1971, Determination of atrazine, cyanuric chloride, hydrogen cyanide, and aliphatic amines in the air. Gigiena । Sanitariya, v. 36, no. 9, p. $67-$ 69.

Russian.

Atmospheric Observations,Analytical Techniques/ Quantification.

CA75(22):132630p.

Miko, M., Dockal, P., and Vajdova, D., 1985, New biochemical method for the evaluation of biocide effectiveness of compounds using activated sludge: Biologia (Bratislava), v. 40, no. 3, p. $277-287$.

Slovenian.

Wastewater Observations,Analytical Techniques/Quantification. CA102(25):216744t.

Millington, D. S., Bertino, D. J., Kamei, T., and Christman, R F., 1983, Analysis of organic compounds adsorbed on granular activated carbon filters used in treatment plants: Water Chlorination: Environmental Impact and Health Effects, v. 4, no. Book 1, p. 445-454.

English.

Analytical Techniques/Quantification, Sorption to Resins. CA98(26):2215406.

Moja, F., Suigo, E., Roveda, M. L., Bezzi, C., Vignanti, G., Pellegatta, U., and Rosso, R, 1988, Problems of environmental contamination: simultaneous analysis of four herbicides by HPLC: Giornale Italiano di Chimica Clinica, v. 13 , no. 2 , p. $145-149$.

Italian.

Analytical Techniques/Quantification.

CA110(11):90474z.

Montgomery, M. L., Botsford, D. L., and Freed, V. H., 1969, Metabolism of hydroxysimazine by com plants: Journal of Agriculture and Food Chemistry, v. 17, no. 6, p. 1241-1243. English.

Degradation Products,Biodegradation/Biotransformation, Analytical Techniques/Quantification.

CA72(1):2396u.

Mueller, B., 1973, Determination of pesticide residues in bee honey. II. Semiquantitative thin-layer chromatographic determination of herbicide residues in bee honey: Nahrung, $v$. 17, no. 3, p. 387-392.

German.

Uptake by Biota,Analytical Techniques/Quantification. CA79(25):144932j.

Muir, D. C. G., and Baker, B. E., 1978, A method for the routine semiquantitative determination of hydroxy-s-triazines in soils: Joumal of Agriculture and Food Chemistry, v. 26, no. 2, p. $420-424$.

English:

Degradation Products,Analytical Techniques/Quantification. CA88(25):184408k.

Murphy, R. T., Hofberg, A. H., and Buser, H. R., 1971, Collaborative study of a gas chromatographic method for the analysis of atrazine: Journal of the Association of Official Analytical Chemists, v. 54, no. 3, p. 697-699.

English.

Analytical Techniques/Quantification.

CA75(1):4306a.
Nastasa, V., and Cuciureanu, R, 1984, Analytical study of some triazine herbicides: Revista Medico-Chirurgicala, v. 88, no. 2, p. 319-323.

Romanian.

Analytical Techniques/Quantification.

CA103(11):83389.

Neale, S., 1980, Development of rapid, economical screening tests to detect carcinogenic or mutagenic compounds of environmental significance: Communications of the European Communities, EUR 6388, Environmental Research Programme, 328-331. English.

Analytical Techniques/Quantification. CA93(5):38723w.

Neubert, P., and Meitrodt, G., 1966, Determination of simazine, propazine, and atrazine in the soil: Archiv Pflanzenschutz, v. 2 , no. 3 , p. $179-194$.

German.

Analytical Techniques/Quantification.

CA68(5):21096e.

Neururer, H., 1975, Bioassays in weed research: Zeitschrift fuer Pflanzenkrankheiten und Pflanzenschutz, v. 82, no. 5, p. 316 328.

German.

Analytical Techniques/Quantification. CA83(21):173703y.

Nikonorov, E. M., Timofeeva, A. N., Bakaleinikov, B. M., and Petrova, L. N., 1982, Reverse-chromatography for study of the thermodynamic properties of lubricating greases: Sbornik Nauchnykh Trudor - Vsesoyuznyi Nauchno-Issledovatel'skii Institute po Pererahotke Nefti, v. 43, p. 72-80. Russian.

Degradation Products,Analytical Techniques/Quantification. CA98(26):218411e.

Nyffeler, A., Gerber, H. R, Hurle, K, Pestemer, W., and Schmidt, R. R, 1982, Collaborative studies of dose-response curves obtained with different bioassay methods for soilapplied herbicides: Weed Research, v. 22, no. 4, p. 213-222. English.

Analytical Techniques/Quantification.

CA97(17):140116v.

Oehmichen, U., and Haberer, K, 1986, Experiments on triazine analysis by HPLC and diode array detection: Gewaesserschutz, Wasser, Abwasser, v. 88, p. 216-227.

German.

Analytical Techniques/Quantification.

CA106(3):14537z.

Oehmichen, U., Karrenbrock, F., and Haberer, K., 1987. Determination of $\mathrm{N}$-pesticides in natural waters: Fresenius' Zeitung fuer Analytical Chemistry, v. 327, no. 7, p. 715-719. English.

Analytical Techniques/Quantification. CA107(10):83598.

Olah, J., Dobi, D., and Gardi, I., 1988, Detection of herbicides by thin layer chromatography and by blocking the Hill reaction: Novenyvedelem (Budapest), v. 24, no. 8, p. 366-369. Hungarian.

Analytical Techniques/Quantification. CA110(1):2741f. 
Ong, B. Y., Falk, R. H., and Bayer, D. E., 1973, Scanning electron microscope observations of herbicide dispersal using cathodoluminescence as the detection mode: Plant Physiology, v. 51 , no. 2, p. $415-420$.

English.

Analytical Techniques/Quantification.

CA78(17):106831x.

Osredkar, R., and Kadaba, P. K, 1982, Application of nuclear double resonance technique for detection of pesticides in water at low concentrations: Bulletin of Environmental Contamination and Toxicology, v. 28, no. 5, p. 513-518. English.

Analytical Techniques/Quantification. CAO7(7):51117d.

Osselton, M. D., and Snelling, R. D., 1986, Chromatographic identification of pesticides: Journal of Chromatography, $v$. 368 , no. 2, p. 265-271.

English.

Analytical Techniques/Quantification.

CA105(23):204634f.

Ott, D. E., Formica, G., Liebig, G. F., Jr., Eberic, D. O., and Gunther, F. A., 1971, Mechanized extraction and cleanup of atrazine residues in soil prior to gas chromatographic analysis: Joumal of the Association of Official Analytical Chemists, v. 54, no. 6, p. 1388-1395.

English.

Analytical Techniques/Quantification.

CA76(13):69025y.

Owens, D. S., and Sturrock, P. E., 1986, Determination of triazine pesticides by high-performance liquid chromatography with swept-potential electrochemical detection: Analytica Chimica Acta, v. 188, p. 269-274.

English.

Analytical Techniques/Quantification.

CA106(15):115098n.

Pacakova, V., and Kozakova, H., 1978, Determination of 1;3,5triazine herbicides by gas chromatography. Journal of Chromatography, v. 154, no. 2, p. 251-255.

English.

Analytical Techniques/Quantification.

CA89(13):101565f.

Pacakova, V., and Nemec, I., 1978, Gas chromatographic, spectrophotometric and electrochemical behavior of substituted s-triazines: Journal of Chromatography, v. 148, no. 1, p. 273-281.

English.

Chemical/Physical Properties,Analytical Techniques/

Quantification.

CA88(13):84401j.

Pacakova, V., Stulik, K, and Prihoda, M., 1988, High-performance liquid chromatography of s-triazines and their degradation products using ultraviolet photometric and amperometric detection: Journal of Chromatography, v. 442, p. 147-156. English.

Analytical Techniques/Quantification.

CA110(3):23229k
Palusova, O., Sackmauerova, M., and Madaric, A., 1975, Identification and determination of triazine and diazine herbicides in water by thin-layer chromatography: Journal of Chromatography, v. 106, no. 2, p. 405-408.

English.

Analytical Techniques/Quantification. CA83(7):54376j.

Parker, C. E., Haney, C. A., Harvan, D. J., and Hass, J. R., 1982, High-performance liquid chromatography-mass spectrometry of triazine herbicides: Journal of Chromatography, v. 242, no. 1, p. 77-96. English.

Analytical Techniques/Quantification. CA97(7):51123c.

Paschal, D., Bichnell, R, and Siebenmann, K., 1978, Determination of atrazine in runoff water by high performance liquid chromatography. Journal of Environmental Science and Heaith, Part B, v. B13, no. 2, p. 105-115.

English.

Run-off,Analytical Techniques/Quantification. CA89(7):545\%6e.

Pascu, M. L., Pascu, A., Dumbraveanu, G., Caprini, M., Bozdoc, H., Rusu, A., Cristu, D., and Munteanu, M., 1985, Tunable laser applications in spectophotometry. Studii si Cercetari de Fizica, v. 37, no. 6-8, p. 576-587.

Romanian.

Analytical Techniques/Quantification. CA104(17):143775h.

Perkavec, J., Perpar, J., and Brodnik, D., 1969, The paper and thin-layer chromatography of several s-triazine derivatives: Mikrochimica Acta, p. 1224-1228.

Degradation Products,Analytical Techniques/Quantification.

Pestemer, W., and Nordmeyer, H., 1988, Adsorption of selected pesticides on different tubing materials: Zentralblatt fuer Bakteriologie, Mikrobiologie und Hygiene, Series B, v. 186, no. 4, p: 375-379.

German.

Analytical Techniques/Quantification, Sorption to Resins. CA109(15):124297r.

Petrova, T. M., and Andreev, Y. B., 1983, Chromatographic determination of pesticides in the soil: Khimiya $v$ Sel'skom Khozyaistve, no. 11, p. 59-61.

Russian.

Analytical Techniques/Quantification.

CA100(7):46857w.

Petunova, A. A., and Saburova, P. V., 1973, Metody Opredeleniya Fitogormonov, Ingibitorov Rosta, Defoliantov i Gerbitsov, p. 172-180.

Russian.

Analytical Techniques/Quantification. CA80(7):34319.

Pfaender, F. K., 1976, Analytic method developed: ESE Notes, v. 12 , no. 4, p. 4-5.

English.

Analytical Techniques/Quantification.

CA86(4):21672m. 
Polak, J., and Volke, J., 1983, Polarographic determination of triazine herbicides: Ceskoslovenska Farmacie, v. 32, no. 8 , p. 282-290.

Czechoslovakian.

Analytical Techniques/Quantification.

CA100(7):46854t.

Popl, M., Voznakova, Z., and Tatar, V., 1983, Determination of triazines in water by GC and LC: Journal of Chromatographic Science, v. 21 , no. 1, p. $39-42$.

English.

Analytical Techniques/Quantification. CA98(14):113410a.

Pressley, T. A., and Longbottom, J. E., 1982, The determination of triazine pesticides in industrial and municipal wastewater. method 619: EPA-600/4-82-007.

English.

Analytical Techniques/Quantification. CA96(24):205100m.

Pribyl, J., and Herzel, F., 1977, TLC detection of herbicides by dansylation: Fresenius' Zeitung fuer Analytical Chemistry, v. 286, no. 1-2, p. 95-99.

German.

Analytical Techniques/Quantification. CA87(17):128575e.

Purkayastha, R, 1971, Simultaneous detection of the residues of atrazine and linuron in water, soil, plant, and animal samples by thin-layer chromatography. International Journal of Environmental Analytical Chemistry, v. 1, no. 2, p. 147-158. English.

Analytical Techniques/Quantification. CA76(15):84597e.

Purkayastha, R., and Cochrane, W. P., 1973, Comparison of electron capture and electrolytic conductivity detectors for the residue analysis of s-triazine herbicides: Journal of Agriculture and Food Chemistry, v. 21, no. 1, p. 93-98. English.

Analytical Techniques/Quantification. CA78(11):70319v.

Putzien, J., 1986, Determination of pesticides in drinking water by HPLC: Zeitschrift fuer Wasser und Abwasser Forschung, v. 19, no. 6, p. 228-236.

German.

Analytical Techniques/Quantification.

CA106(19): $151460 \mathrm{~h}$

Radke, R. O., Armstrong, D. E.. and Chesters, G., Jan-Feb 1966, Evaluation of the pyridine-alkali colorimetric method for determination of atrazine: Journal of Agriculture and Food Chemistry, v. 14, no. 1, p. 70-73.

English.

Analytical Techniques/Quantification.

Ramsteiner, K. A., Hoermann, W. D., and Eberle, D. O., 1971, Determination of residues of triazine metabolites in soil. Analytical procedures and results from field trials: Mededelingen van de Faculteit Landbouwwetenschappen, Rijksuniversitiet Gent, v. 36, no. 3, p. 1119-1131.

German.

Analytical Techniques/Quantification.

CA77(5):30120w.
Ramsteiner, K. A., and Hoermann, W. D., 1979, High-pressure liquid chromatographic determination of hydroxy-s-triazine residues in plant material: Journal of Agriculture and Food Chemistry, v. 27, no. 5, p. 934-938.

English.

Degradation Products,Analytical Techniques/Quantification. CA91(17):138936v.

Ramsteiner, K, Hoermann, W. D., and Eberle, D. O., 1974, Multiresidue method for the determination of triazine herbicides in field-grown agricultural crops, water, and soils: Journal of the Association of Official Analytical Chemists, v. 57, no. 1, p. 192-201.

English.

Analytical Techniques/Quantification.

CA81(23):146676u.

Rapaport, L. I., and Fedorova, L. N., 1973, Quantitative determination of atrazine in the soil water. Appl. or Pr. 1, 726,625, 5 Nov 1973.

Russian.

Analytical Techniques/Quantification.

CA82(3):12256u.

Rathouska, Z., Hajslova, J., Babicka, L., and Davidek, J., 1987, Investigation of S-triazines in milk and feed in central Bohemia: Sbomik UVTIZ, Potravin Vedy, v. 5, no. 2, p. 109. 118.

Czechoslovakjan.

Analytical Techniques/Quantification.

CA107(21):196658r.

Rees, G. A. V., and Au, L., 1979, Use of XAD-2 macroreticular resin for the recovery of ambient trace levels of pesticides and industrial organic pollutants from water. Bulletin of Environmental Contamination and Toxicology, v. 22, no. 4-5, p. $561-566$

English.

Analytical Techniques/Quantification, Sorption to Resins. CA91(24):198543z.

Regtuit, H., Vrins, E., and Hofshcreuder, P., 1988, The tunnel impactor. a multiple inertial impactor for coarse particles: Journal of Acrosol Science, v. 19, no. 7, p. 983-986. English.

Degradation Products,Analytical Techniques/Quantification. CA110(14):120320r.

Reichling, J., 1976, Chromatography of s-triazines on basic zinc carbonate: Fresenius' Zeitung fuer Analytical Chemistry, v. 278; no. 2, p. 125-126.

German.

Analytical Techniques/Quantification. CA84(17):116748p.

Reichling, J., and Fischer; H., 1975, Chromatographic separation of herbicial s-triazine on various polyamide thin layers: Journal of Chromatography, v. 115, no. 2, p. 670-672. German. Analytical Techniques/Quantification. CA84(11):70203b. 
Repasi, G., Rokonay, M. J., and Pinter, Z., 1972, Gaschromatographic data of alkylamino-s-triazines: Magyar Kemiai Folyoirat, v. 78 , no. $2-3$, p. 166-168.

Hungarian.

Chemical/Physical Properties,Analytical Techniques/

Quantification.

CA77(2):9940d.

Reupert, R, and Ploeger, E., 1988, Determination of nitrogencontaining pesticides by HPLC with diode-array detection: Fresenius' Zeitung fuer Analytical Chemistry, v. 331, no. 5, p. 503-509.

German.

Analytical Techniques/Quantification.

CA109(17):144474z.

Richard, E. P., Jr., Goss, J. R., Amtzen, C. J., and Slife, F. W., 1983, Determination of herbicide inhibition of photosynthetic electron transport by fluorescence: Weed Science, v. 31, no. 3, p. 361-367.

English.

Analytical Techniques/Quantification,Uptake by Biota. CA99(3):17988v.

Richard, J. J., Junk, G. A., Avery, M. J., Nehring, N. L., Fritz, J. S., and Svec, H. J., 1975, Analysis of various lowa waters for selected pesticides: atrazine, DDE, and dieldrin-1974: Pesticide Monitoring Journal, v. 9, no. 3, p. 117-123. English.

Analytical Techniques/Quantification,Surfacewater Observations,Sorption to Sediments.

CA84(23):160585g.

Richard, J. J., and Junk, G. A., 1986, Solid phase versus solvent extraction of pesticides from water. Mikrochimica Acta, v. 1, no. 5-6, p. 387-394.

English.

Sorption to Resins,Analytical Techniques/Quantification. CA107(1):2495s.

Rieger, S., and Husek, A., 1987, Analysis of some triazine herbicides in water using HPLC: Acta Universitatis Palackianae Olomucensis, Facultas Rerum , v. 88, no. Chem 26, p. 159-166.

English.

Analytical Techniques/Quantification.

CA108(20):173267u.

Ripley, B. D., and Braun, H. E., 1983, Retention time data for organochlorine, organophosphorus, and organonitrogen pesticides on SE-30 capillary column and application of capillary gas chromatography to pesticide residue analysis: Journal of the Association of Official Analytical Chemists, v. 66, no. 5, p. $1084-1095$.

English.

Analytical Techniques/Quantification.

CA99(23):189593d.

Rivera, J., Ventura, J., Caixach, J., De Torres, M., and Figueras, A., 1987, GC/MS, HPLC and FAB mass spectrometric analysis of organic micropollutants in Barcelona's water supply: International Journal of Environmental Analytical Chemistry, v. 29, no. 1-2, p. 15-35.

English.

Analytical Techniques/Quantification.

CA107(6):45928c.
Ross, J. A., and Tweedy, B. G., 1970, Mass spectra of chloro-, aminochloro-, and ethylaminochloro-s-triazines: Organic Mass Spectrometry, v. 3, no. 2, p. 219-229.

English.

Analytical Techniques/Quantification. CA72(22):115863n.

Sackmauerova, M., and Kovac, J., 1978, Thin-layer chromatographic determination of triazine and urea herbicides in water by Hill reaction inhibition detection technique: Fresenius' Zeitung fuer Analytical Chemistry, v. 292, no. 5, p. 414-415. English. Analytical Techniques/Quantification. CA90(7):49425q.

Sackmauerova, M., and Palusova, O., 1975, Doklady Soobshcheniva Mezhdunarodnyi Kongress po Zashchite Rastenii, 8th, p. 142147.

Russian.

Analytical Techniques/Quantification. CA88(19):131811e.

Sackmauerova, M., Palusova, O., and Madaric, A., 1975 Chromatographic methods for determining chlorotriazine and methlythiotriazine herbicides in waters: Vodni Hospodarstvi, B, v. 25 , no. 6, p. $166-168$.

Slovenian.

Analytical Techniques/Quantification. CA84(16):111182q.

Saito, S., 1978, Sublimatographic analysis; sublimatographic separation of melamine, ammeline, ammelide, and cyanuric acid: Bunseki Kagaku, v. 27, no. 6, p. 321-325.

Japanese.

Analytical Techniques/Quantification,Degradation Products. CA89(12):99299b.

Saka, H., and Chisaka, H., 1981, Determination of leaf disk photosynthesis and respiration with oxygen electrode and its application for a simple assay of herbicidal activities: Zasso Kenkyu, v. 26, no. 4, p. 304-310.

Japanese.

Analytical Techniques/Quantification. CA97(5):34609y.

Saka, H., and Chisaka, H., 1985, Photosynthesis measurement by oxygen electrode as a simple bioassay method: JARQ, v. 18, no. 4 , p. 252-259.

English.

Analytical Techniques/Quantification.

CA103(9):67752k.

Saltzman, S., and Heuer, B., 1985, A rapid bioassay for the detection of photosynthesis inhibitors in water. Pesticide Science, v. 16, no. 5, p. $457-462$.

English.

Analytical Techniques/Quantification. CA104(5):30264x.

Samosvat, L. S., and Fedorova, L. N., 1970, Determination of simazine, atrazine, and propazine in biological media by thin-layer chromatography: Gigiena i Sanitariya, v. 35, no. 9, p. 64-66.

Russian.

Analytical Techniques/Quantification.

CA73(25):129768t. 
Samosvat, L. S., and Fedorova, J. N., 1976, Determination of simazine, atrazine, and propazine in water by a thin-layer chromatographic method: Metody Opredeleniya Pestitsidov v Vode, no. 2, p. $72-76$.

Russian.

Analytical Techniques/Quantification.

CA87(23):178807c.

Sayk, F., and Schmidt, C., 1986, Algae fluorescence autometer for a computerized bioassay: Zeitschrift fuer Wasser und Abwasser Forschung, v. 19, no. 5, p. 182-184.

German.

Analytical Techniques/Quantification,Toxicity. CA106(7):45146a.

Schmidt, C, 1987, Poesible use and results of an algal fluorescence bioassay: Ergebnisse Limnologie, v. 29, p. 107. 116.

German.

Analytical Techniques/Quantification,Toxicity. CA108(21):181559f.

Schmoranzer, A., Neumann, G., Theimann, K. G., and Strohbach, C. 1974, Simazine as a performance-reducing factor in productive livestock and possibilities for analytical assay of triazine derivatives: Monatshefte fuer Veterinaermedizin, v. 29, no. 13, p. 491-493.

German.

Uptake by Biota,Analytical Techniques/Quantification.

CA82(15):93899f.

Schock, R. J., and Braseiton, W. E., 1982, Investigation of the utility of bonded phase packed columns for the identification of organic toxicants by gas chromatography-mass spectrometry (GC-MS): Proceedings of the Annual Meetings of the American Association of Veterinary Laboratory Diagnosticians, v. 25, p. 453-464.

English.

Analytical Techniques/Quantification. CA103(11):82845m.

Schocler, H. F., and Brodesser, J., 1988, An improved extraction method for the quantitative analysis of pesticides in water. Communications of the European Communities, EUR 11350, Organic Micropollutants in the Aquatic Environment, 69-74. English.

Analytical Techniques/Quantification.

CA109(22): 196783 u.

Sharifyanova, L. N., Alyamkin, Y. N., Gerasimova, A. I., and Shabeeva, G. M., 1980, Analytical monitoring of the production of the herbicide ametryne: Khimicheskaya Promyshlennost, Seriya: Metody Analizai Kontrolya Kachestva Produktsii v Khimicheskoi Promyshlennosti, no. 12, p. 1-5. Russian. Analytical Techniques/Quantification. CA94(21):169270q.

Shaw, D. R, Peeper, T. F., and Nofziger, D. L., July/Aug 1986, Evaluation of chlorophyil fiuorescence parameters for an intact-plant herbicide bioassay: Crop Science, v. 26, no. 4, p. $756-760$.

English.

Analytical Techniques/Quantification.

ADL 86066925.
Shaw, D. R., Peeper, T. F., and Nofziger, D. L., 1985, Comparison of chlorophyll fluorescence and fresh weight as herbicide bioassay techniques: Weed Science, v. 33, no. 1, p. 29-33. English.

Analytical Techniques/Quantification. CA102(13):108044f.

Sherma, J., 1986, Determination of triazine and chlorophencxy acid herbicides in natural water samples by solid phase extraction and quantitative thin layer chromatography: Journal of Liquid Chromatography, v. 9, no. 16, p. 3433-3438. English.

Sorption to Resins,Analytical Techniques/Quantification. CA106(13):97891j.

Sherma, J., and Miller, N. T., 1980, Quantitation of the triazine herbicides atrazine and simazine in water by thin layer chromatography with densitometry: Journal of Liquid Chromatography, v. 3, no. 6, p. 901-910.

English.

Analytical Techniques/Quantification.

CA93(11):108748j.

Shin, K. H., and Moon, K. K., 1979, Analysis of atrazine herbicide residue by thin-layer chromatography: Punsok Hwahak, no. 4, p. 30-32.

Korean.

Analytical Techniques/Quantification. CA93(1):2054q.

Shin, K. H., and Mun, G. R., 1979, Determination of residual atrazine by thin layer chromatography: Choson Minjujuui Inmin Konghwaguk Kwahagwon Tongbo, v. 27, no. 4, p. 48-50.

Korean.

Analytical Techniques/Quantification. CA93(15):148222q.

Shmidel, E. B., Kalabina, L. I., and Kolomiets, L. N., 1980, Highly sensitive method for monitoring the level of toxic substances in the air of industrial zones: Neftyanoe Khozyaistvo, no. 1, p. 53-57.

Russian.

Atmospheric Observations,Analytical Techniques/

Quantification.

CA92(22):184965x.

Shoptaugh, N. H., Buckley, L. J., Ikawa, M., and Sasner, J. J., Jr., 1978, Detection of Gonyaulax toxins and other guanidine compounds on thin-layer silica gel chromatograms: Toxicon, $v$. 16 , no. 5 , p. 509-513.

English.

Analytical Techniques/Quantification.

CA90(3):17096s.

Siltanen, H., and Rosenberg, C., 1975, Investigations on pesticide residues 1975: Publication of State Institute of Agricultural Chemistry (Finland), v. 11, p. 63 pp. English.

Analytical Techniques/Quantification.

CA86(11):70230z. 
Simionescu, L., Oprescu, M., Ghinea, E., Ghinea, L., Sahleanu, V., and Dimitriu, V., 1977, The radioimmunological measurement of thyroglobulin secretion in vitro under the influence of some herbicides: Revue Roumaine de Medecine: Endocrinologie, v. 15, no. 4, p. 243-248.

English.

Toxicity,Analytical Techniques/Quantification

CA93(15):143964y.

Singh, I., Lusby, A. F., and McGuire, P. M., 1982, Mutagenicity of HPLC fractions from extracts of AAtrex-treated corn:

Environmental Mutagenesis, v. 4, no. 1, p. 45-53. English.

Toxicity,Analytical Techniques/Quantification. CA96(17):137705k.

Skryabina, T. G., Petrova, L. N., Nikonorov, E. M., and Podvigina, O. A., 1988, Complex methods for studying the composition of lubricants: Khimiya i Tekhnologiya Topliv i Masel, no. 12, p. 29-32.

Russian.

Analytical Techniques/Quantification.

CA110(12):984132.

Smit, N. S. H., and Nel, P. C., 1977, The activity of atrazine on two South African soils: Gewasproduksie, v. 6, p. 67-71. English.

Analytical Techniques/Quantification,Leaching,Sorption to Soil.

CA88(7):46270h.

Smith, A. E., 1981, Comparison of solvent systems for the extraction of atrazine, benzoylprop, flamprop, and trifluralin from weathered field soils: Journal of Agriculture and Food Chemistry, v. 29, no. 1, p. 111-115. English.

Analytical Techniques/Quantification. CA94(9):596232.

Smith, A. E., and Fitzpatrick, A., 1971, Thin-layer chromatographic procedure for the detection in soils and waters of herbicide residues commonly used in Saskatchewan: Journal of Chromatography, v. 57, no. 2, p. 303-308.

English.

Analytical Techniques/Quantification.

CA75(1):4307b.

Smith, C. N., Parrish, R. S., and Carsel, R. F., 1987, Estimating sample requirements for field evaluations of pesticide leaching: Environmental Toxicology and Chemistry, v. 6, no. 5, p. 343-357.

English.

Leaching,Analytical Techniques/Quantification. CA106(25):209321g.

Smolkova, E. J., and Pacakova, V., 1978, Liquid chromatographic separation and behavior of some substituted s-triazines on a CN-bounded stationary phase: Chromatographia, v. 11, no. 12, p. 698-702.

English.

Analytical Techniques/Quantification.

CA90(15):116291h.
Solinas, V., Melis, P., and Gessa, C., 1982, Simultaneous determination of atrazine and hydroxyatrazine by HPLC: Agrochimica, v. 26, no. 2-3, p. 138-145.

Italian.

Analytical Techniques/Quantification.

CA98(17):138861m.

Soulas, G., 1976, Bioassay of soil herbicides through the Stanford and Dement technique: Annales Agronomiques, v. 27, no. 1, p. 101-109.

French.

Analytical Techniques/Quantification.

CA86(21):151340n.

Stalder, L., and Pestemer, W., 1980, Availability of plants of herbicide residues in soil. Part I: a rapid method for estimating potentially available residues of herbicides: Weed Research, v. 20, no. 6, p. 341-347.

English.

Analytical Techniques/Quantification. CA95(3):19519j.

Stankova, O.. Cap, L., Smicka, J., and Lanikova, J., 1987, Gas chromatographic analysis of s-triazines in waters: Acta Universitatis Palackianae Olomucensis, Facultas Rerum, v. 88, no. Chem 26, p. 167-179.

English.

Analytical Techniques/Quantification. CA108(20):173268v.

Stastny, M., Benadikova, H., Nepozitek, J., and Volf, R, 1982, Determination of some s-triazine pesticides by differential pulse polarography: Sbornik Vysoke Skoly ChemickoTechnologicke v Praze, Analyticka Chemie, v. H17, p. 69-85. English.

Analytical Techniques/Quantification. CA98(21):174665j.

Steinheimer, T. R., and Brooks, M. G., 1984, Development and evaluation of a gas chromatographic method for the determination of triazine herbicides in natural water samples: Intemational Joumal of Environmental Analytical Chemistry, v. 17, no. 2, p. 97-111.

English.

Analytical Techniques/Quantification.

CA101(8):59881v.

Steinke, W., Hacker, R, Becker, K. H., and Irmer, L., 1971, Distillative separation of water vapor-volative substances: Appl. or Pr. WP 12a/149 106, 27 Jul 1970.

German.

Analytical Techniques/Quantification.

CA77(6):37031b.

Steinwandter, H., 1988, Contributions to the application of gel chromatography in residue analysis. II. A new get chromatographic system using acetone for the separation of pesticide residues and industrial chemicals: Fresenius' Zeitung fuer Analytical Chemistry, v. 331, no. 5, p. 499-502. English. Analytical Techniques/Quantification. CA110(1):2740e. 
Stoks, P. G., and Schwartz, A. W., 1979, Determination of striazine derivatives at the nanogram level by gas-liquid chromatography: Journal of Chromatography, v. 168, no. 2, p. 455-460.

English.

Degradation Products,Analytical Techniques/Quantification. CA90(12):971075.

Subach, D. J., 1981, Liquid chromatography of the s-triazines: Chromatographia, v. 14, no. 6, p. 371-373.

English.

Analytical Techniques/Quantification.

CAO6(8):62336e.

Subra, P., Hennion, M. C., Rosset, R, and Frei, R. W., 1988, Recovery of organic compounds from large-volume aqueous samples using on-line liquid chromatographic preconcentration techniques: Journal of Chromatography, v. 456, no. 1, p. 121 141.

English.

Sorption to Resins,Analytical Techniques/Quantification. CA110(6):44622y.

Supin, G. S., Fainshraiber, M. Y., Mel'nikova, I. A., and Motorova, T. N., 1977, Polarography of some derivatives of striazines: Zhumal Obshchei Khimii, v. 47, no. 10, p. 23382342.

Russian.

Analytical Techniques/Quantification.

CA88(4):29579y.

Suprock, J. F., and Vinopal, J. H., 1987, Behavior of 78 pesticides and pesticide metabolites on four different ultrabond gas chromatographic columns: Journal of the Association of Official Analytical Chemistists, v. 70, no. 6, p. 1014

1017.

English.

Analytical Techniques/Quantification.

CA108(7):50716g.

Surzhikova, L. V., and Vasil'ev, A. F., 1970, Quantitative ir absorption spectrometric analysis of atrazine, simazine, and propazine in commercial products and wetting powders: Khimicheskie Sredstva Zashchity Rastenii, v. 1, p. 210-216. Russian.

Chemical/Physical Properties,Analytical Techniques/Quantification. CA78(11):68013x.

Suzuki, K, Miyashita, K, and Kashiwa, T., 1970, Systematic identification and determination of pesticides. 2. Lower limits detection of pesticides on thin layer plates: Noyaku

- Kensasho Hokoku, v. 10, p. 24-31.

Japanese.

Analytical Techniques/Quantification.

CA75(1):4461x.

Suzuki, K, Nagayoshi, H., and Kashiwa, T., 1976, Studies on the systematic identification and determination of pesticides. Part X. The systematic separation and identification of pesticides in the fourth division: Agricultural and Biological Chemistry, v. 40, no. 5, p. 845-850. English.

Analytical Techniques/Quantification. CA85(7):42005r.
Suzuki, K, Nagayoshi, H., and Kashiwa, T., 1974, Systematic identification and determination of pesticides. VIII. Systematic separation and identification of pesticides in the second and third division: Agricultural and Biological Chemistry, v. 38, no. 8, p. 1433-1442. English.

Analytical Techniques/Quantification. CA82(5):26671n.

Swain, D. J., 1979, Effects of drying and duration of storage on the extractable atrazine content of soil samples: Journal of Agriculture and Food Chemistry, v. 27, no. 4, p. 915-916. English. Analytical Techniques/Quantification. CA91(7):50933f.

Szlobodnyik, J., Dura, G., and Desi, I., 1980, Electromyographic methods in the study of pesticide toxicology: Nehezvegyipari Kutato Intezet Kozlemenyei, v. 10, p. 183-190. Hungarian. Toxicity,Analytical Techniques/Quantification. CA94(11):78015u.

Szocs, J., 1977, The identification, separation and semiquantitative determination of certain triazinic pesticides using thin-layer chromatography: Revue de Medecine (Tirgu-Mures), v. 23, no. 1, p. 82-84.

Romanian.

Analytical Techniques/Quantification. CA88(15):100192z.

Tafuri, F., Patumi, M., Marucchini, C., and Businelli, M., 1982, Extraction and identification of a new degradation product of atrazine in the soil: Pesticide Science, v. 13, no. 6, p. 665-669.

English. Degradation Products,Analytical Techniques/Quantification. CA99(19):153762u.

Tanaka, A., Massago, H., Hara, Y., and Ujiie, A., 1984, Studies on simple analytical methods for trace amounts of agricultural chemicals in water and acute toxicities for fishes. IV. Simple and rapid simultaneous multicomponent analysis for organic nitrogen agricultural chemicals and acute toxity of carbamate and dinitroaniline pesticides: Yosui to Haisui, v. 26, no. 12, p. 1306-1316. Japanese.

Toxicity,Analytical Techniques/Quantification. CA102(21):180478t.

Tancogne, J., 1987, Biological methods for measuring residual pesticides in tobacco: Annales du Tabac, Section 1 or 2. Spec., p. 69-77.

French.

Analytical Techniques/Quantification. CA109(7):51950m.

Tatar, V., Popl, M., and Spalova, J., 1985, A comparison of injection systems for capillary columns for the gas chromatographic trace analysis of pesticides using FID and NP detectors: Sbornik Vysoke Skoly Chemicko-Technologicke v Praze, Analyticka Chemie, v. H20, p. 147-163.

English.

Analytical Techniques/Quantification.

CA106(11):80207t 
Tchan, Y. T., and Chiou, C. M., 1977, Bioassay of herbicides by bioluminescence: Acta Phytopathologica Academiciae

Scientriarum Hungaricae, v. 12, no. -12, p. 3-11.

English.

Analytical Techniques/Quantification.

CA88(21):147229g.

Tchan, Y. T., Roseby, J. E., and Funnell, G. R., 1975, New rapid specific bioassay method for photosynthesis-inhibiting herbicides: Soil Biology and Biochemistry, v. 7, no. 1, p. 39-44.

English.

Analytical Techniques/Quantification.

CA82(25):165722t.

Tehrani, A. Y., 1985, Automating an existing analytical chromatograph for preparative HPLC (high performance liquid chromatography): American Laboratory (Fairfield, Conn.), v. 17 , no. 2 , p. $42,44,46,49-50$.

English.

Analytical Techniques/Quantification.

CA103(9):70865e.

Tekel, J., Farkas, P., Kovacicova, J., and Szokolay, A., 1988, Analysis of herbicide residues in sugar beet and sugar: Nahrung, v. 32, no. 4, p. 357-363.

English.

Analytical Techniques/Quantification.

CA109(17):148067s.

Tekel, J., Spanar, M., and Kovacicova, J., 1988, Residues of triazine herbicides in milk: Ceskoslovenska Hygiena, v. 33, no. 9, p. 531-537.

Slovenian.

Analytical Techniques/Quantification,Miscellaneous

Environmental.

CA110(7):56071f.

Tekel, J., Farkas, P., Schultzova, K., Kovacicova, J., and Szokolay, A., 1988, Analysis of triazine herbicide residues in butter and pasteurized milk: Zeitschrift fuer Lebensmittel - Untersuchung und Forschung v. 186, no. 4, p. 319-322. English.

Analytical Techniques/Quantification.

CA109(9):72128q.

Tekel, J., and Farkas, P., 1988, Determination of triazine herbicide residues in butter. Sbornik UVTIZ, Potravin Vedy, v. 6 , no. 1 , p. $23-28$

Slovenian.

Analytical Techniques/Quantification.

CA109(11):91398u.

Thiede, H., 1977, Experiences with a plant bioassay for the determination of herbicide residues in soil: Gesunde Pflanz, v. 29 , no. 10 , p. 224-226, 228.

German.

Analytical Techniques/Quantification.

CA88(7):46264j.
Thompson, J. F., Mann, J. B., Apodaca, A. O., and Kantor, E. J., 1975, Relative retention ratios of ninety-five pesticides and metabolites on nine gas-liquid chromatographic columns over a temperature range of 170 to 204.deg. in two detection modes: Journal of the Association of Official Analytical Chemists, v. 58 , no. 5, p. $1037-1050$.

English.

Analytical Techniques/Quantification,Chemical/Physical Properties.

CA83(25):202708m.

Thorneburg, R. P., and Tweedy, J. A., 1973, Rapid procedure to evaluate the effect of pesticides on nitrificaiton: Weed Science, v. 21, no. 5, p. 397-399.

English.

Analytical Techniques/Quantification.

CA80(3):11071b.

Tindle, R. C., Gehrke, C. W., and Aue, W. A., 1968, Improved GLC method for s-triazine residue determination: Journal of the Association of Official Analytical Chemists, v. 51, no. 3, p. 682-688.

English.

Analytical Techniques/Quantification.

CA69(7):26088j.

Tompkins, G. A., McIntosh, T. H., and Dunigan, E. P., 1968, Use of the Stanford-DeMent bioassay to study atrazine-soil reactions: Soil Science Society of America, Proceedings, v. 32, no. 3, p. 373-377.

English.

Analytical Techniques/Quantification.

CA69(11):42954u.

Tonogai, Y., Hasegawa, Y., Nakamura, Y., and Itoh, Y., 1988, Simultaneous determination of nine kinds of triazine herbicides in foods by gas chromatography. Eisei Kagaku, v. 34 , no. 5 , p. $421-429$.

Japanese.

Analytical Techniques/Quantification. CA110(3):22409g

Totir, N., Marchidan, S., Volanschi, C., Cimpoeru, N., and Andrei, F. I., 1977, Quantitative determination of trace amounts of s-triazine herbicides in waste waters by physicochemical methods: Revre Roumaine de Chimie, v. 22, no. 1, p. 137-143.

English.

Analytical Techniques/Quantification.

CA87(4):28416k.

Traldi, P., Maccioni, A. M., and Cecchinato, F., 1987, BParticle-induced decomposition of mass-selected ionic species: Organic Mass Spectrometry, v. 22, no. 5, p. 301-303. English.

Analytical Techniques/Quantification.

CA108(3):21230p.

Trofimova, S. I., 1969, Determination of some triazine group herbicides in the air: Gigiena Primeneniya, Toksikologiya Pestitsidov i Klinika Otravienii, v. 7, p. 636-640. Russian.

Atmospheric Observations,Analytical Techniques/

Quantification.

CA76(21):122728h. 
Trofimova, S. I., 1969, Novoe v Oblasti Promyshlenno - Sanitarnoi Khimii, p. 80-83.

Russian.

Atmospheric Observations,Analytical Techniques/

Quantification.

CA72(4):15540m.

Tsimbalist, N. I., 1979, Behavior of some herbicides in soils during its fertilization and liming. Pochvovedenie, no. 3, p. 139-144.

Russian.

Analytical Techniques/Quantification,Leaching. CA91(1):1226u.

Tsukerman, V. G., 1980, Determination of isomers of hexachlorocyclobexane and chlorotriazines in the soil: Khimiya v Sel'skom Khozyaistve, v. 18, no. 10, p. 51-52. Russian.

Analytical Techniques/Quantification. CA93(25):232460y.

Tsukerman, V. G., and Lunev, M. I., 1983, Analysis of chloroorganic and sym-triazine pesticides by gas liquid chromatography and study of their behavior in soil: (s1Sin(s0S Rezul't. Razrab. Metodov Anal. Pochv, Rast. Udobr: Moscow, USSR, Tsentr. Inst. Agrokhim. Obshuzhivaniya Sel'sk. Khoz., p. 113-123.

Russian.

Sorption to Soil,Analytical Techniques/Quantification, Biodegradation/Biotransformation.

CA103(11):83387a.

Turbak, S. C., Olson, S. B., and McFeters, G. A., 1986, Comparison of algal assay systems for detecting waterborne herbicides and metals: Water Research, v. 20, no. 1, p. 9196.

English.

Toxicity,Surfacewater Observations,Analytical Techniques/ Quantification.

CA104(8):56040w.

Turcu, S., Cirstea, M., Chivulescu, E., and Dragusin, E., 1978, Thermal decomposition of 2-substituted 4,6-bis(alkylamino)striazines: Revista de Chimie (Bucharest), v. 29, no. 2, p. 109-113.

Romanian.

Hydrolysis/Chemical Reactions,Analytical Techniques/

Quantification.

CA89(13):107554y.

Ullman, F. g., June 1976, Investigation of laser raman spectroscopy for analysis of water quality. U.S. NTIS, PB Rep, PB-261238.

English.

Analytical Techniques/Quantification. CA87(20):156860n.

Van Buuren, C., Lawrence, F. J., Brinkman, U. A. T., Honigberg, I. L., and Frei, R W., 1980, Reversed-phase liquid chromatography of basic drugs and pesticides with a fluorigenic ion-pair extraction detector: Analytical Chemistry, v. 52, no. 4, p. $700-704$.

English. Analytical Techniques/Quantification.

CA92(19):159896t.
Van den Heede, M., and Heyndrickx, A., 1976, Gas chromatographic procedure for the determination of s-triazine herbicides in biological samples: Mededelingen van de Faculteit

Landbouwwetenschappen, Rijksuniversiteit Gent, v. 41, no. 2 Pt. 2, p. 1529-1542.

English.

Analytical Techniques/Quantification. CA86(11):66305k.

Van den Heede, M., and Heyndrickx, A., 1976, A thin layer chromatographic separation of some symmetric-triazine herbicides: Mededelingen van de Faculteit

Landbouwwetenschappen, Rijksuniversiteit Gent, v. 41, no. 2, Pt. 2, p. 1457-1465.

English.

Degradation Products,Analytical Techniques/Quantification. CA86(13):84568c.

Van Dyk, L. P., Lotter, L., De Beer, P. R, Reyskens, D. H. J.P., Viljoen, A. J., and Prinsloo, S. M., 1985, Inter-laboratory calibration for the quality control of pesticide analysis (1982-1983): Analyst (London), v. 110, no. 9, p. 1053-1058. English.

Analytical Techniques/Quantification. CA104(9):67585d.

Vassalli, C., Levi, Y., Gibert, M., Rosset, R., and Dutang, M., 1987, Detection of organic pollutants in surface water by liquid chromatography and diode array spectrometry: Journal Francais d'Hydrologie, v. 18, no. 1, p. 37-47.

French.

Analytical Techniques/Quantification.

CA108(14):118575t.

Vermeulen, N. M. J., Apostolides, Z., Potgieter, D. J. J., Nel, P. C., and Smit, N. S. H., 1982, Separation of atrazine and some of its degradation products by high-performance liquid chromatography: Journal of Chromatography, v. 240, no. 1, p. 247-253.

English.

Chemical/Physical Properties,Analytical Techniques/

Quantification,Degradation Products. CA97(9):67613y.

Vickrey, T. M., Karlesky, D. L., and Blackmer, G. L., 1980, Colorimetry and high performance liquid chromatography of atrazine residues in soil: comparison of methods: Journal of the Association of Official Analytical Chemists, v. 63, no. 3, p. $506-510$.

English.

Analytical Techniques/Quantification.

CA93(5):39281n.

Viden, I., Rathouska, Z., Davidek, J., and Hajsłova, J., 1987, Use of gas liquid chromatography/mass spectrometry for triazine herbicide residues analysis in forage and milk: Zeitschrift fuer Lebensmittel - Untersuchung und - Forschung v. 185 , no. 2, p. 98-105.

English.

Analytical Techniques/Quantification. CA107(17):152983p. 
Violova, A., Hauskrecht, P., Antalova, O., and Dubalaj, J., 1986, Isolation of 2-(isopropylamino)-4-(ethylamino)-6-chloro-striazine: Appl. 82/9125, 14 Dec 1982.

Slovenian

Hydrolysis/Chemical Reactions,Analytical Techniques/

Quantification.

CA106(1):5089c.

Violova, A., Hauskrecht, P., Antalova, O., Dubalaj, J., and Cerny, P., 1986, Isolation of 2-(isopropylamino)-4 (ethylamino)-6-chloro-s-triazine: Appl. 82/9126, 14 Dec 1982. Slovenian.

Analytical Techniques/Quantification,Hydrolysis/Chemical Reactions.

CA106(1):5090w.

Virchenko, E. P., Bobovnikova, T. I., Ladonin, V. F., and Lunev, M. I., 1983, Seedling method as a biotest for evaluating the phytotoxicity of herbicide residues in the soil: Khimiya $v$ Sel'skom Khozyaistve, no. 4, p. 17-18. Russian.

Analytical Techniques/Quantification. CA98(25):211435g.

Vitali, T., Gaetani, E, Laureri, C. F., and Branca, C., 1976, Liquid-liquid chromatography at high pressures. Correlation between retention time and biological activity for 1,3,5triazine derivatives: Farmaco, Edizione Scientifica, v. 31, no. 1, p. $58-65$.

Italian.

Analytical Techniques/Quantification.

CA84(13):85601d.

Von der Hude, W., Behm, C., Guertler, R, and Basler, A., 1988, Evaluation of the SOS chromotest: Mutation Research, v. 203, no. 2, p. 81-94.

English.

Analytical Techniques/Quantification.

CA109(1):2124m.

Voss, G., and Blass, W., November 1973, A solvent-saving extraction-evaporation apparatus developed for residue analysis of pesticides: Analyst, v. 98, no. 1172, p. 811-812. English.

Analytical Techniques/Quantification.

Voyksner, R. D., McFaddden, W. H., and Lammert, S. A., 1987, Application of thermospray HPLC/MS/MS for determination of triazine herbicides: Chemical Analysis (N.Y.), v. 91, no.

Appl. New Mass Spectrom. Tech. Pestic. Chem., p. 247-258.

English.

Analytical Techniques/Quantification.

CA108(3):17662p.

Voznakova, Z, Ondrej, J., and Popl, M., 1982, Determination of trace quantities of s-triazines in waters: Sbornik Vysoke Skoly chemicko-Technologicke v Praze, Analyticka Chemie, v. H17, p. 57-68.

English.

Analytical Techniques/Quantification.

CA98(22):185260z.
Voznakova, Z., Popl, M., and Schaab, E., 1988, Determination of atrazine, chlorpropham and triallate in soil: Sbornik Vysoke Skoly Chemicko-Technologicke v Praze, Analyticka Chemie, v. H22, p. 131-147.

English.

Analytical Techniques/Quantification.

CA108(17):145286f.

Wachob, G. D., 1984, Solid-phase extraction of triazine herbicides from soil samples: Liquid Chromatography, v. 2, no. 10 , p. $756,758-759$.

English.

Analytical Techniques/Quantification,Sorption to Soil. CA102(1):1838r.

Walters, S. M, 1983, Preliminary evaluation of high-performance liquid chromatography with photoconductivity detection for the determination of selected potential food contaminants: Journal of Chromatography, v. 259, no. 2, p. 227-242.

English.

Analytical Techniques/Quantification.

CA98(25):214229d.

Wegman, R. C. C., Van den Broek, H. H., Hofstee, A. W. M., and Marsman, J. A., 1984, Determination of triazines, organophosphorus containing pesticides and aromatic amines in soil samples: Mededelingen van de Faculteit

Landbouwwetenschappen, Rijksuniversiteit Gent, v. 49, no. 3b, p. 1231-1239.

English.

Analytical Techniques/Quantification.

CA102(9):73989p.

Wiemer, B., 1985, Thin-layer chromatographic separation and determination of triazines: Acta Hydrochimica et Hydrobiologica, v. 13, no. 4, p. 527-529.

German.

Analytical Techniques/Quantification.

CA103(15):118044r.

Williamson, J. E., and Evans, N., 1981, Rapid combined liquid chromatography/mass spectrometry method for quantitative analysis of atrazine: Journal of High Resolution

Chromatography and Chromatography Communications, v. 4, no. 3, p. 131-131.

Engtish.

Analytical Techniques/Quantification.

CA94(25):203694t.

Wilson, B. P., and Cochrane, W. P., 1975, Comparison of the Coulson and Hall electrolytic conductivity detectors for the determination of nitrogen-containing pesticides: Journal of Chromatography, v. 106, no. 1, p. 174-179.

English.

Analytical Techniques/Quantification. CA83(7):54375h.

Wilson, H. P., and Ilnicki, R. D., 1968, Combinations of oils and surfactants for enhancing the postemergence activity of atrazine in corn: Proceedings of the Northeastem Weed Control Conference, v. 22, no. Jan., p. 110-114.

English.

Analytical Techniques/Quantification.

CA68(19):86342b. 
Wood, G., and Halliday, C. G., 1981, Proceedings of the Annual Workshop on Pesticide Residue Analysis (West Canada), 16th, p. 168-169.

English.

Analytical Techniques/Quantification.

CA96(1):1966p.

Woodrow, J. E., Majewski, M. S., and Seiber, J. N., 1986, Accumulative sampling of trace pesticides and other organics in surface water using XAD-4 resin: Journal of Environmental Science and Health, Part B, v. B21, no. 2, p. 143-164.

English.

Analytical Techniques/Quantification.

CA105(3):20342c.

Xu, Y., Lorenz, W., Pfister, G., Bahadir, M., and Korte, F., 1986, Residue analysis of triazine herbicides in soil: comparison of a capillary gas chromatographic and a highperformance liquid chromatographic method: Fresenius' Zeitung fuer Analytical Chemistry, v. 325, no. 4, p. 377-380.

English.

Analytical Techniques/Quantification.

CA106(1):1720d.

Young, H. Y., and Chu, A, 1973, Microdetermination of chloro-striazines in soil by gas-liquid chromatography with nickel electron capture or electrolytic conductivity detection: Journal of Agriculture and Food Chemistry, v. 21, no. 4, p. 711-713.

English.

Analytical Techniques/Quantification.

CA79(15):88145r.

Zadrozinska, J., and Klosinska, J., 1984, Determination of herbicide residues from a group of derivatives of aromatic acids in plant material: Roczniki Panstwowego Zakladu Higieny, v. 35, no. 5, p. 423-429.

Polish.

Analytical Techniques/Quantification.

CA103(5):36261v.

Zadrozinska, J., Ludwicki, J. K, and Klosinska, J., 1985, Determination of residues of triazine herbicides in plant material: Roczniki Panstwowego Zakladu Higieny, v. 36, no. 4, p. 313-321.

Polish.

Uptake by Biota,Analytical Techniques/Quantification. CA105(3):20341b.

Zawadzka, H., Adamczewska, M., and Elbancwska, H., 1973, Determination of herbicides Simazine, Atrazine, and Prometryne in natural water and sewage by thin-layer chromatography: Chemica Analityczna (Warsaw), v. 18, no. 2, p. 327-331.

Polish.

Analytical Techniques/Quantification.

CA79(19):112259d.

Zemanek, J., Kovar, J., and Sterba, R, 1976, Biological methods of herbicide residue determination in water. Ochr Rostl, $v$. 12, no. 2, p. 99-107.

Czechoslovakian.

Leaching,Analytical Techniques/Quantification.
Zielinski, W. L., Jr., Fishbein, L., and Martin, L. J., 1967, Relation of structure to sensitivity in the electron capture analysis of pesticides: Journal of Gas Chromatography, v. 5, no. 11, p. 552-555.

English.

Chemical/Physical Properties,Analytical Techniques/

Quantitication.

CA68(5):21156z. 
Albert, R. E., 1980, Herbicidal complex and formulation: Appl. or Pr. 917938, 22 Jun 1978.

English.

Degradation Products.

CA93(15): $144728 \mathrm{~m}$.

Ali, A., and Souza Machado, V., 1984, A comparative analysis of leaf chlorophyll fluorescence, Hill reaction activity and $14 \mathrm{C}$-atrazine tracer studies to explain differential atrazine susceptibility in wild tumip rape (Brassica campestris) biotypes: Canadian Journal of Plant Science, v. 64, no. 3, p. 707-713.

English.

Uptake by Biota,Biodegradation/Biotransformation,Degradation Products.

CA101(21):186049e.

Allan, G. G., 1986, Liquid biologically active compositions: Appl. 85/11421, 13 Nov 1985; US Appl. 671731, 15 Nov 1984. English.

Degradation Products.

CA105(9):74412u.

Allan, G. G., 1985, Wood pulping with s-triazines for improved paper: Appl. 84/15011, 28 Sep 1984; US Appl. 537876, 30 Sep 1983; US Appl. 537926, 30 Sep 1983; US Appl. 537927, 30 Sep 1983; US Appl. 651751, 19 Sep 1984.

French.

Degradation Products.

CA104(8):52348e.

Andriska, V., Gorog, K, and Grega, E., 1975, Doklady i Soobshcheniva - Mezhdunarodnyi Kongress po Zashchite Rastenii,8th, p. 29-39.

Russian.

Degradation Products.

CA89(3):18230x

Anon., 1984, Oxygen-containing organic compounds: Appl. 83/78153, 2 May 1983.

Japanese.

Degradation Products.

CA102(24):205747v.

Anon., 1978, 2-Cyanamino-4,6-bis-<alkyl(dialkyi)amino>-symtriazines: Appl. or Pr. 76/147586, 7 Dec 1976.

Japanese.

Degradation Products.

CA90(1):6424w.

Anon., 23 Nov 1979, Atrazine: tolerances for residues: Federal Register, v. 44, no. 227, p. 67115-67116.

English.

Uptake by Biota,Degradation Products.

CA92(11):92849j.

Anon., 1970, Chloroamino-S-triazines: Rom. RO 52080, 24 Apr 1970 , 3 p.

Romanian.

Hydrolysis/Chemical Reactions, Degradation Products.

CA73(25):131044x.
Anon., 1979, Continuous process for chiorobis(alkylamino)-striazines: IT Appl. 77/25474, 7 Jul 1977.

French.

Degradation Products.

CA91(23):193340w.

Anon., 1969, Herbicidal 2-chloro-4,6-disubstituted-amino-striazines: Fr. FR 1562266, 4 Apr 1969, 7 p.

French.

Degradation Products.

CA72(11):55457w.

Anon., 1985, Nitrolime: Appl. 83/220300, 22 Nov 1983.

Japanese.

Degradation Products.

CA104(5):33560b.

Anon., 1982, Piperazine derivative: Appl. 81/116539, 24 Jul 1981. Japanese.

Degradation Products.

CA97(25):216228f

Anon., 1983, Positive-type photoresists: Appl. 82/74417, 30 Apr 1982.

Japanese.

Degradation Products.

CA100(20):165446w.

Anon., 1969, Preparation of 2-chloro-4,6-di(alkylamino)-striazines: Rom. RO 52054, 18 Nov 1969, 5 p.

Romanian.

Degradation Products.

CA73(13):66628z.

Anon., 1983, Regenerating agents for nitriding and carburizing salt baths: Appl. 82/74836, 4 May 1982.

Japanese.

Degradation Products.

CA100(16):125188g.

Anon., 1 Apr 1975, Simazine: Federal Register, v. 40, no. 63, p. 14592.

English.

Degradation Products.

CA83(1):7336m.

Anon., 1 Apr 1975, Simazine. Tolerances for residues: Federal Register, v. 40, no. 63, p. 14597.

English.

Degradation Products.

CA83(1):7333h:

Anon., 12 Jan 1978, Simazine; tolerances for residues: Federal Register, v. 43, no. 8, p. $17 \%$.

English.

Degradation Products.

CA88(15):103440q.

Anon., 1979, Substituted triazine: US Appl. 871656, 23 Jan 1978.

Japanese.

Degradation Products.

CA91(25):211446s. 
Anon., F. R. Ger., 1980, Manufacture of hydrophobic cyanuric chloride particles: DE Appl. 2839384, 11 Sep 1978.

Japanese.

Degradation Products.

CA93(13):132520z.

Badilescu, S., Talpus, V., and Racota, R, 1978, Dissociation constants of some hydroxy-s-triazines: Revista de Chimie (Bucharest), v. 29, no. 11, p. 1072-1074.

Romanian.

Degradation Products, Chemical/Physical Properties. CA9O(17):137128a.

Bakke, J. E., Larson, J. D., and Price, C. E., 1972, Metabolism of atrazine and 2-hydroxyatrazine by the rat: Journal of Agriculture and Food Chemistry, v. 20, no. 3, p. 602-607. English.

Degradation Products,Biodegradation/Biotransformation. CA77(11):71068d.

Baldi, L., Ferrari, C, and Francese, R, 1980, Chloroamino-striazines: IT Appl. 75/7013, 3 Jan 1975.

Italian.

Hydrolysis/Chemical Reactions,Degradation Products. CA94(23):192386r.

Baldi, L., Giorcelli, G., and Francese, R, 1980, Chlorobis(alkylamino)-s-triazines: Tr Appl. 77/28808, 20 Oct 1977.

English.

Degradation Products.

CA92(25):215467t.

Barer, S. J., Stockel, R. F., and Vit, J., 1976, Tri-substituted triazines: Appl. or Pr. 360,740, 16 May 1973.

English.

Degradation Products. CA84(15):105662e.

Behki, R. M., and Khan, S. U., July/Aug 1986, Degradation of atrazine by Pseudomonas: N-dealkylation and dehalogenation of atrazine and its metabolites: Journal of Agriculture and Food Chemistry, v. 34, no. 4, p. 746-749.

English.

Analytical Techniques/Quantification,Biodegradation/ Biotransformation,Degradation Products.

CA105(5):37405y.

Beremzhanov, B. A., Nurakhmetov, N. N., and Nurlybaev, I. N., 1973, Thermal characteristics of urea and its salts:

- Prikladnaya i Teoreticheskaya Khimiya, v. 3, p. 5-15.

Russian.

Degradation Products.

CA83(25):205733b.

Berkowitz, S., 1980, <(Monotrichloro)tetra(monopotassium dichloro) > pentaisocyanurate: Appl. of Pr. 78/18194, 16 Jun 1978.

French.

Degradation Products. CA93(1):8218t.

Berkowitz, S., 1978, Dihalogenated isocyanurate salts: US Appl. 721297,8 Sep 1976.

German.

Degradation Products.

CA88(25):190909r.
Berikowitz, S., 1979, Preparation of

<mono(trichloro)tetra(monopotassium)dichloro)> pentaisocyanurate: Appl. or Pr. 78/26446, 7 June 1978. English.

Degradation Products,Hyrtrolysis/Chemical Reactions. CA93(9):95300e.

Berkowitz, S., and Juelke, C. V., 1976, Thermal high-pressure hydrolysis of acid waste waters containing cyanuric acid and its derivatives: US Appl. 569019, 17 Apr. 1975.

German.

Degradation Products.

CA86(14):95617u.

Bertelli, G., and Locatelli, R, 1982, Self-extinguishing polyolefinic compositions: Appl. 82/103721, 30 Apr 1982; IT Appl. 81/21459, 30 Apr 1981.

English.

Degradation Products,Hydrolysis/Chemical Reactions. CA98(10):73419b.

Bitzer, D., 1980, Diamino-s-triazines: Appl. or Pr. 2834543, 14 Feb 1980, 16 p.

German.

Hydrolysis/Chemical Reactions, Degradation Products. CA93(1):8217s.

Bitzer, D., 1981, Diamino-s-triazines: Appl. or Pr. 2940780, 8

Oct 1979.

German.

Hydrolysis/Chemical Reactions,Degradation Products. CA95(5):43177s.

Blank, 1., 1973, Acrylic or methacrylic copolymers: GB Appl. 37, 936/71, 12 Aug 1971.

German.

Degradation Products. CA79(3):14455v.

Boitsov, E. N., Mushkin, Y. I., and Kartik, V. M., 1969, Analysis of cyanamide derivatives with the separation of mixtures on ion-exchange resins: Zavodskaya Laboratoriya, v. 35, no. 7, p. $790-792$.

Russian.

Degradation Products.

CA72(6):28231m.

Bostian, L. C, 1972, Trisubstituted s-triazine chloroacetaldehyde adducts as herbicides: Appl. or Pr. 869, 378, 24 Oct 1969.

English.

Degradation Products.

CA81(9):49705v.

Bradway, D. E., Lores, E. M., and Edgerton, T. R, 1980, Minimizing occupational exposure to pesticides: recent developments in methodology for monitoring pesticide metabolites in human urine: Residue Reviews, v. 75, p. 51-65. English.

Degradation Products,Analytical Techniques/Quantification. CA94(26):213335r. 
Bradway, D. E., and Moseman, R. F., 1982, Determination of urinary residue levels of the $\mathrm{N}$-dealkyl metabolites of triazine herbicides: Joumal of Agriculture and Food Chemistry, v. 30, no. 2, p. 244-247.

English.

Degradation Products,Analytical Techniques/Quantification, Uptake by Biota,Biodegradation/Biotransformation.

CA96(13):98864q.

Brechbuehler, H. U., and Mattern, G., 1983, Triazine diptericides: Appl. 78/12886, 19 Dec 1978.

German.

Degradation Products.

CA100(7):47095h.

Bromby, N. G., 1972, Lowering the primary aryl amine content in diarylamines: GB Appl. 8941/71, 7 Apr 1971.

German.

Degradation Products.

CA78(1):3927d.

Brown, C. B., and White, J. L, 1969, Reactions of 12 s-triazines with soil clays: Soil Science Society of America,

Proceedings, v. 33, no. 6, p. 863-867.

English.

Degradation Products, Chemical/Physical Properties,Sorption to Soil,Hydrolysis/Chemical Reactions.

CA72(9):42089c.

Brown, M. S., 1974, Substituted triazines: Appl. or Pr. 142,758, 12 May 1971.

English.

Degradation Products.

CA81(15):91586g.

Bunting, K. R, Dobry, A., and Gorman, J., 1971, Statistical studies of high-temperature grease life tests: NLGI (National Lubrication and Grease Institute) Spokesman, v. 35, no. 4, p. 106-115.

English.

Degradation Products.

CA75(14):89775a.

Burrows, E. P., Brueggemann, E. E., Hoke, S. H., McNamee, E. H., and Baxter, L. J., 1984, Nitroguanidine wastewater pollution control technology: phase II. Wastewater characterization and analytical methods development for organics: Report, USAMBRDL-TR-8311.

English.

Degradation Products, Wastewater Observations,Analytical Techniques/Quantification.

CA102(2):12055j.

Burton, W. B., 1982, Synthesis of 4-azido-2-isopropylamino-6ethylamino-s-triazine (ring UL 14C): Microchemical Journal, v. 27 , no. 3, p. $429-432$.

English.

Degradation Products,Hydrolysis/Chemical Reactions.

CA98(1):4521s.
Businelli, M., Patumi, M., Marucchini, C., and Tafuri, F., 1978, Atrazine and atrazine metabolite residues in soil and maize: Annali della Facolta di Agraria, University degli Studi di Perugia, v. 32, no. 2, p. 891-901.

Italian.

Degradation Products,Field Residuals,Volatilization. CA92(1):1573a.

Busse, W. F., and Bruner, W. M., 1969, Flame-retardant poly(oxymethylene) composition: U.S. US 3485793, 23 Dec 1969, 5 p.

English.

Degradation Products.

CA72(10):44503g.

Capriel, P., and Haisch, A, 1983, Uptake of atrazine metabolites by oats nine years after the herbicide application:

Zeitschrift fuer Pflanzenemaehrung und Bodenkunde, v. 146, no. 6, p. $736-740$.

German.

Uptake by Biota,Degradation Products.

CA100(9):63427y.

Capriel, P., Haisch, A., and Khan, S. U., 1985, Distribution and nature of bound (nonextractable) residues of atrazine in a mineral soil nine years after the herbicide application: Journal of Agriculture and Food Chemistry, v. 33, no. 4, p. 567-569.

English.

Sorption to Soil,Degradation Products,Analytical Techniques/ Quantification,Wadj.

CA103(5):33437w.

Ceausescu, E., Comilescu, A., Dimonie, M., Nicolescu, E. Popescu, M., Coca, S., Nicu, M., Pete, D., Moraru, I., and et al., 1984, Cyclopentene polymerization: Appl. 107933, 21 Jun 1982.

Romanian.

Degradation Products.

CA104(6):34487v.

Chen, J. T., 1967, Infrared absorption spectra and polymeric structures of three s-triazine herbicides and their metabolites: Journal of the Association of Official Analytical Chemists, v. 50, no. 3, p. 595-600.

English.

Degradation Products, Chemical/Physical Properties. CA67(13):63556q.

Chepurova, M. B., Kobzova, R. I., and Skryabin, V. P., 1981, Effectiveness of ammeline greases in rolling friction: Khimiya i Tekhnologiya Topliv i Masel, no. 5, p. 23-25. Russian.

Degradation Products.

CA95(20):172202v.

Chepurova, M. B., Kobzova, R. I., Sazonova, N. S., and Sidor, K. S., 1984, Thermal oxidation stability of ammeline lubricating greases: Khimiya i Tekhnologiya Topliv i Masel, no. 2, p. 3941.

Russian.

Degradation Products.

CA100(16):123659n. 
Chepurova, M. B., and Kobzova, R. 1., 1985, Thermal stability of ammeline greases: Khimiya i Tekhnologiya Topliv i Masel, no. 5, p. 41.

Russian.

Degradation Products.

CA103(6)39464z.

Christian, J. B., 1979, Torque characteristics of lubricating greases in miniature bearings: NLGI Spokesman, v. 43, no. 5 , p. 160-165.

English.

Degradation Products, Chemical/Physical Properties. CA91(20):160011m.

Christian, J. B., 1970, Grease compositions stable up to 600 .deg F: U.S. US 3525690, 25 Aug 1970, 3 p.

English.

Degradation Products.

CA73(16):79214m.

Christian, J. B., 1970, Grease composition based upon an inhibited silicone fluid, for use at high temperatures and high speeds: U.S. US 3518189, 30 Jun 1970, 2 p.

English.

Degradation Products.

CA73(12):57758q.

Christian, J. B., 1970, Grease compositions for vacuum and high temperature applications: U.S. US 3536621, 27 Oct 1970, 2 p. English.

Degradation Products.

CA74(2):5314t.

Christian, J. B., 1973, Grease composition: Appl. or Pr. 881,918, 3 Dec 1969.

English.

Degradation Products, Chemical/Physical Properties.

CA79(2):7706z.

Christian, J. B., and Bunting, K. R, 1967, Advanced aerospace greases: Industrial and Engineering Chemistry Product

Research and Development, v. 23, no. 2, p. 52-56.

English.

Degradation Products.

CA67(2):4583y.

Colby, T. H., Freitas, E. R., and Durland, W. R, 1979, Substituted triazine: US Appl. 871656, 23 Jan 1978. English.

Hydrolysis/Chemical Reactions,Degradation Products. CA92(9):76558h.

Conti, G. G., Quintodei, V., Aquilanti, A., and Sprocati, M. T., 1983, Evaluation of the behavior of residues of atrazine and its dealkylated metabolites. I. Determination of residues in the soil: Notizario Sulle Malattie delle Piante, v. 104, p. 147-168.

Italian.

Degradation Products,Biodegradation/Biotransformation,Field Residuals,Analytical Techniques/Quantification. CA100(25):204976r.
Cook, A. M., Beilstein, P., and Huetter, R, 1983, Qualitative analysis of wastewater from ametryne production: International Journal of Environmental Analytical Chemistry, v. 14 , no. 2 , p. $93-98$

English.

Degradation Products,Analytical Techniques/Quantification. CA98(26):221492n.

Cook, A. M., and Huetter, R, 1982, Ametryne and prometryne as sulfur sources for bacteria: Applied Environmental Microbiology, v. 43, no. 4, p. 781-786.

English.

Degradation Products,Biodegradation/Biotransformation. CA97(3):20413t.

Cook, A. M., and Huetter, R, 1984, Deethylsimazine: bacterial dechlorination, deamination, and complete degradation: Journal of Agriculture and Food Chemistry, v. 32, no. 3, p. 581-585.

English.

Degradation Products,Biodegradation/Biotransformation. CA100(25):204726j.

Cook, A. M., and Huetter, R, 1986, Ring dechlorination of deethylsimazine by hydrolases from Rhodocoecus corallinus: FEMS Microbiology, v. 34, no. 3, p. 335-338.

English.

Degradation Products,Biodegradation/Biotransformation. CA105(7):56842e.

Costache, S., Dejan, O., Simulescu, I., Rizoiu, M., Anghel, I., Militaru, C., Manolache, E., Dejan, M., and Ciocan, C., 1978, (Methylthio)diamino-s-triazines: Appl. or Pr. 77114, 25 Dec 1973.

Romanian.

Degradation Products. CA92(7):58832p.

Daugherty, G. H., Evers, W. J., and McCracken, P. G., 1971, 2,3Dichloro-6-amino-s-triazines: Ger. Offen. DE 2032861, 9 Jun $1971,18 \mathrm{p}$.

German.

Degradation Products.

CA75(11):76850w.

Degani, I., Fochi, R, and Regondi, V., 1982, Organic sulfides: Appl. 82/103046, 8 Apr 1982; IT Appl. 81/21263, 17 Apr 1981. English.

Degradation Products.

CA98(19):160238k.

Dejan, O., Dejan, M., Petrescu, D., Tincu, V. L., Velea, S., and Zaharia Emitie Monique, 1977, 2-Mercapto-4,6-bis(alkylamino)s-triazine derivatives: Appl. or Pr. 73301, 25 Dec 1972.

Romanian.

Degradation Products.

CA92(17):146811m.

Dergunov, Y. I., Vostokov, I. A., Gordetsov, A. S., and Gal'perin, V. A., 1976, Synthesis of germanium- and tincontaining s-triazines: Zhurnal Obshchei Khimii, v. 46, no. 8, p. 1910

Russian.

Degradation Products.

CA86(1):5562v. 
Dovlatyan, V. V., Khachatryan, L. A., and Ambartsumyan, E. N., 1979, 2-(Cyanoamino)-4,6-bis(alkyl(dialkyl)amino)-sym-triazines: Armyanskii Khimicheskii Zhurnal, v. 32, no. 7, p. 569-573.

Russian.

Degradation Products.

CA93(5):46611y.

Doviatyan, V. V., and Khachatryan, L. A., 1978, 2-Cyanamino-4,6bis <alkyl(dialkyl)amino >-sym-triazines: Appl. or Pr. 2653834, 26 Nov 1976.

German.

Degradation Products.

CASO(13):104019n.

Dragusin, E., Florescu, S., and Has, T., 1978, Chlorodiamino-striazines: Appl. or Pr. 76331, 15 Oct 1973 .

Romanian.

Degradation Products.

CA92(11):944392.

Eastin, E. F., 1967, Effects of atrazine and hydroxyatrazine on nitrogen metabolism of selected plant species, Dissertation submitted in partial fulfilment of $\mathrm{Ph} . \mathrm{D}$. requirements,

Auburn University, Auburn, Alabama, USA.

English.

Degradation Products.

CA66(25):114819s.

Eastin, E. F., and Davis, D. E., 1967, Effects of atrazine and hydraxyatrazine on nitrogen of selected species: Weeds, $v$. 15 , no. 4, p. 306-309.

Engiish.

Degradation Products.

CA68(3):118896.

Eaton, D. C., and Leyland, B. N., 1971, Rubber compositions reinforced with a stabilized polyester. Ger. Offen. DE 2051521, 29 Apr 1971, 27 p.

German.

Degradation Products.

CA75(6):37648s.

Ebel, K, and Reuther, W., 1986, Aminoalkylmelamines and their amides: Appl. 3438694, 23 Oct 1984.

German.

Degradation Products.

CA105(10):79864c.

Ebel, K, and Reuther, W., 1987, Polyoxyalkylated melamines: Appl. 3531912, 7 Sep 1985.

German.

Degradation Products.

CA107(4):24217e.

Erickson, M. D., Frank, C. W., and Morgan, D. P., 1979, Determination of s-triazine herbicide residues in urine: studies of excretion and metabolism in swine as a model to human metabolism: Joumal of Agriculture and Food Chemistry, v. 27 , no. 4 , p. 743-746.

English.

Degradation Products,Analytical Techniques/Quantification, Biodegradation/Biotransformation.

CA91(7):50677a.
Fhaolain, 1. N., and Coughlan, M. P., 1978, Further observations on the effects of s-triazine derivatives on purine metabolizing enzymes: International Journal of Biochemistry, v. 9, no. 9, p. 659-662.

English.

Degradation Products,Biodegradation/Biotransformation. CA90(5):35516h.

Foster, T. S., Khan, S. U., and Akhtar, M. H., 1980, Metabolism of deethylatrazine, deisopropylatrazine, and hydroxyatrazine by the soluble fraction $(105000 \mathrm{~g})$ from goose liver homogenates: Journal of Agriculture and Food Chemistry, v. 28, no. 6, p. 1083-1085.

English.

Degradation Products.

CA93(23):216300r.

Francese, R, and Esposito, R, 1980, Chlorobis(alkylamino)-striazines: IT Appl. 77/28810, 20 Oct 1977.

English.

Degradation Products.

CA93(1):8216r.

Fredrick, J. F., 1981, Antimicrobial embalming preparations: US Appl. 786460, 11 Apr 1977.

English.

Degradation Products, Toxicity.

CA95(19):163056y.

Freiberg, R, and Bulka, E., 1985, Synthesis of 2,4 bis < alkyl(aryl)amino >-6-(cyanoamino)-1,3,5-triazines: Journal fuer Praktische Chemie, v. 327, no. 3, p. 471-478.

German.

Hydrolysis/Chemical Reactions,Degradation Products. CA104(9):68822r.

Freiman, A., 1977, Coating compositions used to control barnacles: Appl. or Pr. 142041, 10 May 1971.

English.

Degradation Products.

CA86(25):184577y.

Fujimoto, T., Katagiri, H., and Seta, S., 1976, Fire-resistant polyamide compositions: Appl. or Pr. 75/51537, 30 Apr 1975. Japanese.

Degradation Products.

CA86(12):73767r.

Gal'perin, V. A., Kartik, V. M., Finkel'shtein, A. I., Zagranichnii, V. I., and Al'tschuler, L. N., 1972, Pyrolysis of cyanuric acid under pressure of the evolved gases: Trudy Nauchno - Issledovate'skii i Proektnyi Institut po Azotn. Prom. Prod. Org Sin., v. 16, p. 48-55.

Russian.

Degradation Products.

CA79(17):105205e.

Gass, K., and Vogel, C., 1972, Herbicidal 2-(alkoxymethylamino)4-alkylamino-s-triazines: CH Appl. 12,341/70, 19 Aug 1970. German.

Degradation Products. CA77(3):19684n. 
Gaucher, A, and Guilhot, G., 1975, Maintaining the cyanide content in cyanate-containing salt baths at low values: FR Appl. 74 17,195, 17 May 1974.

German.

Degradation Products.

CA85(14):97722c.

Gaynor, J. D., 1973, Atrazine, Terbutryne, and GS-14254 adsorption, desorption, and solubility in salt solutions and movement in soil materials, Dissertation submitted in partial fulfillment of Ph.D. requirements, Oregon State University, Corvallis, Oregon, USA.

Univ. Microfilms, Ann Arbor, Michigan, Order No. 73-21,305. Degradation Products. CA80(11):56365s.

Giardi, M. T., Giartina, M. C., and Filacchioni, G., June 1985, Chemical and biological degradation of primary metabolites of atrazine by a Nocardia strain: Agricultural and Biological Chemistry, v. 49, no. 6, p. 1551-1558.

English.

Degradation Products,Analytical Techniques/Quantification, Biodegradation/Biotransformation.

CA103(13):100291j.

Giardi, M. T., Giardina, M. C., and Brancaleoni, E., 1983, An improved method of isolation and characterization of atrazine metabolites: Analytical Chemistry Symposium Series, v. 13, no. Chromatogr. Biochem., Med. Environ. Res. 1, p. 53-61. Engtish.

Degradation Products,Analytical Techniques/Quantification. CA98(23):193244n.

Giardina, M. C., Giardi, M. T., and Filacchioni, G., 1980, 4 amino-2-chloro-1,3,5-triazine: a new metabolite of herbicide atrazine by a soil bacterium Nocardia, phytotoxic activity: Agricultural and Biological Chemistry, v. 44, no. 9, p. 2061 2066.

English.

Degradation Products,Biodegradation/Biotransformation. IND 81000006.

Giardina, M. C., Giardi, M. T., and Filacchioni, G., 1980, 4 Amino-2-chloro-1,3,5-triazine: a new metabolite of atrazine by a soil bacterium: Agricultural and Biological Chemistry, v. 44 , no. 9 , p. $2067-2072$.

English.

Degradation Products,Biodegradation/Biotransformation. CA93(21):199220v.

Giardina, M. C., Giardi, M. T., and Buffone, R, 1979, Soil enrichment studies with atrazine. Long-term atrazine effects on degradation and microbiological composition: Chemosphere, v. 8 , no. $11-12$, p. $831-834$.

English.

Degradation Products,Biodegradation/Biotransformation. CA92(15):123353z.

Goetz, A. J., Wehtje, G., Walker, R. H., and Hajek, B., 1986, Soil solution and mobility characterization of imazaquin: Weed Science, v. 34, no. 5, p. 788-793.

English.

Degradation Products,Sorption to Soil,Leaching. CA105(19):166811b.
Gontarz, Z, and Podsiadlo, S., 1984, Stages of reaction between boron oxy compounds and compounds of the urea group. Part I. Classification and reaction stages of the synthesis of boron nitride with the use of urea, biuret and dicyandiamide: Polish Joumal of Chemistry, v. 58, no. 1-2-3, p. 3-11. English.

Degradation Products,Hydrolysis/Chemical Reactions. CA102(14):124446u.

Gordetsov, A. S., Vostokov, I. A., Oleinik, E. P., Samarina, L. V., and Vasileiskaya, N. S., 1976, Synthesis of organotin, organogermanium, and organosilicon sym-triazines: Trudy GIAP, v. 42, p. 63-73.

Russian.

Degradation Products.

CA91(7):57126d.

Gordetsov, A. S., Vostokov, I. A., Oleinik, E. P., Samarina, L. V., Vasileiskaya, N. S., and Dergunov, Y. I., 1976, Synthesis of organotin, -germanium, and -silicon s-triazines: Trudy GLAP, no. 42, p. 63-72.

Russian.

Degradation Products.

CA91(5):39602b.

Gordetsov, A. S., Vostokov, I. A., Gal'perin, V. A., and Dergunov, Y. I., 1976, Synthesis of silicon-substituted amino(oxy)-s-triazines: Zhurnal Obshchei Khimii, v. 46, no. 7, p. 1654-1655.

Russian.

Degradation Products.

CA85(19):143186f.

Gordetsov, A. S., Vostokov, 1. A., Trub, E. P., Egorochkin, A. N., Skobeleva, S. E., Kosolapova, I. G., and Dergunov, Y. I. 1979, Synthesis of tris(dimethylsilyl)amino(oxy)-s-triazines: Zhurnal Obshchei Khimii, v. 49, no. 5, p. 1057-1060.

Russian.

Degradation Products.

CA91(5):39575v.

Gorog, M. L., Andriska, V., Nemesanyi, M. Z, Kiraly, G., Vig, M. G., Nadasy, M., Grega, M. J., Gribovszki, P., Marosvolgyi, S., and et al., 1972, Ureido-s-triazine herbicides: Appl. or Pr. NE-478, 6 Nov 1970.

Hungarian.

Degradation Products.

CA78(25):159687m.

Gorski, A., and Podsiadlo, S., 1984, Stages of reaction between boron oxy compounds and compounds of the urea group. Part II. Stages of boron nitride synthesis triuret and striazines and general scheme of the processes: Polish Journal of Chemistry, v. 58, no. 1-2-3, p. 13-21.

English.

Degradation Products,Hydrolysis/Chemical Reactions. CA102(14):124447v.

Goswami, K. P., and Green Richard Ervin, 1971, Microbial degradation of the herbicide atrazine and its 2 -hydroxy analog in submerged soils: Environmental Science and Technology, v. 5, no. 5, p. 426-429.

English.

Degradation Products,Biodegradation/Biotransformation. CA74(25):139847c. 
Goswami, K. P., and Green, R. E., 1971, Microbial degradation of the herbicide atrazine and its 2-hydroxy analog in submerged soils: Environmental Science and Technology, v. 5, no. 5, p. 426-429.

English.

Degradation Products,Biodegradation/Biotransformation, Sorption to Soil,Surfacewater Observations,Hydrolysis/ Chemical Reactions.

CA74(25):139847c.

Goswami, K. P., and Green, R. E., 1973, Simultaneous extraction of hydroxyatrazine, atrazine, ametryne from some Hawaiian soils: Soil Science Society of America, Proceedings, v. 37, no. 5 , p. $702-707$.

English.

Anahytical Techniques/Quantification,Degradation Products, Sorption to Soil.

CA80(1):663v.

Goto, T., and Nagano, M., 1972, Etherification of polymers possessing hydrophilic groups. III. Reaction of poly(vinyl alcohol) with 2-substituted 4-amino-6-chloro-1,3,5-triazines: Nippon Kagaku Kaishi, no. 8, p. 1514-1518.

Japanese.

Degradation Products.

CA77(26):165133y.

Grayson, B. T., 1980, Hydrolysis of cyanazine and related diaminochloro-1,3,5-triazines. Part II. Hydrolysis in sulfuric acid solutions: Pesticide Science, v. 11, no. 5, p: 493-505.

English.

Degradation Products,Hydrolysis/Chemical Reactions. CA94(21):173869j.

Gressel, J., Shimabukuro, R. J., and Duysen, M. E., 1983, NDealkylation of atrazine and simazine in Senecio vulgaris biotypes: a major degradation: Pesticide Biochemistry and Physiology, v. 19, no. 3, p. 361-370.

English.

Biodegradation/Biotransiormation,Degradation Products, Toxicity.

CA99(1):1752c.

Gromova, T. I., Lyubarskii, M. V., and Sukhanova, T. G., 1984, Heats of combustion and formation of sym-triazine derivatives: Zhurnal Fizicheskoi Khimii, v. 58, no. 6, p. 1556-1558.

Russian.

Degradation Products, Chemical/Physical Properties. CA101(10:79448n.

Grossenbacher, H., Horn, C., Cook, A. M., and Huetter, R., 1984, 2-Chloro-4-amino-1,3,5-triazine-6(5H)-one: a new intermediate in the biodegradation of chlorinated striazines: Applied Environmental Microbiology, v. 48, no. 2, p. $451-453$.

English.

Degradation Products,Biodegradation/Biotransformation. CA101(13):107137f.
Hagimoto, H., Arai, T., Yoshikawa, H., Watanabe, M., and Okada, Y., 1973, Herbicidal 2-(benzylthio-1,3,4-oxo(or thia)diazoles: Appl. or Pr. 11,901/70, 12 Mar 1970.

English.

Degradation Products.

CA79(5):28394m.

Halpern, Y., 1982, Intumescent flame retandant compositions: Appl. 280569, 6 Jul 1981.

English.

Degradation Products.

CA97(22):183482d.

Hammons, R. H., May 1977, Atrazine persistence in a valentine loamy fine sand profile, Dissertation submitted in partial fulfillment of $\mathrm{Ph} . \mathrm{D}$. requirements.

English.

Degradation Products, Biodegradation/Biotransformation. OWRT B-030-NEB(4).

Hance, R. J., and Chesters, G., 1970, Extraction of hydroxyatrazine from soil: Analyst (London), v. 95, no. 1126, p. 106.

English.

Degradation Products,Analytical Techniques/Quantification, Sorption to Soil.

CA72(21):110029k.

Hance, R. J., and Chesters, G., 1969, Fate of hydroxyatrazine in a soil and a lake sediment: Soil Biotogy and Biochemistry, v. 1 , no. 4, p. 309-315.

English.

Degradation Products,Biodegradation/Biotransformation, Sorption to Sediments.

CA72(21):110138v.

Honda, I., Unishi, T., Hashimoto, Y., and Shimomura, Y., 1980, Syntheses and oxidation of hydrazino-1,3,5-triazines. V. Reactions of chloro-1,3,5-triazines with arylhydrazines: Kenkyu Hokoku - Asahi Garasu Kogyo Gijutsu Shoreikai, v. 36, p. 153-167. Japanese.

Degradation Products,Hydrolysis/Chemical Reactions. CA95(9):808992.

Hormann, W. D., Tournayre, J. C., and Egli, H., 1979, Triazine herbicide residues in central European streams: Pesticide Monitoring Journal, v. 13, no. 3, p. 128-131.

English.

Degradation Products,Surfacewater Observations. CA92(17):141785w.

Hugl, H., and Wolfrum, G., 1975, Dyeing fiber materials: Appl. or Pr. P 2404 977.2, 1 Feb 1974.

German.

Degradation Products. CA84(2):6402p.

Ikonen, R, Kangas, J., and Savolainen, H., 1988, Urinary atrazine metabolites as indicators for rat and human exposure to atrazine: Toxicology Letters, v. 44, no. 1-2, p. 109-112. English. Degradation Products,Biodegradation/Biotransformation. CA110(3):19608r. 
Inoue, Y., Uejima, K. Inouye, S., Keumi, T., and Kitajima, H., 1978, Synthesis of p-nitrophenylazo-s-triazines: Yuki Gosei Kagaku Kyokaishi, v. 36, no. 9, p. 779-783.

Japanese.

Degradation Products.

CA9O(15):121520m

Jackle, W. A., Mazzeo, M. P., and Gillis, M. N., 1976, Hardenable polyurethane substances: US Appl. 585150, 9 Jun 1975. German.

Degradation Products.

CA86(16):107827c.

Janzowski, C., Klein; R, and Preussmann , R, 1980, Formation of $\mathrm{N}$-nitroso compounds of the pesticides atrazine, simazine and carbaryl with nitrogen oxides: LARC Science Publication, v. 31, no. N-Nitroso Compd.: Anal., Form. Occurrence, p. 329-339. English.

Hydrolysis/Chemical Reactions,Degradation Products. CA95(9): $74984 \mathrm{~g}$.

Jensen, K. I. N., 1976, Atrazine detoxification in three gramineae subfamilies, Dissertation submitted in partial fulfillment of Ph.D. requirements, Univ. Guelph, Guelph, Ont., Can.. English.

Degradation Products.

CA85(23):172675v.

Jessee, J. A., Benoit, R. E., Hendricks, A. C., Allen, G. C., and Neal, J. L., 1983, Anaerobic degradation of cyanuric acid, cysteine, and atrazine by a facultative anaerobic bacterium: Applied Environmental Microbiology, v. 45, no. 1, p. 97-102. English.

Degradation Products,Biodegradation/Biotransformation. CA98(10):77581w.

John, W. W., Pilgram, K. H., and Martin, M. E. F., 1985, Acylthio-substituted triazines: Appl. 613495, 24 May 1984. English.

Degradation Products, Chemical/Physical Properties. CA104(1):5896x

Jones, T. W., Kemp, W. M., Stevenson, J. C., and Means, J. C., October-December, 1982, Degradation of atrazine in estuarine water/sediment systems and soils: Journal of Environmental Quality, v. 11, no. 4, p. 632-638.

English.

Biodegradation/Biotransformation,Associations with Surfactants,Field Residuals,Sorption to Sediments,Sorption to Soil,Degradation Products. CA97(25):210373e.

Jones, T. W., and Winchell, L., April-June 1984, Uptake and photosynthetic inhibition by atrazine and its degradation products on four species of submerged vascular plants: Joumal of Environmental Quality, v. 13, no. 2, p. 243-247. English. Associations with Surfactants, Uptake by Biota,Degradation Products, Toxicity.

CA101(1):2244k.
Jursinic, P., and Stemler, A., Nov 1983, Changes in 14C atrazine binding associated with the oxidation-reduction state of the...: Plant Physiology, v. 73, no. 3, p. 703-708. English.

Uptake by Biota,Associations with Plants,Degradation Products.

IND 83126519

Kajiyama, S., 1977, Safety and Health with Plastics, National Technical Conference, Society of Plastics Engineers, Denver, p. $178-180$.

English.

Degradation Products, Chemical/Physical Properties. CA88(6):38416v.

Karlik, V. M., Roshnova, M. V., Finkel'shtein, A. I., Zagranichnyi, V. I., and Al'tshuler, L. N., 1980, Melem: Appl. or Pr. 2585271, 1 Mar 1978 (From: Otkrytiyz, Izobret., Prom. Obraztsy, Tovarnye Znaki 1980. (1), 95).

Russian.

Degradation Products.

CA93(5):4672n

Karlik, V. M., and Zagranichnyi, V. I., 1971, Kinetics of the hydrolysis of triazines. Hydrolysis of melamine, ammeline, and ammelide: Zhurnal Vsesoyuznogo Khimicheskogo Obshchestva, v. 16 , no. 1 , p. 116

Russian.

Hydrolysis/Chemical Reactions,Degradation Products.

CA74(25):140431u.

Katagiri, H., Fujimoto, T., and Uenosono, I., 1977, Fireresistant modified poly(phenylene oxide) compositions: Appl. or Pr. 75/117141, 30 Sep 1975.

Japanese.

Degradation Products.

CA87(2):6988w.

Kaufman, D. D., and Blake, J., 1970, Degradation of atrazine by soil fungi: Soil Biology and Biochemistry, v. 2, no. 2, p. 73-80.

English.

Biodegradation/Biotransformation,Degradation Products. CA73(9):42596m.

Kawahara, F. K, 1966, Lubricating greases: U.S. US 3278435, 11 Oct 1966, 4 p.

English.

Degradation Products. CA66(4):12786m.

Kearney, P. C., Oliver, J. E., Helling, C. S., Isensee, A. R, and Kontson, A, 1977, Distribution, movement, persistence, and metabolism of $\mathrm{N}$-nitrosoatrazine in soils and a model aquatic ecosystem: Journal of Agriculture and Food Chemistry, v. 25 , na. 5 , p. $1177-1181$.

English.

Degradation Products,Leaching,Sorption to Soil.

CA87(19):146889q.

Keller, A. E., and Guth, J. A., 1981, Theory and Practice in the Use of Soil Applied Herbicides, Symposium, p. 80-88.

English.

Degradation Products,Biodegradation/Biotransformation. CA97(25):210328s. 
Kern, E., Hacker, R, and Steinke, W., 1975, Purification of methylmercapto-bis-alkylamino-s-triazines: Appl. or Pr. 144 313, 15 Dec 1969.

German.

Degradation Products:

CA84(19):135723t.

Khan, S. U., and Foster, T. S., 1976, Residues of atrazine and its metabolites in chicken tissues: Journal of Agriculture and Food Chemistry, v. 24, no. 4, p. 768-771. English.

Uptake by Biota,Degradation Products. CA85(7):45015e.

Khan, S. U., and Saidak, W. J., 1981, Residues of atrazine herbicide applied to maize and its metabolites after prolonged usage: Weed Research, v. 21, no. 1, p. 9-12. English.

Biodegradation/Biotransformation,Degradation Products, Field Residuals.

CA95(11):92225q.

Khan, S. U., and Akhtar, M. H., 1983, In vitro releace of bound (nonextractable) atrazine residues from com plants by chicken liver homogenate and bovine rumen liquor. Journal of Agriculture and Food Chemistry, v. 31, no. 3, p. 641-644. English.

Toxicity,Degradation Products,Uptake by Biota,Associations with Plants.

CA98(23):192994v.

Khan, S. U., Greenhalgh, R, and Cochrane, W. P., 1975, Chemical derivatization of hydroxyatrazine for gas chromatographic analysis: Journal of Agriculture and Food Chemistry, v. 23, no. 3 , p. $430-434$.

English.

Analytical Techniques/Quantification,Degradation Products. CA83(5):38612c.

Khan, S. U., Kacew, S., and Molnar, S. J., 1985, Bioavailability in rats of bound carbon-14 residues from com plants treated with (14C)atrazine: Journal of Agriculture and Food Chemistry, v. 33, no. 4, p. $712-717$.

English.

Uptake by Biota,Degradation Products,Toxicity. CA103(5):33244f.

Khan, S. U., and Marriage, P. B., 1977, Residues of atrazine and its metabolites in an orchard soil and their uptake by oat plants: Journal of Agriculture and Food Chemistry, v. 25, no. 6, p. 1408-1413.

English.

Field Residuals, Uptake by Biota,Biodegradation/

Biotransformation,Degradation Products.

CA87(23):178954y.

Khmel'nitskaya, E. Y., 1977, Polanography of s-triazine series compounds. III. Mechanism of the electrochemical reduction of arylaminochlorotriazines: Zhumal Obshchei Khimii, v. 47, no. 5, p. 1158-1165.

Russian.

Hydrolysis/Chemical Reactions,Degradation Products. CA87(13):101655u.
Kobzova, R. I., and Chepurova, M. B., 1982, Ammeline - new heatresistant thickener for greases: Plastichnye Smazki, p. 8-18. Russian.

Degradation Products.

CA98(14):110080g.

Kobzova, R. I., and Chepurova, M. B., 1982, Ammeline as a new thermally stable thickener for lubricating greases: Sbornik Nauchnykh Trudov-Vsesoyuznyi Nauchno-Issledovatel'skii Institute po Pererabotke Nefti, v. 43, p. 8-18.

Russian.

Degradation Products.

CA99(4):25123z.

Kobzova, R. I., Shul'zhenko, I. V., Chepurova, M. B., and Shneerova, R. N., 1977, Study of the effect of a thickening agent on the radiation resistance of high-temperature lubricants: Neftepererabotka i Neftekhimiya (Moscow), no. 12, p. 19-20. Russian.

Degradation Products.

CA88(16):107647k

Kollar, T., Bacalogdu, R, and Safta, M., 1979, Syntheses of formaldehyde stabilizers: Bulletinul Stiintific si Tehnic al Institutului Politehnic "Traian Vuia" Timisoara, Seria Chimie, v. 24, no. 1, p. 97-101.

German.

Hydrolysis/Chemical Reactions,Degradation Products. CA95(15):132822r.

Konno, K, Araki, K, Sasaki, N., Endo, K, Hikido, M., and Sugaya, K, 1987, (Fluoroalkyl)triazines, herbicidal compositions containing them, and a method for controlling weeds: Appl. 86/16460, 26 Nov 1986; JP Appl. 85/263783, 26 Nov 1985.

French.

Degradation Products.

CA109(15):129060t.

Koshar, R. J., Husted, D. R., Wright, C. D., and Zollinger, J. L., 1975, Tris(difluoroamino)methyl compounds: Appl. or Pr. 425,113, 8 Jan 1965.

English.

Degradation Products.

CA84(17):121102c.

Krakhmalev, S. I., Litvinenko, S. N., Klimov, K. I., and Nikonorov, E. M., 1976, Biological stability of greases: Trudy Vsesoyuznogo Nauchno-Issledovatel'skogo Instituta po Pererabotke Nefti, v. 16, p. 17-24.

Russian.

Degradation Products. CA88(18):123488q

Ladlie, J. S., Meggitt, W. F., and Penner, D., 1976, Effect of soil pH on microbial degradation, adsorption, and mobility of metribuzin: Weed Science, v. 24, no. 5, p. $47-481$.

English.

Degradation Products,Biodegradation/Biotransformation, Sorption to Soil. CA85(23): $172771 y$. 
Lawrence, J. F., Brinkman, U. A. T., and Frei, R. W., 1979, Continuous post-column ion-pair extraction detection of some basic organic compounds in normal-phase chromatography: Journal of Chromatography, v. 185, no. 1, p. 473-481. English.

Degradation Products,Analytical Techniques/Quantification. CA92(14):116528g.

Lawrence, J. F., 1976, Confirmation of some organonitrogen herbicides and fungicides by chemical derivatization and gas chromatography: Journal of Agriculture and Food Chemistry, v. 24 , no. 6, p. $1236-1238$. English.

Degradation Products,Analytical Techniques/Quantification. CA85(23):175659.

Lawrence, J. F., and Leduc, R, 1978, High performance liquid chromatography of acidic and basic organic compounds on silica gel with mobile phases containing organic acids: Analytical Chemistry, v. 50, no. 8, p. 1161-1164. English.

Degradation Products,Analytical Techniques/Quantification, Sorption to Resins. CA89(5):37888j.

Leclereq, P. A., and Pacakova, V., 1979, Gas chromatography and mass spectrometry of bis(alkylamino)-s-triazines: Journal of Chromatography, v. 178, no. 1, p. 193-207.

English.

Degradation Products,Analytical Techniques/Quantification, Chemical/Physical Properties. CA92(15):128188j.

Loffelman, F. F., and Brady, T. E., 1974, Iminodiacetonitriles as bleaching activators: US Appl. 343,314, 21 Mar 1973.

German.

Degradation Products.

CA82(18):113499f.

Loffelman, F. F., and Brady, T. E., 1974, Substituted halotriazine derivatives as peroxygen bleach activators: US Appl. 343,313, 21 Mar 1973.

German.

Degradation Products.

CA82(6):32776s.

Loos, M. A., and Kearney, P. C., 1978, Thin-layer and paper chromatography of potential degradation products of striazine herbicides: Journal of Chromatographic Science, $v$. 16 , no. 2, p. $86-89$.

English:

Degradation Products,Analytical Techniques/Quantification. CA89(19):158611x.

Lukman, M., Zuran, A., and Megusar, F., 1987, Atrazine and ammonifying, nitrifying and denitrifying potential in soils: Zbornik Biotehnice Fakulty Univ. Edvarda Kardelja Ljubl. Kmetijstvo., no. 47, p. 167-179.

Slovenian.

Biodegradation/Biotransformation,Degradation Products. IND 87110521.
Lunev, M. I., 1986, Evaluation of permissible levels of xenobiotics and their metabolites in plants: Tsentral'nyi Institut Agrokhimicheskogo Obsluzhivaniya Sel'skogo Khozyaistva, Trudy, no. 1, p. 62-63.

Russian.

Toxicity, Degradation Products.

CA104(13): 108040t

MacDonald, A. A, 1975, Allyloxalyl amino-substituted s-triazine herbicides: Appl. or Pr. 347,296, 2 Apr 1973.

English.

Degradation Products.

CA84(11):74317q.

MacDonald, A. A., 1974, Herbicidal 2-<(alkoxalyl)amino>-4-aminos-triazines: US Appl. 347,296, 2 Apr 1973.

German.

Degradation Products.

CA82(1):4312u.

Mackenzie, H. I., and Van Rensburg, I. B. J., 1968, Ammelide and ammeline as nonprotein nitrogen suppiements for sheep: Journal of the South African Veterinary Medical Association, v. 39 , no. 2 , p. $41-45$.

English.

Degradation Products. CA70(13):55356w.

Malan, C., Visser, J. H., and Van de Venter, H. A., 1986, Quantitative estimation of atrazine, hydroxyatrazine and 6methoxy-2-benzoxazinone (MBOA) in maize plants: South African Journal of Plant Soil, v. 3, no. 2, p. 82-84.

English.

Degradation Products,Analytical Techniques/Quantification. CA105(7):55762s.

Matnishyan, A. A., Zhukhovitskii, V. B., and Aleksanyan, R. Z., 1977 , Mono diazotized melamine as an intermediate for ammeline (cyanurodiamide) preparation: Appl. o: Pr. 2300573, 17 Dec 1975.

Russian.

Degradation Products.

CA87(25):201590n.

Matsuki, M., Kawasalci, H., and Yoshida, K, 1978, Fire-resistant molded polyamides: Appl. or Pr. $7 / 58804,23$ May 1977. Japanese. Degradation Products. CA90(24):187936h.

McCarthy, P. R, and Orem; T. R., 1970, High-temperature lubricating greases: U.S. US 3505224, 7 Apr 1970, 5 p. English.

Degradation Products. CA73(2):5756t.

MeCracken, P. G., Myatt, H., and Petree, H. E., 1978, 2-Chloro-4, 6-bis(alkylamino)-s-triazines: US Appl. 753032, 22 Dec 1975. German.

Degradation Products. CA90(1):6423v. 
McCracken, P. G., Myatt, H., and Petree, H. E., 1981, Causticfree process for monochloro-diamino-s-triazines: Appl. 118375, 4 Feb 1980; US Appl. 753032, 22 Dec 1976; US Appl. 933375, 14 Aug 1978; US Appl. 48868, 15 Jun 1979. English.

Degradation Products,Hydrolysis/Chemical Reactions. CA96(3):20129j.

McEnerney, J. T., and Davis, D. E., 1977, Metabolism of atrazine and its degradation products by fiddler crabs (Uca pugnax) (Abstract only): Proceedings of the Southern Weed Science Society, v. 30, p. 354.

English.

Biodegradation/Biotransformation,Degradation Products. CAIN 779078053.

Medikhanov, D. G., Korobochkin, V. P., and Shchepetkin, A. A., 1982, Thermal decomposition of dimethylurea and its salts. Communication 1: Deposited Doc., VINTIT 356-382, 8 p. Russian. Degradation Products. CA98(19):160056z.

Messori, V., Francese, R, and Esposito, R., 1981, Chlorobis(alkylamino)-s-triazines: Appl. or Pr. 2939530, 28 Sep 1979.

German.

Toxicity,Degradation Products.

CA95(7):62268p.

Mikhailov, B. I., Gololobov, Y. G., and Kofman, L. P., 1972, 2<(2-Hydroxyethyl)thio>-4,6-diamino-s-triazines: USSR SU 348564, 23 Aug 1972.

Russian.

Degradation Products.

CA78(3):16232y.

Mills, T. N., and Cameron, A., 1977, The lubricating character of greases using a new test method: U.S. NTIS, AD Rep., ADA038793, $27 \mathrm{p}$.

English.

Degradation Products, Chemical/Physical Properties.

CA87(18):138244k.

Mlochowski, J., Skrowaczewska, M. Z, and Tyka, R., 1971, Factors affecting the condensation reaction of melamine with formaldehyde: Chemia Stosowana, v. 15, no. 4, p. 403-414. Polish.

Degradation Products.

CA77(3):19612n.

Mocquart, B., 1973, Herbicidal triazine derivatives: Appl. or Pr. $7132,085,6$ Sep 1971.

French.

Degradation Products.

CA79(13):78854g

Mohiuddin, S., and Qureshi, S. A., 1973, Screening tests of substituted phosphine oxides, phosphonic amides, methylmelamines, and diaminotriazines for sterilization of laboratory-reared strain of houseflies, Musca domestica: Pakistan Journal of Scientific and Industrial Research, v. 16, no. 5, p. 182-187.

English.

Degradation Products, Toxicity.

CA81(5):22222y.
Montgomery, M. L., Botsford, D. L., and Freed, V. H., 1969, Metabolism of hydroxysimazine by corn plants: Joumal of Agriculture and Food Chemistry, v. 17, no. 6, p. 1241-1243. English.

Degradation Products,Biodegradation/Biotransformation, Analytical Techniques/Quantification.

CA72(1):2396u.

Morita, E., Sullivan, A. B., and Coran, A. Y., 1985,

Vulcanization chemistry: Rubber Chemistry and Technology, $v$. 58, no. 2, p. 284-294.

English.

Degradation Products.

CA103(20):161627v.

Muir, D. C., and Baker, B. E., 1976, Detection of triazine herbicides and their degradation products in tile-drain water from fields under intensive com (maize) production: Joumal of Agriculture and Food Chemistry, v. 24, no. 1, p. 122-125. English.

Surfacewater Observations,Degradation Products. CA84(9):55294p.

Muir, D. C. G., and Baker, B. E., 1978, The disappearance and movement of three triazine herbicides and several of their degradation products in soil under field conditions: Weed Research, v. 18, no. 2, p. 111-120.

English.

Degradation Products,Biodegradation/Biotransformation,Field Residuals,Leaching CA89(17):141769g.

Muir, D. C. G., and Baker, B. E., 1978, A method for the routine semiquantitative determination of hydroxy-s-triazines in soils: Journal of Agriculture and Food Chemistry, v. 26, no. 2, p. 420-424.

English.

Degradation Products,Analytical Techniques/Quantification. CA88(25):184408k.

Muller, J. C, and Ramux, H., 1980, Pharmaceutical oxadiazolotriazine derivatives and intermediate products: $\mathrm{CH}$ Appl. 78/8184, 31 Jul 1978.

German.

Degradation Products. CA93(17):168252c.

Murai, H., and Aoyagi, Y., 1977, N-Substituted trialkoxybenzylpiperazine derivatives: JP Appl. 76/40782, 9 Apr 1976.

German.

Degradation Products. CA88(3):22979v.

Nikonorov, E. M., Timofeeva, A. N., Bakaleinikov, B. M., and Petrova, L. N., 1982, Reverse-chromatography for study of the thermodynamic properties of lubricating greases: Sbornik Nauchnykh Trudov - Vsesoyuznyi Nauchno-Issledovatel'skii Institute po Pererahotke Nefti, v. 43, p. 72-80.

Russian.

Degradation Products,Analytical Techniques/Quantification. CA98(26):218411e. 
Nishimura, T., Toku, H., and Misu, T., 1970, Synthesis of ammeline from 1-amidino-3-nitrourea: Nippon Kagaku Zasshi, v. 91 , no. 8, p. 766-767.

Japanese.

Degradation Products.

CA73(23):120592y.

Pape, B. E., and Zabik, M. J., 1970, Photochemistry of bioactive compounds. Photochemistry of selected 2-chloro- and 2methylthio-4,6-di(alkylamino)-S-triazine herbicides: Journal of Agriculture and Food Chemistry, v. 18, no. 2, p. 202-207. English.

Photolysis,Degradation Products.

CA72(21):110111f.

Perkavec, J.; Perpar, J., and Brodnik, D., 1969, The paper and thin-layer chromatography of several s-triazine derivatives: Mikrochimica Acta, p. 1224-1228.

Degradation Products,Analytical Techniques/Quantification.

Perronnet, J., and Teche, A., 1972, Herbicidal 2-amino-4 <(tetrahydro-2-pyranyi)amino >-s-triazines: FR Appl. 7,119, 239, 27 May 1971.

German.

Degradation Products.

CA78(11):72222g.

Petri, R, and Nutiu, R, 1970, Combinations of dilituric acid with cyanuric bases: Analele Universitatii din Timisoara, Stiinte Fizice-Chimice, v. 8, no. 1, p. 51-55.

Romanian:

Degradation Products.

CA78(23):146960v.

Pillai, C. G. P., Weete, J. D., and Davis, D. E., July/Aug 1977, Metabolism of atrazine by Spartina alternifolia.1. chloroform metabolites: Journal of Agriculture and Food Chemistry, v. 25 , no. 4, p. 852-855.

English.

Degradation Products,Biodegradation/Biotransformation. CAIN 779079637.

Pillai, C. G. P., Weete, J. D., and Davis, D. E., 1977, Watersoluble atrazine metabolites from Spartina alternifolia (Abstract only): Proceedings of the Southem Weed Science Society, v. 30, p. 368.

English.

Degradation Products,Surfacewater Observations.

Plimmer, J. R, Keamey, P. C., and Klingebiel, U. I., 1971, sTriazine herbicide dealkylation by free-radical generating systems: Journal of Agriculture and Food Chemistry, v. 19, no. 3, p. 572-573.

English.

Degradation Products,Hydrolysis/Cliemical Reactions. CA75(3):1906\%

Ramsteiner, K. A., and Hoermann, W. D., 1979, High-pressure liquid chromatographic determination of hydroxy-s-triazine residues in plant material: Journal of Agriculture and Food Chemistry, v. 27, no. 5, p. 934-938.

English.

Degradation Products,Analytical Techniques/Quantification. CA91(17):138936v.
Regtuit, H., Vrins; E, and Hofshcreuder, P., 1988, The tunnel impactor: a multiple inertial impactor for coarse particles: Journal of Aerosol Science, v. 19, no. 7, p. 983-986. English.

Degradation Products,Analytical Techniques/Quantification. CA110(14):120320r.

Reitter, L., and Leissl, E., 1974, Ammeline: Appl. or Pr. P 2258 816.5, 1 Dec 1972.

German.

Degradation Products.

CA81(13):77972y.

Rejto, M., Saltzman, S., Acher, A. J., and Muszkat, L., 1983, Identification of sensitized photooxidation products of striazine herbicides in water. Journal of Agriculture and Food Chemistry, v. 31, no. 1, p. 138-142.

English.

Degradation Products, Photolysis.

CA98(5):29596h.

Roberts, G. C., Sirons, G. J., Frank, R, and Collins, H. E, 1979, Triazine residues in a watershed in southwestern Ontario (1973-1975): Journal of Great Lakes Research, v. 5, no. $3-4$, p. 246-255.

English.

Degradation Products,Surfacewater Observations. CA92(13):105833b.

Roginskaya, T. N., Spasskaya, R. L, and Finkel'shtein, A. I., 1975, Structure of methylol derivatives of ammelide and ammeline studied from ir spectra: Zhumal Prikladnoi Spektroskopii, v. 22, no. 5, p. 938-940.

Russian.

Degradation Products.

CA83(3):27201s.

Saito, S., 1978, Sublimatographic analysis; sublimatographic separation of melamine, ammeline, ammelide, and cyanuric acid: Bunseki Kagaku, v. 27, no. 6, p. 321-325.

Jepanese.

Analytical Techniques/Quantification,Degradation Products. CA89(12):992990.

Saito, S, Kinoshita, M, and Endo, K., 1966, Sublimatography. VI. Sublimatographic separation of melamine, ammerine, ammeride, and cyanuric acid: Shinku Kagaku, v. 14, no. 1, p. 10-13.

Japanese.

Degradation Products. CA68(11):49564e.

Sato, Y., Sato, K., Nakajima, S., Yoshida, R., Shiba, H., and Fujii, T., 1973, Hygienic chemical studies on melamine-resin tableware: Tolyo Toritsu Eisei Kenkyusho Kenkyu Nempo, no. 24, p. 285-289.

Japanese.

Degradation Products. CA81(17):100265f. 
Schiavon, M., 1988, Studies of the leaching of atrazine, of its chlorinated derivatives, and of hydroxyatrazine from soil using carbon-14 ring-labeled compounds under outdoor conditions: Ecotoxicology and Environmental Safety, v. 15, no. $1, \mathrm{p}: 46-54$.

English.

Leaching,Degradation Products,Sorption to Soil,

Biodegradation/Biotransformation.

CA108(23):200133f.

Schmid, K, 1986, Conversion of high molecular-weight carbon- and hydrogen-containing material: Appl. 3431940, 30 August 1984. German.

Degradation Products.

CA105(10):82095h.

Seibert, K, Fuhr, F., and Cheng, H. H., 1981, Symposium on the Theory and Practice of the Use of Soil Applied Pesticides: Proceedings, p. 137-146.

English.

Degradation Products,Biodegradation/Biotransformation. CA97(25):210330m.

Shimabukuro, R. H., Walsh, W. C., Lamoureux, G. L., and Stafford, L. E., Nov/Dec 1973, Atrazine metabolism in sorghum: chloroform-soluble intermediates in the $\mathrm{N}$-dealkylation and glutathione conju...: Journal of Agriculture and Food Chemistry, v. 21, no. 6, p. 1031-1036.

English.

Biodegradation/Biotransformation,Degradation Products.

Shimabukuro, R. H., 1967, Significance of atrazine dealkylation in root and shoot of pea plants: Journal of Agriculture and Food Chemistry, v. 15, no. 4, p. 557-562.

English.

Biodegradation/Biotransformation,Degradation Products. CA67(13):631\%6x.

Shinagawa, Y., and Shinagawa, Y., 1971, Electron state of triazine diuretics: Igaku No Ayumi, v. 79, no. 13, p. 633634.

Japanese.

Degradation Products.

CA77(3):13873b.

Siele, V. I., and Gilbert, E. E., 1975, Utilization of ammelide (by-product from guanidine nitrate production): U.S. NTIS, AD Rep., AD-A021343, 12 p.

English.

Degradation Products.

CA8S(18):130074t.

Sirons, G. J., Frank, R, and Sawyer, T., November/December 1973, Residues of atrazine, cyanazine, and their phytotoxic metabolites in a clay loam soil: Joumal of Agricultural and Food Chemistry, v. 21, no. 6; p. 1016-1020.

English.

Field Residuals,Degradation Products,Sorption to Soil, Biodegradation/Biotransformation,Hydrolysis/Chemical Reactions.
Spasskaya, R. I., Finkel'shtein, A. I., Zil'berman, E. N., and Roginskaya, T. N., 1980, Effect of impurities on the condensation of melamine with formaldehyde: Plasticheskie Massy, no. 3, p. 7-9.

Russian.

Degradation Products. CA92(22):1819402.

Spilker, C. W., and Cleek, G. K., 1966, Urea-formaldehyde adhesives modified with ammelide, ammeline or mixtures: U.S. US 3278475, 11 Oct 1966, 4 p.

English.

Degradation Products.

CA6(2):3374y.

Steinke, W., and Kem, E., 1975, 2-Methylmercapto-4,6-bisalkylamino-s-triazines: Appl. or Pr. 137 736, 11 Feb 1969. German. Degradation Products. CA84(15):105664g.

Stoks, P. G., and Schwartz, A. W., 1979, Determination of striazine derivatives at the nanogram level by gas-liquid chromatography: Journal of Chromatography, v. 168, no. 2, p. 455-460.

English. Degradation Products,Analytical Techniques/Quantification. CA90(12):97107j.

Stoks, P. G., and Schwartz, A. W., 1981, Origin of Life, Proceedings of the ISSOL Meetings, 3rd, 1980, p. 59-64. English.

Degradation Products. CA96(18):146585y.

Stratton, G. W., Jan 1984, Effects of the herbicide atrazine and its degradation products, alone and in combination, on phototrophic microorganisms: Archives of Environmental Contamination and Toxicology, v. 13, no. 1, p. 35-42. English. Toxicity,Degradation Products. CA100(21):169601r.

Sugano, J., Kakuda, M., and Tsuiki, T., 1974, Activators for bleaching agents: JP Appl. 72 75,537, 29 Jul 1972.

German.

Degradation Products.

CA81(4):14993k.

Tafuri, F., Patumi, M., Marucchini, C., and Businelli, M., 1982, Extraction and identification of a new degradation product of atrazine in the soil: Pesticide Science, v. 13, no. 6, p. 665-669.

English.

Degradation Products,Analytical Techniques/Quantification. CA99(19):153762u.

Takahashi, T., 1970, Organic fluorescent sustance: Japan. JP 45/ 37301 (70/37301), 26 Nov 1970, 2 p.

Japanese.

Degradation Products.

CA75(16):103575u. 


\section{DEGRADATION PRODUCTS}

Takakuwa, Y., Kokubo, R., Shiroishi, A., and Murakami, T., 1978, Development of a process for the purification of crude melamine manufactured from urea: Kagaku Kogaku Rombunshu, v. 4 , no. 3, p. 305-311.

Japanese.

Degradation Products. CA90(3):21876p.

Takic, Z. D., and Ries, S. K, 1971, Thermal and ultrasonic dealkylation of s-triazines via the cyclic transition state: Journal of Agriculture and Food Chemistry, v. 19, no. 1, p. 46-49.

English.

Degradation Products,Hydrolysis/Chemical Reactions. CA74(9):38271e.

Takimoto, M., 1982, Studies of: Nippon Kagaku Kaishi, no. 4, p. 662-669.

Japanese.

Photolysis, Degradation Products.

CA97(9):72331j.

Tincu, V. L., Oprea, C., Velea, S., Dragos, C. E., Stepan, E., Caravaniez, D. M., Zugravescu, M., and Zaharia, E. M., 1979, Methoxydialkylamino-s-triazines: Appl. or Pr. 90390, 19 May 1977.

Romanian.

Degradation Products,Hydrolysis/Chemical Reactions. CA95(3):251442.

Toth, D., and Tomasovicova, D., 1979, Effect of pesticides on the survival of Tetrahymena pyriformis in Danube water. Biologia (Bratislava), v. 34, no. 3, p. 233-239.

English.

Degradation Products, Toxicity,Surfacewater Observations. CA91(1):1033d.

Truchlik, S., Splhacek, R, Muchova, J., Paldan, M., and Mostecky, J., 1987, Production of stable mixture of striazines as herbicides physico-chemically stable mixture production: Appl. 84?1455, 1 Mar 1984.

Slovenian.

Hydrolysis/Chemical Reactions,Degradation Products. CA108(13):108168y.

Ulery, H. E., 1973, Lubricant greases: Appl. or Pr. 40,347, 25 May 1970.

English.

Degradation Products.

CA79(8):44190x.

Van den Heede, M., and Heyndrickx, A., 1976, A thin layer chromatographic separation of some symmetric-triazine herbicides: Mededelingen van de Paculteit Landbouwwetenschappen, Rijksuniversiteit Gent, v. 41, no. 2, Pt. 2; p. 1457-1465.

English.

Degradation Products,Analytical Techniques/Quantification. CA86(13):84568c.

Vasastko, E, 1985, Antistatic and flameproofing agents for polymers: Appl. 81/970, 10 Feb 1981.

Czechoslovalian.

Degradation Products.

CA104(18):150089r.
Vermeulen, N. M. J., Apostolides, Z, Potgieter, D. J. J., Nel, P. C., and Smit, N. S. H., 1982, Separation of atrazine and some of its degradation products by high-performance liquid chromatography. Journal of Chromatography, v. 240, no. 1, p. 247-253.

English.

Chemrcal/Physical Properties,Analytical Techniques/ Quantification,Degradation Products.

CA97(9):67613y.

Volk, F., 1985, Determination of gaseous and solid decomposition products of nitroguanidine: Propellants, Explosives, Pyrotechnics, v. 10, no. 5, p. 139-146.

English.

Degradation Products, Chemical/Physical Properties. CA104(2):7866m.

Volk, F., 1984, Determination of gaseous and solid decomposition products of nitroguanidine: Proceedings of the International Pyrotechnies Seminar, 9th, p. 665-684.

English.

Degradation Products, Chemical/Physical Properties. CA102(6):48246m.

Vollbrecht, H. R, and Wagner, F., 1979, Mixture containing cyanuric chloride for synthesis of cyanuric acid derivatives: Appl. or Pr. 2839384, 11 Sep 1978.

German.

Degradation Products.

CA92(7):58830m.

Vorob'eva, S. M., and Smimov, R. P., 1976, Macroheterocyclic compounds: Appl. or Pr. 1,949,410, 16 Jul 1973.

Russian.

Degradation Products. CA84(21):150676y.

Vorob'eva, S. M., and Smirnov, R. P., 1974, Synthesis and study of the properties of macroheterocyclic compounds with a methyne group in the reaction center. Izvestiya Vysshikh Uchebnykh Zavedenii, Khimiya i Khimicheskaya Tekhnologiya, v. 17 , no. 12 , p. $1828-1832$.

Russian.

Degradation Products.

CA82(21):140095c.

Watchorn, N., and Broome, A. W. J., 1970, Improvements in protein supplements for ruminant feeds: Brit. GB 1191470, 13 May $1970,6 \mathrm{p}$.

English.

Degradation Products. CA73(11):54802p.

Weete, J. D., Pillai, P., and Davis, D. D., 1980, Metabolism of atrazine by Spartina alterniflora. 2. Water-soluble metabolites: Journal of Agriculture and Food Chemistry, v. 28 , no. 3, p. 636-640.

English.

Degradation Products,Biodegradation/Biotransformation. CA92(25):210078g. 
Wells, R. L., Ulmer, H. E., and Mason, P. J., 1972, Substituted s-triazine/formaldehyde adducts as herbicides: Appl. or Pr. 884,000, 10 Dec 1969.

English.

Degradation Products.

CA80(9):48040s.

Werle, P., Focke, H., Popp, K, and Merk, W., 1983, Bismelamines: Appl. 3143920, 5 Nov 1981.

German.

Degradation Products.

CA99(4):24426p.

Werle, P., Focke, H., and Boes, A., 1986,

Dodecamethylenebismelamine for stabilizing aqueous

formaldehyde solutions: Appl. 3509056, 14 Mar 1985.

German.

Degradation Products.

CA106(2):5944c.

Wojtowicz, J. A., 1977, Trichloroisocyanuric acid from selected symmetrical triazines: Appl. or Pr. 699825, 25 Jun 1976.

English.

Degradation Products,Hydrolysis/Chemical Reactions. CA88(5):37846y.

Wojtowicz, J. A., 1977, Trichloroisocyanuric acid from selected symmetrical triazines: Appl. or Pr. 660962, 24 Feb 1976.

English.

Degradation Products.

CA86(23):171510w.

Wolf, D. C., and Martin, J. P., 1975, Microbial decomposition of carbon-14 ring-labeled atrazine, cyanuric acid, and 2-chloro4,5-diamino-s-triazine: Journal of Environmental Quality, v. 4, no. 1, p. 134-139.

English.

Degradation Products,Biodegradation/Biotransformation.

CA83(1):1813t.

Wolfe, N. L, Zepp, R. G., Gordon, J. A, and Fincher, R. C., Mar 1976, N-nitrosamine formation from atrazine: Bulletin of Environmental Contamination and Toxicology, v. 15, no. 3, p. 342-347.

English.

Degradation Products, Biodegradation/Biotransformation, Hydrolysis/Chemical Reactions.

CA85(9):57729d.

Zagranichnyi, V. I., Boitsov, E. N., Karlik, V. M., Gorodova, G. E., and Arakelyan, S. A., 1970, Effect of some impurities on the polycondensation of melamine with formaldehyde: Plasticheskie Massy, no. 7, p. 16-17.

Russian.

Degradation Products.

CA73(14):67161d:

Zeyer, J., Bodmer, J., and Huetter, R, 1981, Microbial degradation of ammeline: Zentralblatt fuer Bakteriologie, Mikrobiologie, und Hygiene, Abteilung 1, Orig. C, v. 2, no. 3, p. 289-298.

English.

Degradation Products,Biodegradation/Biotransformation. CA96(11):81319t. 
Adler, I. D., 1980, A review of the coordinated research effort on the comparison of test systems for the detection of mutagenic effects, sponsored by the E.E.C.: Mutation Research, v. 74, no. 2, p. 77-93.

English.

Toxicity, Miscellaneous Environmental.

CA93(1):1551n.

Anon., 27 Dec 1968, Atrazine; tolerances for residues: Federal Register, v. 33, no. 251, p. 19800-19801.

English.

Miscellaneous Environmental.

CA70(13):56381n.

Barbulescu, N, Barbulescu, E., Sintamarian, A., Moga-Gheorghe, S., Magyari, A., Brad, E., Bohacs, L., Petcu, M., Schimpf, E. Z, and Pana, M., 1984, Pesticidal smoke generation comprising amines and weakly-nitrated cellulose nitrate: Appl. 108528, 27 Aug 1982.

Romanian.

Miscellaneous Environmental.

Brockway, D. L., Smith, P. D., and Stancil, F. E., 1984, Fate and effects of atrazine in small aquatic microcosms: Bulletin of Environmental Contamination and Toxicology, v. 32, no. 3, p. 345-353.

English.

Toxicity,Biodegradation/Biotransformation,Miscellaneous Environmental.

CA100(21):169612v.

Caligiuri, C., Dracos, A., Magiola, M., Palmieri, A., Petrelli; G.. Siepi, G., and Verdecchia, A., 1987, Major herbicides used in Italy: production, usage patterns and bibliographic information: Rap ISTISAN, ISTISAN 87/22, 89 p.

Italian.

Toxicity,Miscellaneous Environmental.

CA108(5):33546j.

Camoni, I., Di Muccio, A., Bellisai, M. S., Bersacchi, M., and Citti, $P$., 1988, Pesticide residues in local foods (19831985): Rap ISTISAN, ISTISAN 88/17, 88 p.

Italian.

Miscellaneous Environmental.

CA110(7):56185w.

Crutchfield, D. A., Clar, R. N., and Wiese, A. F., 1977 , Deposition of atrazine and trifluralin with sprinkler irrigation (Abstract only): Proceeding of the Southern Weed Science Society, v. 30, p. 428.

* English.

Miscellaneous Environmental. CAIN 779078099.

Fuehr, F., Biehl, H. M., and Thielert, W., 1983, Methods for the ecotoxicological cvaluation of chemicals. Vol. 2 Soils and model systems. Working Group in Soils and Chemicals. Report 1979-1983: Spez. Ber. Kernforschungsanlage Juelich, JuelSpez-224, 110 p.

German.

Miscellaneous Environmental.

CA100(15):1161042.
Grauer, T., 1968, 2-Chloro-4,6-bis(alkylamino)-s-triazines: U.S. US 3376302, 2 Apr 1968, 6 p.

English.

Miscellaneous Environmental.

CA69(15):59290x.

Gyorfi, L., Ambrus, A., and Bolygo, E., 1987, Pesticide Science and Biotechnology, Proceedings of the International Congress of Pesticide Chemists, 6th, 1986, p. 353-356.

English.

Analytical Techniques/Quantification,Miscellaneous

Environmental.

CA107(15):132730a.

Gysin, H., 1977, Pesticide developments and the question of side effects and environmental hazards: Proceedings of the International Congress of Entomologists, 15th, p. 737-740. English.

Miscellaneous Environmental.

Hanthorn, M., Osteen, C., McDowell, R, and Roberson, L., 1982, 1980 pesticide use on field com in the Com Belt: ERS Staff Rep. U.S. Dept. Agr. Econ. Res. Serv. Wash. D.C., The Service..

English.

Miscellaneous Environmental.

AGE 81919917.

Hanthom, M., Osteen, C., McDowell, R, and Roberson, L., 1982 , 1980 pesticide use on field com in the Northern Plains: ERS Staff Rep. U.S. Dep. Agric. Econ. Res. Serv. Wash. D.C., The Service.

English.

Miscellaneous Environmental.

AGE 82919919.

Hanthorn, M., Osteen, C., and McDowell, R. L., 1982, 1980 pesticide use on field com in the major producing states: ERS Staff Rep. U.S. Dep. Agric. Econ. Res. Serv. Wash., D.C., The Service.

Engtish.

Miscellaneous Environmental.

AGE 82919921.

Hanthorn, M., Osteen, C, McDowell, R, and Roberson, L., 1982, 1980 pesticide use on field com in the Lake States: ERS Staff Rep. U.S. Dep. Agric. Econ. Res. Serv. Wash. D.C., The Service.

English.

Miscellaneous Environmental. AGE 82919915.

Jansen, L. L, 1973, Enhancement of herbicides by silicone surfactants: Weed Science, v. 21, no. 2, p. 130-135. English. Miscellaneous Environmental. CA78(19):120110t.

Keamey, P. C., Muldoon, M. T., and Somich, C. J., 1987, UVozonization of eleven major pesticides as a waste disposal pretreatment: Chemosphere, v. 16, no. 10-12, p. 2321-2330. English.

Miscellaneous Environmental. CA108(20):172928y. 


\section{MISCELLANEOUS \\ Miscellaneous Environmental}

Khan, S. U., Foster, T. S., and Akhtar, M. H., 1979, In-vitro metabolism of a mixture of atrazine and simazine by the soluble fraction $(105,000 \mathrm{~g})$ from goose, pig, and sheep liver-homogenates: Pesticide Science, v. 10, no. 6, p. 460-466. Engtish.

Miscellaneous Environmental,Toxicity.

CA93(5):38960w.

Lowder, S. W., and Weber, J. B., 1978, Lime and tillage effects on atrazine efficacy in a clay soil: Proceedings, Southern Weed Science Society, v. 31, p. 73.

English.

Miscellaneous Environmental.

CAIN 789169716.

Magirescu, M., Ioneci, A., Teodoru, A., Popa, C., and Bancila, V., 1987, Drying system for solid organic products: Appl. 116239, 10 Now 1984.

Romanian.

Miscellaneous Environmental.

CA108(14):114810t.

McCoy, F. C., and Swanson, C. L. W., 1972, Oil-solubilizing, nitrogen-containing pesticidal conmpounds: Appl. or Pr. 878, 586, 20 Nov 1969.

English.

Miscellaneous Environmental.

CA77(23):148531j.

Merezhinskii, Y. G., and Sosnovaya, O. N., 1983, Fiziol. Osn.

Vys. Prod. Kukuruzy, p. 165-169.

Russian.

Miscellaneous Environmental.

CA103(11):83085a.

Mindreboe, K. J., 1970, Weed control with preemergence herbicides in relation to rainfall: Weed Research, v. 10, no. 1, p. 71-

74.

English.

Miscellaneous Environmental.

CA72(25):131337z.

Murkowski, A., 1975, Mekh. Deistviya Gerbits. Sint. Regul. Rosta Rast. Ikh Sud'ba Biosfere, Mater. Mezhdunar. Simp. StranChlenov SEV, 10th, p. 187-193.

Russian.

Miscellaneous Environmental.

CA89(1):1364w.

Neururer, H., and Strecha, A., 1969, Chemical control of weeds in ditches, banks, and water. 1 . Chemical weed control on embankments and banks: Pflanzenschutzberichte, v. 40 , no. 7 8, p. 89-116.

English.

Miscellaneous Environmental. CA72(11):53963j.

Nevell, T. G., and Williams, G. D., 1988, Release of phenylurea and triazine herbicides from elastomer formulations into water. Intemational Biodeterioration Bulletin, v. 24, no. 4 5, p. 255-263.

English.

Miscellaneous Environmental.

CA110(13):110055u.
Poor, R, Lacko, J., and Smida, T., 1987, Atrazine formulation: Appl. 82/2170, 29 Mar 1982.

Slovenian.

Miscellaneous Environmental.

CA108(3):17769d.

Schapira, J., Vincent, J., Droniou, P., and Fuchs, J. J., 1987, Disintegrable plant-pesticide granules: Appl. 85/16297, 4 Now 1985.

French.

Miscellaneous Environmental.

CA108(1):2168h.

Scheunert, I., and Korte, F., 1985, Interactions in the fate of chemicals in terrestrial systems: Ecotoxicology and

Environmental Safety, v. 9, no. 3, p. 385-391.

English.

Biodegradation/Biotransformation,Miscellaneous Environmental, Sorption to Soil.

CA103(7):49747h.

Schober, U., and Lampert, W., 1977, Effects of sublethal concentrations of the herbicide Atrazine on growth and reproduction of Daphnia pulex Bulletin of Environmental Contamination and Toxicology, v. 17, no. 3, p. 269-277. English.

Toxicity,Miscellaneous Environmental. CA87(3):16835h.

Spynu, E. I., and Sova, R. E., 1980, Migr. Zagryaz. Veshchestv Pochvakh Sopredel'nykh Sredakh, Tr. Vses. Soveshch, 2nd, 1978, p. 36-41.

Russian.

Miscellaneous Environmental.

CA96(1):1724h.

Stojanovic, B. J., Hutto, F., Kennedy, M. V., and Shuman, F. L., Jr., 1972, Mild thermal degradation of pesticides: Journal of Environmental Quality, v. 1, no. 4, p. 397-401.

English.

Miscellaneous Environmental.

CA78(13):80904w.

Stritzke, J. F., and Stymiest, C., 1967, Use of oil fractions in weed control: FL-67-58, 3 p, National Petroleum Refiners Association (Technical Publication).

English.

Miscellaneous Environmental.

CA71(17):80039y.

Tekel, J., Spanar, M., and Kovacicova, J., 1988, Residues of triazine herbicides in milk: Ceskoslovenska Hygiena, v. 33 , no. 9, p. 531-537.

Slovenian.

Analytical Techniques/Quantification,Miscellaneous

Environmental.

CA110(7):56071f.

Thompson, L. J., 1972, Metabolism of simazine and atrazine by wild cane: Weed Science, v. 20, no. 2, p. 153-155.

English.

Miscellaneous Environmental.

CA77(3):15409d. 
Vacher, C., 1984, Pay attention to atrazine residues: Perspectives in Agriculture, no. 84, p. 66.

French.

Miscellaneous Ervironmental.

IND 85043901.

Von Rumker, R, Lawless, E. W., Meiners, A. E., Lawrence, K A., and Kelso, G. L., March 1974, Production, distribution, use and environmental impact potential of selected pesticides: Council on Environmentat Quality, Wash., D.C., Final Report, MRI Project No. 3749-C, 439 p..

English.

Miscellaneous Environmental.

Watkins, R, and Hardwick, C, May/June 1981, How to handle herbicide damage. Atrazine, seeding rates, soybeans.:

Soybean Digest, v. 41, no. 7, p. 60-61.

English.

Miscellaneous Environmental.

IND 81049873.

Yadav, S. K, and Singh, D. P., 1981, Effect of irrigation and antitranspirants on evapotranspiration, water use efficiency and moisture extraction petterns of bariey. Irrig. Sci., $v$. 2, no. 3, p. 177-184.

English. Miscellaneous Environmental.

CA95(25):216310k. 
Anon., 1981, Herbicide compositions: Research Disclosure, v. 209, p. $338-340$.

English.

Chemical/Physical Properties.

CA95(23):198882s.

Badilescu, S., Talpus, V., and Racota, R, 1978, Dissociation constants of some hydroxy-s-triazines: Revista de Chimie (Bucharest), v. 29, no. 11, p. 1072-1074.

Romanian.

Degradation Products, Chemical/Physical Properties. CA90(17):137128a.

Best, J. A., 1973, Effect of soil pH on s-triazine dissipation using a balance-sheet approach, Dissertation submitted in partial fulfillment of $\mathrm{Ph}$.D. requirements, North Carolina State University, Raleigh, N.C., USA.

English.

Chemical/Physical Properties.

CA81(21):131453v.

Bollag, J. M., and Henninger, N. M., 1976, Influence of pesticides on denitrification in soil and with an isolated bacterium: Journal of Environmental Quality, v. 5, no. 1, p. 15-18.

English.

Chemical/Physical Properties.

CA84(15):100537h.

Bozzay, J., David, A., Ekes, G., and Rusznak, I., 1979, On the solubility of pesticides and compounds of pesticide type: Periodica Polytechnica, Chemical Engineering, v. 23, no. 2, p. 87-97.

Einglish.

Chemical/Physical Properties.

CA91(13):103705s.

Braumann, T., Weber, G., and Grimme, L. H., 1983, Quantitative structure-activity relationships for herbicides. Reversedphase liquid chromatographic retention parameter, $\log \mathrm{kw}$, versus liquid-liquid partition coefficient as a model of the hydrophobicity of phenylureas, s-triazine and phenoxycarbonic acid derivatives: Journal of Chromatography, v. 261, no. 3, p. 329-343.

English.

Chemical/Physical Properties,Analytical Techniques/

Quantification.

CA99(5):34410t.

Brown, C. B., and White, J. L., 1969, Reactions of 12 s-triazines with soil clays: Soil Science Society of America,

Proceedings, v. 33, no. 6, p. 863-867.

English.

Degradation Products, Chemical/Physical Properties,Sorption to Soil,Hydrolysis/Chemical Reactions.

CA72(9):42089c.

Brueggemann, R., Matthies, M., and Rohleder, H., 1987, Quantitative Structure Activity Relationships in Environmental Toxicology, Proceedings of the International Workshop, 2nd, 1986, p. 25-42.

English.

Chemical/Physical Properties.

CA108(16):137260c.
Cairns, J., Pratt, J. R., Niederiehner, B. R, and Bowers, N. J., 1988, Structural and functional responses to perturbation in aquatic ecosystems: Report, AFOSR-TR-88-0223.

English.

Chemical/Physical Properties.

CA110(8):63365h.

Calvet, R, and Tabareau, A. M., 1977, Kinetic study of dissolution phenomena in aqueous phases. Application to the dissolution of atrazine: Annales Agronomiques, v. 28, no. 2 , p. 117-136.

French.

Chemical/Physical Properties,Sorption to Soil.

CA87(17):128876d.

Calvet, R., Terce, M., and Le Renard, J., 1975, Kinetics of dissolution of atrazine, propazine, and simazine in water. Weed Research, v. 15, no. 6, p. 387-392.

Weed Res.

Chemical/Physical Properties.

CA84(21):146105u.

Calvet, R, 1976, Rapid measurement of the diffusion coefficient of atrazine in aqueous solution: Weed Research, v. 16, no. 1, p. 53-55.

French.

Chemical/Physical Properties,Sorption to Soil.

CA84(17):116749q.

Calvet, R, and Terce, M., 1975, Solubility of atrazine in calcium montmorillonite gels: C.R. Hebd. Seances Acad. Sci., Ser. D, v. 281, no. 4, p. 247-250.

French.

Chemical/Physical Properties,Sorption to Soil. CA84(1):1213t.

Cesareo, D., Tosato, M. L., and Clementi, S., 1987, Modeling phytotoxic activity of herbicidal triazines by molecular properties: a PLS approach: Environmental Toxicology and Chemistry, v. 6, no. 11, p. 839-845.

English.

Chemical/Physical Properties.

CA108(1):2116q.

Chen, J. T., 1967, Infrared absorption spectra and polymeric structures of three s-triazine herbicides and their metabolites: Journal of the Association of Official Analytical Chemists, v. 50, no. 3, p. 595-600.

English.

Degradation Products, Chemical/Physical Properties.

CA67(13):635569.

Chepurova, M: B., Kobzova, R. I., and Mikheev, V. A., 1981, Antiwear and antifriction properties of ammeline greases: Khimiya i Tekhnologiya Topliv i Masel, no. 9, p. 29-30. Russian:

Run-off,Chemical/Physical Properties. CA96(6):38000v.

Christian, J. B., 1979, Torque characteristics of lubricating greases in miniature bearings: NLGI Spokesman, v. 43, no. 5 , p. $160-165$.

English.

Degradation Products, Chemical/Physical Properties. CA91(20):160011m. 
Christian, J. B., 1972, Grease compositions of perfluoroolefin epoxide polyethers: Appl. or Pr. 668,236, 15 Sep 1967. English.

Chemical/Physical Properties. CA77(4):22562b.

Christian, J. B., 1973, Grease composition: Appl. or Pr. 881,918, 3 Dec 1969.

English.

Degradation Products, Chemical/Physical Properties. CA79(2):7706z.

Connell, D. W., and Schueuermann, G., 1988, Evaluation of various molecular parameters as predictors of bioconcentration in fish: Ecotoxicology and Environmental Safety, v. 15, no. 3, p. 324-325.

English.

Chemical/Physical Properties.

CA109(13):105954m.

Deming, J. M., and Surgant, J. M., 1988, Water-dispersible granules comprising encapsulated and nonencapsulated pesticides: Appl. 87/870096, 8 Jul 1987; US Appl. 883801, 9 Jul 1986; US Appl. 58072, 16 Jun 1987.

English.

Chemical/Physical Properties.

CA103(23):200231m.

Diner, B. A., and Petrouleas, V., 1987, Light-induced oxidation of the acceptor-side iron(II) of photosystem II by exogenous quinones acting through the QB binding site. II. Blockage by inhibitors and their effects on the iron(III) EPR spectra: Biochimica et Biophysica Acta, v. 893, no. 2, p. 138-148. English.

Chemical/Physical Properties.

CA107(19):172722f.

Ellgehausen, H., D'Hondt, C., and Fuerer, R, 1981, Reversedphase chromatography as a general method for determining octan-1-ol/water partition coefficients: Pesticide Science, v. 12 , no. 2, p. $219-227$.

English.

Chemical/Physical Properties.

CA95(9):79870b.

Freitag, D., Ballhom, L, Geyer, H., and Korte, F., 1985, Environmental hazard profile of organic chemicals. An experimental method for the assessment of the behavior of organic chemicals in the ecosphere by means of simple laboratory tests with carbon-14-labeled chemicals:

Chemosphere, v. 14, no. 10, p. 1589-1616.

English.

Chemical/Physical Properties,Biodegradation/

Biotransformation,Associations with Plants.

CA103(25):208313g

Freitag, D., Lay, J. P., and Korte, F., 1984, Quantitative Structure/Activity Relationships in Environmental Toxicology, Proceedings of the Workshop, 1983, p. 111-136. English.

Chemical/Physical Properties,Uptake by Biota,Toxicity. CA102(16):137152v.
Galassi, S., 1987, Chemical and physical properties of atrazine in relation to environmental contamination: Inquinamento, $v$. 29 , no. 11, p. $65-68$.

Italian.

Surfacewater Observations, Chemical/Physical Properties. CA108(17):145370d.

Gardi, I., Gorog, K, Gaal, S., Dudar, E., Koscis, M., and Tasnadi, M., 1981, Selective herbicide compositions: Appl. or Pr. 17034, 2 Mar 1979.

English.

Chemical/Physical Properties.

CA94(23): $186834 u$.

Gaynor, J. D., and Van Volk, V., 1981, s-Triazine solubility in chloride salt solutions: Journal of Agriculture and Food Chemistry, v. 29, no. 6, p. 1143-1146.

English.

Chemical/Physical Properties.

CA95(19):163733s.

Gerber, H. R, 1977, Crop Protection Agents - Their Biological Evaluation, Proceedings of the International Conference. 1975, p. 307-321.

English.

Chemical/Physical Properties,Sorption to Soil,Analytical Techniques/Quantification.

CA89(9):71961n.

Getzen, F. W., and Ward, T. M., 1971, Influence of water structure on aqueous solubility. Industrial and Engineering Chemistry Research and Development, v. 10, no. 2, p. $122-132$. English.

Chemical/Physical Properties. CA75(4):26029q.

Gore, R. C., Hannah, R W.: Pattacini, Silvio C., and Porro, T. J., 1971, Infrared and ultraviolet spectra of seventy-six pesticides: Journal of the Association of Official Analytical Chemists, v. 54, no. 5, p. 1040-1082.

English.

Photolysis, Chemical/Physical Properties. CA75(19):117202g.

Gromova, T. I., I.yubarskii, M. V., and Sukhanova, T. G., 1984, Heats of combustion and formation of sym-triazine derivatives: Zhurnal Fizicheskoi Khimii, v. 58, no. 6, p. 1556-1558.

Russian.

Degradation Products, Chemical/Physical Properties. CA101(10:79480.

Henriet, M. M., Mitchell, R. W., and Prill, E. J., 1985, Emulsion flowable formulation containing a mixture of alachloratrazine as the active agent: Appl. 84/870135, 17 Sep 1984; US.Appl. 533696, 19 Sep 1983.

English.

Chemical/Physical Properties. CA103(9):66774g

Hirschberg, J., and McIntosh, L, 1983, Molecular basis of herbicide resistance in Amaranthus hybridus: Science, v. 222, no. 4630 , p. $1346-1349$.

English.

Chemical/Physical Properties.

CA100(11):80654n. 
Hoermann, W. D., and Eberie, D. O., 1972, Aqueous solubility of 2-chloro-4-ethylamino-6-isopropylamino-1,3,5-triazine (atrazine) obtained by an improved analytical method: Weed Research, v. 12, no. 2, p. 199-202.

English.

Chemical/Physical Properties.

CA77(15):97577u.

Hormann, W. D., and Eberie, D. O., June 1972, The aqueous solubility of 2-chloro-4-ethylamino-6-isopropylamino-1,3,5triazine obtained by an improved analytical...: Weed Research, v. 12, no. 2, p. 199-202.

English.

Chemical/Physical Properties.

CAIN 729076987.

Hurle, K. B., and Freed, V. H., 1972, Effect of electrolytes on the solubility of some 1,3,5-triazines and substituted ureas and their adsorption on soil: Weed Research, v. 12, no. 1, p. 1-10.

English.

Sorption to Soil, Chemical/Physical Properties. CAT7(3):15466v.

Janos, E., Cserhati, T., Bordas, B., and Dobrovolszky, A., 1985, Lipophilicity of triazine herbicides measured by gas chromatography: Acta Phytopathologica Academiciae Scientriarum Hungaricae, v. 20, no. 1-2, p. 219-224. English.

Analytical Techniques/Quantification,Chemical/Physical Properties. CA105(1):2089w.

John, W. W., Pilgram, K. H., and Martin, M. E. F., 1985, Acylthio-substituted triazines: Appl. 613495, 24 May 1984. English.

Degradation Products, Chemical/Physical Properties. CA104(1):5896x

Kajiyama, S., 1977, Safety and Health with Plastics, National Technical Conference, Society of Plastics Engineers, Denver; p. $178-180$.

English.

Degradation Products,Chemical/Physical Properties. CA88(6):38416v.

Karlhuber, B. A., Hormann, W. D., and Ramsteiner, K. A., 1975, Pesticide residue analysis by mass fragmentography: Analytical Chemistry, v. 47 , no. 14 , p. $2450-2452$.

English.

Chemical/Physical Properties,Analytical Techniques/

Quantification.

CA83(25):202637n.

Karlik, V. M., and Selivanov, V. D., 1974, Physicochemical properties of some derivatives of sym-triazine and symheptazine: Azotnaya Promyshlennost, no. 6, p. 30-32. Russian.

Chemical/Physical Properties.

CA84(7):43133x.
Kenyon, W. H., Duke, S. O., and Paul, R. N., 1988, Effects of temperature on the activity of the p-nitrosubstituted diphenyl ether herbicide acifluorfen in cucumber (Cucumis sativus L.): Pesticide Biochemistry and Physiology, v. 30, no. 1, p. 57-66.

Engtish.

Chemical/Physical Properties.

CA108(9):70568p.

Kerier, F, and Schoenherr, J., 1988, Permeation of lipophilic chemicals across plant cuticles: prediction from partition coefficients: Archives of Environmental Contamination and Toxicology, v. 17, no. 1, p. 7-12.

English.

Chemical/Physical Properties,Associations with Plants. CA108(9):70365r.

Khanvilkar, S. A., Singh, N. P., and Hukkeri, S. B., 1987, Response of spring sunflower to irrigation, mulch and antitranspirants: Journal of Maharashtra Agricultural University, v. 12, no. 3, p. 322-325.

English.

Chemical/Physical Properties.

CA108(17):145427c.

Khmel'nitskaya, E. Y., 1975, Polarography of s-triazine compounds. I. Mechanism of the reduction of chlorosubstituted s-triazine studied by the latent limiting current method: Elektrokhimiya, v. 11, no. 6, p. 873-881.

Russian.

Chemical/Physical Properties,Analytical Techniques/

Quantification.

CA83(18):154656u.

Korolev, B. A., and Mal'tseva, M. A, 1973, Basicity of anilines and heterocyclic bases in nitromethane and water. Place of protonation of 2-substituted 4,6-diamino-s-triazines: Zhurnal Obshchei Khimii, v. 43, no. 7, p. 1556-1564.

Russian.

Chemical/Physical Properties.

CA80(11):59276z.

Korte, F., Pfister, G., and Bahadir, M., 1988, Pesticides: Food and Environmental Implications, Proceedings of the International Symposium, 1987, p. 195-203.

English.

Chemical/Physical Properties.

CA110(11):90598t.

Kuemmel, R, and Krusch, C., 1982, Adsorption of urea from an aqueous solution onto activated carbon: Acta Hydrochimica et Hydrobiologica, v. 10, no. 1, p. 61-68.

German.

Run-off,Chemical/Physical Properties. CA96(22):187849f.

LeClair, F. J., and Surgant, J. M., 1982, Flowable compositions comprising 2-chloro- $\mathrm{N}$-isopropylacetanilide and s-triazine herbicides: Appl. 82/301553, 24 Mar 1982; US Appl. 247679, 26 Mar 1981.

English.

Chemical/Physical Properties.

CA98(11):84905h 
Leclercq, P. A., and Pacakova, V., 1979, Gas chromatography and mass spectrometry of bis(alkylamino)-s-triazines: Journal of Chromatography, v. 178, no. 1, p. 193-207.

English.

Degradation Products,Analytical Techniques/Quantification, Chemical/Physical Properties. CA92(15):128188j.

Levin, E. S., and Vinogradova, N. P., 1966, Vibration spectra of 2,4,6-halo and aminohalo derivatives of 1,3,5-triazine: Zhurnal Prikiadnoi Spektroskopii, v. 4, no. 4, p. 330-338. Russian.

Chemical/Physical Properties.

CA66(8):33226u.

Mailman, R. B., and Hodgson, E., 1972, Cytochrome P-450 substrate optical difference spectra of pesticides with mouse hepatic microsomes: Bulletin of Environmental Contamination and Toxicology, v. 8, no. 3, p. 186-192.

English.

Chemical/Physical Properties.

CA78(3):12412j.

Marozzi, E., Gambaro, V., Lodi, F., and Pariali, A., 1977, Systematic, generic, chemicotoxicological research in forensic toxicology. Part III. Comparison of IR and .DELTA.IR obtained under programmed and isothermal temperature conditions: Farmaco, Edizione Pratica, v. 32, no. 7, p. 330-362.

Italian.

Chemical/Physical Properties.

CA87(17):1282201

Messori, V., and Francese, R, 1980, Chioro-bis(alkylamino)-striazines: IT Appl. 78/28219, 29 Sep 1978.

English.

Hydrolysis/Chemical Reactions, Chemical/Physical Properties. CA94(11):84177q.

Micev, N., and Bubalov, M., 1972, Interaction between soil microflora and herbicide agelon: Symposia Biologica Hungarica, v. 11, p. 379-384.

English.

Toxicity,Chemical/Physical Properties.

CA79(13):74561m.

Middleton, M. R, and Coffee, R. A., 1980, Pesticidal formulations: GB Appl. 79/16862, 15 May 1979. English.

Chemical/Physical Properties.

CA94(13):98004t.

Mills, T. N., and Cameron, A., 1977, The lubricating character of greases using a new test method: U.S. NTIS, AD Rep., ADA038793, $27 \mathrm{p}$.

English.

Degradation Products, Chemical/Physical Properties. CA87(18):138244k.
Mitsutake, K., Iwamura, H., Shimizu, R, and Fujita, T., 1986, Quantitative structure-activity relationship of photosystem II inhibitors in chloroplasts and its link to herbicidal action: Joumal of Agriculture and Food Chemistry, v. 34, no. 4, p. $725-732$.

English.

Chemical/Physical Properties.

CA105(5):37397x

Modi, J. J., 1986, Evaluation of water soluble polymers as cosuspending agents for flowable pesticides: American Soriety of Testing Materials, Special Technical Publication, v. 915, no. Pesticide Formulations and Application Systems, p. 65-77. English.

Chemical/Physical Properties, Associations with surfactants. CA106(17):133777n.

Moncharzh, E. M., and Finkel'shtein, A. I., 1974, Calculation of ionization potentials of molecules by an improved PariserParr-Pople method: Zhural Strukturnoi Khimii, v. 15, no. 4, p. 752-753.

Russian.

Chemical/Physical Properties.

CA82(7):427492.

Morgan, L. J., and Bell, M., 1987, Aqueous suspension concentrate compositions of pendimethalin: Appl. 87,107496, 22 May 1987; US Appl. 867106, 23 May 1986; US Appl. 866864, 23 May 1986. English.

Chemical/Physical Properties.

CA108(21):182245n.

Morimoto, G., 1966, Infrared spectra of 6-substituted 2,4 diamino-1,3,5-triazines: Nippon Kagaku Zasshi, v. 87, p. 797 801.

Japanese.

Chemical/Physical Properties.

CA66(9):37209p.

Morimoto, G., 1966, Ultraviolet spectra of 6-substituted 2,4diamino-1,3,5-triazines: Nippon Kagaku Zasshi, v. 87, p. 785. 790.

Japanese.

Chemical/Physical Properties.

CA66(9):37197h.

Pacakova, V., and Nemec, I., 1978, Gas chromatographic, spectrophotometric and electrochemical behavior of substituted s-triazines: Journal of Chromatography, v. 148, no. 1, p. $273-281$.

English.

Chemical/Physical Properties,Analytical Techniques/

Quantification.

CA88(13):84401j.

Papamichael, S., and Dyer, R. M. W., 1975, Herbicidal compositions: Appl. or Pr. 10,751/72, 8 Mar 1972. English.

Chemical/Physical Properties.

CA84(1):1239f. 


\section{MISCELLANEOUS Physical/Chemical Properties}

Petree; H. E., 1972, Suppression of tris(alkylamino)-s-triazine formation in the production of chloro bis(alkylamino)-striazines through the use of additional cyanuric chloride: Appl. or Pr. 103,249, 31 Dec 1970. English. Chemical/Physical Properties. CA77(19):126696q.

Pitts, G., Rodriguez-Kabana, R, and Curl E.A., Jan 1974, Effect of the herbicide atrazine and two carbon levels on enzyme activities in soil monocultures of Sclerotium rolfsii: Journal of the Alabama Academy of Science, v. 45, no. 1, p. $54-65$. English. Chemical/Physical Properties,Toxicity. CA82(15):94097e.

Plato, C., 1972, Differential scanning calorimetry as a general method for determining purity and heat of fusion of highpurity organic chemicals. Application to 64 compounds: Analytical Chemistry, v. 44, no. 8, p. 1531-1534.

English.

Chemical/Physical Properties.

CA77(10):69809c.

Polos, E., Mikulas, J., Szigeti, Z, Matkovies, B., Do Quy Hai, Parducz, A., and Lehoczki, E., 1988, Paraquat and atrazine co-resistance in Conyza canadensis (L.) Cronq: Pesticide Biochemistry and Physiology, v. 30, no. 2, p. 142-154. English.

Chemical/Physical Properties. CA108(23):200162q.

Prill, E. J., 1985, Storage stable emulsion flowable formulation containing a mixture of alachlor/atrazine as the active agent: Appl. 84/870134, 17 Sep 1984; US Appl. 533685, 19 Sep 1983.

English.

Chemical/Physical Properties.

CA103(11):83529y.

Querzola, G., Formigoni, A, and Epis, G., 1985, Stabilized fluid suspension of antiparasites in unchlorinated organic solvents and use thereof: Appl. 85/100098, 7 Jan 1985; IT Appl. 84/ 19218 , 18 Jan 1984.

English.

Chemical/Physical Properties.

CA103(13):100418f.

Renger, G., Fromme, R, and Hagemann, R, 1988, The modification of atrazine binding by the redox state of the endogenous high-spin iron and by specific proteolytic enzymes in photosystem II membrane fragments and intact thylakoids: Biochimica et Biophysica Acta, v. 935, no. 2, p. 173-183. English.

Chemical/Physical Properties,Hydrolysis/Chemical Reactions. CA109(21):187528n.

Repasi, G., Rokonay, M. J., and Pinter, Z., 1972, Gaschromatographic data of alkylamino-s-triazines: Magyar Kemiai Folyoirat, v. 78, no. 2-3, p. 166-168.

Hungarian.

Chemical/Physical Properties,Analytical Techniques/

Quantification.

CA77(2):9940d.
Sapozhnikov, Y. E., Yasman, Y. B., Sukhanova, T. G., and Danilov, V. A., 1984, Electronic effects in chlorine-containing heterocyclic compounds. 1. Amino derivatives of 2,4,6trichloro-1,3,5-triazine: Organic Reactivity (Tartu), v. 21, no. 4 , p. $441-448$.

English.

Chemical/Physical Properties.

CA105(3):23852e.

Saxton, W. L., 1987, Emergence temperature indexes and relative retention times of pesticides and industrial chemicals determined by linear programmed temperature gas chromatography: Journal of Chromatography, v. 393, no. 2, p. 175-194.

English.

Chemical/Physical Properties.

CA107(18):168002d.

Selivanov, V. D., Karlik, V. M., and Zagranichnyi, V. I., 1973, Standard enthalpies of formation of ammeline, ammelide, melem, and melon: Zhumal Fizicheskoi Khimii, v. 47, no. 2, p. 476.

Russian.

Chemical/Physical Properties.

CA78(22):141105k.

Shimizu, R, Iwamura, H., and Fuhita, T., 1988, Quantitative structure-activity relationships of photosystem II inhibitory anilides and triazines: Joumal of Agriculture and Food Chemistry, v. 36, no. 6, p. 1276-1283.

English.

Chemical/Physical Properties.

CA109(25):226882v.

Siek, T. J., Osiewicz, R. J., and Bath, R. J., 1976, Identification of drugs and other toxic compounds from their ultraviolet spectra. Part III: Ultraviolet absorption properties of 22 structural groups: Joumal of Forensic Sciences, v. 21, no. 3, p. 525-551.

English.

Chemical/Physical Properties.

CA88(15):99813u.

Stancheva, P., 1978, Infrared spectra of some metal-triazine preparations: Nauchni Trove - Vissh Selskostopanski Institut "Vasil Kolarov", Plovdiv, v. 23, no. 2, p. 25-30.

Bulgarian.

Chemical/Physical Properties.

CA91(15):118642t.

Stevens, C., Jenkins, D. K. W., and Wilson, D. C., 1983, Testing procedure for evaluating codisposal of industrial wastes and municipal refuse with particular reference to pesticides: American Society for Testing Material, Special Technical Publication, v. 805, no. Hazardous and Industrial Solid Waste Testing, p. 111-126. English:

Leaching,Chemical/Physical Properties. CA102(10):83864h.

Stransky, Z, 1985, Isotachophoresis of cationic herbicides in waters and soils: Journal of Chromatography, v. 320, no. 1, p. 219-231.

English.

Chemical/Physical Properties.

CA102(15):127117y. 
Stransky, Z, and Opalkova, I., 1987, Isolation of triazine herbicides from water and soil: Acta Universitatis

Palackianae Olomucensis, Facultas Rerum , v. 88, no. Chem 26, p. 149-157.

English.

Chemical/Physical Properties.

CA108(23):200071j.

Strzelec, A., 1980, The effect of phosphorus on the dynamics of atrazine disappearance from soil and Penicillium citrinum culture fluid: Acta Microbiologica Polonica, Series B, v. 29, no. 2 , p. $167-171$.

English.

Chemical/Physical Properties.

CA94(7):46071t.

Surzhikova, L. V., and Vasil'ev, A. F., 1970, Quantitative ir absorption spectrometric analysis of atrazine, simazine, and propazine in commercial products and wetting powders: Khimicheskie Sredstva Zashchity Rastenii, v. 1, p. 210-216. Russian.

Chemical/Physical Properties,Analytical Techniques/ Quantification.

CA78(11):68013x.

Swanson, R. A., and Dutt, G. R, 1973, Chemical and physical processes that affect atrazine and distribution in soil systems: Soil Science Society of America, Proceedings, v. 37, no. 6, p. $872-876$.

English.

Chemical/Physical Properties,Field Residuals. CA80(17):91996v.

Thompson, J. F., Mann, J. B., Apodaca, A. O., and Kantor, E J., 1975, Relative retention ratios of ninety-five pesticides and metabolites on nine gas-liquid chromatographic columns over a temperature range of 170 to 204.deg. in two detection modes: Journal of the Association of Official Analytical Chemists, v. 58 , no. 5 , p. $1037-1050$.

English.

Analytical Techniques/Quantification,Chemical/Physical

Properties.

CA83(25):202708m.

Tosato, M. L., Marchini, S., Passerini, L., Cesareo, D., Bonelli, D., Cruciani, G., and Clementi, S., 1988, Modelling phytotoxicity of herbicidal triazines: Chimica Oggi (Chemistry Today), no. 4, p. 55-59.

English.

Chemical/Physical Properties. CA110(13):110040k.

Trebst, A, Donner, W., and Draber, W., 1984, Structure activity correlation of herbicides affecting plastoquinone reduction by photosystem II: electron density distribution in inhibitors and plastoquinone species: Zeitschrift fuer Naturforschung, C: Biosciences, v. 39C, no. 5, p. 405-411. English.

Chemical/Physical Properties.

CA101(7):50054v.

Triola, P. d. La, Aug 1969, Properties and effects of selective herbicides: Cult. Mod., v. 52, no. 8, p. 45-46.

Spanish.

Chemical/Physical Properties.

CAIN 709043640.
Tseng, C. K, and Mihailouski, A., 1977, Carbon-13 NMR studies of substituted bisalkylamino-s-triazines in acidic media:

Organic Magnetic Resonance, v. 10, p. 224-225.

English.

Chemical/Physical Properties.

CA89(17):145974t.

Vermeulen, N. M. J., Apostolides, Z, Potgieter, D. J. J., Nel, P. C., and Smit, N. S. H., 1982, Separation of atrazine and some of its degradation products by high-performance liquid chromatography: Journal of Chromatography, v. 240, no. 1, p. 247-253.

English.

Chemical/Physical Properties,Analytical Techniques/

Quantification,Degradation Products.

CA97(9):67613y.

Volk, F., 1985, Determination of gaseous and solid decomposition products of nitroguanidine: Propellants, Explosives, Pyrotechnics, v. 10, no. 5, p. 139-146.

English.

Degradation Products, Chemical/Physical Properties. CA104(2):7866m.

Volk, F., 1984, Determination of gaseous and solid decomposition products of nitroguanidine: Proceedings of the International Pyrotechnics Seminar, 9th, p. 565-684.

English.

Degradation Products, Chemical/Physical Properties. CA102(6):48246m.

Walker, A, 1972, Influence of soil factors on availability of atrazine and linuron to plants. (Wheat): British Weed Control Conference Proceedings, 11th, v. 2, p. 800-805.

English.

Chemical/Physical Properties,Sorption to Soil. CA85(5):29458w.

Ward, T. M., and Weber, J. B., 1968, Aqueous solubility of alkylamino-s-triazine as a function of $\mathrm{pH}$ and molecular structure: Journal of Agriculture and Food Chemistry, v. 16, no. 6, p. 959-961.

English.

Chemical/Physical Properties. CA70(4):14869x.

Zielinski, W. L., Jr., Fishbein, L., and Martin, L. J., 1967, Relation of structure to sensitivity in the electron capture analysis of pesticides: Journal of Gas Chromatography, v. 5, no. 11, p. 552-555.

English.

Chemical/Physical Properties,Analytical Techniques/

Quantification.

CA68(5):211562 
Abdel Fattah, H. M., Abdel Kader, M. I. A., and Hamida, S., June 20,1983 , Selective effects of two triazine herbicides on Eqyptian soil fungi: Mycopathologia, v. 82, no. 3, p. 143151.

English.

Toxicity.

IND 83103593.

Abhayavardhani, P., and Sarma, Y. S. R.K., 1982, Effects of herbicides simazine and atrazine on the cytology of Oedogoniom gunnii Wittr. Algae.: Cell Chromosome Research, v. 5, no. 3.

English.

Toxicity,Surfacewater Observations.

IND 83112778.

Abraham, A. D., and Pop, M., 1979, Effect of atrazine on learning and biochemical changes of the brain and adrenals of white rats: Studia Universitatis Babes-Bolyai, Series, Biology, v. 24 , no. 2, p. 32-35.

French.

Toxicity.

CA92(17):141433e.

Adler, I. D., 1980, A review of the coordinated research effort on the comparison of test systems for the detection of mutagenic effects, sponsored by the E.E.C.: Mutation Research, v. 74, no. 2, p. 77-93.

English.

Toxicity,Miscellaneous Environmental.

CA93(1):1551n.

Ahmed, A. A., Hamed, R. I., and El-Mansoury, H. A. M., 1983, Effect of organic herbicide Gesaprim on the thyroid activity, cholesterol and body weight of Balady rabbits: Journal of the Egyptian Veterinarian Medical Association, v. 43, no. 3, p. 289-297.

English.

Toxicity.

CA103(5):33252g

Aliev, S. A., Septner, V. A., and Stonov, L. D., 1973, Effect of prometryn and atrazine on the agrochemical properties and microflora of the piedmont Crimea soils: Khimicheskie Sredstva Zashchity Rastenii, v. 3, p. 110-117.

Russian.

Toxicity.

CA82(13):81587q.

Andersen, K. J., Leighty, E. G., and Takahashi, M. T., May/June 1972, Evaluation of herbicides for possible mutagenic. properties: Journal of Agriculture and Food Chemistry, v. 20, no. 3, p. 649-656.

English.

Toxicity.

Anon., 1966, Bulletin Office International des Epizooties, v. 65 , no. 5-6, p. 663-669.

Toxicity.

Astier, c., Vernotte, C., and Joset-Espardellier, F., 1981, Photosynthesis, Proceedings of the International Congress, Sth, 1980, p. 185-195.

English.

Toxicity.

CA97(9):69416k.
Atkins, C. A., and Tchan, Y. T., 1967, Soil algae. VI. Bioassay of atrazine and the prediction of its toxicity in soils using an algal growth method: Plant Soil, v. 27, no. 3, p. 432-442. English.

Toxicity,Analytical Techniques/Quantification. CA68(7):28687g.

Baart, E. A. E., and Zonderwijk, P., 1970, Chemical control of submerged water plants: , Proefsta. Akker- Weidebouw, Wageningen, Gestencilde Versi. Interprov. Proeven, No. 142, 44 pp..

Netherlands.

Toxicity.

CA75(7):47690p.

Bainova, A., Zaprianov, Z, and Kaloyanova-Simeonova, F., 1980, Proceedings of the International Congress on Occupational Health, 19th, 1978, p. 531-535.

English.

Toxicity.

CA94(23):186536y.

Bakalivanov, D., 1984, Adaptation of soil microorganisms to decomposition of some herbicides: Tasks for Vegetation Science, v. 13, no. Being Alive Land, p. 313-317.

English.

Toxicity, Biodegradation/Biotransformation.

CA101(23):205664v.

Bakalivanov, D., 1972, Biological activity of certain herbicides on microscopic soil fungi: Symposia Biologica.Hungarica, v. 11, p. 373-377.

English.

Toxicity.

CA79(9):52290v.

Bakalivanov, D., 1971, Kongres po Microbiologiya, Materiali ot Kongres na Mikrobiolozite v Bulgariya, 2nd, 1969, p. 259-261. Bulgarian.

Toxicity.

CA78(7):38932d.

Bakalivanov, D., 1975, Interaction of the herbicide atrazine with the microflora of different soils: Rastitelna Zashtita, $v$.

23 , no. 11 , p. 20-25.

Bulgarian.

Toxicity.

CAIN 779026014.

Bakalivanov, D., 1983, Soil microbiological aspects of herbicide contamination: Zentralblatt fuer Mikrobiologie, v. 138, no. 2. p. 83-97.

German.

Toxicity.

CA101(5):34426n.

Bakalivanov, D., and Kostov, A, 1981, Detoxication of the herbicide atrazine, and microorganisms in water-logged soils: Pochvoznanie i Agrolkhimiya, v. 16, no. 6, p. 102-106.

Bulgarian.

Biodegradation/Biotransformation, Toxicity.

CA97(5):34697a. 
Bakalivanov, D., and Lalova, M., 1979, Effect of the herbicides alachlor and atrazine on soil micmflora of chernozemsmolnitza soils: Pochvoznanie i Agrokhimiya, v. 14, no. 1, p. 82-88.

Bulgarian.

Toxicity.

CA92(15):123286e.

Baker, R L, and Powell, J., 1979, Arid Land Plant Resources, Proceedings of the International Arid Lands Conference, 1978, p. $564-573$.

English.

Toxicity.

CA92(3):17073y.

Bakke, J. E., and Price, C. E., 1973, Rat urinary metabolites from 2-methoxy-4,6-bis(isopropylamino)-s-triazine (prometone): Journal of Agriculture and Food Chemistry, v. 21, no. 4, p. 640-644.

English.

Uptake by Biota,Toxicity.

CA79(25):143365q.

Balicka, N., and Sobieszczanaki, J., 1969, Effect of herbicides on soil microflora. I. The effect on the number of soil microorganisms in a field experiment: Acta Microbiologica Polonica, Series B, v. 18, no. 1, p. 3-6.

English.

Toxicity.

CA70(21):95639x.

Balicka, N., Sobieszezanski, J., and Niewiadoma, T., 1969, Effect of herbicides on soil microflora. IV. the action of herbicides on soil microorganisms: Acta Microbiologica Polonica, Series B, v. 18, no. 1, p. 11-14.

English.

Toxicity.

CA70(21):95641s.

Barabasz, W., 1982, Effect of selected pesticides and mycotoxins on the development of phages of soil bacteria of the genera. Arthrobacter, Azotobacter, and Bacillus: Acta Agraria et Silvestria, Series Agraria, v. 21, p. 138-151.

Polish.

Toxicity.

CA99(25):207986r.

Barthova, J., Kalaxova, H., Pacakova, V., and Leblova, S., 1985, The effect of s-triazine-type pesticides and chlorinated hydrocarbons on lactate dehydrogenase: Environmental Research, v. 36, no. 1, p. 26-31.

English.

Toxicity.

CA102(13): $107825 z$

Bashmurin, A. F., 1974; Toxicity of atrazine for animals: Sbornik Rabot - Leningradskii Veterinamyi Institut, v. 36, p. 5-7.

Russian.

Toxicity.

CA82(19):119795w.
Bathe, R., Sachsse, K, Ulimann, L., Hoermann, W. D., Zak, F., and Hess, R, 1975, Evaluation of fish toxicity in the laboratory. Proceedings of the European Society of Toxicologists, v. 16, no. Dev. Genet. Aspects Drug Environ. Toxic., Proc. Meet., 1974, p. 113-124.

English.

Toxicity.

CA85(1):945s.

Bathe, R, Ullmann, L, and Sachsse, K, 1972, Toxicity determination of plant-protective agents on fish: Schriftenreihe des Vereins fuer Wasser, Boden und Lufthygiene, v. 37, p. 241-256.

German.

Toxicity.

CA79(1):1073u.

Bather, R, Ullmann, L., Sachsse, K, and Hess, R, 1976, Relation between toxicity to fish and to mammals: a comparative study under defined laboratory conditions: Proceedings of the European Society of Toxicologists, v. 17, no. Predictions of Chronic Toxicity, Short Term Studies, 1975, p: 351-355.

English.

Toxicity.

CA86(19):134577c.

Bauer, N. J., Seidler, R. J., and Knittel, M. D., November 1981, A simple, rapid bioassay for detecting effects of pollutants on bacteriax Bulretin of Environmental Contamination and Toxicology, v. 27, no. 5, p. 577-582.

English.

Toxicity,Analytical Techniques/Quantification.

Beaumont, G., Bastin, R, and Therrien, H. P., Nov/Dec 1976, Physiological effects of sublethal doses of atrazine on Lemna minor L.: Nature Canada, v. 103, no. 6, p. 527-533.

French.

Toxicity.

CAIN 779064243.

Beaumont, G., Bastin, R, and Therrien, H. P., Nov/Dec 1976, Physiological effects of sublethal doses of atrazine on Lemna minor L.: Nature Canada, v. 103, no. 6, p. 535-541.

French.

Toxicity.

Beaumont, G., Lord, A., and Grenier, G., July 15, 1980, Physiological effects of sublethal doses of atrazine on Lemna minor L.: Canadian Joumal of Botany, v. 58, no. 14, p. 15711577.

French.

Toxicity.

IND 80133037.

Bednarz, T., 1981, The effect of pesticides on the growth of green and blue-green algae cultures: Acta Hydrobiologica, v. 23 , no. 2 , p. $155-172$.

English.

Toxicity.

CA97(15):121674j. 
Bednarz, T., 1981, The evaluation of the adaptation ability of some green algae to 2,4-D acid, monuron, and diuron admixtures, under laboratory conditions: Acta Hydrobioligica, v. 23, no. 3, p. 251-257.

English.

Toxicity.

CA97(15):121675k.

Bel'kov, V. P., and Semenova, A. K., 1969, Gerbitsidy i

Arboritsidy v Lesnom Khozyaistve, Materialy na

Koordinatsionno - Metodicheskom Soveshchanii, Leningrad, p. 91-96.

Russian.

Toxicity.

CA76(9):42665v.

Belobrov, A. V., 1972, Effect of simazine and atrazine on microflora and dynamics of soil nutrients around tree trunks in an orchard in a zone of fluctuating moisture content in the Ukrainian forest steppe: Khimiya v Sel'skom Khozyaistve, v. 10 , no. 5, p. 372-373.

Russian.

Toxicity.

CA77(13):84310b.

Benecke, G., 1980, Development of a biological rapid test method for signaling algae-toxic substances especially regarding herbicides, and demonstration of water-relevant usage possibilities of the method: Veroeffentlichungen des Instituts fuer Wasserforschung Dortmund und der Hydrologischen Abteilung der Dortmunder Stadtwerke, v. 33, p. 333 pp..

German.

Toxicity.

CA94(25):203349j.

Benigni, R, Bignami, M., Camoni, I., Carere, A., Conti, G., lachetta, R, Morpurgo, G., and Ortali, V., 1979, A new in vitro method for testing plant metabolism in mutagenicity studies: Joumal of Toxicology and Environmental Health, v. 5, no: 5, p. 809-819:

English.

Toxicity.

CA92(5):35239m.

Benson, B., and Boush, G. M., 1983, Effect of pesticides and PCBs on budding rates of green hydra: Bulletin of Environmental Contamination and Toxicology, v. 30, no. 3, p. 344-350.

English.

Toxicity.

CA98(21):174432f.

Berndt, J., and Messner, B., 1979, Vortragsveranstaltung Umweltchemikalien der AGF, p. 83-88.

German.

Toxicity.

CA94(1):7495.

Bettini, P., McNally, S., Sevignac, M., Darmency, H., Gasquez, J., and Dron, M., Aug 1987, Atrazine resistance in Chenopodium album. Low and high levels of resistance to the herbicide are related to the same: Plant Physiology, v. 84, no. 4, p. 1442-1446.

English.

Toxicity.

ADL 87086728.
Bhattacharjee, S. K, and David, K. A. V., 1987, UV-sensitivity of cyanobacterium Anacystis nidulans: Part II. A model involving photosystem (PSII) reaction center as lethal target and herbicide binding high tumover $B$ protein as regulator of dark repair. Indian Journal of Experimental Biology, v. 25, no. 12 , p. $837-842$.

English.

Toxicity.

CA108(17):146282p.

Bhattacharjee, S. K., Mathur, M., Rane, S. S., and David, K. A. V., 1987, UV-sensitivity of cyanobacterium Anacystis nidulans: Part I. Evidence for photosystem II (PSI) as a lethal target and constitutive nature of a dark-repair system against damage to PSII: Indian Journal of Experimental Biology, v. 25, no. 12, p. 832-836.

English.

Toxicity.

CA108(17):146281n.

Bhutani, V. P., Bhan, S., and Chopra, S. K., 1984, The influence of herbicides on the soil microflora in a plum orchard: Scientia Horticulture (Amsterdam), v. 23, no. 2, p. 191-194. English.

Toxicity.

CA101(17):145546w.

Bielecki, K., Doroszewicz, H., Grzys, E., and Szuwalska, Z, 1982, A method for rapid testing of the photosynthesisinhibiting activity of herbicides by leaf disk: Acts. Agrobotanica, v. 35, no. 1, p. 123-131.

English.

Toxicity.

CA104(9):64057x.

Birge, W. J., Black, J. A., and Kuehne, R. A., 1980, Effects of organic compounds on amphibian reproduction: Report, RR-121, W80-03438, OWRT-A-074-KY(2).

English.

Toxicity.

CA93(17):162104j.

Birge, W. J., Black, J. A., Westerman, A. G., and Ramey, B. A., 1983, Fish and amphibian embryos - a model system for evaluating teratogenicity: Fundamentals of Applied Toxicology, v. 3, no. 4, p. 237-242.

English.

Toxicity.

CA99(21):17114p.

Birge, W. J., Black, J. A., and Bruser, D. M., 1979, Toxicity of organic chemicals to embryo-larval stages of fish: EPA/560/ 11-79/007.

English.

Toxicity.

CA93(5):38750c.

Blein, J., 1980, Culture of cells from young Chenopodium album $L$. plants sensitive or resistant to atrazine: Physiologie Vegetale, v. 18 , no. 4, p. 703-710.

French.

Toxicity.

IND 81067381. 
Blein, J. P., 1982, Action of some herbicides on growth, respiration, plasmalemma integrity, and proton extrusion of Acer pseudoplatanus cells. II. Amides, diphenyl ethers, nitriles, phenols, triazines, and uracils: Pesticide Biochemistry and Physiology, v. 17, no. 2, p. 156-161. English. Toxicity. CA96(21):176024g.

Boehm, H., Kochmann, W., Barth, A., Guenther, G., Kramer, W., Drueger, H., and Loettge, W., 1972, Screening process for biochemically active substances such as pesticides: DD Appl. WP 152,888, 28 Sep 1972, 31 p.

German.

Toxicity. CA78(1):1043p.

Borie, F., Chantrier, N., Huve, J. L., and Thomson, M. A., 1981, Use of rainbow trout olfactory bulb bioelectric activity for pesticide detection: C.R. Seances Academy of Sciences, Series 3, v. 292, no. 2, p. 235-238.

French.

Toxicity.

CA95(16): $138175 d$.

Bowman, M. C., Oller, W. L., Cairns, T., Gosnell, A. B., and Oliver, K. H., 1981, Stressed bioassay systems for rapid screening of pesticide residues. Part I: Evaluation of bioassay systems: Archives of Environmental Contamination and Toxicology, v. 10, no. 1, p. 9-24.

English.

Toxicity.

CA94(21):172950s.

Braginskii, L. P., 1964, Application of the oxygen method in algotoxic investigations: Radioactiva Isotopy V.C.-Idrosbiol. I Metody Sanit. Gidrobiol. Akademii Nauk SSR Zool. Inst., p. 108-116.

Russian.

Toxicity.

Braginskii, L. P., 1970, Voprosy Vodnoi Toksikologii, p. 81-88. Russian.

Toxicity.

CA74(17):86691p.

Braginskii, L. P., and Migal, A. K., 1973, Effect of atrazine on the vital activity of some aquatic plants: Elssperimental'naya Vodnaya Toksikologiya, v. 5, p. 179-187.

Russian.

Toxicity.

CA86(19):134542n.

Braginskii, L. P., Sirenko, L. A., Stetsenko, N. M., Merezhko, A. I., Arendarchuk, V. V, and Bereza, V. D., 1969, Organic algicides: "Tsvetenie" Vody, v. 2, p. 169-186.

Russian.

Toxicity.

CA73(3):13405t.

Brar, S. S., and Sethi, R. P., 1972, Effect of herbicides on microorganisms: Indian Journal of Microbiology, v. 12, no. 4, p. 2208-233.

English.

Toxicity.

CA79(19):112197g.
Bringmann, G., and Kuehn, R., 1976, Comparative results of the damaging effects of water pollutants against bacteria (Pseudomonas putida) and blue algae (Microcystis aeruginosa): GWF, das Gas- Wasserfach: Wasser/Abwasser, v. 117, no. 9, p. 410-413:

German.

Toxicity.

CA86(13):84321s.

Bringmann, G., and Kuehn, R, 1978, Limiting values for the noxious effects of water pollutant material to blue algae (Microcystis acruginosa) and green algac (Scenedesmus quadricauda) in cell propagation inhibition tests: Vom Wasser, v. 50, p. $45-60$.

German:

Toxicity.

CA89(23):191911t.

Bringmann, G., and Kuehn, R., 1978, Testing of substances for their toxicity threshold: model organisms Microcystis (Diplocystis) aeruginosa and Scenedesmus quadricauda: Mitteilungen - Internationale Vereinigung fuer Theoretische und Angewandte Limnologie, v. 21, no. Symp.: Exp. Use Algal Cult. Limnol., 1976, p. 275-284.

English.

Toxicity.

CA89(23):191890k.

Bringmann, G., and Kuchn, R, 1977, Limiting values for the damaging action of water pollutants to bacteria (Psuedomonas putida) and green algae (Scenedesmus quadricauda) in the cell multiplication inhibition test: Zeitschrift fuer Wasser und Abwasser Forschung, v. 10, no. 3-4, p. 87-98.

German.

Toxicity.

CA88(3):16562n.

Brockway, D. L., Smith, P. D., and Stancil, F. E., 1984, Fate and effects of atrazine in small aquatic microcosms: Bulletin of Environmental Contamination and Toxicology, v. 32, no. 3, p. 345-353.

English.

Toxicity,Biodegradation/Biotransformation,Miscellaneous Environmental. CA100(21):169612v.

Brown, A. E., Gilbert, C. W., Guy, R., and Amtzen, C. J., Oct 1984, Triazine herbicide resistance in the photosynthetic bacterium Phodopseudomonas sphaeroides: Proceedings of the National Academy of Sciences, U.S.A., v. 81, no. 20, p. 6310 6314.

English.

Toxicity.

IND 85021896.

Buday, F., 1979, Wirkungsmechanismen voa Herbiziden und Synthetischen Wachstumsregulatoren, (Bericht zum Symposium der Wissenschaftlichen Koordinierungskonferenz zum RGW), 12th, p. 147-150.

German.

Toxicity. CA93(9):89818p. 
Burrell, R. E., Inniss, W. E., and Mayfield, C. I., 1985, Detection and analysis of interactions between atrazine and sodium pentachlorophenate with single and multiple algalbacterial populations: Archives of Environmental

Contamination and Toxicology, v. 14, no. 2, p. 167-177. English.

Toxicity,Surfacewater Observations.

CA102(19):161847w.

Butler, G. L., Deason, T. R, and O'Kelley, J. C., 1975, Loss of five pesticides from cultures of twenty-one planktonic algae: Bulletin of Environmental Contamination and Toxicology, $v$. 13, no. 2, p. 149-152.

English.

Toxicity,Biodegradation/Biotransformation.

CA82(23): $150200 x$.

Buzby, J. S., Mumma, R. O., Bryant, D. A., Gingrich, J., Hamilton, R. H., Porter, R. D., Mullin, C. A., and Stevens, S. E., Jr., 1987, Progress in Photosynthesis Research, Proceedings of the International. Congress on Photosynthesis, 7th, 1986, p. 757-760.

English.

Toxicity.

CA107(3):18621r.

Cadron, J., Remy, C., and Verstraete, W., 1983, Use of the Belser nitrification and the Rush enumeration tests to estimate side-effects of pesticides on soil microorganisms:

Mededelingen van de Faculteit Landbouwwetenschappen,

Rijksuniversiteit Gent, v. 48, no. 4, p. 1093-1100.

English.

Toxicity.

CA100(9):63353w.

Calero, B. J., and Arcia, F. J., 1980, Effects of distinct atrazine levels on microflora in brown soil with various carbonate contents: Ciencias de la Agriculture, v. 5, p. 135-140.

Spanish.

Toxicity.

CA94(11):78416a.

Caligiuri, C., Dracos, A., Magliola, M., Palmieri, A., Petrelli, G., Siepi, G., and Verdecchia, A., 1987, Major herbicides used in Italy: production, usage patterns and bibliographic information: Rap ISTISAN, ISTISAN 87/22, 89 p. Italian.

Toxicity,Miscellaneous Environmental. CA108(5):33546j.

Cardina, J., Hartwig. N. L., and Lukezic, R. L., May 1986, Herbicidal effects on crownvetch rhizobia and nodule activity: Weed Science, v. 34, no. 3, p. 338-343.

English.

Toxicity.

IND 87040842 .

Castano, P., Ferrario, V. F., and Vizzotto, L., 1982, Sciatic nerve fibers in albino rats after atrazine treatment: a morpho-quantitative study: International Journal of Tissue Reactions, v. 4, no. 4, p. 269-275.

English.

Toxicity.

CA98(13):102332a.
Cervelli, S., and Rolston, D. E., 1983, Influence of atrazine on denitrification in soil columns: Joumal of Environmental Quality, v. 12, no. 4, p. $482-486$.

English.

Toxicity.

CA100(1):2087r.

Chendrayan, K, and Sethunathan, N., 1980, Effects of HCH, carbaryl, benomyl, and atrazine on the dehydrogenase activity in a flooded soil: Bulletin of Environmental Contamination and Toxicology, v. 24, no. 3, p. 379-382.

English.

Toxicity. CA92(23):192722f

Chesebro, J. W., 1970, The influence of atrazine and alachlor on corn, soil-borne fungi pathogenic to corn, and the severity of diseases of corn, Dissertation submitted in partial fulfillment of Ph.D. requirements, University of Missouri, Missouri.

English.

Toxicity.

CAT 82768233.

Chio, H., and Sanborn, J. R, 1977, Atrazine inhibition of carbofuran metabolism in the house cricket: Journal of Economic Entomology, v. 70, no. 5, p. 544-546.

English.

Biodegradation/Biotransformation,Toxicity. CA87(25):195491n.

Chopra, P., and Magu, S. P., 1985, Effect of selected herbicides and city compost on the rhizospheric microflora of wheat and maize: Indian Journal of Agronomy, v. 30, no. 1, p. 5-9.

English.

Toxicity.

CA103(17):137168a.

Chopra, P., and Magu, S. P., 1985, Interaction of selected herbicides and city compost on soil respiration and crop yield of maize: Indian Journal of Agronomy, v. 30, no. 1, p. 50-54.

English.

Toxicity.

CA103(17):137049n.

Clert, G. C., and Bimpong, C. E., 1969, Influence of three herbicides on germination of sclerotium of Sclerotium rolfsii: Ghana Journal of Science, v. 9, no. 2, p. 115-118. English.

Toxicity.

CA72(15): $77756 \mathrm{v}$.

Cohn, S. L., 1985, An evaluation of the toxicity and sublethal effects of atrazine on the physiology and growth phases of the aquatic macrophyte Vallisneria americana L, Dissertation submitted in partial fulfillment of $\mathrm{Ph} . \mathrm{D}$. requirements, American University, Washington, DC, USA.

English.

Toxicity.

CA103(25):208482m. 
Cole, M. A., 1976, Effect of long-term atrazine application on soil microbial activity: Weed Science, v. 24 , no. 5 , p. 473476.

English.

Toxicity.

CA85(21):154838w.

Conrady, D., 1986, Ecological studies on the effect of pesticides on the animal community of a meadow: Pedobiologia, v. 29, no. 4, p. 273-284.

German.

Toxicity.

CA106(25):209083f.

Correll, D. L., and Wu, T. L, 1982, Atrazine toxicity to submersed vascular plants in simulated estuarine microcosms: Aquatic Botany, v. 14, no. 2, p. 151-158.

English.

Toxicity.

CA98(7):48281t.

Cossarini-Dunier, M., 1987, Effects of the pesticides atrazine and lindane and of manganese ions on cellular immunity of carp, Cyprinus carpio: Journal of Fish Biochemistry, v. 31, no. Suppl. A, p. 67-73.

English.

Toxicity.

CA108(13):107810q.

Costantini, F., and Panella, F., 1974, Herbicides and fauna.

III. Effects of herbicides on the embryonic and

postembryanic development of Bufo vulgaris and enzymic changes in the larvae: Annali della Facolta di Agraria, Univ. degli Studi d Perugia, v. 29, p. 419-440.

Italian.

Toxicity,

CA84(15): 100497 .

Couch, R W., 1966, The effect of atrazine, bromacil, and diquat on $14 \mathrm{C}$ fixation in corn, cotton, and soybeans, Dissertation submitted in partial fulfillment of $P h . D$. requirements, Aubum University, Aubum, Ala., USA.

English.

Toxicity.

CA66(25):114817q.

Cox, H. W., Jr., 1982, The effect of 2,4-D, atrarine, and diuron on algal physiology and population dynamics, Dissertation submitted in partial fulfillment of Ph.D. requirements, Virginia Polytech. Inst. and State University, Blacksburg. VA. English.

Toxicity.

CA99(9):65573c.

Cunningham, J. J., Kemp. W.M., Lewis, M. R., and Stevenson, J. C. December 1984, Temporal responses of the macrophyte, Potamogeton perfoliatus $\mathrm{L}$, and its associated autotrophic community to atrazine exposure in estuarine microcosms: Estuaries, v. 7, no. 48 , p. $519-530$.

English.

Toxicity.
Dabydeen, S., and Leavitt, J. R. C., 1981; Absorption and effect of simazine and atrazine on Elodea canadensis: Bulietin of Environmental Contamination and Toxicology, v. 26, no. 3, p. 381-385.

English.

Uptake by Biota,Toxicity.

CA95(5):36948r.

Darwazeh, H. A., and Mulla, M. S., 1974, Toxicity of herbicides and mosquitoe larvicides to the mosquito fish Gambusia affinis: Mosquito News, v. 34, no. 2, p. 214-219.

English.

Toxicity.

CA81(19):115615u.

Daubner, I., and Toth, D., 1981, The effect of some water pollutants on microbial activity: Verhandlungen -

Internationale Vereinigung fuer Theoretische und Angewandte Limnologie, v. 21, no. 3, p. 1406-1409.

English.

Toxicity.

CA96(17):137315h.

David, K. A. V., Rane, S. S., Mathur, M., and Bhattacharjee, S. $\mathrm{K}, 1988$, Herbicide mediated UV-resistance in cyanobacteria: on the role of photosynthetic electron transport system rather than replicative DNA as lethal target determining dark-survival of Anacystis nidulans: Photochemistry and Photobiology, v. 47, no. 1, p. 107-113.

English.

Toxicity.

CA108(13):109665v.

Davies, H. A., and Greaves, M. P., 1981, Effects of some herbicides on soil enzyme activities: Weed Research, v. 21, no. 5, p. 205-209.

English.

Toxicity.

CA96(1):2134c.

Davis, D. E., 1980, Effects of herbicides on submerged seed plants: Report, W80-06685, OWRT-A-067-ALA(2).

English.

Toxicity.

CA94(17):133651a.

De Bertoldi, M., Griselli, M., Giovannetti, M., and Barale, R, 1980, Mutagenicity of pesticides evaluated by means of geneconversion in Saccharomyces cerevisiae and in Aspergillus nidulans: Environmental Mutagenesis, v. 2, no. 3, p. 359-370. English.

Toxicity. CA99(19):153540v.

De Bertoldi, M., Griselli, m., Giovannetti, M., and barale, R, 1980 , Mutagenicity of pesticides evaluated by means of geneconversion in Saccharomyces cerevisiae: Environmental Mutagenesis, v. 2, no. 3, p. 359-370.

English.

Toxicity.

CA94(7):42342j. 
Dejan, O., Costche, S., Dejan, M., Visan, D., German, I. A., Sarpe, Nicolae, Anghelescu, G., and Barbulescu, D., 1978, Synergistic herbicidal composition for sterilizing the soil: Appl. or Pr. 79220, 19 Jun 1974.

Romanian.

Toxicity.

CA93(1):2270g

Delcour, J. M. A.G., Colson-Corbiser, A. M. J.C.G., DeBaetsellier-Van Broekoven, A., and Colson, C., 1984, Genes conferring to yeasts a resistance to herbicides: Appl. 84/ 11698, 8 May 1984; LU Appl. 84795, 9 May 1983.

English.

Toxicity.

CA102(9):73543p.

Delistraty, D. A., and Hershner, C., 1984, Effects of the herbicide atrazine on adenine nucleotide levels in Zostera marina L. (eelgrass): Aquatic Botany, v. 18, no. 4, p. 353 369.

English.

Toxicity.

CA101(17):145553w.

Demidecki-Demidowicz, M. R, and Fewkes, D. W., 1971, Insecticidal activity of two triazine herbicides:

Naturwissenschaften, v. 58, no. 5, p. 270.

English.

Toxicity.

CA75(11):75277c.

DeNoyelles, F., Kettle, W. D., and Sinn, D. E., 1982, The responses of plankton communities in experimental ponds to atrazine, the most heavily used pesticide in the United States: Ecology, v. 63, no. 5, p. 1285-1293.

English.

Surfacewater Observations, Toxicity.

CA98(3):12624t.

Deshmukh, V. A., and Shrikhande, J. G., 1974, Effect of pre- and postemergence treatment of herbicides on soil microflora and two microbial processes: Journal of the Indian Society of Soil Science, v. 22, no. 1, p. 36-42.

English.

Toxicity.

CA82(1):1043w.

Desi, I., 1983, Neurotoxicological investigation of pesticides in animal experiments: Neurobehavioral Toxicology and Teratology, v. 5, no. 5, p. 503-515.

English:

Toxicity.

CA100(11):80979x

Desi, I., Farkas, I., Gonczi, C. M., Tozser, O., and Juhasz, A., 1983, Neurotoxicological study of pesticides in animal experiments: Egeszsegtudomany, v. 27, no. 2, p. 121-137. Hungarian.

Toxicity.

CA100(7):46436h.
Desi, I., and Hajtman, B., 1983, Uniform toxicological evaluation of various pesticides: Egeszsegtudomany, v. 27, no. 2, p. 105-119.

Hungarian.

Toxicity.

CA100(7):46435g.

Dewey, S. L., 1986, Effects of the herbicide atrazine on aquatic insect community structure and emergence: Ecology, v. 67, no. 1, p. 148-162.

English.

Toxicity,Surfacewater Observations.

CA104(17):143522y.

Diskus, A., Auer, E., and Leitner, H., 1985, Herbicidal composition: Appl. 3419050, 22 May 1984.

German.

Toxicity.

CA104(5):30446h.

Dobolyi, C., Pasztor, Z, and Kecskes, M., 1977, Xenobiotics and soil microbiota affected by xenobiotic interactions. III.

Sodium-2,4-D and the species composition of fungi in a chernozem: Acta Phytopathologica Academiciae Scientriarum Hungaricac, v. 12, no. 1-2, p. 81-87.

English.

Toxicity.

CA88(23):165291a.

Dobrovodsky, J., and Longauer, S., 1977, Effect of single crop corn cultivation with the use of herbicides on agrocenoses and soil microflora: Agrochemia, v. 17, no. 9, p. 249-252.

Slovenian.

Toxicity.

CA88(1):1476p.

Doebereiner, J., 1976, Influence of environmental factors on the occurrence of Spirillum lipoferum in soils and roots: Ecology Bulletin, v. 26, no. Environ. Role Nitrogen-Fixing Blue-Green Algae Asymbiotic Bact., p. 343-351.

English.

Toxicity.

CA90(13):102624g.

Dogadina, T. V., Krainyukova, A. N., and Mironenko, V. I., 1976, Effect of some pesticides on algal flora of drainage canals: Form, v. 3, p. 59-64.

Russian.

Toxicity.

CA91(11):84623v.

Donna, A., Betta, P. G., Gagliardi, F., Ghiazza, G. F., Gallareto, M., and Gabutto, V., 1981, Preliminary experimental contribution to the study of possible carcinogenic activity of two herbicides containing atrazinesimazine and trifluralin as active principles: Pathologica, v. 73, no. 1027 , p. $707-721$.

English.

Toxicity.

CA98(11):84658e. 
Donna, A., Betta, P. G., Robutti, F., and Bellingeri, D., 1986, Carcinogenicity testing of atrazine: preliminary report on a 13-month study on male Swiss albino mice treated by intraperitoneal administration: Giomale Italiano di Medicina del Lavoro, v. 8, no. 3-4, p. 119-121.

English.

Toxicity.

CA109(11):87930u.

Drogoszewski, B., 1969, Application of Simazin and Atrazin in pine cultures on previously arable land. I. Sensitivity of one year old seedlings of Pinus silvestris to Simazin and Atrazin: Poznanskie Towarzystwo Przyjaciol Nauk, Prace Komisji Nauk Rolniczych i Komisyi Nauk Lesnych, v. 28, p. 65-81. Polish.

Toxicity.

CA73(17):86823n

Drogoszewski, B., 1973, Application of simazine and atrazine in pine plantings on precultivated land. IV. Sensitivity of pine seedlings to simazine and atrazine applied in small areas of the plantings: Poznanskie Towarzystwo Przyjaciol Nauk, Prace Komisyi Nauk Rolniczych i Komisji Nauk Lesnych, v. 36, p. $19-26$.

Polish.

Toxicity.

CA80(9):44659c.

Drogoszewski, B., 1980, Results of the toxic effect of triazines applied to the foliage of seedlings and cuttings of some forest tree species. III. Sensitivity of cuttings of some poplar varieties to the effect of triazines: Prace Komisyi Nauk Rolniczych i Komisyi Nauk Lesnych, Poznanskie Towarzystwo Przyjaciol Nauk, v. 50, p. 3-10. Polish.

Toxicity.

CA94(5):25908f.

Drogoszewski, B., 1975, Studies concerning the sensitivity of common pine seedlings to the activity of some herbicide preparations from the triazine group: Roczniki Akademii Rolniczej w Poznaniu Prace Habilitacyjne, v. 58, p. 42 pp.. Polish.

Toxicity,

CA85(13):88231q.

Drogoszewsici, B., 1978, Study of the toxic effect of triazines applied to the foliage of seedlings and one-year old plants of some forest tree species. Part II. Sensitivity of seedlings and one-year-old plants of some forest species to the effect of triazines: Proce-Komisyi Nauk Rolniczych i Komisyi Nauk Lesnych, Poznanskie Towarzystwo Przyjaciol Nauk, v. 46, p. 19-25.

Polish.

Toxicity.

CASO(5):34597\%.

Drogoszewski, B., and Smigielska, G., 1976, Sensitivity of the forest tree seeds to triazine herbicides: Prace Komisyi Nauk Rolniczych i Komisyi Nauk Lesnych, Poznanskie Towarzystwo Przyjaciol Nauk, v. 42, p. 53-63.

Polish.

Toxicity.

CA85(19):138243t.
Drogszewski, B., 1977, Study of the toxic effects of triazines applied to seedlings and seedling foliage of some forest tree species. Part I. Sensitivity of seedlings and one-year-old seedlings of Pinus silvestris L., Picea excelsa (Lam.) Lk. and Larix decidua Mill: to the effect of triazines: Prace Komisyi Nauk Rolniczych i Komisyi Nauk Lesnych, Poznanskie Towarzystwo Przyjaciol Nauk, v. 44, p. 33-38.

Polish.

Toxicity.

CA87(21):162448a.

Dubovska, A., 1971, Influence of herbicides on microbiological conditions: Acta Botanica, v. 1, p. 53-65.

English.

Toxicity.

Dunachie, J. F., and Fletcher, W. W., 1970, Toxicity of certain herbicides to hens' eggs assessed by the egg-injection technique: Annals of Applied Biology, v. 66, no. 3, p. 515520.

English.

Toxicity.

CA74(19):98665w.

Durner, J., Thiel, A., and Boeger, P., 1986, Phenolic herbicides: correlation between lipophilicity and increased inhibitory sensitivity of thylakoids from higher plant mutants:

Zeitrschrift fuer Naturforschung, C: Biosciences, v. 41, no. 9-10, p. 881-884.

Engish.

Toxicity.

CA105(25):220902x.

Dzugeli, M. G., 1982, Action of atrazine on the microflora of brown forest soil: Khimiya $\mathrm{v}$ Sel'skom Khozyaistve, no: 4, p. 38-39.

Russian.

Toxicity.

CA96(23):195036d.

Egli, M. A., Low, D., White, K. R, and Howard, J. A., 1985, Effects of herbicides and herbicide analogs on (14C)leucine incorporation by suspension-cultured Solanum nigrum cells: Pesticide Biochemistry and Physiology, v. 24, no. 1, p. 112-

118.

English.

Toxicity.

CA103(13):100253y.

Eglite, A., and Folkmane, A., 1967, Effect of simazine, atrazine, and dalapon on microbiological processes and mineralization of nitrogen in the soil: Les Sreda, p. 53-77.

Russian.

Toxicity:

CA70(19):86484r.

Eglite, A., Spalvins, Z., Follmane, A., and Goba, A., 1979, Effect of dalapon and atrazine on forest biogecenoses: Jaunakais Mezsaimn., v. 21, p. 61-70.

Latvian.

Leaching, Toxicity.

CA93(1):2144u. 
Ehling, U. H., 1980, Chemically-induced mutations in mice: Commications of the European Community, (Rep.) EUR, EUR 6388 Environmental Research Programme, 234-239.

English.

Toxicity.

CA93(7):63212m.

Eisenbrand, G., Ungerer, O., and Preussmann, R, 1975, Formation of $\mathrm{N}$-nitroso compounds from agricultural chemicals and nitrite: IARC Science Publication, v. 9, no. N-Nitroso Compd. Environ., Proc. Work. Conf., 1973, p. 71-74.

English.

Toxicity.

CA83(17):142687s.

El-Din, A. T.F. Tag, El-Deeb, S. T., Komeil, A. A, and ElNawawy, A. S., 1977, Pesticides and soil-enzymes relationships. II. Effect of three different herbicides on the activity of soil-dehydrogenase: Alexandria Joumal of Agricultural Research, v. 25, no. 3, p. 507-511.

English.

Toxicity.

CASO(1):1567k.

El-Gohary, F. A., Nasr, F. A., and Aly, O. A., 1986, Biogas Technology and Transfer Diffusion: Proceedings of the International Conference, 1984, p. 454-462.

English.

Toxicity.

CA105(19):166533n.

El-Nawawy, A. S., El-Din, A. T., Komeil, A. M., Khalifa, M. A. S., El-Deeb, S. T., Donia, S. A., and Kadous, E. A., 1977 , Effect of several pesticides on the activity of soil enzymes: Mededelingen van de Faculteit Landbouwwetenschappen, Rijksuniversiteit, Gent, v. 42, no. 2, Pt. 1, p. 901-909.

English.

Toxicity.

CA88(17):116346p.

Elguindi, K, and Rajhans, G. S., 1979, Occupational health hazards and their control in the manufacture and handling of pesticides in Ontario: Berichte ueber das Internationale Kolloquium ueber die Verhuetung von Arbeitsunfaellen Berufskrankheiten in der Chemischen Industrie, 6th, p. 441-466. English.

Toxicity.

CA92(26):220183b.

Enslein, K., Tuzzeo, T. M., Borgstedt, H. H., Blake, B. W., and Hart, J. B., 1987, Quantitative Structure/Activity Relationships in Environmental Toxicology, Workshop Proceedings, 2nd, 1986, p. 91-106.

English.

Toxicity.

CA108(15):126169d.

Ercegovich, C. D., Chrzanowski, R. L., Cole, H., Herendeen, N., and Witkonton, S., 1973, Relation between the chemical structure of s-triazines and fungitoxicity to Sclerotium rolfsii: Canadian Journal of Microbiology, v. 19, no. 3, p. 329-334.

English.

Toxicity.

CA79(9):49697c.
Felix, H. R, Chollet, R, and Harr, J., 1988, Use of the cell wall-less alga Dunaliella bioculata in herbicide screening tests: Annals of Applied Biology, v. 113, no. 1, p. 55-60. English.

Toxicity.

CA109(19):165623n.

Fernando, T., Bean, G., and Glenn, S., 1986, Effect of atrazine on growth, production of aflatoxin, and fatty acid and sterol biosynthesis by Aspergillus spp: Weed Research, v. 26, no. 6 , p. 415-419.

English.

Toxicity.

CA106(11):79985p.

Fetvadzhieva; N., Stoimenova; I., Simeonova, I., and Taleva, A., 1981, Symposium on the Theory and Practice of the Use of Soil Applicd Herbicides: Proceedings, p. 275-282.

French.

Toxicity.

CA97(21):176917w.

Forney, D. R, 1980, Effects of Atrazine on Chesapeake Bay aquatic plants, Dissertation submitted in partial fulfillment of Ph.D. requirements.

English.

Run-off, Toxicity.

OWRT-A-067-ALA(1).

Fomey, D. R, and Davis, D. E., 1981, Effects of low. concentrations of herbicides on submersed aquatic plants: Weed Science, r. 29, no. 6, p. 677-685.

English.

Toxicity.

CA96(7):47283s.

Forney, D. R, 1979, Effects of atrazine on Chesapeake Bay aquatic plants: Report, W81-00046, OWRT-A-67-ALA. English.

Toxicity,Surfacewater Observations. CA94(21):169051u.

Foster, T. S., and Khan, S. U., 1976, Metabolism of atrazine by the chicken: Journal of Agriculture and Food Chemistry, v. 24 , no. 3, p. 566-570.

English.

Toxicity.

CA85(1):949w.

Frankenberger, W. T., Jr., and Tabatabai, M. A., 1981, Amidase activity in soils: IV. Effects of trace elements and pesticides: Journal of the Soil Science Society of America, v. 45, no. 6, p. 1120-1124.

English.

Toxicity.

CAS6(13):99408t.

Fredrick, J. F., 1981, Antimicrobial embalming preparations: US Appl. 786460, 11 Apr 1977.

English.

Degradation Products, Toxicity.

CA95(19):163056y. 
Freitag, D., Lay, J. P., and Korte, F., 1984, Quantitative Structure/Activity Relationships in Environmental Toxicology, Proceedings of the Workshop, 1983, p. 111-136.

English.

Chemical/Physical Properties, Uptake by Biota,Toxicity. CA102(16):137152v.

Fricke, G., and Steubing, L, 1985, The blue alga Phormidium uncinatum - a sensitive test organism for water pollutants: Forum Staedte-Hygiene, v. 36, no. 3, p. 114-120.

German.

Toxicity.

CA103(17):136967y.

Fridman, E. B., and Nezefi, T. A., 1969, Change in vessel-tissue permeability during the chronic action of monuron, atrazine, and their mixtures: Zdravookhranenie Turkmenistana, v. 10, p. 9-12.

Russian.

Toxicity

CA73(19):97725h.

Frioni, L, 1981, Atrazine, linuron and 2,4-D amine effects on some biological properties of a soil. 1. Field trial:

Revista Argentina de Microbiologia, v. 13, no. 1, p. 1-8. Spanish.

Toxicity.

CA95(25):216383m.

Frioni, L., 1981, Effect of atrazine, linuron and 2,4-D amine on some biological properties of soil. II. Laboratory trial: Revista Argentina de Microbiologia, v. 13, no. 1, p. 9-16. Spanish.

Toxicity.

CA95(25):216384n.

Gadkari, D., 1988, Effects of atrazine and paraquat on nitrifying bacteria: Archives of Environmental Contamination and Toxicology, v. 17, no. 4, p. 443-447.

English.

Toxicity.

CA109(3):18513y.

Gadkari, D., 1988, Effect of some photosynthesis-inhibiting herbicides on growth and nitrogenase activity of a new isolate of cyanobacteria, Nostoc G3: Journal of Basic Microbiology, v. 28, no. 7, p. 419-426.

English.

Toxicity.

CA110(7):54392n.

Gaines, T. B., and Linder, R. E., 1986, Acute toxicity of pesticides in adult and weanling rats: Fundamentals of Applied Toxicology, v. 7, no: 2, p. 299-308.

English.

Toxicity.

CA105(19):166543r.

Galassi, S., Battaglia, C., and Vigano, L., 1988, A toxicological approach for detecting organic micropollutants in environmental samples: Chemosphere, v. 17, no. 4, p. 783-787.

English.

Toxicity.

CA109(3):18276y.
Galassi, S., Gussella, L, and Sora, S., 1989, Mutagenic potential of drinking waters from surface supplies in northern Italy. Environmental Toxicology and Chemistry, v. 8, no. 2 , p. $109-116$.

English.

Toxicity, Observations in Drinking Water. CA110(14):120804b.

Galassi, S., Vigano, L., and Battaglia, C., 1985, Toxic effects of trace organic pollutants in surface waters: Acqua Aria, no. 9, p. $821-826$.

Italian.

Toxicity.

CA104(15):124841k.

Garcia-Baudin, J. M., Lansac, A. R., Ayerbe, L., Tenorio, J. L., and Cadahia, $E_{,}, 1985$, Use of substituted urea herbicides for weed control in Euphorbia lathyris $L$, a potential fuelproducing crop: Weed Research, v. 25, no. 5, p. 319-322. English.

Toxicity.

CA103(25):20877m.

Gasquez, J., and Compoint, J. P., 1981, Isoenzymic variations in populations of Chenopodium album L resistant and susceptible to triazines: Agro-Ecosystems, v. 7, no. 1, p. 1-10.

English.

Toxicity.

CA95(7):58227g.

Gavrilenko, A. P., 1973, Khimicheskii i Ukhod za Lesom. p. 171174.

Russian.

Toxicity.

CA86(25):184443b.

Gavrilenko, A. P., 1969, Gerbits. Arboritsidy Les. Khoz. Mater. Koord.-Metod. Soveshch., p. 116-118.

Russian.

Toxicity.

CA76(5):21904g.

Gentile, J. M., and Plewa, M. J., 1983, The maize-microbe bioassay: a unique approach to environmental mutagenesis: NATO Conference Series (Series 1), v. 5A, no. In Vitro Toxicity Testing of Environmental Agents: Current and Future Possibilities, Part A, p. 151-165.

English.

Toxicity.

CA98(17):138526f.

Geyer, H., Scheunert, I., and Korte, F., 1985, The effects of organic environmental chemicals on the growth of the alga Scenedesmus subspicatus: a contribution to environmental biology: Chemosphere, v. 14, no. 9, p. 1355-1369.

Engtish.

Toxicity.

CA103(21):173558m.

Ghiazza, G., Zavarise, G., Lanero, M., and Ferraro, G., 1984, SCE (sister chromatid exchanges) induced in human lymphocyte chromosomes by triflurain: Bollettino - Societa Italiana de Biologie Sperimentale, v. 60, no. 11, p. 2149-2153.

Italian.

Toxicity.

CA102(13):107956t. 
Ghinea, E., Simionescu, L., and Oprescu, M., 1979. Studies on the action of pesticides upon the endocrines using in vitro human thyroid cells culture and in vivo animal models. I.

Herbicides - aminotriazole (amitrol) and atrazine: Revue

Roumaine de Medecine: Endocrinologie, v. 17, no. 3, p. 185190.

English.

Toxicity.

CA93(11):108503a.

Giavini, E., 1987, Toxicological aspects of atrazine:

Inquinamento, v. 29, no. 11, p. 68-70.

Italian.

Toxicity.

CA108(15):125949w.

Giovannetti, M., and Verona, O., 1976, The antifungal action of cyanamide in the presence of atrazine in vitro: Agricultura Italiana (Pisa), v. 76, no. 1-2, p. 1-15.

Italian.

Toxicity.

CA85(23):172587t.

Giurgea, R, 1979, Thymus reaction in white Wistar rats treated with atrazine and prometryn: Studii si Cercetari de Biologie, Seria Biologie Animala, v. 31, no. 2, p. 119-121.

Romanian.

Toxicity.

CA92(21):175421q.

Giurgea, R., Borsa, M., and Bucur, N., 1981, Immunological reactions of Wistar rats to administration of atrarine and prometryn: Archiv fuer Experimentelle Veterinaermedizin, $v$. 35, no. 6, p. 811-815.

German.

Toxicity.

CA96(21):175712t.

Giurgea, R, and Koszta, M., 1979, Action of the herbicide atrazine on thymus and bursa of chickens: Archiv fuer Experimentelle Veterinaermedizin, v. 33, no. 5, p. 703-707. German.

Toxicity.

CA93(3):20365w.

Gluth, G., and Hanke, W., 1984, A comparison of physiological changes in carp, Cyprinus carpio, induced by several pollutants at sublethal concentration - II. The dependency on the temperature: Comparative Biochemistry and Physiology, C: Comparative Pharmacology and Toxicology, v. 79C, no. 1, p. 39-45.

English.

Toxicity.

CA102(1):1659h.

Gluth, G., and Hanke, W., 1985; A comparison of physiological changes in carp, Cyprinus carpio, induced by several pollutants at sublethal concentrations. I. The dependency on exposure time: Ecotoxicology and Environmental Safety, v. 9 , no. 2, p. 179-188.

English.

Toxicity.

CA102(25):216555g.
Goguadze, V. D., 1969, Change in the composition of soil microflora during the use of herbicides at various stages of grapevine development under alluvial soil conditions: Subtropicheskie Kul'tury, no. 5, p. 139-143.

Russian.

Toxicity.

CA73(5):24151h

Goldsborough, L. G., and Robinson, G. G. C., September 1983, The effect of two triazine herbicides on the productivity of freshwater marsh periphyton: Aquatic Toxicology, v. 4, no. 2, p. $95-112$.

English.

Toxicity.

Gonzalez-Murua, C., Munoz-Rueda, A., Hernando, F., and SanchezDiaz, M., Feb 1985, Effect of atrazine and methabenzthiazuron on oxygen cvolution and cell growth of Chlorella pyrenoidosa: Weed Research, v. 25, no. 1, p. 61-66.

English.

Toxicity.

IND 85052691.

Gorlenko, M. V., Lebedeva, G. F., and Manturovskaya, N. V., 1969, Triazine derivatives and soil mycoflora: Agrokhimiya, no. 8, p. 122-128.

Russian.

Toxicity.

CA71(25):122653b.

Goryacheva, N. V., 1978, Resistance of Bodo marina Braarud flagellates to toxicants: Biologiya Vnutrennykh Vod, v. 37, p. 39-42.

Russian.

Toxicity.

CA93(3):20379d.

Grahl, K, 1983, Classification of substances contained in water from their toxicity potential in aquatic organisms: Acta Hydrochimica Hydrobiologica, v. 11, no. 1, p. 137-143. German.

Toxicity.

CA98(25):211052e.

Grant, M. A., and Payne, W. J., 1982, Effects of pesticides on denitrifying activity in salt marsh sediments: Journal of Environmental Quality, v. 11, no. 3, p. 369-372.

English.

Toxicity.

CA97(17):140267v.

Grappelli, A., and Rossi, W., 1979, Effect of herbicides on growth, respiration and LAA biosynthesis in Arthrobacter species: Chemosphere; v. 8, no. 6, p. 377-382. English.

Toxicity.

CA91(11):84663h.

Grenier, G., Marier, J. P., and Beaumont, G., 1982, Physiological effects of sublethal doses of atrazine on Lemna minor. VI. Effect on the important classes of phospholipids...: Physiologie Vegetale, v. 20, no. 2, p. 179-185.

French.

Toxicity.

IND 82107778 
Grenier, G., and Beaumont, G., 1983, Physiological effects of sublethal doses of atrazine on Lemna minor. VII. 1,2(14C)acetate incorporation into the groups of lipids and their fatty acids: Physiology Plantarum, v. 57, no. 4, p. 477884 .

French.

Uptake by Biota,Toxicity. CA98(23):195046y.

Gressel, J., Shimabukuro, R. J., and Duysen, M. E., 1983, NDealkylation of atrazine and simazine in Senecio vulgaris biotypes: a major degradation: Pesticide Biochemistry and Physiology, v. 19, no. 3, p. 361-370.

English.

Biodegradation/Biotransformation,Degradation Products, Toxicity.

CA99(1):1752c.

Grimalouskii, A. M., 1988, Effect of herbicides on the biological activity of soil under corn monoculture on unirrigated land: Agrokhimiya, no. 1, p. 93-100.

Russian.

Toxicity.

CA108(13):108087w.

Grizeau, D., Jeanne, N., and Calvayrac, R., 1985, Isolation and characterization of a DCMU (3-(3,4-dichlorophenyl)-1,1dimethylurea) resistant strain of a marine alga, Dunaliella bioculata: Physiology Plantarum, v. 65, no. 2, p. 189-195. English.

Toxicity.

CA103(25):211463m.

Grover, R., Morse, P. M., and Huang, P. M., Apr 1983, Bioactivity of atrazine in nine Saskatchewan soils: Canadian Plant Science Review, v. 63, no. 2, p. 489-496.

English.

Sorption to Soil,Toxicity.

CA99(1):1764h.

Gruen, G., Sadek, H., and Clausing, P., 1982, Evaluation of acute toxicity of plant protection agents in birds in relation to possible side effects in the field: Nachrichtenblatt fuer den Pflanzenschutzdienst in der DDR, v. 36, no. 6, p. 127-130. German.

Toxicity.

CA97(19):157672w.

Guddewar, M. B., and Dauterman, W. C., 1979, Studies on a glutathione $S$-transferase preparation from mouse liver which conjugates chloro-s-triazine herbicides: Pesticide Biochemistry and Physiology, v. 12, no. 1, p. 1-9.

English:

Toxicity.

CA91(21):170495m.

Gunkel, G., 1981, Bioaccumulation of a herbicide (atrazine, sTriazine) in the whitefish (Coregonus fera 3.): uptake and distribution of the residue in fish: Archives of

Hydrobiology, Supplement, v. 59, no. 2-3, p. 252-287.

English.

Toxicity.

CA95(25):216089v.
Gunkel, G., and Kausch, H., 1976, Acute toxicity of atrazine(striazine) on Coregonus fera Jurine under starvation conditions: Archives of Hydrobiology, Supplement, v. 48, no. 2, p. 207-234.

German

Toxicity.

CA86(11):66492u.

Gunker, G., 1983, Studies on the ecotoxicological effect of a herbicide in an aquatic model ecosystem. I. Sublethal and lethal effects: Archives of Hydrobiology, Supplement, v. 65, no. 2-3, p. 235-267.

German.

Toxicity.

CA100(3):18969r.

Guthrie, F. E., Shah, P. V., and Moreland, D. E., 1974, Efiects of pesticides on active transport of giucose through the isolated intestine of the mouse: Joumal of Agriculture and Food Chemistry, v. 22, no. 4, p. 713-715.

English.

Toxicity.

CA81(25):164349u.

Guy, R. D., and Narine, D. R., 1978, A model system for the investigation of methods of herbicide speciation:

Environmental Science and Research, v. 16, no. Hydrocarbons Halogenated Hydrocarbons Aquat. Environ., p. 417-434. English.

Toxicity.

CA92(25):209870c.

Gzhegotskii, M. I., Shklyaruk, L. V., and Kychok, L. A., 1977, Toxicological characteristics of the herbicide Zeazin: Vrachebnoe Delo, no. 5, p. 133-136.

Russian.

Uptake by Biota,Toxicity.

CA87(15):112660t.

Hamala, J. A., and Kollig, H. P., 1985, The effects of atrazine on periphyton communities in controlled laboratory ecosystems: Chemosphere, v. 14, no. 9, p. 1391-1408. English.

Toxicity,Surfacewater Observations. CA103(21):173655r.

Hamed, A. S., Mahmoud, S. A. Z., Zaki, M. M., and Sahab, A. F., 1980, The effect of the herbicide atrazine on rhizosphere microflora of broad bean plants, infested with Fusarium oxysporum f. fabae and Rhizoctonia solani: Zentralblatt fuer Bakteriologie, Parasitenkde, Infektionskrankheiten und Hygiene, Abteilung 2, Naturwissenschaftliche, v. 135, no. 1, p: $60-69$.

English.

Toxicity.

CAS2(23): $192487 \mathrm{~h}$.

Hamilton, P. B., Jackson, G. S., Kaushik, N. K., Solomon, K. R, and Stephenson, G. L., 1988, The impact of two applications of atrazine on the plankton communities of in situ enclosures: Aquatic Toxicology, v. 13, no. 2, p. 123-140. English.

Toxicity.

CA110(9):70813f. 
Hanke, W., Gluth, G., Bubel, H., and Mueller, R., 1983, Physiological changes in carp induced by pollution: Ecotoxicology and Environmental Safety, v. 7, no. 2, p. 229-241.

English.

Toxicity.

CA99(1):1500u.

Haque, A., and Ebing, W., 1983, Toxicity determination of pesticides to earthworms in the soil substrate: Zeitschrift fuer Pflanzenkrankheiten Pflanzenschutz, v. 90, no. 4, p. $395-408$.

English.

Toxicity.

CA100(5):30677b.

Hartman, W. A., and Martin, D. B., 1985, Effects of four agricultural pesticides on Daphnia pulex, Lemna minor, and Potamogeton pectinatus: Bulletin of Environmental Contamination and Toxicology, v. 35, no. 5, p. 646-651. English.

Toxicity.

CA104(1):1925h

Hauke-Pacewiczowa, T, 1971, Effect of herbicides on the activity of soil microflora: Pamietnik Pulawski, v. 46, p. 5-48.

Polish.

Toxicity.

CA77(3):15241t

Hawkins, A. F., 1973, Control of algae: Outlook on Agriculture, v. 7, no. 1, p. 21-26.

English.

Toxicity.

Haworth, P., and Steinback, K E., 1987, Interaction of herbicides and quinone with the QB-protein of the diuronresistant Chlamydomonas reinhardtii mutant Dr2: Plant Physiology., v. 83, no. 4, p. 1027-1031.

English.

Toxicity.

CA107(3):19389h.

Heath, R. G., Spann, J. W., Hill, E. F., and Kreitzer, J. F., 1972, Comparative dietary toxicities of pesticides to birds: United States, Fish and Wildlife Service, Special Science Report: Wildlife, v. 152, p. 57 pp..

English.

Toxicity.

CA81(19):115610p.

Heimbach, F., 1985, Comparison of laboratory methods, using Eisenia foetida and Lumbricus terrestris, for the assessment of the hazard of chemicals to earthworms: Zeitschrift Pflanzenkrankheiten Pflanzenschutz, v. 92, no. 2, p. 186-193. English.

Toxicity.

CA103(13):99844h.

Helmeczi, B., 1977, The effect of herbicides on soil bacteria belonging to certain physiological groups: Acta Phytopathologica Academiciae Scientriarum Hungaricae, v. 12, no. 1-2, p. $41-49$.

English.

Toxicity.

CA88(25):184212s.
Herman, D., Kaushik, N. K, and Solomon, K. R., 1986, Impact of atrazine on periphyton in freshwater enclosures and some ecological consequences: Canadian Journal of Fisheries and Aquatic Science, v. 43, no. 10, p. 1917-1925.

English.

Toxicity.

CA105(25):220542e.

Hersh, C. M., and Crumpton, W. G., 1987, Determination of growth rate depression of some green algae by atrazine: Bulletin of Environmental Contamination and Toxicology, v. 39, no. 6, p. 1041-1048.

English.

Toxicity.

CA108(9):70375y.

Hickisch, B., 1981, Side-effects of agrochemicals on soil microorganisms: Wissenschaftliche Zeitschrift - Martin Luther Universitaet Halle-Wittenberg, Mathematisch-

Naturwissenschaftliche Reihe, v. 30, no. 3, p. 127-132.

German.

Toxicity.

CA96(13):99049q.

Hickisch, B., Machulla, G., and Mueller, G. J., 1984, Side effects of herbicides on soil organisms after a single and repeated applications. 2. Communication: Zentralblatt fuer Microbiologie, v. 139, no. 1, p. 13-20.

German.

Toxicity.

CA101(5):34428q.

Hickisch, B., and Machulla, G., 1984, Side effects of herbicides on soil organisms after a single and repeated applications: Zentralblatt fuer Mikrobiologie, v. 139, no. 1, p. 3-11.

German.

Toxicity.

CA101(5):34427p.

Hickisch, B., Nguyen Tran Oanh, Sternkopf, G., and Tischer, S., 1986, Side effects of herbicides on soil organisms after one and several applications. Part 5. Field trial without crop plants; effects of repeated herbicide applications at rates commonly used in practice: Zentralblatt fuer Microbiologie, v. 141 , no. 8 , p. $583-590$

German.

Toxicity.

CA106(17):133408t.

Hill, E. F., Heath, R. G., Spann, J. W., and Williams, J. D., 1975, Lethal dietary toxicities of environmental pollutants to birds: United States Fish and Wildlife Service, Special Science Report: Wildlife, v. 191, p. 61 pp.

English.

Toxicity.

CA84(19):131017t.

Hill, E. R., 1967, Response of Echinochloa crusgalli at various stages of development to 2-chloro-4-ethylamino-6isopropylamino-s-triazine, Dissertation submitted in partial fulfillment of Ph.D. regquirements, University of Massachusetts, Amherst, Mass., USA.

English.

Toxicity.

CA69(9):34842r. 
Hiltibran, R. C., 1967, Effects of some herbicides on fertilized fish egs and fry. Transactions of the American Fisheries Society, v. 96, no. 4, p. 414-416.

English.

Toxicity.

CA68(7):28689j.

Hiranpradit, H., 1974, Atrazine movement with water and effects of contaminant levels on nontarget organisms, Dissertation submitted in partial fulfillment of Ph.D. requirements, Virginia Polytech. Inst., Blacksburg, VA, USA.

English.

Toxicity, Leaching.

CA83(13):109521k.

Hoffman, D. J., and Albers, P. H., 1984; Evaluation of potential embryotoxicity and teratogenicity of $\mathbf{4 2}$ herbicides, insecticides, and petroleum contaminants to mallard eggs: Archives of Environmental Contamination and Toxicology, $v$. 13 , no. 1, p. 15-27.

English.

Toxicity.

CA100(15):116116e.

Hollister, T. A., and Walsh, G. E., 1973, Differential responses of marine phytoplankton to herbicides. Oxygen evolution: Bulletin of Environmental Contamination and Toxicology, v. 9, no. 5, p. 291-295.

English.

Toxicity.

CA79(9):49642f.

Hopkins, R, and Kain, J. M., 1971, Effect of marine pollutants on Laminarea hyperborea: Marine Pollution Bulletin, v. 2, no. 5, p. $75-77$

English.

Toxicity,Surfacewater Observations.

CA75(11):72650h.

Houseworth, L. D., and Tweedy, B. G., 1973, Effect of atrazine in combination with captan or thiram upon fungal and bacterial populations in the soil: Plant Soil, v. 38, no. 3, p. 493500.

English.

Toxicity.

CA79(11):65150z.

Hrlec, G., and Ostec, L., 1981, Activity of pesticide residues and their effect on soil microarthropods: Agrohemija, no. 78, p. 291-296.

Slovenian.

Toxicity.

CA96(7);47263k.

Hugar, P. V., and Hosmani, M. M., 1977, Effect of atrazine on soil microorganisms: Madras Agricultural Journal, v. 64, no. 4, p. $272-274$.

English.

Toxicity.

CAIN 789052363
Hughes, J. S., Alexander, M. M., and Balu, K, 1988, An evaluation of appropriate expressions of toxicity in aquatic plant bioassays as demonstrated by the effects of atrazine on algae and duckweed: American Society of Testing Materials, Special Technical Publication, v. 971, no. Aquatic Toxicology Hazand Assessment: Volume 10, p. 531-547.

English.

Toxicity.

CA109(11):87787c.

Hung, T. V., Janowski, W. K, and Prager, R. H., 1985, Central nervous system active compounds. XV. 2-Arylisoxazol-5(2H)ones: Australian Journal of Chemistry, v. 38, no. 6, p. 931937.

English.

Toxicity.

CA104(11):88467g.

Hutber, G. N., Rogers, L. J., and Smith, A. J., 1979, Influence of pesticides on the growth of cyanobacteria: Zeitschrift fuer Allgemeine Mikrobiologie, v. 19, no. 6, p. 397-402.

English.

Toxicity.

CA91(17):135214x.

Ichim, A, and Stoian, N., 1983, Introduction of pT (toxicity potential) as a means of expressing acute pesticide toxicity: Revista de Igrena, Bacteriologie, Virusologie, Parazitologie, Epidemiologie, Pneumoftiziologie, Bacteriologia, Vinusologia, Parazitologia, Epidemiologia, v. 32, no. 3, p. 205-209.

Romanian.

Toxicity.

CA100(7):46636y.

Il'nskaya, S. P., Usataya, A. S., and Katruk, E. A., 1985, Effect of triazine herbicides on the soil dehydrogenase activity: Izvestiya Akademii Nauk Moldavskoi SSR, Seriya Biologicheskikhi Khimicheskikh Nauk, no. 4, p. 67-69. Russian.

Toxicity. CA103(25):208801q.

Imam, M., and Ghabbour, S. I., 1967, Effect of five herbicides on the aquatic oligochaete, Branchiura sowerbyi: Bochu Kagaku, v. 31 , no. 4 , p. $147-148$.

English.

Toxicity.

CA68(7):28679f.

Infurna, R, Levy, B., Meng، C., Yau, E., Traina, V., Rolofson, G., Stevens, J., and Barnett, J., 1988, Teratological evaluations of atrazine technical, a triazine herbicide, in rats and rabbits: Journal of Toxicology and Environmental Health, v. 24, no. 3, p. $307-319$.

English.

Toxicity.

CA109(13):106298n.

Inoue, Y., Yaginuma, N., Ogawa, T., Konishi, K, and Shibata, K. 1972, Environmental Toxicology oi Pesticides, Proceedings U.S.-Japanese, 1971, p. 549-570.

English.

Toxicity.

CA81(3):10306r. 
Ionescu, M., 1974, Deleterious action of atrazine on the intensity of photosynthesis in green algae: Studii Protectia Calitatii Apelor, v. 16, p. 23-35.

Romanian.

Toxicity.

CA84(11):70061d.

Ivashchenko, A. I., 1974, Effect of herbicides on the viability, growth, and development of apple tree seedlings: Khimiya $v$ Sel'Skom Khozyaistve, v. 12, no. 2, p. 134-136.

Russian.

Toxicity.

CA83(7):54416x

Jan, P., Maynadier, M., and Fabre, E., 1981, Theory Pract. Use Soil Appl: Herbic., Symp., p. 208-215.

French.

Toxicity.

CA97(21):176916v.

Jarzynka, W., and Put, A., 1985, Effect of some herbicides on the parotid glands and oral mucosa in rats: Czasopismo Stomatologiczne, v. 38, no. 3, p. 198-204.

Polish.

Toxicity.

CA104(1):1905b.

Johannes, H., Heri, W., and Reynaert, J., 1975, Triazine in the struggle to control algae and vascular submersed plants: Notiziario: Sulle Malattie delle Piante, v. 92-93, p. 39.59. Italian.

Toxicity,Surfacewater Observations. CA88(1):1232f.

Johnson, B. T., 1986, Potential impact of selected agricultural chemical contaminants on a northem prairie wetland: a microcosm evaluation: Environmental Toxicology and Chemistry, v. 5, no. 5, p. 473-485.

Engiish.

Toxicity,Associations with Surfactants. CA105(1):1958s.

Jones, K. H., Sanderson, D. M., and Noakes, D. N., 1968, Acute toxicity data for pesticides (1968): World Review of Pest Control, v. 7, no. 3, p. 135-143.

English.

Toxicity.

CA71(1):2442k.

Jones, T. W., and Estes, P. S., 1984, Uptake and phytotoxicity of soil-sorbed atrazine for the submerged aquatic plant, Potamogeton perfoliatus L.: Archives of Environmental Contamination and Toxicology, v. 13, no. 2, p. 237-241. English. Associations with Plants, Uptake by Biota, Toxicity. CA100(19):152227a.

Jones, T. W., Kemp, W. M., Estes, P. S., and Steverson, J. C., 1986, Atrazine uptake, photosynthetic inhibition, and shortterm recovery for the submersed vascular plant, Potamogeton perfoliatus L.: Archives of Environmental Contamination and Toxicology, v. 15, no. 3, p. $277-283$.

English.

Uptake by Biota,Toxicity.
Jones, T. W., and Winchell, L., April-June 1984, Uptake and photosynthetic inhibition by atrazine and its degradation products on four species of submerged vascular plants: Journal of Environmental Quality, v. 13, no. 2, p. 243-247. English.

Associations with Surfactants, Uptake by Biota,Degradation Products,Toxicity.

CA101(1):2244k.

Jose, G., and Chowdary, Y. B. K, 1977, Physiology of MicroOrganics, Symposium, 1976, p. 119-133.

English.

Toxicity.

CA91(25):205566q.

Joshi, O. P., Sachdev, M. S., Sahrawat, K. L., and Kohli, B. N., Apr 1976, Effect of simazine and atrazine on the mineralization of fertilizer and manure nitrogen: Plant and Soil, v. 44, no. 2, p. 367-375.

English.

Hydrolysis/Chemical Reactions, Toxicity. CA85(3):19749.

Jowett, P. L. H., and Gamble, G. A., 1986, Tissue levels of atrazine in a case of bovine poisoning. Veterinary and Human Toxicology, v. 28, no. 6, p. 539-540.

English.

Uptake by Biota,Toxicity. CA106(7):45421m.

Jury, W. A., Spencer, W. F., and Farmer, W. J., 1984, Behavior assessment model for trace organics in soil: III. Application of screening model: Journal of Environmental Quality, v. 13, no. 4, p. 573-579.

Engish.

Toxicity, Volatilization, Leaching. CA101(25):224814k

Kallio, S., and Wilkinson, R. E., 1977, The effects of some herbicides on nitrogenase activity and carbon fixation in two subarctic lichens: Botanical Gazette (Chicago), v. 138, no. 4, p. $468-473$.

English.

Toxicity.

CA88(19): $131897 \mathrm{n}$.

Kappas, A., 1988, On the mutagenic and recombinogenic activity of certain herbicides in Salmonella typhimurium and in Aspergillus nidulans: Mutation Research, v. 204, no. 4, p. 615-621.

English.

Toxicity.

CA108(23): $199940 \mathrm{~h}$

Kariander, E. P., Mayasich, J. M., and Terlizzi, D. E., 1983, Effects of the herbicide atrazine on an oyster-food organism: Report, TR-73, OWRT-A-060-MD(1).

English.

Toxicity.

CA101(23):205705j. 
Karpiak, S. E., and Iwanowski, H., 1969, Effect of herbicides on soil microflora. VII. Respiration of bacteria isoiated from maize rhizosphere: Acta Microbiologica Polonica, Series B, v. 18 , no. 2, p. 47-52.

English.

Toxicity.

CA72(1):2379r.

Kecskes, M., Borbely, F., and Borbely, I., 1977, Xenobiotics and soil microbiota affected by xenobiotic interactions. V. Lupine-rhizobium symbiosis and herbicide combinations: Acta Botanica, v. 23, no. 3-4, p. 357-360.

English.

Toxicity.

CA89(19):158439x.

Kemp, H. T., Littie, R. L., Holoman, V. L., and Darby, R. L., September 1973, Water quality criteria data book - vol. 5 effects of chemicals on aquatic life: EPA, Water Pollution Control Research Series, Report 18050HLA09/73.

English.

Toxicity.

Kemp, W. M., Boynton, W. R, Cunningham, J. J., Stevenson, J. C. Jones, T. W., and Means, J. C., 1985, Effects of atrazine and linuron on photosynthesis and growth of the macrophytes, Potamogeton perfoliatus and Myriophyllum spicatum in an estuarine environment: Marine Environmental Research, v. 16, no. 4, p. 255-280.

English:

Toxicity,Associations with Surfactants.

CA104(11):83390s.

Kenaga, E. E., 1982, Predictability of chronic toxicity of chemicals in fish and aquatic invertebrates: Environmental Toxicology and Chemistry, v. 1, no. 4, p. 347-358.

English.

Toxicity.

CA98(15):120935d.

Kettle, W. D., DeNoyelles, F. J., Heacock, B. D., and Kadoum, A. M., 1987, Diet and reproductive success of bluegill recovered from experimental ponds treated with atrazine: Bulletin of Environmental Contamination and Toxicology, v. 38, no. 1, p. 47-52. English.

Toxicity,Associations with Surfactants. CA106(13):97704a.

Khalaim, O. V., Shelar, I. N., Velkova, E. A., and Portnoi, M. M., 1985, Effect of several years application of herbicides on the microfiora of eroded vineyard soil: Sadovodstvo Vinogradarstvo i Vinodelic Moldavii, no. 12, p. 46-48. Russian.

Toxicity. CA104(15):124580z

Khan, S. U., and Kacew, S., 1986, Quantification and Natural Bioavailability of Bound 14C-Pesticide Residues in Soil, Plants, and Food, Proceedings of the Final Research Coordinators Meeting, 1985, p. 103-113. English.

Toxicity. CA107(13):110721w.
Khan, S. U., and Akhtar, M. H., 1983, In vitro release of bound (nonextractable) atrazine residues from com plants by chicken liver homogenate and bovine rumen liquor. Journal of Agriculture and Food Chemistry, v. 31, no. 3, p. 641-644. Englist:

Toxicity,Degradation Products, Uptake by Biota,Associations with Plants.

CA98(23):192994v.

Khan, S. U., Foster, T. S., and Akhtar, M. H., 1979, In-vitro metabolism of a mixture of atrazine and simazine by the soluble fraction $(105,000 \mathrm{~g})$ from goose, pig, and sheep liver-homogenates: Pesticide Science, v. 10, no. 6, p. 460466.

English.

Miscellaneous Environmental,Toxicity. CA93(5):38960w.

Khan, S. U., Kacew, S., and Molnar, S. J., 1985, Bioavailability in rats of bound carbon-14 residues from com plants treated with (14C)atrazine: Joumal of Agriculture and Food Chemistry, v. 33, no. 4, p. 712-717.

English.

Uptake by Biota,Degradation Products, Toxicity. CA103(5):33244f.

Khanumova, T., Popova, D., and Donkova, R, 1984, Effect of atrazine and ethalfluralin, combined or supplied alone, on soil microflora as related to soil moisture content: Pochvoznanie.i Agrokhimiya, v. 19, no. 5, p: 88-98. Bulgarian.

Toxicity.

CA102(15):127227j.

Khurana, S. M. Paul, and Singh, S., 1972, Growth response of Curvularia lunata to various herbicides in liquid culture: Chemie, Mikrobiologie, Technologie der Lebensmittel, v. 2, p. 63-65.

English.

Toxicity.

CA77(19):122965d.

Kiene, R. P., and Capone, D. G., 1984, Effects of organic pollutants on methanogenesis, sulfate reduction and carbon dioxide evolution in salt marsh sediments: Marine Environmental Research, v. 13, no. 2, p. 141-160. English.

Toxicity,Surfacewater Observations. CA102(12):100452s.

Kinewald, J., Peruzovic, M., Gojmerac, T., Milkovic, K, and Kniewald, Z, 1987, Indirect influence of s-triazines on rat gonadotropic mechanism at early postnatal period: Journal of Steroid Biochemistry, v. 27, no. 4-6, p. 1095-1100. English.

Toxicity.

CA108(11):89240x

Klein, W., Geyer, H., Freitag, D., and Rohleder, H., 1984, Sensitivity of schemes for ecotoxicological hazard ranking of chemicals: Chemosphere, v. 13, no. 1, p. 203-211.

English.

Toxicity.

CA100(25):204576k. 
Klepper, L. A., 1979, Effects of certain herbicides and their combinations on nitrate and nitrite reduction: Plant Physiology, v. 64, no. 2, p. 273-275.

English.

Toxicity.

CA91(19):152641b.

Klepper, L., 1988, Synergistic levels of nitrogen oxide emissions from soybean leaves caused by a combination of salicylic acid and photosynthetic inhibitor herbicides: Pesticide

Biochemistry and Physiology, v. 32, no. 2, p. 173-179.

English.

Toxicity.

CA109(23):206678e.

Kniewald, J., and Kniewald, Z., 1983, Effects of s-triazine herbicides on the mode of androgen action on calf pituitary: Periodicum Biologicum, v. 85, no. Suppl. 1, p. 115-121. English.

Toxicity.

CA99(19):153508r.

Kobel, W., Sumner, D. D., Campbell, J. B., Hudson, D. B., and Johnson, J. L, 1985, Protective effect of activated charcosl in cattle poisoned with atrazine: Veterinary and Human Toxicology, v. 27, no. 3, p. 185-188.

English.

Sorption to Resins, Toxicity, Uptake by Biota. CA103(15):117775t.

Kopriva, J., and Svobodova, Z, 1981, Toxicity of triazine and diazine based herbicides to fishes: Agrochemia (Bratislava), v. 21 , no. 12 , p. $344-347$.

Czechoslovakian.

Toxicity.

CA96(13):99058s.

Kosinski, R. J., and Merkle, M. G., 1984, Effect of four terrestrial herbicides on the productivity of artificial stream algal communities: Journal of Environmental Quality, v. 13 , no. 1, p. $75-82$.

English.

Toxicity,Surfacewater Observations.

Kosinski, R. J., 184, The effect of terrestrial herbicides on the community structure of stream periphyton: Environmental Pollution, Series A, v. 36, no. 2, p. 165-189.

English.

Toxicity,Surfacewater Observations.

CA101(23):205681y.

Kosinski, R. J., and Merkle, M. G., 1984, The effect of four terrestrial herbicides on the productivity of artificial stream algal communities: Journal of Environmental Quality, v. 13 , no. 1 , p. $75-82$

English.

Toxicity.

CA100(15):116105a.
Kosinski, R. J., Wren, S. W., and Soukup, L. E., 1983, The effect of terrestrial herbicides on the productivity of agricultural stream communities: Canadian Plains Proceedings, v. 11, no. Proceedings - Biennial Plains Aquatic Research Conference, p. 3-13.

English.

Toxicity,Surfacewater Observations.

CA99(21):170997s.

Kostov, O., and Bakalivanov, D., 1981, Effect of the herbicide atrazine on some chemical and biological indicators of waterlogged alluvial soil: Pochvoznanie i Agrokhimiya, v. 16, no. 4, p. 59-65.

Bulgarian.

Toxicity.

CA96(23):195026a.

Kovalenko, A. V., 1966, Toxicological and hygienic characteristies of atrazine: Zashchita Ovoshchnylkh Kul'tur ot Vreditelei, Boleznei i Sornyakov, p. 242-246.

Russian.

Toxicity.

CA70(7):27894b.

Kovrevskaya, M. M., Ul'yanova, I. P., and Nazarenko, G. P., 1974, Effect of diuron and atrazine on the viability of microorganisms in aqueous media: Problemy Okhrany Vod, no. 5, p. 40-47.

Russian.

Toxicity.

CA84(11):70056f.

Kramer, C. R, 1987, Screening tests for the characterization and selection of plant-growth effectors, such as herbicides: Appl. 291909, 30 Jun 1986.

German.

Toxicity.

CA109(3):18844g.

Krieger, K. A., Baker, D. B., and Kramer, J. W., 1988, Effects of herbicides on stream Aufwuchs productivity and nutrient uptake: Archives of Environmental Contamination and Toxicology, v. 17, no. 3, p. 299-306.

English.

Toxicity,Surfacewater Observations.

CA108(17):145058h.

Krienitz, L., Wenzel, W., and Boehm, H., 1980, Behavior and sensitivity of Stigeoclonium helveticum Vischer to algicides under conditions of intensive culturing: Archives of Hydrobiology, Supplement, v. 56, no. 4, p. 455-463.

German.

Toxicity.

CA93(25):232556j.

Krolikowska, J., 1976, Physiological effect of triazine herbicides on Typha latifolia L.: Polish Archives of Hydrobiology, v. 23, no. 2, p. 249-259.

English.

Toxicity.

CA86(19):134818g. 
Kruglov, U. V., Gersh, N. B., Pertseva, A. N., Bei-Bienko, N. V., and Mikhailova, E. I., 1975, Effect of long-term herbicide application on microflora and some biochemical processes in soil: Roczniki Gleboznaweze, v. 26, no. 2, p. 159-164.

English.

Toxicity.

CA84(11):70049f.

Krugiov, Y. V., 1983, Mechanisms for the distribution of microorganisms in soil after pesticide treatment: Trudy Vsesoyuznogo Nauchno-Issledovatel'skogo Instituta S-kh. Mikrobiologiya, v. 52, p. 32-36.

Russian.

Toxicity.

CA101(3): 18935x.

Krugiov, Y. V., 1980, Some principles in the reaction of soil microflora to pesticides: Trudy Vsesoyuznogo NauchnoIssledovatel'skogo Instituta Sel'skokhozyaistuennoi Mickrobiologiya, v. 49, p. 95-113.

Russian.

Toxicity.

CA95(11):92034b.

Krugiov, Y. V., and Gersh, N. B., 1976, Voprosy Ekologii i Fiziologii Mikroorganizmov, Ispol'znemykh v Sel'skom Khozyaistve, p. 61-67.

Russian.

Toxicity.

CA88(17):116267p.

Kuemmerlin, R, 1986, Interactions between the sorption of the herbicide atrazine and the physiological condition of planktonic algae: Archives of Hydrobiology, Supplement, v. 66 , no. 4 , p. $495-571$.

English.

Toxicity.

CA105(5):36929k.

Kulakov, A. E., 1970, Voprosy Gigieny i Toksikologii Pestitsidov, Trudy Nauchnoi Sessii Akademii Meditsinskikh Nauk SSSR, 1967, p. 173-177.

Russian.

Toxicity.

CA74(19):98619j.

Kulakov, A. E., 1970, Cytogenetic analysis of the bone-marrow cells in rats exposed to the action of herbicides of the triazine group: Farmkolologiya i Toksikologiya (Moscow), v. 33 , no. 2, p. 224-227.

Russian.

Toxicity.

CA73(3):13375h.

Kulshrestha, G., Yaduraju, N. T., and Mani, V. S., 1982, The relative toxicity of the s-triazine herbicides atrazine and simazine to crops: Joumal of Environmental Science and Health, Part B, v. B17, no. 4, p. 341-354.

English.

Toxicity.

CA97(9):67488m
Kuz'mina, I. V., 1968, Microbiological characteristics of a low thick moor and the action of herbicides on soil: Sbornik

Studencheskikh Nauchnykh Rabot, Moskovskaya

Sel'skolkhozyaistvennaya Akademiya, v. 16, p. 268-272.

Russian.

Toxicity.

CA72(9):42086z.

Kuzyakina, T. I., 1971, Effect of simazine and atrazine on separate strains and groups of microorganisms isolated from the soil: Doklady TSKHA, v. 169, p. 183-187.

Russian.

Toxicity.

CA76(23):136702g.

Ladonin, V. F., and Lunev, M. I., 1983, Determination of pesticide residues from the phytotoxic index: Zashchita Rastenii (Moscow), no. 4, p. $28-29$.

Russian.

Toxicity,Analytical Techniques/Quantification.

CA99(3):17924w.

Larsen, D. P., DeNoyelles, F. J., Stay, F., and Shiroyama, T., 1986, Comparisons of single-species, microcosm and experimental pond responses to atrazine exposure:

Environmental Toxicology and Chemistry, v. 5, no. 2, p. 179190.

English.

Toxicity,Surfacewater Observations.

CA104(19):163335t.

Larsen, G. L., and Bakke, J. E., 1975, Metabolism of 2-chloro-4 cyclopropylamino-6-isopropylamino-s-triazine (cyprazine) in the rat: Journal of Agriculture and Food Chemistry, v. 23, no. 3, p. 388-392.

English.

Toxicity,Uptake by Biota.

CA83(9):73051r.

Lay, J. P., Mueller, A., Peichl, L., Klein, W., and Korte, F., 1984, Long-term effects of the herbicides atrazine and dichlobenil upon the phytoplankton density and physicochemical conditions in compartments of a freshwater pond: Chemosphere, v. 13, no. 7, p. 821-832.

English.

Surfacewater Observations, Toxicity.

CA101(15):124486m.

Lazarescu, D., and Mlak, E., 1977, Experimental results on control of water "bloom" using algicides: Studii Alimentari cu Ape, v. 10, p. 195-202.

Romanian.

Toxicity.

CASO(17):133878x.

Lebedeva, G. F., Chemova, N. I., and Epishina, L. V., 1978, Persistence of sym-triazines in sod-podzolic soil and their effect on microflora: Vestnik Moskovskogo Universiteta, Seriya 16: Bioiogiya, no. 2, p. 44-46.

Russian.

Biodegradation/Biotransformation,Toxicity. CA89(17):141772c. 
Leblova, S., and Rcvenska, J., 1987; Effect of pollutants on alcohol dehydrogenase isolated from peanut (Arachis hypogaea): Biologia (Bratislava), v. 42, no. 4, p. 347-357. English.

Toxicity.

CA107(5):34701x.

Lefebvre-Drouet, E., and Calvet, R, 1983, Use of a biological dosage of atrazine for algae (Chlorella) for studying the adsorption-phytotoxicity relation: Chemosphere, v. 12, no. 910 , p. $1355-1362$

French.

Toxicity, Uptake by Biota.

CA100(1):2068k.

Leoni, V., D'Alessandro De Luea, E., Belisario, M. A., and Pampena, A., 1982, Study of N-nitroso derivatives of agricultural pesticides: Contaminants in technical products, nitroso derivatives of atrazine, carbaryl, and chlorbromuron, mutagenesis and environmental hazards.: Igiene Moderna, v. 78 , no. 3, p. 301-320.

Italian.

Toxicity.

CA98(7):482872.

Leszczynska, D., 1970, Effect of some herbidies on yeast from the rhizosphere of cultivated plants: Mededelingen van de Faculteit Landbouwwetenschappen, Rijksuniversiteit Gent, v. 35 , no. 2, p. 637-645.

English.

Toxicity.

CA75(17):108849w.

Liang, T. T., and Lichtenstein, E. P., 1974, Synergism of insecticides by herbicides. Effect of environmental factors: Science, v. 186, no. 4169 , p. 1128-1130.

English.

Toxicity, Leaching.

CA82(21):133984p.

Lichtenstein, E. P., 1975, Origin and Pate of Chemical Residues in Food, Agriculture and Fisheries, Proceddings, Report 2, 1973-1974, p. 3-7.

English.

Toxicity.

Ca85(25):187465a.

Lichtenstein, E. P., Kunstman, J. L., Fuhremann, T. W., and Liang, T. T., 1979, Effects of atrazine on the toxicity, penetration and metabolism of carbofuran in the house fly. Journal of Economie Entomology, v. 72, no. 5, p. 785-789. English.

Toxicity.

CA92(19):158909n.

Lichtenstein, E. P., Liang, T. T., and Anderegg, B. N., August 1973, Synergism of insecticides by herbicides: Science, $v$ : 181 , no. 4102 , p. $847-849$.

English.

Toxicity,Analytical Techniques/Quantification.
Lisi, P., Caraffini, S., and Assalve, D., 1987, Irritation and sensitization potential of pesticides: Contact Dermatitis, $v$. 17 , no. 4, p. 212-218.

English.

Toxicity.

CA108(3): $17485 \mathrm{~h}$.

Lisi, P., Caraffini, S., and Assalve, D., 1986, A test series for pesticide dermatitis: Contact Dermatitis, v. 15 , no. 5 , p.

266-269.

English.

Toxicity.

CA106(15):114892e.

Liu, L. C., and Cibes-Viade, H. R., 1972, Effect of various herbicides on the respiration of soil microorganisms: Journal of the Agricultural University of Puerto Rico, v. 56, no. 4, p. 417-425.

English.

Toxicity.

CA78(7):38942g.

Loeppky, C., and Tweedy, B. G., 1969, Effects of selected herbicides growth of soil algae: Weed Science, v. 17, no. 1, p. 110-113.

English.

Toxicity.

CA70(13):55183n

Loprieno, $\mathbf{N}$, 1980, Investigations on the relationship between metabolic conversion and mutagenic activity of environmental chemicals with potential cancerogenic activity:

Communications of the European Community, EUR 6388,

Environmental Research Programme, 285-289.

English.

Toxicity.

CA93(7):63214p.

Loprieno, N., 1981, Molekulyarnye Osnovy Geneticheskikh Protsessov, Trudy Mezhdunarodnogo Geneticheskogo Kongressa, 14th, 1978, p. 127-138.

Russian.

Toxicity.

CA96(21): $175797 \mathrm{z}$.

Lorz, H. W., Glenn, S. W., Williams, R H., Kunkel, C. M., Norris, L. A., and Loper, B. R, 1979, Effects of selected herbicides on smolting of coho salmon: EPA-600/3-79-071, 103 p.

English.

Toxicity.

CA93(1):1839n.

Lunev, M. L, 1986, Evaluation of permissible levels of xenobiotics and their metabolites in plants: Tsentral'nyi Institut Agrokhimicheskogo Obsluzhivaniya Sel'stogo Khozyaistva, Trudy, no. 1, p. 62-63.

Russian.

Toxicity, Degradation Products.

CA104(13):108040t. 
Lusby, A. F., Simmons, Z, and McGuire, P. M., 1979, Variation in mutagenicity of s-triazine compounds tested on four Salmonella strains: Environmental Mutagenesis, v. 1, no. 3, p. 287-290.

English.

Toxicity.

CA94(5):25959y.

Ma, T. H., Harris, M. M., Anderson, V. A., Ahmed, I., Mohammad, K, Bare, J. L., and Lin Guangheng, 1984, TradescantiaMicronucleus (Trad-MCN) tests on 140 health-related agents: Mutation Research, v. 138, no. 2-3, p. 157-167.

English.

Toxicity.

CA102(15):126979u.

Macek, K. J., Buxton, K. S., Sauter, S., Gnilka, S., and Dean, J. W., 1976, Chronic toxicity of atrazine to selected aquatic invertebrates and fishes: U.S. NTIS PB Rep. PB-255439, 60 p. English.

Toxicity.

CA86(3):124912.

Machulla, G., Hickisch, B., and Muller, G., 1987, Influence of a single or multiple herbicide application upon biological activity and microflora of soils: Ekologiya (Sverdlowsk), no. 4, p. $52-55$.

Russian.

Toxicity.

CA107(21):192624d.

Mahmoud, S. A. Z. Hamed, A. S., Zaki, M. M., and Sahab, A. F., 1980, Growth and nitrogen metabolism of Fusarium oxysporum $f$. fabae in response to pesticides nuvacron and atrazine: Egyptian Journal of Microbiology, v. 15, no. 1-2, p. 33-40. English.

Toxicity.

CA95(1):1726q.

Malanchuk, J. L., and Kollig, H. P., 1985, Validation and Predictability of Laboratory Methods for Assessing the Fate and Effects of contaminants in aquatic ecosystems. A Symposium Sponsored by the American Institute of Biology, The Applied and Aquatic Section of the Ecological Society of America, and American Society of Testing Materials Committee EO47, 8 Aug 1983, p. 212-224.

English.

Toxicity,Surfacewater Observations.

CA104(7):46893n.

Malik, R. K, Pahuja, S. S., and Balyan, R. S., Jan 1982, Response of cowpea to herbicidal polluted water. Atrazine, diuron, phytotoxicity: Geobios, v. 9, no. 1, p. 8-10. Engish.

Toxicity.

IND 82051648

Malkomes, H. P., and Behr, U., 1987, Effect of the mode of application of chlortoluron and its combination with atrazine on microbial activities in soil: Nachrichtenblatt des Deutschen Pflanzenschutzdienstes (Braunschweig), v. 39, no. 12, p. 183-188.

German.

Toxicity.

CA108(19):163211g.
Mallison, S. M., III, and Cannon, R. E., 1984, Effects of pesticides on cyanobacterium Plectonema boryanum and cyanophage LPP-1: Applied Environmental Microbiology, v. 47, no. 5, p. 910-914.

English.

Toxicity.

CA101(1):2198y.

Mansour, F., 1987, Effect of pesticides on spiders occurring on apple and citrus in Israel: Phytoparasitica, v. 15, no. 1, p. 43-50.

English.

Toxicity.

CA107(15):128747u.

Manturovskaya, N. V., 1970, Action of symmetric triazines on soil fungi in a pure culture: Vestnik Moskovskogo Universiteta, Biologiya, Pochvovedenie, v. 25, no. 3, p. 31-36.

Russian.

Toxicity.

CA73(23):119509v.

Marchini, S., Passerini, L., Cesareo, D., and Tosato, M. L., 1987, Application of structure-activity analysis for estimation of potential effects of pesticides on environmental biological targets: NATO ASI Ser., Ser. H, v. 13, no. Toxicology of Pesticides: Experimental, Clinical and Regulatory Perspectives, p. 285-290.

English.

Toxicity.

CA108(15):126264f.

Marchini, S., Passerini, L., Cesareo, D., and Tosato, M. L., 1988, Herbicidal triazines: acute toxicity on Daphnia, fish, and plants and analysis of its relationships with structural factors: Ecotoxicology and Environmental Safety, v. 16, no. 2, p. 148-157.

English.

Toxicity.

CA110(7):52617r.

Marcoci, S., and Cusa Eugen, 1982, Establishment of maximum levels of toxic substance mixtures in surface waters:

Hidrotehnica, v. 27, no. 7, p. 206, 211.

Romanian.

Surfacewater Observations, Toxicity. CA98(19):1563869.

Marcoci, S., and lonescu, M., 1976, Effect of some triazinic derivatives on photosynthesis of the green algae Scenedesmus quadricauda and Chlorella vulgaris: Stzdii Protectia Calitatii Apelor, v. 17, p. 94-110.

Romanian.

Toxicity.

CA89(13):101620v.

Marcoci, S., and lonescu, M., 1979, Relation between the concentration of some symmetrical triazine compounds and their lethal effect on fish: Studii Protectia Calitatii Apelor, v. 19, p. 58-74.

Romanian.

Toxicity.

CA95(11):92011s. 
Mareckova, H., and Husarova, M., 1977, Effect of long-term systemic herbicide application on Rhizobium survival in soil: Acta Phytopathologica Academiciae Scientriarum Hungaricae, v. 12, no. 1-2, p. 19-21.

English.

Toxicity.

CA88(25):184210q

Maria, C. S., Moreno, J., and Lopez-Campos, J. L., 1987, Hepatotoxicity induced by the herbicide atrazine in the rat: Journal of Applied Toxicology, v. 7, no. 6, p. 373-378.

English.

Toxicity.

CA108(7):50947h.

Marquardt, H., 1980, Further improvement of a genetic prescreening test pattern for carcinogenic effects of environmental chemicais: Commications of the European Communities, EUR 6388, Environmental Research Programme, 248252.

English.

Toxicity.

CA93(5):39108m.

Martinez, R, 1976, Diez Anos Colab. Cient. Cuba-RDA, p. $80-89$. Spanish.

Toxicity.

CA88(5):33063t.

Martinez Viera, R, Auchet Jenckens, F., and Novo Sordo, R, 1981, Influence of environmental factors on the effect of some triazines on microorganisms and nitrification in red ferralitic soils: Ciencias de la Agriculture, v. 8, p. 195 115.

Spanish.

Toxicity.

CA96(13):99404b.

Martinez Viera, R, and Pagel, H., 1978, Studies of the effect of atrazine and simazine on nitroger-binding bacteria. Azotobacter and Beijerinckia in ferralitic soils of Cuba: Beitrichte der Tropischen Landwirtschaft und Veterinaermedizin, v. 16, no. 2, p. 137-144. German.

Toxicity.

CA90(9):67694f.

Martino, K. R., 1971, Pathological changes observed in fishes following poisoning by granulated herbicides-atrazine and diuron: rapid determination of the toxicity of low pesticide concentrations: Trudy Kaspiiskii Nauchno-Issledovatel'skii Institut Rybnogo Khozyaistva, v. 26, p. 245-249.

Russian.

Toxicity.

Mathias, M., 1987, Comparison of the genotoxic activity of two preparations of atrazine in the yeast: Bulletin de la Societe Royale des Sciences de Liege, v. 56, no. 5-6, p. 425-432. French.

Toxicity.

CA109(1):2134q.
Matsubara, H., and Obara, Y., 1978, Studies on the biological activity of hetercyclic compounds. Part III. Blindness from pyridines, diazines, s-triazines, triazoles and their related compounds in chicks: Nippon Nogei Kagaku Kaishi, v. 52, no. 3; p. 123-127.

Japanese.

Toxicity.

CA89(19):158399j.

Maule, A., and Wright, S. J. L., 1984, Herbicide effects on the population growth of some green algae and cyanobacteria: Journal of Applied Bacteriology, v. 57, no. 2, p. 369-379. English.

Toxicity.

CA101(25):224727j.

Mayasich, J. M., Karlander, E. P., and Terlizzi, D. E., Jr., 1986, Growth responses of Nannochloris oculata Droop and Phaeodactylum tricornutum Bohlin to the herbicide atrazine as influenced by light intensity and temperature: Aquatic Toxicology, v. 8, no. 3, p. 175-184.

English.

Toxicity.

CA105(17):147825t.

Maydani, M., and Hathcock, J. N., 1984, Effect of dietary methionine on methylmercury and atrazine toxicity: Drugs and Nutrients: the Interactive Effects, v. 2, no. 4, p. 217-233. English.

Toxicity.

CA101(7):49706c.

McBride, R. K, and Richards, B. D., 1975, Effects of some herbicides and pesticides on sodium uptake by isolated perfused gills from the carp Cyprinus carpio: Comparative Biochemistry and Physiology: C, v. 51, no. 1C, p. 105-109. English.

Toxicity.

CA83(17):142695t.

McElhannon, W. S., Mills, H. A., and Bush, P. B., 1984, Simazine and atrazine - suppression of denitrification: HortScience, v. 19 , no. 2, p. 218-219.

English.

Toxicity.

CA101(3):19016k

McGrath, D., and McCormack, R. J., 1979, Herbicide activities in Irish soils: Iranian Journal of Agricultural Sciences, v. 18, no. 1, p. 89-96.

English.

Toxicity.

CA91(21):169845u.

McLaughlin, R. D., 1975, Atrazine phytotoxicity as a function if its concentration in displaced soil solution, Dissertation submitted in partial fulfillment of Ph.D. requirements, Auburn University, Auburn, Ala., USA.

English.

Toxicity.

CA84(19):131403r. 
Means, J. C., Plewa, M. J., and Gentile, J. M., 1988, Assessment of the mutagenicity of fractions from s-triazine-treated Zea mays: Mutation Research, v. 197, no. 2, p. 325-336. English.

Toxicity.

CA108(19):163018z

Meijers, A. P., 1988, Organic micropollutants in the water and in the bank infiltration water of the river Rhine: GWF, Gas-und Wasserfach: Wasser/Abwasser, v. 129, no. 3, p. 208-211. German.

Toxicity,Surfacewater Observations.

CA109(2):11361p.

Melius, T. O., 1975, Effects of atrazine on penned hen pheasants: Proceedings of the South Dakota Academy of Science, v. 54; p. 137-142.

English.

Toxicity.

CA85(23):17245\%c.

Merenyuk, G. V., 1986, Status and methods for the regulation of soil microbiocenoses during intensive farming in the Moldavian SSSR: Izvestiya Akademii Nauk Moldavskoi SSR, Seriya Biologicheskikhi Khimicheskikh Nauk, no. 6, p. 3-8. Russian.

Toxicity.

CA106(13):101287m.

Merenyuk, G. V., Emnova, E. E., Karlina, N. N., and Kodryan, V. A., 1983, Criteria for classifying pesticides by their antimicrobial properties: Izvestiya Akademii Nauk Moldavskoi SSR, Seriya Biologicheskikhi Khimicheskikh Nauk, no. 3, p. 45-48.

Russian.

Toxicity.

CA99(15):117715x.

Merenyuk, G. V., Usataya, A. S., Emnova, E. E., Katruk, E. A., and Kodryan, V.A., 1987, Sym-triazıne herbicides effect on soil microflora and substantiation of their MACs in soit by the microbiological risk factor. Gigiena i Sanitariya, no. 5, p. 20-22.

Russian.

Toxicity.

CA107(5):34698b.

Mereshko, M. Y., 1969, Effect of herbicides on biological activity of microflora in chernozem soils: Mikrobiologicheskii Zhumal (Kiev), v. 31, no. 5, p. 525-529. Ukrainian.

Toxicity.

CA72(15):77775a.

Merinov, G. P., 1978, Sensitivity of tree species to a simazine and atrazine in the arable layer of ordinary Chernozems: Nauchnye Trudy - Nauchno Issledovatel'skii Institut Sel'skogo Khozyaistua Tsentr Chernozem Polosy, v. 15, no: 1, p. 104 109.

Russian.

Toxicity.

IND 84051050.
Merriam, T. L, and Axtell, R. C., 1983, Relative toxicity of certain pesticides to Lagenidium giganteum (Oomycetes: Lagenidiales), a fungal pathogen of mosquito larvae: Environmental Entomology, v. 12, no. 2, p. 515-521. English.

Toxicity.

CA99(25):207961d.

Mersch-Sundermann, V., Dickgiesser, N., Hablizel, U., and Gruber, B., 1988, Mutagenicity of organic microcontaminations in the environment. Part 1. The mutagenicity of selected herbicides and insecticides in the Salmonella-microsome test (Ames test) in consideration of the pathogenicity of contaminated ground and drinking waters: Zentralblatt Bakteriologie, Mikrobiologic und Hygiene, Series B, v. 186, no. 3, p. 247 260.

German.

Toxicity.

CA109(16):134599e.

Messner, B., Berndt, J., and Still, J., 1979, Increases in rat liver cyclic AMP and glycogen phoshorylase activity caused by the herbicide atrazine: Biochemical Pharmacology, v. 28, no. 2, p. $207-210$.

English.

Toxicity. CA91(3):14848y.

Messori, V., Francese, R, and Esposito, R, 1981, Chlorobis(alkylamino)-s-triazines: Appl. or Pr. 2939530, 28 Sep 1979.

German.

Toxicity,Degradation Products. CA95(7):62268p.

Meydani, M., and Hathcock, J. N., 1984, Effect of dietary methionine on methylmercury and atrazine toxicity: Drug and Nutrients: Their Interactions, v. 2, no. 4, p. 217-233. English.

Toxicity.

IND 84072449.

Meydani, M., 1982, Effect of dietary methionine on methylmercury and atrazine toxicities, Dissertation submitted in partial fulfillment of $\mathrm{Ph} . \mathrm{D}$. requirements, lowa State University, Ames, IA, USA.

English.

Toxicity.

CA98(3):12541p.

Meydani, M., Meydani, S. N., and Hatheock, J. N., 1984, Effects of dietary methionine, methylmercury, and atrazine on ex vivo synthesis of prostaglandin E1 and thromboxane B2: Prostaglandins, Leukotrienes Medicine, v. 14, no. 2, p. 267 278.

English.

Toxicity.

CA101(11):85192r.

Micev, N., and Bubalov, M., 1972, Interaction between soil microflora and herbicide agelon: Symposia Biologica Hungarica, v. 11, p. 379-384.

English.

Toxicity,Chemical/Physical Properties.

CA79(13):74561m. 
Micev, N., and Bubalov, M., 1969, Effect of herbicides Gesaprim 1798 and VSC 438 + dicambra on soil and rhizoshpere microflora: Godisen Zbornik na Zemjodelsko-Sumarskiot Fakultet na Univerzitetot, Skopje, Zemjodelstvo, v. 22, p. 19-24.

Macedonian.

Toxicity.

CA73(21):108542z.

Mickouski, M., 1968, Effect of triazine herbicides on the microflora of some soils in Macedonia: Mikrobiologiya, v. 5, no. 2, p. 285-296.

Croatian.

Toxicity.

CA71(25):122679q.

Miele, S., Vannozzi, G. P., and Mazzini, M. P., 1978, Biological tests for determining the residual effects of atrazine: Mededelingen van de Faculteir Landbouwwetenschappen, Rijksuniversiteit Gent, v. 43, no. 2 Pt. 2, p. 1109-1115. French.

Toxicity.

CA90(19):146882u.

Mikhailova, E. I., and Kruglov, Y. V., 1973, Effect of some herbicides on soil algoflora: Pochvovedenie, no. 8, p. 81-85. Russian.

Toxicity.

C.480(3):10973k.

Mills, H. A., 1984, A procedure for rapidly evaluating the effect of chemicals on denitrification: Communications in Soil Science and Plant Analysis, v. 15, no. 9, p. 1007-1016. English.

Toxicity.

CA101(15):129496z.

Mohiuddin, S., and Qureshi, S. A., 1973, Screening tests of substituted phosphine oxides, phosphonic amides, methylmelamines, and diaminotriazines for sterilization of laboratory-reared strain of houseflies, Musca domestica: Pakistan Joumal of Scientific and Industrial Research, v. 16, no. 5, p. 182-187.

English.

Degradation Products, Toxicity.

CA81(5):22222y.

Mola, L., Sabatini, M. A., Fratello, B., and Bertolani, R, 1987, Effects of atrazine on two species of Collembola (Onychiuridae) in laboratory tests: Pedobiologia, v. 30, no. 3, p. 145-149.

English.

Toxicity.

CA107(21):192599z.

Molnar, V., 1971, Symtomatology and morphopathology of experimental intoxication caused by herbicide atrazine: Revista Medica (Tirgu-Mures), v. 17, no. 3-4, p. 271-275. Romanian.

Toxicity.

CA77(3):15237w.
Monein, A., and Krugiov, Y. V., 1981, Effect of atrazine

herbicide on the biological activity of the soil and microflora of the com rhizosphere: Pochvovedenie, no. 5, p. 64-68.

Russian.

Toxicity.

CA95(5):37031y.

Moorhead, D. L., and Kosinski, R. J., 1986, Effect of atrazine on the productivity of artificial stream algal communities:

Bulletin of Environmental Contamination and Toxicology, v. 37, no. 3, p. 330-336.

English.

Toxicity,Surfacewater Observations.

CA105(21):185562n.

Moosbeckhofer, R, 1983, Laboratory studies on the effect of some plant protection agents on egg and larval stages of Poecilus cupreus L. and P. sericeus Fischer d.W. (Col., Carabidae): Zeitschrift fuer Angewandte Entomologie, v. 95, no. 5, p. 513-523.

German.

Toxicity.

CA99(15):117474t.

Morgun, V. V., Logvinenko, V. F., Merezhinskii, Y. G., Lapina, T. V., and Grigorenko, N. V., 1982, Cytogenetic and genetic activity of the herbicides atrazine, simazine, prometryne and linuron: Tsitologiya i Genetika, v. 16, no. 1, p. 38-41.

Russian.

Toxicity.

CA96(17):137898a.

Motoya, H., DeNoyelles, T. F. J., and Sze, H., 1983, Differential atrazine herbicide sensitivity of algae (Kirchneriella lunaris, Oocystis sp., Cryptomonas sp.): Current topics in plant biochemistry and physiology.

English.

Toxicity.

IND 84080542.

Mozhaev, V. G., 1975, Aftereffect of herbicides on the weediness of forest plantings: Khimiya v Sel'skom Khozyaistve, v. 13, no. 11, p. 853-855.

Russian.

Toxicity.

CA84(13):85435g.

Mukhopadhyay, S. K, 1980, Effects of herbicides and insecticides alone and their combinations on soil microflora: Indian Journal of Weed Science, v. 12, no. 1, p. 53-60.

Engish.

Toxicity. CA95(15):126986.

Mullins, J. S., 1975, Effects of dalapon and atrazine on com (Zea mays L.) bacteria, Dissertation submitted in partial fulfillment of $\mathrm{Ph}$.D. requirements, North Dakota State University, Fargo, N. Dak., USA.

English.

Toxicity.

CA85(9):57982f. 
Murnik, M. R, and Nash, C. L., 1977, Mutagenicity of the triazine herbicides atrazine, cyanazine, and simazine in Drosophila: Journal of Toxicology and Environmental Health, v. 3, no. 4, p. $691-697$.

English.

Toxicity.

CA88(15):100018x.

Nardi, S., and Dell'Agnola, G., 1984, Effects of herbicides on the transformation of organic substances in the soil: Agrochimica, v. 28, no. 5-6, p. 489-495.

Italian.

Toxicity.

CA103(21):174015u.

Nehring, D., 1966, Toxicity of new pesticides and sewage treatment agents to fish: Zeitschrift fuer Fischerei und Deren Hiltswissenschaften, v. 14, no. 1-2, p. 1-8.

German.

Toxicity.

CA66(5):18253g.

Nepomiluev, V. F., and Kuzyakina, T. I., 1972, Action of atrazine and simazine on the soil fungi, and decomposition of the herbicides in soil: Biologicheskie Nauki, v. 15, no. 8, p. 127-131.

Russian.

Toxicity,Biodegradation/Biotransformation.

CA78(3):12585t.

Neuhold, J. M., 1987, The relationship of life history attributes to toxicant tolerance in fishes: Environmental Toxicology and Chemistry, v. 6, no. 9, p. 709-716.

English.

Toxicity.

CA107(21):192530v.

Neuville, D., Daste, P., and Longchamp, R., 1974, Comparative toxicity of various pesticides with regard to Diatoma used in oyster culture: C.R. Hebd. Seances Acad. Sci., Ser. D., v. 279, no. 8, p. 675-678.

French.

Toxicity.

CA82(17):107197q.

Nezefi, T. A., 1971, Morphological changes in white rats during the prolonged action of atrazine: Zdravookhranenie

Turkmenistana, v. 15, no. 3, p. 9-12.

Russian.

Toxicity.

CA76(3):10860p.

Nezefi, T. A., 1974, Morphological changes in white rat organs under the influences of some herbicides: Zdravookhrenie Turkmenistana, v. 18, no. 3, p. 24-25.

Russian.

Toxicity.

CA81(25):164295y.

Nezefi, T. A., 1971, Pathomorphological changes of white rat organs with administration of threshold dose of monumn and its mixture with atrazine: Zdravookhranenie Turkmenistana, $v$. 15 , no. 1 , p. 8-11.

Russian.

Toxicity.

CA75(15):96892q.
Nicolau, G. Y., 1982, Pesticide effects upon the circadian time structure in the thyroid, adrenal and testis in rats: Revue Roumaine de Medecine: Endocrinologie, v. 20, no. 2, p. 73 90.

English.

Toxicity.

CA98(3):12628x.

Nikolaeva, N. G., 1986, Plodorodie i Obrabotka Pochvy v Sevooborotakh, p. 86-91.

Russian.

Toxicity.

CA106(23):191076u.

Nishiuchi, Y., 1980, Effect of $\mathrm{pH}$ on the toxicity of pesticides to aquatic animals. II: Seitai Kagaku, v. 3, no. 2, p. 7379.

Japanese.

Toxicity.

CA93(21):1987976.

Nishiuchi, Y., 1977, Toxicity of formulated pesticides to some freshwater organisms: Suisan Zoshoku, v. 24, no. 4, p. 140145.

Japanese.

Toxicity.

CA88(23):165137e.

Nishiuchi, Y., 1982, Toxicity of pesticides to freshwater organisms. LXXX. Differences of the sensitivity of two carp species to pesticides: Suisan Zoshoku, v. 30, no. 3, p. 163166.

Japanese.

Toxicity.

CA99(19):153514q.

Nishiuchi, Y., 1982, Toxicity of pesticides to freshwater organisms. LXXIX. Effects of water temperature on the sensitivity of Daphnia pulex to pesticides: Suisan Zoshoku, v. 30 , no. 3 , p. $158-162$.

Japanese.

Toxicity.

CA99(19):153513p.

Nishiuchi, Y., and Asano, K, 1979, Toxicity of pesticides to some freshwater organisms: Suisan Zoshoku, v. 27, no. 1, p. 48-55.

Japanese.

Toxicity.

CA92(11):88958b.

Nishiuchi, Y., 1981, Evaluation of the effect of pesticides on some aquatic organisms I. Effect of pesticides on some aquatic insects: Seitai Kagaku, v. 4, no. 2, p. 31-46.

Japanese.

Toxicity.

CA95(21):181948v. 
Nollenberger, E. L., 1981, Toxicant-induced changes in brain, gill, liver, and kidney of brook trout exposed to carbaryl, atrazine, 2,4-D, and parathion: a cytochemical study, Dissertation submitted in partial fulfillment of $\mathrm{Ph} . \mathrm{D}$. requirements, Pennsytvania State University, University Park, PA, USA.

English.

Toxicity.

CA97(3):18731b.

Notten, W. R. F., and Henderson, P. T., 1974, Alteration in urinary $\mathrm{D}$-glucaric acid excretion as an indication of exposition to xenobiotics: Communication of the European Community, EUR 5360, Proceedings of the International Symposium on Recent Advances in the Assessment of Health Effects Environmental Pollutants, Vol. 4, 2047-2060. English.

Toxicity.

CA87(15):112549p.

Ohta, T., Watanabe, M., Tsukamoto, R., Shirasu, Y., and Kada, T., 1986, Antimutagenic effects of 5-fluorouracil and 5 fluorodeoxyuridine on UV-induced mutagenesis in Escherichia coli: Mutation Rescarch, v. 173, no. 1, p. 19-24.

English.

Toxicity.

CA104(15):125733p.

Okamura, M. Y., 1984, On the herbicide binding site in bacterial reaction centers: UCLA Symposium on Molecular and Cellular Biology, New Series, v. 14, no. Biosynth. Photosynth. Appar., p. $381-390$.

English.

Toxicity.

CA102(7):57682c.

Ordog, V., 1981, Statistical evaluation of the toxicological algal bioassay: Acta Hydrochimica et Hydrobiologica, v. 9, no. 6, p. $607-612$.

English.

Toxicity.

CA96(17):137219e.

Ordog, V., 1979, Effect of triazine herbicides on the growth of the green algae Ankistrodesmus angustus Bern: Hidrologiai Kozlony, v. 59, no. 7, p. 323-328.

Hungarian.

Toxicity.

CA91(25):205565p.

Osterioh, J., Letz, G., Pond, S., and Becker, C., 1983, An assessment of the potential testicular toxicity of 10 pesticides using the mouse-sperm morphoiogy assay: Mutation Research, v. 116, no. 3-4, p. $407-415$.

English.

Toxicity.

CA98(15):120982s.

Palacios-Mayorga, S., and Mier-Herrera, L. B., 1978, Effect of a herbicide of the chloro-S-triazine group on microflora of some soils in the Toluca Valley. State of Mexico: Revista Universidad Nacional Autonoma de Mexico, Instituto de Geologia, v. 2, no. 2, p. 194-199.

Spanish.

Toxicity.

CA92(13):105420q.
Pantera, H., 1970, Effect of herbicides on algae in the soil: Mededelingen van de Faculteit Landbourwwetenschappen, Rijksuniversiteit Gent, v. 35, no. 2, p. 847-854.

English.

Toxicity.

CA75(17):108799e.

Pantera, H., 1972, Effect of high doses of herbicides on some groups of soil microorganisms: Pamietnik Pulawski, v. 51, p. 69-76.

Polish.

Toxicity.

CA77(23):148201b.

Paromenskaya, L. N., 1980, Effect of pesticides on symbiotic relation of Rhizobium with leguminous plants: Trudy Vsesoyuznogo Nauchno-Issledovatel'skogo Instituta Sel'skokhozyaistvennogo Mikrobiologiya, v. 50, p. 91-111. Russian.

Toxicity.

CA95(9):75047r.

Parthasarathy, S., and Purushothaman, D., 1975, Changes in spectral properties of chlorophyll due to herbicide treatment: Indian Journal of Agricultural Chemistry, v. 8, no. 1-2, p. 247-251.

English.

Toxicity.

CA87(15):112896z.

Pasztor, Z., Dobolyi, C., and Kecskes, M., 1978, The effect of different pesticides on the mycoflora of an "chernozem" ecosystem: Proceedings of the Hungarian Annual Meeting of Biochemists, v. 18, p. 21-22.

English.

Toxicity.

CA90(7):49624d.

Paterson; D. M., and Wright, S. J. L., 1988, Diffusion gradient plates for herbicide toxicity tests on micro-algae and cyanobacteria: Letters of Applied Microbiology, v. 7, no. 4, p. 87-90.

English.

Toxicity.

CA110(11):90254c.

Patil, B. N., Panchal, Y. C., Patil, V. S., and Krishnamurthy, K. A., 1981, Residual toxicity of triazine, phenoxy and amide herbicides on succeeding crops: Indian Journal of Weed Science, v. 13, no. 2, p. 103-110.

English.

Toxicity.

CA97(25):210347x.

Paulov, S., 1976, The effects of the herbicides Burex, Zeazin-50, and Aminex on the development of amphibia: Agrochemia, v. 16, no. 4, p. 102-103.

Slovenian.

Toxicity.

CA85(15):104929f. 
Pecker, I., Ohad, N., and Hirschberg, J., 1986, Progress in Photosynthesis Research, Proceedings of the International Congress on Photosynthesis, 7th, 1986, p. 811-814. English.

Toxicity.

CA107(1):1696w.

Peichl, L., Lay, J. P., and Korte, F., 1984, Effect of dichlobenil and atrazine on the population density of zooplankton in an aquatic outdoor system: Zeitschrift fuer Wasser und Abwasser Forschung, v. 17, no. 4, p. 134-145. German.

Toxicity.

CA101(23):205673x.

Peichl, L., Lay, J. P., and Korte, F., 1985, Effects of atrazine and 2,4-dichlorophenoxyacetic acid on the population density of phyto- and zooplankton in an aquatic outdoor system: Zeitschrift fuer Wasser und Abwasser Forschung, v. 18, no. S, p. 217-222.

German.

Toxicity.

CA103(25):208469n.

Perucci, P., Scarponi, L., and Monotti, M., 1988, Interference with soil phosphatase activity by maize herbicidal treatment and incorporation of maize residues: Biology of Fertilized Soils, v. 6, no. 4, p. 286-291.

English.

Toxicity.

CA109(17):144545y.

Peshakov, G., Ampova, G., Toskov, N., Rankov, V., and Tsirkov, I., 1976, The effect of certain herbicides on microorganisms, isolated from the rhizosphere of different crops: Pochvoznanie i Agrokhimiya, v. 11, no. 5, p. 93-99.

Bulgarian.

Toxicity.

CA86(25):184454f.

Peshakov, G., Raikov, E., and Tsvetanov, D., 1969, Effect of some herbicides on microflora, ammonification, and nitrification in the soil: Pochvoznanie i Agrokhimiya, v. 4, no. 6, p. 89-

94.

Bulgarian.

Toxicity.

CA73(11):54875q.

Peters, J. W., and Cook, R. M., 1973, Effects of atrazine on reproduction in rats: Bulletin of Environmental Contamination and Toxicology, v. 9, no. 5, p. 301-304.

English.

Toxicity.

CA79(9):49644h.

Pidgaiko, M. L., 1971, Metodiki Biologicheskikh Issledovanii po Vodnoi Toksikologii, p. 169-172.

Russian.

Tuxicity.

CA77(9):57308a.
Pino, A., Maura, A., and Grillo, P., 1988, DNA damage in stomach, kidney, liver and lung or rats treated with atrazine:

Mutation Research, v. 209, no. 3-4, p. 145-147.

English.

Toxicity.

CA110(5):35075v.

Pitts, G., Rodriguez-Kabana, R, and Curl E.A., Jan 1974, Effect of the herbicide atrazine and two carton levels on enzyme activities in soil monocultures of Sclerotium rolfsii:

Journal of the Alabama Academy of Science, v. 45, no. 1, p.

54-65.

English.

Chemical/Physical Properties, Toxicity.

CA82(15):94097e.

Plewa, M. J., and Gentile, J. M., 1976, Mutagenicity of atrazine: a maize-microbe bioassay: Mutation Research, v. 38, no. 4, p. 287-292.

English.

Toxicity.

CA85(15):104951g.

Plumley, F. G., and Davis, D. E., 1977, Atrazine effects on selected salt marsh components (Amphora, Algae, Abstract only): Proceedings of the Southern Weed Science Society, v. 30, p. 360.

English.

Toxicity,Surfacewater Observations.

CAIN 779078059.

Plumley, F. G., and Davis, D. E., 1980, The effects of a photosynthesis inhibitor atrazine, on salt marsh edaphic algae, in culture, microecosystems, and in the field: Estuaries, v. 3, no. 4, p. 271-277.

English.

Toxicity.

CA94(17):133648e.

Plumiey, F. G., Davis, D. E., McEnerney, J. T., and Everest, J. W., 1980, Effects of a photosynthesis inhibitor, atrazine, on the salt-marsh fiddler crab, Uca pugnax (Smith): Estuaries, v. 3, no. 3, p. 217-223.

English.

Toxicity.

CA94(7):42335j.

Pokorny, J., 1971, (Microbe) inhibiting concentrations of some pesticides: Ceskoslovenska Hygiena, v. 16, no. 4/5, p. 141145.

Czechoslovakian.

Toxicity.

CA75(13):87409t.

Polakowska, M., 1971, Reaction of two-year-old Pinus silvestris (pine) seedlings to some herbicides during their direct and long-term action on the young part of the shoots: Acta Agrobotanica, v. 24, no. 2, p. 309-317.

Polish.

Toxicity.

CA78(5):25264n. 
Popovici, I., Stan, G., Stefan, V., Tomescu, R, Dumea, A., Tarta, A., and Dan, F., 1977, The influence of atrazine on soil fauna: Pedobiologia, v. 17, no. 3, p. 209-215.

English.

Toxicity.

CA90(3):17576y.

Potrykus, I., Shillito, R. D., and Chilton, M. D., 1987, Direct gene transfer into plastids and mitochondria of plant protoplasts without use of pathogens: Appl. 86/116056, $20 \mathrm{Nov}$ 1986; US Appl. 801014, 22 Nov 1985.

German.

Toxicity.

CA107(23):212989g

Pott, E, 1982, Experimental studies of the effect of herbicides on the food uptake of Daphnia pulicaria Forbes: Archives of Hydrobiology, Supplement, v. 59, no. 4, p. 330-358. German.

Toxicity.

CA98(11):84610h.

Pratt, J. R., Bowers, N. J., Niederlehner, B. R, and Cairns, J. J., 1988, Effects of atrazine on freshwater microbial communities: Archives of Environmental Contamination and Toxicology, v. 17, no. 4, p. 449-457.

English.

Toxicity.

CA109(3):18514z.

Prescott, L. M., Kubovec, M. K, and Tryggestad, D., 1977, The effects of pesticides, polychlorinated biphenyls and metals on the growth and reproduction of Acanthamoeba castellanii: Bulletin of Environmental Contamination and Toxicology, v. 18 , no. 1, p. 29-34.

English.

Toxicity.

CA87(21):162352q.

Prescott, L. M., and Olson, D. L., 1972, Effect of pesticides on the soil amoeba Acanthamoeba castellanii: Proceedings of the South Dakota Academy of Science, v. 51, p. 136-141. English.

Toxicity.

CA81(5):22005e.

Preshing, M., 1985, Effect of certain toxicants on the Daphnia magna Straus survival rate in a three-factor experiment: Gidrobiologie Zhurnal, v. 21, no. 1, p. 72-75.

Russian.

Toxicity.

CA102(21):180461g.

Presing, M., 1987, The effect of atrazine and copper on the survival and reproduction of Daphnia magna (Straus): Hidrologiai Kozlony, v. 67, no. 4, p. 214-219.

Hungarian.

Toxicity.

CA108(17):145028y.

Put, A., Kadlubowska, D., and Kuzna, W., 1987, The influence of herbicides on the cardiovascular system of white rats: Pestycydy (Warsaw), no. 3-4, p. 25-33.

Polish.

Toxicity.

CA109(19):165368h.
Putintseva, L. A., 1969, Effect of herbicides on microflora of sorgo rhizoshpere and accumulation of nitrates: Izuch. Flory Rast. Sev. Kavkaza, p. 133-143.

Russian.

Toxicity.

CA74(13):63391b.

Radoveic, M., Straus, B., and Stankovic, V., 1978, Effects of atrazine on glucose-6-phosphate dehydrogenase and aldolase in rat organs: Acta Pharmaceutica Jugoslavica, v. 28, no. 3-4, p. $127-130$.

English.

Toxicity.

CA90(21):162943v.

Raheel, M., 1988, Dermal exposure to pesticides. The barrier effectiveness of protective clothing. Journal of

Environmental Health, v. 51, no. 2, p. 82-84.

English.

Toxicity.

CA110(8):62932d.

Rajagopal, V., and Vithal Rao, T. M., July 1984, Effect of insecticide-weedicide (thimet and atrazine) application on nitrification in red soil and uptake of nitrogen...:

Pesticides, v. 18, no. 7, p. 47-50.

English.

Toxicity.

IND 84116514.

Rajoo, R. K, and Ghonsikar, C. P., 1975, Studies in the berbicidal influence on microflora and nitrification: Indian Journal of Microbiology, v. 15, no. 2, p. 59-61.

English.

Toxicity.

CA85(3):14963h.

Rathouska, Z., Demnerova, K, Hajslova, Z., Vankova, Z, and Davidek; J., 1987, The effect of triazine herbicides on the biochemical activity of yogurt culture: Sbornik UVTIZ, Potravin.Vedy, v. 5, no. 3, p. 165-171.

Czechoslovalian.

Toxicity.

CA108(13): $110922 \mathrm{~h}$.

Rau, I., and Grimme, L. H., 1971, Influence of different striazines on the green alga Ankistrodesmus braunii: Zeitschrift fuer Naturforschung, B, v. 26, no. 9, p. 919-921. German.

Toxicity.

CA76(11):55122r.

Rees, R. T., Cobb, A. H., and Pallett, K. E., 1985, The potential of isolated cells for the metabolic screening of herbicides: Proceedings, British Crop Protection Conference on.Weeds, no. 1, p. 341-348.

English.

Toxicity.

CA104(13):104222f.

Renosto, F., Nardi, S., and Ferrari, G., 1979, Atrazine inhibition of ion uptake by plant roots: Pesticide Biochemistry and Physiology, v. 11, no. 1-3, p. 243-246. English.

Toxicity. CA91(9):69851z. 
Repova, A., 1986, The effect of Zeazin 50 herbicide on the spectrum of micromycetes in apple orchard soil: Agrochemia (Bratislava), v. 26, no. 8, p. 226-228.

Czechoslovakian.

Toxicity.

CA105(25):220879v.

Richardson, L. T., 1970, Effects of atrazine on growth response of soil fungi: Canadian Journal of Plant Science, v. 50, no. 5, p. 594-596.

English.

Toxicity.

CA73(25):129910h.

Rocchio, P. M., and Malanchuk, J. L., 1986, The effects of atrazine on dissolved oxygen and nitrate concentrations in aquatic systems: Environment International, v. 12, no. 6, p. 597-601.

English.

Toxicity.

CA106(10):72501u.

Rodriguez-Kabana, R., Curl, E. A., and Funderburk, H. H., Jr., 1967, Effect of atrazine on growth response of Sclerotium rolfsii and Trichoderma viride: Canadian Journal of Microbiology, v. 13, no. 10, p. 1343-1349.

English.

Toxicity.

CA67(23):106245g

Rodriguez-Kabana, R, Curl, E. A., and Funderburk, H. H., Jr., 1968, Effect of atrazine on growth activity of Sclerotium rolfsii and Trichoderma viride in soil: Canadian Joumal of Microbiology, v. 14, no. 12, p. 1283-1288.

English.

Toxicity.

CA70(5):17804h.

Rodriguez-Kabana, R, and Curl, E. A., 1970, Effect of atrazine on growth of Fusarium oxysporum $f$. vasinfectum:

Phytopathology, v. 60, no. 1, p. 65-69.

English.

Toxicity.

CA72(13):65667d.

Rodriquez-Kabana, R, and Curl, E. A., 1969, Soil herbicides affect oxalic acid production in Southem Blight fungus: Highlights of Agricultural Research, v. 16, no. 1, p. 8.

English.

Toxicity.

CA71(1):2394w.

Rolston, D. E, and Cervelli, S., 1980, Agrochemical ResidueBiota Interactions in Soil and aquatic Ecosystems, Proceedings and Report of combined Advisory Group Meeting and research Co-ordination Meeting, 1978; p. 189-199.

English.

Toxicity.

CA95(13):113999n.

Roslycky, E. B., 1982, Influence of selected herbicides in phages of some soil bacteria: Canadian Journal of Soil Science, $v$.

62 , no. 1, p. 217-220.

English.

Toxicity.

CA96(17):137989f.
Roslycky, E. B., 1977, Response of soil microbiota to selected herbicide treatments: Canadian Joumal of Microbiology, v. 23 , no. 4, p. 426-433.

English.

Toxicity.

CA87(23):178642v.

Rozsypalova, Z, 1981, Effect of herbicides on soil enzyme activity: Rostlinna Vyroba, v. 27, no. 2, p. 165-171.

Romanian.

Toxicity.

CA95(1):1783f.

Rud, I. A., 1981, Determination of the crystallooptical indexes of toxic agrochemicals and fertilizers: Donskoi

Sel'skokhozyaistvennyi Institu, (Sbornik Nauchnykh Trudov), v. 16 , no. 2 , p. $26-31$.

Russian.

Toxicity.

CA99(5):34399w.

Rudakov, V. O., and Spiridonov, Y. Y., 1982, Fungi as biological indicators of herbicides in the environment: Mikrobiologiya i Fitopatologiya, v. 16, no. 4, p. 359-360.

Russian.

Toxicity.

CA97(21):176839x.

Russo, G., and Calmotti, S., 1988, Atrazine: Chimia e l'Industria (Milan), v. 70, no. 6, p. 40-41.

Italian.

Toxicity.

CA109(19):165610f.

Sabatini, M. A., Pederzoli, A., Pratello, B., and Bertolani, R, 1979 , Microarthropod communities in soil treated with atrazine: Bollettino di Zoologia Padova, Unione Zoologica Italiana, v. 46, no. 4, p. 333-341.

English.

Toxicity.

IND 80133101.

Sachdev, M. S., and Luthra, V. K, 1981, Effect of simazine and atrazine on the decomposition of $14 \mathrm{C}$-glucose in soil: Journal of Nuclear Agriculture and Biology, v. 10, no. 2, p. 53-56. English.

Toxicity,Biodegradation/Biotransformation. CA95(15):127408f.

Sagi, M. M. Enisz, Janos, 1985, Effects of pesticides on phytopathogenic bacteria. Part 2. Agrobacterium radiobacter pv. tumefaciens: Nehezvegyipari Kutato Intezet Kozlemenyei, v. 16, p. $89-95$.

Hungarian.

Toxicity.

CA104(25):220651u.

Salem, F. M. S., Lotfi, M. M., Nounou, A. H., and El-Mansoury, H. A. M., 1985, Acute toxicological study on the herbicide "Gesaprim" in Balady rabbits: Veterinary Medicine Journal, v. 33, no. 2, p. 225-238.

English.

Toxicity.

CA104(7):46900n. 
Salem, F. M. S., Lotfi, M. M., and Nounou, A. H., 1985, Hazardous effect of application of the herbicide "Gesaprim" on balady rabbits: Veterinary Medicine Journal, v. 33, no. 2, p. 239-

250.

English.

Toxicity.

Ca104(7):46901p.

Saly, A, and Stanova, A., 1983, Effect of herbicides on freeliving nematode communities in soils under silage corn crop: Biologia (Bratislava), v. 38, no. 2, p. 159-169.

Slovenian.

Toxicity.

CA98(21):174695u.

Samoshikin, V. I., Antonyuk, V. G., and Chekhova, A. E., 1976, Effect of the systematic use of herbicides on the density of the mycorrhiza of English oak and on the biochemical activity of the soil: Khimiya v Sel'skom Khozyaistve, v. 14, no. 7, p. 60-63.

Russian.

Toxicity.

CA85(19):138484x.

Samson, G., and Popovic, R, 1988, Use of algal fluorescence for determination of phytotoxicity of heavy metals and pesticides as environmental pollutants: Ecotoxicology and Environmental Safety, v. 16, no. 3 , p. $272-278$.

English.

Toxicity.

CA110(11):90247c.

Santa Maria, C., Moreno, J., and Lopez Campos, J. L., Dec 1987, Hepatotoxicity induced by the herbicide atrazine in the rat: Journal of Applied Toxicology, v. 7, no. 6, p. 373-378. English.

Toxicity.

IND 87084160 .

Santa Maria, C., Vilas, M. G., Muriana, F. G., and Relimpio, A. 1986, Subacute atrazine treatment effects on rat renal functions: Bulletin of Environmental Contamination and Toxicology, v. 36, no. 3, p. 325-331.

English.

Toxicity.

CA104(17):143549n.

Sasaki, S., and Kozlowski, T. T., 1969, Effects of herbicides on respiration of red pine (Pinus resinosa) seedlings. I. sTriazine and chlorophenoxy acid herbicides: Advancing Frontiers of Plant Sciences, v. 22, p. 187-202.

English.

Toxicity.

CA72(15):77738r.

Sato, F., Shigematsu, Y., and Yamada, Y., 1988, Selection of an atrazine-resistant tobacco cell line having a mutant psbA gene: Molecular and General Genetics, v. 214, no. 2, p. 358360 .

Engiish.

Toxicity.

CA110(13):109301q.
Sayk, F., and Schmidt, C., 1986, Algae fluorescence autometer for a computerized bioassay. Zeitschrift fuer Wasser und Abwasser Forschung, v. 19, no. 5, p. 182-184.

German.

Analytical Techniques/Quantification,Toxicity. CA106(7):45146a.

Schachler, G., and Graeser, H., Mekhanizm Deistviya Gerbitsidovi Sinteticheskikh Regulyatorov Rosta Rastenii i Ikh Sud'ba v Biosfere, Materialy Mezhdunarodnogo Simposiuma, p. 167-171. Russian.

Toxicity.

CA88(21):147028r.

Schafer, E. W., Jr., Bowles, W. A., Jr., and Hurtbut, J., 1983; The acute oral toxicity, repellency, and hazard potential of 998 chemicals to one or more species of wild and domestic birds: Archives of Environmental Contamination and Toxicology, v. 12, no. 3, p. 355-382.

English.

Toxicity.

CA99(9):65537u.

Schafer, E. W., Jr., Brunton, R. B., Schafer, E. C., and Chavez, G., 1982, Effects of 77 chemicals on reproduction in male and female contumix quail: Ecotoxicology and Environmental Safety, v. 6, no. 2, p. 149-156.

English.

Toxicity.

CA97(1):2241f.

Scheepens, P. C., 1987, Joint action of Cochliobolus lunatus and atrazine on Echinochloa crus-galli (L.) Beauv: Weed Research, v. 27 , no. 1, p. $43-47$.

English.

Toxicity.

CA106(17):133681b.

Schlueter, M., 1969, Determination of fish toxicity of substances in the water and the toxic threshold of herbicides: Zeitschrift fuer Fischerei und Deren Hiltswissenschaften, v. 17 , no. 5-7, p. $457-471$.

German.

Toxicity.

CA73(21):108597w.

Schmidt, C., 1987, Possible use and results of an algal fluorescence bioassay. Ergebnisse Limnologie, v. 29, p. 107116.

German.

Analytical Techniques/Quantification,Toxicity. CA108(21):181559f.

Schober, U., and Lampert, W., 1976, Effects of sublethal concentrations of a herbicide on Daphnia: Naturwissenschaften, v. 63 , no. 5, p. 241-242. English.

Toxicity. CA85(5):29289s. 
Schober, U., and Lampert, W., 1977, Effects of sublethal concentrations of the herbicide Atrazine on growth and reproduction of Daphnia pulex: Bulletin of Environmental Contamination and Toxicology, v. 17, no. 3, p. 269-277. English.

Toxicity,Miscellaneous Environmental. CA87(3):16835h.

Schocken, M. J., Speedie, M. K, and Kirk, P. W., Jr., 1982, Interaction of higher marine fungi with the herbicide atrazine. I. Survey of interactive modes: Mycologia, v. 74, no. 5 , p. 801-808.

English.

Toxicity,Uptake by Biota. CA97(25):212345u.

Schocken, M. J., and Speedie, M. K., 1984, Physiological aspects of atrazine degradation by higher marine fungi: Archives of Environmental Contamination and Toxicology, v. 13, no. 6, p. 707-714.

English.

Toxicity,Biodegradation/Biotransformation. CA102(5):41258h.

Scorgie, H. R. A., and Cooke, A. S., 1979, Effects of the triazine herbicide cyanatryn on aquatic animals: Bulletin of Environmental Contamination and Toxicology, v. 22, p. 135142.

English.

Toxicity.

Seibert, K, and Fuehr, F., 1982, Procedure for measuring the translocation direction of dissolved pesticides in planted soil: Zeitschrift fuer Pflanzenemaehrung und Bodenkunde, v. 145, no. 5, p. 506-509.

German.

Toxicity.

CA98(3):12862u.

Semov, V., and Donchev, V., 1978, Toxicological studies of pesticides using fish test organisms: Trudy Vodosnabdyavane, Kanalizatsiya i Sanitarna Tekhnika, v. 13, no. 2, p. 127-138. Bulgarian.

Toxicity.

CA89(13):101307y.

Semov, V., and losifov, D., 1973, Toxicity of some Bulgarian pesticides studied with the test organism Daphnia magna: Trudy Vodosnabdyavane, Kanalizatsiya Sanitarna Tekhnika, v. 9, no. 2, p. 159-167.

Bulgarian.

Toxicity.

CA81(19):115594m.

Shabana, E. F, 1987, Use of batch assays to assess the toxicity of atrazine to some selected cyanobacteria. I. Influence of atrazine on the growth, pigmentation and carbohydrate contents of Aulosira fertilissima, Anabaena oryzae, Nostoc muscorum and Tolypothrix tenuis: Journal of Basic Microbiology, v. 27, no. 2, p. 113-119.

English.

Toxicity.

CA107(11):91496h.
Shabana, E. F., 1987, Use of batch assays to assess the toxicity of atrazine to some selected cyanobacteria. II. Effect of atrazine on heterocyst frequency, nitrogen and phosphorus metabolism of four heterocystous cyanobacteria: Journal of Basic Microbiology, v. 27, no. 4, p. 215-223.

English.

Toxicity.

CA108(3): $17483 f$.

Shabana, E. F., 1985, Use of algal batch assays to assess the toxicity of atrazine to some selected blue-green algae. I. Influence of atrazine on the growth, pigmentation and carbohydrate contents of Aulosira fertilissima, Anabaena oryzae, Nostoc muscorum and Tolypothrix tenuis: Egyptian Joumal of Physiological Science, v. 12, no. 1, p. 67-76. English.

Toxicity.

CA108(23):200148q.

Shabana, E. F., 1985, Use of algal batch asasys to assess the toxicity of atrazine to some selected blue-grenn algae. II Effect of atrazine on heterocyst frequency, nitrogen and phosphorus metabolism of four heterocystous blue-greens: Egyptian Journal of Physiological Science, v. 12, no. 1, p. $77-89$.

English.

Toxicity.

CA108(23):200149r.

Shah, P. V., Fisher, H. L., Sumler, M. R, Monroe, R. J., Chernoff, N., and Hall, L. L., 1987, Comparison of the penetration of 14 pesticides through the skin of young and adult rats: Joumal of Toxicology and Environmental Health, v. 21, no. 3, p. 353-366.

English.

Toxicity. CA107(7):53845p.

Shcherban, E. P., 1970, Effect of small concentrations of pesticides on the development and quantity of some Cladocera progeny: Gidrobiologicheskii Zhurnal, v. 6, no. 6, p. 101105.

Russian.

Toxicity.

CA75(1):4406h.

Shcherban, E. P., 1972, Effect of small concentrations of atrazine and diuron on the productivity of Cladocera: Gidrobiologicheskii Zhurnal, v. 8, no. 2, p. 71-76.

Russian.

Toxicity.

CA77(17):110243d.

Shcherban, E P, 1973, Effect of atrazine on biological parameters and potential productivity of Daphnia magna and Moina rectirostris: Elsspermental'naya Vodnaya Toksikologiya, v. 4, p. $80-86$.

Russian.

Toxicity.

CA79(25):143398c. 
Shutkina, A. T., and Tolochkina, S. A., 1984, Effect of prolonged use of herbicides on the microbiological activity of vineyard soils: Sodovod. Vinograd. Vinodel. Mold, no. 3, p. 39-41.

Russian.

Toxicity.

CA101(5):34519v.

Siebert, D., 1982, Further improvement of genetic and cytogenetic test pattern with increased relevance for predicting carcinogenic pharmacological effects: Forschungsbericht Bundesminister Forschungs und Technology, BMFT-FB-T 82-116, $12 \mathrm{p}$.

German.

Toxicity.

CA98(9):66865r.

Sieczka, J. B., Boldt, P. F., and Sweet, R. D., 1975, Effect of preplant applications of EPTC to soils with an atrazine residue on potatoes: Proceedings of the Northeastern Weed Science Society, v. 29, p. 284-288.

English.

Toxicity.

CA83(3):23157j.

Simionescu, L., Oprescu, M., Ghinea, E., Ghinea, L., Sahleanu, V., and Dimitriu, V., 1977, The radioimmunological measurement of thyroglobulin secretion in vitro under the influence of some herbicides: Revue Roumaine de Medecine: Endocrinologie, v. 15, no. 4, p. 243-248.

English.

Toxicity,Analytical Techniques/Quantification. CA93(15):143964y.

Simmon, V. F., Kauhanen, K, and Tardiff, R G., 1977, Mutagenic activity of chemicals identified in drinking water:

Developments in Toxicology and Environmental Science, v. 2, no. Progress in Genetics and Toxicology, p. 249-258.

English.

Toxicity.

CA89(7):54202y.

Simon, L., 1976, The influence of herbicides on soil microorganisms: Acta Botanica, v. 5, p. 83-93.

English.

Toxicity.

CA89(23):192488x.

Simon-Sylvestre, G., and Beaumont, A., 1982, Effects of some pesticides on azotobacters: Agrochimica, v. 26, no. 2-3, p. 157-166.

French.

Toxicity.

CA98(19):156114z.

Simon-Sytvestre, G., 1979, Effects of some pesticides on mineralization of soil organic nitrogen, nitrification and cellulose degradation: Annales Agronomiques, v. 30, no. 3, p. 265-279.

French.

Toxicity.

CA92(15):123412t.
Singh, I., Lusby, A. F., and McGuire, P. M., 1982, Mutagenicity of HPLC fractions from extracts of AAtrex-treated corn: Environmental Mutagenesis, v. 4, no. 1, p. 45-53.

English.

Toxicity,Analytical Techniques/Quantification. CA96(17):137705k.

Singh, R. K, and Dwivedi, R. S., 1988, Note on significant changes in colony characters in Sclerotium rolfsii Sacc. under chemical treatments: National Academy of Science and Letters (India), v. 11, no. 8, p. 239-240.

English.

Toxicity.

CA110(7):54405u.

Skarka, B., Drobnica, L., and Zemanovic, J., 1977, Antialgal properties of substances to be used in the protection of industrial cooling waters: Biologia (Bratislava), v. 32, no. 12, p. 989-992.

Czechoslovakian.

Toxicity.

CA88(7):46185j.

Sloof, W., Van Oers, J. A. M., and De Zwart, D., 1986, Margins of uncertainty in ecotoxicological hazard assessment:

Environmental Toxicology and Chemistry, v. 5, no. 9, p. 841-852.

English.

Toxicity.

CA105(19):166462p.

Snider, R. J., Moore, J. C., and Subagia, J., 1985, Effects of paraquat and atrazine on non-target soil arthropods: (s1Sin(s0S A systems approach to conservation tillage: Chelsea, Michigan, Lewis Publishers.

English.

Toxicity.

IND 86063536.

Sobels, F. H., Simons, J. W. I.M., Van Zeeland, A. A., and Knaap, A. G. A.C., 1980, Studies on the induction of point mutations by chemical mutagens in mammalian cells in vitro. Commumications of the European Communities, EUR 6388, Environmental Research Programme, 302-305.

English.

Toxicity.

CA93(5):39110f.

Sobieszczanski, J., Rola, J., and Zurek, M., 1975, Effect of many years of application of high herbicide doses on soil biology. I. Effect of many years of high herbicide doses on the succession of segetal plants and soil microorganisms: Roczniki Gleboznawcze, v. 26, no. 2, p. 165-178. English.

Toxicity.

CA84(11):70236q.

Sobieszczanski, J., 1969, Effect of herbicides on soil microflora. VIII. Effect of herbicides on growth and morphology of some species of bacteria: Acta Microbiologica Polonica, Series B, v. 18, no. 3-4, p. 99-104.

English.

Toxicity.

CA72(9):42038k. 
Sobieszezanski, J., 1969, Effect of herbicides on soil microflora. V. Growth and activity of cellulolytic microorganisms: Acta Microbiologica Polonica, Series B, v. 18 , no. 2 , p. $39-42$.

English.

Toxicity.

CA72(9):42035g

Sobieszczanski, J., 1968, Influence of different herbicides on the growth and development of cellulolytic microorganisms: Annales de l'Institut Pasteur, v. 115, no. 4, p. 613-616. English.

Toxicity.

CA70(7):27834g.

Sonnet, P. E., Lye, T. L., and.Sackett, R. R, 1978, Effects of selected herbicides on the toxicity of several insecticides to honey bees: Environmental Entomology, v. 7, no. 2, p. 254 256.

English.

Toxicity.

CA89(T):54677g.

Sosnovaya, O. N., Merezhinskii, Y. G., and Zhuravskaya, Z. F., 1979, Effect of nutrition on atrazine detoxication by enzymic pathway: Fiziologiya i Biokhimiya Kul'turnykh Rastenii, v. 11 , no. 1 , p. $58-62$.

Russian.

Toxicity.

CA90(19):146662x.

Spiridonov, Y. Y., and Spiridonova, G. S., 1971, Effect of the systematic use of atrazine and simazine on some groups of microorganisms in the soil: Trudy Vsesoyuznogo NauchnoIssledovatel'skogo Instituta Udobrenii i Agropochvovedeniya, v. 51, p. 264-270.

Russian.

Toxicity.

CA78(11):67861k.

Spiridonov, Y. Y., and Spiridonova; G. S., 1973, Effect of the perennial use of s-triazines on the biological activity of soil: Agrokhimiya, no. 3, p. 122-131.

Russian.

Toxicity.

CA79(1):4346w.

Srebocan, V., Plazonic, M., Pompe-Gotal, J., and Brmali, V., 1975, Biochemical mechanism of the toxicity of triazine herbicides: effect on the gluconeogenic activity in chick, liver. Veterinaski Archiv, v. 45, no. 11-12; p. 273-287.

Croatian.

Toxicity.

CA85(15):104934d:

Stalling, D. L., 1976, International Conference on Environmental Sensing Assessment, Proceedings, 1975, p. 4 Pp..

English.

Toxicity.

CA86(5):26580q.
Stay, F. S., Larsen, D. P., Katko, A., and Rohm, C. M., 1985, Effects of atrazine on community level responses in Taub microcosms: American Society for Testing Materials, Special Technical Publication, v. 865, no. Validation and Prediction of Laboratory Methods for Assessing the Fate and Effects of Contamination in Aquatic Ecosystems, p. 75-90.

English.

Toxicity,Surfacewater Observations.

CA104(7):46891k

Stefanic, G., Papacostea, P., Sarpe, N., Popa, E., and Grou, E., 1980, Effects of treatment with atrazine on soil microflora and enzymatic activites: Folosirea rationala a erbicidelor Coordonarea stiintifica: I. Ceausescu.

Romanian.

Toxicity.

IND 83022309.

Stenz, E., and Menzel, G., 1978, Effect of 1,3,5-triazines on the multiplication of prokaryote viruses and their hosts:

Zeitschrift fuer Allgemeine Mikrobiologie, v. 18, no. 2, p.

115-121.

German.

Toxicity.

CA89(13):100754e.

Stepanova, Z A., Gerbitsidy i Arboritsidy v Leskom Khozyaistve, Materialy na Koordinatseonno-Metodicheskom, p. 42-46. Russian.

Toxicity.

CA76(5):21894d.

Stevenson, J. C., Jones, T. W., Kemp, W. M., and Boynton, W. R. December 1982, Overview of atrazine dynamies in estuarine ecosystems: Proceedings of the Workshop on Agricultural and Estuarine Production,Duke University Marine Laboratory, North Carolina, September 18-19, 1980, p. 71-94.

English.

Toxicity.

Stoimenova, I., and Taleva, A., 1981, Effect of some herbicide combinations upon microbiological and biochemical processes in the rhizoshpere of sweet corn: Pochvoznanie i Agrokhimiya, v. 16, no. 4 , p. $88-94$.

Bulgarian.

Toxicity.

CA96(23):195029d.

Stratton, G. W., Jan 1984, Effects of the herbicide atrazine and its degradation products, alone and in combination, on phototrophic microorganisms: Archives of Emvironmental Contamination and Toxicology, v. 13, no. 1, p. 35-42. English.

Toxicity,Deyradation Products. CA100(21):169601r.

Stratton, G. W., 1983, Interaction effects of permethrin and atrazine combinations towards several nontarget microorganisms: Bulletin of Environmental Contamination and Toxicology, v. 31, no. 3, p. 297-303.

English.

Toxicity.

CA99(23): $189340 \mathrm{u}$. 
Stratton, G. W., 1985, Interaction effects of mercury-pesticide combinations towards a cyanobacterium: Bulletin of Environmental Contamination and Toxicology, v. 34, no. 5, p. 676-683.

English.

Toxicity.

CA102(25):216570h.

Stratton, G. W., and Corke, C. T., 1981, Effect of acetone on the toxicity of atrazine towards photosynthesis in anabaena: Journal of Environmental Science and Health, Part B, v. B16, no. 1, p. 21-33.

English.

Toxicity.

CA94(15):115989n.

Stratton, G. W., and Corke, C. T., 1981, Interaction between acetone and two pesticides towards several unicellular green algae: Bulletin of Environmental Contamination and Toxicology, v. 27, no. 1, p. 13-16.

English.

Toxicity.

CA95(11):92038f.

Stratton, G. W., and Smith, T. M., 1988, Interaction of organic solvent with the green alga Chlorella pyrenoidosa: Bulletin of Environmental Contamination and Toxicology, v. 40, no. 5, p. 736-742.

English.

Toxicity.

CA108(25):217499c.

Streit, B., and Peter, H. M., 1978, Long-term effects of atrazine to selected freshwater invertebrates: Archives of

Hydrobiology, Supplement, v. 55, no. 1, p. 62-77.

English.

Toxicity.

CA90(5):34686b.

Streit, B., and Schwoerbel, J., 1977, Verhandlungen Gesellschaft fuer Oekologie, Jahresversammiung, 6th, 1976, p. 371-383.

German.

Toxicity,Uptake by Biota,Surfacewater Observations. CA89(7):54386m.

Strzelec, A., 1982, Effect of copper and zinc on the rate of atrazine degradation and development of soil microflora: Rocznili Gleboznawcze, v. 33, no. 1/2, p. 61-72.

Polish.

Biodegradation/Biotransformation; Toxicity.

CA99(1):1761e.

Strzelec, A., 1977, Residue dynamics of atrazine in different soils: Nachrichtenblatt fuer den Pflanzenschutzdienst in der DDR, v. 31, no. 10, p. 210-214.

German.

Toxicity.

CA88(15):100343z.

Stupnikov, A. A., 1977, Prophylaxis of animal poisoning with herbicides and arboricides: Veterinariya (Moscow), no. 6, p. 89-91.

Russian.

Toxicity.

CA87(17):128414b.
Styring, S., Vernotte, C., and Etienne, A. L., 1987, Progress in Photosynthesis Research, Proceedings of the International Congress on Photosynthesis, 7th, 1986, p. 133-136.

English.

Toxicity.

CA107(1):4533b.

Subagja, J., and Snider, R. J., 1981, The side effects of the herbicides atrazine and paraquat upon Folsomia candida and Tullbergia granulata (Insecta, Collembola): Pedobiologia, v. 22, no. 3, p. 141-152.

English.

Toxicity.

CA96(13):99359r.

Suschetet, M. Leclerc, J., Lhuissier, M., and Loisel, W., 1974, Toxicity and nutritional effects, in the rat, of two herbicides. Picloram (4-amino-3,5,6-trichloropicolinic acid) and atrazine (2-chloro-4-ethylamino-6-isopropylamino-Striazine): Annales de la Nutrition et de l'Alimentation, $v$. 28, no. 1, p. 29-47.

French.

Toxicity.

CA81(23):146568k.

Sutton, W. F., Brown, A. E., and Truelove, B., 1984, Atrazineand diuron-resistant strains of Rhodopseudomonas sphaeroides: Weed Science, v. 32, no. 5, p. 664-669.

English.

Run-off,Toricity.

CA101(21):187877k.

Svobodova, Z, 1980, Acute toxicity of pesticides to fish: Agrochemia (Bratislava), v. 20, no. 11, p. 328-332. Czechoslovakian.

Toxicity.

CA94(17):133627x.

Szende, K, 1974, Genetic effects of environmental mutagens, with special reference to soil biology: Agrartudomanyi

Koztemenyek, v. 33, no. 1, p. 47-55.

Hungarian.

Toxicity.

CA82(5):25804h.

Szlobodnyik, J., Dura, G., and Desi, I., 1980, Electromyographic methods in the study of pesticide toxicology: Nehezvegyipari Kutato Intezet Kozlemenyei, v. 10, p. 183-190.

Hungarian.

Toxicity,Analytical Techniques/Quantification. CA94(11):78015u.

Szocs, J., Ajtay, M., Molnar, V., Balogh, E., and Fulop, I., 1971, Enzymic modification in experimental atrazine intoxications: Revue de Medecine (Tirgu-Mures), v. 17, no. 1, p. 52:55.

Romanian.

Toxicity. 
Tanaka, A., Massago, H., Hara, Y., and Ujiie, A., 1984, Studies on simple analytical methods for trace amounts of agricultural chemicals in water and acute toxicities for fishes. IV. Simple and rapid simultaneous multicomponent analysis for organic nitrogen agricultural chemicals and acute toxity of carbamate and dinitroaniline pesticides: Yosui to Haisui, v. 26, no. 12, p. 1306-1316.

Japanese.

Toxicity,Analytical Techniques/Quantification. CA102(21):180478t.

Tang, S., Li, H., and Shi, J., 1984, Effect of chemical herbicides on microbes and transformation of substances in soil: Turang Xuebao, v. 21, no. 1, p. 95-104.

Chinese.

Toxicity.

CA101(5):34522r.

Thacker, E. J., 1971, International Symposium on the Identification and Measurement of Environmental Pollutants, Proceedings, p. 92-97.

English.

Toxicity, Uptake by Biota.

CA80(15):78934d.

Theodoru, C., and Sands, R., June 1980, Effect of atrazine on nitrogen transformations in forest soils. Increases in soil nitrate, increased uptake of nitrogen and...: Australian Forest Research, v. 10, no. 2, p. 133-139.

English.

Toxicity.

IND 81038661

Thompson, L, 1971, The toxicity and selectivity of atrazine to plants as affected by the environment, Dissertation submitted in partial fulfillment of $\mathrm{Ph}$.D. requirements, University of Illinois, Illinois.

English.

Toxicity.

CAT 80739533.

Thompson, O. C., Truelove, B., and Davis, D. E., 1974, Effects of triazine on energy relations of mitochondria and chloroplasts: Weed Science, v. 22, nu. 2, p. 164-166.

English.

Toxicity.

CA81(17):34182y.

Thomson, J. H., and Mayhead, G. J., 1982, Toxicity of five granular herbicides to Sitka spruce and lodgepole pine: Forestry, v. 55, no. 2, p: 173-182.

English.

Toxicity.

CA98(7):4855\%q.

Torralba Redondo, B., Flores Rodriguez, M., and Viltar Moreno, A. L. 1986, Action of the herbicide atrazine on the growth and nodulation of two Rhizobium strains: Anales de Edafologia y Agrobiologia, v. 45, no. 5-6, p. 817-826.

Spanish.

Toxicity.

CA107(5):34703z.
Torstensson, L., 1988, Effect of fungicides on soil microorganisms: Vaextskyddsrapporter, Jordbruk, v. 49, p. 165-172.

Swedish.

Toxicity.

CA109(11):88047y.

Toth, B., 1977, Effect of a few herbicides on the microbiological decomposition of corn stalle. Acta Phytopathologica

Academiciae Scientriarum Hungaricae, v. 12, no. 1-2, p. 109 112.

English.

Toxicity.

CA88(25):184480c.

Toth, D., Daubner, I., and Tomasovicova, D., 1982, Effects of pesticides on the viability of surface water microorganisms: Pol'nohospodarstvo, v. 28, no. 3, p. 265-273.

Slovenian.

Toxicity.

CA97(3):18716a.

Toth, D., and Tomasovicova, D., 1979, Effect of pesticides on the survival of Tetrahymena pyriformis in Danube water. Biologia (Bratislava), v. 34, no. 3, p. 233-239.

English.

Degradation Products, Toxicity,Surfacewater Observations. CA91(1):1033d.

Trunova, O. N., 1969, Effect of some herbicides and fungicides on the vitality and phaging activity of Paramaecium caudatum in an aqueous medium: Trudy Saratovskogo

Sel'skokhozyaistvennogo, v. 16, p. 196-200.

Russian.

Toxicity.

CA75(3):16587f.

Tscheu-Schlueter, M., 1976, On the acute toxicity of herbicides for selected aquatic organisms. Part 2: Triazine herbicides and amitrole: Acta Hydrochimica et Hydrobiologica, v. 4, no. 2; p. 153-170.

German.

Toxicity.

CA84(23): $160318 x$

Tsirkov, I., Toskov, N., Sapundzhieva, K, and Stanchev, A., 1980, Change in the rhizosphere microflora during monoculture corn cultivation under fertilization and biennial use of atrazine on the soil: Pochvoznanie i Agrokhimiya, v. 15, no. 5, p. 85-91.

Bulgarian.

Toxicity.

CA95(9):75323e.

Tsirkov, I., Toskov, N., and Stanchev, A., 1978, Effect of atrazine on the rhizosphere microflora of a corn monoculture: Rastenievudni Nauki, v. 15, no. 7, p. 31-39.

Bulgarian.

Toxicity.

CA91(13):103306n. 
Tu, C. M., 1988, Effects of selected pesticides on activities of invertase, amylase and microbial respiration in sandy soil: Chemosphere, v. 17, no. 1, p. 159-163.

Engdish.

Toxicity.

CA108(15):126294r.

Tulabaev, B. D., 1971, Effect of the herbicides simazine, atrazine, monuron, phenuron, and diuron on the microflora of meadow soil: Nauchnye Trudy, Samarkandskii

Sel'skokhozyaistvennyi Institut, v. 22, p. 154-159.

Russian.

Toxicity.

CA77(5):30244q.

Tulabaev, B., and Tamikaev, S., 1968, Effects of herbicides on meadow soil microflora: Uzbekskii Biologicheskii Zhurnal, v. 12, no. 2, p. 14-17.

Russian.

Toxicity.

CA69(9):34867c.

Turbak, S. C., Olson, S. B., and McFeters, G. A., 1986, Comparison of algal assay systems for detecting waterborne herbicides and metals: Water Research, v. 20, no. 1, p. 9196.

English.

Toxicity,Surfacewater Observations,Analytical Techniques/ Quantification.

CA104(8):56040w.

Tweedy, B. G., and Loeppky, C., 1968, The use of 14C-labeled glucose, giucuronate, and acetate to study the effect of atrazine, simazine, and fluometuron on glucose catabolism in selected plant pathogenic fungi: Phytopathology, v. 58, no. 11 , p. 1522-1531.

English.

Toxicity.

CA70(5):17847z.

Ulasevych, E. I., and Drach, I. U. O., Nov/Dec 1971, Effect of atrazine on nitrogen-fixing bacteria in the grey podzolized soil and maize rhizosphere: Mikrobiologicheskie Zhurnal, v. 33 , no. 6 , p. $735-736$.

Ukrainian.

Toxicity.

CAIN 729041545.

Usataya, A. S., Katruk, E. A., Merenyuk, G. V., and Tarasevich, L. I., 1985, Effects of sym-triazine group herbicides on chernozem microflora: Izvestiya Akademii Nauk Moldavskoi SSR, Seriya Biologicheskikhi Khimicheskikh Nauk, no. 3, p. 35-38. Russian.

Toxicity.

CA103(19):155745r.

Usataya, A. S., and Katruk, E. A., 1988, Monitoring of the levels of sym-triazine herbicides in soil from microbiological characteristics: Izvestiya Akademii Nauk Moldavskoi SSR, Seriya Biologicheskikhi Khimicheskikh Nauk, no. 2, p. 25-28. Russian.

Toxicity.

CA109(11):88097q.
Van't Hof, J., and Schairer, L. A., 1982, Tradescantia assay system for gaseous mutagens. A report of the U.S.

Environmental Protection Agency Gene-Tox Program: Mutation Research, v. 99, no. 3, p. 303-315.

English.

Toxicity.

CA98(3):12446m

Vazzana, C., Franci, M., and Vecchio, v., 1981, Symposium on the Theory and Practice of the Use of Soil Applied Herbicides: Proceedings.

English.

Field Residuals, Toxicity.

IND 83066729.

Veber, K, Zahradnik, J., Breyl, I., and Kredl, F., 1981, Toxic effect and accumulation of atrazine in algae: Bulletin of Environmental Contamination and Toxicology, v. 27, no. 6, p. 872-876.

English.

Toxicity,Uptake by Biota.

CA96(9):63916f.

Vecchio, V., and Vazzana, C., "Study Days on Weeding," 12 Conference of the French Weed Control Committee, 15-16 December 1983.

French.

Toxicity.

IND 86071664.

Velihii, V. I., 1983, Health hazards evaluation of pesticide and mineral fertilizer use in commercial scale com cultivation: Gigiena i Sanitariya, no. 7, p. 29-33.

Russian.

Toxicity.

CA99(22):180839f.

Verma, R. K., Vyas, S. C., Shastry, P. P., and Jain, A. C., 1979, Laboratory screening of some herbicides against three soilborne pathogens: Indian Phytopathology, v. 32, no. 3, p. 394 396.

English.

Toxicity.

CA93(25):232561g.

Virmani, M., Evans, J. O., and Lynn, R. I., 1975, Effects of striazine, carbamate, urea, and karbutilate herbicides on growth of fresh water algae: Chemosphere, v. 4, no. 2, p. 65-71. English.

Toxicity,Uptake by Biota.

CA83(13):109472v.

Voets, J. P., Meerschman, P., and Verstraete, W., 1974, Soil microbiological and biochemical effects of long-term atrazine applications: Soil Biology and Biochemistry, v. 6, no. 3, p. 149-152.

English.

Toxicity, Field Residuals.

CA81(19):115614t. 


\section{MISCELLANEOUS}

Toxicity

Volskay, V. T., Jr., and Grady, C. P. Leslie, Jr., 1988, Toxicity of selected RCRA compounds to activated sludge microorganisms: Journal of the Water Pollution Control Federation, v. 66, no. 10, p. 1850-1856.

English.

Toxicity.

CA110(1):2341a.

Vong, P. C., and Schiavon, M., 1982, Effect of atrazine on the mineralization of organic materials in soils and in the presence of carbon-14-labeled substrates: Bulletin de l'Ecole Nationale Superieure d'Agronomie et des Industries Alimentaires, v. 24, p. 43-53.

French.

Toxicity,Biodegradation/Biotransformation,Sorption to Soil. CA99(21):171257n.

Vorosbaranyi, J., 1983, Effect of prolonged use of herbicides on the cellulose-decomposing activity of soil microorganisms: Acta Agronomica Academiae Scientiarum Hungaricae, v. 32, no. 3-4, p. 257-260.

English.

Toxicity

CA100(3):19287d.

Vos, J. G., and Krajnc, E. I., 1983, Immunotoxicity of pesticides: Developments in Toxicology and Environmental Science, v. 11, no. Developments in Science and Practices of Toxicology, p. 229-240.

English.

Toxicity.

CA101(15):124459e.

Vos, J. G., Krajnc, E. I., Beekhof, P. K, and Van Logten, M. J., 1983, Pesticide Chemistry: Human Welfare and the

Environment, Proceedings of the International Congress on

Pesticide Chemistry, 5th, 1982, p. 497-504.

English.

Toxicity.

CA99(13):100605p.

Wacha, A. G., and Tiffany, L. H., 1979, Soil fungi isolated from fields under different tillage and weed-control regimes: Mycologia, v. 71, no. 6, p. 1215-1226.

English.

Toxicity.

CA92(21):175755b.

Walker, E. M., Jr., Gale, G. R, Atkins, L. M., and Gadsden, R H., 1979, Some effects of atrazine on Ehrlich ascites tumor cells in vitro and in vivo: Bulletin of Environmental Contamination and Toxicology, v. 22, no. 1-2, p. 95-102. English.

Toxicity:

CA91(7):50728t.

Walsh, A. H., and Ribelin, W. E., 1975, The pathology of pesticide poisoning: (s1Sin(sos Ribelin, W. E., ed., The pathology of fishes: Madison, Wisconsin, University of Wisconsin Press, p. 515-541.

English.

Toxicity.
Walsh, G. E., 1983, Cell death and inhibition of population growth of marine unicellular algae by pesticides: Aquatic Toxicology, v. 3, no. 3, p. 209-214.

English.

Toxicity.

CAS8(25):211201c.

Waish, G. E., Hansen, D. L, and Lawrence, D. A., 1982, A flowthrough system for exposure of seagrass to pollutants: Marine Environmental Research, v. 7, no. 1, p. 1-11.

English.

Toxicity.

CA97(15):121602j.

Walsh, G. E., McLaughlin, L. L., Yoder, M. J., Moody, P. H., Lores, E. M., Forester, J., and Wessinger-Duvall, P. B., 1988, Minutocellus polymorphus: a new marine diatom for use in algal toxicity tests: Environmental Toxicology and Chemistry, v. 7, no. 11, p. 925-929.

English.

Toxicity.

CA110(3):19459.

Walter, B., and Bastgen, D., 1971, Soil respiration and enzyme activities of herbicide-treated vineyard soils. III:

Weinberg Keller, v. 18, no. 10, p. 465-575.

German.

Toxicity.

CA76(7):33143w.

Wang, C.-C., Tsai, R.-C., and Huang, T.-C., 1977, Effects of types of herbicides, their concentrations, and application methods on residual toxicity in soil. II. Studies on the residual toxicity of herbicides in soil: Chung-Hua Nung Hsueh Hui Pao, v. 100, p. 103-116.

Chinese.

Toxicity.

CA89(1):1374z.

Ward, G. S., and Ballantine, L., 1985, Acute and chronic toxicity of atrazine to estuarine fauna: Estuaries, v. 8, no. 1, p.

22-27.

English.

Toxicity.

CA103(1):1805y.

Weaver, S. E., and Warwick, S. I., Sept 1982, Competitive relationships between atrazine resistant and susceptible populations of Amaranthus retroflexus and Amaranth...: New Phytology, v. 92, no. 1, p. 131-139.

English.

Toxicity.

IND 82106848.

Wegrzyn, T., 1971, Effect of some herbicides on Azotobacter chroococcum: Acta Microbiologica Polonica, Series B, v. 3, no. 3, p. 131-134.

English.

Toxicity.

CA76(3):10869y. 
Welp, G., and Bremmer, G. W., 1988, Determination of no-effect levels and additional toxicity characteristics of environmental chemicals for various soils with microorganism tests: Spez. Ber. Kernforschungsanlage Juelich, Juel-Spez441, Methoden Oekotoxikol. Bewertung Chem., Band 11, 27-55. German.

Toxicity.

CA109(19):165407v.

Wenzel, W., Krienitz. L, and Boehm, H., 1975, Mekhanizm Deistviya Gerbitsidov i Sinteticheskikh Regulyatorov Rosta Rastenii i Ikh Sud'ba v Biosfere, Materialy Mezhdunarodnogo Sympoziuma, p. 197-202.

Russian.

Toxicity.

CA88(21):147029s.

Werner, W., Ellenberg, H., Stickan, W., Schaefer, M., StrueveKusenberg, R., Khairy, A., Mueller-Wegener, U., and Ziechmann, W., 1983, Effects and distribution of pollutants in a terrestrial-ecosystem model: Verhandiungen Gesellschaft fuer Oekologie, v. 11, p. 425-436.

German.

Toxicity.

CA100(7):46652a.

Wolf, D. C., 1973, Degradation of bromacil, terbacil, 2,4-D, and atrazine in soil and pure culture and their effect on microbial activity, Dissertation submitted in partial fulfillment of Ph.D. requirements, University or California, Riverside, California.

English.

Biodegradation/Biotransformation,Toxicity.

CA81(13): $73262 \mathrm{u}$.

Worth, G., Straus, B., and Stankovic, V., 1982, Effects of atrazine on ceruloplasmin and acid phosphatase in rat liver, kidney, and spleen: Acta Pharmaceutica Jugaslavica. v. 32, no. 1, p. 53-57.

Engiish.

Toxicity.

CA96(25):212165q.

Yeomans, J. C., and Bremner, J. M., 1985, Denitrification in soil: effects of herbicides: Soil Biology and Biochemistry, v. 17 , no. 4 , p. $447-452$.

English.

Toxicity.

CA103(15):118242d.

Yeomans, J. C., and Bremner, J. M., 1987, Effects of dalapon, atrazine and simazine on denitrification in soil: Soil

Biology and Biochemistry, v. 19, no. 1, p. 31-34.

English.

Toxicity.

CA106(25):213022c.

Zanin, G. L., Margherita, and Olivieri, A. M., 1983, Genetic behavior of atrazine resistance in Solanum nigrum L: Rivista di Agronomia, v. 17, no. 4, p. 459-464.

Italian.

Toxicity.

CA101(11):85614e.
Zeiger, E., Anderson, B., Haworth, S. L., Timothy, and Mortelmans, K, 1988, Salmonella mutagenicity tests: IV. Results from the testing of 300 chemicals: Environmental Molecular Mutagenicity, v. 11, no. Suppl. 12, p. 1-157.

English.

Toxicity.

CA108(17):145157q.

Zelles, L., Bahig, M. E., Scheunert, I., Klein, W., and Korte, F., 1984, Measurement of bioactivity based on carbon dioxide release and ATP content in soils after different treatments: Chemosphere, v. 13, no. 8, p. 899-913.

English.

Toxicity.

CA101(19):165040e.

Zelles, L., Scheunert, I., and Korte, F., 1985, Side effects of some pesticides on nontarget soil microorganisms: Journal of Environmental Science and Health, Part B, v. B20, no. 5, p. 457-488.

English.

Toxicity.

CA104(9):63777v.

Ziegler, P., and Ashton, A. R., 1987, Progress in Photosynthesis Research, Proceedings of the International Congress on Photosynthesis, 7th, 1986, p. 803-806.

English.

Toxicity.

CA107(5):36806j.

Zinchenko, V. A., Osinskaya, T. V., and Prokudina, N. A., 1969, Effect of herbicides on the biological activity of the soil: Khimiya v Sel'Skom Khozyaistve, v. 7, no. 11, p. 850-853. Russian.

Toxicity.

CA72(25):131326v.

Zlateva, P., 1977, Study of the toxicity of some pesticides to algae with Scenedesmus quadricauda $L$ as the test organisms: Trudy Vodosnabdyavane, Kanalizatsiya Sanitarna Tekhnika, v. 12 , no. 2, p. $177-186$.

Bulgarian.

Toxicity.

CA87(19):146677u.

Zubets, T. P., 1970, Effect of herbicides on nitrifying bacteria: Nauchnye Trudy - Severo - Zapadnyi Nauchno-Issledovatel'skii Institut Sel'skogo Khozyaistua, v. 19, p. 46-49.

Russian.

Toxicity.

CA7S(5):34340z.

Zubets. T. P., 1973, Residual action of simazine and atrazine on the microflora and enzyme activity in sod-podzolic soil: Nauchnnye Trudy - Severo - Zapadnyi Nauchno-Issledovatel'skii Institut Sel'skogo Khozaistua, v. 24, p. 103-109.

Russian.

Toxicity.

CA82(3):12090k. 